DEPARTAMENTO DE URBANISMO

Título de la Tesis:

RASTREO DE LAS INFLUENCIAS Y PRECEDENTES EN LA COMPOSICIÓN ARQUITECTÓNICA DE LAS IGLESIAS TRADICIONALES DE CHILOE.

Lorenzo Berg Costa, Arquitecto. Diploma de Estudios Avanzados DEA 2009

Director de Tesis: D. Antonio José Mas-Guindal Lafarga, Dr. Arquitecto

2015

POLITÉCNICA 
Tribunal nombrado por el Magfco. y Excmo. Sr. Rector de la Universidad Politécnica de Madrid, el día de 20.....

Presidente: Julio Pozueta Echavarrui. (UPM)

Vocal : Pilar Chias (Catedrática de la Universidad de Alcalá de Henares)

Vocal : Enrique Nuere Matauco. (investigador doctor)

Vocal : Isidro Gordejuela (Universidad CEU San Pablo, catedrático)

Secretario : Pilar Rodríguez Monteverde.(UPM)

Suplente 1: Francisco Gil Carrillo (Profesor Universidad Camilo José Cela)

Suplente 2 : Farzic Mokthar Noriega (Profesor Universidad Camilo José Cela)

Realizado el acto de defensa y lectura de la Tesis el día de de 201..... en la E.T.S. Arquitectura.

CALIFICACIÓN:

EL PRESIDENTE

LOS VOCALES

EL SECRETARIO 
Al apoyo intelectual permanente de Gian Piero Cherubini Z. de mi hija Eileen Berg L. y Soledad Díaz de la Fuente L. 
Esta investigación se debe a todos aquellos que han contribuido a escribir sobre las Iglesias de Chiloé, especialmente el Arquitecto Hernán Montecinos, Padre Gabriel Guarda e Historiador Rodolfo Urbina.

Se agradece en forma especial al Archivo Franciscano y Fray Rigoberto Iturriaga; Fundación Cultural Iglesias de Chiloé y Katerine Araya; Biblioteca Facultad de Arquitectura y Urbanismo Universidad de Chile 
ÍNDICE

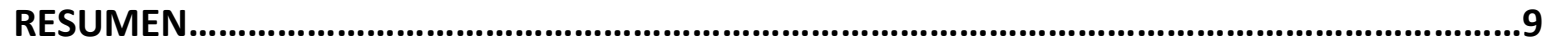

PRIMERA PARTE

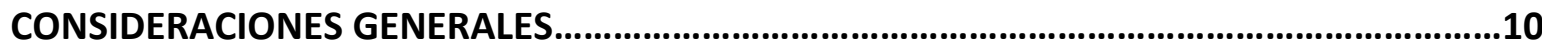

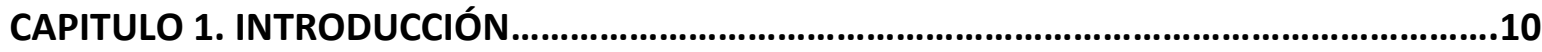

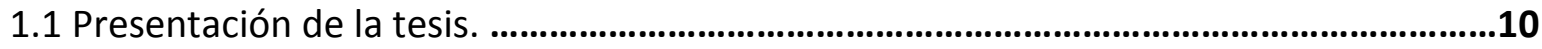

1.2 Justificación del tema y estado de la cuestión. ..............................................................12

Origen y desarrollo de los sistemas arquitectónicos de Chiloé. ...............................14

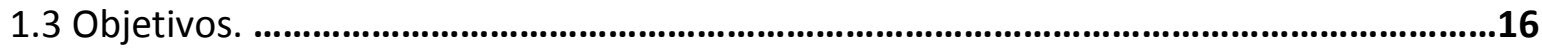

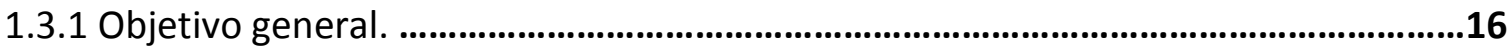

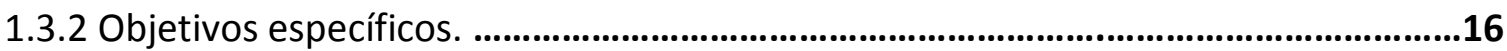

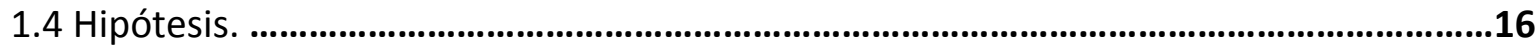

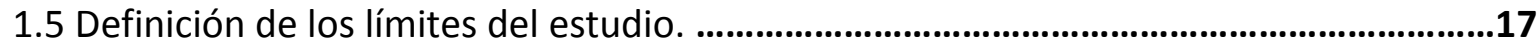

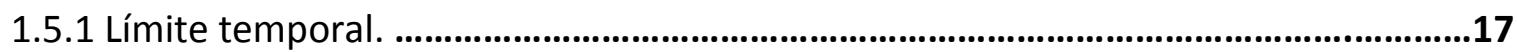

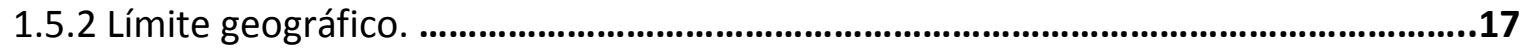

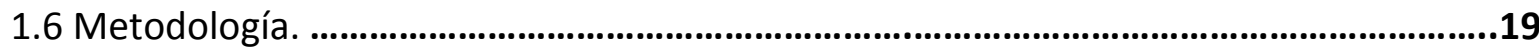

1.6.1 Campos de análisis e interpretación

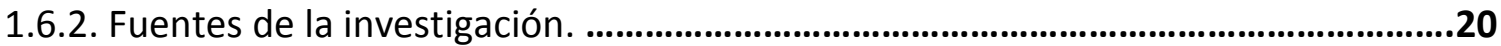

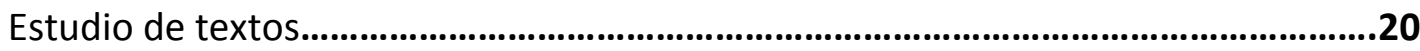

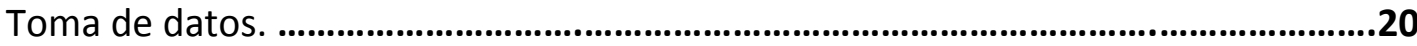

Análisis de la documentación y datos. .........................................................................20

1.7. Alcances y Limitaciones. ...................................................................................................20

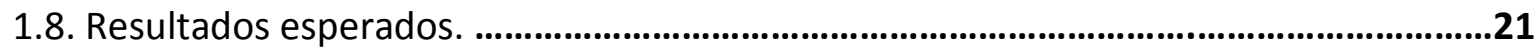

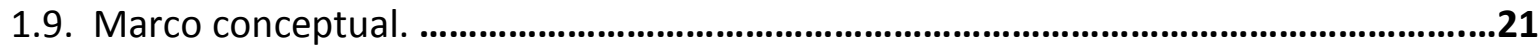

1.9.1 Arquitectura Cultural. . .................................................................................................21

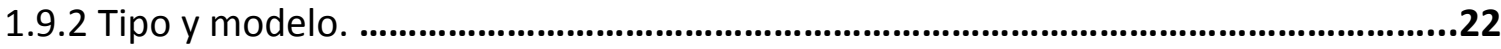

1.9.3 Arquitectura tradicional de Chiloé. ................................................................................22

1.9.4 Tipologías y modelos religiosos tradicionales de madera chilotes. ...........................22

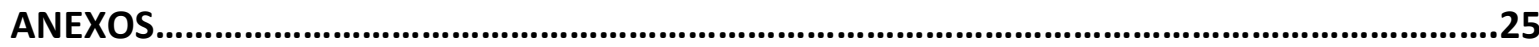

CAPITULO 2. AVANCES PREVIOS Y ESTADO DEL ARTE EN LA ARQUITECTURA RELIGIOSA

DE MADERA EN CHILOÉ. ............................................................................................29

2.1 Una revisión actual de las capillas: Las imágenes del siglo XIX, XX y XXI........................29

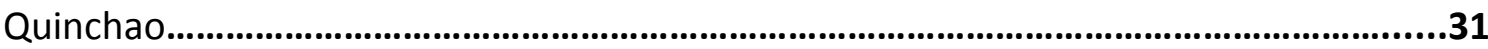

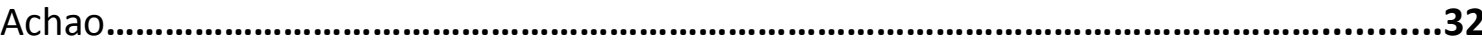

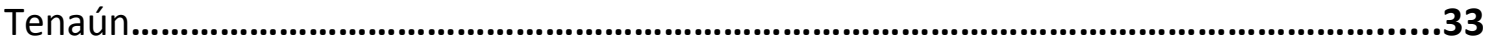

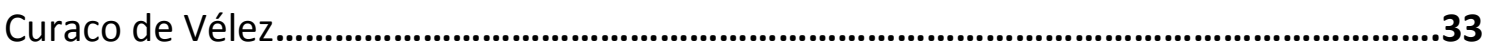

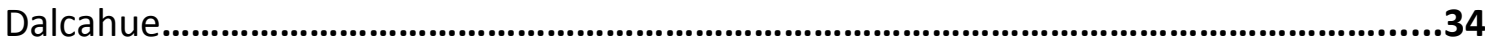

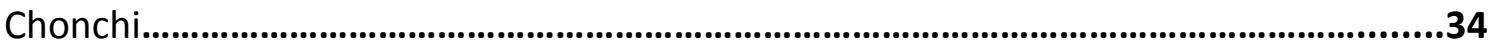

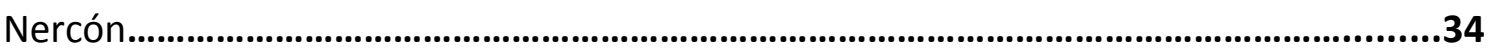

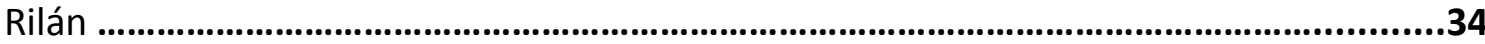

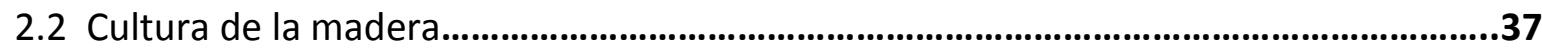

2.3 El estado de la arquitectura y la carpintería local. ...........................................................40 


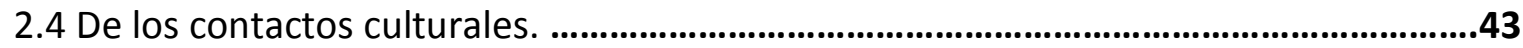

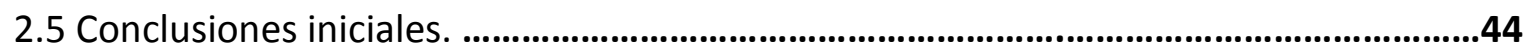

2.6 Orientación de los capítulos siguientes......................................................................48

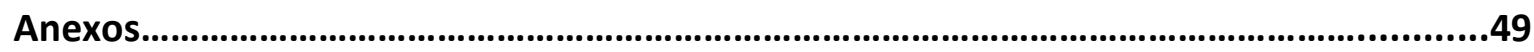

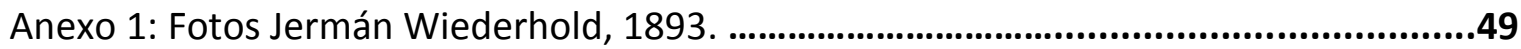

Anexo 2: Cuadro de subtipologías capillas de Chiloé. ..................................................50

Anexo 3: Levantamiento crítico capillas de Chiloé. ........................................................51

CAPITULO 3. LOS PRIMEROS CONTACTOS: LA MISIÓN JESUITA.....................................52

Antecedentes etnoculturales previos. ...................................................................52

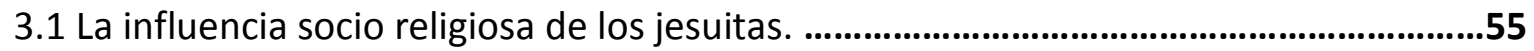

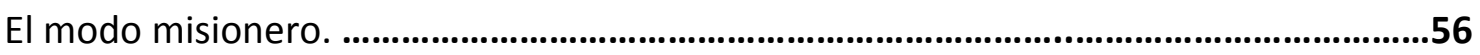

La formación pedagógica. ................................................................................................57

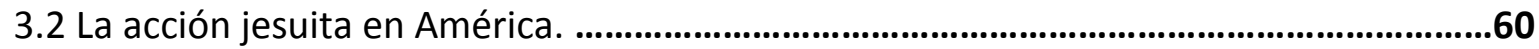

3.3 El Urbanismo y la arquitectura jesuita en Chiloé. .........................................................61

La misión circular, la refundación del "hue" insular. ....................................................61

Las capillas, origen del urbanismo insular. ...................................................................64

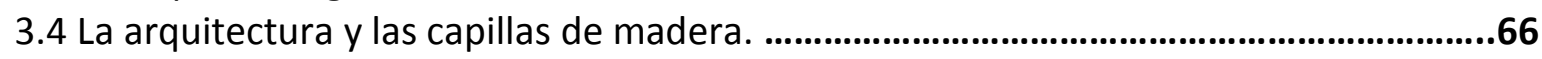

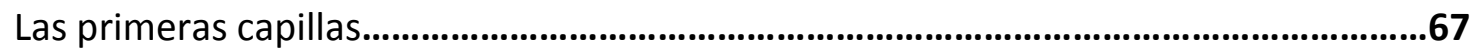

Composición arquitectónica y constructiva de las capillas jesuíticas. ................................67

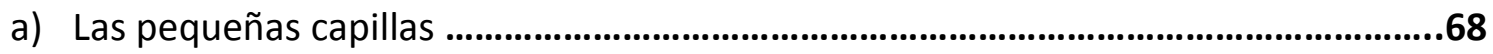

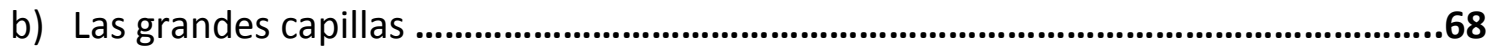

3.5 Estudios de Casos: Castro y Achao ...........................................................................71

3.5.1 La Iglesia de la Compañía de Castro. ..................................................................71

3.5.2 La Capilla Santa María de Achao.................................................................................73

Estudio de medidas y proporciones de Achao. ..................................................................74

Dirección de la fábrica y aspectos constructivos en Achao. ..........................................78

3.6 La arquitectura religiosa jesuita en Chile. .....................................................................80

La Iglesia de Calera de Tango. .........................................................................................81

Apuntes históricos. ...............................................................................................................82

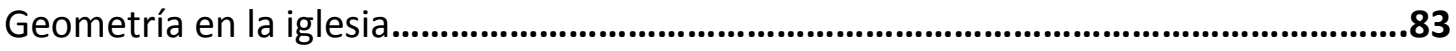

3.7 Antecedentes de la arquitectura de los Jesuitas, en Europa. ......................................87

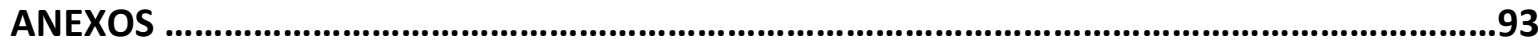

Anexo 1. Descripciones de Iglesia de Castro en 1741........................................................93

Anexo 2. Inventario de la Residencia de los Jesuitas en Santa María de Achao (15-2-1769). 
CAPITULO 4. LA LLEGADA DE LOS FRANCISCANOS Y LA IMAGEN DEL NEOCLÁSICO........98

4.1 Contexto: nuevos misioneros para la República. ......................................................98

4.2 El modo y la arquitectura franciscana. ........................................................................99

4.2.1 La arquitectura en Chile y su relación con el período de los franciscanos..............102

4.3 La huella de los Franciscanos en el contexto de Chiloé. ................................................105

4.4 El periodo de San Idelfonso de Chillán 1767-1771. .....................................................105

4.5 El periodo de El Colegio de Santa Rosa de Ocopa 1771-1820 (aprox.) ........................107

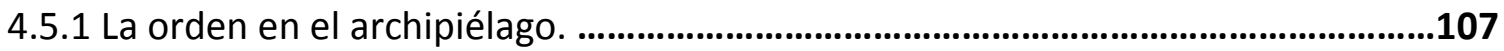

4.5.2 El Colegio de Ocopa y sus figuras constructoras. ...................................................109

4.5.3 El surgimiento de la Villa de San Carlos (Ancud) y las nuevas Capillas. .................113

4.6 Los Franciscanos Italianos (1837-1905). ......................................................................16

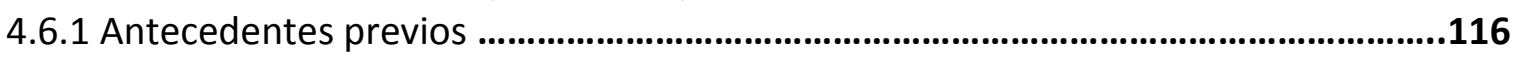

4.6.2 La nueva dimensión administrativa y territorial. ....................................................118

4.6.3 La figura de Diego Chuffa, el impulsor del Colegio de Castro. ................................119

4.6.4 El Colegio de Castro y su influencia..........................................................................121

4.6.5 La Iglesia franciscana de Castro: La matriz tipológica de las Iglesias tradicionales de

Chiloé.

.126

4.6.5.1 Evolución histórica arquitectónica del conjunto convento e iglesia de Castro en

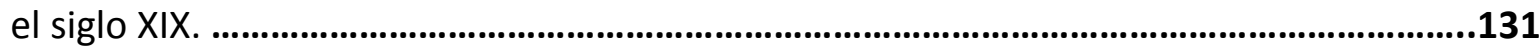

4.6.5.2 La gestión de la obra en Castro. .........................................................................135

4.6.5.3 Antecedentes arquitectónico de la Iglesia: Neoclásico y madera. .....................140

4.6.5.4 Análisis arquitectónico de la Iglesia. ......................................................................142

4.6.5.5 Análisis del estilo dórico en la Iglesia. ............................................................149

4.7 El caso de Osorno, la escuela franciscana italiana se impone. ...................................151

Evolución histórica arquitectónica de la iglesia de Osorno en el siglo XIX. .................154

4.8 Conclusiones de las Misiones en Osorno y Castro. ......................................................159

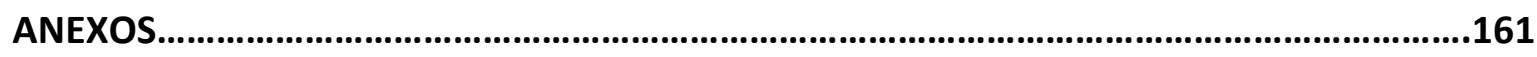

Anexo 1. Parroquias y vice parroquias atendidas por el Colegio de Castro, 1845- 1905.

.

Anexo 2. Cartas entre Intendencia de Chiloé y Colegio de Castro (1839-1857) .................162

Anexo 3. Documento contable la Iglesia de Castro de 1883. Extracto. Primera partida

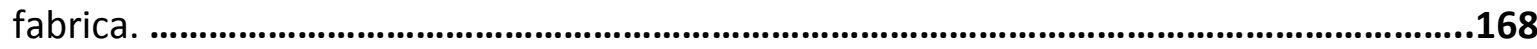

Anexo 4. Documento contable de la Iglesia de Castro, 1887. Extracto: Solicitud de

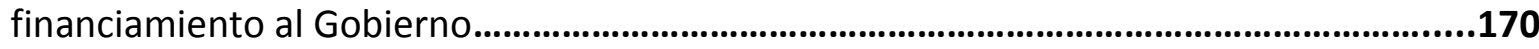

Anexo 5: Documento contable de la Iglesia de Castro 1888. Extracto. Nombramiento de la Comisión de Fábrica .

171

Anexo 6: Plano de Iglesia de Castro de Eduardo Provasoli. Proyecto ideado con estructura

en madera de inicio del siglo XX.

172 
5.1.1 La colonización alemana (Neoclásico, mecanización y el sistema fachwerk) .....175

5.1.2Arquitectura Portuaria. ¿Sistema De Plataforma O Ballón Frame?. ......................181

5.1.3 Nuevos Imaginarios, Simbología Y Materiales. ......................................................183

5.2 Iglesias en el territorio de la colonización del lago Llanquihue. .................................185

CAPITULO 6. LA REALIZACION DE LAS CAPILLAS TRADICIONALES DEL SIGLO XIX........191

6.1 La configuración tipológica de las capillas tradicionales de Chiloé. ...........................191

La estética epocal. ...............................................................................................................192

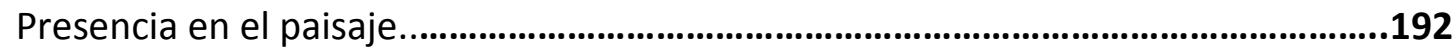

Racionalidad y Economía formal. ...........................................................................193

6.2 La multiplicación del tipo en modelos por el archipiélago, la racionalidad constructiva.

6.2.1 Sistema estructural y constructivo o implicancias composicionales del sistema

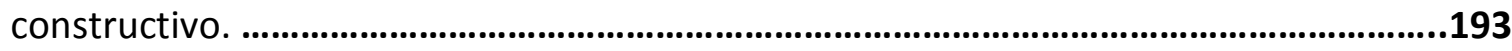

6.2.2 Racionalidad constructiva, prefabricación y efecto estético. ...............................200

6.2.2.1 Épocas y dimensiones del madereo del alerce. ...............................................201

6.2.3 Cuatro proyectos originales para la construcción de iglesias y una interpretación geométrica.

a) Plano de Nuestra Señora de Gracia de Quinchao. ..............................................204

b) La torre de Guaiquio para la iglesia de Tenaún. ..................................................206

c) La iglesia de Curaco de Vélez: el proyecto del padre Franz Bohle. ......................208

d) La iglesia de San Juan: sofisticado ejercicio geométrico. ....................................211

e) La iglesia nueva de Chonchi. Intuición constructiva. ...........................................214

6.3 La fábrica de madera: sistema estructural y proceso constructivo. ...........................215

6.3.1. Fundaciones y envigados de piso. ............................................................................219

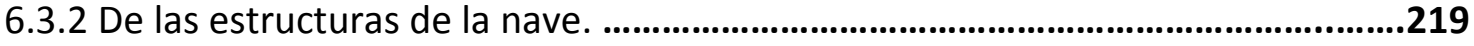

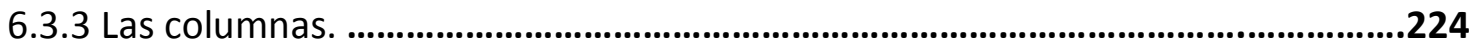

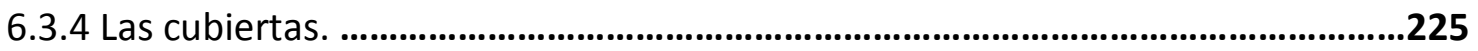

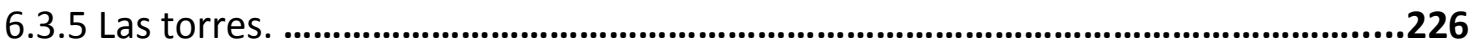

6.4 Los carpinteros chilotes. .....................................................................................228

6.4.1. La experiencia con los carpinteros actuales chilotes .........................................230

6.5 Agustín Guaiquio, gran maestro carpintero de capillas. ............................................235

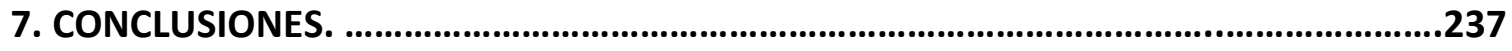

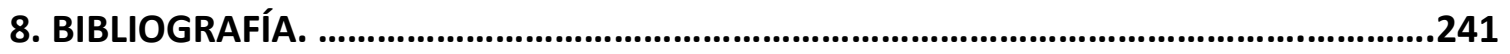




\section{RASTREO DE LAS INFLUENCIAS Y PRECEDENTES EN LA COMPOSICIÓN ARQUITECTÓNICA DE LAS IGLESIAS TRADICIONALES DE CHILOE.}

\section{RESUMEN}

Las capillas tradicionales en madera de Chiloé constituyen el primer conjunto arquitectónico declarado Patrimonio de la Humanidad en Chile. Fundamentalmente por ser una muestra del proceso de sincretismo en las dimensiones intangibles y tangibles entre lo nativo y lo europeo. Hasta la fecha siempre se había señalado que estas construcciones habían sido resultado de la influencia jesuita durante la Colonia. Sin embargo, la tipología tradicional con torre fachada central surge a mediados del siglo XIX casi un siglo después de la expulsión jesuítica de América. Esta investigación rastrea los orígenes y posterior desarrollo de estos edificios religiosos íntegros construidos en madera a través del estudio histórico de los contactos culturales para registrar patrones de permanencia y cambio. Se logra asentar que es, con la llegada de misioneros franciscanos italianos al archipiélago en 1837 durante el periodo de la postindependencia, quienes son los principales artífices de la introducción de los patrones neoclásicos que serán rápidamente adoptados y adaptados por los carpinteros chilotes al imaginario local. Este tipo de fábrica por su sistema de carpintería de armar alcanza un grado de racionalidad constructiva y composicional que se adapta a las exigencias simbólicas y clima austral, lo que sería fundamental para propagarse como arquitectura de carácter tradicional en el archipiélago y su contexto geográfico cultural.

\section{TRACKING INFLUENCES AND PRECEDENTS IN THE ARCHITECTURAL COMPOSITION OF CHILOE'S TRADITIONAL CHURCHES.}

\section{ABSTRACT}

Chiloé's traditional wooden chapels are the first architectural buildings in Chile to be listed as World Heritage Site. This is due to the fact that they are an example of tangible and intangible syncretism process between native and European influences. Up until today, it has been commonly stated that these constructions were the result of Jesuit influence in the colonial period. Nonetheless, the traditional style with central facade tower emerged in the XIX century, almost a century after the Jesuits were expelled from Latin America. This research traces the origins and subsequent development of these religious timber buildings through the historical study of cultural relationships and recorded patterns of permanence and change. It will be stated that the Italian Franciscan missionaries who arrived to the archipelago in 1837, during the post-independence period, are the main builders of these structures and also introduced the neoclassical patterns. These were quickly adjusted and adapted by Chiloe carpenters into the local identity. Their timber fabrication techniques and composition reaches a high degree of rationalization that is adapted to the symbolic requirements and southern climate. This feature is key to explain the rapid spread of this traditional architectural character of the archipelago and its geographical and cultural context. 


\section{PRIMERA PARTE: CONSIDERACIONES GENERALES}

\section{CAPITULO 1. INTRODUCCIÓN}

\subsection{Presentación de la tesis.}

Las iglesias de Chiloé, se emplazan en el archipiélago del mismo nombre en el sur de Chile. Este contexto geográfico de la llamada Isla Grande y más de cincuenta islotes menores desde tiempos inmemoriales de las glaciaciones dan cuenta de una ocupación humana temprana ${ }^{1}$.

En estas latitudes de clima lluvioso y bosque frío siempre verde, se gestaron pueblos nómades de canales (chonos) y sedentarios de tierra (huilliches). Ambos con una cultura especializada en la vida de bordemar y el manejo de la madera.

Las Iglesias tradicionales de Chiloé, son el capítulo culmine de la madera. Tales edificios son el mejor ejemplo del mestizaje insular y europeo, razón por la cual fueron denominados Patrimonio de la Humanidad en el 2000 por la Unesco. Son el resultado de un proceso que empieza con la etapa de colonización hispánica como simples edificios hasta el XIX y, en dos siglos de transformaciones, pasan a ser gigantes de madera con algunas torres de hasta $40 \mathrm{mts}$ de altura y capaces de mantenerse en pie con temporales de vientos que alcanzan los $100 \mathrm{~km} / \mathrm{hr}$ y sismos de grado entre 8 y 9 escala Richter. Construidos íntegramente en diversas maderas nativas de largas y gruesas dimensiones (mínimos secciones de 5x5"). Cada especie maderera tiene un fin determinado según su función estructural, revestimientos y/o terminaciones.

Básicamente la iglesia se compone de dos partes, un volumen horizontal con cubierta a dos aguas que da cabida a una planta basilical y un volumen vertical que corresponde a la torre fachada. Todo el conjunto de piezas de la estructura está conectado en las uniones por sistemas de ensambles y de tarugos, casi no hay uso de clavos o conectores metálicos (Figura N¹). Este gran "mecano" o "fábrica de la iglesia" es equilibrado no sólo por la geometría y sistema constructivo, sino que por su tremendo peso. Además, la gran nave aunque adosada a las esbeltas torres, son estructuralmente y constructivamente independientes entre ellas. La techumbre de la nave es una estructura de tijerales de par y nudillo, del cual cuelga la bóveda a manera de bote invertido.

Hasta ahora y pese a los numerosos estudios sobre estas iglesias aún no está claramente evidenciado cuales fueron las influencias y factores que determinaron la tipología arquitectónica y constructiva, para al canzar su momento culmine durante el siglo XIX.

\footnotetext{
${ }^{1}$ El sitio de Monteverde da cuenta de la ocupación humana 12.000 años AC, revolucionandolas hipótesis migratorias hacia América (Berg \& Cherubini, 2009).
} 


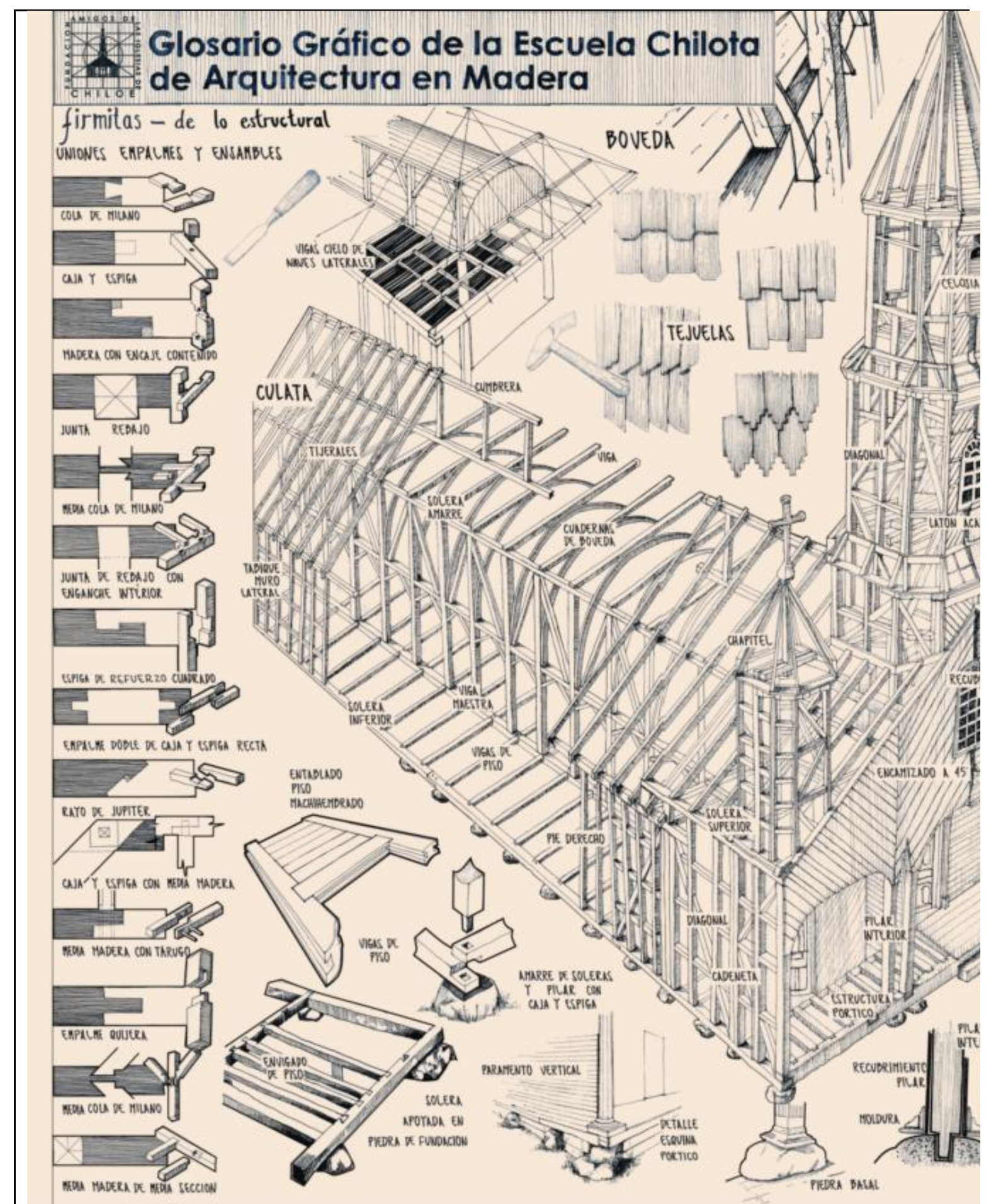

Figura № 1. Detalles de ensambles tipo y Capilla de Tenaun. Dibujo: Fuente Fundamich 


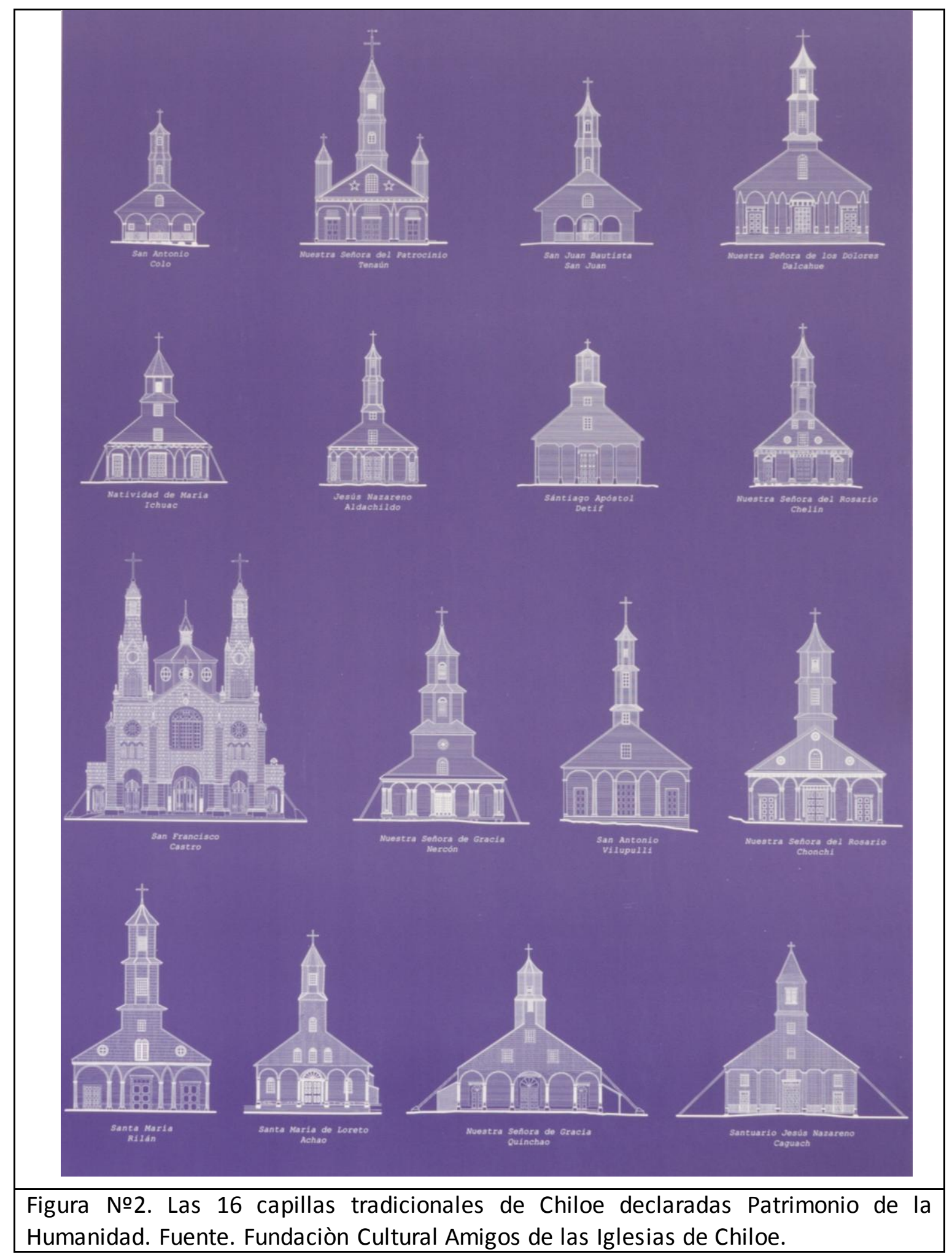

\subsection{Justificación del tema y estado de la cuestión.}

A partir del trabajo de investigación tutelado previo a la presente tesis y el estado actual del conocimiento acumulado sobre la arquitectura de Chiloé y en específico a las iglesias tradicionales se sostiene que: 
- La arquitectura de Chiloé y su reconocida cultura de la madera se encuentra en cuestionamiento, pasando a otro ciclo de ajuste y probable nueva síntesis en tiempos de globalización. La madera ya no sería el material principal y las Iglesias tradicionales sus mayores y últimos exponentes. Por tal razón es fundamental conocer y mantener adecuadamente estos edificios.

- Las investigaciones realizadas no han estudiado suficientemente en la arquitectura de Chiloé los fenómenos de transformaciones formales, funcionales y tecnológicas que ocurren como procesos culturales insulares. Identificar, describir e interpretar estos hechos y realizaciones permitirían modelar las operaciones arquitectónicas, que permanecen y cambian, de una historia constructiva en el caso de las capillas.

- Describir el proceso y modelar las operaciones constructivas permiten no solo develar el pasado sino que son posibles fuentes para crear, a partir de estas claves, un futuro sostenible en cuanto a aportar en la dimensión cultural y ambiental para Chiloé.

Una revisión del estado actual de la teoría y la práctica de la arquitectura de Chiloé, permite afirmar que representa un continum histórico, dinamizado por los diferentes momentos y contactos culturales, como el indiano, el hispano, más tardíamente el chileno, el alemán y la modernidad (ver cuadro 1), que aún son distinguibles en sus dimensiones tangibles e intangibles de la sociedad y territorio insular, que se recoge en cerca de 40 años de investigación, que han sido fundamentales para ponerla en valor, con el hito que ha significado la declaración de las iglesias como Patrimonio de la Humanidad, siendo el primer conjunto arquitectónico en Chile que alcanza esta categoría (Figura $\mathrm{N}^{\circ} 2$ ).

\begin{tabular}{|c|c|c|c|c|}
\hline $\begin{array}{l}\text { Grandes } \\
\text { Eventos }\end{array}$ & Contexto & $\begin{array}{l}\text { Nivel } \\
\text { territorial }\end{array}$ & $\begin{array}{l}\text { Nivel } \\
\text { edificios } \\
\text { espacio/ } \\
\text { forma }\end{array}$ & $\begin{array}{l}\text { Nivel edificios } \\
\text { tecnología }\end{array}$ \\
\hline $\begin{array}{l}\text { Desembarco } \\
1 .\end{array}$ & \multirow[b]{2}{*}{$\begin{array}{l}\text { Ocupación de } \\
\text { exploradores } 12000 \\
\text { AC y diversificación } \\
\text { étnica de clanes } \\
\text { nómades/sedentari } \\
\text { os hasta } 1500 \text { DC. }\end{array}$} & \multirow[b]{2}{*}{$\begin{array}{l}\text { Ocupan el } \\
\text { mar interior } \\
\text { abrigado y en } \\
\text { forma } \\
\text { dispersa. }\end{array}$} & \multirow[b]{2}{*}{$\begin{array}{l}\text { Rucas y } \\
\text { Chozas } \\
\text { mono } \\
\text { espaciales } \\
\text { con formas } \\
\text { orgánicas. }\end{array}$} & \multirow{2}{*}{$\begin{array}{l}\text { Uso de troncos } \\
\text { y ramas con } \\
\text { uniones de } \\
\text { fibra vegetal. }\end{array}$} \\
\hline INDIANO & & & & \\
\hline $\begin{array}{l}\text { Desembarco } \\
2 .\end{array}$ & \multirow{2}{*}{$\begin{array}{l}\text { Ocupación insular } \\
\text { de la corona } \\
\text { española } 1567 \text { DC. }\end{array}$} & \multirow{2}{*}{$\begin{array}{l}\text { Fundan } \\
\text { ciudades } \\
\text { según ley de } \\
\text { indias, no }\end{array}$} & \multirow{2}{*}{$\begin{array}{l}\text { Edificio } \\
\text { ortogonales } \\
\begin{array}{ll}\text { de } 1 \text { y } 2 \\
\text { pisos con }\end{array}\end{array}$} & \multirow{2}{*}{$\begin{array}{l}\text { Uso inicial del } \\
\text { tapial y } \\
\text { posterior de la } \\
\text { madera con }\end{array}$} \\
\hline HISPANICO & & & & \\
\hline
\end{tabular}




\begin{tabular}{|c|c|c|c|c|}
\hline & & prosperan. & $\begin{array}{l}\text { diversidad } \\
\text { de recintos. }\end{array}$ & $\begin{array}{l}\text { postería } \\
\text { labrada } \\
\text { mano. a }\end{array}$ \\
\hline $\begin{array}{l}\text { Desembarco } \\
3 \text {. }\end{array}$ & \multirow{2}{*}{$\begin{array}{l}\text { Independencia } 1810 \\
\text { y apertura } \\
\text { comercial } \\
\text { pacífico. }\end{array}$} & \multirow{2}{*}{\begin{tabular}{ll|} 
Red & de \\
ciudades & \\
puertos. &
\end{tabular}} & \multirow[b]{2}{*}{$\begin{array}{l}\text { Llegada de } \\
\text { las formas } \\
\text { neoclásicas, } \\
\text { arquitectur } \\
\text { a portuaria } \\
\text { y de la } \\
\text { colonización } \\
\text { alemana. }\end{array}$} & \multirow[b]{2}{*}{$\begin{array}{l}\text { Estructura de } \\
\text { madera con } \\
\text { sistema de } \\
\text { plataforma, } \\
\text { unión } \\
\text { ensamblada y } \\
\text { revestimiento } \\
\text { en tejuela. }\end{array}$} \\
\hline $\begin{array}{l}\text { REPUBLICAN } \\
0\end{array}$ & & & & \\
\hline $\begin{array}{l}\text { Desembarco } \\
4 .\end{array}$ & \multirow{2}{*}{$\begin{array}{l}\text { La industrialización } \\
\text { y los cánones de la } \\
\text { modernidad y el } \\
\text { terremoto de } 1960 .\end{array}$} & \multirow[b]{2}{*}{$\begin{array}{l}\text { La } \\
\text { infraestructur } \\
\text { a vial insular } \\
\text { y la } \\
\text { urbanización } \\
\text { de la } \\
\text { periferia. }\end{array}$} & \multirow[b]{2}{*}{$\begin{array}{l}\text { La } \\
\text { "modernida } \\
\text { d regional" } \\
\text { con } \\
\text { pluralidad } \\
\text { de formas } \\
\text { básicas. }\end{array}$} & \multirow{2}{*}{$\begin{array}{l}\text { Sistemas } \\
\text { constructivos } \\
\text { mixtos de } \\
\text { materiales e } \\
\text { industrializado } \\
\text { s. }\end{array}$} \\
\hline $\begin{array}{l}\text { MODERNIDA } \\
\text { D }\end{array}$ & & & & \\
\hline \multicolumn{5}{|c|}{$\begin{array}{l}\text { Cuadro 1. Cuadro síntesis de grandes eventos chilotes. Se consideran los principales } \\
\text { desembarcos o llegadas de influencias externas que han transformado el territorio y la } \\
\text { cultura insular. } \\
\text { Fuente: Elaboración propia a partir de "Guía de Arquitectura de Chiloé" (Lobos, Berg \& } \\
\text { Rojas, 2006) }\end{array}$} \\
\hline
\end{tabular}

Todos los estudios, desde las diferentes disciplinas, destacan la capacidad de la cultura chilota en asimilar influencias externas apropiándose de ellas (Cárdenas, 1997. Mansilla, 2006), que implican procesos de síntesis, sin embargo, el soporte formal y cultural de estas síntesis no ha sido suficientemente sistematizado.

\section{Origen y desarrollo de los sistemas arquitectónicos de Chiloé.}

Para dar con un análisis que pueda describir la cosmovisión y cultura singular de Chiloé hemos considerado aquellas formas de habitar que constituyen las esenciales configuradoras del modo de vida insular y que se reconocen en tres sistemas que son, de asentamiento, de creencias y el de producción.

En las bases de la interpretación de los fenómenos socio culturales en la arquitectura, pueden advertirse que las investigaciones nos muestran instantáneas de ciertos momentos y algunos hechos que demuestran ciertas variaciones en el tipo (Guarda, 1984. Modiano, 1994. Berg, 2005), ver esquema 1, incluso en los temas más estudiados como las iglesias (Montecinos, 1995) existen muchas interrogantes, donde se muestra el plano base de la Iglesia de Quinchao que origina el tipo que conocemos como el templo tradicional, sin embargo la planimetría es una planta cruciforme muy distinta a la que se construye. Por lo tanto, qué hace que se tomen decisiones tan distintas, como precisas, para fundar un tipo arquitectónico tan particular. 
Adicionalmente, hay interrogantes sobre el cómo en una zona altamente sísmica, con vientos de $100 \mathrm{~km}$ por hora. Y con una cultura constructiva que tendía a lo horizontal se logra materializar estructuras como las torres de la iglesia, que en el caso de Rilán y Castro alcanzan los 35 y $40 \mathrm{mts}$. de altura respectivamente.

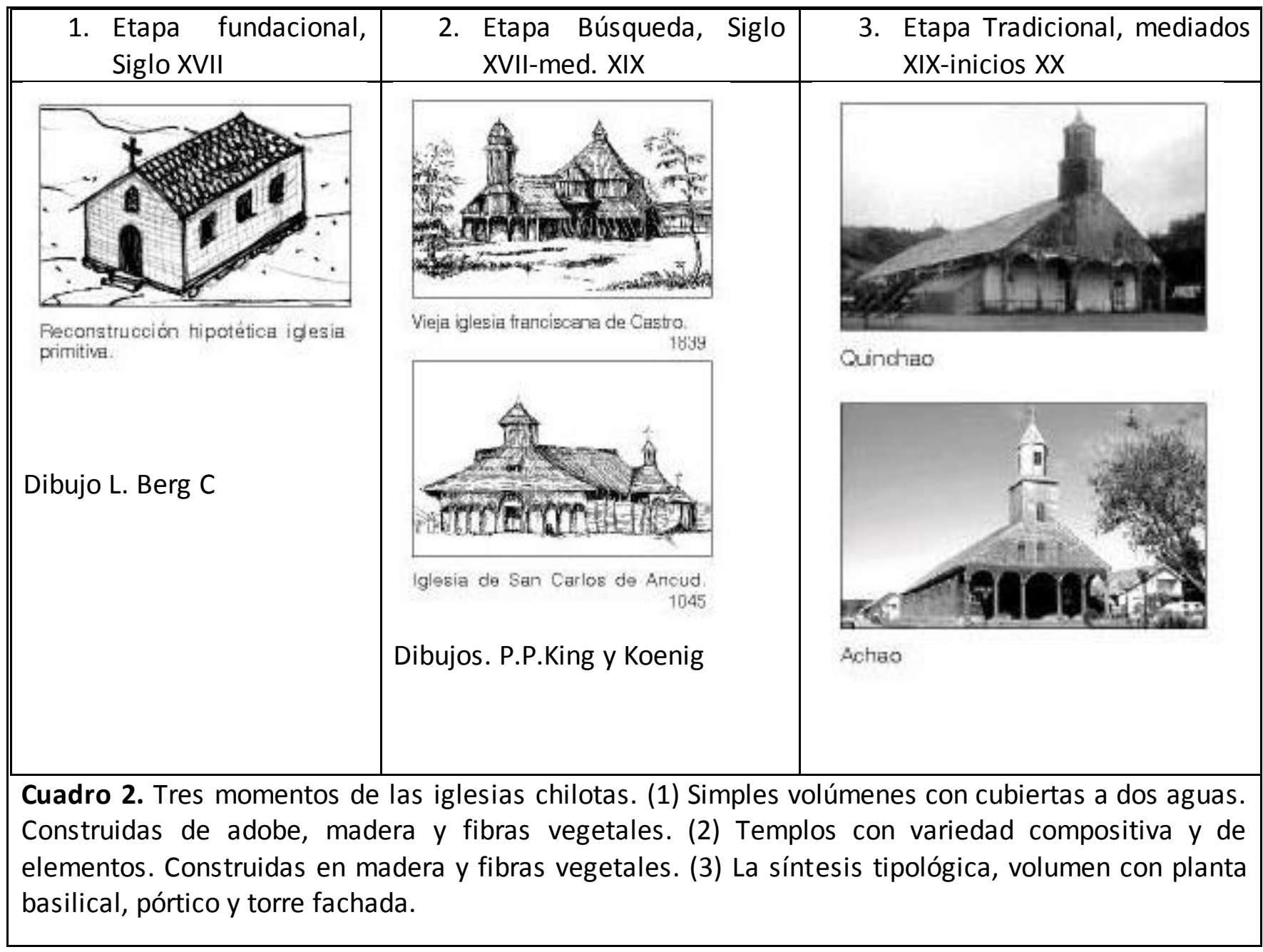

En el Expediente de Postulación de la Iglesias de Chiloé a Patrimonio de la Humanidad (1999) se expresa

mucho tiempo se sostuvo que la arquitectura religiosa de Chiloé fue introducida por los misioneros jesuitas originarios (van der Bergh y otros) de países de Europa Central...., sin embargo investigaciones recientes han determinado que la torre fachada solo alcanza su madurez en el siglo XIX, en circunstancias que la orden Jesuita hubo de dejar el territorio americano en la segunda mitad del siglo XVII ( p.17)

Las investigaciones citadas (Montecinos, 1995), constatan este hecho, pero no hay indagaciones de cómo se llegó a desarrollar la tipología y los diversos modelos. Se sabe que la colonización alemana en la zona continental a partir de 1850 influyó trayendo los cánones de la arquitectura neoclásica (Berg \& Cherubini, 2009), pero igualmente las ilustraciones de P.P. King ya muestran en 1829 elaboraciones de torreones en las iglesias. 
El destacado arquitecto y sacerdote benedictino Gabriel Guarda, Premio Nacional de Historia, en su libro Tradición de la Madera dice,

la influencia que debieron ejercer (los jesuitas) resulta indiscutible, toda vez que, como se dijo, la tipología de las iglesias de madera no existe en España y, en cambio, sí en los países centroeuropeos. Aunque lo ideal hubiese sido encontrar los nexos exactos para confirmar en forma definitiva nuestra hipótesis, una simple mirada a los antecedentes más conocidos nos permite asentar las bases para lo que puede resultar una apasionante investigación. (Guarda, 1995, p.236).

\subsection{Objetivos.}

\subsubsection{Objetivo general.}

Determinar las influencias externas e internas y rastrear el proceso de formalización de las características compositivas, geométricas y constructivas de las iglesias que surgieron a fines del siglo XIX, hoy declaradas Patrimonio de la Humanidad.

\subsubsection{Objetivos específicos.}

a) Indagar las características e influencias socio-culturales en la zona de Chiloé donde surgieron y se difundieron las iglesias, como posibles condicionantes de su construcción.

b) Explicar razonadamente el proceso de formalización arquitectónica de la iglesia de la época en estudio, la constitución de tipo tradicional chilote y sus variantes.

c) Catalogar y definir las características geométricas de las iglesias, en cuanto a sus dimensiones, proporciones y criterios de composición.

d) Establecer las características constructivas de las iglesias, tanto de las tipologías existentes, los materiales empleados y los elementos constructivos que las conforman.

e) Conocer el traspaso des de la idea arquitectónica a la materialidad de la obra.

\subsection{Hipótesis.}

La formalización arquitectónica de las Iglesias es resultado casi exclusivamente de la influencia externa europea y el aporte local radica principalmente en el oficio de la mano de obra y la materialidad en madera.

Se plantea que después de la primera gran introducción de los modelos jesuitas, el proceso de síntesis y de surgimiento de la llamada "escuela chilota" viene dada por la colonización alemana del siglo XIX del sur de Chile y la presencia de franciscanos italianos. Estos ilustran con sus modelos y técnicas a los carpinteros locales, quienes las reproducen en forma más simplificada o sintetizada, una suerte de reinterpretación chilota.

En el traspaso hay una depuración de un tipo "clásico" para decantar en una versión "tradicional" reconocida como la arquitectura religiosa chilota.

La mayor contribución local sería de los carpinteros en la capacidad de representación y oficio técnico para reproducir grandes edificios de madera a partir de la ideación de 
planos "mentales" por sobre planos arquitectónicos y constructivos. Aquí estaría el mejor reconocimiento a lo chilote: el aprender a hacer, de los desconocidos artífices de este patrimonio de la humanidad.

\subsection{Definición de los límites del estudio.}

\subsubsection{Límite temporal.}

Los primeros templos chilotes directamente vinculados con las iglesias tradicionales de Chiloé se remontan al período de las misiones jesuíticas en el archipiélago a partir del siglo XVII con la iglesia de Achao, construida alrededor de 1750 y siendo la única existente en la actualidad, aunque remodelada en variadas ocasiones, demostrando muchas de las características comunes de la denominada escuela chilota que se irá gestando en el tiempo.

A mediados del siglo XIX, con la apertura al Pacifico, el desarrollo económico y portuario de Chiloe y la llegada de la colonización alemana a la zona, se produce una fuerte influencia cultural y arquitectónica desde Europa que impactará en la sociedad insular.

A partir de este período y hasta la primera década del siglo XX surge prácticamente toda la formalización de las Iglesias tradicionales de Chiloé, hoy declaradas Patrimonio de la Humanidad.

Por lo expuesto y dado que el periodo de cristalización del tipo de iglesia chilota se encuentra comprendida en el siglo XIX, se ha considerado conveniente fijar este lapso como marco temporal del estudio.

\subsubsection{Límite geográfico.}

Las Iglesias que son objeto de este estudio se encuentran en el archipiélago de Chiloé, el cual se extiende entre los 41영 y los 4327' S, entre el Canal de Chacao y el Golfo del Corcovado, y entre el meridiano 73 y el 74015' W. Emplazado en el sur de Chile, en la Patagonia insular, siendo un territorio esculpido por las heladas masas glaciares que, al retirarse en el pleistoceno, fue ocupado por aguas oceánicas, dando origen a un "mar interior» que contiene más de cincuenta islas.

La Isla Grande de Chiloé es la segunda en tamaño después de Tierra del Fuego, con más de $2.000 \mathrm{~km} 2$, actúa como un biombo que protege el mar interior de los fuertes vientos y lluvias provenientes del océano Pacífico; también condiciona el flujo y reflujo de las aguas que van y vienen desde el mar exterior al interior, entregándole al lugar un ritmo propio, el de las mareas que regula la vida de los habitantes.

Esta área por sus condiciones peculiares geográficas ha tenido desde época precolombina características étnicas culturales que la han diferenciado del resto de las poblaciones emplazadas en la zona austral de Chile. Tales diferencias con la Ilegada española y sucesivas inmigraciones han generado cambios sociales importantes, no obstante Chiloé ha mantenido una diferenciación cultural con el resto del país. 
Según esto, más que un territorio administrativo, Chiloé es un territorio cultural particular y en tal sentido dar cuenta de su diversidad de secuencias de divisiones políticas, no cobra sentido.

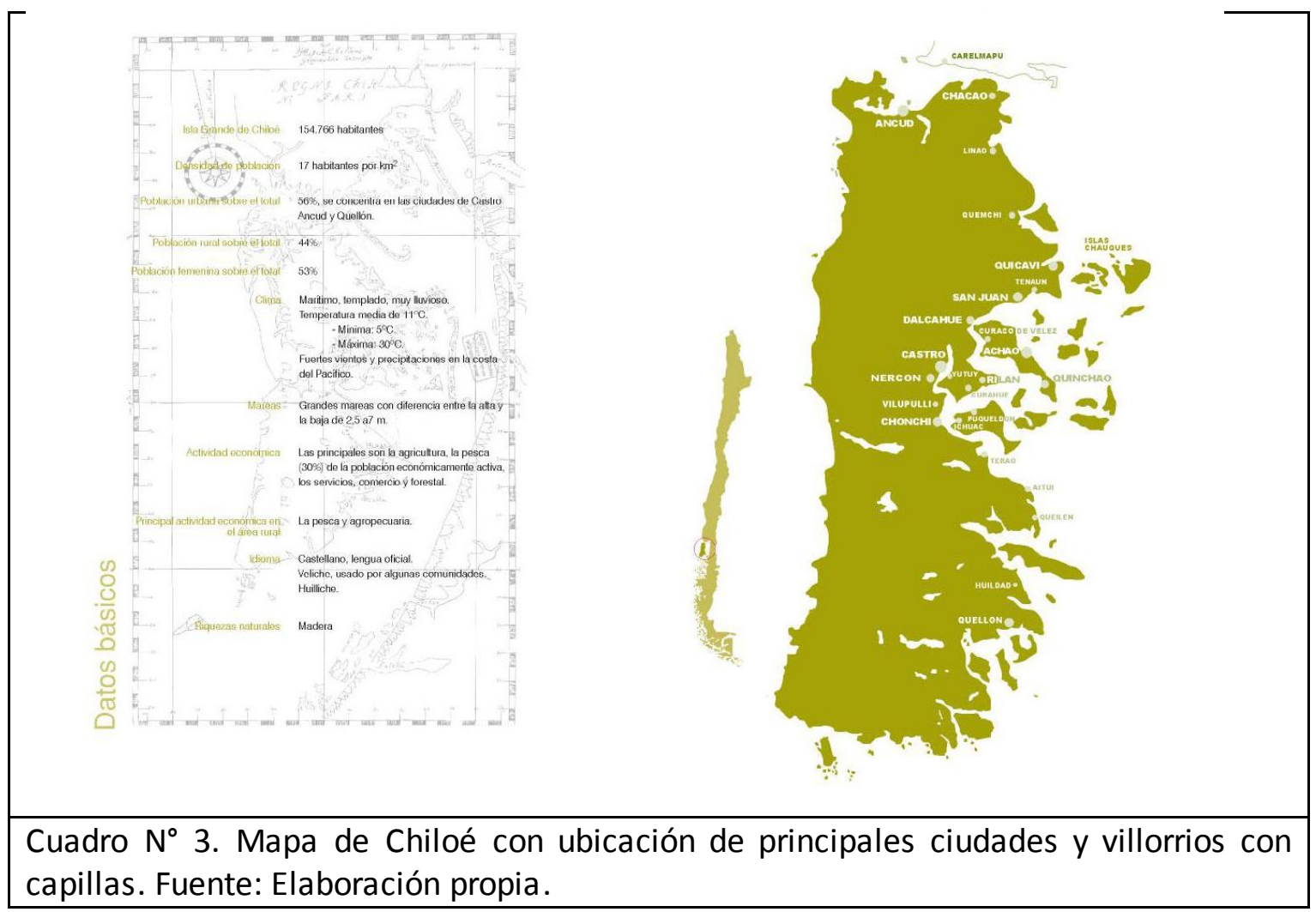

Las capillas tradicionales de Chiloé se estiman en alrededor de 80, la mayoría de ellas realizadas durante el siglo XX. Como se ha señalado, el estudio se centra en las realizadas en el siglo XIX y primer decenio del siglo pasado, que son las principales y donde se encuentran casi la totalidad de aquellas distinguidas Patrimonio de la Humanidad (Cuadro $\left.n^{\circ} 4\right)$.

\begin{tabular}{|c|c|c|c|}
\hline Cuadro $n^{\circ} 4$ & \multicolumn{3}{|c|}{ Elenco de Capillas } \\
\hline CAPILLA & COMUNA & DATA APROX & CASO DE ESTUDIO \\
\hline Achao & Quinchao & 1750 & SI \\
\hline Quinchao & Quinchao & 1860 & $\mathrm{SI}$ \\
\hline Castro & Castro & $1857-1902$ & $\begin{array}{l}\text { SI, se estudia la } \\
\text { antigua de } 1807 \\
\text { (incendiada) }\end{array}$ \\
\hline Rilán & Castro & 1908- 2013 & $\begin{array}{l}\text { SI. Se estudia la } \\
\text { antigua de } 1908 \\
\text { (desarmada el 2013) }\end{array}$ \\
\hline Nercón & Castro & 1879 & SI \\
\hline
\end{tabular}




\begin{tabular}{|l|l|l|l|}
\hline Chelín & Castro & 1890 & \\
\hline Aldachildo & Puqueldón & 1900 & \\
\hline Ichuac & Puqueldón & $1930 ?$ & \\
\hline Detif & Puqueldón &.. & \\
\hline Vilupulli & Chonchi & 1920 & \\
\hline Chonchi & Chonchi & 1895 & SI \\
\hline Tenaún & Quemchi & 1875 & SI \\
\hline Colo & Quemchi & $1880 ?$ & \\
\hline San Juan & Dalcahue & 1910 & Si \\
\hline Dalcahue & Dalcahue & 1893 & SI. Se estudia Ia \\
\hline Caguach & Dalcahue & -- & antigua \\
\hline $\begin{array}{l}\text { Curaco de Vélez (capilla no } \\
\text { declarada Patrimonio de la } \\
\text { humanidad) }\end{array}$ & Quinchao & 1901 & (incendiada) \\
\hline
\end{tabular}

\subsection{Metodología.}

\subsubsection{Campos de análisis e interpretación.}

- Significar la arquitectura como un proceso de creación colectiva de desarrollo cultural y de adaptación al medio, a través del tiempo, en cuanto a formas de habitar que surgen desde las experiencias y conocimientos de los grupos humanos. Así, la arquitectura está compuesta por sistemas simples en su origen histórico, que se complejizan por fenómenos graduales de invención, donde es tan importante lo que permanece, como lo que cambia. De esta manera, se puede sostener un carácter orgánico de la arquitectura tradicional, que muta según las experiencias de sus habitantes y constructores, generando nuevas síntesis, a partir de ciertos procesos de ensayo y error.

- Comprender cuáles son aquellos aspectos de la arquitectura, entendida como sistemas de relaciones internas y externas, que van configurando una condición de estructura abierta, que cambia, y de estructura cerrada, que permanece. La realización de este estudio, permitirá ilustrar, visibilizar y valorizar esta historia de la arquitectura, como proceso de construcción, transformación y adaptación a un territorio con una cultura tradicional, como es el caso de Chiloé, donde operarían las dinámicas identitarias de la arquitectura, sobre el cual ya se tiene un nivel de conocimiento desde diversas disciplinas, de su reconocida cultura de la madera, y que permitiría llegar a un nivel de interpretación superior e integrador de los sistemas del habitar en general y en particular el de asentamientos, de creencias y de producción. Se podría aventurar que en el desarrollo de la tesis se concentrará en uno de estos como eje fundamental de descripción.

El propósito de la investigación es, por tanto, describir e interpretar el proceso histórico de adaptación cultural de las formas arquitectónicas en el Archipiélago de 
Chiloé, a partir del conocimiento/ reconocimiento de estas formas, para intervenir pertinentemente en la creación de los sistemas de formulación de la arquitectura.

\subsubsection{Fuentes de la investigación.}

Se usarán las modalidades habituales de uso de fuentes directas e indirectas para cada una de las tres partes fundamentales de la investigación: la fundamentación teórica, los procesos históricos y el proceso de realización de las Capillas.

\section{Estudio de textos.}

Se hizo una búsqueda especial de fuentes documentales directas y de cada época tanto en materias teóricas, históricas y arquitectónicas de manera de disponer los textos originales (descripciones, crónicas, iconografía). Paralelamente se registra fuentes documentales posteriores y actuales que tratan tales materias de interés en forma general o específica. Esta operación permite contrastar la información histórica y reciente de modo de verificar y levantar una base de datos más confiable sobre la cual analizar e interpretar mejor los contextos y contactos culturales que inciden en proceso de realización de las capillas, para alcanzar un nivel más objetivo.

\section{Toma de datos.}

Corresponde principalmente al registro de las capillas en particular. Esta labor es fundamental para comprender las transformaciones formales de la arquitectura.

Se ha enfocado en los levantamientos existentes actuales homologados en una representación grafica común respecto a las planimetrías (plantas, elevaciones y cortes), a partir de fuentes existentes y debidamente realizadas (levantamientos críticos y otros) para disponer una imagen actual de ellos.

La otra vertiente y principal es la recolección de todas las fuentes iconográficas (planos, dibujos, fotos, grabados, etc) posibles de las capillas de su evolución y especialmente del siglo VIII y XIX. Igualmente la revisión de documentos escritos que describan tales edificios en diversas fuentes institucionales como Obispado, universidades, museos y Archivo Memoria Chilena, como de libros históricos y diarios.

\section{Análisis de la documentación y datos.}

El análisis se realiza a partir de las secuencias históricas y arquitectónicas de las diferentes capillas chilotas en el tiempo y de las cuales se han podido registrar iconográficamente sus transformaciones. De manera de registrar períodos y dataciones generales o específicas de composiciones tipológicas, modelos, sistemas constructivos, medidas, elementos comunes y divergentes.

Se considera este análisis dentro del archipiélago y su contexto cultural territorial de influencia.

Este análisis de transformaciones (permanencias y cambios) permite ilustrar desde el lenguaje de la arquitectura, identificando el proceso que va decantando y consolidando la tipología estilística "chilota".

\subsection{Alcances y Limitaciones.}

La investigación está sujeta a las fuentes históricas y particularmente iconográficas que se encuentren sobre las capillas de Chiloé, que son relativamente escasas, sin embargo se considera que como alcanzan en un momento un tipo arquitectónico muy 
especifico, los casos escogidos serán claves. La revisión acuciosa de estos casos escogidos permitirá avanzar hacia los objetivos planteados y dar cuenta de la hipótesis de investigación.

\subsection{Resultados esperados.}

- Distinguir con mayor precisión los estadios culturales en la evolución y consolidación de las capillas, las influencias principales, los protagonistas de las obras y las formas de producción de estas.

-Disponer de un conocimiento más preciso de los patrones de composición arquitectónica/constructivo, los antecedentes histórico culturales de la gesta y aportar una mayor base para la conservación patrimonial de estos inmuebles catalogados Patrimonio de la Humanidad.

\subsection{Marco conceptual.}

\subsubsection{Arquitectura Cultural.}

La arquitectura como expresión de cultura, ha venido siendo uno de los campos explicativos de la disciplina, que permite un acercamiento interesante en Chiloé, desde los trabajo de Rapoport (1969) donde trata el tema del por qué de las morfologías de las viviendas en el mundo, entre los cuales la posibilidad de escoger formas libremente ha sido el más importante y que estas obedecen a factores más allá de los climáticos y ambientales, esta manera de someter la cultura como un aspecto central de la arquitectura se amplía y profundiza con Norberg-Schulz (1983) que la entiende como una historia de formas existenciales en que

... las necesidades fundamentales del hombre es la de experimentar significados en el ambiente que lo circunda. Cuando esto se verifica, el espacio se convierte en un conjunto de lugares. Entonces el término lugar determina algo conocido y concreto. Tal descripción de lugares y de sistemas posee una base fenomenológica convencional de obras arquitectónicas en términos geométricos e iconográficos (Norberg- Schulz, 1983, p.223).

Por lo tanto según el mismo autor

La Historia de la arquitectura describe el desarrollo y el uso de los sistemas simbólicos arquitectónicos $y$, por consiguiente, forma parte de la historia de la cultura. En términos generales puede decirse que la historia de la cultura es la historia de las formas significativas simbólicas y, por lo tanto, es la historia de las posibilidades existenciales (Norberg- Schulz, 1983, p.228)

Esta manera de entender la arquitectura como hecho simbólico, de algún modo nos acerca a interpretar las cosmovisiones de los diferentes pueblos a través del tiempo, según lo cual las formas expresan y se materializan en claves espaciales, los profundos sentimientos de las sociedades de sus maneras de estar en el mundo, a palabras de Coppola (1999) "La arquitectura es el arte de habitar la vida y su finalidad es la de dar forma y significado a la habitación humana; es un arte capaz de representar, a través de la organización del espacio construido". (Coppola, 1999, p.87). 
Todos los estudios, desde las diferentes disciplinas, destacan la capacidad de la cultura chilota en asimilar influencias externas a una adaptación propia y singular (Cárdenas, 1997. Mansilla, 2006), que implican procesos de síntesis, sin embargo, el soporte de estas síntesis no ha sido suficientemente sistematizado.

\subsubsection{Tipo y modelo.}

El avance del discurso tipológico contemporáneo en arquitectura, permite acercarnos a las formas como invariantes y variantes de las expresiones culturales, Chuecagoitía (1981), identifica aquellos que son parte de la arquitectura española y numerosos autores han identificado aquellos invariantes que se han trasladado a la América hispánica, en Gutiérrez (1992). Martí (1993), define que el tipo arquitectónico es un concepto que describe una estructura formal, y agrega que mientras la historia muestra los procesos de cambio, el análisis tipológico atiende a lo que, en esos procesos, permanece idéntico. Martí establece dos arquetipos primordiales que son el espacio centralizado y el espacio longitudinal, si esto fuera así podríamos aventurar que nuestra herencia indígena, para los sistemas espaciales de creencias se basa en el arquetipo centralizado, mientras que nuestra herencia española en el arquetipo longitudinal. No obstante lo anterior, la presente investigación apunta a reconocer tipos o invariantes en los sistemas habitables, pero sobre todo las variantes que procesa la historia cultural chilota a partir de los tipos esenciales o matrices espaciales.

\subsubsection{Arquitectura tradicional de Chiloé.}

Se entiende por la arquitectura tradicional chilota como la obra mayor de una cultura, definida como mestiza. Por tanto es el resultado de las diversas influencias externas incorporadas a lo largo de la historia y de sus permanentes reinterpretaciones y apropiaciones locales, las que se sintetizan en una arquitectura de gran simplicidad formal, flexible y cambiante. Dando cuenta de una diversidad que mantiene una unidad, principalmente por ser una arquitectura preponderantemente de madera, de un "tejido" de baja altura, de elementos aislados y continuos constituidos por tipologías elementales, íntimamente ligadas y vinculadas al espacio geográfico del archipiélago (Berg, Muñoz \& Rojas, 2008) ${ }^{2}$

\subsubsection{Tipologías y modelos religiosos tradicionales de madera chilotes.}

Como ya se ha señalado, esta tipología de capilla se compone de dos partes:

- Un volumen horizontal con cubierta a dos aguas de planta rectangular y basilical, para dar cabida espacial a la asamblea y en el extremo el altar, sacristía y contrasacristía.

- Un volumen vertical que corresponde a la torre fachada. Compuesto por el pórtico, frontón o hastial y torre telescópica en base a tambores que corresponden al acceso, coro y elemento simbólico para las campanas, respectivamente.

\footnotetext{
${ }^{2}$ Documento inédito.
} 
Sobre esta tipología resultan una variedad de modelos que varían según tamaños, proporciones, geometría y formas, que son resultantes de las condiciones del lugar y comunidad en que se emplazan y le dan identidad única a este.

Toda la fábrica y ornamentación está ejecutada completamente en madera, los elementos de la estructura están conectados en las uniones por sistemas de ensambles y de tarugos. Normalmente la cubierta está ejecutada con tejuela de alerce y el edificio va fundado sobre basas de piedra. (Figura 1 y 2 )

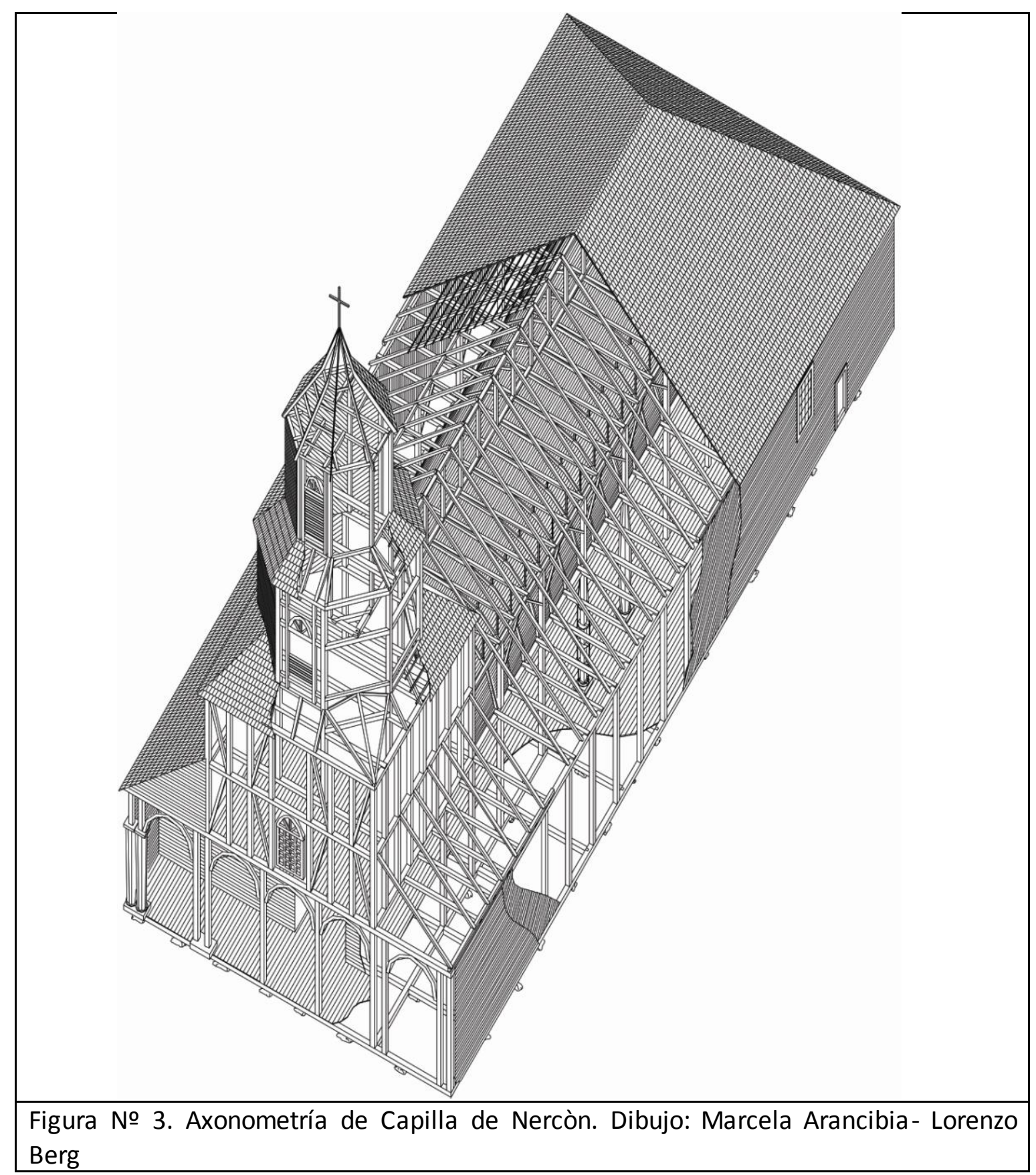




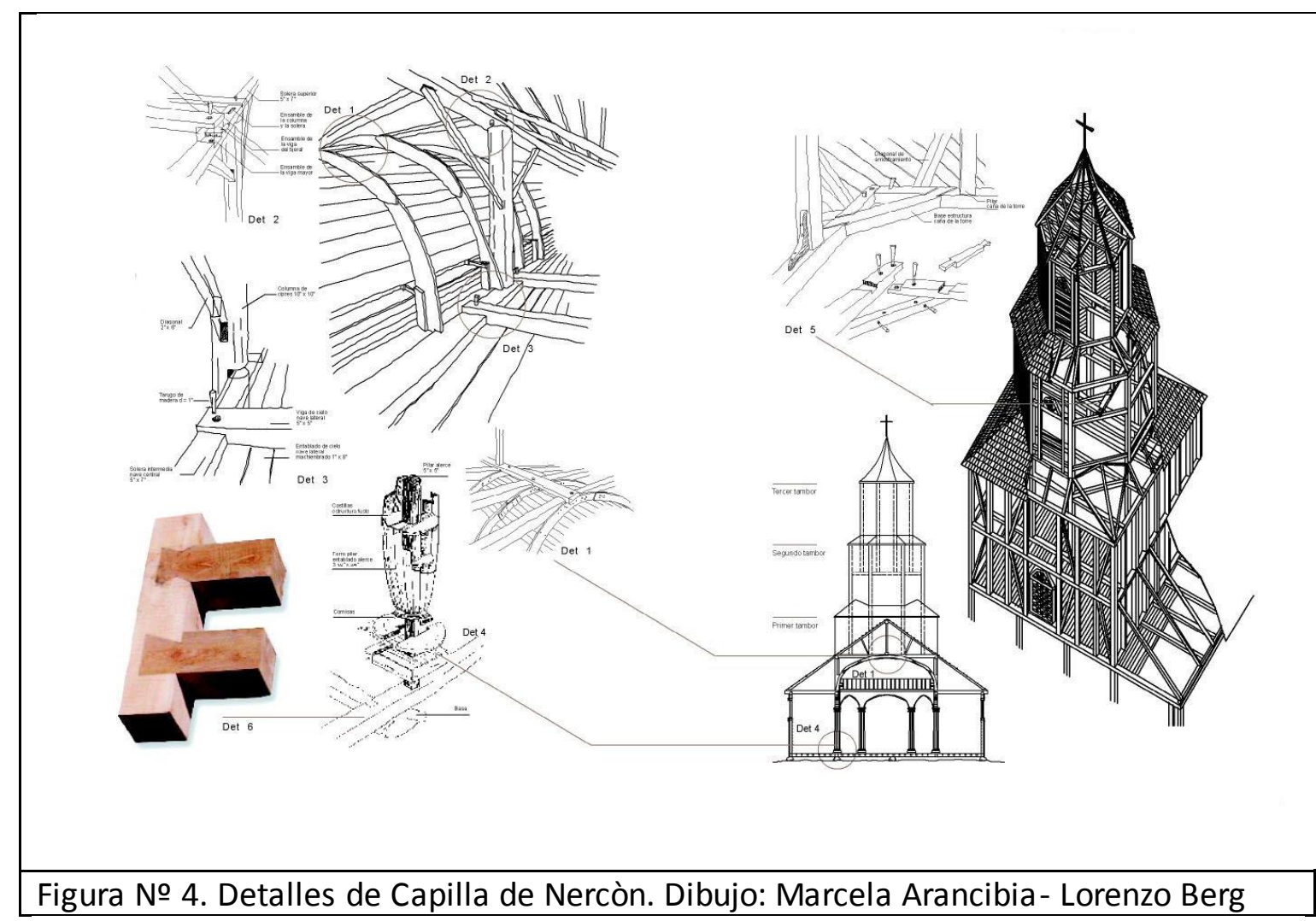




\section{ANEXOS}

ANEXO 1. ELENCO DE CAPILLAS CHILOTAS TRADICIONALES. Fuente: Iglesias misionales de Chiloé, Montecinos, Hernán, Ignacio Salinas y Patricio Basáez, Departamento de Historia y Teoría de la Arquitectura, Universidad de Chile, Santiago, 1995.

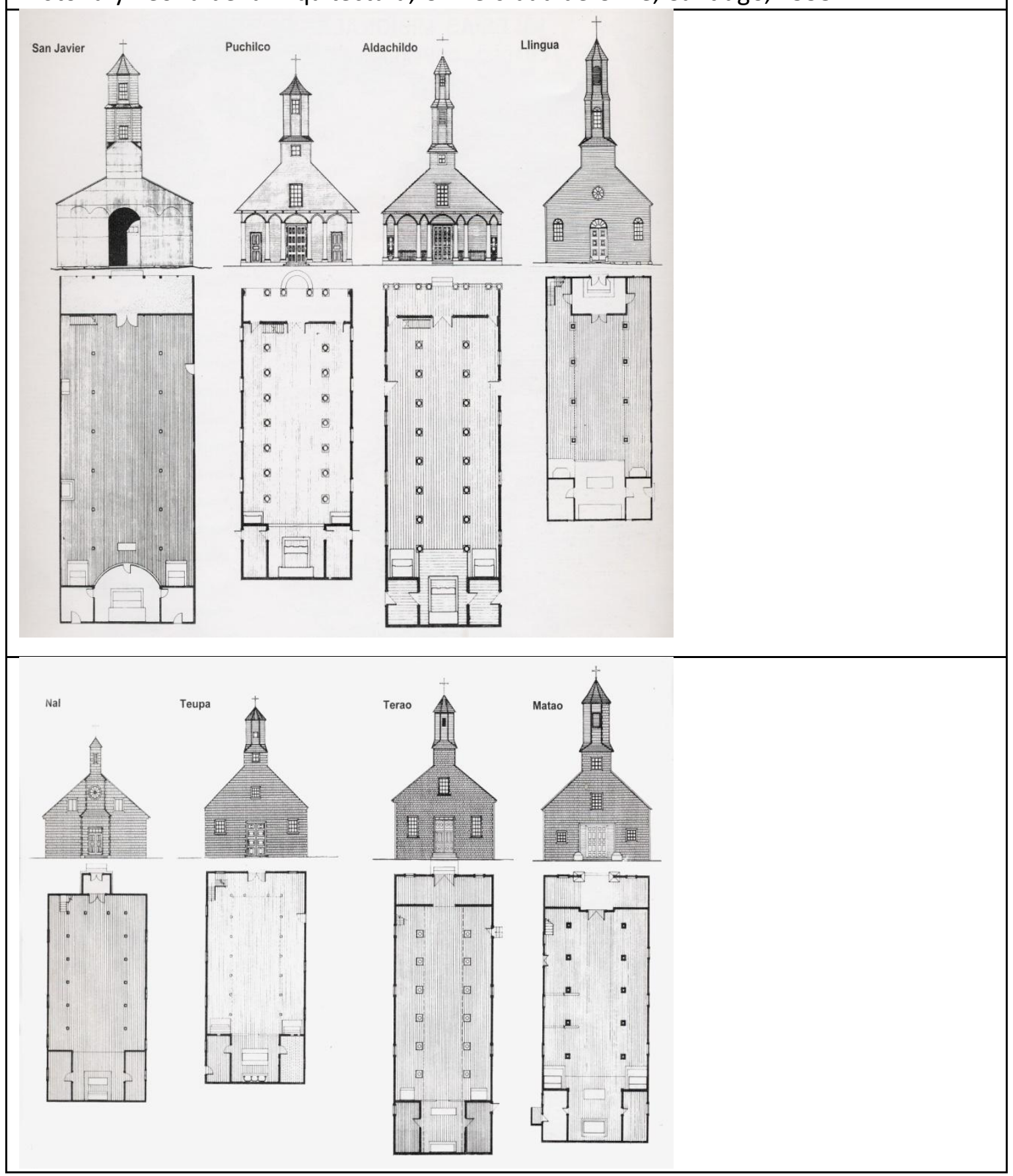




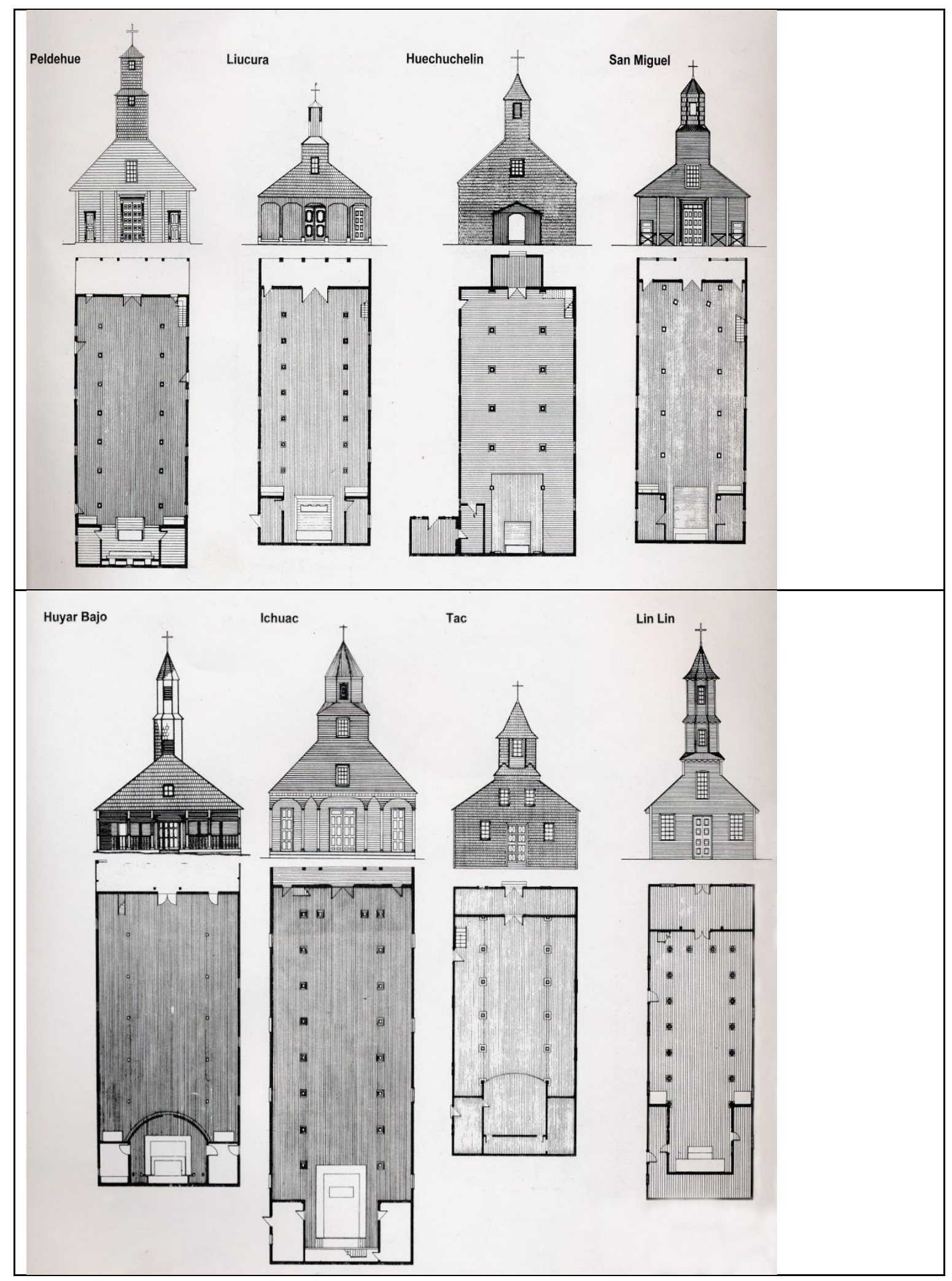




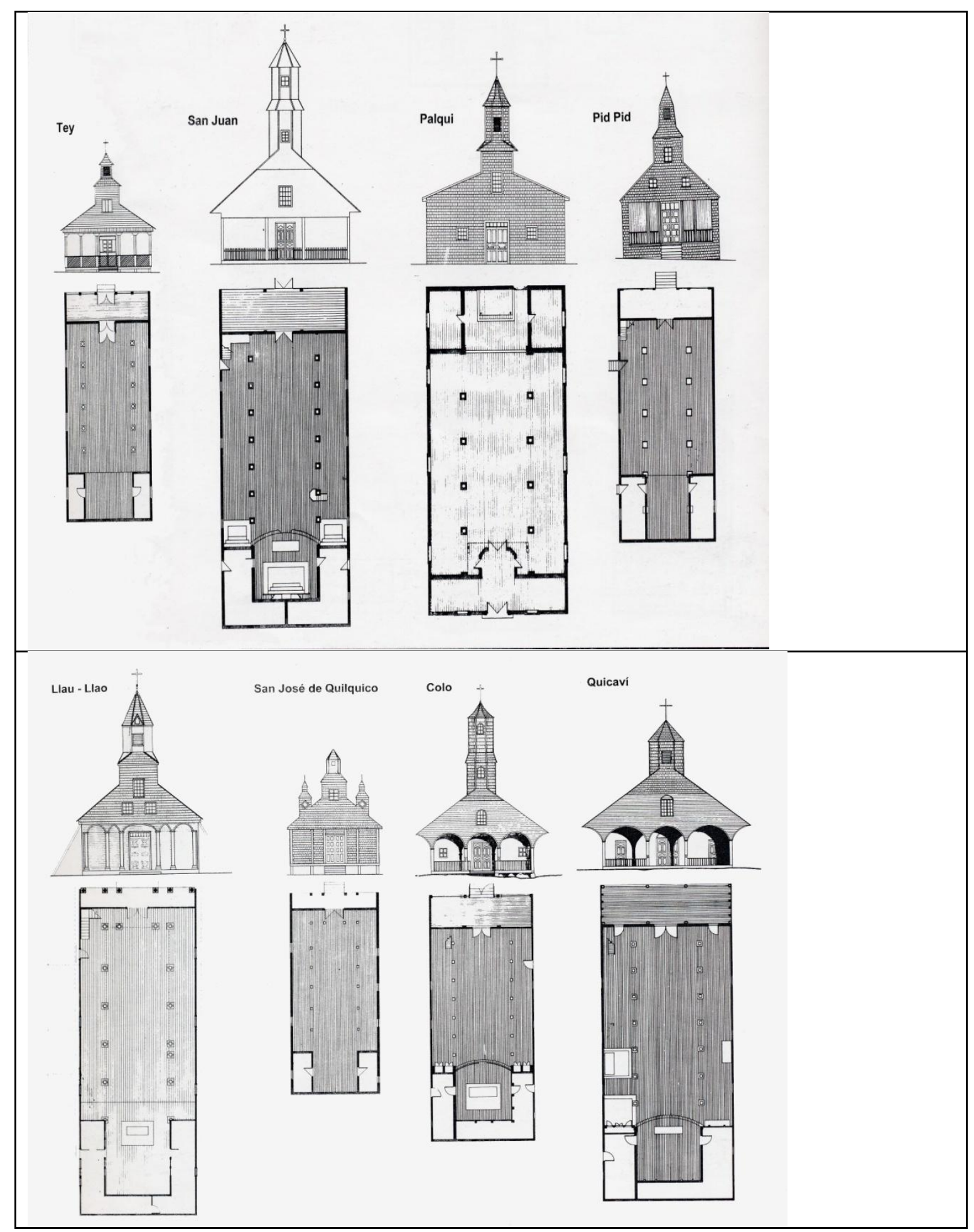




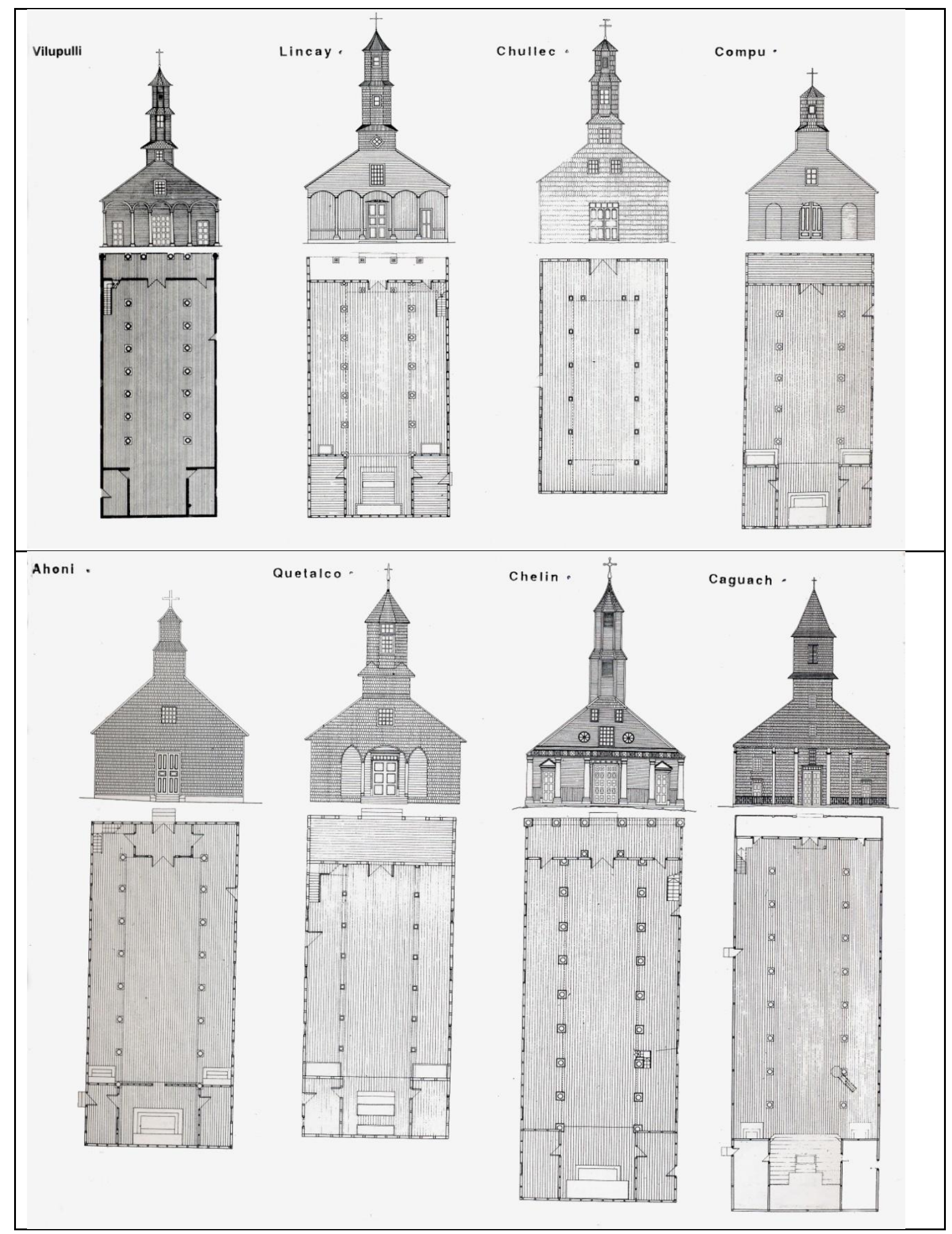




\section{CAPITULO 2. Avances previos y estado del arte en la arquitectura religiosa de madera en Chiloé.}

En este capítulo se propone centrar un análisis resumido en aquellos aspectos que resultan significativos para los objetivos de la tesis, revisando las investigaciones y documentaciones actualizadas y relevantes que han señalado un derrotero en la historiografía de la arquitectura religiosa insular. Enfocándose en aquellos que entregan valiosos resultados pero también dejan enigmas y surgen nuevas preguntas por resolver, es justamente en este contexto que interesa realizar una reflexión y dar con una discusión que permita orientar hacia mayores y mejores resultados investigativos.

Básicamente los principales temas de análisis y discusión son: La imagen de las capillas tradicionales desde la actualidad, la cultura de la madera, el estado de la arquitectura y la carpintería y, por último, contactos culturales.

\subsection{Una revisión actual de las capillas: Las imágenes del siglo XIX, XX y XXI.}

Se ha planteado que las investigaciones sobre la historia cultural y arquitectónica es vasta y elaborada por distintos autores que han hecho una labor significativa para el reconocimiento internacional del archipiélago y sobre todo para crear una fuerte apropiación de identidad entre los propios isleños, es decir se ha valorizado un patrimonio local. Sin embargo, en el caso que nos interesa de las iglesias chilotas, desde una mirada histórica y arquitectónica, los análisis se han concentrado en la imagen actual de estos edificios como modelos que se han mantenido casi intactos en el tiempo.

Quizás la falta de investigaciones mas acuciosas en las dinámicas de transformación de estos edificios ha causado ciertos mitos, leyendas y verdades a medias, que han llevado a conclusiones inexactas, las cuales han sostenido diversos discursos académicos y populares manteniendo por bastantes tiempo un imaginario colectivo difícil de cambiar, respecto a confundir la imagen de las capillas actuales o de las existentes en el siglo XX como coincidentes con la misma capilla en el siglo XIX.

Para ejemplificar esto un caso señero es la situación de la capilla de Achao, que ha sido consignada como la más antigua de la isla datándose del año 1750 y ejecutada por los jesuitas, esta caracterización ha guiado a gran parte de la historiografía de la isla a convertirla en una leyenda y una definición absoluta: La Iglesia de Achao es una iglesia jesuita realizada en el siglo XVIII. Esto, en parte es verdad, en lo que se refiere a las naves interiores, sin embargo se ha constatado en los últimos años (Montecinos, 1995) que el conjunto del pórtico y la torre es absolutamente posterior en un siglo y realizado con una composición y sistema constructivo distinto a su precedente jesuita. Es decir el cuerpo del pórtico y la fachada reemplazó a uno anterior y se sobrepuso a las naves. El uso de un material como la madera homogeneiza lo suficiente a través de la pátina y el tiempo, como para generar una imagen de un edificio unitario física y espacialmente, aunque temporalmente no lo sea. Es esta imagen unitaria de tremenda pregnancia formal que ha llevado a autores macizos como Modiano (1994) a 
considerarlo como un edificio jesuita y a relacionarlo como un modelo muy vinculado a la arquitectura de madera de centro europa en el siglo XVIII, de donde venían muchos religiosos a misionar en Chiloé. Esto en gran parte es efectivo, sin embargo no hay antecedentes de cuerpo fachada con torre central elevada en la iglesia de Achao en el siglo XVIII. Si bien las similitudes formales entre esta capilla de Chiloé y los ejemplos europeos de Modiano son evidentes, estos no son concluyentes.

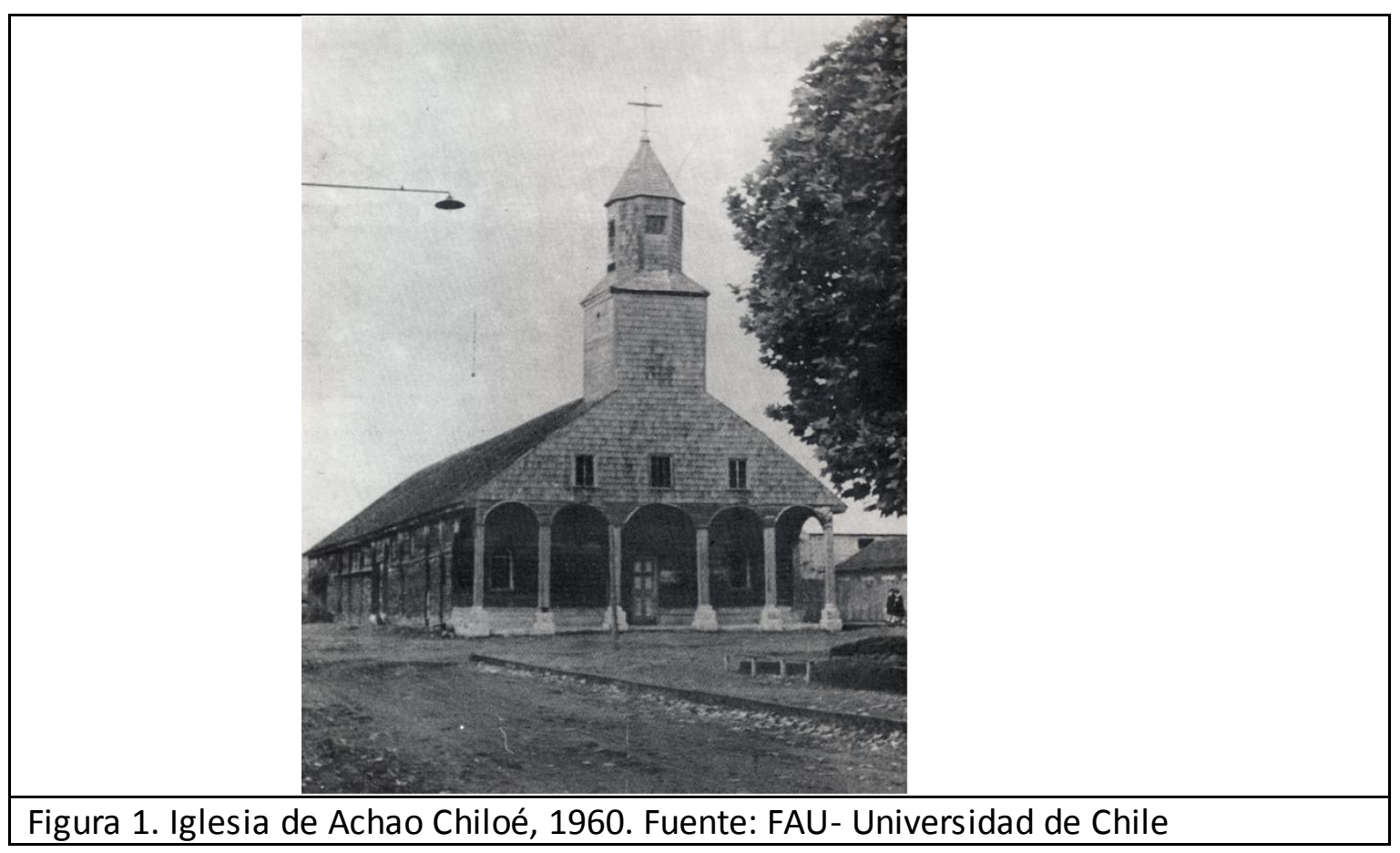

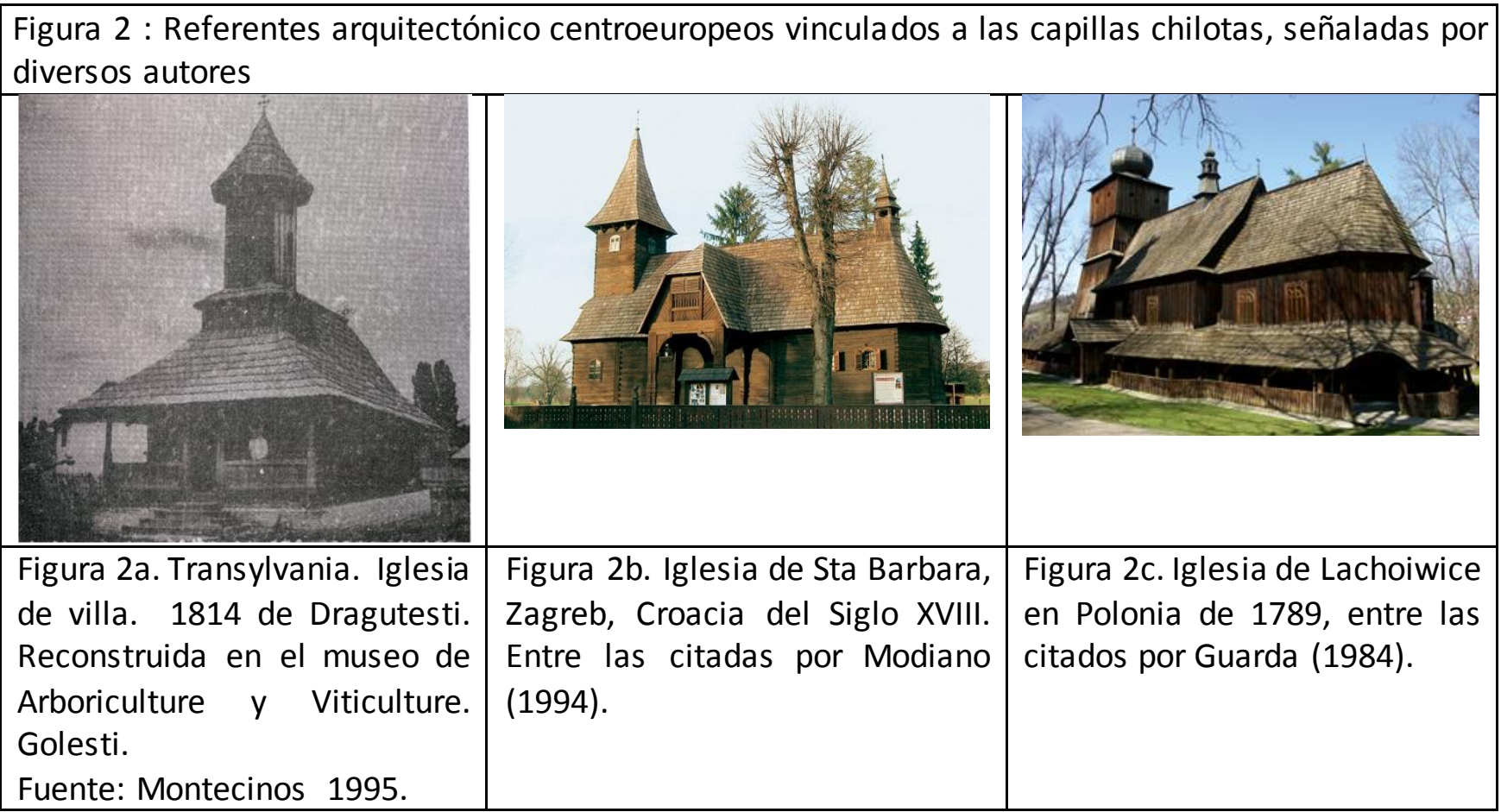

En la misma línea pero con más prolijidad trata este tema de las influencias el destacado Padre Guarda, quien hace una delicada y exhaustiva relación con los 
misioneros jesuitas bávaros, considerando nombres, procedencias y sus cargos durante los siglos XVII y XVIII en Chiloé hasta su expulsión en 1767 (Guarda, 1984 ). A su vez aporta con un minucioso y detallado elenco de todas las capillas del archipiélago, sistematizado a partir de las fuentes parroquiales en su mayoría, donde se consignan las fechas fundacionales y algunos otros datos históricos que permiten disponer del panorama cronológico de ellas. En algunos casos como, Dalcahue y Chonchi, hay estimaciones de data de las capillas que son reportadas, pero que estudios posteriores han desestimado en función de archivos documentales mas fidedignos y evidencias de levantamientos críticos arquitectónico-arqueológico in situ (Montecinos, 1995. Berg, 2005). Esto se consigna por la relevancia que tiene en los procesos de composición de los modelos y tipos de templos chilotes.

Las primeras y únicas investigaciones que se detienen y tratan los fenómenos de transformaciones de las Iglesias son los realizados por algunos especialistas durante los años 90, en este aspecto resalta el mayor avance realizado a través del Proyecto Fondecyt (Fondo Nacional de Desarrollo Científico y Tecnológico) desarrollada durante los años 1990 y 1991, titulada "Las Iglesias Misionales de Chiloé". Dicha investigación guiada por el arquitecto y profesor Hernán Montecinos, culmina con la publicación del libro "Iglesias Misionales de Chiloé: documentos históricos" cuyo objetivo es que "constituya un avance al estudio de las iglesias insulares que suma a los estudios de Montandón (1964) y Pereira Salas (1965) sobre la Iglesia de Santa María de Achao y del P. Gabriel Guarda (1984) referido al conjunto de estas iglesias" (Montecinos, 1995, p.10). En el cual como ya se ha mencionado logra dar con el momento de la aparición del tipo, a mediados del siglo XIX, pero sin profundizar de por qué dicho resultado formal. El avance es notable y es significativo el aporte en publicar los registros del Obispado de Ancud que contienen archivos parroquiales de capillas que son Quinchao, Achao, Tenaún, Curaco de Vélez, Dalcahue, Chonchi, Nercón y Rilan ${ }^{3}$. Estos archivos documentan fechas de obras y una escasa planimetría de dichas parroquias, pero todas de gran valor históricos e iconográficos, en estos últimos las imágenes son las siguientes (ver figuras):

Quinchao: Plano de planta y elevación de 1863, de autor desconocido. El estudio señala que a la fecha sería el primer rastro de la constitución del tipo. Hay que consignar que la obra realizada no es tal cual al plano. Adicionalmente está el proyecto del altar mayor, Figura 3.

\footnotetext{
${ }^{3}$ Estos son los únicos archivos conocidos y publicados a la fecha de esta tesis y que corresponden a la cosntruccion de capillas chilotas durante el sigloXIX. Dichos archivos están transcritos en el libro "Iglesias Misionales de Chiloé: documentos históricos" (Montecinos, 1995) y son 45 pags.
} 

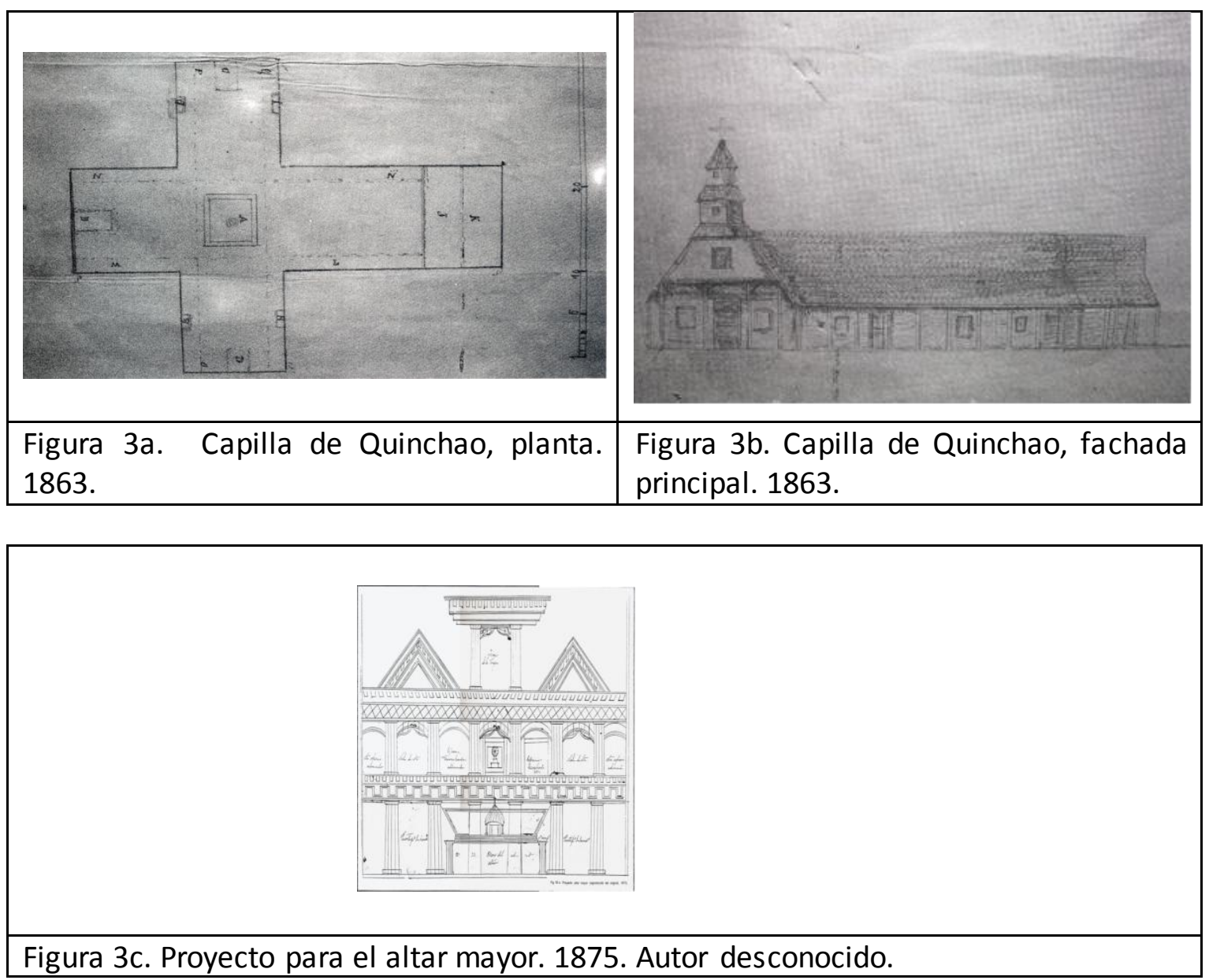

Achao: Plano de planta de la plaza del pueblo con la elevación lateral de la iglesia en forma esquemática del año 1898. Figura 4.

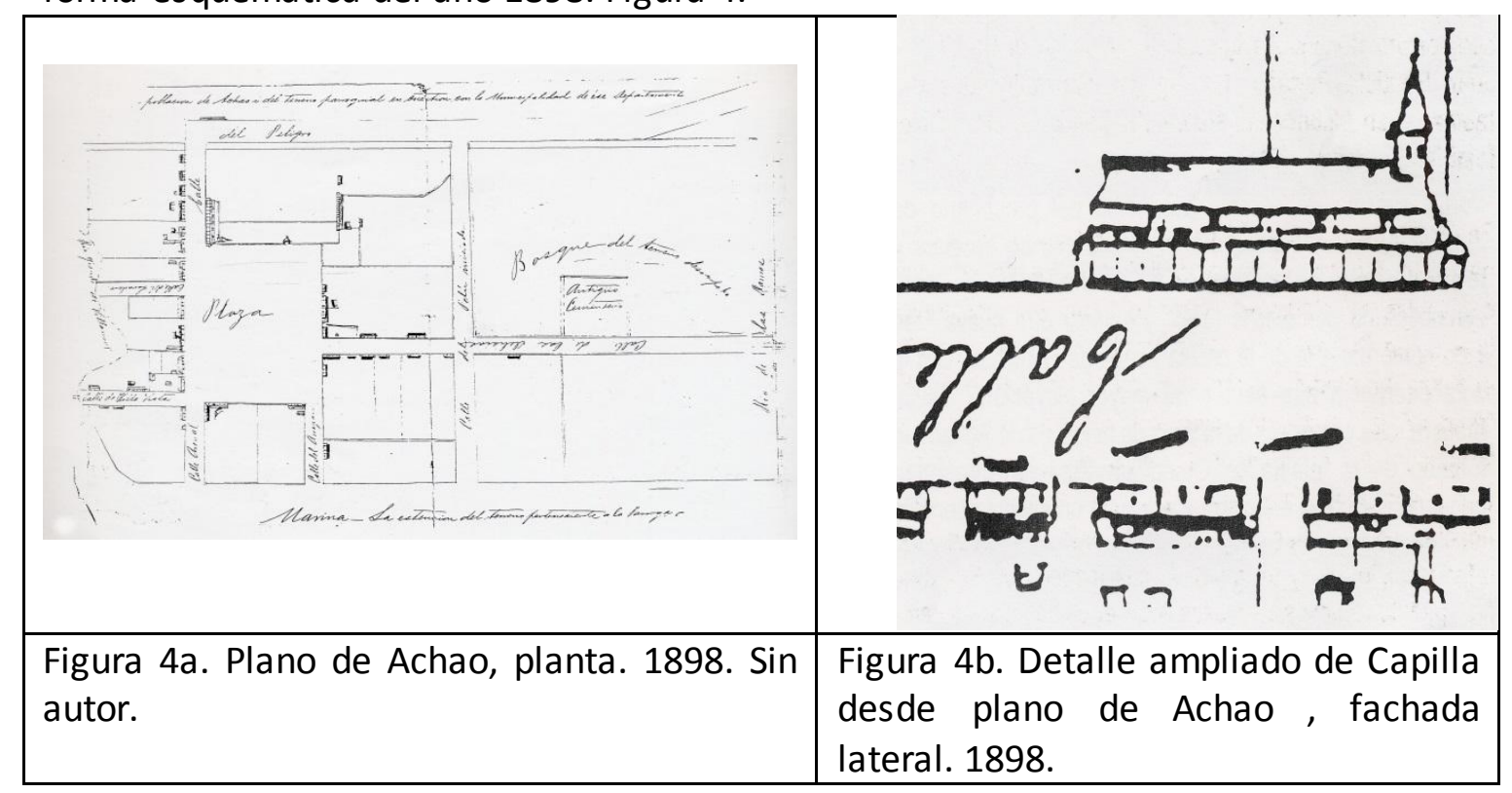


Tenaún: Plano esquemático del pueblo con una elevación también esquemática de la capilla existente, del año 1875. Figura 5.

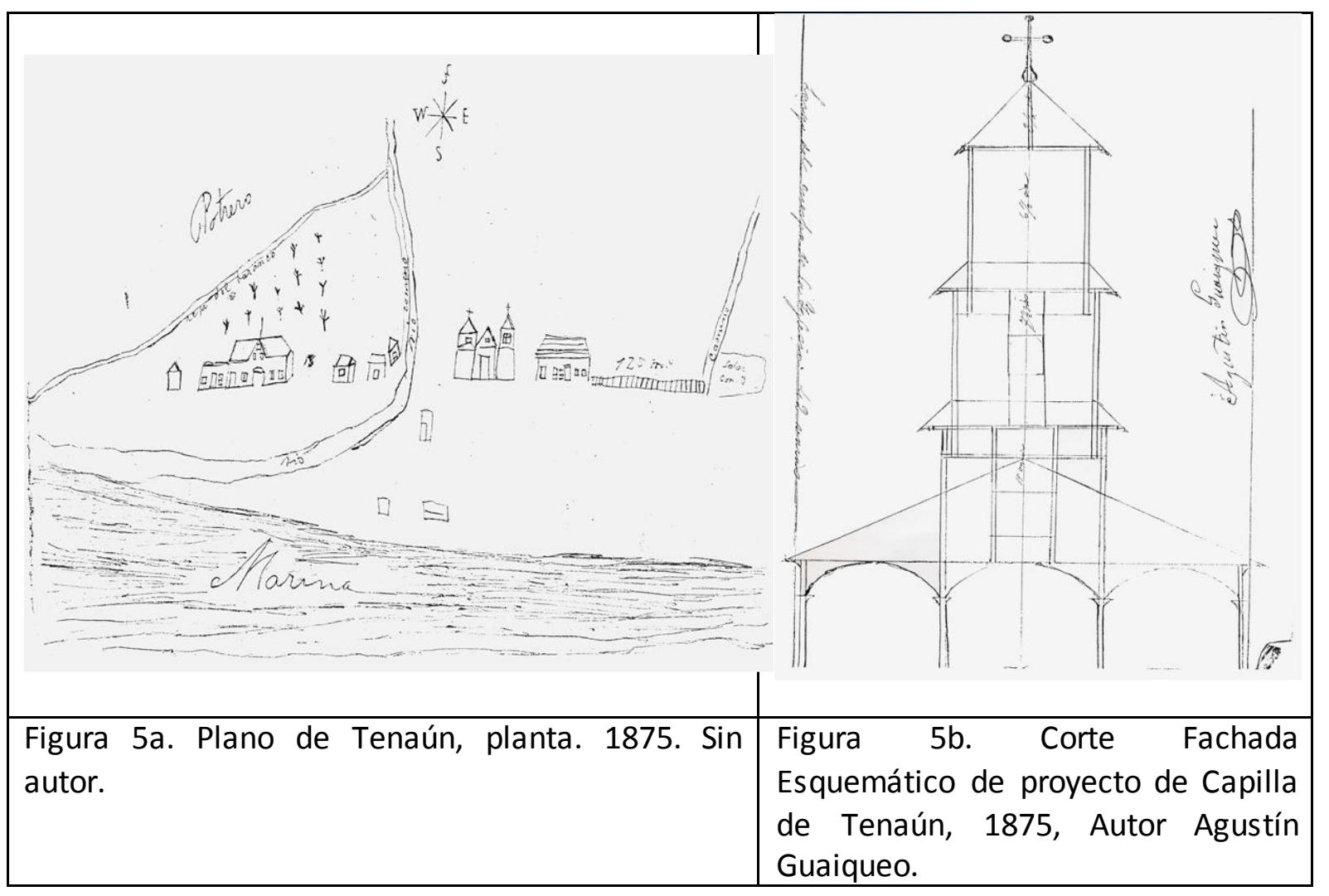

Curaco de Vélez: Planos de planta, elevación principal y posterior (culata) y dos cortes, pasados por la nave y torres respectivamente. Todos son planos estructurales de la capilla del año 1901 y están firmados por Padre Francisco Bohle S. Esta capilla se incendia en 1971. Figura 6.

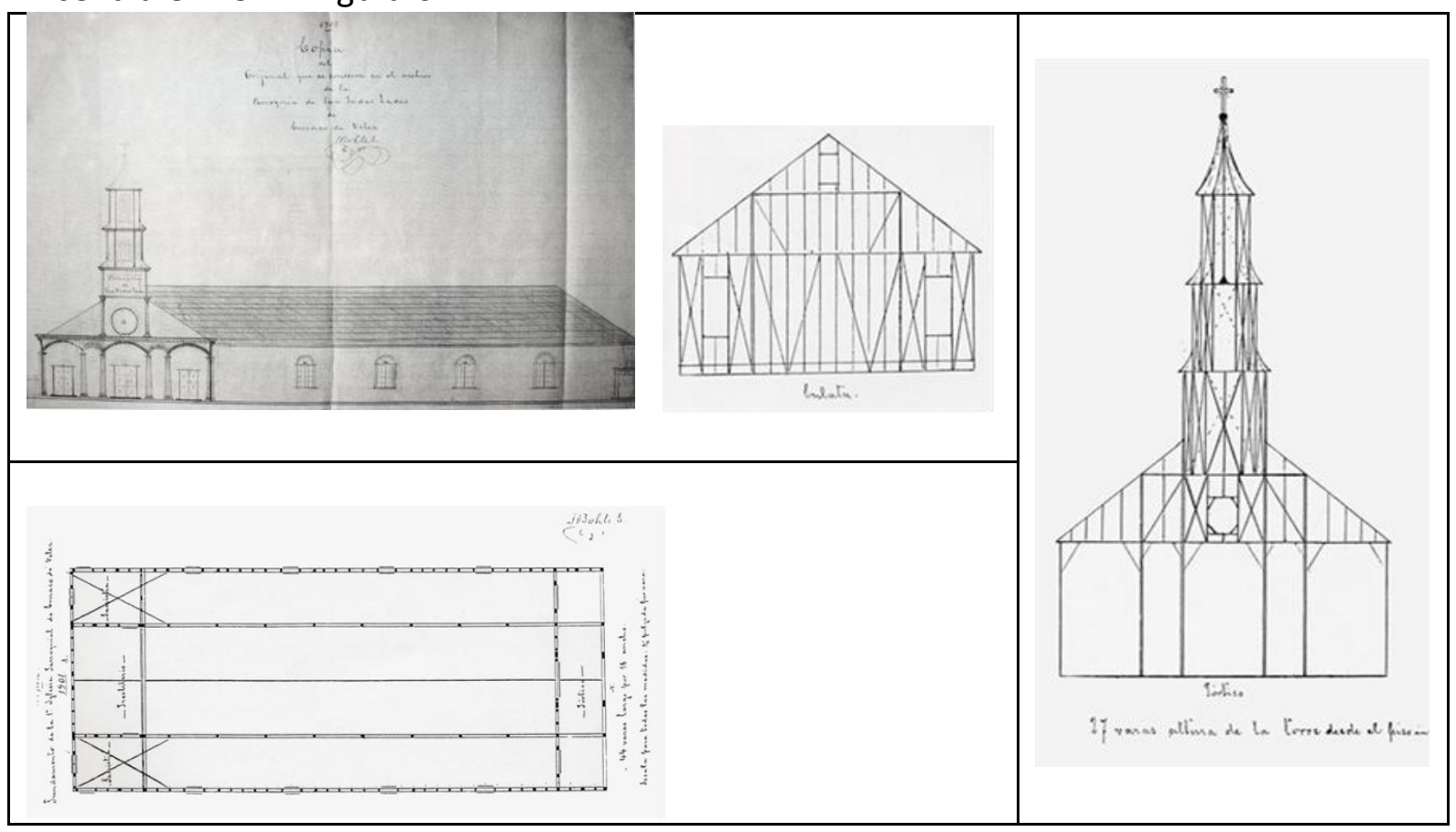




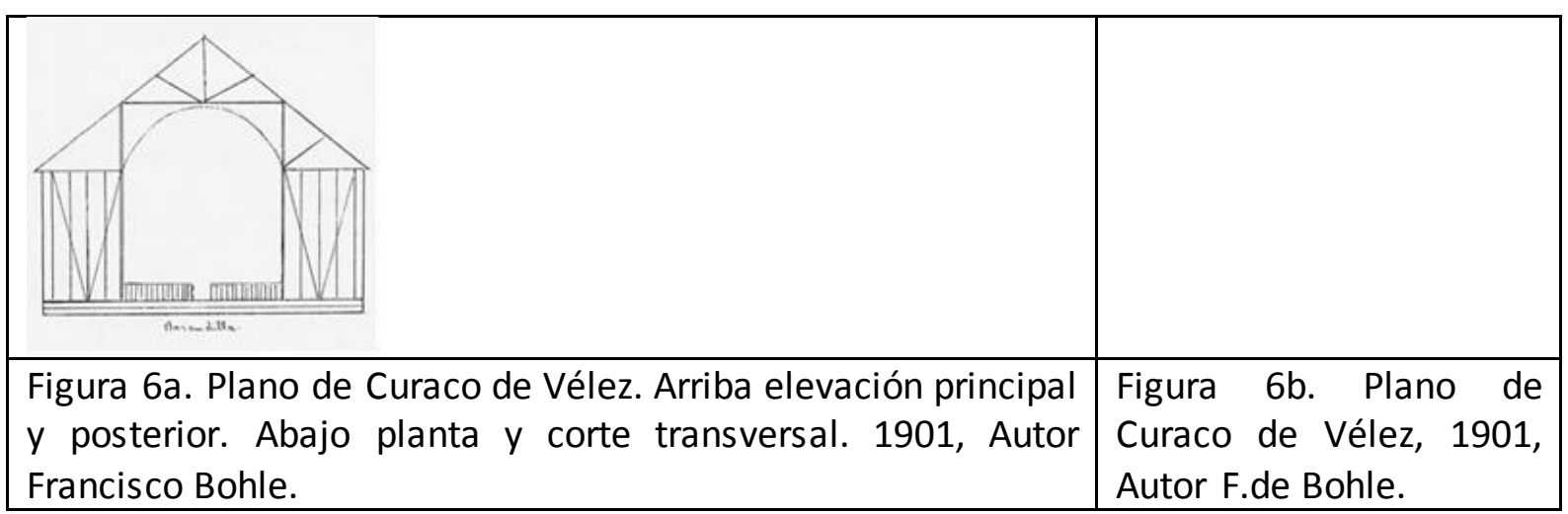

Dalcahue: No hay planos rescatados, pero se menciona "Presentaron los carpinteros Agustín Guaiquin y Dn. Vital Cárcamo a la vista el plano levantado al efecto para este trabajo hemos convenido con ellos..." (Montecinos, 1995, P.100)

Chonchi: Solo planos del proyecto de altar de 1866. Figura 7.

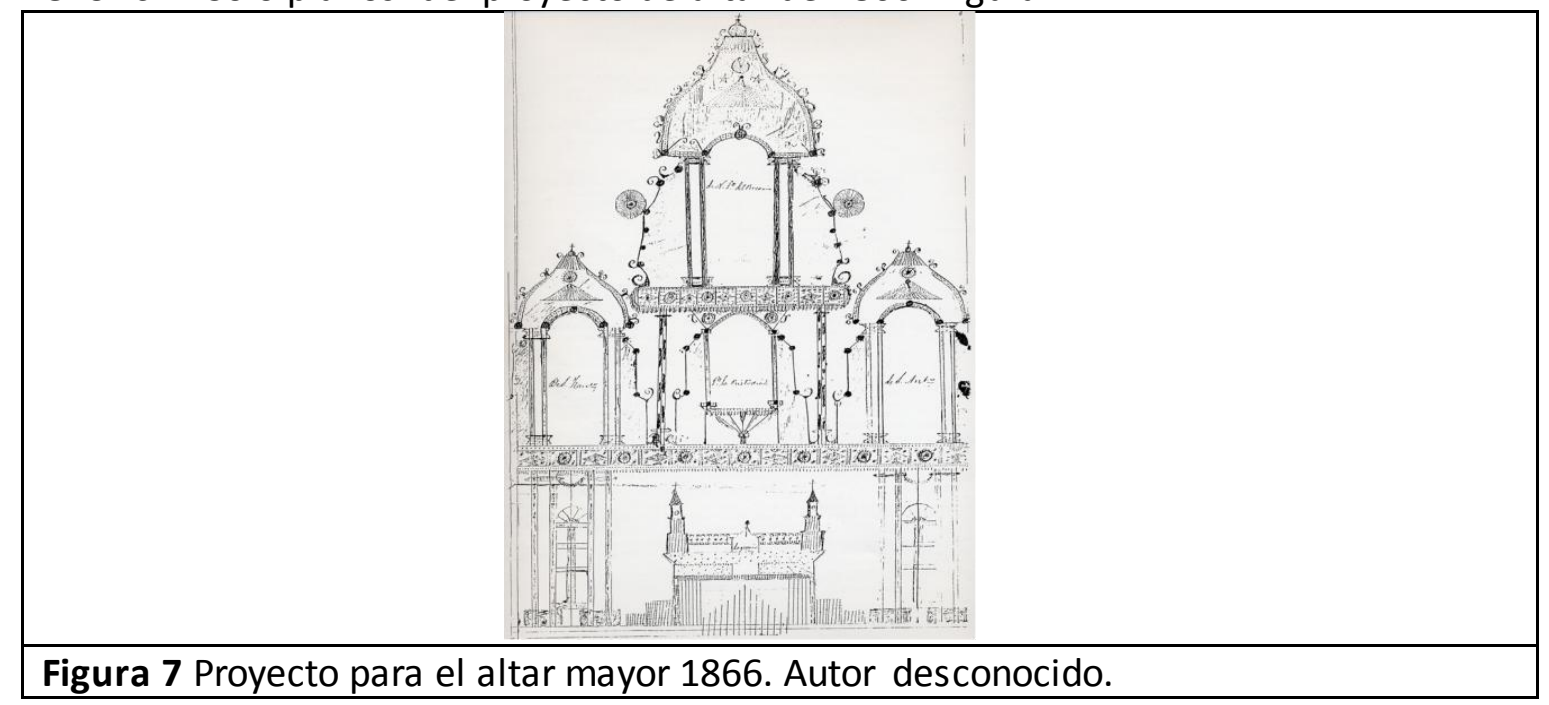

Nercón: No hay planos.

Rilan: No hay planos.

Esta documentación que es sistematizada por los investigadores, da cuenta de nueva información de la evolución de esta llamada Escuela religiosa en muchos aspectos históricos, arquitectónicos y constructivos. Estos permiten aclarar aspectos relevantes de la historiografía de la arquitectura religiosa y al mismo tiempo se mantendrán y surgirán otras inquietudes. En tal sentido es tremendamente ilustrador el siguiente texto del libro:

En relación al origen de la torre fachada los historiadores han señalado semejanzas con modelos europeos: Pereira Salas señala la existencia de jesuitas bávaros activos en Chiloé los que podrían haber traído la imagen de las iglesias propias de la región centro europea. Modiano ha señalado cómo esta imagen de la torre fachada aparece por primera vez en un grabado de la iglesia de 
María Inmaculada en Ratisbona, Alemania, de 1520, donde los elementos que en ella están presentes todavía no configuran una unidad (26). El Padre G. Guarda se refiere a la relación que estas iglesias podrían tener en su elemento torre-fachada con las iglesias de madera en la región de Zagreb en Croacia.

En 1976 hacíamos notar las semejanzas formales de las iglesias chilotas con formas religiosas populares del sur de Alemania como la iglesia de San Sebastián de Binzwanger o Santa María de Kloster Schultz e incluso "con edificios civiles como es el caso de ayuntamiento de Rothenburg obder Tauber"

Los antecedentes obtenidos en esta investigación permiten afirmar que el modelo de la torre fachada, tal como hoy la conocemos se constituye como elemento tipológico en la segunda mitad del siglo XIX y por lo tanto el modelo u origen hay que buscarlo en otras regiones o en otros momentos históricos, vinculados en el siglo XIX a los templos de los franciscanos considerando los aportes que ellos puedan haber efectuado provenientes de su propia tradición en una manifestación tardía del racionalismo neoclásico. (Montecinos, 1995, p.29)

En esta cita se agrega una pista interesante en relación a los franciscanos, pero que los autores no desarrollan, solo se hace dicha mención a lo largo del estudio, dejando propuesta la interrogante. Asimismo sucede con otros muchos elementos que son fundamentales para entender el proceso edificatorio y evolutivo de las capillas de una manera más detallada como es la investigación y correlación interpretativa de las imágenes, planimetrías, autores, carpinteros, etc, los cuales no son analizados a fondo. Lo importante es que han dejado a la vista una serie de elementos y documentos que son interesantísimos y conforman parte de la línea de base sobre la cual se asienta la presente investigación. Por lo tanto, un merecido reconocimiento a dichos autores sobre lo que avanzaron y han dejado como legado abierto para ampliar y profundizar en la historiografía de la arquitectura religiosa chilota.

Así como se señalara respecto a la imagen de Achao que ha sido reiteradamente considerada una auténtica iglesia jesuita del siglo XVIII, por otro lado hay casos que la historiografía ha olvidado revisar. Uno de los ejemplos más singulares ha sido el caso de la Iglesia de Castro, ya que solo ha sido estudiado el edificio actual, el cual data su proyecto y construcción de la segunda década del siglo XX, siendo efectivamente un ejemplar espectacular, pero nadie se ha detenido a estudiar el modelo anterior al presente de Castro ejecutado en el siglo XIX. Es más, ni siquiera ha sido motivo de interés cómo era formalmente. Resulta casi un descuido histórico cuando en dicho período fue formulada la tipología y el rol de este templo de ser sede de la orden religiosa a cargo de las capillas del archipiélago y erigirse allí el Colegio de Misioneros de Castro.

En tal sentido, incluso al inicio de la presente investigación, no estaba considerada la Iglesia de Castro como caso de estudio debido a que la existente, junto con datar de inicios de siglo XX, siempre se ha considerado que no representa el modelo tradicional 
chilote por disponer de dos torres, corte basilical y crucero con lucernario. Es probable que si Montecinos en su investigación hubiese considerado dicho caso habría alcanzado un avance superior aún al logrado en todo su trabajo.

Una foto encontrada de la iglesia de Castro precedente a la actual, registrada por Jerman Wiederhold y otras más en 1893 (Anexo1), durante el desarrollo de la presente investigación, junto con el rastreo de la labor de los misioneros franciscanos abrieron un nuevo capítulo histórico para comprender la evolución compositiva en las iglesias chilotas.

A este momento es necesario refrendar las siguientes palabras de la propia institución católica

muchos aspectos de la historia de Chiloé durante el siglo XIX, y de la historia de la iglesia en concreto, nos son prácticamente desconocidos. De seguro la falta de información, los deterioros que han sufrido algunos fondos documentales, ya fuese por incendios o descuidos, como también la carencia de interés por parte de los investigadores para ahondar en los temas relativos a la historia religiosa; han contribuido a la sensación de que estas temáticas no tienen mayor interés o que lisa y llanamente no se pueden estudiar. (León, 2005, p.9)

En síntesis, lo anterior es la línea base de esta investigación, un siglo XIX que dispone de elementos visibles e invisibles para un revisión más detallada y honda de los edificios y su contexto histórico religioso y social. Es entonces el principal rastreo a realizar: El siglo XIX con la silenciosa misión franciscana y su desconocida contribución a la identidad cultural de Chiloé.

En efecto, se ha planteado la situación de dos tipos de testimonios sustanciales para la investigación, que son primero los estudios más importantes y recientes registrados en las publicaciones de Guarda (1984) y Montecinos (1995), por otra parte está el análisis directo de las capillas, que son el objeto de estudio. Éstas, hasta fines del siglo XX, han mantenido en general su diseño, forma, técnicas y elementos originales (Berg, 2005), sin embargo a partir de la nominación a Patrimonio de la Humanidad han sido sujetas a unas intervenciones muy invasivas y particularmente en el caso de las torres fachadas que han sido desarmadas completamente y reconstruidas totalmente con nuevos maderos, y en muchos casos eliminando elementos que eran fundamentales de la historia constructiva de las capillas. Llegando a situaciones como la capilla de Rilan que fue reconstruida completamente y se retiraron incluso varias basas de piedras, o la capilla de Tenaún que se cambió la geometría de encuentro entre la torre fachada y nave ${ }^{4}$. Estas situaciones han incorporado mayores transformaciones a las capillas en la actualidad, no obstante mantengan su imagen histórica, lo que dificulta hacer un análisis centrado en el siglo XIX con capillas que recientemente en el siglo XXI

\footnotetext{
${ }^{4}$ También se modificaron en Tenaún (las torrecillas que eran de otra capilla más antigua); Colo (las columnas endentadas en el pórtico) Nercón (los huecos en la torre donde se fijaba los apoyos de andamios); Quinchao (los pilares internos de algunas columnas de la capilla original y más rústica que hubo antes de ser revestida); Aldachildo (las piezas de antigua capilla que fueron reutilizadas).
} 
han tenido un importante grado de modificaciones en la búsqueda actual de lograr nuevos edificios construidos casi a la perfección, desestimando ciertas características peculiares de cada capilla. En tal sentido los análisis de esta tesis se han centrado en base a los planos históricos del siglo XIX y los levantamientos críticos de la Fundación de las Iglesias de Chiloé realizados previo a las intervenciones recientes (En Anexos capitulo 6 ).

\subsection{Cultura de la madera.}

La arquitectura de Chiloé ha sido ampliamente descrita por dos aspectos culturales que están fuertemente arraigados a su proceso histórico, social y territorial y que la determinarían como única y propia. Estos aspectos son cultura del bordemar y cultura de la madera ${ }^{5}$. El primero se refiere a la ocupación humana temprana (prehistórica) y permanente en la costa oriental de la isla grande, dado que es un mar interior, de aguas tranquilas y no expuesto al océano, que provee de un fácil sustento de maricos y peces, artes en los cuales los chilotes se volvieron expertos, desarrollando una técnica particular como fueron los corrales de pesca "... de piedra y rama a medio sumergir, para que en las altas mareas quedase cautivo en ellos el pescado que el ocaso conducía a esos lugares" (Pérez Rosales, 1882 p. 564). El segundo y que interesa más en el contexto de este estudio es la noción de cultura de la madera, en efecto la súper abundancia de este material propició su uso y la elaboración de prácticamente todos los objetos producidos en Chiloé, no solo la arquitectura, sino que imaginería religiosa, embarcaciones, artesanías, instrumentos musicales, e incluso se usaron como monedas de intercambio tablas de alerce ${ }^{6}$.

El estadio cultural que se llega con las grandes capillas chilotas a fines del siglo XIX y del XX va acompañado con el despliegue de un sinnúmero de poblados y arquitectura de madera, amén de los ya indicados diversos artefactos culturales realizados con este material. Tal proceso de creación cultural ha estado condicionado en gran medida por los diversos contactos que ha recibido el archipiélago desde el exterior, situación similar al resto de Sudamérica, con la diferencia que la condición insular de Chiloé más las propios sustratos étnicos culturales al interior, van marcando diferencias. En tal sentido no es novedad que la conquista y ocupación hispánica en un territorio habitado por naturales iniciara el primer proceso de cambios. Asimismo sucederá con la posición y control que adoptan los misioneros jesuitas en Chiloé, que si bien los autores citados describen que éstos traen los modelos arquitectónicos y las técnicas desde Europa, pero las tipologías tradicionales se construirían posteriormente, cabe

\footnotetext{
${ }^{5}$ El concepto de cultura del bordemar lo instala el Taller Puerta Azul en su publicación “Chiloe, cultura y bordemar" Edward Rojas y Renato Vivaldi, 1979.

El concepto de cultura de la madera lo instala el Taller Chiloé en su publicación "Arquitectura de Chiloé" Hernán Montecinos y otros, 1976.

${ }^{6}$ En los siglos XVII y XVIII las tablas de al erce eran apreciadas en Lima, único lugar con el que los chilotes practicaban el comercio, cuando en verano Ilegaban los barcos desde el Callao a la feria de Chacao. Estas tablas fueron la moneda de Chiloé colonial, donde no existía circulante sino que el comercio se practicaba como trueque, mucho más valiosa que los otros productos que se exportaban, como jamones ahumados, pescado seco o ponchos, y que se intercambiaban por azúcar, sal, ají, añil, aguardiente, "ropa de la tierra y ropa de Castilla" (Urbina, M. Ximena, 2011).
} 
entonces la pregunta ¿qué sería lo chilote en este proceso? ¿serían ellos los que logran desde el interior alcanzar tal estadio cultural? ¿Hay o no otras influencias culturales?. Sin lugar a dudas que si hay otros contactos en el caso de las capillas tradicionales y particularmente las de mayores tamaño, que tienen un marcado acento neoclásico, estas composiciones arquitectónicas de origen europeo llegaron a toda América y en Chiloé serían introducidas por navegantes, inmigrantes o vía catálogos (Fischer, 1987). La cuestión de la realización de las capillas evidencia claramente otros y nuevos contactos que lo deja entrever Montecinos (1995) al descubrir que surgen durante el periodo franciscano, pero se mantienen interrogantes relevantes como: ¿son los frailes directamente los constructores o las encargan? ¿Tenían la capacidad técnica para hacerlo o la delegaron?¿ Cuál es el papel de los carpinteros chilotes?.

Por otra parte prácticamente en la misma época y territorio hay una importante llegada de Colonos alemanes que se asientan en la zona y traen toda su cultura carpintera con la cual levantan poblados y caseríos de madera. Con los aserraderos construyen iglesias, fábricas, edificios de uso público, muelles, etc. Por supuesto también viviendas rurales y urbanas tanto en estilos vernáculos, como en improntas neoclásicas y eclécticas. Sin embargo a la fecha no hay investigaciones publicadas que hagan relación entre la arquitectura de la colonización alemana y la arquitectura chilota, en un periodo tan relevante y fundacional de toda un edilicia en madera como es la segunda mitad del siglo $X X^{7}$. De manera que perfectamente se puede sostener, una de las hipótesis de esta tesis, que la colonización alemana fue un importante agente cultural que gatilló no solo un tipo de composición arquitectónica, la corriente neoclásica, sino que también las técnicas carpinteras para llevar a cabo las capillas chilotas, ya que son prácticamente las mismas. Más aún cuando uno de los planos más elaborados que se tienen, como el caso de la capilla de Curaco de Vélez en Chiloé, viene firmada por el padre Bohle de origen alemán.

A este punto se puede señalar que hay vastas materias y múltiples aristas que no están suficientemente consideradas para alcanzar un mayor conocimiento del origen tipológico y difusión modelística de las capillas chilotas. Se hace necesario hacer una revisión de la historia de los contactos culturales en el archipiélago. Esto sin lugar a dudas pone en cuestión o puede dejar en segundo plano la idea de las capillas como un constructo puramente chilote, las evidencias indican que el aporte interno o local en la constitución de tales edificios parece también fundamental.

La idea de las capillas como un constructo cultural propio chilote, es bastante generalizado en la población y si bien Montecinos (1995) se refiere e instituye la noción de Escuela chilota de Arquitectura religiosa, "Creemos haber demostrado que las iglesias misionales chilotas forman una "escuela" según el significado que este concepto tiene en la historia del arte: la constitución de un tipo como resultado de un proceso, fases o etapas en su desarrollo, elementos definitorios que se mantienen constantes y su transformación cultural en arquetipo". Se deduce que en ningún caso

\footnotetext{
7 Solamente investigaciones del Arquitecto Gian Piero Cherubini (2015) han buscado establecer conexiones y divergencias. (Documento inédito)
} 
es una Escuela formal e instituida como tal, sino más bien al reconocimiento de una manera de lograr una arquitectura particular la cual se ha trasmitido en forma tradicional, conocimientos y habilidades, siendo muy propio en oficios como la carpintería donde se trasmite de maestros a aprendices (Cherubini, 2015). Por lo tanto si bien no existió una Escuela de carpinteros propiamente tal en Chiloé, no hay antecedentes que lo demuestren, carpinteros chilotes si fueron adiestrados por los jesuitas y también los hay como ejecutores de capillas durante la época franciscana. Las preguntas persisten en cuál fue el rol y nivel de autonomía de tales carpinteros para la realización de las capillas, entendiendo realización desde el proceso de ideación a construcción del edificio.

En los documentos del Obispado de Ancud (Montecinos, 1995) indican que participaron maestros o carpinteros locales en la construcción de diversas capillas, sin embargo en dicha investigación solo se mencionan y no es analizado el rol o grado de participación técnica de tales artífices. Otro aspecto que indican los documentos es que los trabajos de carpintería son remunerados y por lo tanto echa en parte por tierra la idea de que éstos se hacía en general bajo la figura de mingas ${ }^{8}$, trabajo colectivo no pecuniario o gratuito. Si los antecedentes escritos e históricos del propio Obispado demuestran contratos en alguna medida revelan un reconocimiento de la Curía hacia un oficio que requería cierta calificación.

De lo expuesto surge la disyuntiva nada fácil del presente estudio, de como despejar las incógnitas entre cuánto es local y cuánto es foráneo. La línea a seguir es primero despejar la historia de los contactos ya que serían éstos los que entregarían la internalización desde el exterior, la matriz tipológica, que es la planta basilical y la torre fachada, así como la imagen estilística del neoclásico. En suma, es absolutamente evidente que la forma arquitectónica de las capillas desembarcó desde ultramar y que los carpinteros chilotes se adiestraron o fueron adiestrados para levantar capillas. Aquí estaría la llamada capacidad de reinterpretación de modelos foráneas en formas locales y que caracteriza la cultura y arquitectura de Chiloé (Fischer, 1987). Esta situación se puede ver desde bicicletas, anclas (sacho) hechas de madera o la actual Iglesia de Castro, construida entre 1912 y 1916, a partir de planos muy generales realizados por el arquitecto Eduardo Provasoli y que es Ilevada a cabo por carpinteros chilotes (Berg, Lobos y Rojas, 2006) por los antecedentes disponibles sin la guía de su autor o profesionales. El nivel de complejidad y envergadura de este edificio entero de madera y solo revestido en metal por el exterior, que posee dos torres, linterna sobre el crucero, demuestra que la llamada reinterpretación también requiere de una capacidad técnica constructiva solvente. No obstante el primer modelo de esta Iglesia se haya iniciado en 1912 y derrumbada por un temporal mientras se encontraba en fase de estructuración. Probablemente el segundo modelo y que persiste, puede haber

\footnotetext{
${ }^{8}$ La Minga es una expresión de la solidaridad del chilote. Esta es una tradición que se hunde en el pasado precolombino de América, y se puede definir como un trabajo comunitario voluntario, y recíproco. Previamente a su realización el beneficiario "suplica" ayuda a sus vecinos y amistades, comunicándole su intención de realizar un trabajo específico como sembrar o cosechar papas, hasta trasladar una casa, destacando la necesidad que tiene de su ayuda. El día señalado, quienes concurren a ayudar son atendidos con comida y bebida por los dueños de casa, quienes contraen el deber de devolver el día trabajando cuando sus vecinos lo "supliquen".
} 
sido a cuesta de un proceso de aprendizaje o de ensayo y error, llevado a cabo con mayores sobredimensionamientos de piezas u otras mejorías que se desconocen, junto a todo el procedimiento de armado de la fábrica. Esto demuestra tanto, la falta de conocimiento e información al presente, de la historia constructiva de tales capillas, como la manera que los carpinteros locales lograban perfeccionarse en este tipo de edificios mayores.

\subsection{El estado de la arquitectura y la carpintería local.}

La lejanía y el aislamiento geográfico fueron factores que determinaron el desarrollo cultural y tecnológico de Chiloé. Desde la fundación de Castro en 1567 la pobreza y la precariedad formaron parte de la vida insular. La dispersión de los habitantes dificultó la innovación en las formas de vida y en sus manifestaciones arquitectónicas, produciendo una sociedad conservadora y solidaria, en base a mingas. Desde dentro, el territorio ofrecía lo necesario para vivir, solo había que criar algunos animales, mantener una huerta de papas y salir a mariscar, cuando las condiciones climáticas lo permitían. Desde fuera era vista como una sociedad sumida en la pobreza y la escasez de lo necesario para vivir.

Carlos Beranguer en 1773 describe las construcciones de Castro notando que

la fábrica de las iglesias conventos i colegios, casa de cabildo y las demás de particulares son todas de madera, material que ofrece abundante el país en sus montes que no tiene otro recurso la provincia porque falta la cal i la piedra a propósito, operarios i facultades para otra construcción más costosa, los techos de los edificios de iglesias, conventos i cabildos, son de tablas, i tal cual casa de particular que tiene algún posible, todas las demás se hayan con paja, pero son de poca duración y es necesaria anualmente refaccionarlas y renovarles el techo para poder librarse de las lluvias que son continuas en el temperamento. Esta fábrica es igual a toda la provincia como a su distribución interior i colocación de fogata que se pone en su medio, cuyo humo que deben sufrir a costa de infinitas incomodidades les complacen porque les conservan sus techos i a sus cosechas, son habitaciones que publican por sí mismas su miseria y desidia, pues no son otra cosa que unas chozas o cabañas (Beranguer, 1773 p. 19-20).

En esta descripción Beranguer establece primero el uso de la madera como principal material de construcción, por su abundancia en el archipiélago y por la carencia de otros materiales así como de mano de obra calificada para trabajar la piedra. Después destaca la diferencia entre los edificios de instituciones religiosas y de gobiernos, con los de habitación. La principal diferencia se encontraba en el techo de tablas de los primeros, lo que es un indicador de un nivel tecnológico superior al de las casas, así como de los requerimientos de vida diferentes que tenían los usuarios, quienes generalmente provenían de fuera del archipiélago, como era el caso de los gobernadores y de los sacerdotes, quienes además tenían maneras diferentes de habitar. Sin embargo, a pesar de esto, Byron describe el palacio del gobernador como 
un sencillo galpón (Byron 1996), mientras el gobernador Espejo dirá de esta construcción que era "un barracón de madera de dos pisos" (Olguín, 1971 p. 29). Según Beranguer las casas eran sencillas, con el fogón en el centro el cual llenaba de humo el interior, lo que impermeabilizaba la cubierta hecha de gravillas de paja, a la usanza de la ruka mapuche, a la que había que hacerle mantención anual, además el humo servía para secar y conservar alimentos como las cuelgas de mariscos. El humo traía como consecuencia que fueran frecuentes las enfermedades a los ojos (Tornero, 1871). Para Beranguer, que veía la realidad de Chiloé con la mirada crítica del afuerino, estas "chozas" como las llamó, eran un indicador del estado de pobreza en que estaba sumido el archipiélago.

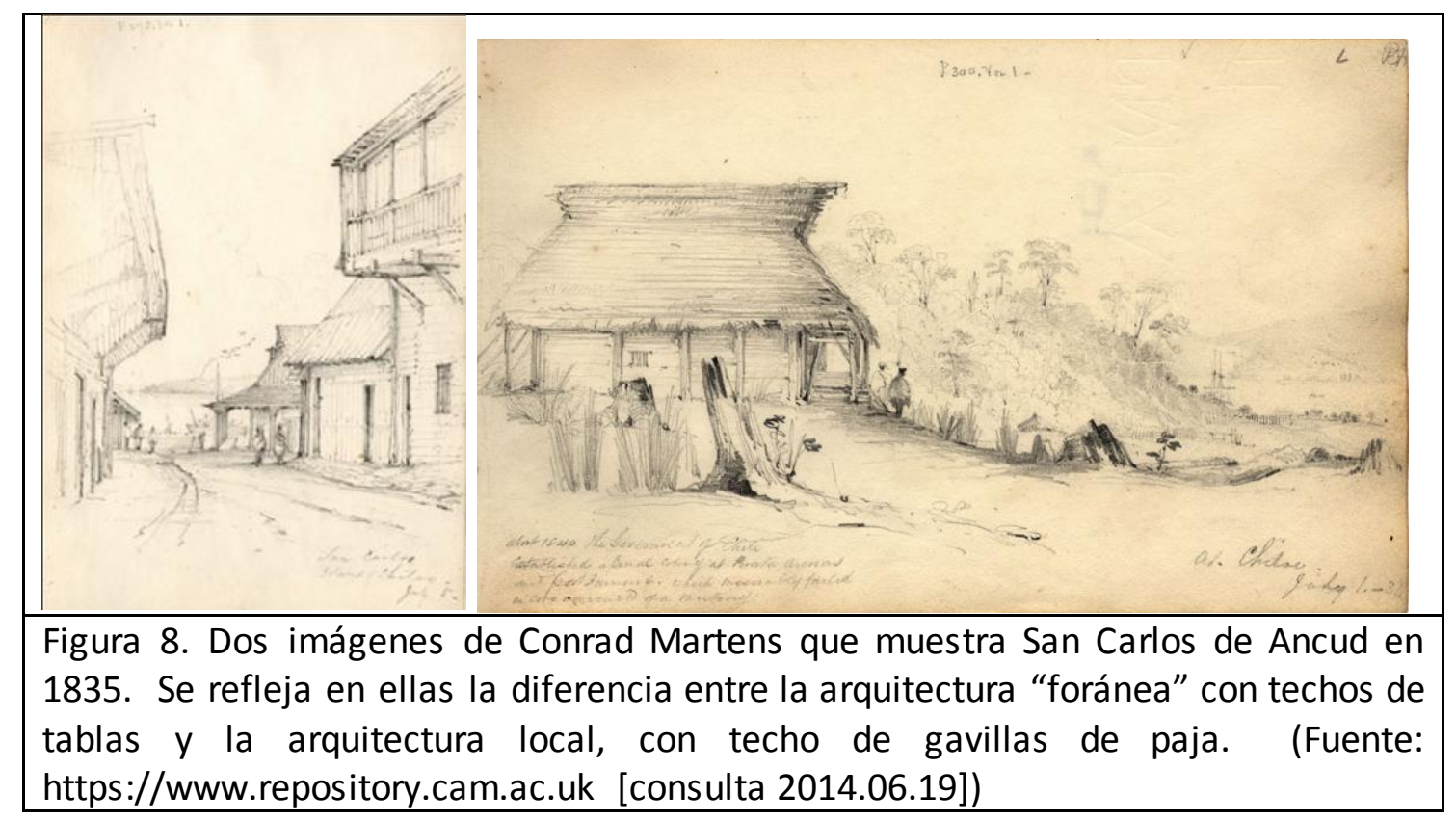

Seis décadas después Conrad Martens dibujó estas construcciones de postes clavados en el suelo, como los describe Guarda (1995), cuyos intersticios se sellaban con musgo o barro, para que no se cuele el viento, con una viga central que recibía los tijerales o vigas inclinadas, sobre las que se amarraban las costaneras que recibían finalmente las gavillas que daban forma a la cubierta, tenía gran pendiente para que escurra el agua y no afecte la estructura de madera (Tornero, 1871). En los extremos de la cubierta sendas aperturas, que aun así eran insuficientes, permitían la ventilación y salida del humo.

Estas construcciones derivaban de la ruka mapuche, pero sin el sentido antropológico que estos le daban. Eran mono-espaciales y multifuncionales, (Cherubini, 2011), es decir que en torno al fogón que ardía constantemente en su centro, se conversaba, se contaban historias y leyendas, se cocinaba, se comía y se dormía, compartiendo junto a los animales domésticos el calor del hogar (Pérez Rosales, 1882)

En lo que respecta a los edificios religiosos también había una diferencia en su construcción. Las capillas en el siglo XVII, desperdigadas por las islas del archipiélago, "aunque sus paredes fuesen de solo madera y los tejados de paja, eran siempre casas de Dios" (Enrich, 1891, T I, p. 432). Sin embargo el padre Enrich al referirse a la iglesia de Castro escribe que en 1643 "las paredes de nuestra iglesia, que era de tapiales, y no 
de pura madera como los demás edificios", además, techada con tejas (Enrich, 1891, T I, p. 491).

Durante el siglo XVIII las capillas continuaron siendo construidas con las mismas técnicas y materiales de las habitaciones a tal punto que se les denominó "capillas pajizas" por el material de su techumbre. A su vez las iglesias principales se construyeron de madera, con tres naves como la de Achao, Chonchi, Calbuco y Castro. Las dimensiones de estas iglesias hacen referencia a sistemas constructivos con algún grado de sofisticación en las uniones, como se ha logrado ver en las sucesivas restauraciones de la de Achao (Berg, 2005).

Se podría considerar que la precariedad de la arquitectura es el reflejo del conocimiento de quienes la construyeron. A este respecto José de Moraleda quién hizo la exploración hidrográfica del archipiélago entre 1787 y 1796 describió a los carpinteros chilotes como poco prolijos, calificándolos de "carpinteros toscos", que desconocían las cualidades de la madera (Moraleda, 1888, p. 207). A su vez el padre Guarda señala la destreza con la que usaban el hacha (Guarda, 1995).

Este hecho plantea una cuestión sobre la que se ha estudiado poco y que deja una cierta laguna histórica de la arquitectura en madera posterior a los jesuitas y que es de las preguntas fundamentales de esta tesis. Pero también sobre el destino de los conocimientos y técnicas con las que estos misioneros construyeron sus iglesias. Al menos de los jesuitas se puede deducir de dos hechos. El primero es la presencia en el país de los hermanos coadjuntores Juan Bitterlich, artesano escultor, Miguel Herre, maestro cantero y Antonio Miller, maestro carpintero, quienes eran experimentados también en la arquitectura, apoyados por el hermano arquitecto Pedro Vogel, en la definición dimensional de las mismas. Participaron en el alajamiento y construcción de los edificios de la Compañía y "Si en Chiloé han dejado de existir las grandes iglesias que ellos en Kaylin, Chonchi y Castro ${ }^{9}$ habían levantado las cuales con ser de madera eran buenas y hermosas, queda todavía la de Achao; que a pesar de no haber sido la mejor de las cuatro, es aún hoy la más bella que posee aquel archipiélago" (Enrich, 1891, T.II, p. 354). No se tiene la certeza documental de la presencia de estos hermanos coadjutores en Chiloé, pero se sospecha que puedan haber influido en las obras del archipiélago a supervisar las obras.

El segundo hecho es la gran cantidad de herramientas anotadas en los catastros de las pertenencias de los jesuitas expulsos el año 1767 de Chiloé, en donde se encontraron martillos, limas, barrenos, junteras (prensas), sierras de una y de dos manos, azuelas de una y dos manos, cepillos, guillames, formones, escoplos y gubias, compases, etc. (Vásquez de Acuña, 1956. Urbina, 1990), todas herramientas que permiten el trabajo de la madera, desde piezas en bruto hasta aquellas terminadas. Algunas de estas herramientas fueron encontradas en las habitaciones de los padres, lo que es un indicador de que ellos también sabían usarlas.

Estos conocimientos a tal nivel técnico pareciera no prosperaron. Pareciera ser que chilotes y descendientes de españoles, en cierto modo despreciaron las artes mecánicas o manuales. (Pérez Rosales, 1882. Philippi, 1901. Weber, 1903.), "creyendo que el trabajo deshonra y que ha sido inventado solo para la plebe" (Guarda, 1979, p. 66).

La de Castro se quemó el año 1861 y la de Chonchi fue derribada debido a su estado ruinoso en el último cuarto del siglo XIX 
Estas impresiones históricas van delineando una imagen poco alentadora del estado cultural que presentaba Chiloé hasta fines del Siglo XIX.

\subsection{De los contactos culturales.}

En este nivel de la evidencia, cobra importancia el análisis des de la perspectiva de la toma de decisiones ¿qué es lo que permanece para que aquello que cambia no transforme la capacidad de decidir desde la cultura propia?. Si bien es probable que esta tesis no resuelva a cabalidad esta pregunta, si parece importante considerar que implica la variable del contacto cultural y enfrentar el análisis desde las influencias externas y de qué manera influyen en lo interno, lo que no necesariamente implica una desvaloración de lo local. Al respecto, la teoría del control cultural, proporciona herramientas de análisis para la comprensión del fenómeno, toda vez que, como sostiene Bonfil (1987, 1988, 1992), la relación significativa y necesaria para conceptualizar y reconocer a un conglomerado humano, una comunidad o pueblo, es aquella que se establece entre el grupo determinado, relativamente permanente (una sociedad), y su cultura propia, la que es tal en la medida que el grupo tiene un cierto grado de control sobre los elementos o recursos culturales que la constituyen. Esa relación se define como "control cultural" y se comprende como el sistema según el cual se ejerce la capacidad social de decisión sobre los componentes de una cultura, que resulta necesario poner en juego para realizar las acciones colectivas y propósitos sociales. Los elementos culturales pueden ser propios o ajenos. Son elementos propios los que la unidad social considerada ha recibido como patrimonio cultural heredado de generaciones anteriores y los que produce, reproduce, mantiene o transmite según la naturaleza del elemento cultural de que se trate. Inversamente, son elementos culturales ajenos aquellos que forman parte de la cultura en que vive el grupo, pero que éste no ha producido ni reproducido. En relaciones de contacto cultural, como en el caso de Chiloé, la cultura etnográfica (entendida como el inventario total de los elementos culturales presentes en la vida del grupo), incluirá tanto elementos propios como ajenos. Al relacionar el universo de elementos culturales, propios y ajenos, que forman la cultura etnográfica de un grupo en un momento dado, con la condición propia o ajena de las decisiones sobre esos mismos elementos, Bonfil (1992), establece cuatro ámbitos o espacios dentro de la cultura total, diferenciados en función del sistema de control cultural existente. La síntesis de este planteamiento puede apreciarse en el siguiente esquema:

\begin{tabular}{|l|l|l|}
\hline $\begin{array}{l}\text { Elementos o Recursos } \\
\text { Culturales }\end{array}$ & DECISIONES & AJENAS \\
\cline { 2 - 3 } PROPIOS & PROPIAS & \\
\hline & CULTURA AUTONOMA & CULTURA ENAJENADA \\
\hline AJENOS & CULTURA APROPIADA & CULTURA IMPUESTA \\
\hline
\end{tabular}

Cuadro 1. Matriz de Bonfil. 
De acuerdo a la síntesis señalada, la capacidad de decisión sobre los elementos culturales define cuatro ámbitos posibles dentro de la cultura, en función de quien ejerce el control cultural. El primer ámbito de ejercicio es el de la cultura autónoma, donde los elementos son propios del grupo y también lo es la capacidad de decisión. En este ámbito se definen los aspectos compartidos de una cosmovisión distintiva, indispensables para la existencia de una identidad colectiva. En oposición, está el ámbito de la cultura impuesta. En este caso ni los elementos culturales ni las decisiones son del grupo considerado, no obstante la cultura impuesta forma parte de la cultura que vive la colectividad; se trata de elementos extraños, ajenos, que actúan en obediencia a decisiones también extrañas, es decir, no se tiene control sobre ellos. Cuando se alcanza la capacidad de usarlos, pasan a ser elementos de cultura apropiada, los que en el momento en que son producidos y/o reproducidos, pasan a formar parte del campo de la cultura autónoma, convirtiéndose en un recurso cultural propio. Por último, el ámbito de la cultura enajenada es un campo de conflicto permanente. Los recursos culturales están ahí, forman parte de la cultura del grupo, pero éste no tiene capacidad para decidir sobre ellos. Así, cultura autónoma y cultura apropiada integran el campo de la cultura propia; cultura impuesta y cultura enajenada constituyen el ámbito de la cultura ajena.

El esquema presentado anteriormente, debe ser relacionado dinámicamente en función de seis procesos principales que afectan a los grupos que se encuentran en contacto cultural: a) Proceso de imposición; b) Proceso de supresión o eliminación; c) Proceso de enajenación o expropiación; los que, a su vez, generan otros tres procesos, existiendo cierta correspondencia inversa entre ambos conjuntos de procesos. a) Proceso de resistencia; b) Proceso de apropiación; y c) Proceso de innovación. El conjunto total de procesos, según Bonfil (op. cit.), permiten comprender el desarrollo de las relaciones interculturales, en términos del control cultural.

\subsection{Conclusiones iniciales.}

Los registros iconográficos del Obispado de Ancud (Montecinos, 1995) sumado a los recientes registros fotográficos publicados de Wiederhold de 1893, permiten dar un avance al estado formal de las capillas en el siglo XIX. Con los cuales se puede hacer una cierta línea de tiempo y organizarlos en un cuadro (Cuadro №2) donde se pueden establecer evoluciones o proceso de transformación de cada capilla así como relaciones entre ella y describir algunos patrones de permanencia y cambio hasta hoy. Esta es una primera sistematización de la investigación que permite ilustrar ciertos momentos y que son claves para el análisis histórico-arquitectónico a desarrollar. 


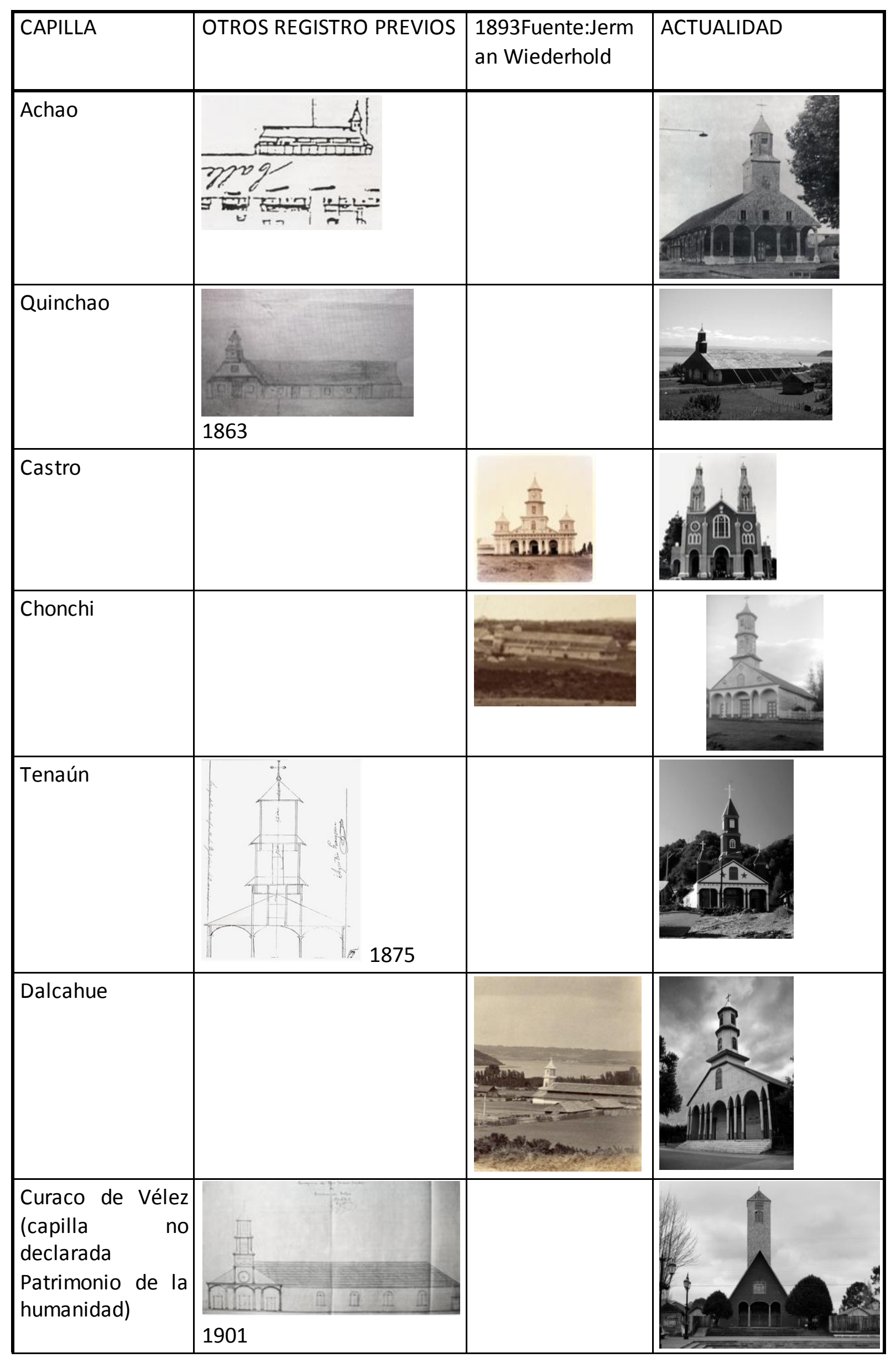




\begin{tabular}{|l|l|l|l|}
\hline $\begin{array}{l}\text { Puqueldòn } \\
\text { (capilla no } \\
\text { declarada } \\
\text { Patrimonio de la } \\
\text { humanidad) }\end{array}$ & & & \\
\hline $\begin{array}{l}\text { Quemchi no } \\
\text { (capilla } \\
\text { declarada } \\
\text { Patrimonio de la } \\
\text { humanidad) }\end{array}$ & & & \\
\hline
\end{tabular}

Se puede vislumbrar el caso de Castro, la capilla actual y la anterior, donde se notan modelos sustancialmente distintos. O el caso de Puqueldon que se visualiza en 1893 una perfecta capilla chilota, mientras la actual difiere con aquellas que reconocemos como tradicional. Situación similar sucede con Quemchi, en la foto de Wiederhold se ve una magnifica capilla, en cambio la actual contiene una diversidad de elementos composicionales. En el caso de Chonchi se puede observar con dos torreones bajos laterales y una nave con corte basilical para 1893, la capilla que conocemos hoy se inicia su construcción justo en esta época y sería la cuarta capilla erigida en este lugar (Berg, 2005) adquiriendo las características tipológicas y formales de las tradicionales aunque hayan varias intervenciones realizadas sobre ella. Situación similar sucede con Dalcahue que presenta en 1893 ya la clásica torre fachada chilota, mientras la nave es de corte basilical, también se encontraría en este periodo en su fase de adquisición de la tipología tradicional.

De lo anterior se desprende que hay capillas actuales que no clasifican como tradicionales o dentro de la escuela chilota, Quemchi y Puqueldon, pero que las fotos de Wiederhold atestigua que si lo fueron. Mientras en otras como Dalcahue y Chonchi muestran justo el momento de transformación y de constitución de la clásica tipología chilota que representan estos casos y se les ha reconocido como Patrimonio de la Humanidad. Desde esta perspectiva se revela que los modelos antecesores de Quemchi y Puqueldon ya contenían la formula arquitectónica tradicional como para ser catalogadas sitio patrimonio mundial, pero que se perdieron posteriormente.

Lo fundamental es que hay evidencias que la tipología de la capilla tradiclonal chilota ya está constituida en las fotos de 1893 de Wiederhold y esta se encuentra en su fase de propagación por el archipiélago, por lo tanto se puede afirmar que es el tiempo previo a este donde hay que investigar profundamente.

El universo de capillas tradicionales actualmente, como ya se ha señalado, son aproximadamente 80. Las 16 enlistadas como Patrimonio de la Humanidad, no le quitan méritos a las restante, sino que representan un puñado de los edificios más 
significativos ya sea porque son varias de ellas sede parroquial ${ }^{10}$ y por lo tanto relevantes simbólicamente como la de Castro, Dalcahue, Achao, Chonchi, Tenaùn. Otras que son significativas por ser sedes de importantes fiestas patronales, Quinchao y Caguach, otras por méritos arquitectónicos, históricos o sociales. Pero no cabe duda que así como se encuentran las capillas de Ichuac o Detif entre las 16 reconocidas mundialmente, perfectamente también lo podrían haber sido otras como Caylin al norte de la isla grande o Compu y Quellon Viejo emplazadas hacia el sur.

Este gran número de capillas y el hecho de las transformaciones derivadas en el tiempo, donde los registros iconográfico y escritos en el siglo XIX e inicios del XX son bastantes escasos, impiden disponer con claridad de cuanto se puede haber intervenido en el tiempo cada modelo y por lo tanto cuanto de cada uno se mantiene o ha cambiado. Para efectos de la investigación, que se sitúa desde el presente para rastrear sobre el pasado en aquellos modelos que puedan dar mejores luces del proceso de cristalización tipológica, ya se ha descrito en el capítulo 1 (1.8.4 Tipologías y modelos religiosos tradicionales de madera chilotes) que las capillas se componen esencialmente de dos volúmenes la nave y la torre fachada. Como en ocurre en cualquier matriz tipológica la arquitectura de las capillas posee elementos únicos sobre los cuales se componen, estructuran y materializan. De esta tipología resultan una variedad de modelos que varían según tamaños, proporciones, geometría y formas que le dan la identidad única al modelo.

De tal modo que en los elementos principales compositivos de cada capilla están tanto lo que las familiariza como lo que las diferencia. En tal sentido todas disponen de torre fachada con pórtico, donde la geometría de la torre escalonada o telescópica es la que varía y también la composición del pórtico. Sin lugar a dudas las similitudes y diferencias también pueden estar en elementos menores como columnatas, ventanas u otros. A efectos de hacer una clasificación inicial se ha hecho a partir de los componentes fundamentales de la tipología como para reconocer subtipologìas y modelos, que permita caracterizarlos, se estima innecesario e improductivo llevarlos a los elementos secundarios ya que sería una lista interminable de elementos. Por lo tanto se consideran que con los dos elementos composicionales básicos la torre fachada y nave (en rigor todas de planta basilical y por lo tanto de tres naves) en cuanto a medidas y formas. Además, incorporando los datos de fechas y sistemas constructivos, se pueden evidenciar las relaciones y ciertas tendencias epocales ( Anexo № 2 ).

Es necesario insistir que a este punto aún estamos viendo capillas des de la actualidad, y los casos de Chonchi, Dalcahue, Quemchi, Puqueldon o Castro hace un poco más de un siglo ciertamente la situación en el sitio de cada una de estas capillas era distinta. Por lo tanto es evidente que se requiere hacer una revisión histórica más minuciosa para seguir el proceso de arquitecturizaciòn de estas capillas y que esta primera sistematización permite disponer solo de una mirada inicial que no necesariamente está colocando todas las capillas en un mismo período temporal, sino que justamente es un reconocimiento de esta superposición de tiempos constructivos existentes en la capillas. Centrándose en las capillas declaradas Patrimonio de la Humanidad

\footnotetext{
${ }^{10}$ La parroquia es la sedeadministrativa de un territorio y donde vive el sacerd ote a cargo de dicha jurisdicción.
} 
Según lo descrito el estado de las capillas $^{11}$ actuales pueden diferir en diferentes grados formales de aquellas que se estudiaran. Sin embargo se ha hecho para efectos de una mejor ilustración de las capillas de un detallado registro de levantamientos crítico realizados sobre las 16 declaradas Patrimonio de la Humanidad, previos a una serie de intervenciones recientes que han modificado su integridad física e histórica. Se adjuntan en anexo las planimetrías.

\subsection{Orientación de los capítulos siguientes}

De lo expuesto los capítulos siguientes se centran en recabar la historia arquitectónica de los contactos culturales que van provocando los principales elementos de cambio.

En el tercer capítulo se profundiza el periodo de los jesuitas que siendo el más estudiado y conocido interesa relevar con la mayor claridad posible las iglesias que ellos introdujeron, pero sobretodo cuáles fueron aquellas tipologías arquitectónicas y constructivas que ellos dejaron como herencia al final del período, año 1767 de la expulsión de los misioneros, de manera de situar el estado del arte de la arquitectura religiosa de Chiloé. Asimismo reconocer el contexto de todas sus enseñanzas, ya hicieron un cambio fundamental en la cosmovisión indígena, instalando una fundación cultural occidental. Se puede decir que este periodo desde el punto histórico es la línea de base de la tesis.

Los principales documentos a revisar es la bibliografía de variados autores jesuitas de la época y posteriores, asi como historiadores contemporáneos especialistas en tal período como el caso de Rodolfo Urbina.

En el cuarto capítulo y central de la tesis, es la investigación del periodo franciscano, época en la cual surgen estas capillas que han sido poco estudiadas desde la historiografía de la arquitectura. Esta investigación se centrará en los documentos epocales tanto del obispado como de la propia curia franciscana de la época y posteriores que han sido escasamente revisados al momento de la presente tesis. Esta labor exige la mayor atención para disponer de una información suficiente que permita conocer cuál fue la injerencia o no de esta orden, y sobre todo de registrar una sistematización de datos que permita identificar el proceso arquitectónico constructivo de las capillas que fueron elaboradas en la época.

El quinto capítulo se centra en la colonización alemana que se inicia también a mediados del siglo XIX y que introduce el arte de la carpintería de armar en el territorio inmediatamente al norte de Chiloé. Lo que indiscutiblemente influirá en el desarrollo de la arquitectura de madera chilota.

Por último el sexto capítulo, viene a ser una decantación de los capítulos anteriores y procurar a través del estudio de casos más detallado, comprender el proceso composicional de las capillas chilotas.

\footnotetext{
${ }^{11}$ Se usara el termino capillas para identificar los edificios religioso, siendo el más común utilizado en el archipiélago. Si bien también se usa Iglesia, este se refiere a la Institución. El otro vocablo templo en Chiloe no se usa.
} 
ANEXO 1: Fotos de Chiloé Jermán Wiederhold 1893.

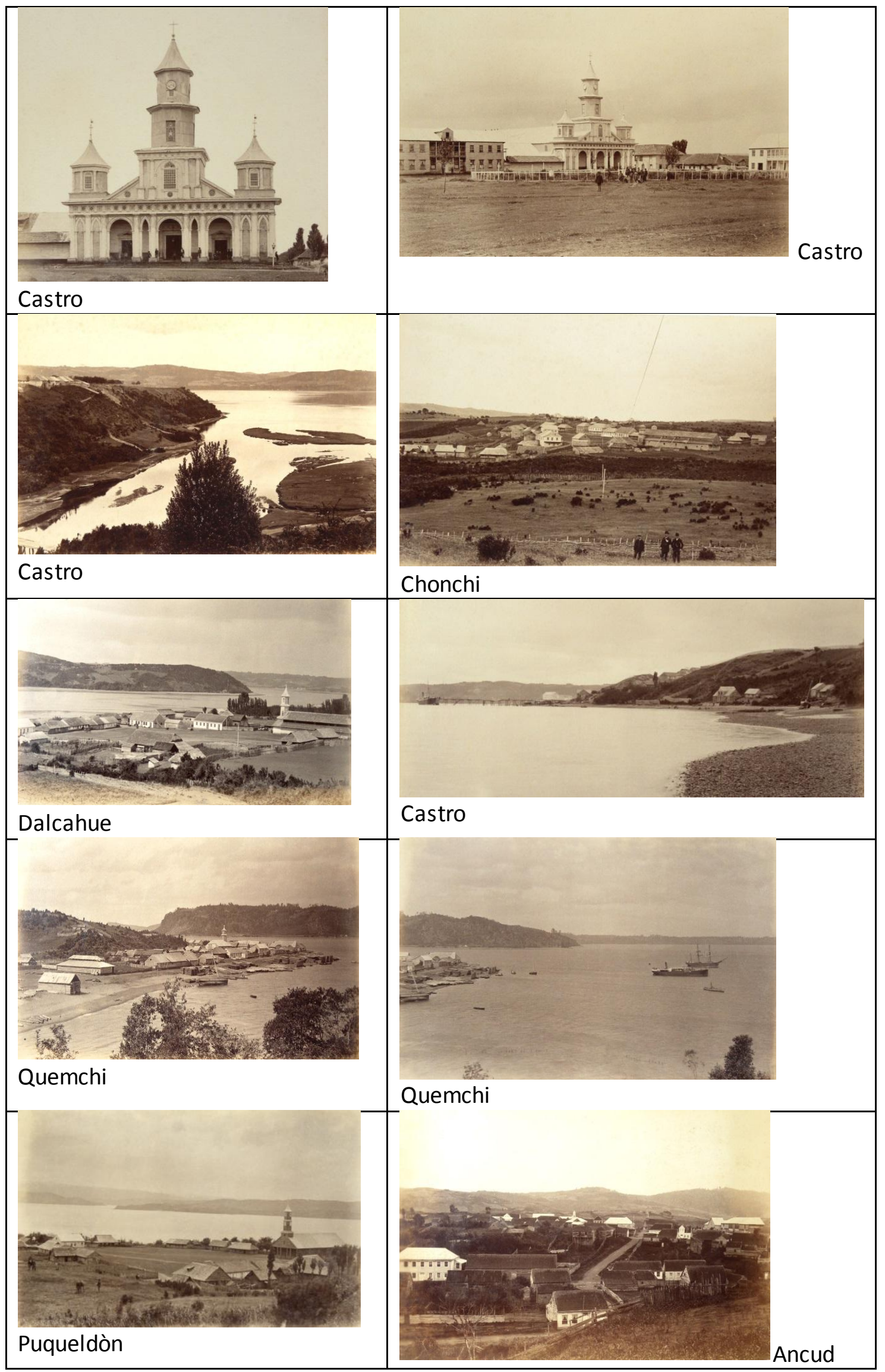


ANEXO 2. RELACION TIPOLOGICA DE LAS CAPILLAS (En archivo adjunto) 
ANEXO 3. LEVANTAMIENTO CRÍTICO ACTUALES DE LAS CAPLLAS (En archivo adjunto) 


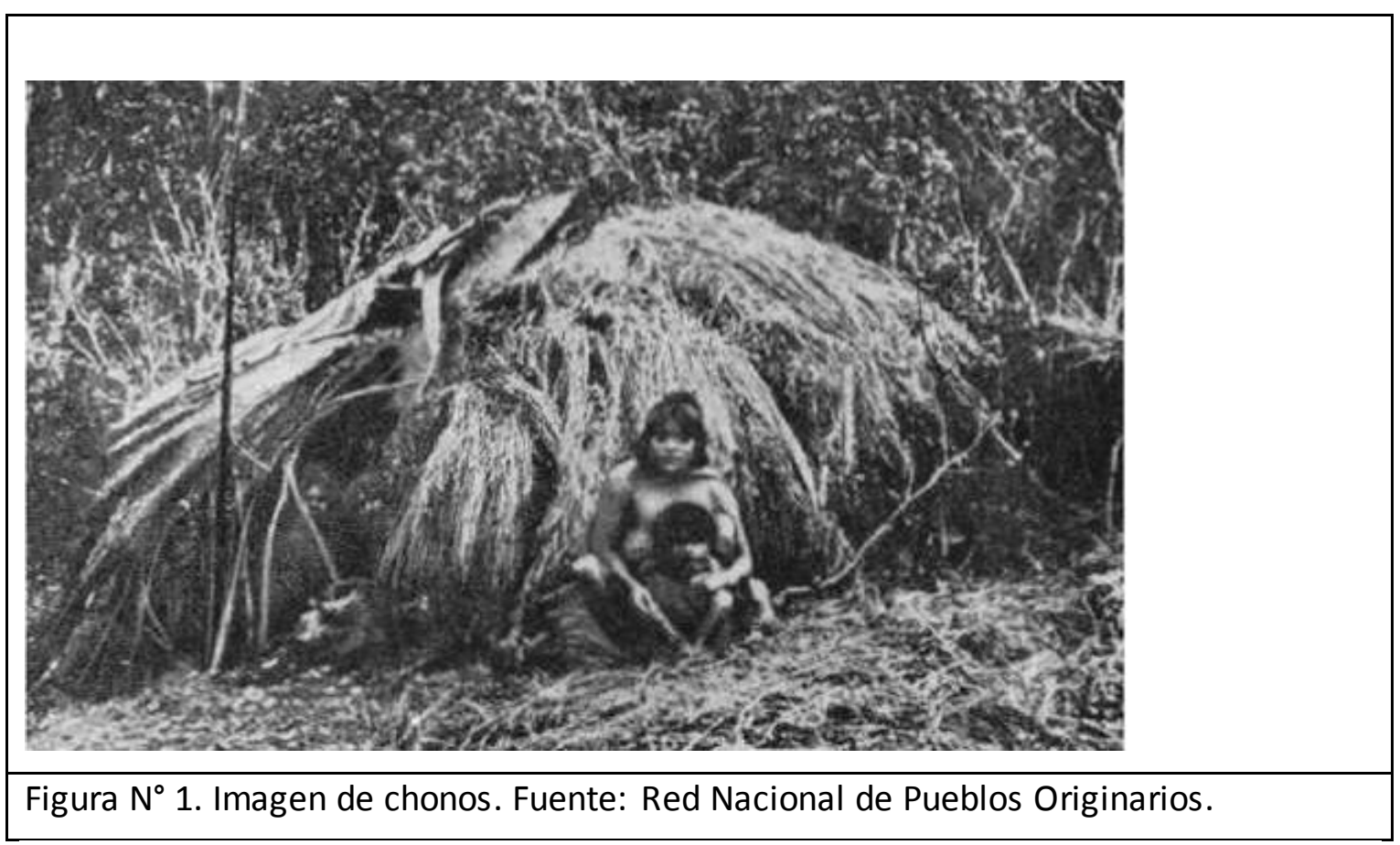

En la actualidad todavía es posible encontrar en algunos parajes insulares a chilotes que probablemente mantengan una forma de vida no muy diferente a la existente previa a la llegada de los colonizadores españoles, aquella que sigue el tiempo de la naturaleza, marcada por el ritmo de las mareas para salir a navegar, pescar y recolectar mariscos. Las fases de la luna y estaciones para saber qué y cuándo sembrar o cosechar, juntarse cerca del fuego durante largas lluvias, vientos y fríos. En suma saber vivir en un estado natural, que comúnmente se denomina primitiva, pero probablemente es un estadio cultural de alta sabiduría o conocimiento para lograr tal nivel de adaptabilidad en un medio ambiente tremendamente difícil. Los pueblos originarios del sur de Chile y la Patagonia ${ }^{12}$ sobresalen porque habitaron en un clima frío y lluvioso con una geografía sísmica plagada de volcanes, glaciares, canales, etc., prácticamente desprovistos de ropa o abrigo, de construcciones y uso de escasas herramientas, pero siendo lo suficientemente hábiles para saber sobrevivir o más bien saber convivir con la naturaleza y ajenos a todo tipo de artificialidad $^{13}$. Fueron importantes étnias también, su diferencia radica en que su cosmovisión y sistema de creencias no estaba centrado en dominar a otros o dominar la tierra sino que en un sentimiento profundo de formar parte del mundo natural.

\footnotetext{
12 Ocupada desde hace 15000 años atrás, datación del sitio de Monteverde en el área continental del archipiélago de Chiloé.

${ }^{13}$ En contraposición con las grandes culturas mesoamericanas o andinas (incas, tiwanaku, etc.) que en a mbientes geográficos más fáciles de habitar tenían una cosmovisión con afanes más civilizatorios y de dominación geopolítica siendo sociedades muy jerarquizadas e imperialistas, entre sus máximas expresiones culturales se destacaron las construcciones y arquitectura megalíticas.
} 
Ante estas formas de habitar desplegadas por tales etnias es posible, por oposición, demostrar que la arquitectura, así como las vestimentas, no tienen simplemente la función de responder a una necesidad primaria de refugio o abrigo sino que son expresión de necesidades más profundas llenas de simbolismos y significados.

A la llegada de los españoles a Chiloé en $1540^{14}$, la colonización propiamente tal fue iniciada en 1567 con la fundación de Castro, se encuentran dos principales etnias: Los Huilliches y los Chonos, su historia en el archipiélago ya tenía milenios; 5.000 años antes del presente, en el caso de los segundos ${ }^{15}$.

Los Huilliches, vinculados a la tierra de tradición horticultora inscrita en el estilo de vida mapuche; sólo ingresaron a la zona, procedentes del continente, alrededor de 900 años atrás, ocupando parte de la Isla Grande y del archipiélago oriental, penetrando hasta los canales e islas de la Patagonia septentrional meridional.

De los chonos hay relatos de cronistas que ilustran su modo de vida. Por ejemplo, de sus habitaciones se señala:

Las de los indios chonos son más fáciles de hazer y más humildes, porque las hazen de unas cortezas de árboles grandes que sirven por un lado de pared y (...) de cubierta. De estas cortezas hacen tinajas para guardar la comida y ollas para cocer el pescado y marisco, de que de ordinario se sustentan por habitar en islas del mar, mudándose de unas en otras con sus casas conforme se acaba el marisco o se huye el pescado. $Y$ porque no parezca novedad dezir que cuecen el pescado en ollas de cortezas, digo que como estos indios no hallan en las islas del mar barro para hazer olla, la necesidad, que es ingeniosa, les enseña a hazerlas de cortezas de árboles y a cocer en ellas quanto quieren. Y el modo es calentando muchas piedras al fuego y echándolas en la olla hasta que yerbe el agua y se cuece el pescado ${ }^{16}$ (Rosales, 1877, Tomo I, p. 151).

Ciencia, religión o paganismo son sistemas de creencias, modos de percibir e interpretar la realidad. Desde el ámbito científico, con su enfoque basado en la razón, objetividad y demostración empírica se puede argüir que entre los pueblos originarios de Chiloé, huilliches y chonos así como tantos otros pueblos paganos del mundo tienen una explicación mágica de la realidad, están colmados de mitos, leyendas, seres sobrenaturales, poderes, espíritus y dioses que subyacen en todo los acontecimientos. Desde esta perspectiva la religión cristiana no es muy diferente, está colmada de

\footnotetext{
${ }^{14}$ Recién en el siglo XVI, el primer español divisa el Archipiélago, Alonso de Camargo en 1540, aunque nada dice sobre las islas que conforman dicho archipiélago. Más tarde, en 1553, Francisco de Ulloa Ladrilleros, enviado por Pedro de Valdivia a ocupar el estrecho de Magallanes, pasa por Chiloé y entrega una primera descripción: Costa limpia, sin bajas, tierra muy poblada hasta la costa, y tierra de muchas ovejas, hay tantas gentes como Arauco... (Lobos, Berg \& Rojas, 2006, p 56.)

15 Este pueblo por estudios del ADN mitocondrial son descendientes directos de primeros humanos asentados en este territorio entre 12000 y 15000 años atrás. Fuente: Programa de Genética Humana de la U. de Chile.

16 ROSALES, P. Diego, S. J. "Las casas de los chonos", en: Historia General del Reyno. Valparaíso: Imprenta de El Mercurio, 1877. Tomo I, p. 151.
} 
figuras mágicas similares: devociones, santos, patronos, parábolas, mitos ${ }^{17}$, etc. Es decir un universo de relatos maravillosos fueron los que trasmitieron los jesuitas a los indígenas o naturales, que no eran tan distintos a las formas de comprender el mundo de estos pueblos. Es probable que tales fórmulas de creencias hayan sido inconscientemente el mejor modo de comunicarse y conquistar, por parte de los misioneros, el espíritu de los isleños: el simbolismo del lenguaje mágico.

De este primer contacto entre isleños e hispanos, vendrá la formación de lo chilote. En el caso de Chiloé dada su australidad, insularidad, aislamiento y pobreza no será un sitio de gran importancia para la corona española, sino que será un espacio territorial entregado fundamentalmente para su evangelización, la que será asumida prácticamente en su totalidad por los misioneros jesuitas.

De aquí en adelante la historia de Chiloé, que había permanecido en una suerte de prehistoria $^{18}$, estará marcada por los contactos externos, que irán incidiendo en la vida social al interior del archipiélago, generándose una particular cultura de permanencias y cambios.

\footnotetext{
${ }^{17}$ El Génesis de la Biblia cristiana sobrela creación del mundo, del hombre, la mujer, el paraíso, el bien y el mal es un relato incuestionablemente maravilloso.

18 Los pueblos originarios no disponían de escritura.
} 


\subsection{La influencia socio religiosa de los jesuitas.}

Para la población indígena "la llegada de los misioneros jesuitas a América $1608^{19}$ 1767) y, en particular, al archipiélago, será el hito de la nueva etapa. Influirán en el sistema de creencias, de asentamiento e incluso de subsistencia" (Berg, Lobos \& Rojas, 2006, p. 64) y marcarán una forma de vida que diferenciará culturalmente a Chiloé del resto del país y del continente hasta el día de hoy.

Los jesuitas son una congregación religiosa formada por San Ignacio de Loyola en 1534. Fueron parte de un movimiento de consolidación religiosa, de la Fe cristiana, en un mundo convulsionado por la reforma religiosa, diferenciada de otras congregaciones por su voto - de obediencia al Papa ${ }^{20}$. Esta congregación es prácticamente contemporánea al surgimiento del protestantismo en Europa, lo que en parte explica su gran desarrollo inicial. Los misioneros enviados a América, utilizan principalmente como instrumento evangelizador un sistema educativo para transformar el alma y el ser de los indígenas. En tal sentido el misionero viene preparado en un rol de educador y su función es "convertir al indígena en súbdito del rey de España, en ciudadano de un municipio, en beneficiario de un futuro mejor $y$, a la vez, dotarlo de la lengua de Castilla y hacerlo hijo de la iglesia católica" (Fajardo, 2007, p.160). Este rol asumido por los misioneros los diferenciará del resto de las funciones de los colonizadores, y en tal condición serán los auténticos formadores de la cultura chilota, que se inicia en este contacto inicial entre lo indígena e hispánico, con la consecuente mestización entre lo profano y religioso que son dimensiones profundas y radicales del espíritu de los pueblos.

El proceso transformador introducido por los misioneros es de tal magnitud que "para el año 1600 ya habían elaborado los jesuitas su carta de navegación, tanto en los mundos de la ciencia y la cultura, como en el de la aculturación religiosa de los nuevos mundos" (Fajardo, 2007, p.11). Este autor, jesuita activo, ilustra y sostiene claramente que como religiosos les interesaba modificar la cosmovisión indígena y someterlos a un proceso de aculturación, lo que implica despojarlos de gran parte de sus creencias y símbolos para conducirlos a otra distinta. Por lo tanto significó cambiar un ritmo y forma de vida condicionado a un entorno absolutamente natural a un entorno gradualmente cada vez más artificial. Esta visión de la misión evangelizadora europea es lo más radical introducido en la vida de los indígenas, ya que irrumpe con la idea del progreso material como factor de bienestar social que hasta ese momento era inexistente e innecesario en estos confines patagónicos

los jesuitas tratarían de romper esa especie de noria circular de la impotencia basada en el binomio falta de necesidades-ausencia de actividad, y para ello crearon nuevas necesidades y con ellas el deseo y la voluntad de obtenerlas,

\footnotetext{
19 Los jesuitas Ilegaron a Chile en 1593. A Chiloé lo hicieron en la primavera de 1609 en la primera misión Ilevada adelante por los pp Melchor Venegas y Juan Bautista Ferrufino que se prolongó hasta 1610. Ese mismo año hicieron la segunda misión (1610-1613), pero esta vez acompañó al padre Venegas el padre Mateo Esteban. En 1617 volvieron el p Venegas acompañado, esta vez por el p. Antonio Prada, para fundar la misión definitivamente (Moreno, 2011).

${ }^{20}$ Este es el famoso Cuarto Voto, exclusivo delos jesuitas cual es el de Obediencia al Papa, pues este, al ser Vicario de Cristo, sabe que es lo que mejor conviene a la Fe. Este cuarto voto permitió liberar a los S.J. de ocupar cargos parroquiales o diocesanos, independizándolos de la autoridad de los obispos, permitiéndoles mayor libertad en la tarea evangelizadora (Moreno, 2007).
} 
pues ese es el móvil principal de las acciones de los hombres (Fajardo, 2007, p.17).

Se gatillará, entonces, el interés de estas etnias y pueblos en la novedad, la invención y el descubrimiento que los sacará para siempre de su ciclo natural de vida, de la memoria oral, la economía de subsistencia que caracteriza la prehistoria, para entrar gradualmente en la historia y el progreso al modo europeo.

\section{El modo misionero.}

El modo jesuita ${ }^{21}$ de convertir a los indígenas y guiarlos hacia un nuevo mundo civilizado y cristiano se basó en diversos instrumentos políticos. Básicamente se pueden considerar tres, la ya comentada educación, la reducción en pueblos y los que es propiamente el proyecto misión. Todos estos instrumentos que configuran el modo jesuita son planes comunes para toda América, sin embargo en cada una de las misiones establecidas van tomando fisonomías y derroteros diferentes. Pues, si algo hace particular a esta orden y su penetración religiosa es que también supo ada ptarse para poder establecerse y relacionarse apropiadamente con el modo indígena. En tal sentido esta fue su mayor virtud de no cambiarlo todo, sino que también reconocer valores en el otro y saber asimilarlas en beneficio común. En este escenario de intercambios culturales, Chiloé no va a ser la excepción sino que por el contrario, por las características étnicas de su población y la condición de archipiélago que se mantendrá muy aislado en la colonia del resto del continente, se irá configurando un proceso propio, diferenciador y de particular identidad.

La preocupación de los jesuitas era finalmente "construir con ellos una sociedad nueva y distinta con parámetros ejemplares que no encontraban en la sociedad europea" (Gutierrez, 2007, p.56). Estos confines y su naturaleza salvaje daban la oportunidad de recrear la utopía del paraíso en la tierra. Esta posibilidad de la utopía y de inventar nuevos mundos es el motor impulsor interno, lo que mueve a los hombres a crear y quizás parafraseando sobre la utopía "se trata del hombre que juega a ser dios, no del hombre que sueña en un mundo divino" (Ruyer, 1950, p.35).

Resulta que finalmente toda esta acción civilizatoria es conducida por el viejo continente con todo un imaginario colectivo y fuerza creadora impulsada en el Renacimiento y con el Barroco en ciernes, hacia el "nuevo continente" para diseñar e

${ }^{21}$ Incluía la contemplación (ejercicios espirituales) y la acción (Misión). La primera era meditación acerca de la misión universal, entendida esta como repetir la misión de Cristo, lo que los convertía en misioneros con una profunda vida interior, o que acentuó su "vocación misionera", llevándolos a desarrollar las Misiones Populares, Misiones Volantes y la afamada Misión Circular en Chiloé, que conjugaba evangelización y aventura. Esta fue una estrategia de evangelización, para lo cual enviaban siempre al más idóneo de acuerdo a cada caso específico y al fin que se pretendía.

Los Jesuitas son una orden religiosa diferente a las que existían en ese momento (similar en ciertos aspectos a los Barnabitas y Teatinos), ya que no eran monjes de clausura ni mendicantes, sino que clérigos regulares (sacerdotes sometidos a una regla), en donde la oración comunitaria se transformó en una obligación personal (sin lugar ni horario fijo), ya que los horarios (cfr. Modo Benedictino), les quitaba autonomía. Además no tenían hábito, sino que podían usar la vestimenta común de los clérigos (Moreno, 2007). 
implementar un esperanzador futuro de la humanidad. Es una suerte de disparo hacia la utopía y porvenir que aspiraban los europeos y que solo hoy se puede entender con la distancia y el tiempo transcurrido. Llegando a provocar sentimientos o expresiones tales como "puede decirse que el descubrimiento de América es el germen y motor de la filosofía moral y política de la modernidad" (Fernández Herrero, 1996, p.7).

\section{La formación pedagógica.}

Hubo una clara intención de guiar al indígena y sus creencias hacia un solo Rey (Imperio Español) y un solo Dios (Iglesia Católica). En estas dobles personificaciones e instituciones se manifiestan y sintetizan las dos realidades de la existencia humana: vida y muerte respectivamente. Por otra parte para guiar un proceso civilizatorio, era necesario cultivar una vida comunitaria para la formación de ciudadanos cultos, probos y virtuosos que dieran paso a la producción del hacer y el saber.

En tal sentido el misionero venía con una preparación sólida para emprender su rol educador y su tarea era traspasar las siguientes enseñanzas:

-El dominio de la cultura clásica y la asimilación de un humanismo nuevo... consistía en despojarse de las concepciones bárbaras de la vida. Por ello, el cultivo de las bellas letras debía transformarse en un movimiento dinamizador de la vida intelectual y religiosa, pues, en definitiva, se trataba de un humanismo moral y profano.

-El método científico otorgado por la filosofía y la teología, y aquí, para simplificar, lo circunscribiremos a la escolástica.

-El ejercicio de las virtudes a través de la ascética y la mística, llamadas también ciencia espiritual o arte de perfección. (Fajardo, 2007, p.22)

De lo anterior se puede desprender que hay una visión integradora "entre una disciplina escolar, una disciplina de pensamiento y una disciplina de lenguaje" (Barthes, 1974, en Fajardo,2007 p.13) que usará el estilo jesuita e irá consolidando la aculturación con el traspaso de habilidades y conocimientos. En este aspecto es singular la transformación buscada y lograda por los misioneros, ya que afincados en el territorio en una vida diaria y permanente con la población local y una férrea disciplina de labores y educación van creando una fuerza de trabajo y de especialización en distintas expresiones artísticas y técnicas

Los jesuitas les enseñaron nuevos oficios y los ayudaron a perfeccionar los ya existentes. Así, la textilería de aquellos grupos que eran agricultores y pastores vio incrementado el universo de sus piezas y la calidad de sus tejidos y diseños, gracias a nuevas tecnologías. Lo mismo ocurrió en el ámbito de los instrumentos de madera, de la cestería y de la cerámica (Consejo de Monumentos Nacionales, 2000, p.34).

Esta situación es de especial relevancia porque se va aquilatando un grupo de artesanos y maestros en nuevos oficios y que reciben de primera mano, desde sus instructores extranjeros, las formas y técnicas con otro imaginario y tradición vinculada a la Europa cristiana. Tales actividades serán fundamentales en el desarrollo posterior y en la formación de mano de obra calificada en distintos rubros, ya que se podría argüir con casi absoluta seguridad que hasta la llegada de los misioneros la 
especialización laboral casi no existía, sino que en general eran compartidas y asumidas por todos los miembros de los grupos y clanes insulares. De esta manera se constituyó un grupo importante de artesanos vinculados a las actividades tradicionales indígenas, pero se introdujeron e innovaron en otras necesarias para sociedades más complejas $^{22}$ o sofisticadas tales como carpinteros, herreros, sastres, zapateros, pintores y escultores, entre otros (Benavides, 1988).

La capacitación permitió entonces cubrir necesidades, crear nuevas y entrar en el círculo o espiral de progreso material y tecnológico que llevará al desarrollo de la infraestructura requerida, entonces será el traspaso desde la confección a mano y utillaje a las herramientas y a la racionalización del trabajo ${ }^{23}$. Siendo la infraestructura la base indispensable para la materialización de la vida comunitaria a través de las reducciones y ciudades a fundar en el archipiélago en el proyecto hispánico y misionero.

Existe documentación suficiente que testimonia este proceso, de aculturación por un lado y de apropiación por otro en la vida indígena, de estas nuevas prácticas y que fueron cultivando y ampliando el universo de manifestaciones culturales que recibían, "la propensión por la novedad y su inclinación a imitar usos extraños hicieron que se introdujesen sin dificultad y desde el primer momento tanto la escuela de primeras letras como la escuela de música" (Gilij, 1965, iii, p. 63-64). "Y el misionero italiano Felipe Salvador Gilij llegará a confesar: $Y$ si he de decir libremente lo que siento, ninguna cosa fue jamás llevada de Europa a aquellos lugares que más les agradase, ninguna que imitaran mejor" (Lemmon, 1979, p. 149-160 en Fajardo, 2007).

El fenómeno de la aculturización es singular en los pueblos indígenas, que absolutamente ajenos a la idea del progreso europeo, aprenden con notable facilidad las enseñanzas que reciben de sus maestros. Esto se expresa, tanto en las dimensiones tangibles del objeto, como intangibles de lo que representan dichos objetos y en la medida que se van internalizando como parte de un nuevo acerbo cultural, haciéndolo propio. La capacidad de darles nuevas reinterpretaciones desde el imaginario local, que será crucial para la mestización.

Si bien hay un proceso de aculturización, que implica despojar a las etnias de su cosmovisión, no obstante, muchos significados ancestrales permanecerán latentes en el inconsciente colectivo, entendido como aquellos símbolos más primitivos que perduran en la memoria personal y compartida de un pueblo (Jung, 1995). Por consecuencia es inevitable que surjan las manifestaciones más profundas e inmemoriales, sumadas a ciertas tradiciones y formas propias que se verán expresadas en el cotidiano vivir. De tal manera que la aculturación no es total sino que los resabios culturales de chonos, huilliches, mapuches y otras etnias patagónicas estarán vigentes y compartirán con lo introducido por los misioneros.

\footnotetext{
22 El término complejo, adj. Que se compone de elementos diversos, según RAE. No obstante, la vida de los pueblos patagónicos precolombinos en un entorno natural muy difícil requiere una sofisticada adaptación y por lo tanto no deja de ser complejo.

${ }^{23}$ En el caso de la arquitectura de Chiloé, que se verá en el ca pítulo 6, la racionalización del trabajo tuvo su expresión en la construcción, la que se realizaba por etapas:(1) recepción y preparación del material, encuentros y uniones; (2) montaje; (3) revestimiento exterior y cubierta; (4) terminaciones.
} 
Por lo pronto es sabido que el sistema educativo y transformador de los jesuitas no es un modelo absolutamente impositivo, sino que buscaba crear diálogos con muchos elementos significativos de los pueblos a evangelizar

Los jesuitas, como en sus otras experiencias misionales, respetaban las creencias de los indígenas en tanto no fuesen contradictorias con la fe católica. Buscaron, como sucediera con los guaraníes, llevarlos de un sistema poligámico a monogámico y persistieron en una prédica tendiente a erradicar las idolatrías (Gutierrez, 2007, p.56).

Se observa, entonces, que las principales actitudes morales que perseguían los misioneros era el monoteísmo y monogamia, condiciones adoptadas formalmente por los habitantes insulares, lo que no implica que haya un irrestricta fidelidad a tales creencias o, dicho de otro modo, una coherencia entre lo que se diga y por otro lado se haga a hurtadillas. Pero para la cosmovisión indígena no existía el concepto de pecado $^{24}$. Esto demuestra el abismo cultural existente entre ambos mundos y

ayuda comprender, las permanentes quejas de los misioneros católicos al referirse a los mapuches como inveterados polígamos y borrachos ${ }^{25}$. Para el indígena tales comportamientos no contravenían ninguna regla social emanada de su propia cultura, así, al no desobedecer sus propios valores y costumbres estos no constituían pecado, por lo que difícilmente se apartarían de ellos (Rondón, 2001, p.12).

En tal sentido para los indígenas de Chiloé, los huilliches, a diferencia de sus parientes continentales, los mapuches, el discurso civilizador cristiano por parte de los jesuitas fue aceptado más tempranamente. Siendo que "no sólo carecían del sentimiento de pecado que les hiciera sentir la necesidad de ser perdonados o redimidos, sino que además, no entendían el impulso occidental de asentarse en pueblos, implementar una jerarquía vertical, como tampoco atesorar bienes materiales" (Rondón, 2001, p.13).

En todo caso la cuestión que interesa destacar en los sistemas de creencias que perduran en la visión insular, se refieren entre otros al universo de seres sobrenaturales que le dan un marco interpretativo y una carga significativa a las experiencias sobre la vida y la muerte que son sustantivas para comprender lo chilote.

La gran preparación y profunda fe de los misioneros jesuitas, así como la convicción en el logro de la misión, les permitía sobreponerse a todas las dificultades, que veían como la cruz de Cristo, en un continente para ellos absolutamente salvaje. Esto les permitió llevar a cabo las reducciones para congregar a los indígenas en un modelo

\footnotetext{
24 "Esta idea que evidentemente no incluía el mundo conceptual mapuche, fue traducido sistemáticamente por hueril, esto es, actuar o hacer mal. Este hecho me ha Ilevado a concebir la idea de que en el pueblo mapuche, así como tal vez en otras etnias americanas, el sentimiento de culpa -y por tanto del pecado- nunca fue concebido o no al menos en el sentido cristiano occidental" (Rondón, 2001, p12.).

${ }^{25}$ Se alude mucho a la chicha entre los indígenas de Chile, bebida alcohólica de la fermentación de la manzana, cebada u otra, con múltiples usos, tales como medicinal, para combatir el frío o para concentrarse y entrar en trance para comunicarse con sus ancestros.
} 
civilizatorio original, que encontró un punto culminante, la fundación de la misión circular en Chiloé, y cuya vigencia se mantiene hasta hoy viva, al igual que las misiones en la Chiquitanía en Bolivia.

\subsection{La acción jesuita en América.}

Conocer el contexto de las misiones en América es fundamental ya que aquí arranca tanto la política religiosa y doctrinal, junto a las primeras formulaciones urbanísticas y arquitectónicas que disponen de varios elementos comunes, de manera que se puede identificar con mayor claridad el arquetipo de templo y espacio religioso "original" de los misioneros, no obstante también existen diferencias entre ellas.

Todo esto porque las distintas misiones jesuíticas americanas se regían bajo los mismos decretos reales y se administraban bajo los mismos criterios y modelos administrativos. Sin embargo, la autonomía de cada región, junto a las diferencias geográficas y culturales, permitió el surgimiento de diferencias, dentro de un marco común estructural (Limpias, 2007, p.76).

Básicamente interesa destacar los aportes fundamentales de las misiones en la formalización del espacio religioso americano, que son ampliamente reconocidos por diversos autores en el estado de la cultura actual, que son necesarios de mantener presente y que sería infructuoso extenderse en su argumentación. Para efectos de lo que nos interesa, tienen que ver con la doctrina y su forma de plasmarse en el espacio urbano y arquitectónico americano.

-La doctrina religiosa de los jesuitas viene imbuida por el espíritu de la contrarreforma y su interés principal es la educación, la predicación y la difusión del mensaje católico, a los cuatro vientos y uno de los vehículos primordiales de propaganda es el arte y por extensión la arquitectura, ya que es fácilmente comunicable (accesible e inteligible) ad maiorem Dei et Ecclesiae gloriam, "A la mayor gloria de Dios y la iglesia". No en vano se ha dicho del "humanismo jesuítico" es el alma de la cultura barroca americana, "cimiento de una ilustración esencialmente literaria y política que... produce el conflicto eminentemente romántico, expresado en dos direcciones: en la ideología política de la independencia...y en el pensamiento crítico de la realidad económica..." (Hernández Sánchez-Barba, 1988, p. 295 en Fajardo, 2007).

En tal sentido construir espacios que acojan a los creyentes e ilustren el poder divino es primordial para la evangelización misionera a la manera barroca, pero no se cristaliza siguiendo las formas originales de la arquitectura de sus creadores principales, Bernini y Borromini, a través de templos y plazas de geometrías curvas (circulares o elípticas) sino que se centra en los contenidos del espíritu de la época barroca de exaltar el encuentro con Dios e incitar a una manifestación festiva.

- En la visión urbanística, "descartan la cuadrícula como alternativa de diseño urbano y más bien aplican un modelo alternativo, de características propias, pero con matices distintos en cada región" (Limpias, 2007, p.76). El centro de la ciudad misionera o reducción se concebirá como un espacio absolutamente sagrado procesional con la plaza ceremonial religiosa y el templo, diferente de la plaza fundacional de la ley de indias de carácter cívico-religioso.

-En la visión arquitectónica ocurre algo similar, no consideran los modelos barrocos sino que retoman la tradición renacentista de templos con naves de ángulos rectos. 
"En toda América el barroco aparentemente encontró dificultades insalvables para incorporar la espacialidad dinámica y compleja que implican los muros curvilíneos, las bóvedas ovoidales y las transparencias fenomenales profundas" (Limpias, 2007, p. 8384). El barroco entonces adquiere profusión en el tratamiento de las superficies arquitectónicas, a un modo escenográfico, en interiores y exteriores de los templos a través de los revestimientos, decorados y policromía que se insertan en el edificio y en el mobiliario.

En el caso de las misiones americanas hay grandes similitudes entre Chiloé y las de Paraguay y Bolivia. Desde el punto de vista urbanístico, en Paraguay, la capilla y sus dependencias se sitúan también en el fondo de la plaza, como en Chiloé. Las iglesias del archipiélago tienen una relación clara con las de la primera etapa de las misiones de Paraguay -que no se han conservado- y con las de Moxos y Chiquitos, particularmente de grandes naves con cubiertas a dos aguas y corredores para protegerse de las lluvias. A una y otras les falta el elemento característico de las iglesias chilotas, la torre fachada. Por otra parte, si en la primera época de las misiones paraguayas, y en Moxos y Chiquitos, se usó madera para construir, junto con otros materiales, en Chiloé se usa exclusivamente madera, y las uniones son de ensambles o tarugos (Consejo de Monumentos Nacionales, 2000).

Desde el punto de vista cultural, Chiloé y Moxos y Chiquitos en Bolivia, son los únicos sistemas misionales que permanecen vigentes y vivos dentro del continente. El caso de Chiloé se diferencia del de Moxos y Chiquitos, en que aquí se trata de misiones dispersas, no de misiones concentradas -reducciones- como en los casos bolivianos. (Consejo de Monumentos Nacionales, 2000)

En las anteriores descripciones se pueden rescatar las principales relaciones de los proyectos jesuíticos y desprender una visión de la arquitectura que compartía la orden para distintos casos en America.

\subsection{El Urbanismo y la arquitectura jesuita en Chiloé.}

\section{La misión circular, la refundación del "hue" insular.}

Los jesuitas vienen con una renovada y sólida vocación. Empeñados en los estudios, la enseñanza y preparados en diversas actividades "mundanas" ${ }^{26}$, fueron capaces de adaptar su doctrina y visión civilizatoria a la realidad que descubrieron en Chiloé. Entretejieron sutilmente su evangelización con las diversas expresiones nativas, incluso con aquellas denominadas paganas, es el caso de la figura de la machi o curandero, que será el "fiscal" de la iglesia y cuyo rol consistió en asumir las funciones necesarias en ausencia del misionero; igualmente el ritual del machitún, ceremonia de sanación colectiva a cargo de la machi, se adapta a la celebración cristiana (Berg, Lobos \& Rojas, 2006).

\footnotetext{
${ }^{26}$ Los Jesuitas, por su carisma (en todo amar y servir) son esencialmente misioneros. La enseñanza (a través de los colegios) es parte de la evangelización. Se envían los más idóneos según la ocasión, prefiriendo aquellos que hablaban la lengua del lugar (o que tenían facilidad para aprenderla). Por eso adaptan y se adaptan, sin renunciar al objetivo de su (la) misión.
} 
Con el propósito de convertir el archipiélago en el "Jardín de la Iglesia", crean la Misión Circular, circuito marítimo para impartir los sacramentos y ritos cristianos a la población durante un viaje que se repetía cada año. ${ }^{27}$

Los jesuitas reconocen el valor del "hue", lugar en lengua veliche, como sitio privilegiado en torno al cual se asentaba en forma dispersa, no concentrada, la población nativa. Por sus características geográficas de bahías o playas costeras del mar interior, reunían las condiciones ideales para fundar; así fortalecieron la estructura nativa, la memoria cultural y natural del archipiélago (Urbina Burgos, 1986).

A partir de estos "hue" se refunda simbólicamente lo nativo, como un espacio concreto, construido ahora para el ritual y la capilla; el lugar de encuentro entre los hombres y de los hombres con Dios. Es en esta acción donde la Misión Circular se echa andar creando lugares organizados y activados en la visita permanente. Estos lugares son el centro de convergencia de los habitantes y hasta el día de hoy conforman el conjunto de poblados que caracteriza el urbanismo insular. (Berg, Lobos \& Rojas, 2006)

El Mapa Missio Chiloensis Geographice Descripta (Figura $N^{\circ} 2$ ), de mediados del siglo XVIII, señala 76 pueblos con 2295 casas y 11047 almas. Esta información no sólo señala datos geográficos sino también reconoce a todos como almas, seres espirituales, nativos y españoles; da cuenta de los sacramentos y resalta los matrimonios, por lo tanto se ha dejado la poligamia. La carta de navegación de la Misión Circular comienza en Ichuac, Isla de Lemuy, antes del inicio de la primavera, por su condición estratégica de caleta abrigada, con población numerosa y relevante cantidad de encomenderos. Se viaja de noche, incluso en otoño e invierno, porque las condiciones de navegación, al contrario de lo comúnmente pensado, son más calmas.

Atendiendo a su importancia, las capillas estaban jerarquizadas, determinando la detención de la misión circulante dos, tres o cuatro días; a este efecto los planos e itinerarios las marcaban con cruces simples, metropolitanas o patriarcales (Guarda, 1984).

\footnotetext{
${ }^{27}$ Se tratará de la adaptación de la clásica misión circulante, propia del instituto, acomodada a las peculiaridades del archipiélago; debe tenerse presente que en oriente, desde los tiempos de San Francisco Javier, pero sobre todo en la misión de Filipinas, los jesuitas habían adquirido análogas experiencias pastorales. (Guarda, 1985)
} 


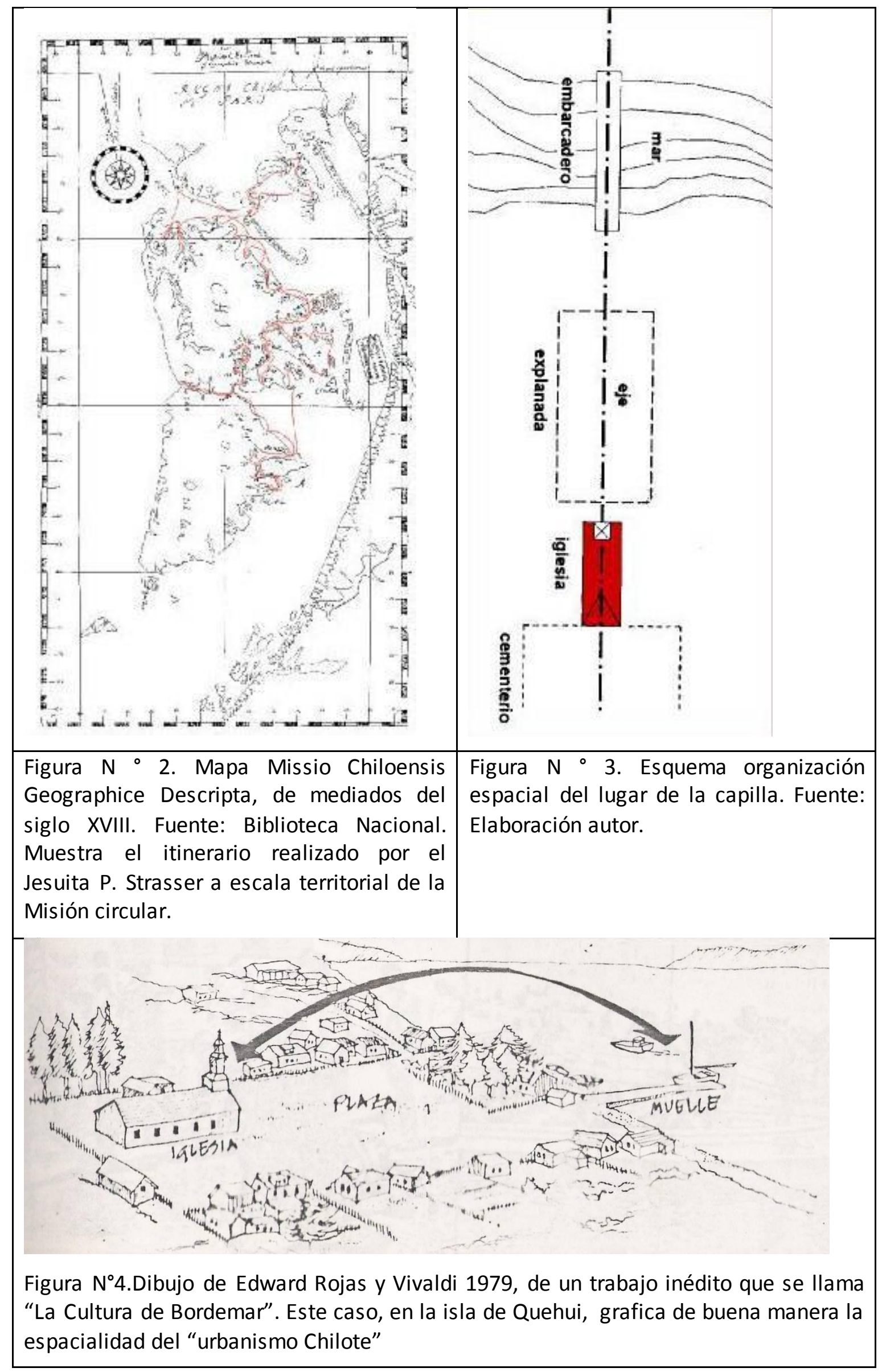




\section{Las capillas, origen del urbanismo insular.}

El sistema de organización espacial de cada lugar de la Misión tenía un patrón conceptual común; un eje vinculaba una secuencia de tres espacios fundamentales (Montecinos, 1977) (Figura $\mathrm{N}^{\circ} 3$ ).

- En un extremo, el embarcadero, como conector entre mar y tierra.

- En el centro la plaza explanada e iglesia, estos son el vacío y edificio respectivamente, de carácter socio-ceremoniales ${ }^{28}$. Es el espacio de encuentro entre la tierra y el cielo. La capilla era el único objeto arquitectónico y símbolo de la nueva cristiandad. El altar era el punto y remate en la capilla al que llegaban todos los caminos del mar y de la tierra.

- Detrás de la capilla, el cementerio, como remate final de este camino de la vida y la muerte.

Así, por ejemplo, esta configuración es rigurosa en casos como Quehui (Figura №4), Vilupulli, Dalcahue o Rilán; en otros casos se va modelando según las situaciones geográficas de cada lugar. En Chonchi, una larga calle sinuosa une la plaza y el embarcadero; en Tenaún, la plaza se alarga paralela al mar y la iglesia, al extremo en escorzo, ofrece una perspectiva casi barroca, cada poblado tiene los mismos elementos espaciales, pero diferenciados y únicos, de acuerdo a las particulares condiciones del temitorio, del "hue". (Berg, 2005)

La visión que nos entregan las ciudades chilotas se distancia del modelo homogéneo del damero hispanoamericano, tanto del promulgado por las leyes de indias, como de aquellos que se ajustaron a otras circunstancias durante la colonización española (Gutierrez, 2006).

Solo se exceptúa la ciudad capital, Santiago de Castro, con trazado damero y fundada en 1567 por Martín Ruiz de Gamboa sobre una planicie a $30 \mathrm{~m}$ de altura al centro de la isla y junto a un canal interior y río. Siendo Castro una pequeña villa para ojos actuales fue una de las ciudades principales de la colonización y por largo tiempo la más austral de América:

Al centro la gran Plaza de Armas con la forma de un damero cuadrado sin construcción como eje urbano y puesta la horca como símbolo de justicia, junto a la columna de piedra o tronco de árbol con el rollo de la públicas entre ellas, al poniente la iglesia, las casas reales que mantenían el estandarte y las cajas de tesorería, el costado Norte se reserva para la casa del Gobernador o Corregidor y el Cabildo con su edificio construido al fundarse la ciudad. Al costado de esta plaza vacía, en medio de la traza fueron construidas las casas principales de mayor calidad y poseían especie de portales eran propiedades de aquellos vecinos más connotados pudientes o influyentes por el cargo ostentado o por ser hidalgos era el principal foco de actividad: el lugar del mercado de las fiestas del ejercicio con las armas, de las procesiones y, a veces, de los ajusticiamientos (Montiel, Dante, año en Berg, Lobos \& Rojas, 2006, p.61).

\footnotetext{
28 Las iglesias se sitúan en un gran espacio vacío, la plaza, útil para la celebración externa de las festividades religiosas, especialmente procesiones, y para las ferias que tradicionalmente las acompañan. Enfrentando la fachada de la iglesia preside una cruz, recuerdo del típico crucero peninsular: se ha visto en esta modalidad una reminiscencia medieval de la plaza-mercado español, antecedente de todas las de América (Guarda, 1985).
} 
Durante más de doscientos años de existencia, Castro, es tan sólo una pequeña villa que mantiene su traza, pero con pocas y sencillas edificaciones. Conserva un rol urbano simbólico, por ser centro religioso, político y social; no obstante estas funciones son más bien administrativas y su ocupación como espacio público es eventual (Berg, Lobos, \& Rojas, 2006). De esta manera Castro capital de la cristiandad insular será un referente urbano principal para efectos de este estudio. Así se señala sobre los "centros urbanos" a propósito de Castro

sabían aprovechar oportunamente las dos ocasiones en que anualmente se reunían todos los que se reputaban por vecinos de ellas, por más que viviesen a muchas leguas de allí, a saber, en semana santa, y el día del apóstol Santiago. En ambas ocasiones armaba cada familia en la ciudad una ramada en que cobijarse aquellos días (Enrich, 1891, TII, p.156).

En general la imagen urbana es muy modesta para los caseríos chilotes en el siglo XVIII.

Todos los poblados carecen por igual de riqueza urbanística. Se les suele calificar de "conjunto de chozas", en algunos casos no van más allá de simples rancheríos que se aglomeran en forma espontánea, en traza irregular. Las casas, iglesias, conventos y otros edificios principales están enteramente construidos de madera (Urbina, 1983, p. 52).

Para darse una imagen de la época solo Santiago de Castro tenía el título de ciudad en el

siglo XVIII, esta casi deshabitada, incluso pierde los vestigios de su primitiva traza.

La población permanente es escasa. En 1755 cuenta con 1.158 habitantes, pero dispersos en los campos aledaños, de los cuales 50 son vecinos encomenderos y escuderos. El censo de 1787 sólo arroja 91 habitantes españoles y 339 indios de residencia de la ciudad, siendo considerada mera aldea "porque sólo encierra un corto y pobre vecindario de los naturales del país, destituido absolutamente de facultades". Hacía 1791, su población es de 150 familias "de continua residencia en ella", y en 1797 se compone de 250 casas". (Urbina, 1983, p. 66).

Esta es la situación social y urbana de la capital del archipiélago en el XVIII. Con respecto a las edificaciones el mismo Urbina señala que solo destacan las casas del Cabildo en la plaza y

que no obstante su triste aspecto urbano, Castro poseía el conjunto de edificios más importantes del archipiélago: una iglesia parroquial o matriz, un convento seráfico de San Francisco, otro de Nuestra Señora de la Merced, un colegio y una iglesia de la Compañía de Jesús, colegio que John Byron describe como "muy extenso", y que con motivo de la expulsión de los jesuitas se entrega a los misioneros del colegio de Chillán y posteriormente a los de Ocopa (Urbina, 1983, p. 67). 
La fundación de los sitios de capillas dada por los jesuitas ya se ha dicho es el inicio de la red de poblados del urbanismo insular, sin embargo es importante al mismo tiempo enfatizar que los llamados pueblos son más un entorno geográfico que un espacio urbano, donde la capilla señala un lugar. "En este sentido se entiende la observación de Amat de que "los pueblos más bien formados de que se compone esta provincia, son los de los indios", De ahí que de los setenta y dos en 1741; setenta y siete en 1750 ; ochenta y tres en 1790, sólo cinco lo sean pueblos de indios en estricto sentido" (Urbina, 1983, p. 52).

Tales cifras nos refieren a que estamos ante la presencia de parajes geográficos y que solo se reconocen como asentamientos 5 pueblos de indios, los cuales corresponden a sencillísimos caseríos de escasas familias asentadas en forma dispersa en torno a la capilla.

\subsection{La arquitectura y las capillas de madera.}

En el inicio del periodo de la colonización hispánica se hacen intentos con el sistema de tapial, pero dada la fragilidad del barro como material de construcción en un ambiente lluvioso y sísmico, este se sustituye. Con la llegada jesuita la arquitectura se va consolidando en el uso de la madera, tanto por ser un fácil recurso local y que los nativos sabían trabajar en sus formas elementales. Las técnicas utilizadas se fueron perfeccionando con el tiempo, los nativos siguieron con su habitual sistema de amarre con fibras vegetales y las maderas son apenas labradas, utilizándose en su condición más natural (ramas y troncos).

Una importante diferencia que realizan los indígenas es en sus viviendas, que dejan las formas orgánicas para reemplazarlas por formas geométricas simples. Más que el aspecto exterior de la vivienda india, la novedad radicaba en el interior. Los jesuitas enseñaron a los naturales a tener habitaciones separadas de padres e hijos. EI padre misionero Arnaldo Jasper, además de las mejoras que hizo en la residencia "dispuso las viviendas de los naturales, dándole una forma más cómoda y más adaptada a conservar la moralidad de las familias" (Enrich, 1891 TII, p. 153).

Todo esto se consiguió al conciliar la ruca con la casa europea. De la primera se respetó la concepción del hogar huilliche ${ }^{29}$ con esta disposición central de la cocina; la casa-fogón, el fuego, lugar de reunión, abrigo, comida, secado de carnes, mariscos y pescados, base de la gastronomía chilota. La cocina era casi toda la casa y allí estaban también los animales. Los dormitorios eran sólo pequeños cuartos donde había un rústico catre y pellejos para cubrirse. Las viviendas de los españoles siguen la misma organización del fogón central, más amplias, pero construidas con mejores maderas y técnicas. Se instaura una tipología que perdurará, las viviendas son un refugio, tienden a ser concentradas para mantener el calor, con pocas aperturas al exterior; se impone la cubierta inclinada y de madera o pajiza, material que es un gran cobertor térmico, pero, al mismo tiempo, combustible y presa de incendios. (Berg, Lobos \& Rojas, 2007)

En suma se va formando un mestizaje, tanto en las formas constructivas como en las formas de convivencia social y lo que se ha denominado en "unión residencial"

\footnotetext{
29 “Lo más importante en ellas es un gran cuarto, generalmente con piso de tierra, destinado al fogón que está permanentemente encendido. Alrededor suyo se reúne la familia” (Urbina, 1983, p.53)
} 
(Urbina, 1983). Nativos y españoles conviven no exentos de conflictos; en el "Jardín de la Iglesia" se casan entre ellos, paganos y cristianos.

Las primeras capillas, de acuerdo a las fuentes escritas se señala que las primeras levantadas fueron muy rústicas

lo primero dispusieron que en Chile todas las iglesias pobladas de indios se hicieran capillas o iglesias para que hubiese parte fija donde todos acudiesen a rezar (...) porque de esta manera no sería necesario ir a buscar de rancho en rancho ni celebrar el santo sacrificio de la misa en el toldo, que más decente era celebrar en casa, aunque pobre, destinada y consagrada a Dios.... Pronto la modalidad se va desarrollando: las fábricas provisorias van sustituyéndose por definitivas; en pueblos más importantes las iglesias se enriquecen, acaso se complican, no en un sentido peyorativo, sino en adornos y virtuosismos constructivos a los conocidos inicialmente. Sorprende la rapidez con que se construyeron, aunque no sean tan elaboradas como la de Achao, que se concluye en el plazo de un año; las más interesantes serán las de Castro, como en el siglo XIX las sucesivas catedrales de Ancud (Guarda, 1995, p. 237).

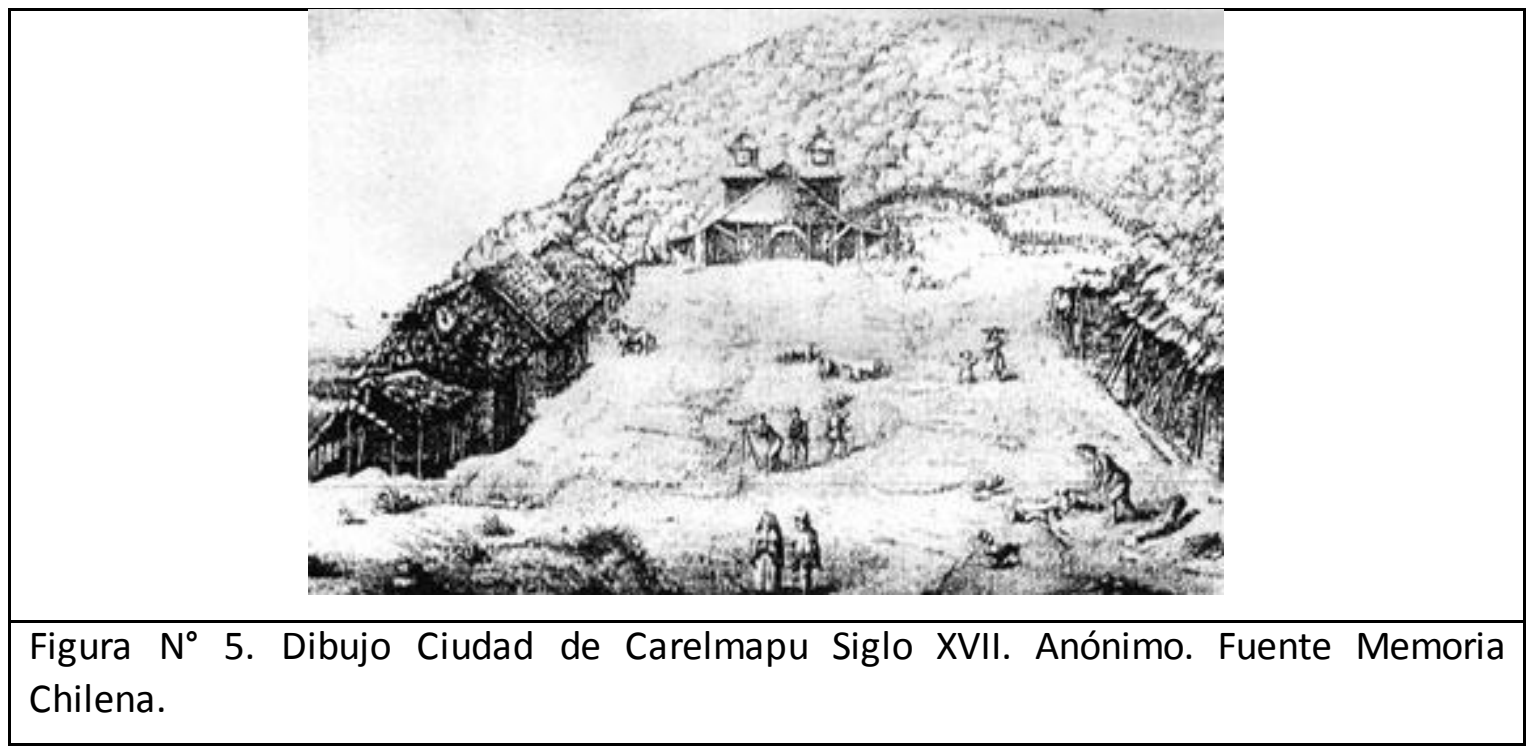

\section{Composición arquitectónica y constructiva de las capillas jesuíticas.}

De la arquitectura de las capillas sólo hay descripciones escritas y bastantes generales referidas a la jesuita, muchos escritos posteriores a esa época citan las mismas frases de las escasas fuentes históricas existentes. No existen registros gráficos ni planimétricos del período jesuita epocales, salvo un dibujo anónimo del siglo XVII (Figura $\mathrm{N}^{\circ}$ ) y otro de Parker King de 1829 (Figura $\mathrm{N}^{\circ} 6$ ) que nos dan una imagen de ellas. En el caso del dibujo anónimo nos acercan a la muy corriente tipología de Iglesia usada durante la colonia en Chile, esto es con dos torres y corredores en los costados de la fachada.

Son las crónicas de la época de Fray González de Agüeros ${ }^{30}$, más las investigaciones contemporáneas publicadas por Urbina, Guarda y Montecinos, los autores que más y

\footnotetext{
${ }^{30}$ Fray Pedro González de Agüeros fue un sacerdote franciscano, nacido en Ávila, en 1768 pasó al Colegio de Ocopa, fue Predicador General Apostólico en Chiloé 1771 y escribió "Descripción Historial de
} 
mejor recaban sobre la arquitectura de la época, dando cuenta del tipo de capillas dejadas por los jesuitas.

De tales estudios y de lo recabado por el presente trabajo se puede inferir la existencia de dos categorías de capillas por el nivel de logro arquitectónico que presentan.

a) Las pequeñas capillas: que corresponden a la mayor cantidad en número y están dispersas en aproximadamente a unos 80 sitios o pueblos. Estas capillas son extremadamente sencillas hechas a la rústica. Tablas de alerce o ciprés sin pulir, ventanas pequeñas. Generalmente cubiertas con pellejos interiores sin forrar y con las vigas a la vista, daban la impresión de casas de indios. No faltaban los calificativos de toscas y poco decentes(Urbina, 1990, p. 69) como solían decir los padres franciscanos refiriéndose al interior de estas capillas Eran construcciones, entonces, muy menores de magnitud y solo un poco más grandes que las rucas indígenas o chilotas, realizadas con estructuras de troncos o levemente mejoradas y muchas uniones realizadas con fibras vegetales forradas con cubierta pajiza. Este sistema de cubierta se usó en otras construcciones hasta muy entrado el siglo XX. Se puede inferir claramente que eran edificaciones con un solo espacio.

Es bastante evidente que en este caso la arquitectura religiosa era casi de emergencia, funcional y simbólica, para dar cabida a actos religiosos esporádicos que se requerían mantener en los diversos sitios fundacionales de la misión en el archipiélago. Hay que consignar que la visita del o los misioneros duraba dos o tres días en cada capilla, y que con el gran despliegue y esfuerzo que implicaba la misión circular, en la mayoría de los sitios solo se podía alcanzar a atender una vez al año a la población. Esta situación que les dio mucho poder a los fiscales, como reemplazantes de los misioneros, llegando a ser figuras fundamentales en las capillas. También están las figuras de los patrones, en "cada comunidad tiene además, un patrón y una patrona, encargados del cuidado de la capilla y casemita, su conservación y limpieza, y su decoración y arreglo para los días de fiesta, visita del padre o de la misión circular." (Urbina, 1983, p. 183). Fiscales y patrones son figuras importantes para las comunidades y para mantener la religiosidad insular, sin embargo para efectos del foco de esta investigación de historiografía arquitectónica no son estudiados en detalle ${ }^{31}$.

De hecho estas capillas pequeñas o menores disponían de un interior absolutamente falto de decorados, imágenes altares, retablos $u$ otros elementos propios y comunes de la fe y practica católica de esa época, cuando lo habitual era un cierta profusión al barroco. Se hace referencia de que las capillas a lo más tenían una mesa y cruz, las imágenes eran llevadas por los misioneros cuando las visitaban según descripciones de la propia época (González de Agüeros, 1791)

b) Las grandes capillas: corresponde a un reducido grupo de edificios religiosos que, a la partida de los jesuitas, alcanzaron a tener un desarrollo arquitectónico mayor. Se

la Provincia de Chiloé" publicado en Madrid,1791. Este autor hace descripciones de las capillas dej adas por los jesuitas.

${ }^{31}$ Los Fiscales, esta figura laica en la institucionalidad religiosa de Chiloé, está muy bien estudiada en Los Fiscales de Chiloé de Ernesto Barruel, 1997; Patrimonios Religiosos de Quinchao de Renato Cárdenas y otros, 2007 y; en Misiones en Chile austral: los Jesuitas en Chiloé, 1608-1768, de Rodrigo Moreno, 2007. Se sabe que debía haber un fisal por capilla, pero en la realidad esto no sucedía. 
tratan de aquellas que eran cabecera en el archipiélago es el caso de Castro, Chonchi, Achao y San Antonio de Chacao, cabe consignar que la ciudad San Carlos de Ancud se funda recién en 1769.

En el caso de Castro la ciudad principal, está sólo descrita la iglesia matriz o parroquial que hizo construir el obispo auxiliar Azua en 1741 y que costara 18.000 pesos. De esta se registra sus características en Anexo №1. Esta evidencia una fábrica importante, de sesenta varas por doce de ancho, con cielo abovedado o cañón, tijerales, toda de madera, tabicadas las paredes, uso de alerce y alhajada a través de donaciones, son características similares al sistema arquitectónico y constructivo que se hallan en la jesuita de Achao.

Sin embargo la mandatada por Azúa, dura poco, ya se encontraba bastante deteriorada en 1771. Se señala que "la torre estaba medio podrida por las muchas goteras; las campanas rotas; los corredores en mal estado. Carecía de corredores que, según plano, debían haberse construido a los lados de la torre y frente a la puerta principal" (Urbina, 1990, p.). De este edificio que no existen registros gráficos, el dibujo anónimo del siglo XVII, puede haber sido similar tipológicamente a su predecesora. El hecho es que descripciones posteriores dan cuenta que esta capilla matriz o parroquial se "desvanece" comenzado el siglo XIX.

El estado del arte o de la arquitectura a finales del periodo jesuita se puede inferir a través del inventario realizado por los franciscanos cuando las reciben en 1769 (En Anexo 2) y de las descripciones dadas por González de Agüeros ${ }^{32}$ que permiten dilucidar relativamente cómo eran.

En el caso de Castro,

estaba la iglesia que los ex jesuitas construyeron... y que los franciscanos repararon en la década del 70. Hacia 1780 se le describe como una construcción grande, de tres naves y dos torres. Tenía dos puertas a la calle. Toda la construcción era de madera y techo de tablas de pizarrita. En sus dos torres había tres campanas. Servía para todas las funciones religiosas después que un incendio consumió la iglesia matriz en 1772 (Urbina, 1990, p. 70).

Esta iglesia aunque es designada con dos torres, con bastante seguridad corresponde a la dibujada posteriormente por Parker King (Figura $\mathrm{N}^{\circ} 6$ ), ya que se puede interpretar como torre mayor la ubicada en el acceso y la torre menor a la ubicada en un costado.

\footnotetext{
32 "Ellos fabricaron la Iglesia de su Colegio en la Ciudad de Castro muy espaciosa, y de tres naves, con Sacristía correspondiente, y ornamentos necesarios, proveída igualmente de vasos sagrados, y precisas alhajas para el culto divino, y adorno de los Altares. El Colegio tiene habitaciones proporcionadas, y oficinas correspondientes, para diez Religiosos: asimismo huerta suficiente y otros prados (ó potreros) con abundantes pastos, y árboles frutales. En el Pueblo de Chonchi fabricaron también la Iglesia más capaz que la de Castro, y las habitaciones para dos Religiosos; pero mejor dispuestas que las del expresado Colegio, y con mas posesión de huerta, y potreros. En la isla de Quinchau, en el sitio de Achau, levantaron Iglesia y habitaciones, siendo todo esto lo mejor que se halla en todo aquel Archipiélago". [González de Agüero 1791, p. 138-160]
} 
Siendo éste el principal registro gráfico existente del edificio y a la dibujada por Darwin (Figura $\mathrm{N}^{\circ} 7$ ). Estos viajeros extranjeros consignaron escasos ilustraciones y expresiones a la arquitectura y poblados en Chiloé, es así como Darwin describe la ciudad de Castro en su visita de 1832 como triste y desierta, la que a fines del siglo XVIII contaba con unas 150 familias y unas 250 casas (Berg, Lobos, Rojas, 2006). De tal modo que en Castro a la época sólo destaca el templo jesuita, el cual es tratado más en detalle en el punto 3.5 .

En el caso de la descripción de ambas iglesias en Castro, la matriz o parroquial ${ }^{33}$ y la jesuita de fines del siglo XVIII, encontramos un patrón que no se repite en los otros casos y es la mención de las torres, ya sea con la existencia de dos o uno de estos elementos. Es muy probable que tal descripción de torres también hayan correspondido a modo de campanarios, es decir elementos independientes al edificio y una estructura volumétrica simple, como se verá ya en ilustraciones de la primera mitad del siglo XIX. También es importante señalar la falta de corredores que se hace mención, es decir algo que se planificaba en el acceso como refugio, pero no necesariamente se realizaba y por último la existencia de un plano según un proyecto inicial.

En el caso de la iglesia de San Carlos de Chonchi, "fabricada también por los jesuitas, calificada de "grande y capaz" y tasada en 3.000 pesos en 1764. Contaba, además con una casa-misión que se componía de casa principal y cinco casitas más que servían de cocina, cuatro con techos de paja y una de tablas de pizarrita" (Urbina, 1990, p.72). Esta capilla en términos monetarios es bastante más económica que la de Castro, en ningún momento se alude a torres o campanarios y en las obras de restauración realizada entre los años 1995-97 fueron encontrado restos de pavimentos en piedras y no lo usual de madera (Berg, 2005). No hay mayores fuentes que hagan referencia a esta capilla de una manufactura muy elaborada en la época jesuita.

Si la iglesia de Castro llamaba la atención por su tamaño, en el caso de la Iglesia de Achao lo hacía por cantidad de detalles y delicadeza siendo la más cercana al espíritu barroco en su interior.

En la Isla de Quinchao en el sitio de Achao, levantaron Iglesia y habitaciones, (los jesuitas) siendo todo esto lo mejor que se halla en todo aquel archipiélago. La iglesia, que es de tres naves, es toda ella, aunque de madera, de particular, y prolija arquitectura (González de Agüeros, 1791, p. 159).

En el inventario realizado por los franciscanos a la partida de los jesuitas se resalta la cantidad de elementos religiosos, como los aspectos de la fábrica y que no estarían terminados. Item. La iglesia de tres naves, por concluir, obra toda de madera. Item. Un techo de tablas de pizarrilla con tres puertas a la calle, coro y el piso enrrajado con presbisterio y dos confesores (En Anexo 2).

En resumen, estas iglesias mayores se diferenciaban de las capillas menores no solo por el tamaño, más complejas y alhajadas sino que también por aspectos composicionales y constructivos. Si las primeras pasaban por "rucas" y su carácter sagrado se denotaba por la existencia de la cruz, en el caso de las capillas mayores si

\footnotetext{
${ }^{33}$ Correspondería a la Iglesia Franciscana.
} 
se reconocían como edificios religiosos y particularmente por el espacio interior, de tres naves y la imaginería religiosa más permanente. En el caso exterior, por su magnitud y presencia de torre(s) o corredor (es).

En todo caso, lo importante es mencionar las características comunes que van conformando hacia el siglo XVIII algunas constantes de la arquitectura religiosa jesuita en Chiloé y que ciertos elementos tipológicos tradicionales posteriores son escasos, como las torres, corredores e incluso la planta basilical. Estos se usarán en forma aislada en las capillas mayores. En síntesis, vemos:

- Edificaciones de madera. Todas las descripciones concuerdan que son completamente ejecutadas con madera, se ha consolidado el uso del material local.

- Plantas de 3 naves, al menos en las capillas mayores. La espacialidad basilical cristiana y uso de cielos abovedados o de cañón.

- Se describen iglesias con torres y están registradas solo en Castro.

- También se acusan existencia de corredores en Castro y Achao.

- Sistemas constructivos más elaborados en las capillas mayores, con uso de ensambles en estructuras, la antigua denominación de paredes entabicadas o postería. Estructura de techumbres con tijerales y cubiertas de tejuela de alerce. Probablemente sólo estas mayores disponen de fundaciones de piedra como el caso de Achao. En cambio, las capillas menores que alcanzan el número de 80 de un total de 84 son muy rústicas.

\subsection{Estudios de Casos: Castro y Achao}

\subsubsection{La Iglesia de la Compañía de Castro.}

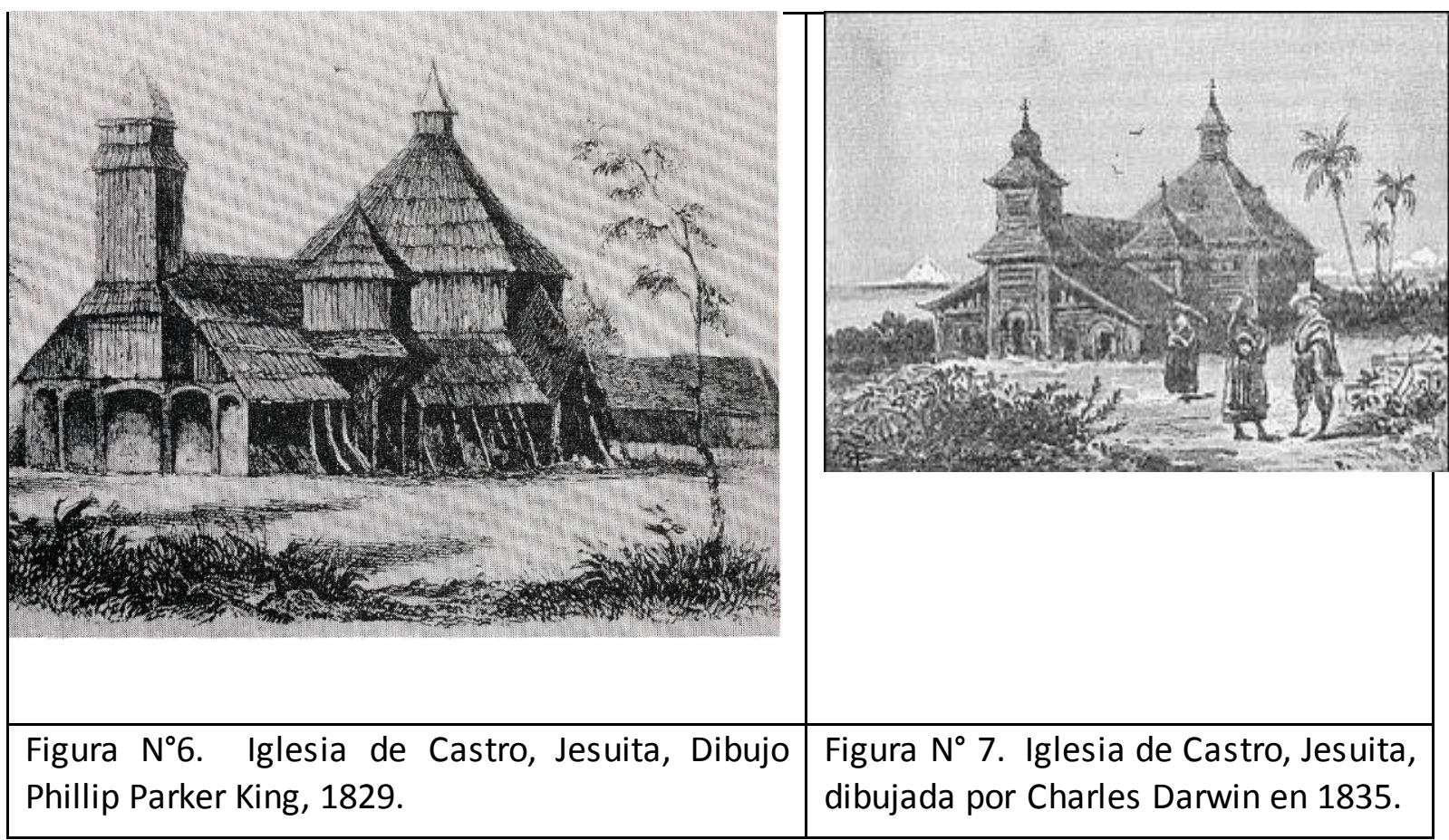

Ya se mencionaba que de este edificio hay solo dos documentos gráficos y no existen mayores antecedentes planimétricos. La versión dibujada por Darwin, es una 
idealización dado el paisaje tropical que muestra, con palmeras inexistentes en Chiloé, seguramente realizada no en forma directa y por lo tanto muy poco confiable, no obstante tiene similares características y elementos compositivos a la versión más realista de Parker King.

El modelo dibujado por Parker King en 1829 da una excelente aproximación al edificio. Se ilustra un edificio de gran tamaño con una variedad de elementos compositivos, que no sabemos si fueron realizados a partir de un proyecto ideado de tal modo o que fue modificándose en el tiempo. Claramente se ve un edificio complejo, con un importante volumen horizontal y techumbre a dos aguas, para acoger la asamblea de fieles, siendo rematado por un volumen y cubierta poligonal ${ }^{34}$, seguramente para cobijar jerárquicamente la zona del altar y una torre menor al costado. Lo que aparentan corredores laterales, más bien parecen puntales para afirmar la fábrica del edificio. En este caso lo que más llama la atención es la torre central en forma de paralelepípedo en el acceso y con pórtico adosado a la nave. Es hasta este momento histórico el único precedente encontrado en Chiloé de una capilla con torre centrada en la fachada, las que tendrán su apogeo en el siglo siguiente. En términos simplistas, si se retiraran los corredores o puntales laterales, el volumen poligonal y el torreón menor se obtendría la fórmula de la tipología alcanzada posteriormente.

La particularidad de esta capilla es la variedad de elementos arquitectónicos, que demuestran una diferenciación formal asignada a los espacios según la función ritual o religiosa, denotando la búsqueda de una mayor simbolización expresiva del templo. Morfológicamente es indudable su similitud con las capillas centro europeas, como se ha señalado

El esquema de única torre es frecuente en Alemania entre los siglos XVI y XIX, especialmente en medios rurales, aunque sin excluir su presencia en ambientes doctos; al igual que las de Chiloé, se sitúa en el centro de la fachada y recibe el nombre de Einturmkirche (Guarda, 1995, p.256).

Dado que gran parte de los jesuitas en Chiloé son de Europa Central (ver Anexo 3). Sin embargo, esta composición de múltiples componentes anexados al volumen principal,

${ }^{34}$ Estos volúmenes son los llamados rotunda y que se usó frecuentemente, Fray Manuel Cárdenas la describe diciendo que "la otra era parroquial, edificada con madera de cipres, alerce y roble, en forma de una rotunda con una gran cúpula en el centro y una torre para las campanas; ésta era obra de los jesuitas. Su patrona era nuestra señora de las Nieves" (Cárdenas, 1990, p. 65). Al respecto conviene citar a Enrich quien describió la iglesia de la residencia de Valparaíso, concluida en 1756 la cual era "no muy grade, pero graciosa, por ser una rotonda, única en su género en Chile. Tenía esta iglesia veintidós varas de diámetro; ocho columnas sostenían una cúpula, el diámetro de cuya base era de doce varas; entre dicha base y el muro quedaba una nave corrida y muy despejada, por no atajar la vista las columnas de solo media vara de diámetro; y saliendo bien poco fuera de la rotonda su pequeño presbiterio, el altar podía ser visto, no solo del centro de la iglesia, sino también desde la mayor parte de las naves. En estas había dos altares muy poco salientes de la pared" (Enrich, 1891, TII p. 242) 
la morfología de torreones y las relaciones métricas de cada uno y entre los distintos elementos compositivos, dan un aspecto de una arquitectura que no se ciñe estrictamente a los trazados más clásicos sobre los cuales se inscribe la arquitectura tradicional religiosa de Chiloé.

Dicho edificio por su variedad formal presenta una serie de puntos "débiles" en su composición y que indudablemente son dificultades que presenta este modelo arquitectónico para mantenerlo o replicarlo. Principalmente la cantidad de encuentros de planos de cubiertas y volúmenes, aumentando el número de limahoyas y por lo tanto las líneas de convergencias de aguas, propensas a las filtraciones de humedad como a las consecuentes pudriciones de la fábrica de madera. Asimismo, la existencia de volúmenes de grandes y altas dimensiones en una zona de fuertes temporales requiere una geometría estructural y constructiva elaborada para una resistencia y estabilidad duradera. Lo que demostraría la necesidad de incorporar puntales o elementos extras para afianzar perimetralmente el edificio, como se ven en el dibujo de Parker King.

\subsubsection{La Capilla Santa María de Achao}

De acuerdo a los antecedentes oficiales la Iglesia de Achao, se cita de mediados de siglo XVIII (Consejo de Monumentos Nacionales, 2000), siendo el edificio de madera más antiguo del sur de Chile. Sin embargo es necesario precisar, que esta data no correspondería a toda la integridad del edificio que hoy conocemos. Está claramente registrado que el pórtico y torre fachada son realizadas a fines del XIX y que además, tanto el cuerpo como la torre y la expresión exterior, han tenido numerosas intervenciones y restauraciones en la década del 60 y 70 del siglo pasado (Montecinos, 1990) (Berg, 2005).

En tal sentido a la fecha, se puede asegurar que el espacio interior del volumen horizontal que cobija las tres naves en su geometría y forma, prácticamente no ha variado, como tampoco sus detalles ornamentales principales fijados a la fábrica edilicia. En tal sentido corresponde a las citas descriptivas antiguas tales como:

En Achao se esmeró el Padre Fr. Alfonso Reyna, de la Provincia de Andalucía, el adorno y compostura de aquella Iglesia: pues hizo nuevo el Altar mayor, y tal cual no hay otro mejor en el archipiélago. (González de Agüero, 1791, p. 177).

"Tiene esta iglesia unas 50 varas de largo, y de tres naves; la bóveda de principal, que es bastante ancha, es de estilo arabesco...; esta bóveda y los techos de las naves laterales con preciosos artesonados". (Enrich, 1891, p. 354).

"Distínguese entre ellas la del curato de Achao ... lo que equivale a decir que es la más antigua de todas. Verdad es que ha sido refaccionada y techada de nuevo hace años, pero, sin embargo, hay que admirar siempre su duración y el trabajo interior, que es el mismo de su primitiva construcción, el cual manifiesta el gusto y perfecto conocimiento que tenían de la arquitectura los citados religiosos" (Guarda, 1985, p. 59).

En el inventario del 15 de febrero de 1769, motivado por el extrañamiento de la Compañía de las posesiones de la Corona Española, se lee: "ítem la iglesia de tres naves por concluir, obra toda de madera". Seguidamente se indica: "ítem un techo de tabla de pizarrilla con tres puertas a la calle, coro y el piso enrajado con presbiterio y dos confesores". (en Anexo 2) 
Por lo anterior se puede inferir que dicho espacio interior ha mantenido en gran parte el diseño barroco jesuita. Es claro que se trata de una planta basilical de tres naves, y en la segunda de un volumen neto, sin pórtico, ya que, como se indica, las puertas se abren directamente al espacio público ${ }^{35}$.

Una descripción similar es la que entrega Fray Pedro González de Agüero en 1791, escribiendo que "la iglesia, que es de tres naves, es toda ella, aunque de madera, de particular y prolixa arquitectura." (González de Agüero, 1791, p. 159).

En estas descripciones no se describe la fachada ni menos la torre, lo que es una clara señal de su inexistencia, ya que un elemento arquitectónico de tanta importancia y visibilidad habría sido descrito como parte del edificio.

Las razones para que esta capilla haya tenido una arquitectura tan particular en su época ${ }^{36}$, se entiende porque Achao fue un asiento principal jesuita para conectarse al mundo rural insular. Esta localidad se encuentra en la isla de Quinchao que conecta la isla grande con el archipiélago del mar interior de Chiloé. Era cabecera de la misión y los jesuitas fundan allí su residencia en 1754, aunque ya la atendían desde antes, a las localidades de Huyar, Palqui, Vutaquinchao, Matao y Curaco en la isla de Quinchao. Pero se agregan habitantes de otras islas como Quenac, Meulín, Llingua y Lin-Lin que acuden regularmente a Achao (Urbina, 1983). Lo que también demuestra la falta de atención de los fiscales locales en algunas islas y ciertamente la necesidad de la población dispersa de asistir a un poblado mayor o pueblo de indios mas constituido.

\section{Estudio de medidas y proporciones de Achao.}

En cuanto a las dimensiones, en los archivos diocesanos se consigna que el año 1870 el templo de Achao medía cincuenta y una varas de largo (Montecinos et al. 1995), sin detallar el ancho. En el mismo archivo se señala que en el año 1888 medía cuarenta y cuatro metros de largo y catorce metros y veinte centímetros de ancho, los que equivalen a cincuenta y dos y media varas de largo y diecisiete varas de ancho, lo que pareciera indicar que al cuerpo principal se le agregó el pórtico de una y media varas de profundidad. Actualmente la iglesia mide cuarenta y seis metros de largo, y catorce metros con veinte centímetros de ancho. El largo equivale a cincuenta y cinco varas, cuatro más que las medidas de 1870, lo que indica la reconstrucción del pórtico de acceso, pero esta vez de cuatro varas de profundidad.

\footnotetext{
35 Intervenciones posteriores como las restauraciones en los años 1970-80, ejecutadas por el taller Puerta Azul (Boldrini, Rojas, Vivaldi.) que restauran el altar siguiendo las formas preexistentes y el pavimento de piso que siendo nuevo, siguen la forma y técnica de tabla trabada que tenía originalmente. Es decir se han perdido el ementos de madera antiguos u originales y reemplazados por nuevos siguiendo las formas y técnicas precedentes.

${ }^{36}$ Esta capilla afortunadamente ha sido valorizada en su época de construcción y posteriormente, lo que ha permitido sularga data de permanencia, situación que no es muy común en Chile.
} 

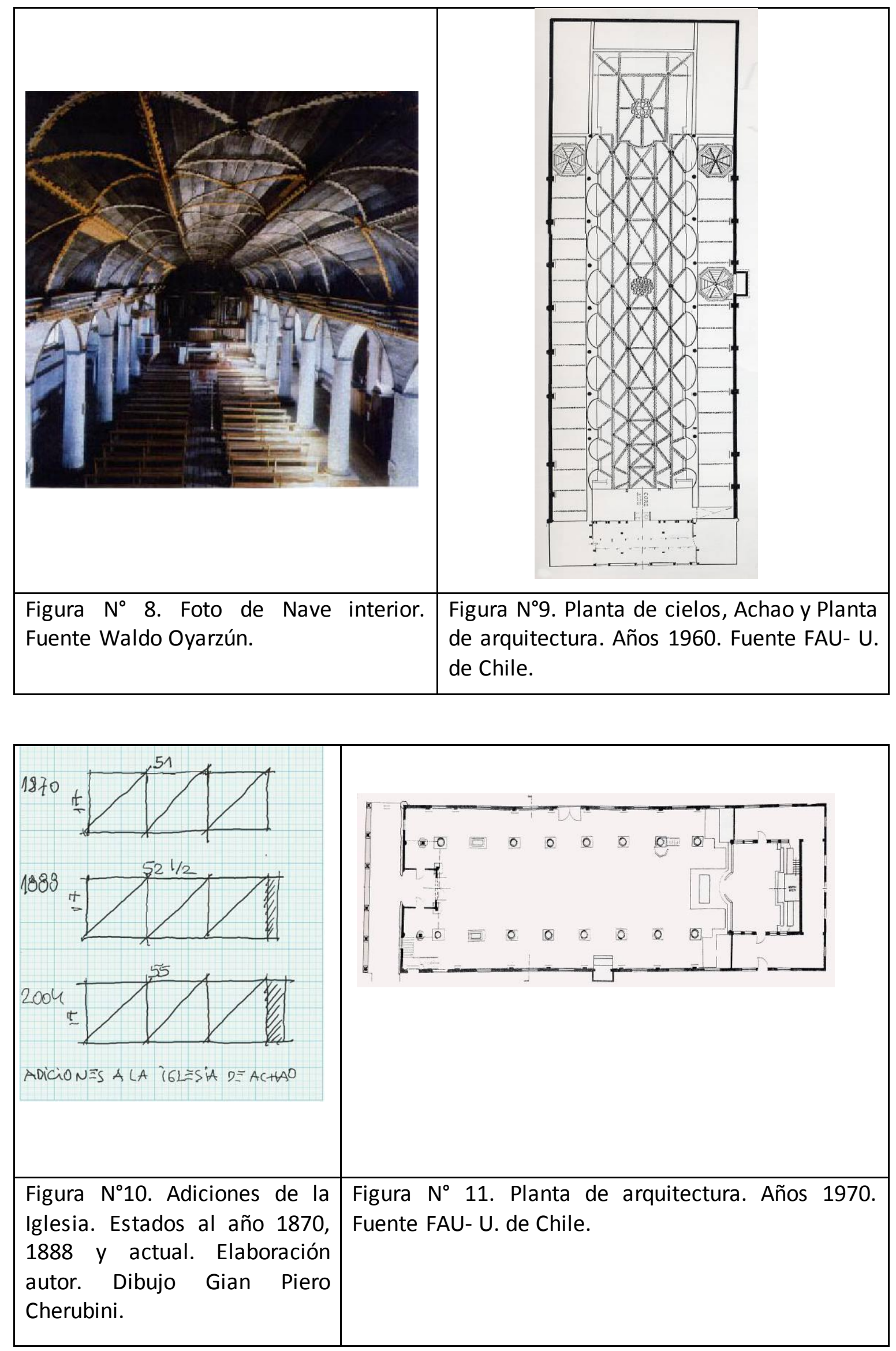
Sobre las dimensiones de la iglesia indicadas para los años 1870 y 1888, destaca el hecho que el ancho de 17 varas corresponde a un número primo, que se forma con la suma de los cuatro primeros números primos $(2+3+5+7=17)$. A su vez el largo de 51 varas equivale a tres veces el ancho $(3 \times 17=51)$ (Figura $N^{\circ} 10$ y 11$)$.

Interiormente, el volumen se divide en dos partes. La primera corresponde a las tres naves, destinada a la asamblea, en la cual se distingue el coro que ocupa el espacio entre los últimos pilares y la fachada; bajo es te está el acceso, formando un pequeño "nartex", antesala al templo. Este "nartex" está aproximadamente en proporción triple (1/3) o diapasón diapente. Una vez cruzado este acceso se llega a la nave central, cuya dimensión es de un poco más de treinta y cinco varas, lo que comparada con el ancho de nueve varas da una proporción cuádrupla (1/4) también Ilamada diapasón. La otra parte reúne en un volumen cerrado el presbiterio, con la sacristía, la contra sacristía y el pasillo trasero; los que en conjunto miden once y media varas. Esta dimensión, comparada con el ancho de diecisiete varas está en proporción sesquiáltera $(2 / 3)$ o diapente.

El espacio interior está compuesto de dos naves laterales de seis pies de altura y una nave central con una compleja bóveda polilobulada (Figura $\mathrm{N}^{\circ} 8$ y 9) cuya altura total es de nueve pies. El intercolumnio de la nave lateral entre la pilastra y la columna es de tres varas, lo que significa que el vano está en proporción dupla $(3 / 6=1 / 2)$ o diapasón. La nave central mide nueve varas de ancho, lo que significa que el vano sin la bóveda está en proporción sesquiáltera $(6 / 9=2 / 3)$ o diapente. La altura de la bóveda es de tres varas, es decir que está en proporción triple. $(3 / 9=1 / 3)$ o diapasón y diapente. El vano más la bóveda de la nave central, suman nueve pies de altura, es decir que está en proporción unísona $(9 / 9=1 / 1)$ que corresponde al tono. En las proporciones de la planta, así como las de la nave central, se repite el número tres que es símbolo de la Santísima Trinidad. (Figura N²12)

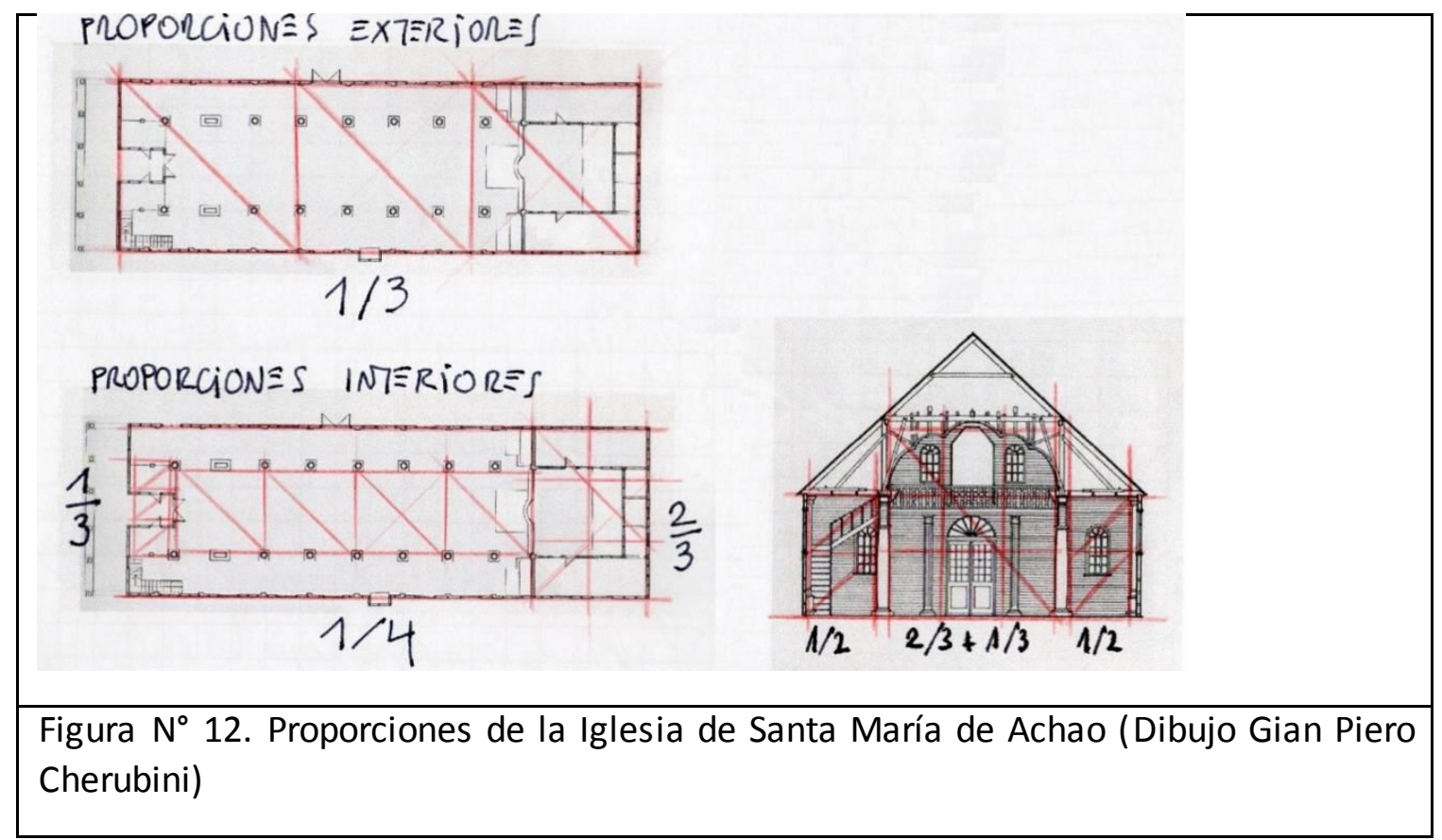


Al interior de las naves, la curiosa disposición de columnas es posible separarlas en dos grupos: la de adelante que son doce, y las de atrás, separadas de las primeras por dos pilares rectangulares, a los que se suman las dos columnas que le siguen, formando un grupo de cuatro, lo que espacialmente genera dos espacios. Las columnas de adelante comparadas con las de atrás, están en proporción triple $(12 / 4=3 / 1)$, o diapasón y diapente. A su vez, si consideramos la totalidad de las columnas y se relacionan con las de atrás, están en proporción cuádrupla (12/4=4/1), o bis diapasón.

El templo es donde habita lo divino, es la casa de Dios, uno y trino, las proporciones generales así lo demuestran. Así mismo Dios es único, como el numero 17, numero primo formado por la suma de los cuatro primeros números primos $(2+3+5+7=17)$.

La relación del templo con la divinidad católica también está expresada en la sección, en la elevación y espacialización de la planta. En las naves laterales se anuncia la trinidad $(1 / 2 ; 1+2=3)$, la que se presenta en la sección inferior de la nave central $(2 / 3)$, alcanzando su plenitud en la adición de la bóveda $(1 / 3+2 / 3=3 / 3=1)$ como expresión adecuada y perfecta del Dios, uno y trino. A su vez, la bóveda polilobulada, adornada con encajes que forman un complejo aparato estético, sin duda de origen barroco es la expresión de un Dios, que como verdad revelada no es posible de entender en plenitud sólo por la razón.

La planta aporta nuevos elementos. El acceso funciona como una señal de la divinidad (1/3). Una vez adentro, el espacio de atrás separado por los pilares, es el espacio donde permanecían aquellos que aún no pertenecían en propiedad a la comunidad, es decir los no bautizados, rodeados por los cuatro evangelistas, primer y principal vínculo para llegar a la verdad revelada de Dios. A su vez la nave principal acoge a la comunidad, que pertenece al mundo terrenal, y por eso la proporción (16/4=4), se refiere al número de los elementos que conforman el mundo (agua, aire, fuego y tierra), lo que reforzado por el número de columnas, cuya separación en dos grupos $(16=12+4 ; 16 / 4=4 ; 12 / 4=3)$, enseña que es en la comunidad eclesial, en la asamblea reunida en el "templo" físico y terrenal del cuerpo, en donde se alcanza la plenitud del alma.

Al relacionar las dimensiones del edificio con el de las medidas de los materiales disponibles, resulta que las naves laterales de tres y media varas, se cubren con vigas de cuatro varas de largo. A su vez la bóveda polilobulada cuelga de la viga que cruza la nave central y se apoya en el tabique de tres varas y dos tercios, el que a su vez se apoya en los ejes longitudinales de columnas y en un puntal por cada lado, lo que acorta la distancia útil de la citada viga a seis y media varas. Sin embargo la nave central mide ocho varas y media lo que obligó a colocar dos vigas maestras intermedias, o a utilizar vigas de sobremedidas. A su vez el intercolumnio central mide tres varas y dos pies, a lo que hay que agregar el diámetro de la columna de dos pies, lo que entrega una distancia interaxial de cuatro varas y un pie. Esto significa que a pesar de la limitante constructiva que impone las dimensiones del material, ésta quedó supeditada a la idea del edificio como complemento doctrinario de la evangelización.

Sin duda, la concepción del edificio era parte del programa educativo y evangelizador de la Compañía. Esta razón explica la repetición de algunas cifras en las dimensiones 
de la iglesia, asociadas a conceptos propios de la religiosidad como el tres y la trinidad, el doce y los apóstoles, y los cuatro elementos que conforman el mundo y lo terreno.

Ya se ha señalado que la capilla en Chiloé es parte de la unidad urbanística original de la formación de los poblados de Chiloé, que junto con la playa, su embarcadero, y la explanada (Montecinos, 1970. Rojas \& Vivaldi 1979), son parte de la procesión que se iniciaba con la llegada de los misioneros a la localidad. Esta procesión es parte de una concepción de la vida como un camino que nos acerca al Señor, en donde el templo, lugar de congregación de la comunidad que forma la iglesia, cumple un rol protagónico como punto final culminante de esta experiencia. Por eso su forma responde a una concepción precisa que busca representar en forma material el relato de la salvación.

\section{Dirección de la fábrica y aspectos constructivos en Achao.}

En el caso en específico de esta capilla, única en todo el archipiélago ${ }^{37}$, la profundidad religiosa y doctrinal del templo no es un hecho fortuito, lo que induce a la tesis de la presencia de un arquitecto o constructor especializado en su realización, como es la participación del padre Michael Choller o Köller y del hermano Antonio Miller, quien se dedicó a la construcción de iglesias (Moreno, 2007). Cabe mencionar que no hay registros escritos de quienes exactamente fueron autores de la fábrica original de Achao, solo la intervención del padre franciscano Reyna en el altar y que es tratado en el capítulo siguiente.

El hermano Miller llegó a Chile junto con otros catorce jesuitas. Estos se juntaron en Génova, siguieron hasta Cádiz, en donde se detuvieron dos meses, para continuar hacia Buenos Aires, Mendoza y finalmente Santiago de Chile, en donde Ilegaron en febrero de 1724. Junto con el hermano Miller viajó el padre Miguel Köller o Choller, quien en 1725 estaba activo como superior de la misión de Quinchao. También viajaron en esa oportunidad los hermanos Pedro Vogl $\left.\right|^{38}$ y Adam Engelhard, ambos de profesión arquitectos, teniendo el primero una destacada participación en diversas obras de arquitectura, entre ellas la Catedral de Santiago, lo que le brindó un gran prestigio (Guarda, 1997).

Es probable que estos dos arquitectos, que sin duda conocían la teoría armónica de Villalpando, hayan participado, o por lo menos influido en el diseño de la iglesia de Achao.

Un aspecto fundamental a considerar en esta capilla y que prácticamente ya no existen, es el sistema constructivo en madera de los muros perimetrales ${ }^{39}$ denominado de postería labrada (Concha, Errázuriz, Gaissinsky, 1979) y la técnica del pavimento de madera en pisos. Cabe destacar que ninguna de las otras iglesias tradicionales del siglo

\footnotetext{
37 La iglesia, de notable arquitectura de tres naves, es "lo mejor que se haya en todo el archipiélago"(Urbina, 1983, p. 72)

38 El hermano coadjutor Pedro Vogl dibujó los planos de la catedral con la que se solicitó la anuencia del emperador de España para su construcción. Además reconstruyó la iglesia de la Compañía reemplazando las dos torres por una sola sobre el acceso, construida en madera. De esta iglesia quedan algunas imágenes del pintor Mauricio Rugendas. Además es autor de la iglesia de la hacienda de la Compañía en Calera de Tango, cuya iglesia ostentaba una el egante torre de tres cuerpos.

39 Este se pudo observar en la antigua casemita, derrumbada y que ya no existe, junto a la capilla de Aldachido en la isla de Lemuy.
} 
XIX existentes en Chiloé utilizan estas técnicas, lo que permite establecer claramente que la data de la estructura muraria de Achao es anterior y corresponde al siglo XVIII, seguramente ejecutada por los misioneros jesuitas.

La particularidad de la técnica muraria consiste en postes o pilares de madera de sección cuadrada de $6 \times 6$ " dispuestos cada 1,15 $\mathrm{mt}$ con un rebaje vertical donde se alojan tablas horizontales de $1 \times 6^{\prime \prime}$ (ver figura $\mathrm{N}^{\circ} 13$ ). Esta solución quedaba a la vista hacia el exterior, situación diferente al tradicional revestimiento de tejuela introducido en el siglo $X X^{40}$. Mientras que por el interior, en el caso de Achao, se utilizaba un revestimiento de tabla de terminación que permitía cubrir la postería labrada y por lo tanto dar un mejor soporte y aspecto sobre el cual se realizaban todos los decorados requeridos y que desde un inicio hizo tan fascinante a esta capilla.

Respecto al pavimento, como ya se indicó, siendo nuevo el actual existente en la capilla, se realizó siguiendo la técnica antigua que consiste en una tabla de piso trabada entre las vigas (ver figura $\mathrm{N}^{\circ} 14$ ).

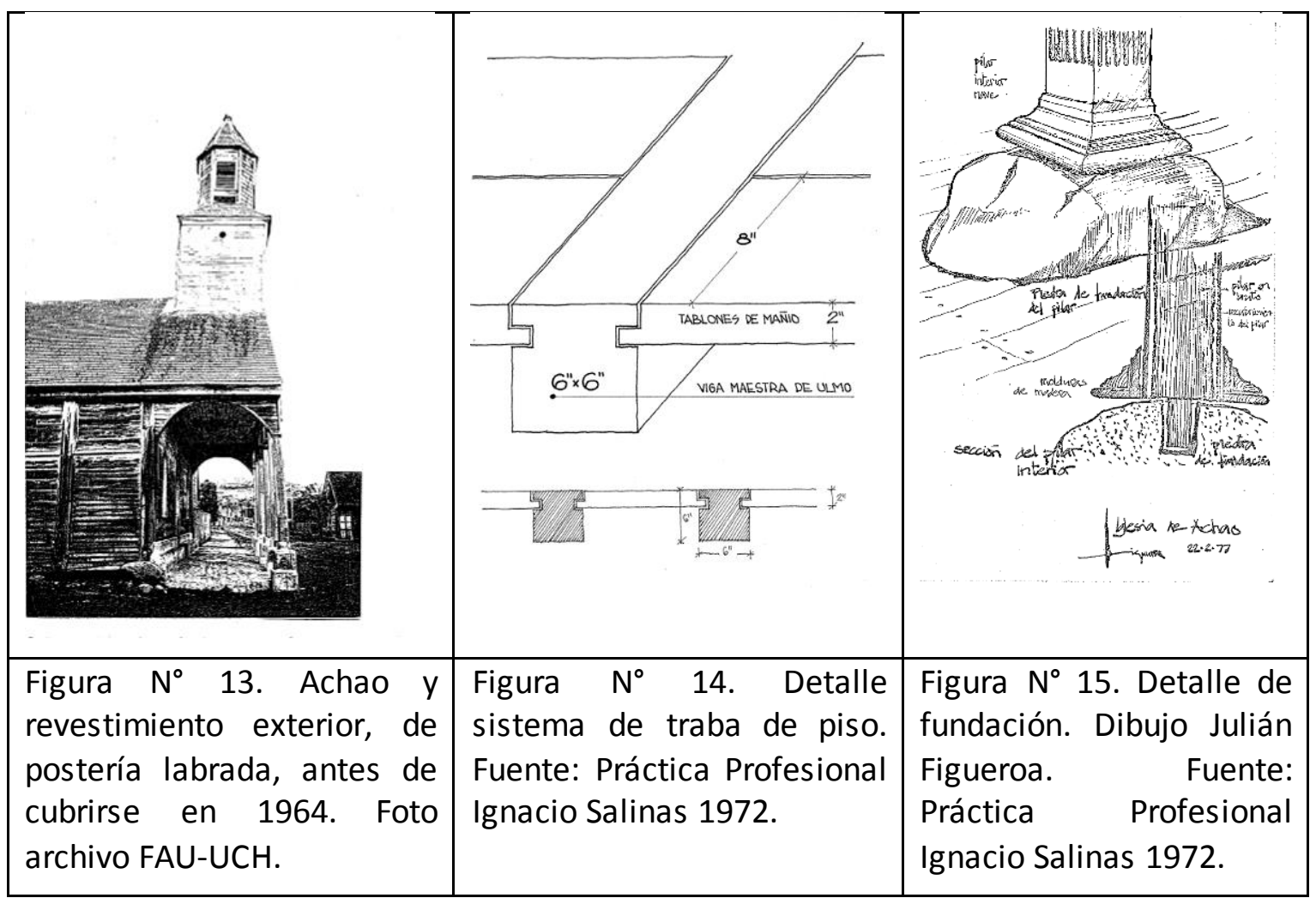

También es importante destacar que la fábrica de madera de esta Iglesia se asienta en grandes basas de piedras, las cuales a su vez están simplemente sobrepuestas en el terreno. De esta manera el edificio mantiene su estabilidad por el peso propio. Las basas de piedra en el caso de Achao, disponen de un rebaje horadado para recibir la espiga del pilar (ver figura $\mathrm{N}^{\circ} 15$ ). Este sistema de fundación seguramente introducido por los jesuitas, bastante común en el centro y norte de Europa, es el que se va a

\footnotetext{
40 La Iglesia de Achao, fue revestida exteriormente con tejuelas en los años 60 en la intervención del Arquitecto Guillermo Ulriksen. Afortunadamente bajo éstas aun se encuentra el sistema original.
} 
imponer posteriormente en todas las iglesias hasta inicios del siglo $\mathrm{XX}$ y en muchos tipos de edificaciones urbanas o rurales del archipiélago.

De todo lo anterior podemos visualizar que la tipología arquitectónica constructiva, siendo más compleja o avanzada que las comúnmente descritas para esa época, todavía no corresponde al nivel de desarrollo que se va utilizar en las iglesias tradicionales de Chiloé. Las cuales consideran en su estructura muraria una mayor diversidad de sistemas de ensambles.

En resumen de los dos casos descritos ya analizados de las capillas de Castro y Achao, correspondiente al período jesuitas en Chiloé, se ilustran entre las escasas capillas mayores, dos tipologías arquitectónicas muy distintas entre ellas. La primera de Castro que corresponde a una mayor complejidad composicional producto de variadas adiciones, pero sin lugar a dudas de tremenda importancia. Esta concepción presenta una serie de puntos débiles para su integridad y mantención en el tiempo, como también las dificultades económicas y constructivas de su realización. En el caso de la segunda, Achao, se presenta de una mayor simpleza al estar acotada a un gran volumen a dos aguas, cuyo interior de planta basilical contiene toda la simbología cristiana a través de sus trazados, como en el tratamiento de decorados e imaginerías en sus paramentos y cielos. De esta manera se concreta un espacio religioso muy a la necesidad y escala de la realidad chilota, siendo también muy consecuente con la visión del "modo nostro" que aspiraba a materializarse en la arquitectura jesuita elaborada desde Europa, tratada más adelante.

Cabe convenir que si bien la arquitectura jesuita de la colonia en Chile no ha sido estudiada, se puede afirmar que dichos edificios tenían el claro objetivo de ser un vehículo de propaganda religiosa y de instrucción civilizatoria. En el presente capítulo de la tesis se ha rastreado aquellos trazados reguladores subyacentes en la arquitectura misional y que permiten configurar la geometría de los templos. Se considera de interés hacer un paralelo de la capilla de Achao con la Iglesia jesuita ubicada en la Hacienda ${ }^{41}$ de Calera de Tango de los misioneros en Chile, debido a las posibles vinculaciones con Chiloé que se detectan y contextualizan mejor el caso en estudio.

\subsection{La arquitectura religiosa jesuita en Chile.}

Focalizado en la arquitectura de los templos se puede considerar que estos eran concebidos como edificios simples, aunque llegaran a disponer de grandes dimensiones. En efecto normalmente disponían de una gran sala o nave que permitiera alojar a los fieles y realizar los actos religiosos en un verdadero sentido de comunidad y comunicación, muy vinculado a la concepción práctica y funcionalista que se venía propagando desde Europa ${ }^{42}$, denominado el modo nostro. Se le daba una importancia expresiva al acceso, sin necesariamente llegar al barroquismo, acompañado normalmente de una torre o campanario adosado. Esta adopción

\footnotetext{
41 Cabe mencionar que los misioneros tenían otras haciendas, en Santiago, en Andalién, en Concepción, en La Serena y en Valparaíso. Estas haciendas constituyeron el sistema productivo que permitió dar viabilidad económica al proyecto jesuita. En parte también fue ella base del desarrollo agrícola de la zona central de Chile durante la Colonia

${ }^{42}$ Tratado en 3.7 Antecedentes europeos de la arquitectura de los Jesuitas.
} 
tipológica es evidente al revisar las ilustraciones que hace el jesuita e historiador Padre Alonso Ovalle en su Libro Historia del Reyno de Chile publicado en 1644. Se puede distinguir claramente iglesias compuestas por un volumen horizontal de una nave, siendo siempre el mismo modelo, acompañado de un elemento vertical. Lo particular que este último elemento vertical es que puede variar su connotación y morfología dependiendo del territorio y contexto geopolítico, así por ejemplo en el caso de Arauco, zona de conflicto con los mapuches, el elemento vertical es una torre fortificada en cambio en Chiloé zona pacificada el elemento vertical es una delicada torre (Figura $\mathrm{N}^{\circ} 16$ ). Esta tipología se puede observar que persiste un siglo después en la Iglesia de Calera de Tango.

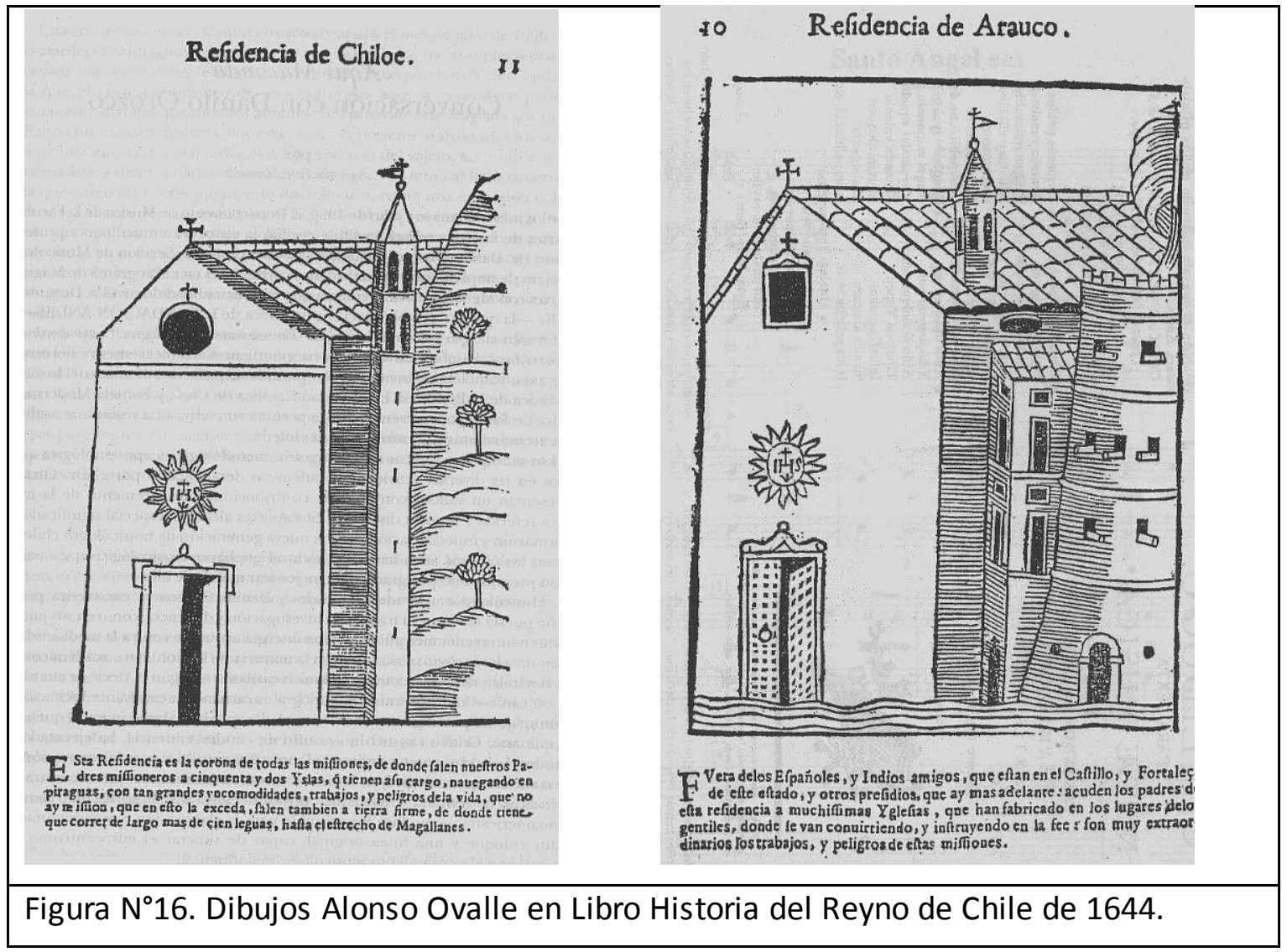

\section{La Iglesia de Calera de Tango.}

Este templo muestra claramente la correspondencia tipológica de gran nave y torre lateral (Figura $\mathrm{N}^{\circ} 17$ ), no obstante estar inserto en un complejo y extenso sistema de construcciones en torno a patios, que fue la configuración espacial común de las haciendas en el Chile colonial (Figura $\mathrm{N}^{\circ} 18$ ). 


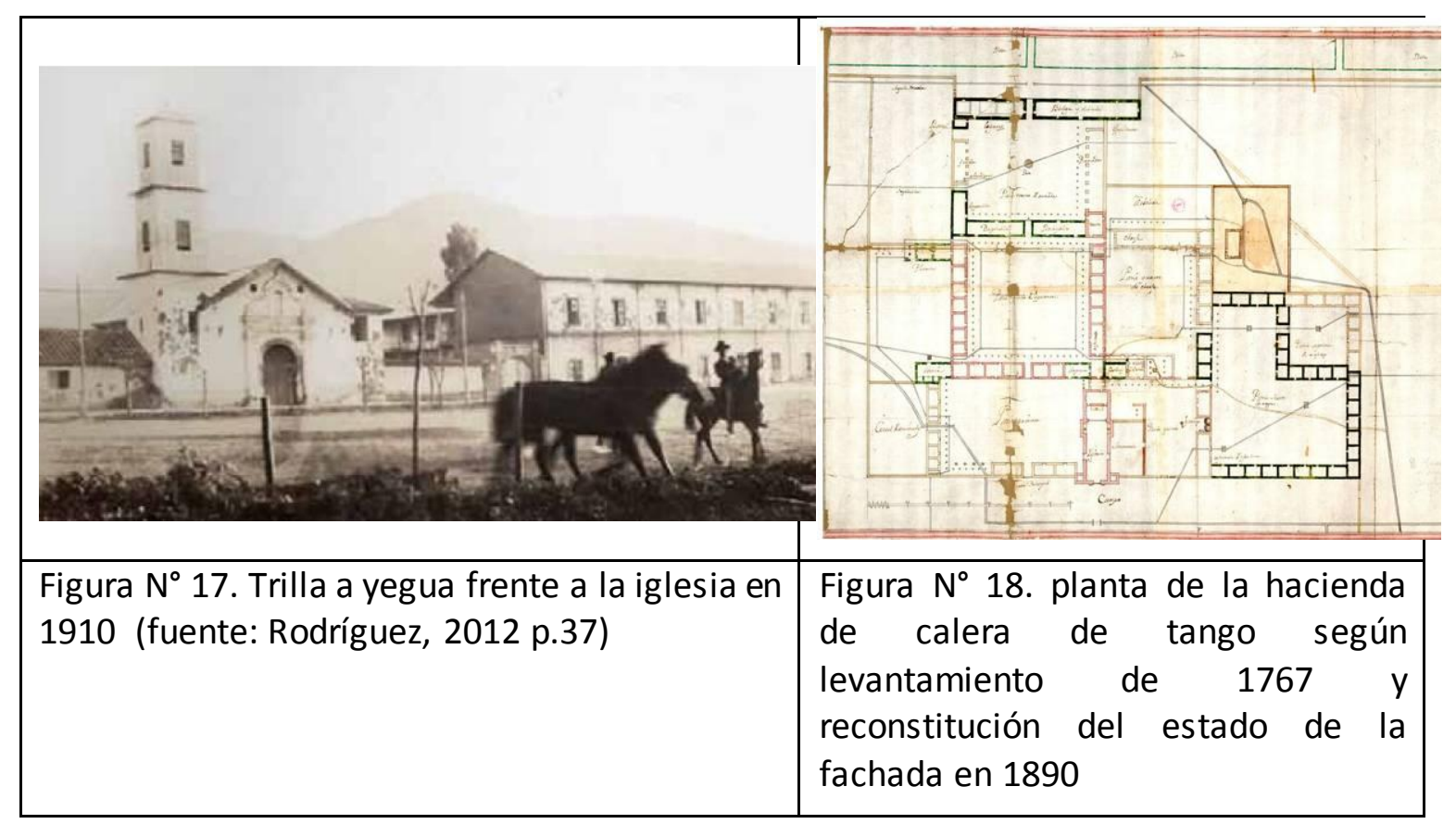

\section{Apuntes históricos.}

En 1685, con la finalidad de poder abaratar los costos de la construcción de la iglesia del Colegio de San Miguel en Santiago, los padres de la Compañía de Jesús, compraron a los padres Mercedarios la hacienda de Calera de Tango, famosa por sus minas de cal de buena calidad (Enrich, 1891. Aránguiz, 1967)

La construcción de la iglesia se inició paralelamente con la de la casa. Entre 1750 y 1753 , los trabajos para su terminación se activaron notablemente y [...] A fines de 1759 se terminaron los muros y se tejaron la capilla y la sacristía; en 1761 los trabajos fueron terminados, colocándose en el frontis la fecha. Al producirse la expulsión de los padres de la Compañía, el inventario practicado dice que la iglesia es de adobe y tejas, entablada, con tres campanas en la torre (Aránguiz 1967, p. 226-227).

Más adelante el mismo autor señala que:

No tenemos noticias exactas de la iniciación de las obras de la casa, pero sabemos, si, que en 1741 se edificó un cuarto de dieciséis varas y un cuarto para guardar aparejos, y en 1742 se construyó un lugar de veinte varas.

En el período 1755 - 1758 se agregó un doblado de noventa y tres varas; tres lagares de cal y ladrillo; un edificio para la matanza; un refectorio; una despensa y se tejaron dos cocinas.

Un año después se terminó el edificio de los hermanos, que contaba con nueve aposentos; se terminó el primer patio y se inició la construcción de la vivienda destinada a los criados. La casa se terminó en 1761 con la construcción de una 
panadería, sala de enfermos y una bodega para guardar lana (Aránguiz, 1967, p. 228-229).

Lo señalado indica que, además de las posibles construcciones que dejaron los padres de la Merced, en 1741 se inició una etapa de construcción que se extendería por veinte años, hasta 1761. En estas obras, en especial en la terminación de la iglesia, fue decisiva la intervención del hermano coadjutor Pedro VogI S.J. (Pereira, 1965).

Fue precisamente en 1740 que Ilegaron a Chile algunos jesuitas alemanes que en la hacienda de Calera de Tango desarrollaron artes manuales e industriales, lo cual transformó a la hacienda en un gran centro artístico e industrial de la colonia chilena.

\section{Geometría en la iglesia}

Este caso de estudio está referido a una iglesia edificada por los padres y hermanos coadjutores de la Compañía de Jesús, por lo cual su construcción está supeditada a los sistemas y formas de medida de la época, así como a los principios confesionales del catolicismo.

Estos edificios fueron concebidos no solo para recibir el culto, sino que además como instrumentos para la enseñanza. Es así que las decisiones para la definición de las medidas, así como la definición de las proporciones y geometría responden a números precisos, cuyo significado es posible colegir de los estudios de la biblia. De esta manera el número uno significa la totalidad, la sustancia de Dios; el dos representa la dualidad, al hombre; el tres señala a la Santísima Trinidad y la dimensión del tiempo (pasado, presente, futuro); el cuatro representa la tierra y el cosmos (cuatro puntos cardinales, los cuatro ríos que regaban la tierra en el paraíso); el siete, como la suma de tres y cuatro, indica perfección (siete sacramentos y siete virtudes: tres teologales y cuatro cardinales); por último el doce es el número de la elección, pues doce fueron las tribus elegidas de Israel, así como doce fueron los apóstoles. Es preciso recordar que tanto el siete como el doce son números que se obtienen con los cuatro primeros, en específico con el tres y el cuatro.

Sin esta concepción de la arquitectura como vehículo de fe, el análisis geométrico y de proporciones queda limitado a un hecho meramente casual, dependiente de la voluntad del artífice, lo que sin duda, no fue así.

Del levantamiento realizado el año 1767 que se conserva en el Archivo Nacional y de su escala gráfica en Varas se deduce que el frente de la iglesia medía veintiuna varas de ancho, mientras el cuerpo de la iglesia tenía trece varas de ancho. A su vez el largo era de cuarenta y cinco varas. Interiormente está dividido en la asamblea que mide diez varas de ancho y veintiocho varas de largo. Dos machones de una y media varas de ancho lo separan del presbiterio que mide seis varas de profundidad, y detrás de él está la sacristía de iguales dimensiones. A su vez los muros de la asamblea, cercanos al presbiterio tienen un nicho con dos altares laterales que ocupan aproximadamente seis varas del largo del espacio destinado a la asamblea. Hay que considerar que en este caso como en otras edificaciones de la zona central de Chile las estructuras murarias eran realizadas normalmente en adobe, ladrillo o piedra, a diferencia de Chiloé que eran de madera. 
Al comparar el ancho con el largo del espacio destinado a la asamblea esta se aproxima a la proporción tripla (3/1) o de diapasón diapente, en términos de la arquitectura clásica. Al ser menor que la proporción indicada, significa que el espacio de la asamblea invade el presbiterio, donde está Dios por medio del cuerpo de Cristo, así como esta invade el espacio de la asamblea, imbricándose, proponiendo la unión de los fieles con el mensaje de Dios. Esto se refuerza por el hecho que el conjunto de la sacristía, el presbiterio y los altares laterales, incluidos los machones y el muro divisorio, están en proporción dupla (2/1) o de diapasón, intersecado este conjunto con el resto de la iglesia. Mientras la sacristía y el presbiterio, espacio restringido a los sacerdotes suma en total doce varas, como los doce apóstoles.

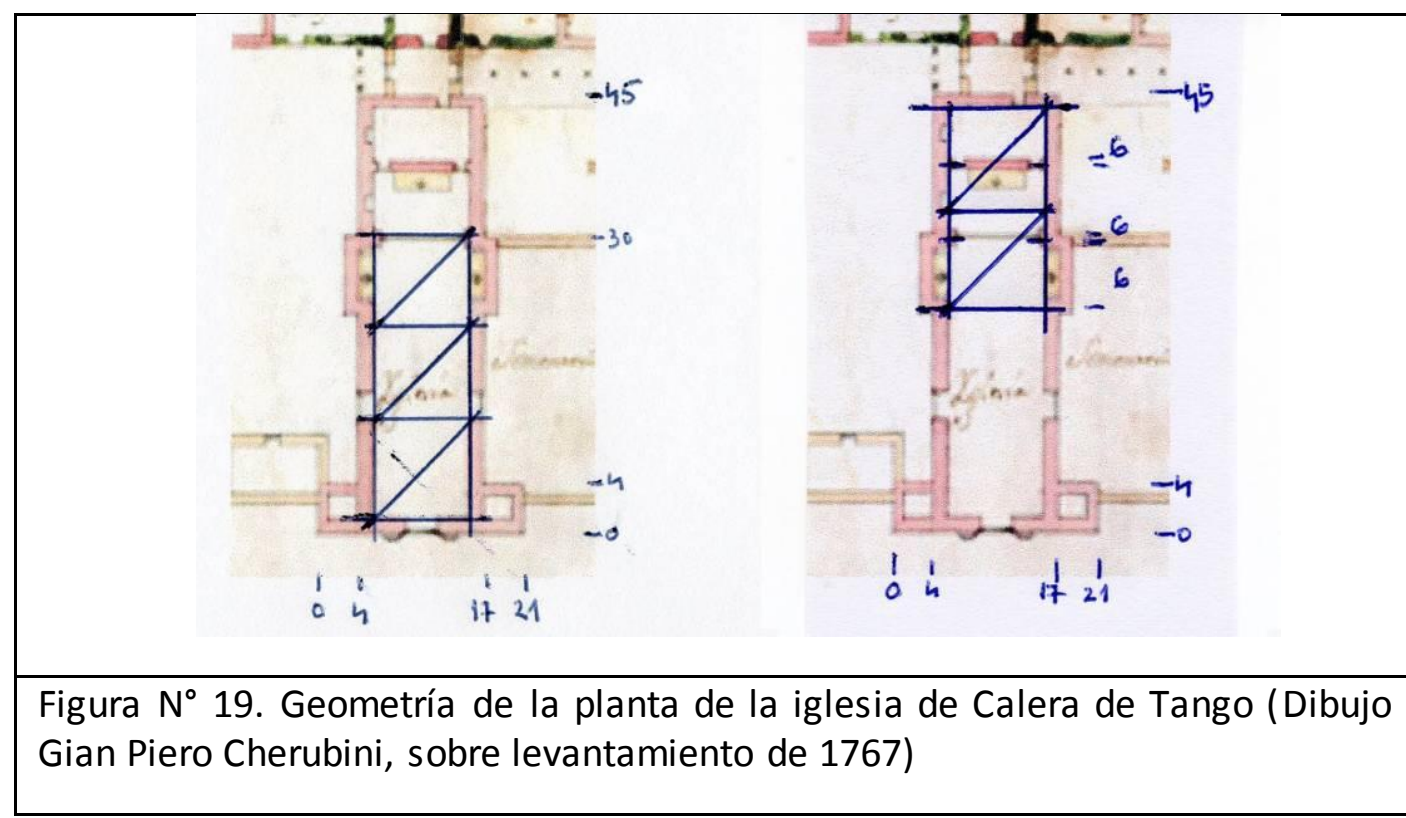

De acuerdo a un diseño de la fachada de la iglesia en 1890 (Rodríguez, 2012, p. 67), esta se presenta con un cuerpo bajo articulado con un tímpano central que destaca la puerta de entrada, la cual se encuentra flanqueada por sendas pilastras que recibían un entablamento. A ambos lados de la puerta se ven dos muros llenos, sobre uno de los cuales se alzan dos cuerpos superpuestos de planta cuadrada que forman la torre, cuya altura es de veintiuna varas. La altura hasta el cuerpo intermedio es de diecisiete varas. Este cuerpo se alza a partir de una altura similar a la mitad del ancho total de la iglesia. La altura del cuerpo lateral opuesto a la torre coincide con el inicio de las pilastras del pórtico, y es equivalente a siete varas.

Si se toma como base esta última altura, es decir siete varas, y se compara con el ancho total de la fachada, esta está en razón tripla (21/7=3/1). El número siete se puede descomponer en tres y cuatro $(7=3+4)$, siendo el tres el número de la Santísima Trinidad y el cuatro el número del mundo terrenal. A su vez, como se indico más arriba, el 7 representa la perfección en la fe. Esto equivale a decir que la iglesia es un lugar en donde el hombre se encuentra con Dios y a través de él perfecciona su fe, y su vida. 


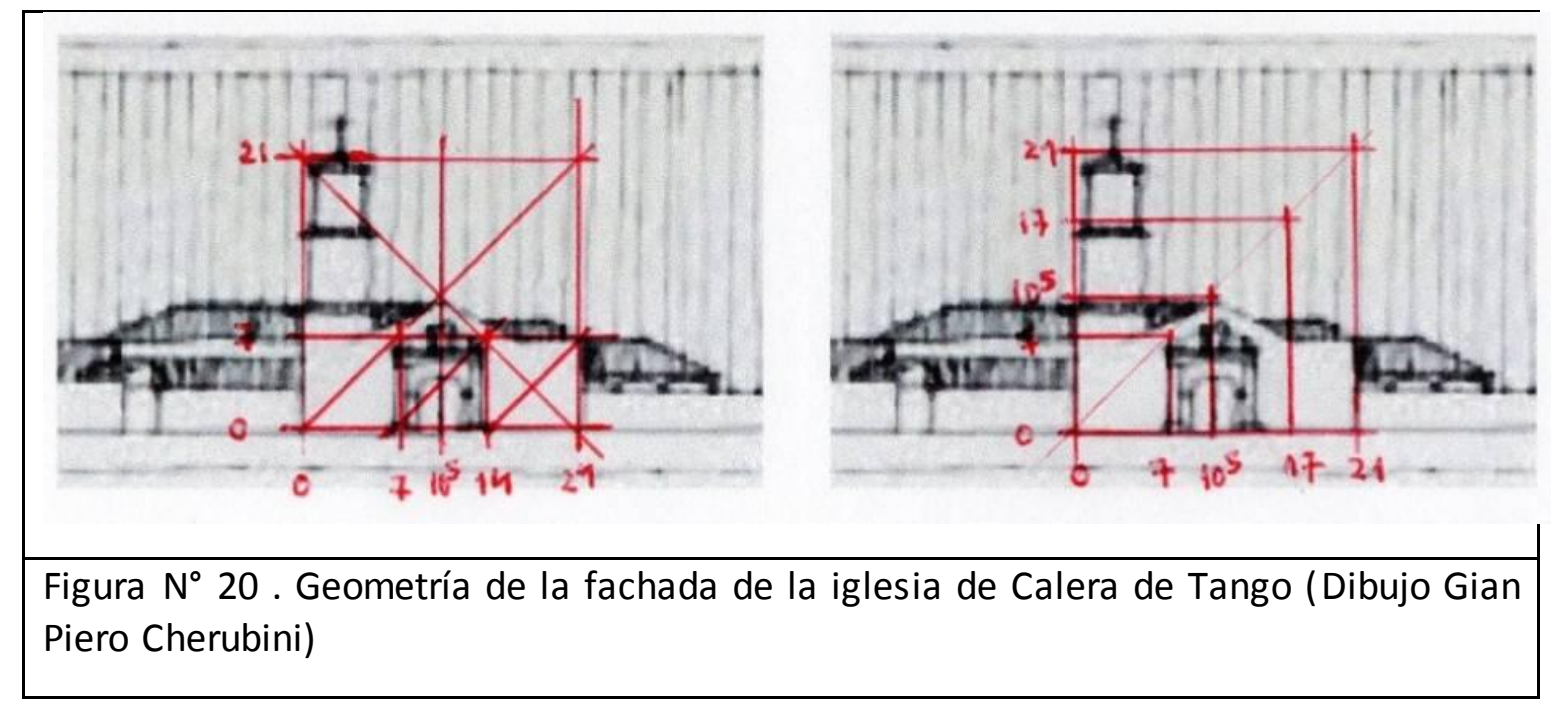

El primer trazado geométrico se establece con la altura del cuerpo bajo que forma una sucesión de tres cuadrados (3/1), y la altura del arranque de la torre en la mitad del ancho $(21 / 2=101 / 2)$. El centro de esta sucesión de cuadrados es ocupado por el pórtico de acceso.

En este conjunto se relaciona el tres, contenido en la parte baja de la fachada, con el cuatro $(2+2=4)$, que se forma en la división en mitades de los lados del cuadrado que la contiene. La síntesis de ambos números es el siete $(3+4=7)$. En la fachada se establece además, la relación proporcional entre siete con diez y medio, y catorce con veintiuno $(7 / 101 / 2=14 / 21=2 / 3)$, en relación sesquiáltera o diapente.

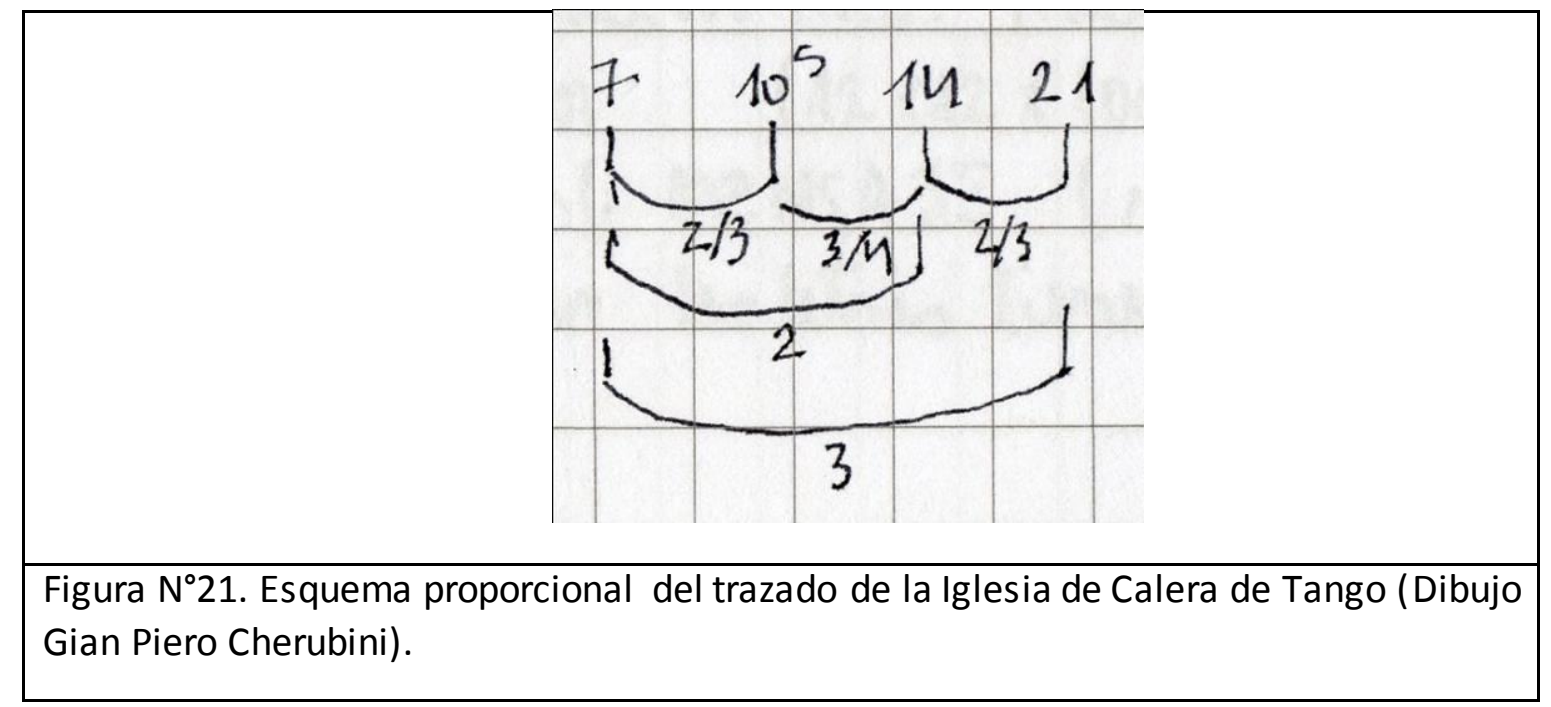

El número diez y medio y el catorce, son la media armónica y aritmética, respectivamente, entre siete y veintiuno: se trata de una progresión de números relacionados con las consonancias musicales, es decir: el unísono (1/1), sesquitercio (3/4), diapente (2/3), diapasón (2/1) y diapasón diapente $(3 / 1)$, las mismas que propone el sacerdote Juan Bautista Villalpando S.J. en su interpretación del templo de Salomón (Wittkover 1962, p. 119). 
El segundo esquema geométrico de la fachada toma la altura de siete varas del cuerpo bajo, el arranque de la torre en diez y media varas, la altura hasta el primer cuerpo en diecisiete varas, y la altura del segundo cuerpo en veintisiete varas, y las relaciona con su correspondiente en el ancho que es el primer tercio de siete varas, el eje de simetría a diez y media varas, el ancho del primer cuerpo lateral y el de la nave, que es de diecisiete varas y el ancho total que suma veintiuna varas. De esta manera se forma una sucesión de cuadrados que se proyecta hacía el infinito.

De acuerdo a lo descrito, es posible señalar que la fachada de la iglesia es una señal que indica que en ese espacio es donde el hombre se encuentra con Dios y a través de él perfecciona su fe, y su vida, pero es necesario atravesarla y entrar para poder participar plenamente de la unión del hombre con Dios.

Sin embargo hay un dato anómalo. El ancho de la fachada se compone de dos cuerpos laterales de cuatro varas de ancho, mientras el cuerpo central mide trece varas. Considerando un cuerpo lateral y la nave central, estos suman diecisiete varas $(4+13=17)$. A su vez el cuerpo de la torre sumado al cuerpo central, enteran, también diecisiete varas. Este es el único número que pareciera no encajar en las series de números usadas por el artífice de la iglesia, salvo que, además de ser un numero primo, es tres unidades mayor que el catorce $([2 \times 7]+3=17)$ y es cuatro unidades menor que veintiuno $([3 \times 7]-4=17)$.

Esta fue una medida usada por el hermano Vogl en la altura de los planos de la catedral realizados el año 1753 (Guarda, 1991, p.168), así como en la altura de los muros en la reedificación de la Iglesia San Miguel o de la Compañía hechos después del terremoto de 1730 (Pereira, 1965, p.110). Esta misma dimensión se encuentra en el ancho de la iglesia de Achao en Chiloé, construida por el hermano Miller S.J., posiblemente aconsejado por el hermano Vogl.

El hecho de que el número diecisiete aparezca en la iglesia de Calera de Tango de manera casi forzada lleva a pensar que esta era una impronta del hermano coadjutor, un característica que imponía a su arquitectura, de esta manera, no sólo construyó un edificio bello porque estaba en armonía con el templo que Dios ordenó construir a Salomón, el cual a su vez estaba en armonía con el universo, sino que además indicó, con este curioso subterfugio, quien fue su autor: HNO.PEDRO.VOGL FECIT. 


\subsection{Antecedentes de la arquitectura de los Jesuitas, en Europa.}

A través del autor Alfonso Rodriguez de Ceballos, se pueden recoger varias claves importantes que tenía la Orden en relación a la arquitectura.

Primeramente sostiene y profundiza, recalcando en lo ya expuesto, el hecho de que los jesuitas hayan sido el principal movimiento de la contrarreforma, pero no significa necesariamente que la arquitectura adoptada sea la barroca en la amplitud de esta compleja corriente artística.

Lo segundo y esto es lo interesante, es que tampoco disponen de un estilo propio en el sentido riguroso de lo que se entiende por un estilo, ya que argumenta

tendría que haber existido una voluntad firme y determinada de imponerlo de manera uniforme en sus edificios por parte de la autoridades de la Orden, así como una maquina legislativa e institucional capaz de llevarlo a la práctica, pero no efectuaron ni una cosa ni la otra (Rodriguez de Ceballos, 2002, p.20)

sino más bien que comparten una visión de carácter práctico que permitirá sostener y llevar a cabo la empresa misionera en una manera eficaz y vinculado al espíritu de austeridad de la orden.

En efecto en el párrafo 38.. decía:

Impóngase a los edificios de las casas y colegios el modo que nos es propio de manera que sean útiles, sanos y fuertes para habilitar y para el ejercicio de nuestros ministerios, en los cuales, sin embargo, seamos conscientes de nuestra pobreza, por lo que no deberán ser suntuosos (Rodriguez de Ceballos, 2002, p21).

La expresión "el modo que nos es propio" aparecerá en otros muchos decretos de las Congregaciones Generales, bien en latín, bien en la traducción italiana "modo nostro". Con los términos de "sanos, fuertes y útiles" se quería crear una tipología funcional de los edificios, no un estilo artístico determinado.

Esta indicación del "modo nostro" es la única premisa que se impone, según los estudios de este autor y la arquitectura de la orden, a pesar de haberse tratado de imponer o utilizar ciertas tipologías edilicias especificas que no prosperaron. Por otra parte se estableció que los proyectos arquitectónicos debían pasar por una aprobación en Roma, esto fue imposible de llevar a cabo, dada la dificultades administrativas y de comunicación en la época para cumplir estos requisitos, lo que de cierta manera también influyo en el control de las formas.

Con todo lo anterior, igualmente lo que se impone es un cierto sentido común entre los jesuitas y que apunta a una tipología concreta y era que "Preferían la iglesia de nave única en cuanto espacio congregacional que se avenía mejor al culto, a la administración de los sacramentos y a la predicación" (Rodriguez de Ceballos, 2002, p.33), no cabe duda que esta tipología de planta arquitectónica es tremendamente funcional, tanto en esa época y hasta hoy, como también es el hecho de dar mayor facilidad para su edificación y por lo tanto también de ajustarse al denominado "modo nostro" de la orden.

Esta visión funcionalista y consciente de una actitud de austeridad de la orden hacia la arquitectura en los templos se mantuvo hasta mediados del siglo XVII, en que se 
contagia definitivamente con el barroco y el sentimiento triunfalista de la iglesia romana en contra de las herejías y el avance sostenido de la fe en las América y Asia. Por lo tanto en los edificios religiosos se incorporó la suntuosidad del barroco, pero en el caso jesuítico fue en el plano decorativo y no espacial.

En la experiencia española, la corriente que ingresa a América, el autor Rodríguez de Ceballos establece y resume los siguientes periodos formales:

El siglo XVII y el triunfo del Barroco. Durante el Quinientos lo que singularizó a las iglesias jesuitas fue la construcción de la gran sala congregacional bordeada o no de capillas, sin que se diese mayor importancia al sistema de cubrición: crucería, bóveda de cañón, bóveda vaída o techumbre plana de madera, esta última utilizada raramente aunque se pensaba que era la mejor para absolver los ecos de la voz durante la predicación. En el transepto, cuando lo había, se levantaba un casquete semiesférico y muy rara vez una cúpula con tambor, calota y linterna. Esta tipología primordial comenzó a variarse durante el XVII, pero sin que los jesuitas se empeñasen en introducir novedades tan radicales como las que experimentaron en la modelación del espacio los genios del barroco italiano.

Iglesias de tres naves. Esta clase de iglesias, al igual que las de planta centralizada, fue excepcional entre los jesuitas españoles, muchos más que en otros países como Francia, Bélgica, el sur de Alemania e Italia, donde se dio con relativa frecuencia. Aunque no se considerasen ajenas a la práctica de la Compañía, las naves laterales suponían, en opinión de muchos, una superfluidad que obstaculizaba el culto. Eran espacios muertos donde el público no veía bien lo que se realizaba en el altar mayor y percibía con poca nitidez las palabras del predicador.

Por ello en la Compañía vino a preferirse la nave única bordeada de capillas laterales con pasadizos que las comunicaban entre sí, siguiendo la matriz dela la Chiesa del Gesú en Roma. Estas capillas se utilizaban para la celebración de las misas privadas y para la colocación discreta de los confesionarios.

El siglo XVIII. Las últimas construcciones.

Las fundaciones y edificaciones de nueva planta cesaron prácticamente durante el Setecientos, arraigada suficientemente e instalada la Compañía en España en los siglo antecedentes. Los jesuitas se dedicaron entonces a ampliar y consolidar sus construcciones $y$, sobre todo, a ornamentar $y$ enriquecer sus iglesias y capillas en un proceso de barroquización galopante (Rodriguez de Ceballos, 2002, p.45).

En síntesis la arquitectura jesuítica se permitió en los templos la suntuosidad como expresión de casa de Dios, pero siempre fue sobre un espacio preexistente de tipo clásico renacentista, que al decir del Padre Oliva, superior de la Orden

No hablo de nuestras iglesias pues éstas, como dedicadas exclusivamente a Dios, no pueden alcanzar ni aproximarse en la majestuosidad de su diseño, y en la riqueza de sus materiales y ornamentos al mérito infinito de la Divinidad. De aquí que en ellas tanto nuestro Padre San Ignacio como todos nosotros, sus hijos, procuremos corresponder la grandeza de su eterna Omnipotencia con 
aquellos aparatos de gloria, cuantos mayores mejor. Sin embargo en nuestro templo no deben sobrepasarse ni las dimensiones del espacio ni su altura, de suerte que impidan nuestros ministerios y obstaculicen no poco la piedad y compunción de los que los frecuentan. Hablo por tanto de nuestros domicilios destinados a nosotros, no a Cristo, los cuales, si alguna vez exceden nuestra moderación y mesura, eso acontece por vicio de ambición, pero me atrevo a afirmar que apenas tiene lugar ni en adelante acontecerá, combatida cualquier sombra de suntuosidad por nuestros estatutos". (Rodriguez de Ceballos, 2002, p48).

En estas obras normalmente "quien dirigía la construcción era un religioso, éste conocía mejor y sabía poner en práctica las escasas regulaciones del "modo" de la Compañía a emplear en sus fábricas, siempre que pudo, mano de obra propia no fue por esa razón, sino para ahorrar los costosos salarios y gastos de arquitectos extraños, cuando las fábricas no andaban sobradas de recursos económicos" (Rodriguez de Ceballos, 2002, p.53). También se daba el caso de no asumir el cargo de la dirección de obra un religioso de la orden, este nombraba un coadjutor con el conocimiento necesario y vinculado a la Compañía, ya sea tuviera la calidad de arquitecto u otra especialidad.

Hay que mantener presente que la Compañía era una orden imbuida por el espíritu Ignaciano, tremendamente comprometida con la preparación intelectual de sus religiosos y cuya formación se realizaba durante siete años en el Colegio Jesuita y esta era una obligación previa de todos los misioneros. (Fajardo, 2007)

Por lo anterior y para conocer la arquitectura jesuita es necesario conocer la instrucción que recibían los religiosos en estas materias y acudir a sus principales maestros, y el asunto no es menor porque revisando la literatura al respecto aparecen nombres relevantes y que son de origen centro europeo, que influyen tempranamente en la orden y debieron marcar ciertas tendencias arquitectónicas al interior de estas, las que se pueden descubrir posteriormente en los templos americanos.

Necesario es revisar que entre las figuras de los contados tratadistas de la época en España que destacan resultan ser jesuitas y profesores de los ramos de aritmética, geometría y arquitectura, son el caso de los padres Jean-Charles de la Faille y Christian Rieger. Ambos enseñaron en los Colegios donde se formaban a los futuros sacerdotes de la Orden, quienes guiarán las obras generales de la Compañía y los templos, y a los que indudablemente les traspasaron los cánones de la formación clásica y centro europea de la arquitectura.

La revisión de la presencia de tales tratadistas permite atender mejor que los jesuitas españoles portaban un conocimiento y una práctica, que hasta el presente se ha soslayado en los estudios de Chiloé, en ciertos cánones arquitectónicos que se han atribuido portados directamente por los jesuitas de origen centroeuropeo llegados al archipiélago. Ante este escenario se puede inferir que tanto los religiosos españoles y centroeuropeos compartían en la disciplina de la arquitectura una base formativa muy similar. 
En el caso del jesuita austriaco Christian Rieger (1714-1780), quien se avecinda en España y escribe dos tratados de arquitectura Universae Architecturae Militaris Elementa (1758) y Universae Architecturae Civilis Elementa brevius recentiorum observationibus illustrata (1756), el primero trata sobre arquitectura militar y el segundo sobre arquitectura civil. Este influyente tratadista del siglo XVIII puede ejemplificar bien cual es la enseñanza y pensamiento sobre la arquitectura que se aplicaba a los estudiantes.

Una de las investigaciones más actuales y profundas del la obra de Rieger es la realizada por Calatrava, Juan y Sambricio, Carlos llamada Christian Rieger y la Teoría de Ia Arquitectura en la España de mediados del siglo XVII, sobre la cual interesa destacar algunas aspectos del tratadista.

Rieger, sigue los principios clásicos y vitrubianos de la proporción, entendida en la relación de las partes y del todo, como principio de la arquitectura pero en vez de atender a la simetría en cuanto a factor de organización la considera más en relación a las razones matemáticas simples (numéricas) las que rigen. Igualmente desarrolla en profundidad los órdenes clásicos.

Al saber de la época considera ciertos axiomas de carácter "científicos" como principales en la arquitectura y que resume en ordenación, decoro, disposición y economía (Calatrava \& Sambricio, 2008). Es conveniente destacar que como buen tratadista e interesado en temas de matemática, geometría, el dibujo, la construcción y los recursos empleados, concibe la disciplina como un proceso de proyectación, y en tal sentido se debe representar previamente para organizar estos axiomas y llevarlos a cabo de modo coherente y simple. Situación a la cual los religiosos o coadjutores de obras se verán muchas veces impedidos de realizar en detalle.

Respecto de los adornos declara que estos deben ser naturales y siempre tender a lo simple, excluyendo los excesos, y que debe ser en correspondencia a todo el edificio así dice entre muchos ejemplos "son más perfectas las molduras que tienen más exacta periferia".

Pero quizás lo más interesante es el hincapié que hace al sentido del progreso de la historia, el paso desde lo más rudimentario a lo funcional y bello, y en este aspecto es un intelectual importante en la formación de la cultura jesuita y en la noción de la arquitectura como portador de avance y futuro, muy cercano al pensamiento de Laugier. (Calatrava \& Sambricio, 2008). Este ultimo con su conocido tratado y dibujo sobre la cabaña primitiva de madera con su aspecto entre estado natural por sus elementos constructivos, pero que adquire un forma edilicia humana, con la cual alude al sentido del progreso.

En las proyectación de las iglesias no privilegia algún tipo u orden en particular, si bien reconoce el valor original del Templo de Salomón en Jerusalén, al igual que Villalpando, del cual por su carácter divino corresponde al verdadero arquetipos del cual se suceden otros, y que los griegos perfeccionarían. También se interesa en la simpleza de la obra de Juan de Herrera en El Escorial y los magníficos logros de la arquitectura en el alto gótico. Por otra parte ilustra en su tratado de la Chiesa del Gesu 
en Roma ${ }^{43}$, obra señera de la orden que resalta por su trazado espacial de una sola gran nave, amplia y de capillas laterales. Su fachada e implantación volumétrica resultaban perfectas para las exigencias de la función litúrgica y de solemne austeridad tratadas en el concilio de Trento, que convertirán a la Chiesa del Gesu consagrado en 1584 en el modelo que influirá en la arquitectura romana y será exportado al resto de Europa.

En el caso de Jean-Charles de la Faille (1597-1652) compuso un breve Tratado de Arquitectura (1636) dedicado al Colegio Imperial de Madrid. De este tratadista de origen Belga los autores lo señalan mas como un recopilador de otros clásicos y que sintetiza en una breve obra que consta de treinta y seis folios y se conserva el manuscrito en la Biblioteca del Palacio Real. Por lo tanto se puede inferir que más bien divulga e ilustra lo ya conocido.

Una apreciación más exacta de su breve obra, da cuenta del interés de algunas novedades en la que brevemente indaga, que son fruto de su calidad de cosmógrafo e interesado en las matemáticas y geometrías elípticas y curvas del espacio astronómico y que deriva, presumiblemente, al arquitectónico y son de interés para el barroco. Sin embargo no se afana en el espacio arquitectónico, se concentra y profundiza en las formas de representación y el trazado de los elementos des de columnas a escaleras de caracol, particularmente en la construcción de fábricas de piedra (Ruiz Rodriguez, 2013).

También se debe considerar a jesuitas españoles y figuras importantes, como es Juan Bautista Villalpando (Córdoba, 1552 - Roma, 22 de mayo de 1608), quien pudo haber influenciado con sus postulados en el caso de Achao como ya se ha expuesto.

Villalpando, fue un arquitecto, matemático, escritor y teólogo. Escribió un Tratado de Arquitectura para teólogos, consistente en una serie de tres tomos entre 1596-1604, el primero realizado junto al escrituario jesuita Jerónimo de Prado, denominado Ezechielem Explanationes et Apparatvs Vrbis, ac Templi Hierosolymitani. Este tratado está dedicado al estudio del Templo de Salomón, el cual habría sido diseñado a partir de las indicaciones dadas por Dios, para el pueblo de Israel en los cuales se vierten una gran cantidad de conocimientos geométricos, matemáticos y bíblicos entre otros, con una serie de ilustraciones detalladas y delicadas que daban cuenta de un edificio perfectamente proporcionado dibujado con la mano celestial. Por lo tanto para estos jesuitas, Villalpando y Prado, realizar teóricamente la Reconstrucción del Templo de Salomón significaba de descubrir las reglas divinas. (Hernandez, 2005, p. 225).

Este tratado fue financiado por Felipe II y toda biblioteca Jesuita que preciara de serlo debía disponer de un ejemplar. Por lo tanto es muy posible que existiera de al menos una copia en Chile y hubiese sido una base teórica importante para los hermanos Jesuitas encargados de la Capilla de Achao.

\footnotetext{
${ }^{43}$ Cabe señalar en esta edificio encargado por el propio Loyola y realizado por los arquitectos lacopo Barrozi da Vignola, y Giacomo della Porta, quienes proyectaron Ia planta y espacialidad interior, el primero, y la fachada, el segundo, mientras la obra fue dirigida por los padres Giovanni Tristano S.J. y Giovanni de Rosis S.J., se apega rigurosamente a las tipologías Renacentista, sin embargo es el mejor ejemplo del posterior uso de la suntuosidad y donde el Fraile Andrea Pozzo hace los más notables aportes de pintura barroca con efectos prospetticos (perspectivas) sobrelas superficies planas de cielos
} 
Por último es importante mencionar otra figura, curiosamente de igual apellido al anterior y que lleva a confusiones, se trata de Francisco de Villalpando (¿Villalpando?, h. 1510 - Toledo, 1561) artesano y autodenominado arquitecto. Su contribución más importante a la arquitectura del momento la constituye su traducción de los libros III y IV del tratado de Sebastiano Serlio, publicada en Toledo en 1552 por Juan de Ayala, fundamental para el conocimiento de las fuentes arquitectónicas en la España de mediados del XVI, del cual en 20 años se realizaron 3 ediciones con aproximadamente 3.000 ejemplares. Tales publicaciones permitían dar a conocer a los profesionales contemporáneos las doctrinas vitruvianas, a través de Serlio, puesto que ésta es la primera traducción española.

Revisados estas figuras centrales en la formación jesuita para la arquitectura española de la época, se observa el nivel de conocimiento que poseían los religiosos sobre el arte de construir y particularmente que podían impregnar en sus templos ciertas reglas implícitas o explicitas como forma de instruir a los pueblos misionados. 


\section{Anexo $N^{\circ} 1$. Descripciones de Iglesia de Castro en 1741}

En HISTORIA. VOL. 19, 1984: 219-254 LA VISITA DEL OBISPO AZUA A CHILOÉ, 1741 INTRODUCCIÓN Y NOTAS DECARLOS OVIEDO CAVADA.

57. Yo el infrascrito secretario certifico como concluido dicho Extracto, a fojas 70 , continúa setenta y dos y setenta y tres, el recibo del nuevo cura de Castro ante el escribano Francisco Javier Gómez, así de los libros parroquianos, papeles e instrucciones que dio su ilustrísima, como de las alhajas que donó, en que se halla en catorce partidas insertas de plata labrada, en vasos sagrados, imágines y ornamentos hasta tres mil setecientos veinte y seis pesos de cuatro reales; con más la iglesia de sesenta varas de largo y doce de ancho, toda levantada con once colleras y sus tijerales, parte de ella en tabicadas las paredes, y entablado arriba, como asimismo el suelo del presbiterio con sus ventanas de balausIrería con más el tabernáculo del altar mayor de tres cuerpos, los dos mayores acabados, el tercero que se estaba labrando, con más siete mil tablas de alerce; las dos mil y quinientas ya puestas con otras muchas más partidas de madera con porción de clavazón y hierro, y una memoria de géneros a precios de Provincia de dos mil y cincuenta y un pesos para la perfección de la fábrica.

58. Y a fojas setenta y una se halla una carta del cura de Castro don Francisco Aguilar, escrita a su llustrísima, fecha en dicha ciudad a veinte y tres de febrero de este año, en que le da razón individual de haberse acabado perfectamente el cañón de la iglesia con el tabernáculo, y colocádose el día de la natividad de Nuestro Señor del año próltimo, concluyendo esta carta con pedir auxilios para perfeccionar los edificios colaterales, corredor y torres, que solo restaban para concluir; según que dicha carta consta, a que en todo me refiero. Y por ser ésta con el recibo citado posteriores al extracto de fojas setenta y dos, pongo para testimonio en relación su contenido, de orden de su llustrísima a continuación...

(Oviedo 1984:241) 
ANEXO 2. Inventario de la Residencia de los Jesuitas en Santa María de Achao (15-21769).

Entrega de Casas Jesuitas Sitas en el Colegio de Castro a los Franciscanos de Chillán (9-2-1769).

Fuente: Documentos Históricos X Región

Elaborado: Dr. Rodolfo Urbina

En nuestro caso tomado de "Las Misiones Franciscanas de Chiloé a Fines del Siglo XVIII: 1771-1800", Rodolfo Urbina Burgos, Instituto de Historia-Universidad Católica de Valparaíso, Serie Mo-nografías Históricas /4, lártole Editorial, H. G. O. Impresores, Viña del Mar, 1990, pp. 149, 150 y 151 [Apéndice Documental].

Documento reproducido con la autorización del Dr. en Historia Rodolfo Urbina Burgos. Contextualización:

El Doctor Rodolfo Urbina nos ilustra, respecto de los Franciscanos de Chillán, diciendo: "Llegaron a la Provincia en febrero de 1769, tomando de inmediato residencia en la ciudad de Castro. El 15 de febrero recibían la misión de Achao y el 18 hacían lo mismo con la de Chonchi. Recibieron también las iglesias y capillas. La ex iglesia jesuita de Castro fue recibida el 9 de fe-brero, la capilla de Achao el 15 y el 18 la de la villa de San Carlos de Chonchi." 1

Y, algunas líneas más adelante:

"Los franciscanos de Chillán tampoco pudieron permanecer mucho tiempo [Llegaron a Chiloé en Febrero de 1769]. Sólo dos años estuvieron ejerciendo en la Provincia. Alcanzaron a realizar dos misiones andantes o circulares: la primera en primaveraverano de 1769-1770 y la segunda en el mismo período de 1770-71. En 1771 hicieron renuncia formal de dichas misiones dando como ra-zones la falta de operarios en el Colegio para atender cada uno de los pueblos de Chiloé y la suma distancia e incomodidad para comunicarse con el resto del reino de Chile. Sus argumentos eran atendibles si tomamos en cuenta que la comunicación entre el Colegio de Chillán y Chiloé debía ha-cerse por la vía de Lima, es decir, navegar primero desde Talcahuano o Valparaíso al Callao y desde este puerto a Chiloé, lo que no sólo era dilatadísimo y oneroso, sino que imposible de hacer-lo en otra estación que en verano. El retorno seguía el mismo camino." 2

Inventario de la Residencia de los Jesuitas en Santa María de Achao.

En la villa de Santa María de Achao a quince de febrero de 1769 años. En cumplimiento de lo mandado por el auto del Sr. gobernador de esta provincia para las diligencias que en él se previenen y asistencia de sujetos nombrados para la entrega del Colegio y demás cosas que fueron de los padres jesuitas expulsos es, a saber, el Sr. don Ignacio de Vargas, corregidor, justicia mayor, capitán aguerra y coronel de milicias de la ciudad de Castro y don Francisco Javier Gómez, contador oficial real. Por ante mí el presente escribano se hizo entrega e inventario en la forma siguiente:

Primeramente un cáliz sobredorado de plata con su patena y cucharita.

Item. Unas imágenes de plata con su plato sobredorado y campanilla de bronce.

Item. Una casulla verde de damasco con senefa morada guarnecida con su franjita de plata falsa y forro de choleta amarilla, estola, manípulo, paño de cáliz y bolsa de lo 
mismo.

Item. Otra casulla negra de tafetán con su guarnición de ojalillo falso de oro forrada con angari-pola con estola, manípulo, paño de cáliz y bolsa de lo mismo, vieja.

Item. Otra casulla blanca de raso blanco a flores, guarnecida con su galón de oro falso forrado en tafetán carmesí con estola, manípulo, paño de cáliz de los mismo.

Item. Cuatro corporales sencillos usados.

Item. Ocho hijuelas, cuatro redondas y cuatro cuadradas.

Item. Un misal con su atril de madera y otro más, quebrado.

Item. Una sobrepelliz, roquete y estola.

Item. Dos albas de bretaña y una con labrado de aguja con su punta de encajes, la otra lo mismo poco menos que la primera.

Item. Dos cíngulos de cinta labrada en China.

Item. Tres amitas.

Item. Dos paños de comunión.

Item. Una maga de cruz de tripí o de medio carro negro, guarnecido con cinta falsa de oro forrada con lienzo de la tierra y la otra blanca de brocatillo, viejas, con su franja de oro forrada de tafetán carmesí.

Item. Un frontal de brocato negro con franja de oro falso forrado en lienzo de la tierra. Item. Otro negro viejo de tafetán con guarnición de cinta blanca angosta.

Item. Otro de raso blanco a flores con chanveri de oro falso.

Item. Otra de colores encarnado viejo de damasco con chanveri de oro falso forrado en crudo.

Item. Seis purificadores.

Item. Dos crimeras, un manual y un fierro de hacer ostias.

Item. Dos bolsas, una con su cajita de plata de llevar el viático y la otra de enfermos.

Item. Dos aras, la una quebrada, tres pares de anillos con arras.

Item. Un Santo Cristo de bronce pequeño en el altar mayor.

Item. Un copón de plata en su bolsa.

Item. Otro Santo Cristo mediano en la mesa de la sacristía.

Item. Un bulto pequeño de San Miguel, muy viejo y muy feo.

Item. Un fierro de cortar formas.

Item. Una imagen de Nuestra Señora vestida con su túnica de cambrai y manto de raso blanco a flores guarnecido con puntilla de oro falso con toca de cambrai coronada de plata con zarcillos de oro y perlas finas chicas y gargantillas de perlas falsas.

Item. Un Niño en sus brazos con su corona de plata y vestido de cambrai.

Item. Catorce estampas con sus marcos de madera.

Item. Un Santo Cristo de metal con su cruz de madera.

Item. Veinte candeleros de madera.

Item. Cuatro laminitas con su vidrio y diez y seis cornucopias.

Item. Un altar mayor con la sobre de una imagen de Nuestra Señora.

Item. Un altar colateral con un lienzo crucificado de Cristo con su velo de sayal de la reina.

Item. Dos pilas de piedras.

Item. Un estandarte de tafetán carmesí con cinta falsa de plata.

Item. Una rueda de diez y seis campanillas.

Item. Dos campanillas de altar.

Item. El velo del copón de vaso con sobrepuesto de cinta falsa de plata. 
Item. La iglesia de tres naves, por concluir, obra toda de madera.

Item. Un techo de tablas de pizarrilla con tres puertas a la calle, coro y el piso enrrajado con pre-bisterio y dos confesores.

Item. Una cortina de tafetán carmesí en nicho de Nuestra Señora.

Item. Dos escanos pequeños y un plumero.

Item. La mesa de la sacristía sin cajones escaparatillo.

Item. Una alfombra pequeña que se compone de tres bordes.

Item. Unas andas pequeñas de madera.

Item. Un (ilegible) forrada de raso verde.

Item. Una araña grande quebrada y dos siriales de madera.

Item. Una casa de vivienda, obra toda de madera, techo de tablas y sus corredores, ventanas, cár-celes, puertas y llaves.

Item. Ocho sillas y seis mesas y tres estantes distribuidos en los cuartos.

Item. Veinte y seis botijas vacías.

Item. Una casa que sirve de cocina, toda de madera, y techo de tablas y una despensa en ella.

Item. Otra casa escuela con techo de tablas y un cuarto más en ella, en la escuela una mesa y cua-tro bancas y un nicho con marquito de Nuestra Señora.

Item. Tres ranchitos con techo de paja y el uno de ellos con horno.

Item. Tres artesas con un cajón grande de guardar harina.

Item. Tres cajas, una con llave y las dos sin ella.

Item. Dos hachas y dos caballos mansos.

Item. Un potrero agregado a la casa que puede tener tres cuadras y una de ancho.

Item. Una arboleda de manzanitos.

Achao, 15 - Febrero - 1769.

1 Urbina Burgos, Rodolfo: "Las Misiones Franciscanas en Chiloé a Fines del Siglo XVIII: 1771-1800", Insti-tuto de Historia-Universidad Católica de Valparaíso, Serie Monografías Históricas /4, lártole Editorial, H. G. O. Impresores, Viña del Mar, 1990, pp. 9 y 10.

2 Ibidem, pp. 10 y 11.

Inventario de la Residencia de los Jesuitas en Santa María de Achao (15-2-1769).

MM. [Manuscritos Medina], T. 325, fs. 128, 129, 130 y 131.

Entrega de Casas Jesuitas Sitas en el Colegio de Castro a los Franciscanos de Chillán (9-2-1769).

MM. [Manuscritos Medina], T. 325, fs. 109 y 110.

Tomado en nuestro caso de "Las Misiones Franciscanas de Chiloé a Fines del Siglo XVIII: 1771-1800", Rodolfo Urbina Burgos, Instituto de Historia-Universidad Católica de Valparaíso, Serie Mo-nografías Históricas /4, lártole Editorial, H. G. O. Impresores, Viña 
del Mar, 1990, pp. 144 y 145 [Apéndice Documental].

Documento reproducido con la autorización del Dr. en Historia Rodolfo Urbina Burgos.

\section{Contextualización:}

El Doctor Rodolfo Urbina nos ilustra, respecto de los Franciscanos de Chillán, diciendo: "Llegaron a la Provincia en febrero de 1769, tomando de inmediato residencia en la ciudad de Castro. El 15 de febrero recibían la misión de Achao y el 18 hacían lo mismo con la de Chonchi. Recibieron también las iglesias y capillas. La ex iglesia jesuita de Castro fue recibida el 9 de fe-brero, la capilla de Achao el 15 y el 18 la de la villa de San Carlos de Chonchi." 44

1 Urbina

$\mathrm{Y}$, algunas líneas más adelante:

"Los franciscanos de Chillán tampoco pudieron permanecer mucho tiempo [Llegaron a Chiloé en Febrero de 1769]. Sólo dos años estuvieron ejerciendo en la Provincia. Alcanzaron a realizar dos misiones andantes o circulares: la primera en primaveraverano de 1769-1770 y la segunda en el mismo período de 1770-71. En 1771 hicieron renuncia formal de dichas misiones dando como ra-zones la falta de operarios en el Colegio para atender cada uno de los pueblos de Chiloé y la suma distancia e incomodidad para comunicarse con el resto del reino de Chile. Sus argumentos eran atendibles si tomamos en cuenta que la comunicación entre el Colegio de Chillán y Chiloé debía ha-cerse por la vía de Lima, es decir, navegar primero desde Talcahuano o Valparaíso al Callao y desde este puerto a Chiloé, lo que no sólo era dilatadísimo y oneroso, sino que imposible de hacer-lo en otra estación que en verano. El retorno seguía el mismo camino." 45

Entrega de Casas Jesuitas Sitas en el Colegio de Castro a los Franciscanos de Chillán. Item. Cuatro casas en cuadro en la iglesia, obra toda de madera y techo de tablas de pizarrilla con sus respectivos corredores.

Item. Diecisiete cuartos con tres despensas enrajado al piso de ellas de tabla y los corredores, de-lanteros, las puertas de los cuartos con sus llaves, ventanas y cárceles, aunque algunos descom-puestos.

Item. Dos cuartitos más con sus escalas que sirven para subir arriba al granero que servía todo fo-rrado en tablas.

Item. Cinco casas más, las dos mayores y las tres medianas, obra toda de madera que sirven de co-cina, despensa, horno y otras oficinas y están dentro del Colegio.

Item. Otra casa mediana con techo pajizo que servía de fragua.

Item. El Colegio tiene de fondo una cuadra en cuadro cercado por dentro de tabla con (ilegible) de ciprés y forro por fuera de estacada de ciprés, y dentro de dicho Colegio su arboleda de manzanas.

Castro, 9 - febrero - 1769.

${ }^{44}$ Urbina Burgos, Rodolfo: "Las Misiones Franciscanas en Chiloé a Fines del Siglo XVIII: 1771-1800", Instituto de Historia-Universidad Católica de Valparaíso, Serie Monografías Históricas /4, lártole Editorial, H. G. O. Impresores, Viña del Mar, 1990, pp. 9 y 10.

45 Ibidem, pp. 10 y 11. 


\section{CAPITULO 4. La llegada de los franciscanos y la imagen del neoclásico.}

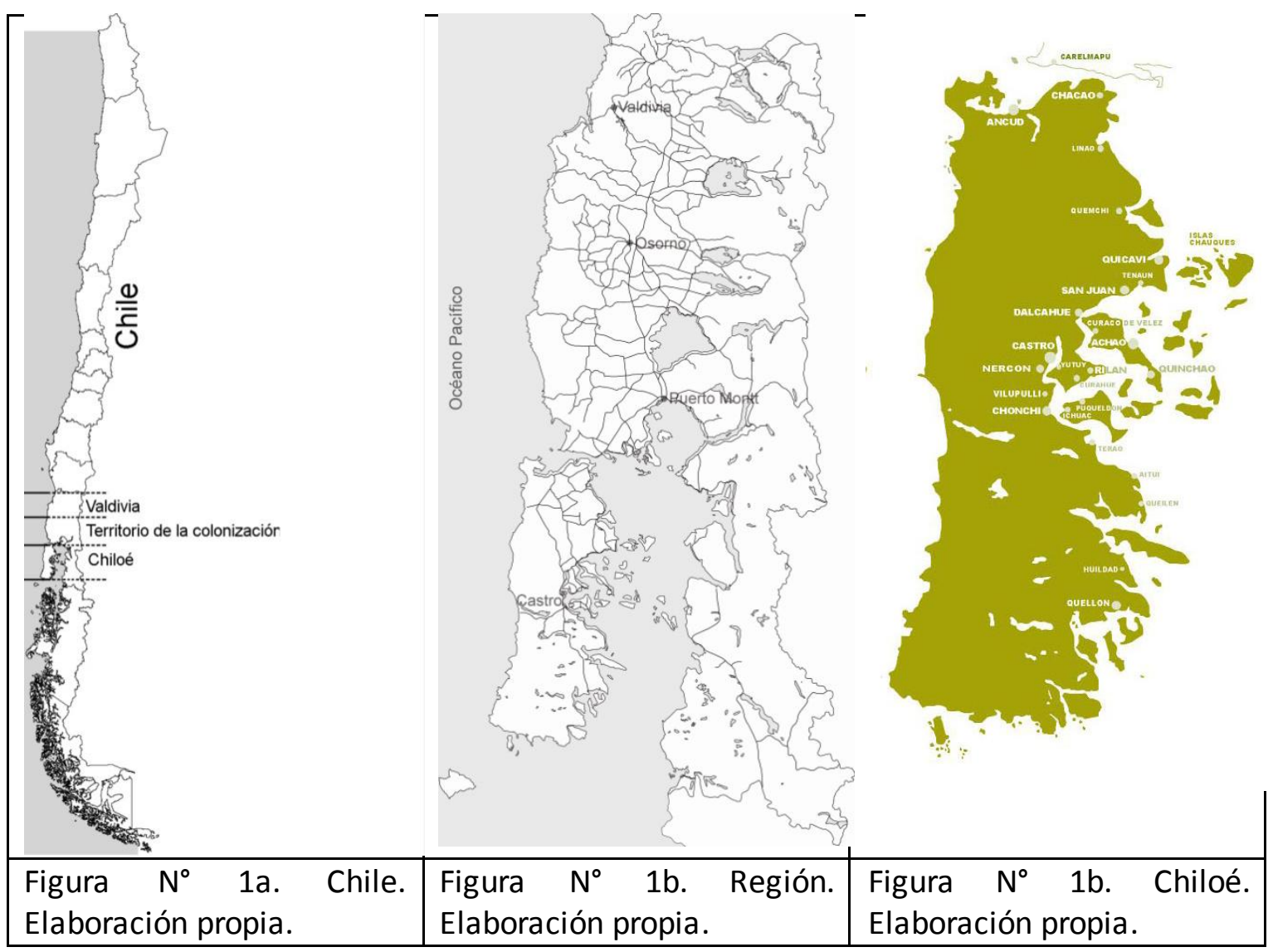

\subsection{Contexto: nuevos misioneros para la República.}

Es en este período que va a surgir definitivamente la impronta tipológica y estilística en la arquitectura religiosa de Chiloé y que hasta el presente estudio no había sido considerada ni estudiada en profundidad, desde la perspectiva histórica arquitectónica que permitirían confirmar la hipótesis planteada en esta investigación y que se desarrolla particularmente en este capítulo.

Las misiones franciscanas tienen tres oleadas o subperíodos que están marcadas según la procedencia de las comunidades religiosas. Estas son Colegio San Idelfonso de Chillán, Monasterio peruano de Santa Rosa de Ocopa y los franciscanos capuchinos italianos respectivamente ${ }^{46}$. Estos últimos llegan en un contexto particularmente diferente, ya que son comisionados a Chile por una necesidad y encargo del propio Gobierno en conjunto con la Iglesia Católica de ese entonces para radicarse en el sur

46 Los religiosos franciscanos tienen tres órdenes. La primera es masculina y tiene tres clases, los religiosos conventuales (Ordo fratum minorum conventualli (O.F.M.Conv.)), los Franciscanos observantes, (Ordo Fratrum Minorum (O.F.M.)), y los Franciscanos capuchinos, Ordo Fratum Minorum Cappuccinorum (O.F.M.Cap.). La segunda orden es femenina e incluye a las Hermanas Clarisas Pobres, (Ordo Sanctae Clarae (O.S.C.)), las Hermanas Clarisas Capuchinas, (Ordo Santae Clarae Capuccinarum (O.S.C.Cap)), y la Orden de la Inmaculada Concepción (concepcionistas franciscanas). Finalmente la tercera orden, también Ilamados terciarios, es la Orden Franciscana Seglar (Ordo Franciscanus Saecularis (OFS)). 
del país. Las razones de esta iniciativa responden a variadas causas, pero la principal es una: La Independencia de Chile del Reino Español.

En efecto, la Independencia Nacional en 1810 marcó un giro en los intereses de esta nueva nación que comenzó a abrirse a los ideales republicanos de otros países Europeos, desligándose de la madre España, principalmente a los aires revolucionarios de Francia como también a Italia, ambos países con raíz latina y por lo tanto mayor afiliación cultural.

En el caso de los franciscanos de Santa Rosa de Ocopa, la orden que había reemplazado a los Jesuitas expulsados de América y Chiloé en 1767, eran en su mayoría frailes de nacionalidad española y por lo tanto proclive a la causa realista, distante al espíritu de la nueva nación independentista. Se suma a esto el escaso número de misioneros activos en el sur de Chile, que hizo necesario traer nuevos contingentes a estas tierras, en pugnas con la población originaria mapuche aun no enteramente cristianizadas. Por lo tanto, también fue parte de un importante proyecto republicano de ejercer soberanía y evangelización del naciente país.

Es entonces, durante el gobierno del presidente Joaquín Prieto, que se lleva a cabo en conjunto con la Iglesia Católica la empresa de traer nuevos y preparados misioneros. Para esto se comisionó al fraile peruano Andrés Herreros O.F.M. y al Fraile Zenón Badía O.F.M. del colegio de Chillán. La misión alcanzó sus frutos cuando, el año 1837 llegaron los frailes italianos, los que se dividieron en dos grupos. Seis pasaron a Valdivia, mientras once lo hicieron a Chiloé ${ }^{47}$. El principal objetivo de esta acción fue la de reforzar las misiones en la Araucanía, así como conformar el Colegio de Castro, el que tendrá no solo una tremenda influencia en el archipiélago.

Al ser nombrado uno de estos misioneros Italianos, fray Bernardo Chuffa ${ }^{48}$, Viceprefecto de Misiones en la Región, se organizará con sus hermanos franciscanos capuchinos italianos para guiar el Colegio, así como las diferentes capillas chilotas, y muchas otras en la Araucanía, en el extremo austral del Estrecho de Magallanes, e incluso la zona central de Chile, en Valparaíso ${ }^{49}$.

Toda la fecunda obra de estos religiosos italianos se extenderá por todo el siglo, que es cuando se instituye la tipología de la Iglesia Tradicional Chilota basada en la fachada neoclásica con torre central como cuerpo de acceso a las capillas.

\subsection{El modo y la arquitectura franciscana.}

Esta orden, que fue de las primeras en llegar a Chile, con cinco sacerdotes en 1553, prácticamente un decenio después del inicio de todo el proceso de conquista y fundación de las primeras ciudades en el nuevo territorio, por parte del colonizador español Pedro Valdivia. Estos frailes también

47 Cfr. Pinto Rodríguez, Jorge. Jesuitas y Franciscanos y Capuchinos italianos en la Araucanía (16001900), en Revista Complutense de Historia de América, $N^{\circ} 19$. Madrid. Editorial Complutense. 1993. Pag. 109 a 147. Los frailes que Ilegaron a Chiloé fueron Diego Chuffa, Francisco Cheri, Domingo de Cesena, Marcos de Cátice, Alejandro de Androcco, Paulino de Acquaparba, José María Romano, Antonio de Carpineto, Salvador de Casello, Carlos de Palestrina y Domingo Passolini. Chuffa, o también Chufas, es la castellanización de Ciuffa, apellido original del fraile.

49 En Valparaíso fundaron la iglesia de San Francisco Barón. 
Venían, como los jesuitas imbuidos del espíritu de la Contrarreforma, y por lo tanto a experimentar un nuevo tipo de religiosidad que se aparta de las adherencias monásticas con el fin de insertarse directamente en la vida del pueblo, viviendo con ellos su fe mediante manifestaciones concretas, como las obras piadosas para los más débiles, los enfermos y los pobres (González, 2004, p. 5).

Esta preocupación emanada de las orientaciones del Concilio de Trento entre 1545 y 1563 son absolutamente compatibles y en el espíritu de la orden fundada por San Francisco de Asís cuatrocientos cincuenta años antes.

Es una herencia que ya tiene siglos de historia a lo largo de los cuales se han sucedido hombres de grandes dimensiones en el campo del saber y de la santidad. Bastaría pensar en el doctor Seráfico, San Buenaventura y en el Doctor Sutil, Beato Juan Duns Escoto, las dos lumbreras que guiaron el primer siglo de la reflexión franciscana y que fueron el punto de referencia de tantos otros hermanos que a lo largo de los siglos contribuyeron en forma eminente a la reflexión teológica de la Iglesia católica (Uribe, 2011, p. 209).

La "teología franciscana" se puede comprender como "una lectura y una confrontación con las problemáticas socio-económicas, espirituales, religiosas, etc., de un determinado contexto cultural, hechas desde dentro de la experiencia cristiana de fe vivida por aquellos

que se consideran y proclaman seguidores de Francisco de Asís" (lammarrone, 1978, p. 344-345) ${ }^{50}$. Esta misión o carisma que caracteriza a la orden, está orientada a reconocer los contextos culturales y también se considera la recurrencia a determinadas arquitecturas. Fray Bernardo Uribe ${ }^{51}$ resume la "teología franciscana" en cinco puntos, para efectos de contextualizar al caso de estudio se citan los dos primeros puntos:

- Una teología que se ha de considerar ante todo como una ciencia práctica, en cuanto no se reduce a un ejercicio racional ni al conocimiento en sí mismo, sino a hacer que la verdad revelada se convierta en un saber que se refleje en la forma de vida y en el servicio apostólico. Esto quiere decir, por una parte, que se alimenta de la práctica de una forma de vida iluminada por la de Francisco de Asís, decantada según las exigencias del momento histórico, por otra parte, que no es una teología de escritorio, ausente de la vida concreta de cada día, sino una búsqueda que tiene en cuenta la cultura y el momento histórico en que se vive, que escucha los clamores y las aspiraciones del hombre.

-Es una teología en que la relación del hombre con Dios se funda esencialmente en la libertad y en el amor, inflamada en el "ardor seráfico" que distinguió a los grandes maestros franciscanos. En este sentido la voluntad tiene un primado determinante que permea todas las dimensiones de la vida humana, sea en

\footnotetext{
${ }^{50}$ Giovanni lammarrone, "Possibilità, senso e compiti di una 'Teologia francescana' in sée per il momento attuale", in Miscellanea Francescana 78 (1978) 344-345.

51 Doctor en Teología. Universidad Pontifica de Roma (Italia).
} 
relación consigo mismo, con los demás, con lo creado y con el Creador. Este voluntarismo constituye precisamente una de las causas de la rica diversidad y del exuberante pluralismo del pensamiento franciscano a lo largo de los siglos, que impide encuadrarlo dentro de los parámetros de una determinada escuela (Uribe, 2011, p.210).

La particularidad de esta orden en su categoría práctica, es la forma de vida asociada y fundada por San Francisco, al ser la primera Orden mendicante ${ }^{52}$ y que se caracteriza por vivir de la limosna de los demás. Por lo tanto hacen votos de pobreza, además de castidad y obediencia.

Gran parte de la obra de San Francisco está inspirada en la frase que habría recibido como voz divina "Francisco, repara mi Iglesia, pues ya ves que está en ruinas" (Iturriaga, 1987, p.19) A partir de entonces, comenzó a visitar y servir a los enfermos en los hospitales. Algunas veces regalaba a los pobres sus vestidos, otras, el dinero que llevaba. De este modo desarrollaba su espíritu de pobreza, su profundo sentido de humildad y su gran compasión. Movido por una fuerza irresistible transportaba las piedras que hacían falta para reparar la iglesia de San Damián, y ayudó en el trabajo o los albañiles. Ídem con la de San Pedro y la Porciúncula.

De las primeras y simples ocupaciones realizadas por el fundador de la orden, sus posteriores seguidores para organizar su forma de vida de fe se instalaron en sistemas conventuales y siguiendo el ejemplo de los monasterios de Regla Benedictina, disponían principalmente de las siguientes dependencias: el claustro, normalmente cuadrado, en torno a un patio con fuente al centro y corredores en los cuatro lados, donde se ubicaban las dependencias de los sacerdotes y presidiendo toda la iglesia, con el altar mayor y presbiterio, la nave o naves para los laicos, y el coro para los fieles, aunque el coro elevado a los pie de la iglesia apareció por primera vez en las cartujas.

Estos sistemas conventuales viajarán a América y la orden mendicante se irá transformando y adecuando. No será distinto en Chile y tal como señalara

A lo largo de la investigación iremos dando cuenta que San Francisco ${ }^{53}$ siempre ha respondido a las tendencias estilísticas-arquitectónicas de su época llamando a trabajar para ello a los principales representantes de los "nuevos tiempos" sin dejar de lado la austeridad y sencillez de la cosmovisión de la congregación (Díaz, 2011, p. 12).

De entre las ordenes católicas, la inspiración franciscana está marcada por su visión hacia el otro como un hermano, llegando a considerar a los animales como hermanos menores. Este carisma franciscano ciertamente en la práctica no siempre fue la regla y hay muchas discusiones encontradas respecto al trato y la forma que fue llevada la evangelización, particularmente en este periodo, sin embargo según estudios de historiadores serios en la materia, como es el caso de Jorge Pinto ${ }^{54}$, reconoce sobre los franciscanos llegados a la zona "que en su propuesta hay tres elementos que los

\footnotetext{
52 Mendicante, del latín mendicare, pedir limosna.

${ }^{53}$ Se refiere a la Iglesia de San Francisco deSantiago de Chile.

54 Premio Nacional de Historia 2012.
} 
acompañan, cual sea el lugar en que se encuentren: la pobreza, el afán de vivir entre los infieles y la firme voluntad de alcanzar la conversión de estos" (Pinto, 1993, p.42). En este sentido el historiador agrega

a diferencia de los jesuitas, los franciscanos italianos que vinieron en 1837, encararon su relación con los mapuches sobre otros fundamentos. Conversores por naturaleza, sus propuestas tuvieron, al menos en el papel, un carácter marcadamente etnocentrico y de connotación casi etnocida, aunque en la práctica hayan sido más tolerantes (Pinto, 1993, p. 26-27).

En tal sentido y con muchos ejemplos, este autor le reconoce a los misioneros italianos una acción cercana a los principios de adaptarse y reconocer al otro como un hermano.

El historiador franciscano y mayor recopilador actual de los archivos de la orden, señala sobre el vasto accionar de sus antecesores

La labor del misionero no puede ni debe ser confundida: aunque tangencial y ocasionalmente lo vemos metido en obras de civilización, educación o promoción humana, o lo encontremos a lo largo de la historia como constructor, lingüista o agricultor, tengamos presente que él ha sido llamado para construir el reino sembrando la semilla del Evangelio y testimoniando con su vida el Mensaje de Jesucristo, especialmente entre aquellos que no lo conocen (Iturriaga, 1987, p.39)

\subsubsection{La arquitectura en Chile y su relación con el período de los franciscanos.}

Con la implantación de la República en Chile, se dará un mayor impulso a obras de gran magnitud tanto en infraestructura vial, portuaria y ferroviaria como en lo que se refiere a la arquitectura civil y religiosa. En relación a la nueva edilicia se iniciará la llegada de los primeros arquitectos ${ }^{55}$, ya que prácticamente hasta mediados del siglo XIX la mayoría de la práctica fue llevada por ingenieros militares, agrimensores y sacerdotes en lo que se refiere a obras de magnitud (Cáceres, 2007). Es en esta época en 1850 que se inician por primera vez en Chile estudios regulares de arquitectura, con la guía del arquitecto francés Claude Francois Brunet de Baines (1799-1855), quien es formado en el taller de Chatillon en la Escuela de Bellas Artes de París y trae consigo los postulados del academicismo, publicando el libro titulado Curso de Arquitectura, con el cual instituye una serie de principios estéticos que van consolidando la corriente neoclásica en Chile a través de los artífices y arquitectos, la cual será adoptada en el repertorio de gusto de diversos grupos sociales.

Esta llegada ilustrada de arquitectos italianos, franceses a los cuales se sumaran algunos alemanes, ingleses y norteamericanos van a cambiar el modo casi vernáculo o

\footnotetext{
55 Previamente destaca la solitaria presencia y llegada en 1780 del arquitecto Italiano Joaquín Toesca (1745-1799), discípulo de Sabatini en Nápoles, quienes proyectan la Catedral de Concepción. Toesca además realiza como arquitecto encomendado por el Reino, grandes obras como la reconstrucción de los tajamares del rio Mapocho y la Casa de la Moneda, actualmente el Palacio Presidencial.
} 
tradicional de la producción pública y privada de mucha edilicia, por ende un cambio notable en la fisonomía de la ciudad. El Intendente Benjamín Vicuña Mackenna de la época quien lleva a cabo el plan de transformación de la capital Santiago, influyendo en el resto del país, escribe

no había sino murallas, estribos, canes metidos y acuñados con llaves en la pared clavos de cobre en puertas tales que las habría envidiado Vauban para sus ciudadelas...pero ciudad propiamente no había, porque no había arquitectura, reglas, proporciones, estimulo, distribución, nada en fin de lo que se llama arte y simetría. (Vicuña Mackenna, 1869, p. 282)

Uno de los arquitectos distinguidos entre los discípulos de Brunet de Baines está la figura de Fermín Vivaceta (1827-1890), quien ha sido reconocido históricamente pero, es escasa la bibliografía relativa a su labor y aporte como arquitecto aunque se le reconocen claramente sus obras. Resalta su labor como profesor e impulsor de iniciativas de instrucción pública para obreros y artesanos participando como director y presidente de la Sociedad de Instrucción Pública y la Sociedad de Unión de Artesanos respectivamente. La singularidad de Vivaceta es que su oficio inicial fue ser carpintero y ebanista, lo que compartió con su trabajo de arquitecto, además ejerció haciendo clases de geometría y matemáticas.

Entre sus obras se cuentan diversos edificios emblemáticos que se realizan en la época y varios perduran hasta hoy en día: la torre de la Iglesia de San Francisco, la torre de la Iglesia de Santa Ana, la torre del cuartel de Bomberos, la torre de la Iglesia de la Recoleta Franciscana, la torre y fachada de la Iglesia de Curimón, la iglesia del Carmen Alto (demolida) y el Mercado Central entre otros. La participación y dirección de estas obras por parte de Vivaceta tienen aspectos importantes a considerar como son el oficio e interés por las torres y los edificios religiosos, siendo en varios de estos casos pertenecientes a la orden franciscana. En este aspecto sus proyectos son en general de una sola torre en la fachada, a diferencia del resto de arquitectos y constructores que realizaban indistintamente una, dos o simplemente ninguna como el caso de Cremonesi. Fue tanta la obsesión por las torres de Vivaceta que según Pereira Salas existía en él una voluntad de altura gótica.

En el caso del trabajo realizado para la torre de la Iglesia de San Francisco en Santiago (1856) hay cierta similitud entre el sistema estructural constructivo realizada en madera de la torre, de factura contemporánea con las homólogas de Chiloé de madera, esto es solo perceptible por el interior donde se puede ver la fabrica edilicia, dado que su exterior aparenta un edificio estucado en una estética neoclásica. Si bien el primer cuerpo es de mampostería de piedra, la torre se encaja en ella, de manera independiente, como las befroi franceses ${ }^{56}$, y se eleva por sobre el cuerpo de piedra totalmente en madera. Lo particular de la propuesta de Vivaceta es que su torre de madera no descanse directamente en el terreno, sino que se afianza a la mitad de la altura del cuerpo de piedra mediante sendas diagonales, por otra parte se utiliza para el escalonamiento de los tambores de la torre, el sistema de plataforma y por ultimo hay una gran cantidad de conectores metálicos para unir elementos estructurales de madera. Todas estas técnicas se distancian de las utilizadas en Chiloé y es posible

\footnotetext{
${ }^{56}$ Se entiende como la estructura de carpintería de madera utilizada para soportar las campanas .
} 
sostener que Vivaceta no actuó directamente en las capillas insulares, lo que un momento de esta investigación era posible suponer, tampoco hay registros escritos al respecto.

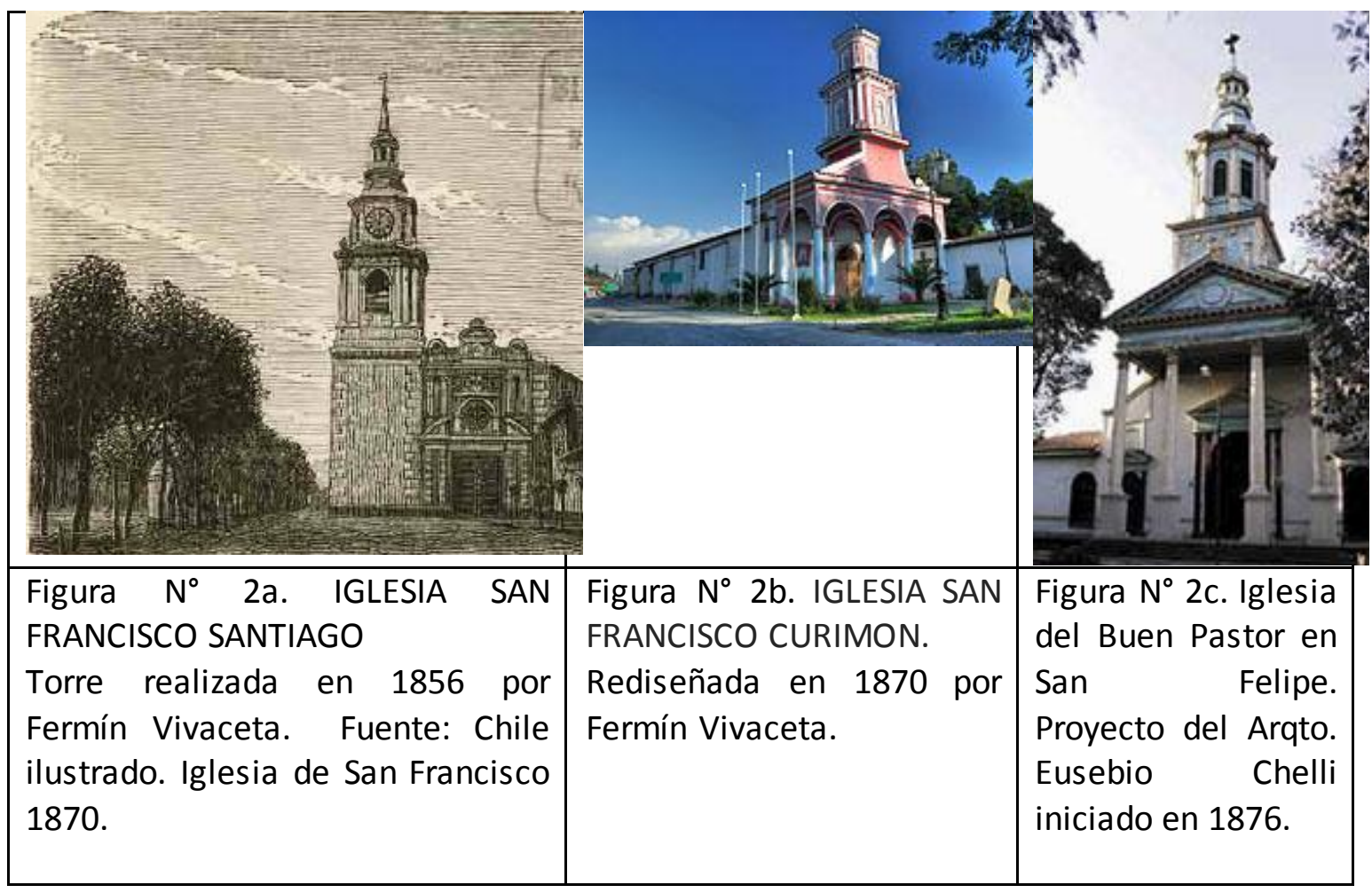

Similar situación se describe para otro importante arquitecto de la época, el italiano Eusebio Chelli (Roma 1820- Santiago 1890) ${ }^{57}$, quien Ilega a Chile en 1853 a proyectar y dirigir diversas obras principalmente religiosas entre las cuales se encuentran varias para la orden franciscana. Este arquitecto viene a representar el espíritu de esta etapa neoclásica, recomendado por el Papa para encargarse de los trabajos del templo Recoleta Dominica: Iglesia y el altar de mármol. De familia de artistas de Carrara, de alma renacentista, trabajó en la Basílica de San Pablo Extramuros en Roma. De clara influencia palladiana, emplea el arco de medio punto, pilastras, antias, columnas con capiteles corintios y jónicos, archivoltas, frontones, hornacinas y balaustradas (Díaz, 2011).

Chelli utiliza frecuentemente la tipología de torre fachada, como es el caso de Iglesia de la Recoleta (1853) o la Iglesia del Buen Pastor en San Felipe (Figura $N^{\circ} 2 \mathrm{c}$ ), iniciada en 1876. Sus modelos arquitectónicos también son similares a los chilotes, pero no hay antecedentes escritos de que haya trabajado para la orden en el sur. Pero es muy

\footnotetext{
57 En 1834 ingresó a la Academia Pontíficia de San Luca en Italia. Entre sus obras: Iglesia de la Recoleta (1853). La iglesia de la Recoleta Dominica (1853),Iglesia de los Capuchinos (1853), Iglesia de las Agustinas (1857), Iglesia del Buen Pastor en Santiago (1862), Palacio Errázuriz Urmeneta (1872), Iglesia de la Preciosa Sangre(1875), Trabajos y conclusión de Catedral Metropolitana, Trabajos de Conclusión del Teatro Municipal de Santiago, Planos de la Iglesia San Ignacio, del Colegio San Ignacio A.O, Basílica menor de la Virgen de Andacollo.(1873 - 1893)
} 
probable que haya influido ya que sus edificios religiosos son de mediados del siglo XIX en adelante, sobre todo si era italiano y contemporáneo a los frailes de la misma nacionalidad que estaban a cargo de la misión en Chiloé y la Araucanía. De hecho algunas de sus obras en la zona central le fueron encargadas por Fray Marco Bulla. "Hacia 1890, Chelli muere a los 70 años; no es menor el hecho que los funerales se efectuaron en agosto en el templo de San Francisco" (Díaz, 2011, p. 22)

\subsection{La huella de los Franciscanos en el contexto de Chiloé.}

Con la retirada de los jesuitas en 1767 del territorio americano y de Chiloé, se produce un vacio, particularmente en la zona sur de Chile, ya que dicha congregación era la protagonista de todo trabajo misional evangelizador. Esta situación ha marcado fuertemente la noción de la historia, dado el tremendo e innegable aporte realizado por los misioneros de la Compañía, pero ha opacado o invisibilizado las influencias paralelas o posteriores que han realizado otras comunidades en los aspectos culturales y arquitectónicos religiosos en la zona.

Esta situación se debe a que, además, los principales historiadores o cronistas de esas épocas hayan sido precisamente Jesuitas, es el caso de Miguel de Olivares, Alonso de Ovalle, Diego de Rosales, Fray González de Agüeros que siendo Franciscano, en su obra "Descripción Historial de la Provincia de Chiloé" de 1791 se detiene bastante en relatos sobre los jesuitas, dada la reciente partida de estos y finalmente Francisco Enrich.

De fechas más recientes son estudios y registros más detallados que permiten ir descubriendo mayores antecedentes de los hechos postjesuíticos, que van más allá de una visión de obra puramente continuista, las más optimistas, u otras bastante limitadas, las más comunes, que se han divulgado particularmente sobre los franciscanos.

En efecto, la propia congregación, a través de un trabajo acucioso de actualización de archivos y documentos históricos en los últimos años, ha dado una base de nueva investigación a numerosas disciplinas. Es este marco el que permite avanzar en el capítulo de la presente investigación.

\subsection{El periodo de San Idelfonso de Chillán 1767-1771.}

El prolífico historiador chilote Dr. Rodolfo Urbina, quien publica en 1990 "Las Misiones Franciscanas de Chiloé a fines del siglo XVIII; 1771-1800", entrega un contexto fundamental para comprender las implicancias dejadas por "150 años de accionar de los jesuitas" los misioneros de la Compañía y que deben asumir los franciscanos de Chillán, señalando que

Tuvieron que asumir la tarea de atender espiritualmente a mas de 10.000 indios y de otros tantos españoles; respetar usos y tradiciones profundamente arraigados por obra de la Compañía de Jesús; reconocer la existencia de instituciones, tales como las de los "fiscales" y "patronos"; festividades religiosas propias de cada pueblo y el compromiso de hacer avanzar la conquista espiritual hacia las fronteras de la Provincia (Urbina, 1990, p.2). 
Este mismo autor menciona que en el momento de la expulsión, los sacerdotes jesuitas regulares eran 14, aclarando que solo 13 activos, ya que uno estaba imposibilitado y postrado ${ }^{58}$. Estos estaban distribuidos en tres lugares: el colegio de la Castro, las misiones de Achao y la de Cailín. Este era el contingente para atender los 74 pueblos de indios situados en tan desmembrada geografía ${ }^{59}$.

Por otra parte entre los franciscanos actuales, encontramos una recopilación histórica elaborada desde diversas fuentes de la congregación, destacando la presencia y continuidad Franciscana en el archipiélago, desde los inicios de la conquista española hasta la actualidad y particularmente en el archipiélago.

Desde 1615 el Archipiélago contó con la eficaz presencia de los Jesuitas, pero ésta acabó en 1767, año en que la Compañía fue expulsada de los dominios de la Corona española. Con motivo de esa salida, todas las misiones chilotas quedaron, nuevamente, en manos de los misioneros franciscanos. Para cubrir ese vacío que dejaban los jesuitas en los sectores que ellos atendían en el Archipiélago de Chiloé, fueron destinados y enviados del Colegio de Chillán, en 1767, los siguientes religiosos Fr. Andrés Martínez, como Presidente, Fr. Miguel Ascorbi, Fr. Domingo Ondarza, Fr. Francisco Arroyo, Fr. Narciso Villar, Fr. Juan Zeldrón, Fr. Iñigo del Río y Fr. Esteban Rosales, de los cuales los 6 primeros eran sacerdotes. Estos tomaron bajo su responsabilidad el cuidado espiritual de todos los sectores del Archipiélago de Chiloé, siendo siempre Castro el centro (Díaz, 1990, p.6-9).

En este breve periodo de participación hay tres aspectos importantes. Primero, que los encomendados viene del Colegio Franciscano de Chillán, ya que en ese momento se consideraban como los misioneros más preparados para asumir tan difícil tarea de evangelizar en tierras australes e indianas (Urbina, 1990, p.9). Segundo, que Castro sigue siendo considerado como centro del archipiélago, es decir geopolíticamente importante. El tercer punto y fundamental, es que entre Chillán y Castro, es decir entre el Rio Biobío y el Canal de Chacao, aproximadamente unos 500 km. de distancia, se encuentra la zona de la Araucanía en permanente estado de guerra y por lo tanto un territorio difícil de transitar.

Esta situación hacía que los viajes debieran realizarse entre Chillan y Castro, vía el puerto de Talcahuano o Valparaíso, este último a más de cuatrocientos kilómetros al norte de Chillán, y de ahí embarcarse a Callao (Lima, Perú), para volver en barco hacia Chiloé, es decir un itinerario con una ruta larga, costosa y difícil de entender en la actualidad. Estas dificultades dieron una corta vida a los misioneros de Chillán en el archipiélago, dejando las misiones en 1771. Ese mismo año el Rey decide que

58 Se refiere al padre Antonio Friedl S.J., de 82 años, nacido en el pueblo aus triaco de Reutte el año 1685, quien ingresó a la Compañía en la provincia de Germania superior el año 1711. En Castro profesó sus votos finales en 1730. Falleció camino al exilio.

59 Enrich cita setenta y siete capillas. (Enrich, TII, 1891, p.284-285). Corresponden a 74 capillas más las residencias. 
El Colegio de Santa Rosa de Ocopa (Lima, Perú) disponía de un contingente más numeroso de operarios, incluso los 28 nuevos frailes colectados en España en 1770, y El Callao tenia comunicación directa, regular y permanente con Chiloé, de modo que los traslados, remesas de sínodos, instrucciones y demás urgencias no tendrían los inconvenientes sufridos por los de Chillan (Urbina, 1990, p.11).

En tal fecha, 1771, se establece la división administrativa religiosa, dejando a la misión de Chiloé a cargo del Colegio Ocopa, entre el Rio Bueno, al sur de Valdivia, y el Cabo de Hornos. Mientras el Colegio de Chillan quedaba a cargo des de la zona de la provincia de Concepción hasta Valdivia. Ambos Colegios son franciscanos. (Urbina, 1990).

\subsection{El periodo de El Colegio de Santa Rosa de Ocopa 1771-1820 (aprox.)}

Por lo expuesto, el Colegio de Ocopa dispone de una mejor accesibilidad al archipiélago y es más fecundo en número de religiosos, por lo tanto parte de este contingente se hace cargo de la misión insular. Las principales tareas encomendadas eran la asistencia espiritual de una población india de más de 10.000 habitantes ${ }^{60}$ que había en el archipiélago y la conquista de los gentiles situados en las fronteras de Chiloé.

La otra actividad no menor y de alto interés es el hacerse cargo de las iglesias, su mantención y reparación. Si bien el historiador chilote Rodolfo Urbina declara que su investigación no se detiene en los templos, hace una descripción bastante ilustradora y que junto con la recopilación de diversos registros realizadas por el Franciscano Bernardino Díaz (Díaz, 1990) permiten sostener que la misión de los de frailes de Santa Rosa de Ocopa en Chiloé fue fecunda, y que consistió en una tarea amplia sobre los templos.

\subsubsection{La orden en el archipiélago.}

La ocupación Ocopa tanto por breve duración, realizaciones y efectos será una suerte de transición pero que logra mantener una estructura orgánica en el territorio. Basados en el modelo evangelizador de los jesuitas, asentándose en los principales pueblos y manteniendo el sistema de la misión circular, es posible dar la atención básica a los indígenas, mestizos y españoles ${ }^{61}$, a pesar de los numerosos desafíos permanentes existentes en el archipiélago, dado por su geografía, clima, aislamiento, sumado a los afanes independentistas. Hay que considerar que Chiloé se mantendrá como último reducto español en el continente hasta el año 1826, con la caída del Gobernador Quintanilla en la Batalla de Mocopulli ${ }^{62}$ frente a los patriotas. Bajo este complejo escenario y con pocos religiosos, los frailes de Santa Rosa de de Ocopa trajeron algunos misioneros que dejaron una impronta tanto en el espíritu de los isleños, como en la arquitectura.

60 Enrich señala que en el momento de la expulsión los jesuitas atendían una población indígena de 10.478 personas (Enrich, TII, 1891).

61 En tal sentido se mantendrá el sistema de fiscales y patrones en las capillas.

62 Cabe señalar que en el resto del territorio Chile logra independizarse transitoriamente en 1810 y definitivamente en 1818 . 
La mayoría de los misioneros del periodo Ocopa realizaban estadías relativamente cortas en el archipiélago y como máximo llegan a cumplir el decenio en Chiloé. Sin embargo y a pesar de sus breves estadías llegarán algunos a ser figuras destacadas de esta época, como fray Pedro González de Agüeros o el padre Fernández, quienes habiendo partido en 1882 vuelven a Chiloé, o el caso de fray Alfonso Reyna que fallece en 1881 en Achao.

Las breves estadías de los religiosos se daban por las dificultades internas que representaba Chiloé, las exigencias en asistir a otras provincias y una política que procuraba mantenerlos al menos por 10 años, llamada la Ley del Decenio ${ }^{63}$, pero que en la práctica difícilmente se cumplía (Urbina, 1990). Todo esto redundó en un permanente traslado y cambio de sacerdotes desde y hacia el archipiélago.

En este periodo se contabiliza un promedio de 15 religiosos anualmente, aunque la cifra ideal eran 25 a 30, para poder atender todas las principales islas pobladas. El detalle de distribución en el Cuadro que sigue, demuestra una ocupación extensiva sobre la red de principales poblados y capillas del archipiélago.

\section{Cuadro 1. DISTRIBUCIÓN DEL PERSONAL MISIONERO COLEGIO DE SANTA ROSA DE OCOPA}

(Díaz, 1990, p.8-9)

Cuando los Padres Misioneros del colegio de Santa Rosa de Ocopa, tomaron las Misiones de Chiloé, se distribuyeron así:

COLEGIO DE CASTRO: Cinco Misioneros, para atender Castro y lugares más inmediatos: Rilán, Curahue, Yutuy, Quilquico, San José, Tey, Putemun, Llaulao, La chacra, Coihunco, Nercón, Pidpid, Mocopulli y Dalcahue.

QUINCHAO: Dos misioneros para atender: Quinchao, Achao, Curaco, San Javier, Uiar, Palqui, Matao, Linlin y Llingua

QUENAC: Un misionero para atender: Qemac, Meulin, Cahuach, Alao, Chaulinec. Chulin, Talcan, Tenaun

LEMUY: Un misionero para atender: Puqueldón, Letif, Ichuac, Aldachildo; San Agustín; Chelín; Huecho, San Miguel, Los Ángeles y Peldehue

CHONCHI: Un misionero para atender: Chonchi, Notuco, Vilupulli, Curaco De Vilupulli, Huillinco, Cucao y Terao.

QUEILEN: Dos misioneros para atender: Quielen, Paidad, Detico, Lelbun, Pureo, Compu, Chadmo, San Juan De Chadmo y Tanqui.

CAILIN ${ }^{64}$ : Dos misioneros para atender las islas de Chonos.

MAULLÍN: Un misionero para atender esa región.

CARELMAPU: Dos misioneros para atender esa región.

CALBUCO: Dos misioneros para atender siete islas: Abtao, Chidhuapi, Caicayan, Menmen, Guar, Puluqui, Malchil, Chope, Llaicha y Tabon.

QUICAVÍ: Un misionero, para atender cuatro lugares de la isla grande y tres lugares de las islas Chauques: Quicavi, Añihue, Chemao, Colu, Chauques, Butachauques,

63 Ley del decenio, comprendía a todos los religiosos que pasaban al nuevo mundo. Cumplidos los diez años de servicio en una región determinada, podían abandonarla definitivamente, desafiliarse incluso del colegio, volver a España y gozar de los privilegios concedidos en estos casos (Urbina, 1990).

64 La misión fue abandonada el año 1796 cuando los indios sefugaron por culpa del administrador que puso allí el gobierno (Enrich, TII, 1891, p. 434). 
Chaurahue, Llipeo y Huitu.

CHACAO: Un misionero, para atender como Párroco de Chacao y como Capellán de las Milicias en Ancud y Quetalmahue, Pudeto, Caipulli, Cogomo, Cailin, Estero, Manao y Linao.

Es interesante revisar las nacionalidades de estos sacerdotes, así como Reyna y González de Agüeros eran españoles, en la primera misión se registran en un documento cinco más de la misma nacionalidad (Díaz, 1990, p.11). En otra fuente solo tres (Urbina, 1990, p.25) este último anota a tres misioneros sin procedencia conocida. En las misiones posteriores también llegaran otros religiosos del Reino, los restantes eran chilenos e incluso chilotes como fray Ignacio Vargas de la misión del año 1771. Se hace esta mención por las indudables presencias e influencias hispánicas de este periodo y los aportes locales o chilotes que se incorporan y otros que perduran desde la época jesuita. En este periodo franciscano es evidente la nula presencia de religiosos de orígenes germánicos, lo que de alguna manera va desdibujando las hipótesis que argumentan una escuela jesuítica alemana, como compositores fundamentales de la arquitectura religiosa tradicional chilota, sino más bien como una fuente primordial o sustrato inicial fundacional, a la que, posteriormente se sumarán otras influencias.

Es necesario indicar que la orden mercedaria mantuvo la permanencia desde la conquista en Chiloé, y también con asiento en Castro, pero sin salir a misionar y con una bajísima presencia de religiosos durante el periodo de los frailes de Santa Rosa de Ocopa. Al inicio hubo solo 1 sacerdote y 1 lego, en un momento llegaron a tener 4 , destinándose algunos de ellos junto a los de Ocopa.

\subsubsection{El Colegio de Ocopa y sus figuras constructoras.}

Es necesario consignar que entre los primeros misioneros que llegaron a Chiloé en reemplazo de los expulsos jesuitas, surge la gran figura del historiador Fray Pedro González de Agüeros, quien ha sido la principal fuente de escritos realizados en este periodo, y quien escribe directamente sobre otro misionero español y que junto a él comparten la misión en Chiloé: "En Achao se esmeró el Padre Fr. Alfonso Reyna, de la Provincia de Andalucía, el adorno y compostura de aquella Iglesia: pues hizo nuevo el Altar mayor, y tal cual no hay otro mejor en el archipiélago." (González de Agüero, 1791, p. 177).

Este hecho no es menor porque es de los pocos escritos epocales que menciona una acción directa en la ejecución de una obra por parte de un franciscano, más aún cuando se trata de un altar mayor de talla barroca y considerada una pieza de arte única en Chiloé. Si bien en el capítulo precedente se reconoce y se aclara que la Capilla de Achao es una obra parcialmente jesuita, el trabajo de Reyna en altares y decorados demuestra el significativo aporte franciscano. Fray Alfonso Reyna (Andalucía ?- Achao 1781) ha sido poco estudiado y salvo estas descripciones de Agüeros no se han hallado otras que ilustren más de su biografía vinculado a la construcción o a las artes. Sin embargo tanto el hecho de su paso por Perú, impregnándose del alto nivel artesanal 
del virreinato, como su procedencia Andaluza es muy posible que haya conocido y se haya capacitado en la carpintería de lo blanco, propia de la península ibérica.

La Carpintería de lo Blanco requiere una breve atención en este apartado, ya que puede dar ciertas pistas que son de interés en la materia que tratamos, en específico de las posibles influencias carpinteras, especialmente porque según el padre Guarda el "Breve compendio de la carpintería de lo blanco, y tratado de alarifes, con la conclusión de la regla de Nicolas Tartaglia, y otras cosas tocantes a la leometria y pvntas del compas", editado el año 1632 por Diego López de Arenas, tuvo amplia difusión en el continente americano durante la colonia (Guarda, 1995, p. 332).

La Carpintería de lo Blanco se orienta básicamente a la construcción con madera y es una de las tres áreas de desarrollo de la carpintería en la península ibérica, junto con la Carpintería de lo Prieto (o duro), usada para fabricar herramientas y artículos de labranza por la dureza de la fibra, y la Carpintería de Ribera que atendía a la construcción de embarcaciones.

Es denominada capintería de lo blanco, por que usa madera de especies leñosas de fibras claras, en general coníferas, que son las que presentan fibras más largas y por lo tanto más útiles para fabricar vigas, pilares, pares, canes y en general cualquier pieza usada en edificación, y en especial la realización de las armadura de lazo. Esta técnica ampliamente realizada en España alcanzó su máximo esplendor entre los siglos XIV y $\mathrm{XVI}$, materializándose sobre todo en inigualables sistema de cielos geometrizados con un altísimo grado de perfección, para adornar y revestir principalmente techumbres (techos falsos) o elementos constructivos a esconder. Según Nuere, el especialista y estudioso en la materia: "La autoría de las obras carpinteras de esta época, ha sido sistemáticamente atribuida por la mayoría de historiadores a carpinteros mudejares, pero sin embargo, encuentro razones para opinar que sus autores fueron mayoritariamente carpinteros castellanos" (Nuere, 2010). Con esto en ningún caso descarta la influencia mudéjar, pero va mas allá haciendo una serie de investigaciones muy acuciosas en las cuales sostiene que:

podremos hablar de una carpintería hecha por musulmanes, (sometidos o no a los cristianos), y otra de carpinteros castellanos. Y si intentamos buscar sus orígenes, llegaremos a la conclusión de que ambas terminaron por utilizar el mismo modelo venido del norte de Europa, traído a España por los visigodos y que arraigó fuertemente en las zonas menos romanizadas de nuestro país (Nuere, 2010, p.14).

Este autor demuestra que la geometría es el aporte mudéjar, y lo que interesa a nuestro caso es que la forma de estructuración fue ampliamente elaborada por los castellanos por la fuerte relación sostenida con pueblos anglosajones y visigodos llegando a sostener que:

Es interesante comprobar que las ordenanzas antiguas de carpinteros alemanes tienen con las nuestras muchos puntos en común, lo que vuelve a hacer pensar en un origen próximo, y por otra parte no sería absurdo deducir que las técnicas avanzadas de carpintería habían de surgir en los países de abundante madera, lo que a su vez presupone climas más lluviosos, que también resultan 
más exigentes a la hora de encontrar eficaces soluciones que superen los problemas que la humedad acaba provocando en la madera (Nuere 2010, p.19).

Con lo anterior se hace evidente que los misioneros venidos des de la península ibérica a Chiloé podían tener un oficio a gran nivel, con conocimientos y raíces similares a los utilizados por jesuitas germánicos: esto es lo que demuestra el Franciscano Andaluz Alfonso Reyna y que también fueron influyentes en la carpintería de Chiloé.

También surge entre los escasos documentos, una segunda figura importante en la labor arquitectónica de estos franciscanos y es el caso de Fray Norberto Fernández, a quien se le atribuye una serie de obras como la capilla de Quicaví, donde edificó Iglesia y casa al igual que en Tenaún y en el Curato de San Antonio de Chacao se le atribuye que fabricó una famosa Iglesia, en forma de rotonda (Díaz, 1990). Esta capilla llamó la atención en su época y si aceptamos la descripción de rotonda, que no deja de ser de gran interés, se inscribiría en otra tipología que se aleja de las tradicionales chilotas.

De Fray Fernández también hay referencias de que en 1771 habría edificado capillas de Tenaún y otras (Schneider, Valassina, 1981). Como también está nombrado por la historia oral de la Familia Bahamondez de San Juan, que el Padre Fernández habría enseñado al indio Guaiqueo las técnicas de construcción y que este se la habría trasmitido a sus descendientes como a Alberto Guaiqueo quien realiza los planos de la capilla de Tenaún en 1875 y sería el constructor de muchas otras ${ }^{65}$.

Las figuras de los frailes Reyna y Fernández son relevantes, sin embargo no se ha podido dar con mas antecedentes sobre ellos. También están los registros de los trabajos realizados por otros franciscanos en Chiloé de este período, e indicados más abajo, que demuestran su aporte constructivo en los templos. En el caso de Chonchi surge la figura de Fray Lineros quien había realizado la torre, además de algunas viviendas. También la figura de Fray Juan Bautista Periano quien construye la Iglesia de Queilén y además fue quien realizó el proyecto de renovación urbana de Achao, después del incendio en 1785 .

Es difícil establecer cuál fue el preciso rol de estos sacerdotes en las fábricas y mejoramiento de las capillas, es decir si tuvieron una participación como administradores, directores y/o constructores de la fábrica y sus alhajamientos. Es muy probable que más de alguno de ellos haya tenido una participación activa directa en la ejecución misma de las obras, como aparecen Reyna y Fernández. También es muy lógico que hayan participado carpinteros chilotes preparados por ellos, o sencillamente que ya habían adquirido capacidades técnicas para asumir con bastante autonomía la ejecución de las obras, que se tratan en el capitulo siguiente. Tampoco hay registros gráficos de los proyectos realizados en este período de ocupación, que permitan visualizar la morfología de las capillas, solamente dibujos posteriores que permiten analizarlas.

Basado en los escritos históricos, las intervenciones realizadas en este época fueron en su mayoría con el objetivo de mantener y reparar los sencillos edificios religiosos

65 Entrevista realizada al Profesor Armando Bahamonde de Calén, en Octubre 2013 por Lorenzo Berg C. 
existentes, procurando principalmente en alhajarlos con mobiliario e imaginería, para darles mayor simbología cristiana como se puede observar en el cuadro adjunto, denominado mejoramiento de las Iglesias durante la época de Ocopa (Cuadro $n^{\circ} 2$ ). Este rol asumido por los franciscanos de Ocopa queda de manifiesto en González de Agüeros

en un informe reservado "sobre lo que no dijo en su Descripción Historial por razones de Estado" (1792) hacía notar al rey Don Carlos IV que "las iglesias o capillas se hayan en total indecencia y sin imagen alguna y solamente aquellas en que ha residido un sacerdote están, en lo que cabe adornadas" (Montecinos, 1995, p. 24).

Este aspecto que ha pasado un tanto desapercibido demuestra un poco la precariedad generalizada que tenían las capillas a la salida de los jesuitas.

Cuadro 2. CUADRO MEJORAMIENTO DE LAS IGLESIAS. En el periodo de los Franciscanos de Ocopa

(Díaz, 1990) en (González de Agüeros, p. 175-178)

MEJORAMIENTO DE LAS IGLESIAS. Se procuró asear y adornar las iglesias del mejor modo que a cada uno de los misioneros le fuera posible, dotándolas de altares, imágenes, vasos sagrados y ornamentos.

CASTRO: Fue la residencia del Presidente de las Misiones de Chiloé. La iglesia la repararon y la conservaron muy mejorada; tanto en ella, como en las casas habitacionales y el Colegio, se hicieron obras de adaptación para el funcionamiento de una Escuela Pública para los niños españoles e indígenas. Se predicaron misiones y se restablecieron todas las funciones de Iglesia que alli habían sino tradicionales, con especialidad la novena de Nuestra Señora del Tránsito, en el mes de agosto, a la que por Ordenanza Antigua concurrían las Compañías de las milicias apostadas en Chiloé y los misioneros con los Cabildos de sus respectivas Iglesias portando sus imágenes patronales.

QUEILEN: en el pueblo de Queilen, Fr. Juan Bta. Periano construyó la nueva iglesia, techada con tablas, y también la casa habitación, con las oficinas necesarias.

CHONCHI: Fr. Linares adornó aquella iglesia con tres altares nuevos e hizo también la torre y muchas obras útiles en las viviendas que fueron de los Jesuitas.

ACHAO: Fr. Alfonso Reina se esmeró en el adorno y compostura de aquella iglesia; hizo un nuevo altar mayor, tal cual no hay otro mejor en el Archipiélago; y construyó otros cuatro altares para el cuerpo de la iglesia; colocó en ellos imágenes correspondientes, y proveyó la sacristía de varios ornamentos, hechos los más por sus propias manos.

QUENAC: En esta isla Fr. Diego Lozano concluyó la fábrica de la iglesia que se había empezado, y la techó con tablas.

CARELMAPU: Fr. Miguel Arnau hizo iglesia nueva dotándola en altares y de muchas alhajas. 
MAULlín: Fr. José Tortosa hizo iglesia nueva y la dotó de todo lo necesario. Fundó la cofradía del Rosario.

QUICAVÍ: Fr. Norberto Fernández construyó la iglesia del pueblo.

TENAUN: Aquí el mismo padre Norberto Fernández construyó la iglesia

CHACAO: Igualmente, fue Norberto Fernández quien construyó la iglesia parroquial, la que fue muy celebrada por todos por sus líneas arquitectónicas y su forma rotonda.

CALBUCO: Fr. Hilario Martínez reparó la iglesia parroquial que amenzaba ruina; la dotó de buenos ornamentos.

ANCUD: Fr. Pedro González de Agüeros se hizo cargo de la Capilla Real de la Guarnición del Puerto, adornándolo y proveyéndola de ornamentos y alhajas. Allí se estableció la Orden Tercera de San Francisco, la que fue un modelo de vida religiosa y de acción social. Posteriormente se construyó, en otro sitio, en Pudeto, una nueva Iglesia de tres naves y con cinco altares, siendo esta construcción costeada por aquellos Hermanos Terceros.

\subsubsection{El surgimiento de la Villa de San Carlos (Ancud) y las nuevas Capillas.}

Sin duda el período Ocopa podría esconder antecedentes importantes aún no develados, hay un hecho fundamental que es la fundación de la Villa de San Carlos de Ancud, entre los años 1768 y 1770 (Guarda, 1978), recién expulsados los jesuitas, que puede dar algunas luces de lo obrado y el estado de la arquitectura religiosa de este período ya que se requirieron hacer nuevas capillas. Aquí se indaga a través de la confrontación de datos escritos e icónicos hasta ahora no realizados.

Ancud se constituye como cabecera urbana norte de Chiloé, justo a la salida de una pequeña bahía del golfo, junto a un arroyo y cercana al río Pudeto. Viene a ser la primera ciudad fuerte y última realizada por la Corona en la isla grande, formada por dos unidades, el Real y el San Antonio ${ }^{66}$. Son estas defensas, la cercanía con el continente y el mayor vínculo con el mar abierto, los factores que permiten a Ancud el desarrollo de una vocación portuaria y comercial. Esto facilitará un proceso de ocupación residencial más intenso y permanente que el resto de los asentamientos en Chiloé, que será significativo a fines del siglo XVIII y durante el siglo XIX (Berg, Lobos \& Rojas, 2006).

66 "La preocupación por parte del reino español de controlar todo el territorio americano y disponer un sistema defensivo desde Cuba a Chiloé hace que a mediados de 1750 se establezca un conjunto fortificado en la península de Lacuy, un amplio golfo abierto al canal de Chacao, donde hoy se encuentra Ancud." Realizada por Carlos de Beranguer bajo mandato de Carlos III, trasladando los habitantes de la Villa de Chacao a este lugar. (Berg, Lobos \& Rojas, 2006, p.69) 
Según se señala de los pocos pero valiosos datos de la genesis de Ancud

Fundada junto al Fuerte real...El resto del vecindario, en cambio ocupaba " una llanura que esta solo dividida y separada por un arroyo cercanos al mar y contiguos a dos caletas para su trafico y comercio". La capilla real, la casa del Gobernador y otro edificios publicos situados contiguos al fuerte, en tanto que la capilla de la Orden Tercera de San Francisco, con su plazuela, en la colina opuesta, al otro lado de la quebrada citada (Guarda, 1978, p.102).

Debido a un incendio en 1794 se decide trasladar los equipamientos hacia el otro lado del estero, hoy calle Prat, donde se ubicaba el grueso de la población y cercano a la capilla Franciscana. En definitiva es en el actual sector de la plaza de armas de la ciudad donde se emplazan estos edificios públicos.

Con estas descripciones históricas, junto a los escasos dibujos de la época que se disponen, realizadas con 10 años de diferencia por ilustres extranjeros como Martens, Gay y Koenig, es posible analizar la capilla real o principal de Ancud (figuras $\mathrm{N}^{\circ} 3 a$ y $\mathrm{N}^{\circ} 3 \mathrm{~b}$ ) las cuales son muy concordantes formal y constructivamente entre ambos.
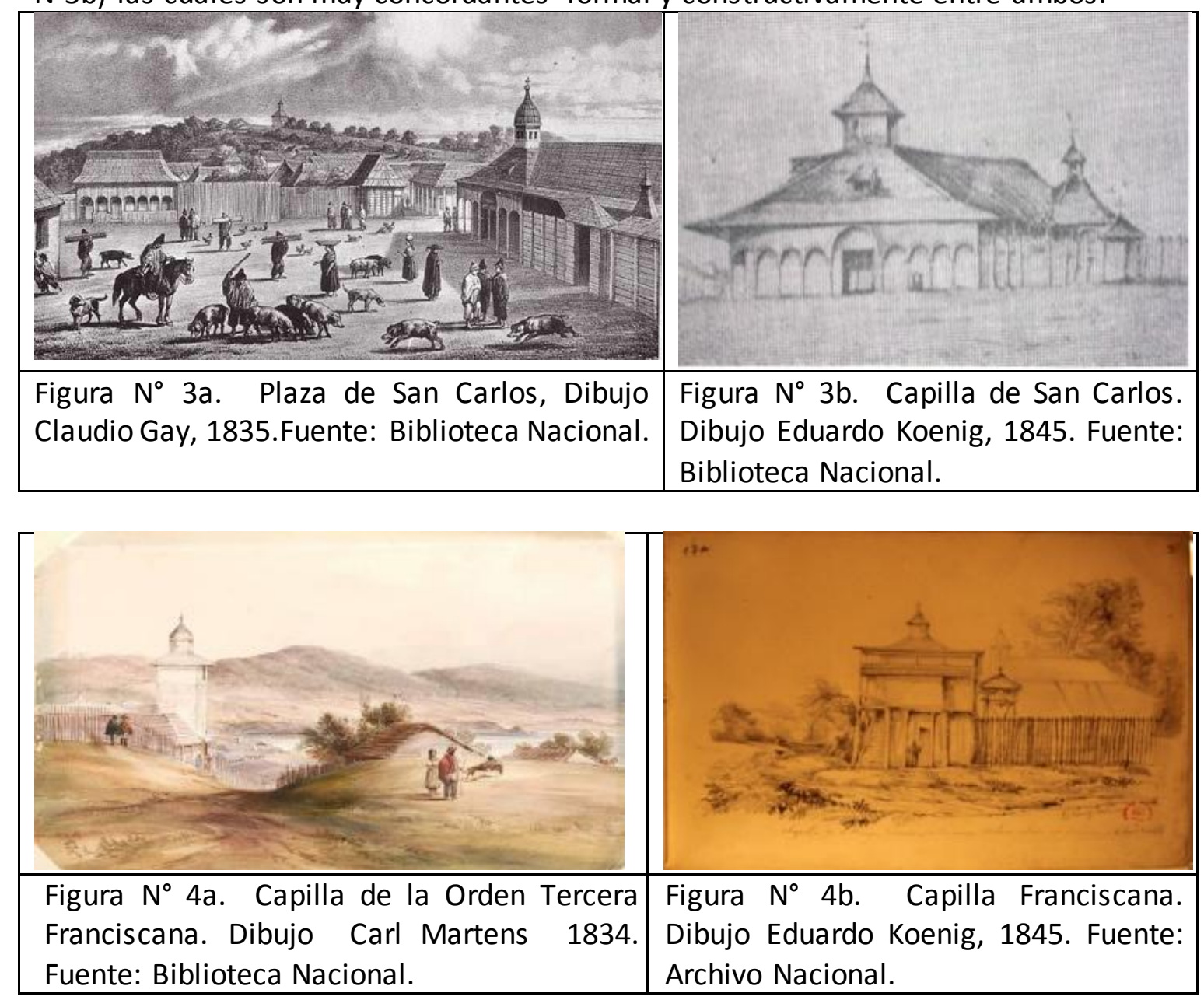

Se puede observar cuál es la tipología arquitectónica considerada para una capilla de primera importancia emplazada en la nueva ciudad sede del Gobernador y desde 1784 sede de la Intendencia de Chiloé. 
El edificio es completo de madera, con un gran volumen horizontal y cubierto a cuatro aguas, coronado en el acceso con una pequeña torrecilla, y rodeado de corredores protectores de la lluvia y de uso como espacio intermedio. Si a escala humana están correctas la alturas de arranque de la techumbre, es de aproximadamente $3 \mathrm{~m}$, ésta con una altura aproximada de $4 \mathrm{~m}$ y la torrecilla de casi unos $2 \mathrm{~m}$, dando un total de 11 $\mathrm{m}$ de piso a cúspide. El frente del edificio aproximadamente sería de $15 \mathrm{~m}$. En el dibujo de Koenig con vista en escorzo, se puede verificar un ábside esquinado que repite el esquema de corredores y torrecilla. La fachada sugiere una probable planta a tres naves, pero no hay certeza al respecto, no hay planos ni descripciones interiores. Otro aspecto fundamental es el constructivo, pues se reconoce claramente que el sistema de tabiquería de muro es similar al de Achao, del periodo jesuita, es decir postería. Recordemos que este consiste en pilares distanciados a los cuales se le encajan tablas horizontales en el eje, ademas con tejuela de madera, seguramente de alerce o ciprés en la cubierta. Por otra parte, pareciera por la llegada de los muros al terreno que hay una ausencia de fundaciones en el edifcio.

El dibujo de Gay que contextualiza con multiples detalles, aunque los personajes son similares a sus dibujos realizados en otros lugares, el paisaje cultural pareciera muy fidedigno. Es más, al fondo en un alto se ve un torreón que debiera corresponder a la capilla de la orden tercera franciscana y que en el dibujo de Martens (figura $\mathrm{N}^{\circ} 4 \mathrm{a}$ ) aparece esta capilla en primer plano, lo que pemite confiar ampliamente en estas iconografías y permiten leer con claridad el incipiente Ancud.

El dibujo de Martens es determinante ya que muestra la capilla franciscana en 1834, y con toda certeza realizada en este período, destaca claramente una alta y esbelta torre, que a pesar de su colorido blancuzco suponemos es de madera, de geometría paralelepípeda y coronada por un tambor menor y cubierta abovedada. Este elemento vertical pareciera ser el gran motivo de la composición, ya que se ve como adosado y aparentemente esquinado al volumen horizontal. En el dibujo de Gay ${ }^{67}$ esta capilla que se ve a distancia con otra apariencia, es una gran cuerpo, casi un cubo, con cubierta a cuatro aguas y pequeña torrecilla central. Aparentemente, los dibujos de estos autores tratan los volumenes con proporciones muy distintas, aunque están realizados con 10 años de diferencia, sin embargo el realizado por Martens sugiere ser más real porque ubica el edificio en primer plano.

A este punto, lo relevante es que se puede deducir que las nuevas capillas edificadas en este período se inscriben en dos tipologías muy distintas. Resumidamente son:

- La Capilla Real localizada sobre el plano horizontal de la plaza y compuesta unicamente por un gran volumen horizontal. Presumiblemente la misma según consta "Fr. Pedro González de Agüeros se hizo cargo de la Capilla Real de la Guarnición del Puerto, adornándolo y proveyéndola de ornamentos y alhajas" (Díaz, 1990, p.15).

67 Es también probable que el dibujo de Gay realizado en 1835, destaque el campanario realizado posteriormente y que se refleja en el dibujo de Koenig hecho en el año 1845. 
- La capilla de la Orden Tercera Franciscana ${ }^{68}$ localizada en pendiente y que destaca por una elevada torre. Un preludio a los faros religiosos que se diseminarán por el archipiélago posteriormente.

Este panorama descrito demuestra que los componentes tradicionales de las capillas chilotas, están latentes y se pueden encontrar de manera aislada en algunos modelos edilicios pero sin conformar aún el sistema característico de la tipología religiosa insular.

Lo mismo sucede con el sistema constructivo de postería que demuestra una calidad y oficio técnico alcanzado en la colonia, introducido por los jesuitas y que persiste en el caso de la capilla Real. Sin embargo la imagen de la Capilla Franciscana, dibujo de Eduardo Koenig de 1845 (Figura $\mathrm{N}^{\circ} 4 \mathrm{~b}$ ) deja entrever detrás del campanario en primer plano, una capilla que se acerca mucho a la tipología tradicional, en el mismo grabado histórico y original reza el texto: "Chapelle du Sn Francois dessinee par les moines Ytaliens del'ordre des franciscaines. En San Carlos." (Iglesia de San Francisco diseñada por los monjes Italianos de la orden de los Franciscanos, en San Carlos.) Que introduce a las fábricas realizadas en el periodo siguiente y producirán la matriz religiosa chilota.

\subsection{Los Franciscanos Italianos (1837-1905).}

\subsubsection{Antecedentes previos}

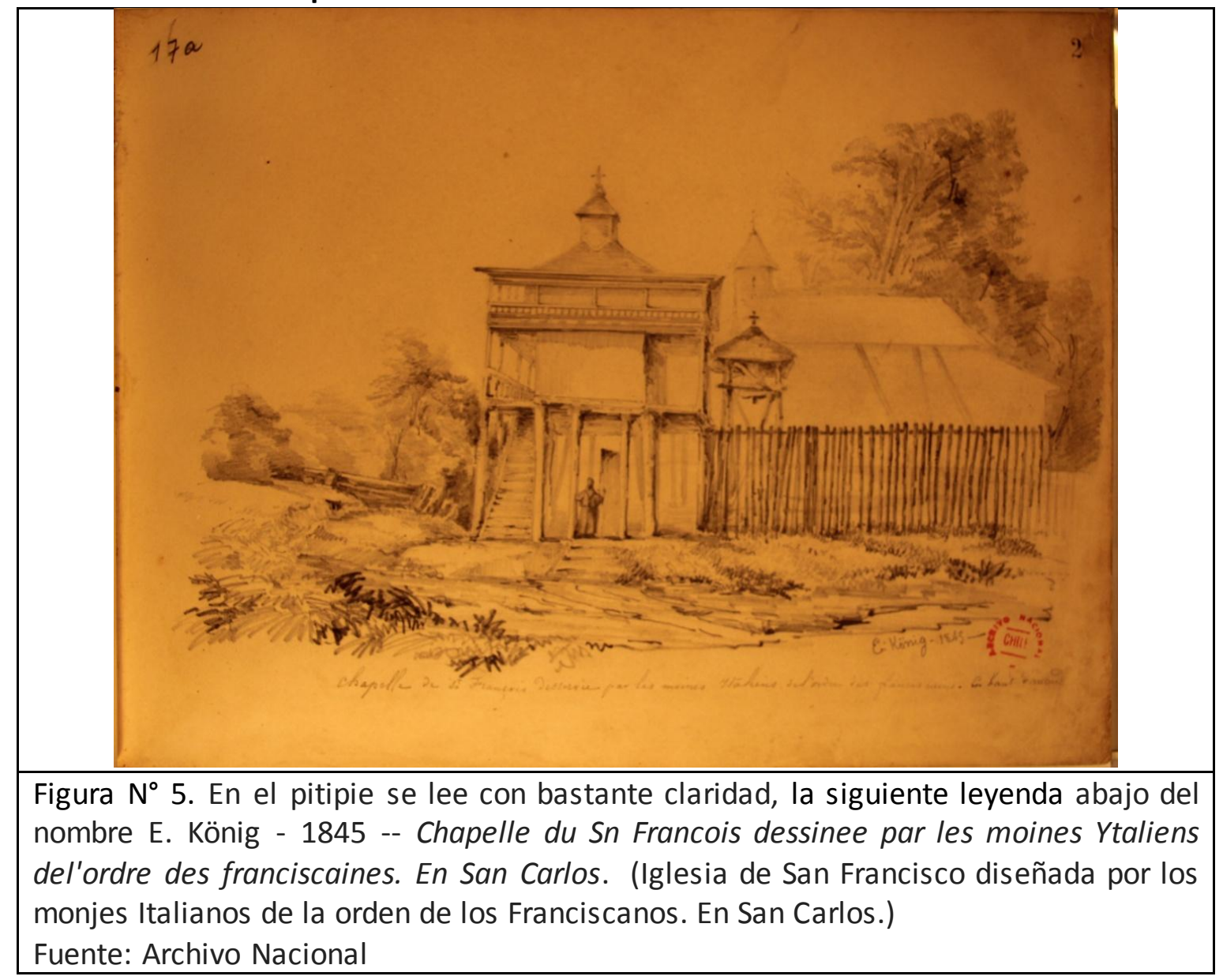

68 Esta capilla en el año 1845 será expropiada a los franciscanos para construir la catedral, lugar que mantiene hasta hoy la sede del obispado con sucesivas reedificaiones de templos. 
El tema de los franciscanos italianos llegados a Chiloé en 1837 ha sido escasamente tratado hasta este momento. A pesar de no haber sido considerado así en el inicio de la tesis, en el transcurso y desarrollo de ella se ha transformado en un período fundamental para comprender el proceso evolutivo y de decantación del tipo y los modelos arquitectónicos chilotes. Para tal efecto se ha hecho una revisión exhaustiva de libros, archivos, documentos e iconografía de la época ${ }^{69}$ que permitan contextualizar el momento y rastrear la construcción cultural religiosa en Chiloé y su área de influencia.

La acción de los franciscanos italianos ha sido tratada en relación al trabajo misional y evangelizador desde otras ópticas o disciplinas, pero no desde la arquitectura. Esto ha sido probablemente porque tuvieron un rol singular tanto en el periodo de la formación republicana de Chile y como en la tarea impuesta por el de un Estado Nacional, decidido a llevar a cabo la llamada "Pacificación de la Araucanía"70, zona donde también fueron asignados. Por lo tanto la importancia de su misión política, vinculadas a la relación Estado- Iglesia, sumado ciertamente al espíritu franciscano de relegar a un segundo plano la labor en el plano físico, bajo lo espiritual, ha dejado escasísimas huellas y escritos de su laboriosa empresa edificatoria de capillas en Chiloé y en la zona sur de Chile, en general.

También es necesario comentar que muchos escritos tratan sobre los innumerables problemas internos entre los propios religiosos de la congregación, con los capuchinos, con los indígenas y por supuesto también con el gobierno. A tal punto que hubo serias presunciones que incendios ocasionados en algunos templos fueron realizados por miembros de la comunidad franciscana.

Muchos aspectos de la Historia de Chiloé durante el siglo XIX, y de la Historia de la Iglesia en concreto, nos son prácticamente desconocidos. De seguro la falta de información, los deterioros que han sufrido algunos fondos documentales, ya fuese por incendios o descuidos, como también la carencia de interés por parte de los investigadores para ahondar en los temas relativos a la historia religiosa; han contribuido a crear la sensación de que estas temáticas no tienen mayor relevancia o que lisa y llanamente no se pueden estudiar (León, 2005, p. 9).

Es posible definir con esta introducción utilizada en un reciente libro de este autor cual es el estado del arte de la iglesia de Castro y Chiloé para el siglo XIX, específicamente entre los años 1837-1905.

\footnotetext{
69 Cabe señalar que al final de este trabajo fueron encontrados una pequeña bodega de libros en el archivo dela Iglesia Franciscana de Castro, dos libros de actas de las iglesias de Castro y Nercón de los años 1870-1880 aprox. Son manuscritos originales de gran valor, pero de difícil lectura, que requiere un largo y especializado trabajo de traducción, que excede el objeto de este trabajo.

${ }^{70}$ Por este solo motivo no dudamos que el progreso intelectual y moral de nuestra República sea sólido y estable porque estando como está felizmente hasta ahora cimentado sobre la indestructible roca de la religión, no puedo menos que permanecer con todos sus beneficios y flujo por todo el tiempo que ella permanezca incólume en su suelo (115) (Cárcamo, 1873, p. 79)
} 
Las situaciones descritas han marcado las orientaciones narrativas y discursivas de este proceso histórico, político y social en la que fueron actores importantes estos misioneros, y se ha omitido o diluido el análisis e investigación en la cultura arquitectónica nacional y local.

La revisión de un sinnúmero de documentos nos lleva a escasos documentos e iconografía sobre las iglesias, así como de proyectos, planos, autores y constructores. Prácticamente se ha revisado toda fuente documental primordial ${ }^{71}$, que constituye igualmente una línea de base suficiente e interesante para una primera investigación más acabada sobre la gesta arquitectónica de esta época, que permite dar nuevas respuestas más clarificadoras del proceso, pero también quedarán muchas preguntas por responder, así como propone otras interrogantes y nuevas inquietudes sobre el pasado de esta misión e iglesias, las que quedan abiertas para el futuro.

\subsubsection{La nueva dimensión administrativa y territorial.}

Si los jesuitas habían sido fundamentales en la influencia y organización territorial durante la colonia, para la república serán otros los actores: la congregación de los Franciscanos. Efectivamente

el Colegio de Misioneros de Castro dentro de un contexto más amplio como es la reorganización de la Iglesia católica en Chiloé después de la Independencia. Al respecto es posible apreciar que tanto el Colegio de Misioneros (1837), como la creación del Obispado de Ancud (1840), inauguraron una presencia efectiva de la parroquia como núcleo de gobierno eclesiástico en las diferentes islas de Chiloé. De hecho, este último, amparado por el nuevo Estado republicano, se sobrepuso a la matriz misionera de antaño ${ }^{72}$..., ya que administrativamente el párroco reemplazó al misionero y la parroquia a las jurisdicciones misionales, sin por ellos neutralizar las formas religiosas definidas desde la época colonial (León, 2005, p. 9).

Las palabras de Juan Rovegno, estudioso del tema, nos ilustran la situación previa y detonante de la traída de misioneros italianos:

El Período de la independencia de Chile tendrá consecuencias fatales para el Colegio. Los misioneros eran todos realistas que defendían la causa de España y fieles a su Rey. En 1809 Fr. Pablo de Moya, Comisario General de Indias residente en Madrid, presintiendo que la invasión napoleónica en España habría de facilitar la insurrección de las colonias hispanoamericanas, dirigió a sus dependencias de América una circular incitando a la defensa de los derechos de España por todos los medios. El año 1817 son derrotadas las

\footnotetext{
${ }^{71}$ Destacar dos libros fundamentales de esta época y escritos por franciscanos egresados del Colegio de Castro que son Cárcamo P., Francisco. El Colegio de Castro, (1873). Reedición PAF N²6, 1993, 178 p. Santiago de Chile y Cárdenas, Manuel J. El Colegio de Misiones de Castro, (1897). Reedición PAF N5, 1990, 76 p. Santiago de Chile (Franciscano).

${ }^{72}$ Como bien lo ha explicado la investigación de Macarena Ponce de León (León, 2005, p. 9).
} 
tropas realistas. Los padres, el 24 de febrero, abandonan el Colegio en dirección a Talcahuano y se embarcan hacia Lima. El Colegio fue reducido a ruinas por las fuerzas patriotas. Desde 1819 hasta 1831 la Provincia de la Santísima Trinidad retoma el convento. Inició los trámites de restablecer el Colegio Fr. Domingo González. Sus esfuerzos se vieron coronados el 11 de enero de 1832. Los miembros debían ser recoletos para misiones entre infieles y colegio para indios jóvenes. Tres años después, Fr. Zenón Badía que vivía en calidad de Cura Doctrinero en la Isla de Lemuy, solicitó al supremo Gobierno el auxilio necesario para pasar a Italia en busca de Misioneros para dotar las antiguas y abandonadas misiones de Araucanía y Chiloé. (Rovegno, 2001, p.13).

Para 1835, era el Estado quien asumía gran parte de la reorganización administrativa de la Iglesia en Chiloé, incorporando las misiones en toda la zona continental al norte del Canal de Chacao, hasta las extensas tierras ocupadas por los mapuches. De hecho "Ios misioneros debían ser distribuidos en Arauco, Valdivia y en el Colegio de Chiloé" (Rovegno, 2001, p.22). Ésta corresponderá a la Viceprefectura de Castro, mientras que la Viceprefectura de Chillán, mantendrá su área emplazada en torno al Rio Biobío. Ambas trabajarán armónicamente entre 1840-1869, posteriormente se van distanciando y solicitarán prefectos propios. La fuerte relación en este periodo entre Iglesia y Estado marcará la permanente preocupación de parte de los sucesivos gobiernos republicanos de mantener apoyo y recursos humanos, físicos y económicos para llevar a cabo tal empresa.

En definitiva el franciscano Badía ${ }^{73}$ recibe la autorización del Gobierno en el año de 1836, por parte del Presidente de la República, Sr. Joaquín Prieto, y su ministro; Sr. Diego Portales, pensando en convertir a todos los infieles en su jurisdicción a la religión cristiana, estando absolutamente impedido de traer misioneros españoles por la guerra entre Chile y España. En virtud de esta delegación, este Padre se dirigió a Roma, llegando a Chile al año siguiente ${ }^{74}$. Trajo ocho sacerdotes y dos legos a Chiloé (Rovegno, 2001, p.22). Otro contingente se dirigirá a Valdivia ${ }^{75}$

\subsubsection{La figura de Diego Chuffa, el impulsor del Colegio de Castro.}

Diego Chuffa ${ }^{76}$ llega a Chile el 1 de agosto de 1837, encabezando el grupo de religiosos traídos de Europa según encargo del Gobierno chileno. Tres años más tarde, el padre Unzurrunzaga, Prefecto Apostólico, le delega antes de morir todas sus facultades, nombrándolo Vice Prefecto y Vice Comisario General de los Colegios y misiones

\footnotetext{
73 Argentino. Nació en 1787. Perteneciente a la Provincia de Buenos Aires. Profesó en 1804 . Se incorporó al Colegio de Chillán en 1813. El gobierno de Prieto lo mandó el año 1835 a Italia para recolectar misioneros para el Colegio de Chillán (Rovegno, 2001, p. 22).

74 El 7 de marzo de 1837 partió de Génova, Italia, el buque que conducía a Chile a los misioneros. El P. Badia se quedó en Roma. Servía de superior de los misioneros Fr. Diego Chuffa. (Cfr. Manuel de Jesús Cárdenas, Apuntes Históricos del Colegio de Jesús en Castro, Santiago, 1897).

${ }^{75}$ Los que partieron a Valdivia fueron los frailes Miguel Angel Astraldis, Romolo Poggi, Jose Marano, Apolinario de Castellumelli, Querubin de Roma y Lorenzo Poggio San Remo, este último lego (Pinto, 1993, p. 39).

${ }^{76}$ Probablemente su apellido era Ciuffa, que es más lógico en italiano, y corresponde a apellid os de la zona de Montecompatri a 20 kilómetros al oriente de Roma. De todos modos, este sacerdote se firmaba Chuffa en Chile para hacerlo más entendible.
} 
existentes en la República de Chile, mediante el decreto del 4 de octubre de $1840^{77}$. Ocupará el cargo de Vice Prefecto durante catorce años, hasta 1854, año "en que renuncia a la Prefectura para ir a Italia a colectar misioneros. Entonces es reemplazado por el P. Antonio Gavilucci". (Menard y Foerster, 2007,p.9).

El Viceprefecto tiene una gran misión, que implica un vasto territorio indígena sobre el cual debe realizar una tarea pacificadora y evangelizadora, esto exige una planificación que tiene ribetes geopolíticos (Menard y Foerster, 2007), sobre el cual no nos detendremos a revisar, pero que exige y requiere una personalidad con una gran capacidad realizadora, la que demuestra con su legado.

Para efectos de este estudio la figura de fray Chuffa es interesante por las realizaciones relativas a las condiciones físicas con las que recibe el Colegio de Castro y que le interesa llevar a cabo para mejorar el nivel de las edificaciones e instalaciones, pero por sobre todo para darle un carácter más civilizador. Es por medio de los escritos de los Frailes Manuel Cárcamo y Manuel de Jesús Cárdenas quienes hacen una serie de referencias a Chuffa, que le conocieron, así como sus propias cartas, lo que ha permitido conocer algunos aspectos de la vida del franciscano.

La primera obra necesaria y fundacional para la orden era la casa franciscana. La existente, si bien regularmente conservada, con su convento en estado habitable, era inadecuada para morar en comunidad, la que debía observar todas las leyes canónicas de clausura y disciplina regular (Cárdenas, 1897).

Fue al reverendo fray Diego Chuffa, a quien se le encomendó la fábrica del Colegio, quien emprendió con decidido entusiasmo su cometido, tocando todos los resortes; movido por su celo por la gloria de Dios y el Orden, lo que impulsaba en todos sus actos. En cuanto estuvieron edificados los tres costados del primer claustro, cerrado el otro por la iglesia y cercadas las dos cuadras, que era el fondo del interior del Convento, trataron los reverendos Padres de abrir el Noviciado, declarando a la vez la clausura canónica. Mientras tanto el Rdo. P. Chuffa proseguía su obra del segundo claustro, oficinas interiores, ampliando una cuadra, más el cercado del claustro por el lado del Tejar (Cárdenas, 1897). También se le reconoce que hace obras avanzadas y únicas para la época, como es dotar el convento de estanque y agua canalizada desde el sector de la Chacra, fuera de la ciudad de Castro, incorporó un molino a este sistema instalándolo en un edificio para tal efecto, como también maquinas para la elaboración de fideos y otras pastas. Estas obras que aparecen tan insignificantes demuestran el estado de las instalaciones y el precario nivel de urbanización de la principal ciudad de Chiloé, pero también demuestra que estos sacerdotes tenían capacidad emprendedora y de realización más allá de las labores religiosas.

\footnotetext{
77 “Aparece en ese momento un primer ejemplo de la serie de conflictos internos al campo de los civilizadores que deberá enfrentar Diego Chuffa a lo largo de su carrera. Como bien explica Etcheberry, la decisión de Unzurrunzaga provocó polémica entre los colegios. El de Castro aprobaba la decisión, pero no así el de Chillán, que se negaba a reconocer a Chuffa como legítimo superior, porque dudaba que el $P$. Unzurrunzaga tuviera la facultad de nombrar su sucesor. Esta polémica terminó cuando la sagrada Congregación Propaganda Fide aprobó la elección hecha por Unzurrunzaga en el P. Chuffa y la confirmó el Papa Gregorio XVI por Decreto expedido en el año 1842" (Menard y Foerster, 2007, p.7).
} 
Después del incendio de 1857 del Convento y templo de Castro, fray Chuffa, es instado por todos los religiosos para que se hiciese cargo de las obras, quien accedió a pesar de su edad. En el mismo lugar del incendiado edificio, aunque en diferente forma, este magnánimo Padre preparó el terreno para la reedificación (Cárdenas, 1897).

Aparte de esta obra, fray Chuffa también llevó adelante la reedificación y las fundaciones de los Hospicios de Osorno y Ancud.

\subsubsection{El Colegio de Castro y su influencia}

La gran diferencia de este periodo misionero, que lo diferencia de los dos anteriores, los de los frailes de Chillán y Ocopa, los que funcionaron como hospicios ${ }^{78}$, es que se impulsa un antiguo y anhelado proyecto que era de formar religiosos en Chiloé y el sur de Chile, se fundó el Colegio el 18 de noviembre de 1837 en las mismas dependencias donde anteriormente habían funcionado los religiosos de Ocopa (León, 2005, p. 9). De acuerdo a descripciones: "Ios misioneros iniciaron la construcción el 2 de febrero de 1838. Se trataba de una edificación de dos pisos que medía 150 varas de largo de este a oeste. El ancho de la iglesia era de 22 varas y su largo 80 , de sur a norte" ${ }^{79}$. Asimismo, "cerraba el cuadrilátero por el norte otro cañón de la misma dimensión que el primero y por el oeste otro del mismo largo que la iglesia" ${ }^{80}$.

Esta iniciativa del Colegio de Castro prospera mediante cursos que se dictarán durante varios años hasta la restructuración administrativa de los franciscanos en 1905, en que se crea la provincia de los 7 gozos, fusionando Castro, Chillán y Santiago. La particularidad y objetivo de los cursos era que la mayoría de los ingresados fueran chilotes, lo que proporcionó una gran cantidad de religiosos insulares a la congregación y al país (Cárcamo, 1873). La religiosa provincia de Chiloé proporciona entonces

un plantel de misioneros celosos que nacidos i educados en inmediato contacto con los indios i animados de su amor, en el más riguroso sentido fraternal, llenarán con ventajas las apostólicas tareas a que se dedicaren, siempre que adquieran la instrucción conveniente a este efecto, se ha establecido una casa de estudios en el colejio de Castro, asignándose a éste la dotación perpetua de mil ochocientos pesos anuales para su subsitencia;... así, al nombre de Pasolini debieron agregarse después los de Gregorio Acuña, Andrés Mariani, Manuel de Jesús Cárdenas, Pedro Antonio Díaz, Daniel Oyarzún, Domingo Gamalleri, Francisco Saldivia, Domingo Pérez, Miguel Aros, Antonio Vargas, Francisco Cárcamo y Mateo Matulski (León, 2005, p. 9).

\footnotetext{
${ }^{78}$ Los hospicios hacían atención tanto espiritual como física, ayuda a enfermos y desvalidos, pero no disponían de formación de religiosos.

${ }^{79}$ Esta iglesia sucumbió a un incendio en 1857. La nueva, construida a partir de 1859 tendrá $21.3 / 4$ varas de ancho y 84 varas de largo.

${ }^{80} \mathrm{Ibid}$.
} 
La otra particularidad de este Colegio y la Misión es que su jurisdicción comprende no solo la zona del archipiélago sino que se extiende mucho más allá de este por buena parte del territorio sur y austral de Chile, desde la Araucanía y las deshabitadas tierras de Aysén y Magallanes. Esta se acota en el año 1849 en la zona poniente de la Araucanía, con la llegada de los capuchinos italianos que se les asigna concentrarse en la zona oriente. Sin embargo la influencia del Colegio de Castro será relevante durante toda la segunda mitad del siglo XIX, ya que desde aquí se dirigirán sacerdotes y actividades pastorales fundamentales hacia el resto del país.

El Colegio de Castro erigió en la misma época, el convento del Señor Crucificado en el cerro Barón de Valparaíso, el convento de San Antonio de San Felipe, y en las nacientes Angol y Mulchén los conventos de San Buenaventura y San Bernardino de Siena ${ }^{81}$. Y entre 1844 y 1878, sacerdotes de este Colegio fueron los capellanes de Fuerte Bulnes en Magallanes (Pape, 2008, p.76).

Por lo tanto, des de Castro se empiezan a liderar proyectos y obras que determinan un protagonismo del Colegio más allá de las fronteras insulares, lo que da un nuevo panorama de la importancia de estos misioneros y sus egresados, en la construcción cultural y arquitectural en Chile.

Son relevantes de ilustrar las obras emprendidas en el puerto de Valparaíso y San Felipe, en las cercanías de la capital Santiago al centro del país, también en Osorno, que se tratará en forma particular más adelante. En el caso del convento de San Francisco de Barón en el puerto de Valparaíso, es una iniciativa llevada a efecto desde Castro, debido a que requerían un lugar para alojarse independiente al otro sitio franciscano de la ciudad. Es más, parte de las colectas en Chiloé apoyaron la edificación de este templo.

Entre los misioneros, además de fray Diego Chuffa, destaca la figura de fray Antonio Gavilucci quien fundó el convento del Almendral en Aconcagua (San Felipe) y construyó su iglesia, que fue bendecida el 8 de octubre de 1878, la cual todavía está en pie (Figura $\mathrm{N}^{\circ} 6$ ).

La figura de Fray Domingo Pasolini, quien reconstruye la iglesia de Ancud y participa en la expedición de la toma del estrecho de Magallanes, en donde funda y construye la Capilla en Fuerte Bulnes. También construye la Iglesia de San Francisco Barón en Valparaíso y Talca, entre otros. Como constructor usa las reglas de las torres únicas. Fue un Fray que frecuentemente se le solicitaba para llevar adelante estas fundaciones y requerimientos físicos (Mansilla, 1983).

${ }^{81}$ Chile a color. Biografías, tomo I. Santiago 1981, Editorial Antártica, pág. 418. 


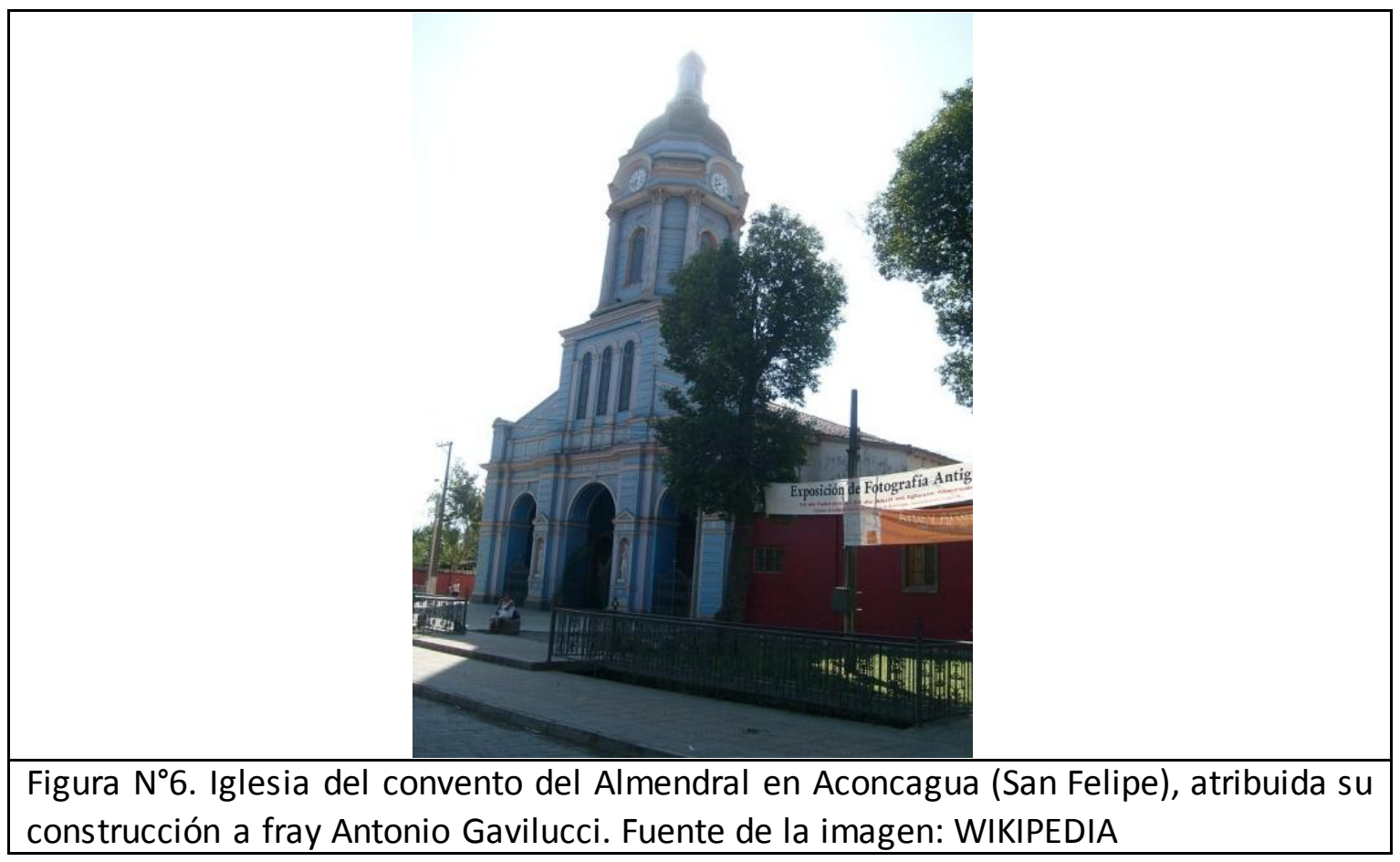

Estas edificaciones, desde un punto de vista estilístico, comienzan a adoptar un marcado acento Neoclásico y algunas que disponen de una torre central como pórtico de acceso, que es la tipología que se empieza a imponer en Chiloé a partir de mediados del siglo XIX.

Si bien no hay certeza de que los autores intelectuales de las obras hayan sido los franciscanos, está claro que dirigieron o por lo menos administraron la ejecución de las fábricas, como se visualiza en el cuadro en que se resumen las actividades principales realizadas por Los ocho sacerdotes y los dos legos de esta primer desembarco en 1837, según Rovegno (Ver cuadro $N^{\circ} 3$ ). Por otra parte, en fuente de la época se menciona

Por ultimo con los sacerdotes italianos habían sido destinados tres religiosos legos, fray Salvador Garver, para correr con la economía de la casa y a ayudar en el canto de la iglesia; fray Lorenzo Pogi para servir de hortelano y cocinero y el tercero, que era el enfermero y boticario, también entendía el arte de la carpintería (Cárdenas, 1890, p. 16)

De éste último su nombre no se ha podido identificar.

Cabe destacar que en la segunda traída que hace Chuffa desde Italia, en 1857, viene un arquitecto entre los Frailes que es Leopoldo Scatulini oriundo de la Toscana (Díaz, 1990) quien es muy probable que haya participado en proyectos insulares como la nueva Iglesia de Castro de $1859^{82}$. También en el desembarco del 57 vienen un herrero, Nazareno Grizzi, y un carpintero, Demian Lavini (Díaz, 1990). Estos se suman al arribado el 37 que se menciona como un lego conocedor del arte de la carpintería,

\footnotetext{
${ }^{82}$ Fray Leopoldo Scatulini es el arquitecto de la Iglesia de Angol (Iturriaga, 2007). También es nombrado como Escatulini en las escasísimas referencias encontradas sobre su trabajo como arquitecto.
} 
de manera que son religiosos y con oficios muy necesarios para los requerimientos "físicos" de la misión.

\section{Cuadro 3. Los ocho sacerdotes y dos legos de este primer desembarco en 1837:}

Fuente: (Rovegno, 2001, p. 23-24)

\section{Sacerdotes}

1.- Padre Diego Chuffa del Montecompatri, de la Provincia Romana Reformada, de 30 años.

Fundador del Colegio de Misiones de Castro. Fue su primer Prefecto de Misiones. En 1844 fundó el convento de Osorno. Al año siguiente hizo las diligencias para la creación de un convento en el cerro Barón en Valparaíso. En 1851 da principio a la fundación de la Iglesia y casa habitación en Ancud. El año 1856 fue a Italia a buscar misioneros y a fines de ese mismo año llegaron 12 religiosos. Falleció el 14 de enero de 1885. Mayores datos en Manuel J. Cárdenas. El Colegio de Misioneros de Castro (Santiago 1990) (Publicaciones del Archivo Franciscano 5) (Reedición fotostática de Apuntes del Colegio de Jesús en Castro, Santiago 1897) pp. 19-22.

2.- Padre Francisco Novelli de Cairo, de la Provincia Reformada de Turín, de 30 años. Fue guardián de Castro en los años 1846- 1850.

3.- Padre Domingo Passolini de Cesena, de la Provincia de Observancia de Bolonia, de 29 años.

Nació en Cesena, Italia el 28 de agosto de 1807. Tomó el hábito en la Provincia de Bolonia el 2 de febrero de 1825. Fue ordenado sacerdote el año 1830. La licencia para venir a Chile se la concede el Ministro General José Alexandría el 25 de noviembre de 1836. Al año siguiente se embarcó junto a los misioneros en Génova. Llegaron a Valparaíso el 10 de agosto del mismo año. El día 4 del mes siguiente se embarcaron con dirección a Chiloé. El P. Passolini, en compañía del P. Hernández Calzada, Fr. Mariano Ramis y Martin Gil, desembarcaron en la Isla. El P. Passolini fue destinado a Pudeto, cerca de Ancud. Allí construyó la iglesia y una casa de ejercicios. Fue guardián de la comunidad de Castro (1841 y 1851). Terminó el colegio y agregó una manzana más. Ejerció de párroco en Castro entre 1842 y 1846 . En 1844 pasó a Magallanes con una expedición del Gobierno a fundar la colonia. En 1850 es nombrado guardián de Ancud. Renunció a esta designación y es trasladado a Valparaíso. El año 1861 solicitó incorporarse a la Provincia de la Santísima Trinidad de Chile. Habitó en el convento máximo de San Francisco de Santiago y el año 1862 fue trasladado a Cauquenes. Construyó la iglesia y restauró el convento. En 1883 fue designado a Talca. Falleció el 17 de junio de 1892.

4.- Padre Antonio Gavilucci de Carpineto, de la Provincia Romana Reformada, de 22 años.

De Carpineto, Italia. Nació en 1803. Profesó en la Provincia Romana el año 1831. Al llegar a chile debió quedarse en Santiago por algunos meses, esperando cumplir la edad otorgada en la dispensa apostólica que traía de Roma, en virtud de la cual, el Obispo Vicuña, le confirió el Presbiterado. Ejerció en Chiloé de profesor de los postulantes. Sirvió de párroco en Castro entre los años 1846-1849 y nombrado guardián el año 1850. Por encargo del Obispo de Concepción fue Vicario Foráneo de la provincia eclesiástica, hasta que el Obispo Jus to Donoso tomó la jurisdicción. Fundó el convento del Almendral en Aconcagua y construyó su iglesia que fue bendecida el 8 de octubre de 1878. Impulsó la Orden Tercera. Falleció el 16 de abril de 1864. 
5.- Padre José María Bonazzi, de Roma, de la Provincia Romana Reformada, de 23 años.

Cuando Ilegó a Chile era diácono. Fue ordenado sacerdote en Santiago. Nombrado Párroco en Lemuy, Tenaún y en la Iglesia catedral de Ancud. Superior de la comunidad de Ancud y director del seminario. Ejerció de Párroco en Castro entre 1840-1842. En 1850 fue enviado a misión en Tucapel. Dos años después pasó a la misión de Nacimiento. El año 1854 se hallaba en el convento de Valparaíso y al año siguiente es nombrado guardián de Osorno. El año 1864 se desincorporó del Colegio de Chiloé y se embarcó para el Perú. Escribió la "Historia de las Misiones en la República de Chile". Falleció en Perú el año 1869.

6.- Padre Paulino de Aquasparta, de la Provincia Reformada del Seráfico, de 25 años.

7.- Padre Alejandro Branchi de Antrodoco, de la Provincia de Observancia Napolitana, de 24 años.

8.- Padre Marco Bulla de Calice, de la Provincia Romana Reformada, de 24 años. Nació el 10 de octubre de 1813 en Calice, Italia. Tomó el hábito en la Provincia Romana el 10 de mayo de 1830. Profesó al año siguiente. Se ordenó sacerdote el año 1836. El 4 de octubre de 1837 se embarcó, junto con los otros fundadores del colegio de Castro, con destino a Ancud fue el primer maestro de novicios de la nueva entidad y ejerció este cargo por veinte años. Fundó la hermandad de Unión Cristiana. Esta consistía en reunir a sus miembros los días festivos, en las iglesias parroquiales y capillas, en todo tiempo oportuno, para explicarles los deberes del cristiano, rezar el rosario y el Vía Crucis. Trabajó de misionero en la Araucanía. El Obispo José Salas lo nombró cura de Corone. En marzo de 1860 fue trasladado al convento máximo de Santiago. Es el primer maestro de novicios de las primeras generaciones de la vida común en la Provincia de la Santísima Trinidad. El 10 de abril de 1863 se incorporó definitivamente a la Provincia. En 1870 fue enviado a Copiapó para recolectar limosnas para levantar el nuevo templo del convento franciscano de la ciudad. Ejerció diversos cargos: fue sacristán mayor (1881) del convento máximo, guardián, Definidor, Custodio y Comisario Provincial. Declaró en el Proceso del Siervo de Dios Fr. Andrés García Acosta, Ofm. Remodeló el templo San Francisco en su interior y la sacristía. Murió el 21 de diciembre de 1896. Se puede complementar su vida en Cárdenas, El colegio de Castro. p. 22-60.

\section{Hermanos legos:}

1.- Fray Salvador Garbero de Saxello, de la Provincia Reformada de Génova, de 32 años.

2.- Fray Carlos de Paolis de Pregneste, de la Provincia Romana Reformada, de 27 años.

Cuadro 4. EL PADRE CHUFFA VIAJA A ITALIA. El año 1856 el Padre Chuffa viajó a Italia a colectar nuevos misioneros, y a fines de ese mismo año, llegaron con él doce Religiosos. (Díaz, 1990, p.18)

Entre los sacerdotes figuraban cuatro profesores:

Fr. Leonardo Tomatis, profesor de Filosofía y Ciencias,

Fr. Isaías Nardocci, profesor de Ciencias Sagradas, 


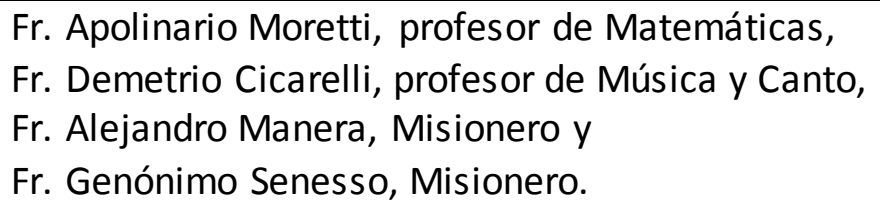

Los hnos. no clérigos tenían cada uno un oficio profesional:

Fr. Felipe Penesso era Médico,

Fr. Amadeo Becherini, Sastre,

Fr. Leopoldo Scatulini, Arquitecto,

Fr. Demian Lavini, Carpintero,

Fr. Inocencio Liberatti, Cocinero y

Fr. Nazareno Grizzi era Herrero.

\subsubsection{La Iglesia franciscana de Castro: La matriz tipológica de las Iglesias tradicionales de Chiloé.}

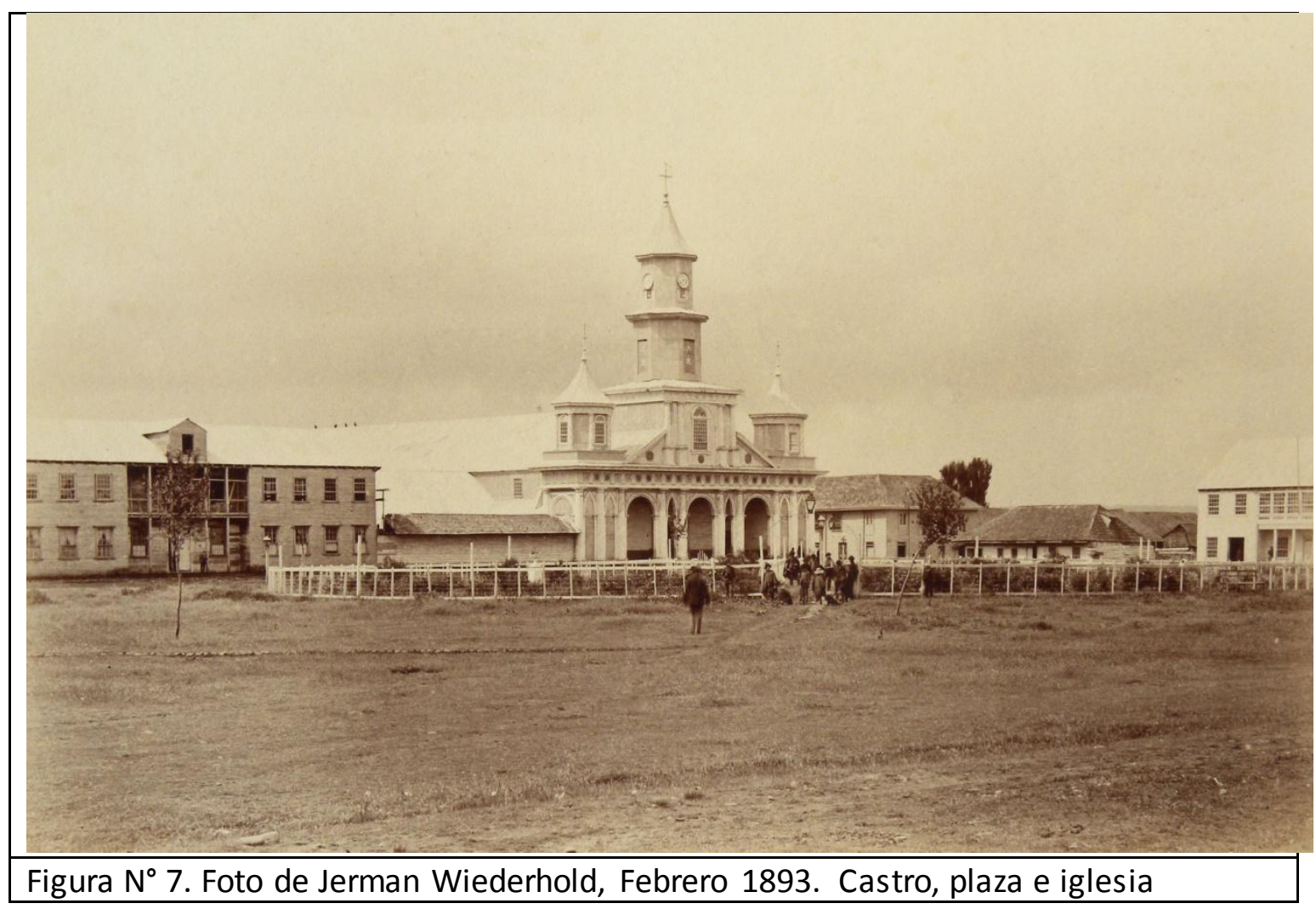

Cuando en la reciente primavera de 2013 se dio a conocer una fotografía de la Iglesia Franciscana de Castro (Figura $\left.\mathrm{N}^{\circ} 7\right)^{83}$, Foto tomada por Jerman Wiederhold en Febrero $1893^{84}$, varios estudiosos de la historia y la arquitectura de Chiloé quedamos

\footnotetext{
${ }^{83}$ Foto que me hizo llegar el arquitecto Edward Rojas, de Chiloé, quien trabajando en una publicación histórica sobrelos palafitos, descubrió con Barbará Elmudesi, sabiendo que yo trabajaba en este tema. 84 La fotografía fue tomada por el fotógrafo osornino Jerman Wiederhold Piwonka (1870-1949). Forma parte de un conjunto de 100 fotografías que abarcan una amplia zona geográfica, entre Rio Bueno y Palena, tomadas entre 1890 y 1893 y reunidas en dos tomos, los que fueron regalados el año 1893 al
} 
atónitos ${ }^{85}$. Se reveló una imagen nunca antes imaginada para este lugar, es tanto o más impresionante que la actual iglesia, declarada Patrimonio de la Humanidad, diseñado por el arquitecto italiano Eduardo Provasoli y construida a partir de 1910. Pero por sobre todo, demuestra que se trataba de un genuino edificio que cumplía claramente con la tipología arquitectónica de las capillas tradicionales chilotas, más aún, demostraba el uso completo de la estilística neoclásica en los elementos de la fachada y con un tamaño ideado a una escala preminentemente urbana y geográfica. Es difícil imaginar que estas caracteristicas se habían utilizado en este antiguo y desconocido modelo de arquitectura religiosa en Chiloé.

En la citada fotografía realizada en 1893 por Jerman Wiederhold aparecen una serie de características, como la composición y dimensiones del pórtico, que son similares al modelo posterior realizado a partir del proyecto de Provasoli. En tal sentido, la llamada reinterpretación y ejecución realizada en madera por carpinteros chilotes a partir de los planos ideados en mampostería por el arquitecto italiano. Da para pensar que dichos artífices insulares tenían probablemente este edificio en parte como modelo, junto con los planos de Provasoli para llevar a cabo su realización. Evidentemente sería deseable que ambos edificios sean motivo de investigaciones acuciosas desde perspectivas historiográficas para la arquitectura y la construcción, sobretodo de cómo fue la gestión del traspaso del proyecto a la obra, en cada uno de los modelos. Especialmente porque existen indicios suficientes de que el proyecto original realizado por el arquitecto italiano Eduardo Provasoli fue realmente proyectado para ser construido con estructuras de madera ${ }^{86}$, y no en piedra $u$ hormigón como se ha entendido originalmente.

Entre los investigadores que recibieron esta foto de la Iglesia Franciscana de Castro de 1893 se encuentra la Dra. en Historia Ximena Urbina, quién escribió en forma instantánea por correo electrónico: "La foto es impresionante. Que elegancia de composición." Ella inmediatamente fue sorprendida por la composición y el mensaje neoclásico ideado por sus autores (arquitectos, artífices y/o directores de obra) era absolutamente claro y se podía trasmitir incluso un siglo después, la que fundamentalmente radica en la depurada composición del cuerpo de fachada.

Esta poderosa imagen, que cautivó a Ximena y a otros investigadores, ciertamente también impresionó a los carpinteros del posterior modelo de Castro y sobretodo en su época a todo el archipiélago y su contexto geográfico y cultural.

Si bien Montecinos intuyó y demostró que podía ser Quinchao la que inicia la denominada Escuela Chilota, lo que fue un acierto según los datos obtenidos en ese momento, sin embargo la fábrica de Castro, datada el año 1857, es seis años previos a la capilla de Quinchao, cuya construcción fue datada de 1863. Por lo tanto, a este

director del coro Teutonia, con ocasión de su alejamiento de Puerto Montt. Fueron dadas a conocer en mayo de 2012 por el coleccionis ta Alejandro Torres.

${ }^{85}$ En lo particular o personal, esta foto fue lo que volvió a detonar mi obsesión y pasión por las iglesias de Chiloé y retomar dicha investigación.

${ }^{86}$ Hay planos poco conocidos realizados por Provasoli y donde se puede ver la planta del edificio estructurada completamente en madera. (Anexo $\left.{ }^{\circ} 4\right)$. Esto puede ser ya que una vez iniciada las obras, estas se derrumbaron, por lo cual se le habría solicitado a Provasoli la ejecución de una versión en madera. 
momento del estado de la investigación no cabría duda de que con el modelo realizado en la ciudad sede del Colegio de misioneros de Castro, se habría inaugurado la tipología y sus características principales para modelar infinitas variantes. Esto es además lógico, ya que Castro fue sede de las misiones jesuitas en el archipiélago y después de los frailes franciscanos del colegio de Chillán, de Santa Rosa de Ocopa, y a partir de 1837, fue el asiento principal de los franciscanos italianos en el archipiélago y de su misión en toda la zona sur austral. Por lo tanto, fundan un símbolo religioso poderoso, ubicado en un lugar estratégico, y que se convierte en la matriz principal de la escuela chilota de iglesias, expresada en sus dimensiones, composición arquitectónica, así como de detalles y ornamentos al interior. En general el resto de las capillas serán más simplificadas a partir de esta matriz, tal como lo será Quinchao.

De los escritos epocales no se sabe si esta versión de 1859, tendría similitudes con la edificada alrededor de $1840^{87}$ por los mismos misioneros franciscanos italianos, guiada por Chuffa. Es muy probable que sí lo fueran, si bien los escritos dicen: "En el mismo lugar del incendiado edificio, aunque en diferente forma, este magnánimo Padre preparó el terreno para la reedificación." (Cárdenas, 1897, p. 72).

Sería especular qué tan distintos o similares eran estos modelos, pero lo relevante es que ya en la de 1859 se define una matriz arquitectónica en el archipiélago. Incluso se adelanta y diferencia a las realizadas por la colonización alemana, que se iniciaba en la zona en la misma época. Esto es tratado en el capitulo siguiente, donde se demuestra que las iglesias de la escuela alemana tienen una impronta inicial en la zona, con imágenes vinculadas a corrientes neorománicas o más eclécticas y la mayoría de ellas son de corte basilical, con una menor profusión estilística y decorados en las fachadas.

Es destacable también, que en la foto se puede observar adosada a la Iglesia, el edificio del Colegio, formado por un cuerpo de dos pisos con acceso estragado y destacado por un mirador angosto al que sigue un cuerpo bajo de un piso, tras el cual se ubicaba el claustro de la iglesia. Este edificio del Colegio en reconstrucción y el pórtico de la iglesia daban la altura máxima de los edificios del entorno.

Para llevar a cabo una obra de estas dimensiones y nivel de composición, es indudable que se requiere de un proyecto previo, una planimetría mínima para su ideación y ejecución. No hay antecedentes ni referencias de que haya sido una copia de otra iglesia, tampoco se puede asociar a alguna en específica, como puede ser el caso de la Iglesia de Puerto Varas de la escuela alemana, edificada entre 1914-1918 ${ }^{88}$ (Figura $\mathrm{N}^{\circ} 8$ ), que es prácticamente una réplica de un modelo en Baden-Wurtemberg, Alemania.

\footnotetext{
${ }^{87}$ De este edificio no se han encontrado antecedentes de sus características arquitectónicas ni registro grafico. Sin embargo se sabe que "El ancho de la iglesia era de 22 varas y su largo 80 , de sur a norte" (León, 2005, p. 9)

${ }^{88}$ La Iglesia del Sagrado Corazón de Jesús de Puerto Varas fue declarada Monumento Nacional, de acuerdo al Decreto Supremo ํo290 del 4 de junio de 1992.
} 


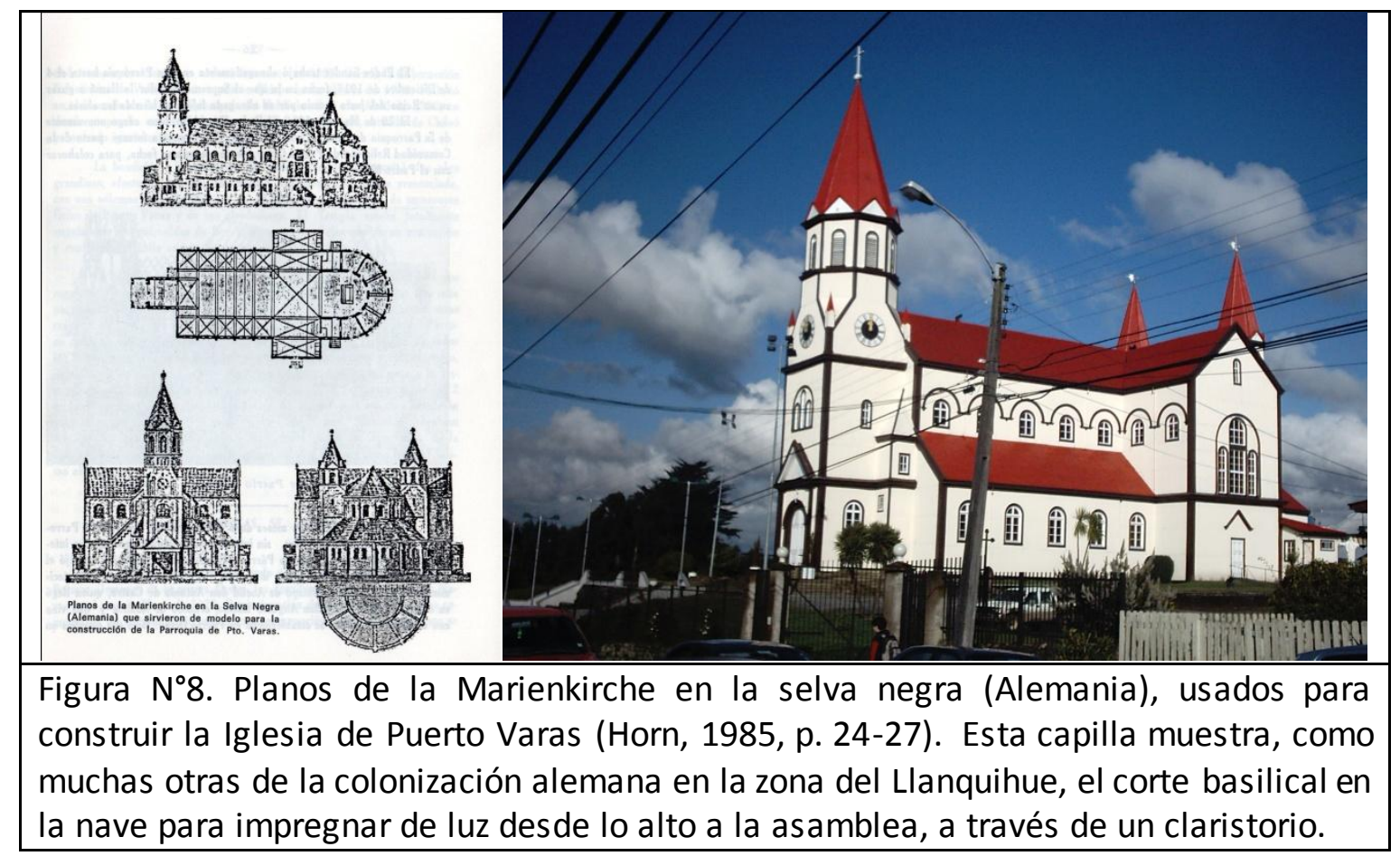

Entre los escasos documentos encontrados de la época están las valiosas cartas entre el Colegio de Castro, el Gobierno Departamental y la Intendencia de Chiloé, situada en Ancud, (Anexo 2). De la revisión y análisis de ellas se pueden desprender importantes antecedentes sobre la realización de este magnífico y espectacular edificio religioso de mediados del siglo XIX. Justamente uno de ellos se refiere a lo ya comentado de la necesidad de un proyecto, según lo prueban los citados intercambios de cartas al respecto.

Con respecto a la planimetría, en carta N ${ }^{\circ} 105$ del 2 de Mayo de 1857 del Gobierno Departamental al Intendente, se refiere a la solicitud presentada por franciscanos de Colegio de Castro para llevar a cabo la reconstrucción del Convento:

Comunico a VS. haber expedido con esta fecha el decreto que sigue

"Visto el plano presentado por el R.P Guardián de la comunidad de regulares de esta ciudad con el fin de reedificar el convento incendiado el 22 de marzo último, y la cantidad de cincuenta mil pesos en que calcula el gasto de la obra presentada en diseño, y considerando $1^{\circ}$ Que para emprender esa fábrica no cuenta aquella comunidad con cantidad alguna de pesos según testimonio del expresado guardián. $2^{\circ}$ Que el plano presentado contiene una superficie de cuatro mil doscientos ochenta y cuatro varas cuadradas de edificio; cuyas comodidades son para ciento treinta religiosos, número demasiado excesivo para que puedan sostenerse según su profesión de la caridad pública en una provincia pobre. $3^{\circ}$ Que de llevarse a cabo según el plano obstruye la apertura de una calle, con lo que se perjudicaría a la convención pública, infringiéndose la disposición suprema acordada en 31 de diciembre 1844 que por el Ministerio del Culto se puso en conocimiento de la Intendencia en nota $n^{\circ} 315.4^{\circ}$ Que al acceder la autoridad a que se levante tan costoso edificio comprometería a la comunidad misma a sufrir crudas necesidades por atender a la conclusión de 
esa dilatada fábrica, legándose por consiguiente a la posteridad de la corporación religiosa un peso insoportable por los muy limitados recursos con que cuenta. $5^{\circ}$ Que habiéndose hecho examinar el expresado plano por el ingeniero Dn. Daniel Shepard lo ha desaprobado en todas sus partes por razones bien calificadas (Carta N 105 del 2 de Mayo de 1857 del Gobierno Departamental al Intendente).

De aquí se desprende que la comunidad Franciscana disponía de un proyecto para la realización de toda la reedificación del convento, este es rechazado por su costo, por superficie considerada sobredimensionada y por ocupar la apertura de una futura calle.

En carta posterior $\mathrm{N}^{\circ} 118$, de parte del gobierno se recomienda realizar el proyecto del Ingeniero norteamericano Daniel Shepard que ofrece una fábrica de ladrillo, se señala que las "grandes ventajas que encierra su edificio de esa naturaleza... y el presupuesto asciende a 23.000 \$ en que dicho ingeniero calcula el costo de aquel edificio trabajado de material." En definitiva el proyecto en albañilería no se realiza, y es probable que el material empleado para las fundaciones si haya sido en ladrillo.

Se señala en las carta N²29 del Gobierno "que antecede por haberse hecho cargo de la obra de Padre Chufas, quien ha principiado con ese dinero y las limosnas colectadas en esta provincia a colocar los mejores cimientos del convento que van a levantar." También en uno de los libros de los franciscanos se señala que "Estaba para concluirse la reedificación de la Iglesia... se había vuelto a reconstruir a fundamentis" (Cárcamo, 1873, p. 77).

Es decir, ya des de las fundaciones los misioneros estaban considerando hacer una obra definitiva y permanente, parafraseando las palabras del evangelio "sobre esta piedra edificaré mi Iglesia, y las puertas del Hades no prevalecerán contra ella" ${ }^{89}$. Además cabe consignar que en las obras de restauración realizadas en este edificio a fines de 1990 fueron encontrados bajo el pórtico fundaciones de ladrillo, a diferencia del resto de las capillas tradicionales chilotas, que en general son piedras o pilotes de madera (Berg, 2005).

Se infiere por las cartas, por la comentada fotografía de 1893 y por descripciones directas realizadas en la época, que hubo una voluntad clara de fundar un edificio absolutamente grandioso, cargado de simbolismo y duradero en el tiempo y la memoria:

Este edificio, aunque todo él es de madera, sin embargo, es el más sólido y bien construido en su género, tanto por la solidez de sus cimientos, como por la inmejorable calidad de sus maderas, que por consiguiente podrá durar por largos años si lo que Dios no permite jamás, otro incendio como el de 1857 no lo concluye y devora. (Cárcamo, 1873, p. 81-82).

89 Evangelio según san Mateo 16, 13-20. 
En relación al proyecto no se sabe quien fue el autor o autores intelectuales de dicho modelo y por lo tanto sería ( $n$ ) el responsable(s) de la fundación de la escuela religiosa tradicional chilota. Está claro que fray Diego Chuffa dirigió la obra, pero no necesariamente fue el diseñador, o tal vez si de la composición y estilística adoptada. Sin embargo esto aun queda en el misterio y solo podemos hacer algunas presunciones, como se indicará más adelante.

Lo importante es que hay una evidente voluntad y decisión del tipo de edificio deseado por los franciscanos y que marcó una tendencia, ya que el edificio en fábrica de ladrillo de Shepard no fue realizado y es altamente probable que tampoco se haya seguido su proyecto arquitectónico. Lo más seguro es que se haya adaptado el proyecto franciscano, más aún si fue dirigido por el propio Chuffa.

Cabe mencionar que el plano o proyecto realizados para este conjunto ha sido objeto de búsqueda de historiadores como Rodolfo Urbina, pero no hay registro de él y lo más probable es que haya sido parte de la importante documentación que se perdió en el incendio del 1902 del convento.

\subsubsection{Evolucion histórica arquitectónica del conjunto convento e iglesia de Castro en el siglo XIX.}

El punto de partida esencial es la llegada de los misioneros italianos en 1837

Primero. Del emplazamiento. Existen dos conjuntos en la plaza el de los jesuitas, al costado poniente de la plaza, y al costado norte, desde la fundación de la ciudad hasta ahora, la iglesia franciscana ${ }^{90}$.

\section{Segundo. Descripción de las iglesias.}

"En la antigua ciudad de Santiago de Castro, capital de la provincia en tiempo de la colonia, muy disminuida ya su población, después de más de once años que se habían retirado los españoles, existían aun dos iglesias: la una franciscana, regularmente conservada, con su convento en esta habitable, pero inadecuado para morar una comunidad religiosa que debía observar todas las leyes canónicas de clausura y disciplina regular; la otra iglesia era parroquial, edificada con madera de ciprés, alerce y roble, en forma de una rotunda con su gran cúpula en el centro y una torre para las campanas; esta era obra de los jesuitas." (Cardenas, 1897, p. 64).

\footnotetext{
90 De la ciudad de Castro y del convento franciscano se escribe que "Sus calles son rectas y parejas, con una plaza en el centro, en cuyo costado del Poniente se halla la iglesia parroquial, construida en 1657, y en el del Norte un vasto convento de misioneros franciscanos, establecidos en 1837, incendiado en 1857 y reedificado después..." Astaburuaga, Francisco S. Diccionario Geográfico de la República de Chile Nueva York, D. Appleton y Compañía, 1867.
} 


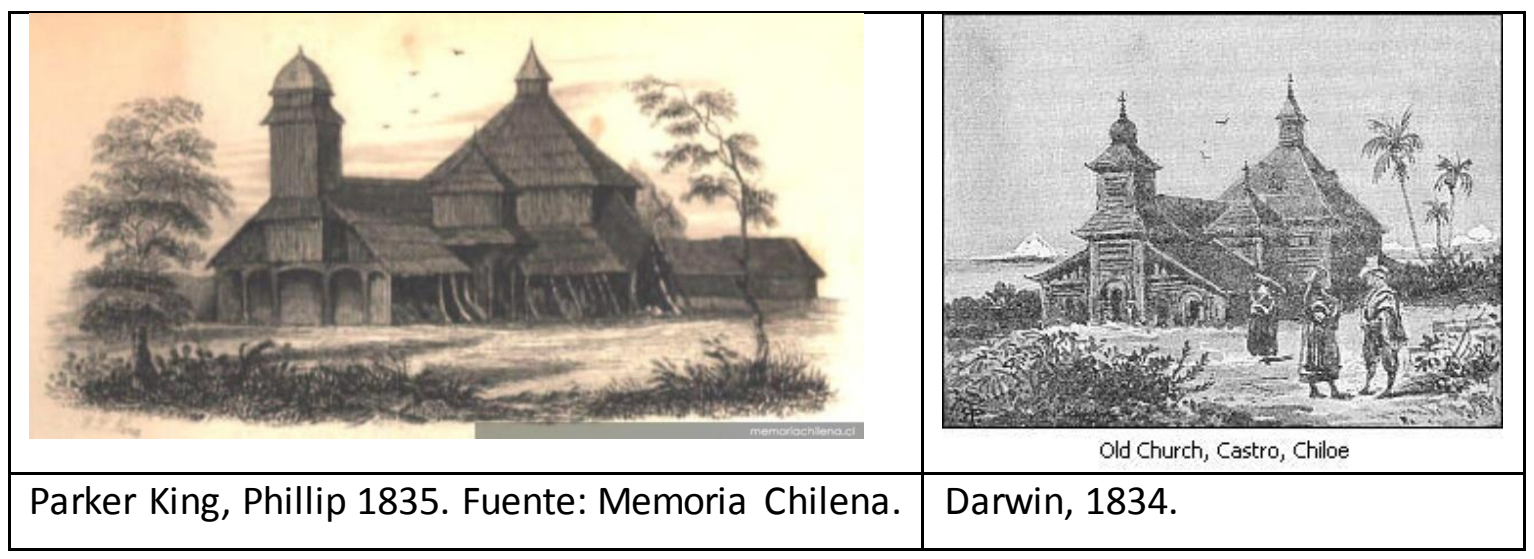

De este modo, según la anterior descripción, la iglesia jesuita corresponde a la dibujada por Parker King en 1830 y Darwin, quien dice de ella "Ia iglesia situada al centro de la población, se halla completamente construida de madera y no carece de aspecto pintoresco ni de majestad" (Darwin, 1834 (1995), p. 159). Es decir, al inglés apenas le llamó la atención este edificio o convento franciscano con su iglesia, ya que no la menciona. Esto también es bastante concordante con la descripción anterior de Fray Cárdenas que la interpreta muy modesta. Se sabe que los efectos del terremoto acaecido en 1837 la deja en muy mal estado ${ }^{91}$.

\section{Tercero. La rápida construcción del Colegio.}

Las condiciones imperantes de estado ruinoso y reciente sismo hacen que los sacerdotes se instalen en la antigua iglesia jesuita e inicien un nuevo y adecuado convento $^{92}$. La realización de la fábrica del convento, dirigida por Diego Chuffa, tomó tres años ${ }^{93}$.

\section{CUARTO. El incendio de $\mathbf{1 8 5 7}$ arrasa el convento e Iglesia nueva inconclusa.}

Durante la Guardianía del R.P. García sucedió el gran incendio que redujo a pavezas aquel bello plantel que tan buenos frutos había producido en los diez y nueve años que habían transcurrido desde su fundación. Estaba para concluirse la reedificación de la

\footnotetext{
${ }^{91}$ La iglesia de San Francisco casi quedó inhabilitada. En ella decían misa a la hora del terremoto algunos de los padres recién llegados. Una tabla del altar que estaba celebrando el Reverendo Padre fray Marcos Bula le cayó en la cabeza, y aunque no fue grave la herida que le produjo, derramó gran cantidad de sangre. Durante un mes continuaron repitiéndose diariamente los movimientos de tierra, hasta que por fin, hubo uno muy recio, pero de corta duración. (Cárdenas ,1897, p. 12)

92 ..existía en la ciudad una antigua casa, que había sido morada de algunos misioneros, y de una iglesia regularmente cuidada por el cura, que a la sazón lo era un religioso también franciscano, fray Antonio Forasté, llegados los fundadores, se les dio posesión de la antedicha iglesia y de la casa o conventillo. Era éste inadecuado, en verdad, para el objeto que se tenía en vista, pero servible entre tanto, mientras se construía un nuevo edificio adecuado para religiosos franciscanos de regular observancia y en el cual debía guardarse la clausura de regla (Cárdenas, 1897, p. 14).

93 Con efecto, tan luego como principió la fábrica del Colegio, los mismos habitantes de Chiloé, especialmente los del Departamento de Castro, activos y laboriosos por carácter, y gran manera devotos y religiosos por inclinación, tomaron con tanto empeño la construcción del Colegio, que en menos de tres años, estuvo totalmente concluida una casa, aunque de madera pero regularmente sólida, que medía dos cuadriláteros de más de sesenta varas cada una, siendo de dos pisos los tres ángulos laterales, y de un solo piso el ángulo divisorio o de medio, con casa para cocina, horno y demás oficinas necesarias para una comunidad bastante numerosa. En un cuadro a la parte del levante lo cerraba la lglesia que era la que habian dejado los expatriados regulares (95). (Cárcamo, 1873, p. 65)
} 
Iglesia, que por inutilización de la antigua que había sido obra de los Padres de la Compañía se había vuelto a reconstruir a fundamentis, cuando el día 22 de Marzo de 1857 , entre las ocho y nueve de la noche, estando toda la comunidad religiosa en el refectorio, un foco de fuego que se advirtió por la parte del noviciado, al lado septentrional del primer cuadrilátero del edificio en los altos junta a la Sacristía, fue suficiente para que en menos de dos horas redujera a cenizas todo aquel vasto edificio incluso la nueva Iglesia. Grandes fueron entonces los quebrantos, que produjo en todos tan aciago momento; incluso las pérdidas que la comunidad tuvo que lamentar, deplorables las desgracias, incluso la muerte de un triste anciano, que por estar enfermo en cama no le fue posible salir, y nadie lo advirtió, en medio de tanta confusión, y forzoso fue que sirviera de pábulo a la voracidad del elemento destructor (Cárcamo, 1873, pág 77).

\section{QUINTO. Se inicia la reedificación completa e inmediata del conjunto convento e Iglesia.}

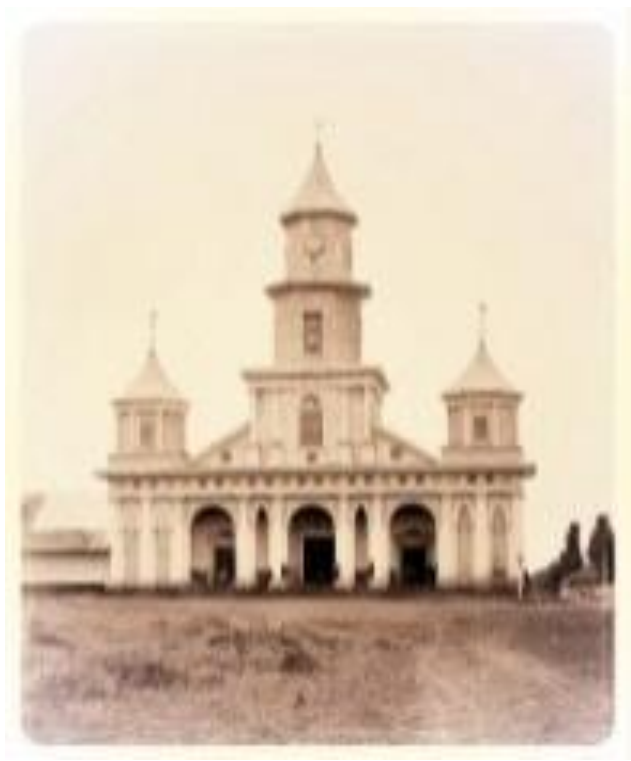

Foto 1893, Jerman Wiedehold

La fábrica del convento se inicia a fines de 1857 y a mediados de 1859 está habilitado para su uso. Este año se inician las obras de la iglesia nueva y en otra "forma" 94 , a partir desde sus cimientos o basamentos sobre el mismo sitio de la anterior incendiada, se termina todo el conjunto en $1866^{95}$.

\footnotetext{
94 Después del incendio, el M. Rvdo. P. Chuffa, instado por todos los religiosos para que se hiciese cargo de la reedificación del Convento y templo, sin amedrentarse por la terrible prueba a que los había sometido Nuestro Señor, accedió y acometió con valor y confianza en la divina Providencia, a pesar de sus años, la magna obra que se le confiaba. En el mismo lugar del incendiado edificio, aunque en diferente forma, este magnánimo Padre preparó el terreno para la reedificación. (Cárdenas, 1897, p. 72). Esta "diferente forma" qua señala Cárdenas, se refiere a la del convento, esta vez de dos pisos.

95 Teniendo ya reunidos los más indispensables elementos para dar la iniciativa a la nueva fábrica, se principió el trabajo del nuevo convento bajo la dirección del M.R.P. Fr. Diego Chuffa a fines de año 1857 y fueron tan rápidos y constantes los esfuerzos en el trabajo, que a mediados del año 1859 ya los religiosos que hasta entonces habían vivido diseminados por clases en varias casas particulares de la ciudad, tuvieron la inexplicable dicha de volver otra vez a estar reunidos para habitar unos claustros que
} 


\section{Sexto. Descripciones históricas de la iglesia ${ }^{96}$ y convento. Características generales}

La Iglesia está ubicada al oriente del primer cuadro que constituye los dos claustros principales en que está dividido el convento, y mide sesenta y seis metros con cuatro centímetros de largo, a los que se le agregan cuatro metros cuarenta centímetros de pórtico. Su anchura es de dieciocho metros veintidós centímetros...La Iglesia es de tres naves, y de dos órdenes de asientos el coro. Los seis altares menores o colaterales son también de orden Dórico, y todos están sostenidos por cuatro columnas cada uno todas del mismo orden... Este edificio, aunque todo él es de madera, sin embargo, es el más sólido y bien construido en su género, tanto por la solidez de sus cimientos, como por la inmejorable calidad de sus maderas, que por consiguiente podrá durar por largos años si lo que Dios no permite jamás, otro incendio como el de 1857 no lo concluye y devora. (Cárcamo, 1873, p. 81-82)

Séptimo. Este conjunto, iglesia y convento, en 1902 se incendia completamente. Se lleva a cabo una nueva iglesia que se encuentra terminada en 1912. En esta época se finalizan las funciones del Colegio de Castro.

En 1910 se inicia la obra según el proyecto original realizado por el arquitecto Eduardo Provasoli ${ }^{97}$ de origen Italiano. El maestro carpintero que trabajó y dirigió los trabajos fue Salvador Calixto Sierpe, de Yutuy, secundado por el carpintero don Santiago Subiabre (Díaz, 1990). El proyecto ideado por Provasoli era una fábrica de mampostería, los carpinteros chilotes siguiendo el diseño general del arquitecto y la realizan en madera, que era la técnica constructiva que dominaban, logrando un espectacular edificio declarado Monumento Nacional (1971) y Patrimonio de la Humanidad (2000). Este edificio de gran interés arquitectónico, sin embargo se sale de la tipología de las Iglesias tradicionales de Chiloé, al disponer tanto de dos torres en el acceso, corte basilical y gran tambor con cúpula sobre el presbiterio. Con ella se culmina el proceso de las grandes iglesias de madera chilotas.

la voracidad de las llamas había dejado totalmente desiertos y solitarios. Cuán grande haya sido su regocijo al ver en tan poco tiempo cubierto de nuevos edificios aquellos pulverizados escombros, solo ellos podían explicarlo, pues, ellos, solo después de tantos sufrimientos eran capaces de saberlo apreciar en su justo valor.

En el mismo año 1859, se pusieron los fundamentos para una nueva Iglesia en el mismo local que ocupaba la antigua que se había destruido en el incendio, y sin descuidar uno y otro trabajo, ya en el año 1866 había un edificio completo que, fuera de la Iglesia, medía como cuatrocientos metros de casa de un solo piso pero muy sólida, dividida en varios departamentos o claustros, con varias casas más para oficinas, y varios otros usos del mismo convento. (Cárcamo, 1873, p. 71)

${ }^{96}$ Fue bendito con toda solemnidad que para tales ceremonias prescribe el rito católico el domingo 3 de Diciembre de 1865, quedando desde ese día a disposición del público ansioso esperaba tener otra vez una casa cómoda y capaz donde derramar sus tiernas preces al Dios de la misericordia. (Cárcamo, 1873, p. 82)

\footnotetext{
97 Además hacelos proyectos de las Iglesias de San Francisco de Barón en Valparaíso, Chillán y Divina Providencia en Santiago. Los planos que hace para Castro, que al parecer nunca visitó, sirvieron para la Iglesia Franciscana de Osorno
} 


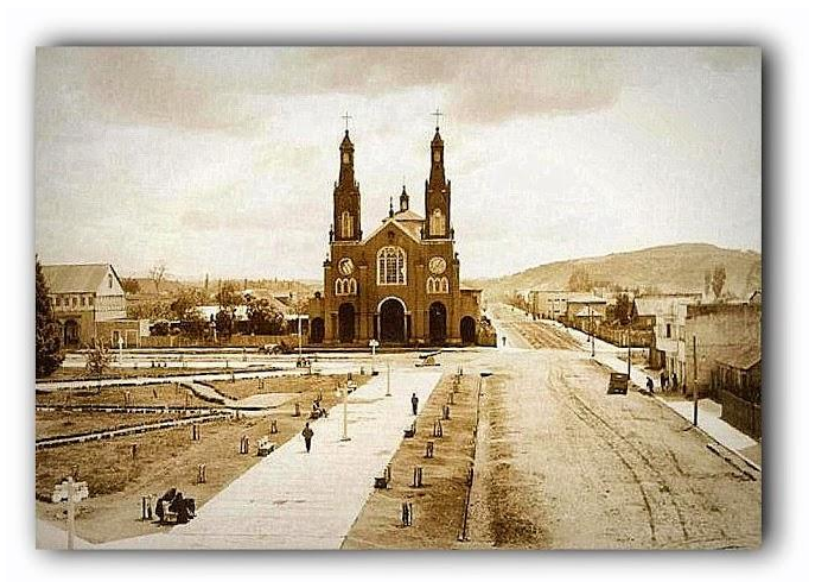

Actual iglesia san Francisco de Castro, foto 1920 aprox. Archivo Museo de Castro

Por otra parte Fray Cárdenas, que durante parte del periodo de edificación del conjunto se encuentra destinado fuera de Castro, señala a propósito de su estado final "Sé que el convento quedó cómodo y capaz para contener una numerosa Comunidad, y la iglesia de grandes dimensiones, sólida de buen gusto y con hermoso coro para la Comunidad, y una buena Capilla para los hermanos Terceros." (Cárdenas, 1897, p. 14)

\subsubsection{La gestión de la obra en Castro.}

La materialización de una fábrica de estas características debió implicar un despliegue considerable de recursos humanos, físicos y económicos, que tuvieron que administrarse en forma efectiva y eficiente para alcanzar tal nivel técnico que es perfectamente visible en las imágenes y descripciones, más aun en el escaso tiempo de ejecución de la obra con un interior casi completamente decorado en un período de seis años y con las escasez de medios existente en el Chiloé de esos tiempos. Ya se hacía mención de la precariedad de la "ciudad", que carecía de un sistema de canalización de aguas y que éste es recién llevado a cabo de la mano de estos misioneros, lo que da una visualización del estado de urbanidad de Castro. Este hecho también es corroborado en la nota №105 fechada el 2 de mayo de 1857 con que el gobierno departamental comunica el decreto que rechaza la petición de reedificación del convento, en cuyo ítem №3 indica que "de llevarse a cabo según el plano obstruye la apertura de una calle, con lo que se perjudicaría la convención pública...", lo que es un claro indicio de que la trama urbana no estaba consolidada.

La preocupación de Estado de Chile por apoyar económicamente y dar los recursos necesarios para cumplir con los intereses de la República, quedan de manifiesto en las cartas entre el Colegio de Castro, el Gobierno Departamental y la Intendencia de Chiloé, para llevar a cabo la edificación de estos edificios, convento e iglesia, ya sea el modelo de 1840 como el iniciado en 1857. Pero el apoyo estatal va más allá del aspecto pecuniario para financiar materiales o mano de obra, y tal como se expresa en la carta $N^{\circ} 229$ de 1857 
Habiendo obrado en la forma ya relacionada VS. verá que de ningún modo ha sido ni es gravoso a la tropa, pues una sola compañía única de carpinteros que hay en el departamento se ocupó en arreglar los maderos, cuyas fuerzas para la parte de la composición de camino que les está designada, será reemplazada por una partida de los que no asistieron en el presente año.

Relato similar se encuentran entre los escritos franciscanos y que atestiguan las dificultades para llevar tal fábrica y el apoyo recibido por parte del gobierno, específicamente "en el capítulo XIII: Comienzo de los trabajos" dice:

Luego después se determinó emprender la obra del edificio que era preciso construir para el establecimiento y recibir sin demora los primeros alumnos, abriendo las clases preparatorias que debían dejarlos en aptitud de recibir el hábito religioso. En una y otra cosa se puso manos a la obra con decidida determinación y con el entusiasmo propio de hombres abnegados y verdaderamente apostólicos. No es fácil decir cuántos inconvenientes tuvieron que vencer estos padres para la realización de aquella magna empresa. La generalidad de los habitantes de Chiloé eran sencillos y honrados; pero tenía que lucharse con otros elementos poco favorables y con la pobreza de aquel archipiélago. Felizmente había en el gobierno de la República voluntad de ayudar a los misioneros: el intendente y los gobernadores recibieron orden superior de recomendar a los comandantes de milicias que se turnasen las compañías para auxiliar el trabajo.

Por otra parte el erario nacional contribuía con dinero a medida de la necesidad y subvencionaba también el colegio con los sínodos correspondientes a cinco misioneros. Estos sínodos no los percibían particularmente, si no que entraban a formar el fondo de la vida común que se guardaba en la casa y a servir a la exigencia de la fábrica. (Cárdenas, 1897, p. 17)

Por lo expuesto, el aporte estatal incluso se extiende a recursos o mano de obra compuesto por carpinteros pertenecientes a la fuerza regular del ejército asentado en la zona y pertenecientes a las compañías dedicadas a obras de caminos u otras necesarias para fines militares o civiles. Se desprende que este contingente tuvo una importante participación, al menos para el caso de esta Iglesia ya que estaría desmitificando una cierta exclusividad de la llamada escuela carpintera chilota como artífices únicos de estos edificios. Es muy probable que la participación del contingente de carpinteros militares se haya concentrado "en arreglar los maderos relativos" principalmente en la etapa de estructuración de la fábrica, materia para la cual debieron estar sólidamente entrenados y eran tareas que normalmente realizaban, tales como caminos, puentes o fortificaciones. Así como de disponer toda la suerte de equipos, materiales y herramientas necesarias para tales construcciones y por extensión útil para levantar una fábrica con naves y torres de elevada altura, como la Iglesia de Castro.

El "arreglo de maderos", al que hace referencia la nota, se enmarca en una de las etapas del proceso constructivo de preparación de las piezas necesarias, previo al armado de la estructura. Estas faenas incluían el dimensionamiento de las escuadrías, lo que se hacía con azuela, ya que en general la madera llegaba "en bruto", es decir 
con muchas y variadas irregularidades en la sección. Además se cortaban las piezas del largo adecuado a su función y se preparaban las uniones, es decir que se hacían las escopleaduras y rebajes para las uniones de caja y espiga entre soleras y pies derechos y los rebajes de los empalmes en rayo de Júpiter o a media madera.

De todos modos los carpinteros chilotes serán protagonistas indiscutibles en este periodo y de esta obra, tal como se registra en un documento ${ }^{98}$ de carácter contable hallado en enero de 2014, en una pequeña biblioteca de la casa de los franciscanos en Castro $^{99}$ (Anexo $\mathrm{N}^{\circ} 3$ ) y que se usó para la administración de las obras de reparaciones del convento después del amago de incendio de 1882 y que se inician en 1883 y finalizan en 1890. En este documento se lleva un gran detalle de las partidas de trabajos, los valores, erogaciones y en algunos casos se menciona a los carpinteros.

Otro aspecto fundamental y seguramente tanto para avanzar en forma acelerada la edificación, por el tamaño de esta, así como por la disponibilidad de recursos en forma parcelada, es que se dispuso de diversos equipos de carpinteros para realizar el conjunto, aunque se les asignaban partes del edificio debidamente definidas, como los actuales subcontratos. Así, se puede constatar diversas partidas de obra encargadas en forma paralela durante el año 1888 por una suma total 2500 pesos. Entre estas se pueden referenciar: "data ciento cuarenta pesos a Enrique Zuñiga por hacer una biblioteca de 13 varas largo i $41 / 2$ de alto con unos estantes respectivos, pilastras i cornisas, puerta i ventanas i una escalera de 9 varas de alto con baranda según R. N. 29", (DIC, 1883-90, p. 24). O la colocación de vidrios, realización de pinturas y empapelados de una pieza de 10 varas con sala y dormitorio a Antonio Arancibia por el valor de 15.00 pesos (DIC, 1883-90, p. 19). En otros casos hay encargos de trabajos de herrería a Pedro Telleo o, a Purísimo Cárcamo de un cañón de edificio de 44 varas de largo por 115.00 pesos (DIC, 1883-90, p. 23-24). También esto demuestra una probable especialización en la mano de obra local, pero también el uso de materiales tales como herrajes, vidrio, pinturas, barnices y empapelados para una terminación más sofisticada del edificio.

Una realización más notable aún detectada en el libro contable que fue solicitada el año 1889: "Data a Don Francisco Águila Ruiz según planilla de (...), 27: por la construcción de torres laterales de la iglesia conventual a 200 \$ c. u. -según contrata suma de la vuelta ${ }^{100}$ - por otros trabajos hechos en la misma iglesia...150.000 pesos “(DIC, 1883-90, p. 33-34).

De estas notas se desprende que las torres laterales no eran parte del proyecto original, lo que se reafirma al confrontar la nota con la fotografía de Wiederhold, como se verá más adelante ${ }^{101}$.

\footnotetext{
98 Documento inédito para estos efectos Ilamados DIC (Documento Iglesia de Castro).

99 Este libro se encuentra en la pequeña sala de la iglesia y es un manuscrito del periodo de edificación del modelo de 1859. Dicho manuscrito de letra ilegible se encuentra junto a otro similar referido a la Iglesia de Nercón en su periodo de construcción.

${ }^{100}$ Esta frase se refiere al cambio de folio o de hoja que hace el libro contable

101 Esta afirmación pareciera contradecir la descripción hecha por fray Francisco Cárdenas el año 1873.

Sin embargo significa que el pórtico fue construido, en principio, sin las torres.
} 
Estas torres laterales es posible que no hayan estado consideradas en el proyecto inicial, o al menos ser realizadas con posterioridad al término general de la fábrica y su puesta en uso en 1863. Es decir seguramente el templo estuvo 30 años con una sola torre, lapso durante el cual se disemina el modelo y la regla de las torres únicas. De la anterior descripción se da a conocer el nombre de un chilote como carpintero mayor, Francisco Águila Ruiz, quien aparte de haber llevado a cabo estas importantes torres laterales realizó otras partes del convento, y por lo tanto maestro de gran oficio y que presumiblemente realizó otras capillas, aunque no se ha encontrado documentación al respecto.

También de este documento contable que registra la actividad realizada en la década de 1883-90, se hace mención al nombramiento de la comisión de fábrica del Convento, esta es aprobada y decretada por La Intendencia según Decreto $N^{\circ} 27$ de 1888, y designa a José Antonio García B. y Daniel Gómez M. Según consta en el mismo documento contable: "La comisión informada de los trabajos proyectados por el R. $P$ Guardián Jesús M. Barría" (DIC, 1883-90, p. 13-14). Es muy posible deducir en estos registros que la Comisión de fábrica es la encargada de la administración económica de la obra, para cautelar el buen uso de los aportes del estado a la construcción, por parte del gobierno, pero no de los lineamientos proyectuales que vendrían decididos por el Padre Guardián del convento, de acuerdo al plano disponible por parte de los Franciscanos.

Se desprende del documento contable que las compras de materiales y particularmente las maderas requeridas para determinados elementos del conjunto eran compradas o adquiridas a distintos proveedores, es el caso de muchas partidas como por ejemplo maderas, se pueden constatar en compras realizadas el mismo día de "tablas de alerce mejoradas" a Paulino Barría y Antonio Villegas a igual precio, cinco pesos cincuenta centavos el ciento (p. 18), en tal sentido no habría suficiente disponibilidad de oferta de maderas por parte de un solo suministro o proveedor, por lo que se recurría a varios de ellos.

Por otro lado se puede vislumbrar en la foto que las cubiertas del conjunto fueron realizadas en fierro galvanizado, ya que se puede observar la adquisición de este material: 45 atados fierro galvanizado acanalado 8 pies...\$ 940.80 (DIC, 1883-90, p. 33). Seguramente es este edifico el que inaugura la utilización de metal en los modelos religiosos del archipiélago, Basta señalar que en 1906 se trató de cubrir la iglesia de Achao con este material (Montecinos, 1995), sin embargo era muy costoso y no prosperó tal iniciativa. Las planchas eran importadas y de hecho la compra en Castro se hace a Rose-Innes $i$ Cia. Se desprende que se trata del representante de una compañía británica, así como otras compras realizadas a otras casas comerciales con nombres extranjeros y que demuestran ya un nivel importante de importación existente en aquella época en la isla y que ya surtían de elementos como herrerías, clavos, pinturas, barnices y papeles murales entre los más destacables.

Esta gestión llevada a cabo en la fábrica del convento de Castro, que contempla aportes sustantivos del Estado y participación de múltiples equipos de carpinteros, no 
se puede considerar como una regla común para las capillas de esta época, sino una de las tantas formas en que se financiaban las obras, más bien acotados probablemente solo a algunos a los conventos y templos de los asentamientos principales, referidos a Los Curatos, Parroquias y vice parroquias atendidas por el Colegio de Castro (Cuadro $N^{\circ} 5$ y Anexo 1), tales como Ancud, Castro, Osorno, Chacao o Calbuco. De hecho, Montecinos (1995) indica la necesidad del aporte estatal o de la iglesia para financiar las obras, lo que ha dejado como resultado algunos planos de iglesias, que acompañaban los presupuestos.

Cuadro № 5. Puntos de servicio exterior desempeñados por el Colegio de Castro en Chiloé, 1840. León, 2005, p. 31.

\begin{tabular}{|l|l|l|l|l|}
\hline Curatos & № de capillas & Indígenas & $\begin{array}{l}\text { Feligresía } \\
\text { Españoles } \\
\text { mestizos }\end{array}$ & Yotal \\
\hline $\begin{array}{l}\text { San Carlos de } \\
\text { Ancud }\end{array}$ & 7 & 746 & 3404 & 4150 \\
\hline Castro & 9 & 1878 & 6662 & 8540 \\
\hline Calbuco & 15 & 1666 & 4334 & 6000 \\
\hline Achao & 7 & 1878 & 4986 & 6864 \\
\hline Doctrinas & & & & \\
\hline Chacao & 8 & 1934 & 8 & 1942 \\
\hline Quenac & 8 & 1707 & 1293 & 3000 \\
\hline Lemuy & 8 & 2401 & 2919 & 5320 \\
\hline Tenaún & 11 & 1526 & 2110 & 3636 \\
\hline Carelmapu & 5 & 1438 & 162 & 1600 \\
\hline Chonchi & 7 & 3017 & 188 & 3205 \\
\hline Queilen & 8 & 1800 & 0 & 1800 \\
\hline & 94 & 19991 & 25967 & 45958 \\
\hline
\end{tabular}

Fuente: ANCh, Ministerio del Interior. Vol. 169 A MPF 1837-1850. Informe de la Prefectura General de Misiones al Ministerio de Justicia, Culto e Instrucción Pública, 20 de marzo de 1840.

P. 59- 60

En el caso de Nercón, capilla tradicional a unos $5 \mathrm{~km}$ al sur de Castro, realizada entre 1879- 1897, es la única otra obra del periodo documentada con mayor precisión, de que la comisión de fábrica estaba constituida por miembros de la Junta de vecinos y fue dirigida por Francisco Bórquez, siendo financiada con erogaciones de la localidad $^{102}$. Es interesantísimo aquí constatar que los insumos, materiales y/o elementos constructivos como de alhajamiento fueron financiados por diferentes personas. Es decir, las erogaciones que recibían los franciscanos iban traspasadas a bienes materiales o servicios específicos, de tal modo que una determinada persona 0 personas destinaban su aporte por ejemplo, a una cierta cantidad de madera, ventanas, algún mobiliario religioso o artículo litúrgico, entre otros múltiples requerimientos.

\footnotetext{
102 Documento inédito para estos efectos Ilamados DIN (Documento Iglesia de Nercón).
} 
Esta modalidad de realización y financiamiento descrito de Nercón se considera la generalizada para casi la totalidad de las capillas tradicionales de Chiloé. Lo que permite a su vez considerar que la Iglesia de Castro, tal vez por su condición de Templo principal y matriz tipológica de las capillas tradicionales, recibió un importante financiamiento por parte del Estado comprometido con la empresa misionera en el principal Colegio del sur de Chile.

\subsubsection{Antecedentes arquitectónico de la Iglesia: Neoclásico y madera.}

Como ya se ha reiterado, no hay plano de la iglesia, pero no cabe duda que lo hubo, ya que es prácticamente imposible llevar a cabo una obra de arquitectura de estas características geométricas y constructivas sin un proyecto, al menos básico. "El dibujo es imprescindible en la arquitectura. No puede haber arquitectura tal y como hoy la entendemos sin dibujo previo" (Nuere, 2010, p.5). Este autor lo argumenta inclusive para efectos de obras muy tradicionales como puede ser la carpintería, la que tiene sus reglas geométricas y por lo tanto la necesidad de dibujarse previamente. La Iglesia de Castro se tuvo que construir sobre la base de una ideación previa plasmada en el dibujo, que guiara las relaciones, trazados, proporciones o medidas, no solo para transmitirlas a los ejecutores, sino que la propia forma compositiva del edificio delata y exige una representación grafica y arquitectónica. Así como también se requirieron y existen, al menos escasos pero elaborados dibujos de la época, de elementos interiores menores, como son los retablos de Chonchi y Quinchao (Figura $\mathrm{N}^{\circ} \mathrm{9a}$ y $9 \mathrm{~b}$ ) para llevara cabo la idea o imagen del lenguaje neoclásico que se quería expresar, por lo tanto, y con mayor razón para una obra arquitectónica de gran envergadura de detalles. El dibujo también tiene la particularidad de ser un lenguaje universal y representar con mayor claridad y nitidez lo que se quiere expresar visualmente sin necesidad de palabra alguna (Nuere, 2010).

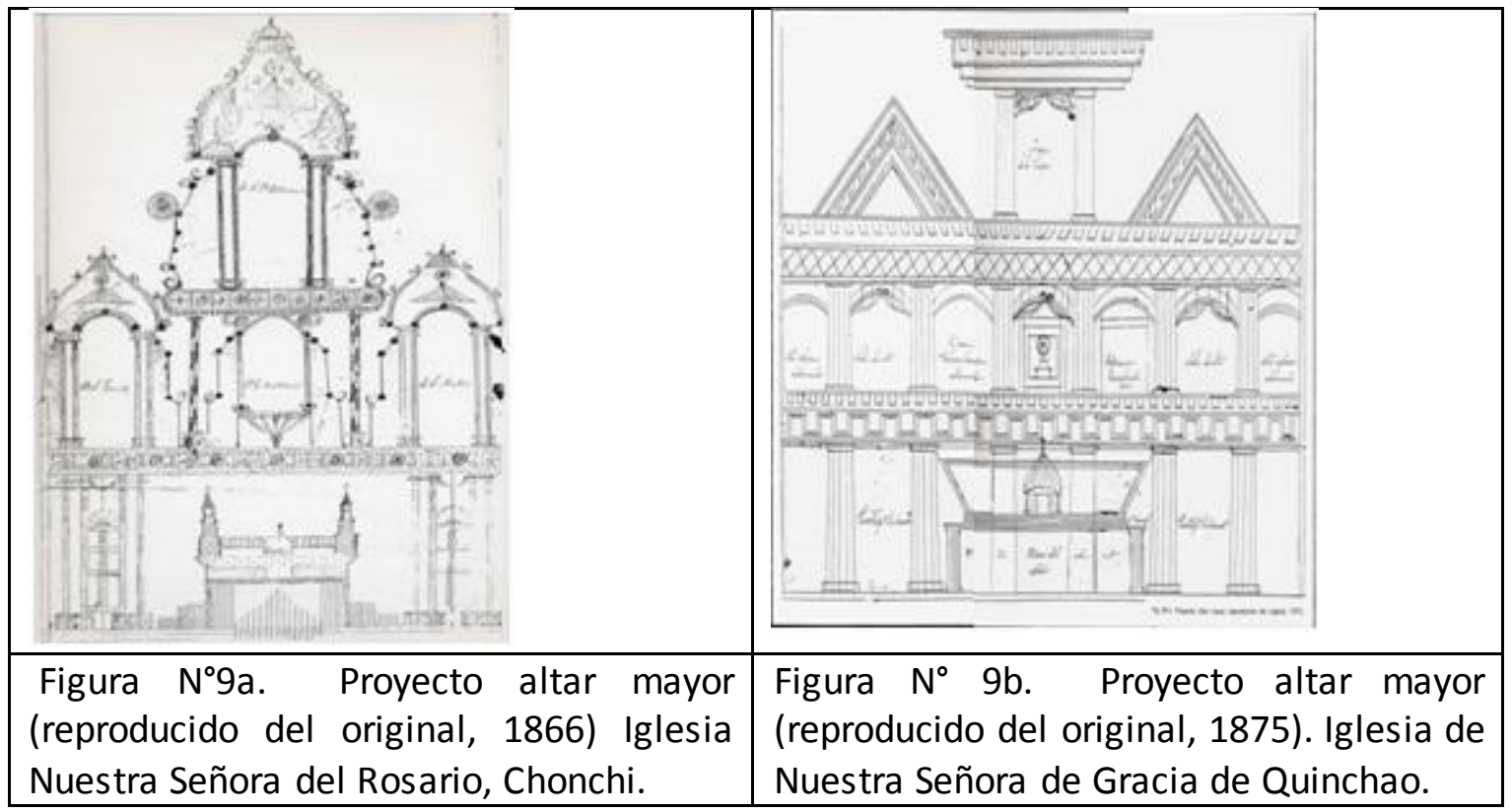

En suma, la hipótesis aquí es que la matriz tipológica chilota viene dada por un plano realizado o encargado directamente por los Franciscano italianos y que expresaba claramente su visión de una arquitectura culta o ilustrada: en ese momento era la 
corriente neoclásica. Es la expresión clarísima del cuerpo fachada y esta arquitectura requiere ser previamente dibujada.

El neoclásico es una reinterpretación del lenguaje grecorromano y del renacimiento, basados en la organización geométrica y de órdenes arquitectónicos mediante convenciones reguladas. Cuando se veían casos emblemáticos de los periodos precedentes en Chiloé, como la iglesia de la Compañía en Castro o la Iglesia Matriz de Ancud del período Ocopa, se puede observar que los pórticos en las fachadas son ejecutados con pilares de madera de sección cuadrada o circulares sin revestimiento y se distingue el sistema de postería en los muros. En el caso del templo franciscano de Castro, no será así, si bien la arquitectura neoclásica fue pensada y ejecutada en piedra o en su defecto ladrillo y más tardíamente hormigones estucados, pintados y los más significativos revestidos en mármol desde su país de origen, (Francia o Italia como uno de los principales centros difusores de esta corriente) también será realizada en madera en distintos puntos del orbe, como los países nórdicos, norte y centroamérica. En el caso de países mediterráneos se estructuraron en madera, por los terremotos de 1755 en Portugal y en 1783 en el sur de Italia, se idean sistemas constructivos antisísmicos denominados gaiola y gabbia en los respectivos países, que son mejoramientos del tradicional Fachwerk alemán o Colombage francés muy difundido en Europa y serán preludios del ballom frame o platform. Un caso señero es la casa Baraccata di Vivenzio, (figura N 10) (Tampone, 1996, p. 144-145).

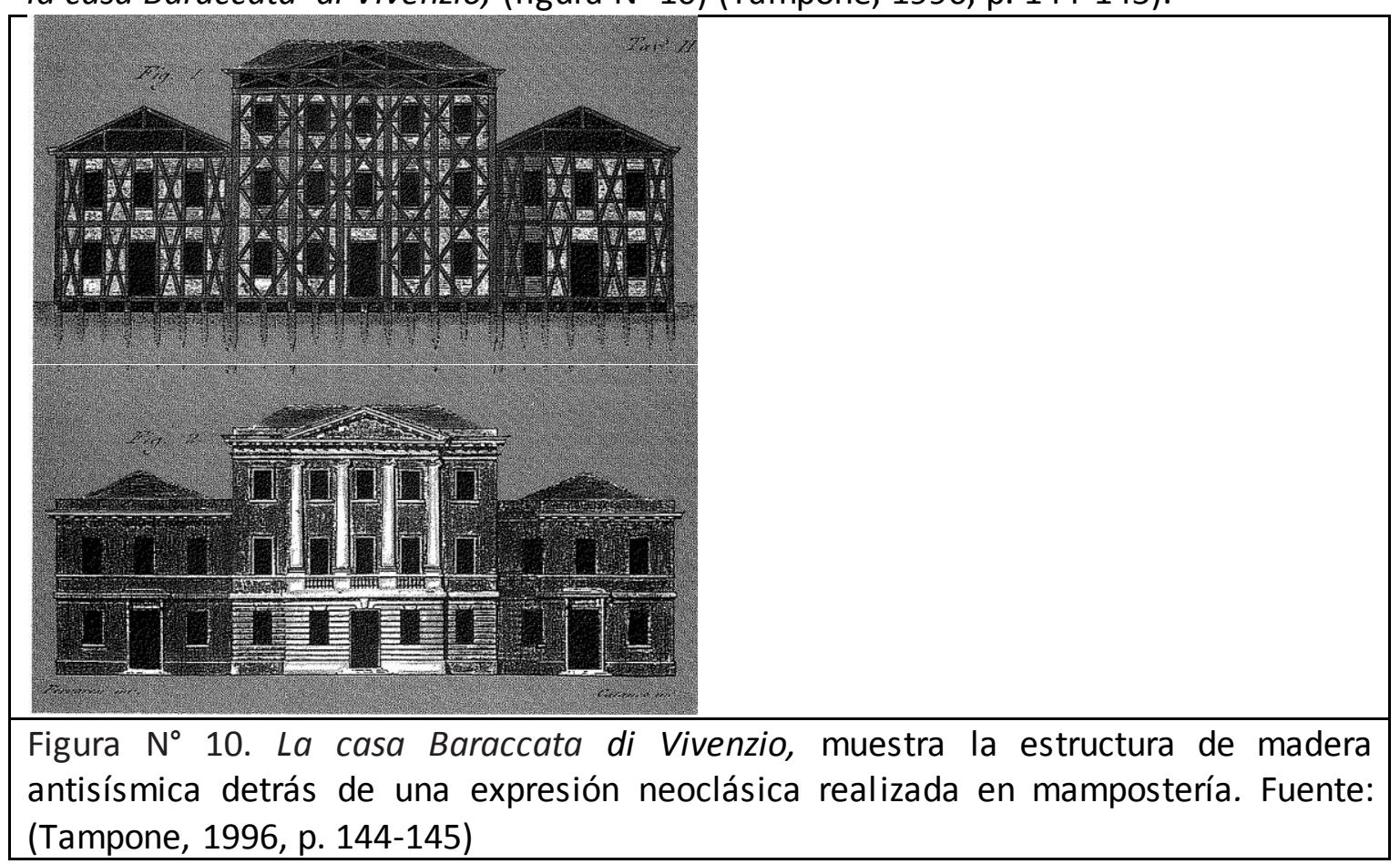

La arquitectura de Chiloé no será la excepción. Usará una técnica constructiva similar, dado el recurso natural que dispone por doquier que es la madera, sumado a los riesgos permanentes de incendios y terremotos. De hecho los misioneros franciscanos llegaron a Chile poco después de un gran sismo y pensaron que el fin del mundo estaba cercano. Si no introdujeron ellos este modo de construir, es razonable pensar en una convergencia cultural ya que a problemas específicos el razonamiento humano da soluciones similares. 
De esta manera la madera se enmascarará de otro lenguaje al habitual, es el caso de la expresión en los pilares de la fachada que ya no será tan elemental, como fue durante jesuitas y franciscanos de Ocopa, sino que se ejecutará a modo de columnas pertenecientes a un orden clásico, en este caso el dórico, modalidad que se multiplicará en toda la zona. Por lo tanto hay una exigencia técnica mayor y deberán revestir el pilar central con tablas dispuestas en forma vertical finamente pretrazadas y con plantillas previamente realizadas, para posteriormente ser ajustadas a su posición curva, que a veces incluía éntasis, y con una suerte de mezcla llamada estopa ${ }^{103}$, de aserrín y cola carpintera, usada en mueblería y en embarcaciones, para dar un contacto y superficie homogénea entre tablas. Asimismo se usa papel mural, simulando mármol o sencillamente se pintan las columnas imitado las vetas de este tipo de piedra, situación que todavía puede verse a simple vista en Chelín o Nercón, y ya tapadas con otras pinturas como en Chonchi o Dalcahue. Esta antigua técnica de aparentar un material algo que no es, viene ocupada desde tiempos de los Romanos y se denomina far finta ${ }^{104}$.

Para efectos del templo franciscano de Castro, esta técnica de far finta será ampliamente usada como el modo de atenuar el efecto de la madera para expresar otra realidad o materialidad en consonancia con el neoclásico. Ésta quizás sea una de las mayores características y virtudes de esta arquitectura chilota en madera, la de reinterpretar y asumir otras cualidades.

\subsubsection{Análisis arquitectónico de la Iglesia.}

Primero, el edificio dispone de la torre fachada con pórtico, las 3 naves y bóveda de cañón, toda de madera, cumpliendo las características esenciales de la arquitectura tradicional religiosa de Chiloé, sumado a ello el repertorio estilístico a imagen del neoclásico.

La fachada está absolutamente reglada, compuesta por una torre centrada mayor, sobre pórtico con cornisamento y hastial o frontón, en los flancos dos torres menores. Si se excluyen estas torres y sus bases, se ve la composición clásica de las capillas tradicionales, que aparentemente esconden un volumen menor a un agua, según se desprende de foto en escorzo de 1893.

Este modelo de la iglesia de Castro, iniciada en 1857, estaba lista dos años después, y fue bendecida y abierta al público el 3 de diciembre de 1865 . Ocho años después de su inauguración y quince años después del inicio de la construcción fue descrita por fray Manuel Cárcamo, quien fuera alumno de estos misioneros italianos en el Colegio de Castro, demostrando que hay un claro dominio del lenguaje de la arquitectura neoclásica. De estas descripciones podemos inferir la planta esquemática de la Iglesia, su espacialidad interior, así como la estructura constructiva de la fachada y geometría arquitectónica entre otras cualidades. El texto es como sigue:

\footnotetext{
${ }^{103}$ La estopa es un término usual en carpintería de ribera, lo que hace pensar en una constante migración de términos entre la carpintería de ribera y la de armar.

${ }^{104}$ Far finta es un término italiano que significa fingir, a parentar.
} 
La Iglesia está ubicada al oriente del primer cuadro que constituye los dos claustros principales en que está dividido el convento, y mide sesenta y seis metros con cuatro centímetros de largo, a los que se le agregan cuatro metros cuarenta centímetros de pórtico. Su anchura es de dieciocho metros veintidós centímetros. La altura del pavimento a la bodega es de once metros ochenta y cuatro centímetros y todo el interior del edificio está sostenido por veintiocho grandes columnas todas ellas de orden Dórico como lo es toda la Iglesia. El pórtico se apoya sobre 10 hermosas columnas con grandes bases de piedra graminea ${ }^{105}$. El Altar Mayor está colocado como unos cincuenta y cuatro metros más que menos distante de la puerta principal; es de tres cuerpos; los dos primeros son de orden Corintio, y el tercero que constituye la coronación es de orden Jónico, sostenido todo el por seis columnas de orden también Corintio.

La parte inversa del altar mayor, es decir la que mira al coro, los dos primeros cuerpos son de orden Jónico, y el tercero es Dórico.

Tanto la cornisa de adentro como la del pórtico o frontis es de orden Dórico denticular, siendo del mismo orden el coro, con solo la diferencia que está es modular.

La Iglesia es de tres naves, y de dos órdenes de asientos el coro. Los seis altares menores o colaterales son también de orden Dórico, y todos están sostenidos por cuatro columnas cada uno todas del mismo orden.

El púlpito es de orden Jónico y Dórica la baranda del presbítero, estando todo el interior de la iglesia como también los altares pintados al óleo. La sacristía está todavía inconclusa por falta de recursos pecuniarios para su total conclusión. Al lado poniente de la Iglesia, algunos metros distantes de la puerta, hay una entrada espaciosa que da vista a una hermosa capilla que sirve para las distribuciones ordinarias de la Venerable Orden Tercera de Penitencia.

Este edificio, aunque todo él es de madera, sin embargo, es el más sólido y bien construido en su género, tanto por la solidez de sus cimientos, como por la inmejorable calidad de sus maderas, que por consiguiente podrá durar por largos años si lo que Dios no permite jamás, otro incendio como el de 1857 no lo concluye y devora. (Cárcamo, 1873, p. 81-82)

Esta interesante descripción, junto con las fotos tomadas en 1893 por Jerman Wiederhold, permiten hacer una reconstrucción, aunque incompleta, del templo, por medio de la información que entrega fray Cárcamo acerca de las dimensiones del templo así como los estilos que señala que tenía edificio.

La iglesia medía sesenta y seis metros con cuatro centímetros a los que habría que agregar el portal de cuatro metros y cuarenta y cuatro centímetros, lo que equivale a ochenta y cuatro varas y un palmo en total y cinco varas y un cuarto para el portal. El ancho era de dieciocho metros y veintidós centímetros, es decir veintiuna varas y dos pies. Al comparar ambas dimensiones están aproximadamente en proporción

\footnotetext{
${ }^{105}$ Seguramente se refiere a la piedra granítica, propia dela zona.
} 
cuádruple (1/4) o bisdiapasón. A su vez entre el acceso y el altar mayor habían cincuenta y cuatro metros, que es igual a sesenta y cuatro varas y un codo, comparada con el ancho está en proporción triple (1/3) o diapasón diapente.

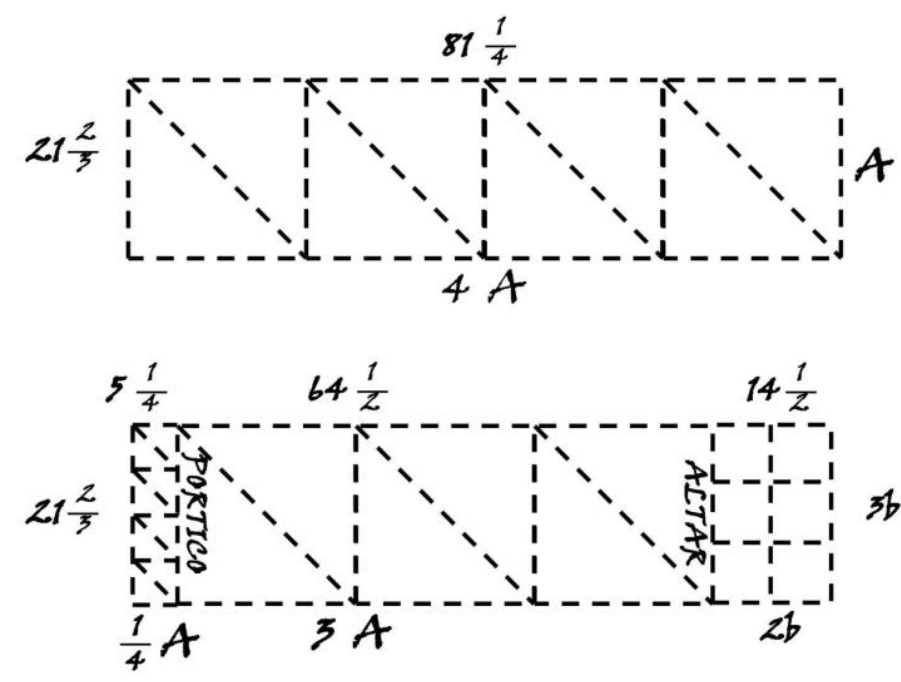

RSOURMA PROPORCIONAL DRL TKMPIO DE SAN FRANCISCO DE CASTRO CONSTRUIDO ENTRE 1857 Y 1864

Figura $\mathrm{N}^{\circ} 10$. Esquema proporcional del templo franciscano de Castro construido entre 1857 y 1864.

El cuatro representa lo terrenal (los cuatro elementos: aire, agua, tierra y fuego), mientras el tres se asocia a lo divino, (La Santísima Trinidad). De esta manera el edificio es entendido como lugar donde se une lo terreno con lo divino, como el cuerpo humano. Esta idea de asociar el templo o el edificio con el cuerpo es un tema apasionante que ha ocupado a la teoría de la arquitectura desde Vitruvio, y que encuentra en los esquemas proporcionales una de sus interpretaciones.

Además, pareciera ser que el ancho del templo no fue elegido por casualidad ya que veintiuno es el producto de tres por siete, el numero tres simboliza a Dios como ser total y único, y el siete representa la perfección de la conjunción entre lo divino y lo terreno por medio de los siete sacramentos y los sietes dones.

Otra dimensión que entrega Fray Manuel Cárcamo es la que había entre el pavimento y la bodega, sin especificar a qué recinto se refiere la dicha bodega, la que mide en once metros y ochenta y cuatro centímetros, lo que equivale a catorce varas y una sexma (medio pie). Puede tratarse de algún recinto en la torre del campanario, sobre el coro, que seguramente había sobre el pórtico de acceso, como sucede generalmente en las iglesias de Chiloé, ya que la dimensión es superior al de la cumbrera, estimada de acuerdo a la fotografía de Wiederhold, en aproximadamente once varas, es decir en nueve metros y veinte centímetros. Esta dimensión anotada por Fray Manuel Cárcamo comparada con el ancho del templo, está en proporción de dos tercios (2/3), sesquiáltera o diapente. 
Finalmente, en cuanto a las dimensiones, señala que el interior tiene veintiocho columnas y tres naves, lo que significa que están distribuidas en dos filas de catorce cada una. Suponiendo que el coro detrás del altar estaba flanqueado por dos piezas que correspondían a la sacristía y contra sacristía, propias de la planta tradicional de la iglesia de la escuela chilota, se pude pensar que las columnas se distribuían en la distancia entre el acceso y el altar, es decir en sesenta y cuatro varas y un codo, lo que significa que la distancia interaxial entre las columnas es de cuatro varas y un pie.

En cuanto al estilo, Fray Cárcamo indica que era el dórico "denticular" para las columnas del pórtico y para la cornisa, que al ver la fotografía se refiere al entablamento compuesto de arquitrabe, friso y cornisa. A su vez la definición del estilo como "denticular" es una tautología, ya que el estilo dórico incluye los dentículos, también llamados gotas, que se colocaban sobre y bajo el triglifo y sobre las metopas, en cantidad de siete. Esta definición deja en claro la influencia neoclásica que recibió el edificio, seguramente debido al deseo de Fray Diego Chuffa que fue el franciscano a cargo de la construcción. Estilo que estaba en pleno auge en Europa en el momento del traslado de los frailes a Chile.

Lo anterior se corrobora al mirar con detención la fachada. Las lesenas son de un sólido estilo dórico, que soporta el entablamento. En este, el friso sigue un riguroso orden de metopas y triglifos, que distingue el estilo dórico de los otros órdenes clásicos. A su vez las columnas centrales son pareadas con un machón con una cornisa a la altura de la imposta del arco, el que es ojival en entre las columnas pareadas y de medio punto en el arco central y los laterales.

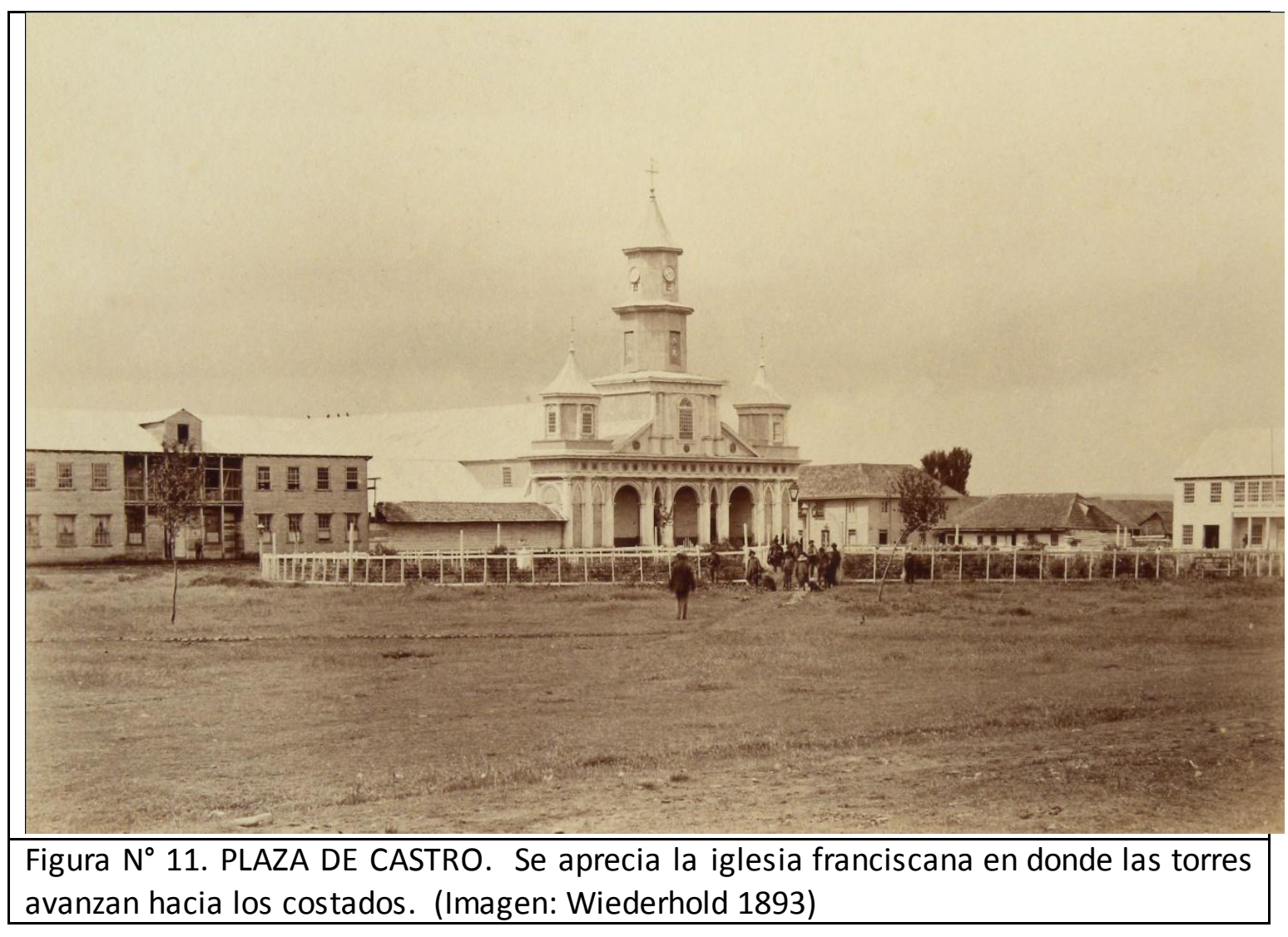


Curioso resulta destacar el hecho que frente a la claridad de ciertas definiciones, en otras resultan confusas, como sucede por ejemplo al denominar columnas a las pilastras y lesenas exteriores e identificar el entablamento con la cornisa. Esta confusión, debido seguramente a la falta de experiencia de Fray Manuel Cárcamo, está también presente en la definición estilística de los altares, que si hubiesen sobrevivido, serían piezas únicas de arte. En efecto señala el franciscano, que el altar mayor tiene tres cuerpos con los dos primeros de orden corintio, el superior de orden jónico. Así mismo señala que la parte de atrás del altar, la que mira el coro también tiene tres niveles, los dos primeros son de orden jónico y orden dórico el superior. En este aspecto, el cánon establecía que los órdenes, tal como estaba presente en el coliseo romano, se sobreponían principiando por los más robustos abajo y los mas gráciles arriba, de esta manera sobre el dórico, se sobreponía el jónico y sobre este el corintio. En el acceso del altar de la iglesia los órdenes están invertidos, es decir los dos de abajo corresponden a un orden más grácil que el que sostienen, como es la superposición del orden jónico sobre el corintio y el del orden dórico sobre el jónico. "Esta libertad artística" es el principal elemento que le otorga al altar un alto valor, cuya desaparición producto del incendio que consumió la iglesia el año 1902, impiden valorarlo adecuadamente.

A partir de las fotografías de Jerman Wiederhold, es posible definir la geometría que organiza la fachada. La primera de ellas permite establecer que en apariencia, las torres laterales fueron construidas con posterioridad, ya que se aprecia que avanzan hacia los lados del volumen principal que cubre las dos aguas. Esto se confirma al ver la foto frontal en donde las cornisas tapareglas terminan en la cornisa del entablamento, justo donde arrancan las torres laterales; al prolongarlas termina bajo el arquitrabe, lo que indicaría que la nave lateral quedaría muy baja, casi a la altura del dintel de las puertas, lo que no sucede, ya que la canaleta de la cubierta inclinada se encuentra a la misma altura de la cornisa del entablamento.

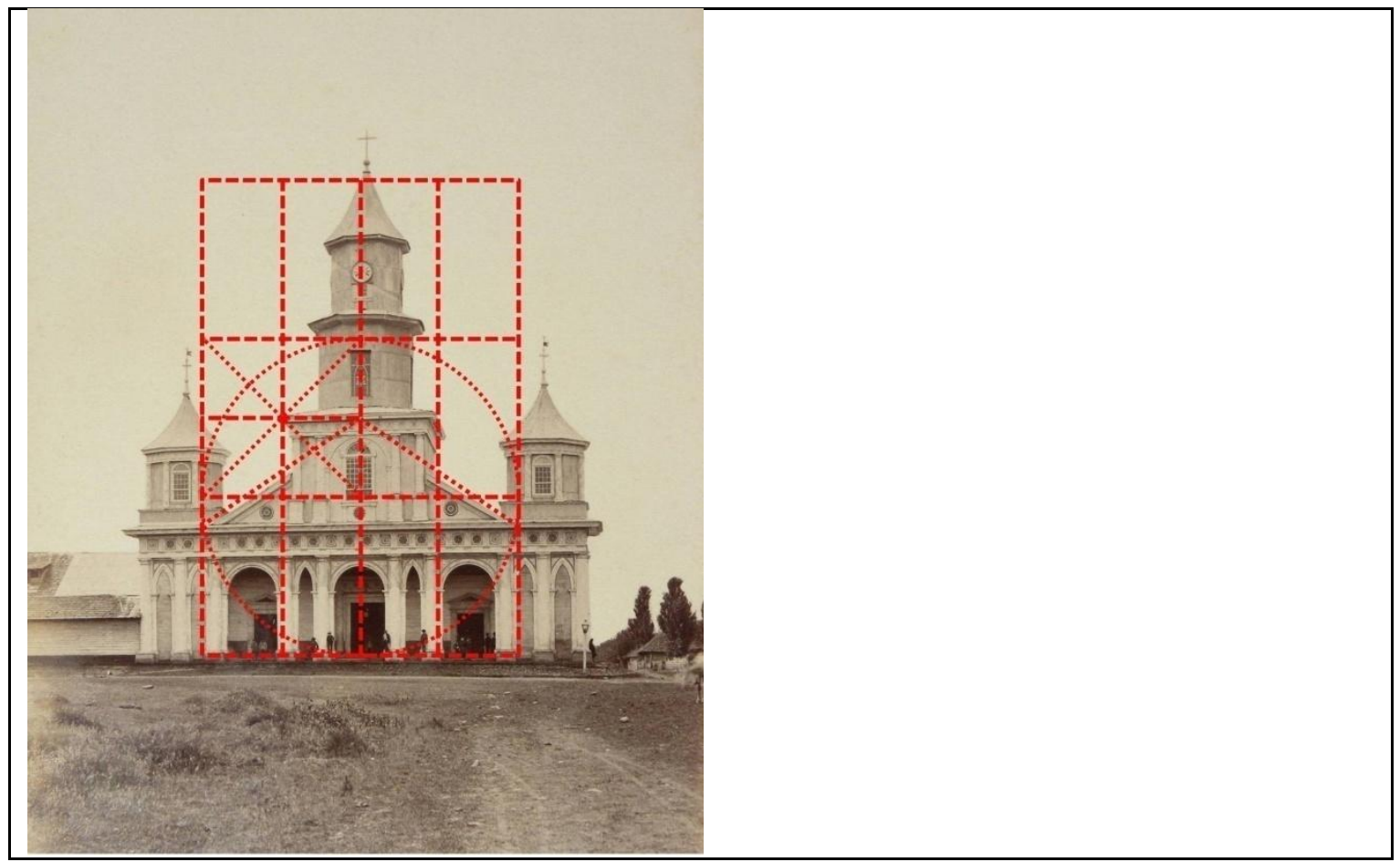




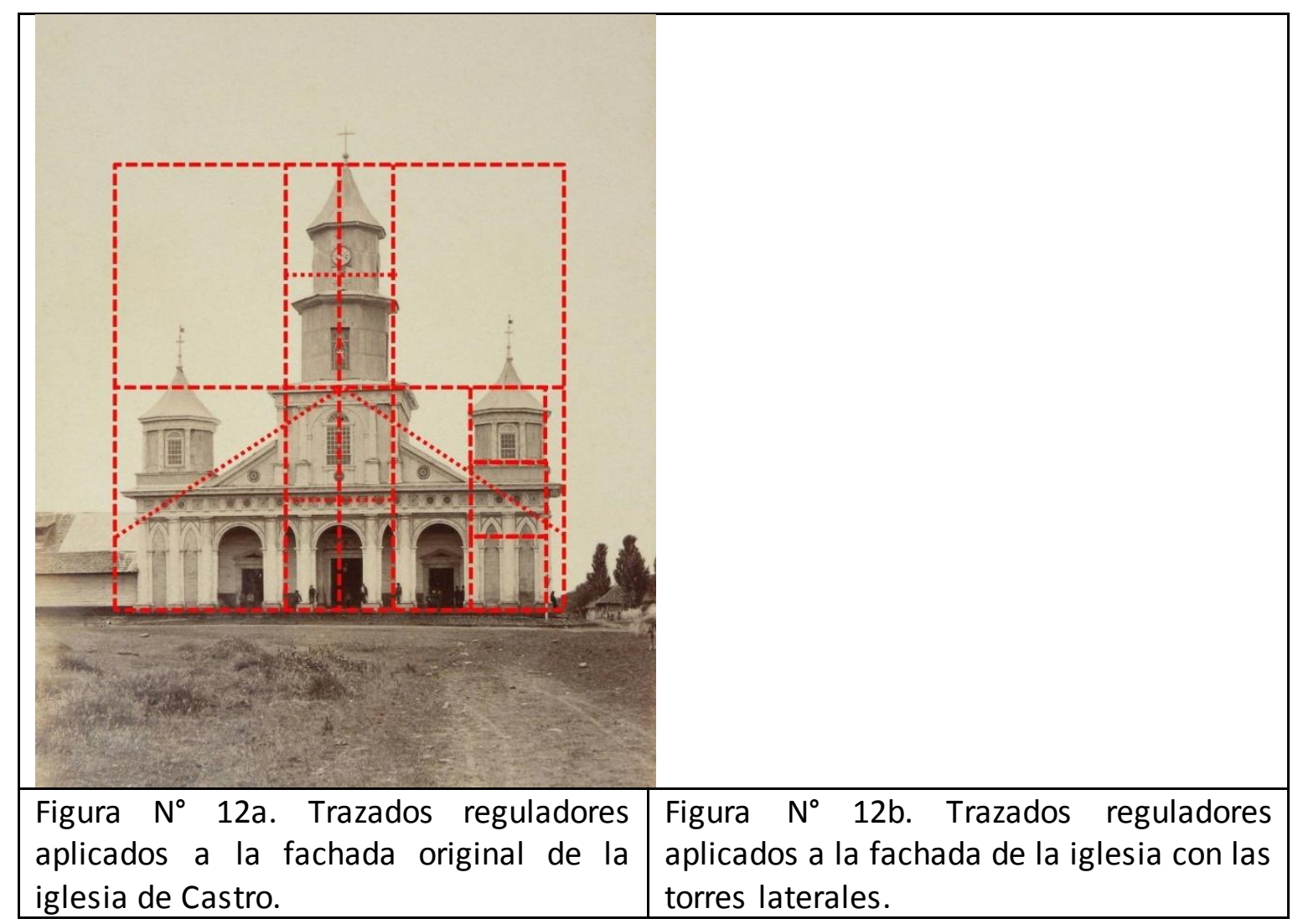

A partir de esta definición es posible establecer dos trazados reguladores.

El primero corresponde a la fachada original, tal y cual la construyó el revdo. Padre Fray Diego Chuffa, es decir sin las torres laterales. Este trazado está en proporción sesquiáltera, o sea de dos tercios (2/3) o diapente, la misma del área del coro de la iglesia y del área central de la fachada hasta la altura del dado. Además, si se considera la altura hasta el dado y se compara con el ancho, esta está en proporción sesquitercia, o sea de tres cuartos (3/4) o diatesarón. En este trazado la cumbrera del volumen de la iglesia se encuentra en la mitad de la altura tomada hasta la cúspide del chapitel.

Después de adicionada las torres laterales es posible destacar que la fachada queda incluida en un cuadrado, es decir la proporción unísona, cuyo centro se encuentra en la cumbrera, es decir, a la altura del dado de la torre. Interesante que esta proporción simboliza la unidad de la iglesia en torno a un solo Dios, lo que plantea la interrogante si este concepto tuvo que ver en la construcción de las torres laterales. Interesante destacar que después de la construcción de estas torres el pórtico quedó cerrado, es decir convertido en nártex.

También es posible visualizar algo muy propio de la época, como es la reinterpretación estilística, y sus mezclas que dan resultados un tanto ecléctico. Ya que el cuerpo base de la fachada, el pórtico y hastial, se inscriben claramente con el neoclásico, en cambio la torre central se acerca al neogótico, muy usado para los edificios religios os ya que acentúa la búsqueda de la verticalidad. Estas partes, el volumen horizontal y vertical provienen de dos tipos histórico-arquitectónicos muy distintos, como es el templo 
clásico griego- romano y la torre cristiana respectivamente, que en esta nueva tipología se superponen. Una conexión, que siempre será difícil resolver arquitectónicamente, por ende también estrcutural y constructivamente. En las capillas chilotas no será la excepción, y la conexión entre el hastial y la torre será un tema fundamental a resolver y marcarán una de las principales diferencias modelísticas entre ellas y que a cada una le darán parte de su identidad morfológica.

Respecto de la torre central, se puede observar en la imagen que es escalonada o telescópica, propia de la escuela chilota, siendo los dos tambores superiores octogonales y están simplemente forrados en fierro galvanizado y no tienen el tratamiento ornamental de las menores, exenta de pilastras y cornisas de madera. Seguramente no fue terminada por razones económicas y/o técnicas, por las dificultades que implica realizar tales trabajos de terminación desde el exterior a esa altura. Hay que considerar que se estima esta alcanzaba una altura cercana a los $30 \mathrm{~m}$, la que se puede deducir dado que conocemos el ancho de la nave. Esta altura inusitada en Chiloé representa un extraordinario logro técnico para la época.

Lo más probable es que el espacio interior de tres naves se haya inscrito dentro del ancho del pórtico, sin considerar las torres laterales, tal como lo representa el corte de la alternativa 1 (Figura $\mathrm{N}^{\circ} 13 \mathrm{a}$ ), y si bien hay una alternativa 2 (Figura $\mathrm{N}^{\circ} 13 \mathrm{~b}$ ), esta se descarta, porque las naves laterales habrían ocupado un ancho fuera del estado de proyecto y obra, que describe Fray Cárcamo. La alternativa 1 puede acoger perfectamente la solución clásica chilota, de nave central con cañón y naves laterales con cielo raso, que justifican las ventanas altas, que se visualizan en la foto de escorzo de 1893, para ingresar luz desde lo alto.

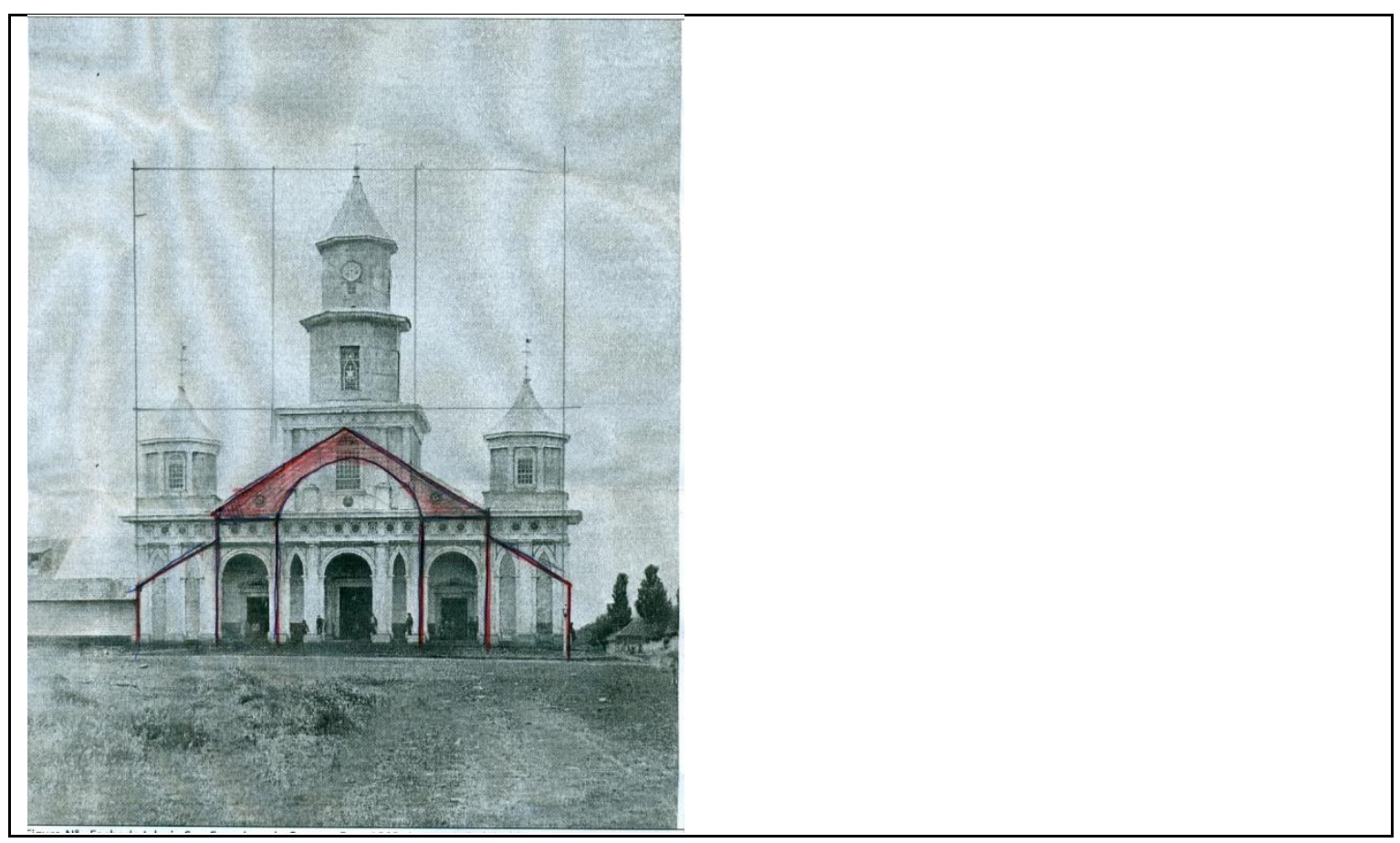




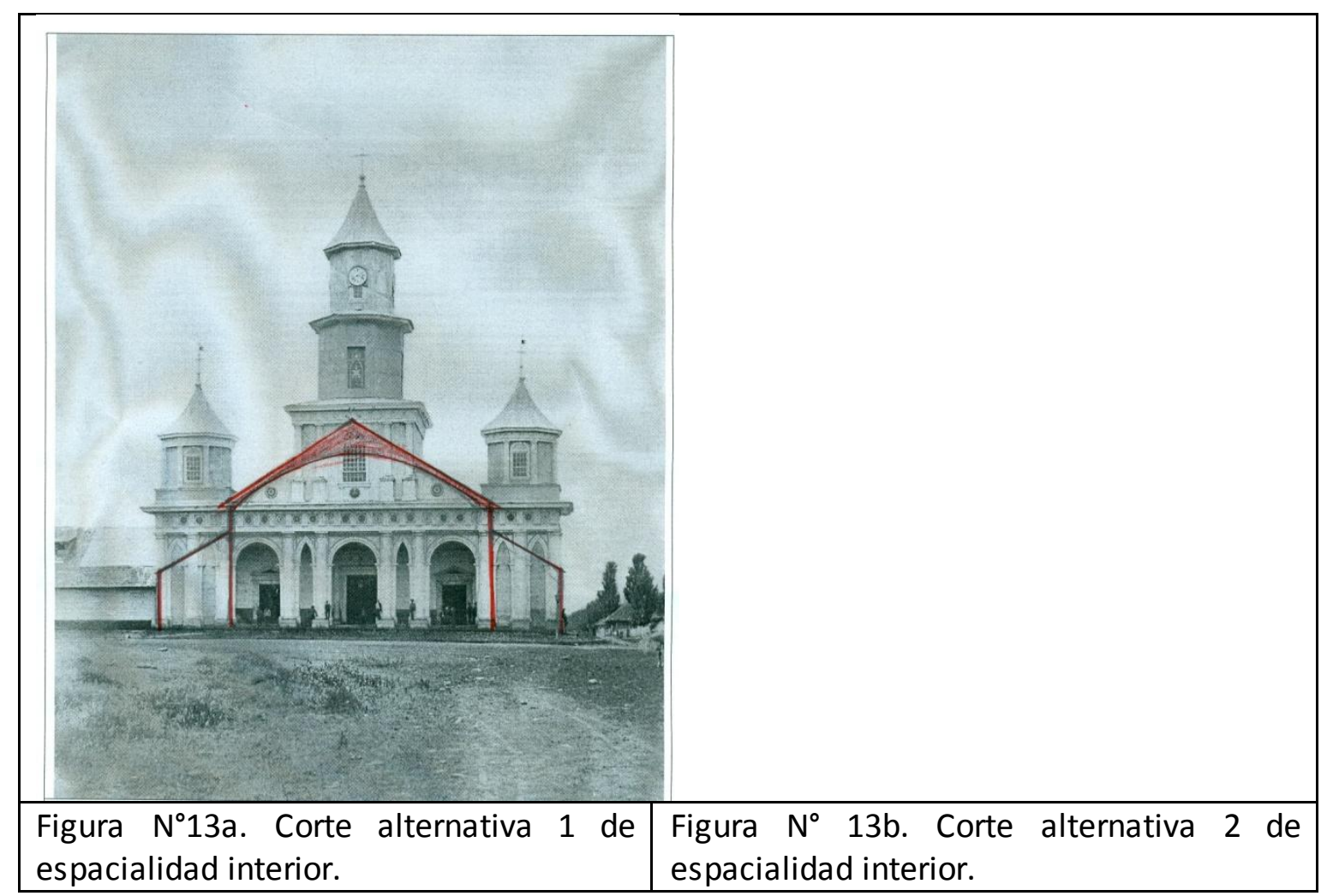

\subsubsection{Análisis del estilo dórico en la Iglesia.}

Según Fray Manuel Cárdenas "tanto la cornisa de adentro como la del pórtico o frontis es de orden dórico denticular", lo que se corrobora al observar la mentada foto de Wiederhold.

Tomando como base esta fotografía se comparará con el orden descrito por Palladio en "Los Cuatro Libros de la Arquitectura" ${ }^{106}$, haciendo la salvedad que la fotografía no permite ver todos y cada uno de las partes que componen el orden del edificio. Sin embargo, el carácter modular ${ }^{107}$ del orden arquitectónico, basado en las proporciones entre las partes facilita la comparación.

Palladio señala que "el modulo en este orden únicamente es de solo la mitad del diámetro de la columna", refiriéndose al diámetro tomado con la base de la columna. Como no es posible conocer la medida real debido a que el edificio sucumbió a un incendio, basta tomar la dimensión con un compás y transportarla a una regla para usarla como base de comparación.

El estilo arquitectónico se compone de pedestal, columna y entablamento. A su vez el pedestal se compone de base, dado y cornisa, la columna se divide en base, fuste y capitel, y el entablamento en arquitrabe, friso y cornisa.

\footnotetext{
${ }^{106}$ Se ha usado para esta comparación lo indicado en Palladio, Andrea. 2005. Los cuatro libros de la arquitectura. Traducción al español por Arq. Carlos Pérez Infante de la versión en inglés de Isaac Ware (1738). Limusa Noriega Editores. México D.F. Pág. 334. Pp. 44 a 49

107 El modulo se refiere a la mitad basal dela columna, en este caso son más pilastras y lesenas, es decir que son elementos decorativos, no estructurales.
} 
Palladio señala que "en los edificios antiguos de este orden no se observa pedestal, aunque si existe en los modernos". En el caso de la iglesia de Castro las lesenas tienen un pequeño pedestal de dos módulos y dos tercios de altura que dibuja Palladio en su tratado.

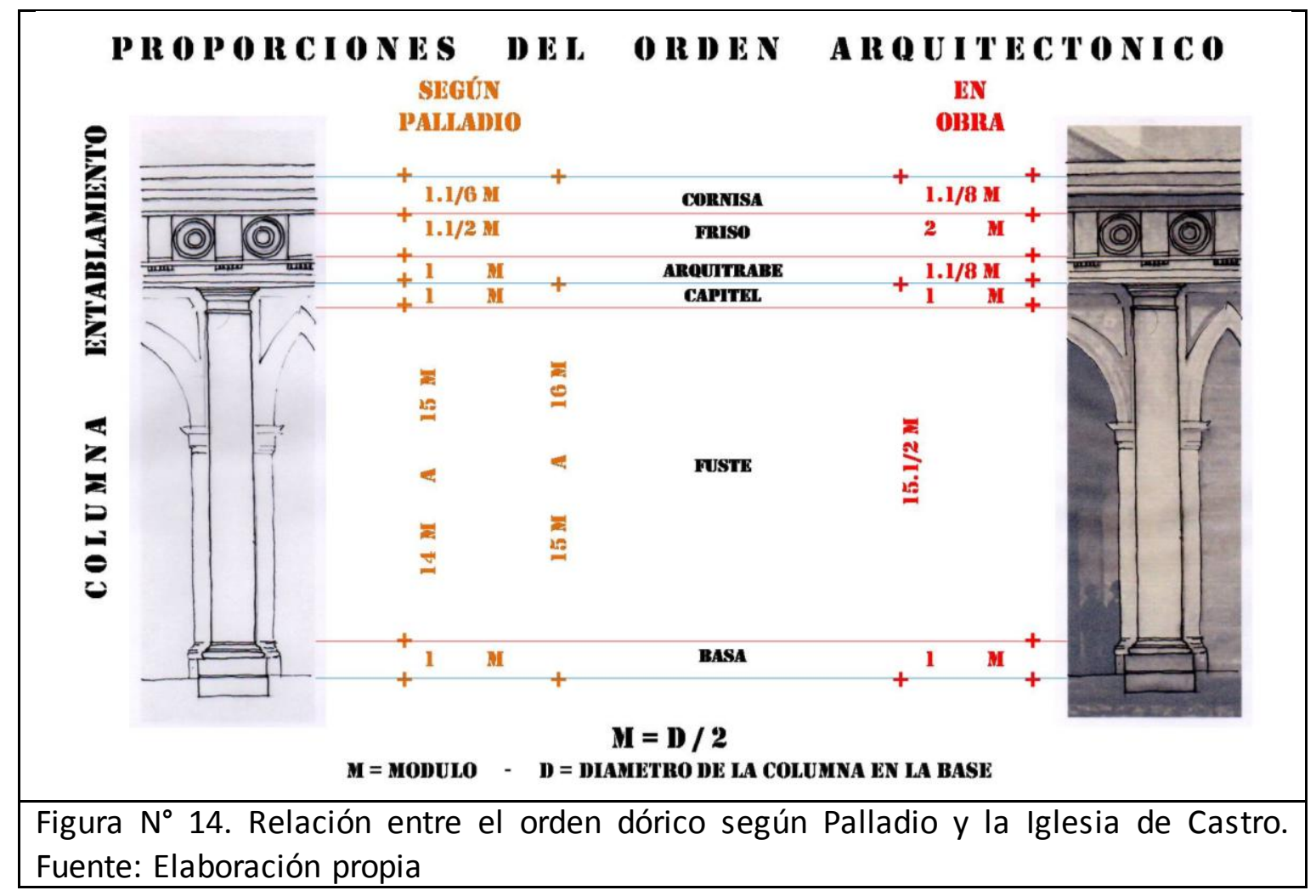

Para la columna señala que "este orden no tiene base propia ... pero algunas veces se le adosa la base ática", cuya altura será de un módulo o la mitad del diámetro, lo que aproximadamente corresponde con la base de la lesena construida en Castro, ya que esta es aproximadamente un octavo más baja. En cuanto a la composición se trata de una base simplificada ya que elimina el plinto, el caveto y el toro superior, dejando el toro inferior apoyado directamente sobre el pedestal y sobre un listel, una gola inversa y la cimbia o filete que conecta la base con el fuste, lo que resulta más parecida a la base del estilo toscano.

Sobre la base de la columna se coloca el fuste y sobre ésta el capitel que se compone del astrágalo, el que se une a la parte superior del fuste, y a él se sobreponen el collarín, los anilletes o graditas, el óvalo, el ábaco y el cimacio, el que debe medir según Palladio un módulo, la misma medida comparada de la obra franciscana de Castro.

La columna que en el caso del orden dórico solo se compone de fuste y capitel "debe tener siete diámetros y medio u ocho de altura", es decir entre quince y dieciséis módulos. La columna de la iglesia de Castro, incluyendo el fuste y el capitel tiene quince módulos y medio. Cabe destacar que la columna carece de estrías, es decir que 
es lisa, como en el orden toscano, pero este es menos esbelto que el dórico, al cual se ajustan las proporciones del orden de la fachada de la iglesia de Castro ${ }^{108}$.

El arquitrabe es un octavo de módulo más alto que lo señalado por el tratadista del renacimiento. A su vez el friso es medio módulo más alto y la cornisa es un veinticincoavo más alto.

A pesar de estas diferencias, se aprecia claramente las metopas cuadradas, reforzadas con un diseño de círculos concéntricos, así como los triglifos con su capitel superior y las gotas, en número de seis bajo la tenia, elementos propios y característicos del friso dórico.

Todo lo anterior significa que los frailes estaban en conocimiento de las obras clásicas $^{109}$, o que por lo menos hubiesen tenido, como se ha señalado, planos con las indicaciones necesarias para ejecutar la obra con, por lo menos, la precisión que se ha señalado.

\subsection{El caso de Osorno, la escuela franciscana italiana se impone.}

En este punto resulta interesante analizar, aunque brevemente, la obra realizada por la orden de los Franciscanos Menores en Osorno.

El Convento Franciscano de Osorno, llamado de la Inmaculada Concepción, es un caso más allá de las fronteras de Chiloé y fuera del ámbito territorial de este estudio, pero que sirve para utilizar comparativamente y demostrar cómo los franciscanos a través de la misión van gestando una realización cultural arquitectónica similar a la llevada en el archipiélago.

Luego de la creación del Colegio de Castro, a cargo de franciscanos italianos, el padre Diego Chuffa resolvió fundar un colegio en la ciudad de Osorno, emplazado en el continente en zona de frontera mapuche, a unos $150 \mathrm{~km}$ del archipiélago por el antiguo Camino Real . Por tal motivo recurrió a la Municipalidad, la que en sesión el 22 de abril de 1844 aceptó la fundación y en sesión del 6 de mayo se resolvió entregar el terreno, que coincide con el lugar que tuvo el convento franciscano en el siglo XVI.

Con el apoyo de las autoridades y del pueblo de Osorno, pronto se instaló la primera comunidad, compuesta por los Padres Diego Chuffa, Hilario Misquiante y Apolinario Guardini. Se construyeron los edificios, que desde 1854 a 1879 albergó también al Seminario del Colegio de Castro. Durante ese tiempo fueron ordenados aquí 31 sacerdotes, la mayoría originarios de Chiloé.

\footnotetext{
108 De hecho, la columna toscana mide siete módulos, incluyendo la base, el fuste y el capitel.

109 En este caso se usó el tratado de Palladio como elemento de comparación, lo que no significa quelos franciscanos hayan usado este tratado.
} 


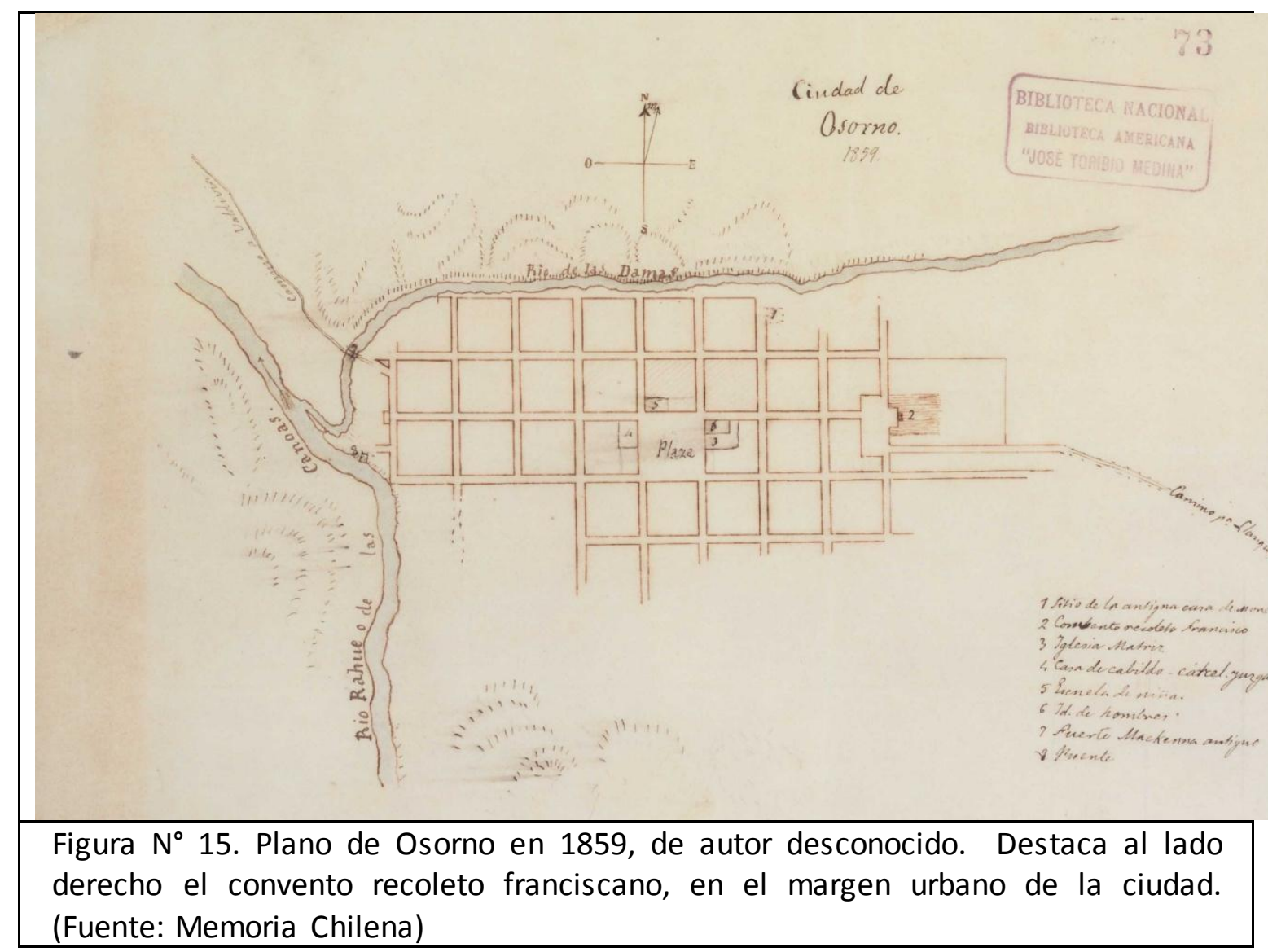

Durante varias décadas los Padres del convento franciscano debieron atender a los vecinos de Osorno por ausencia del párroco de la ciudad, colaborando con éstos en la atención del sector rural, como ocurrirá en el sector de Remehue, donde levantan la capilla dedicada a la Virgen de la Candelaria (Pape, 2008, p. 76).

Terminado de construir el año 1848, el conjunto urbano y arquitectónico sucumbió en un trágico incendio en el año 1896, por lo que no se han podido encontrar mayores antecedentes de las edificaciones, salvo una foto que en 1893 tomó Jerman Wiedehold de calle Letelier, en donde la perspectiva de la calle remata en la iglesia franciscana apenas perceptible por la bruma, la que presenta los elementos que caracterizan las iglesias de la escuela chilota, como son el volumen a dos aguas acusado en la fachada, el pórtico en el acceso y la torre sobre éste, composición denominada "torre fachada".

Si bien es cierto que en esta imagen no se ve la totalidad del frontis, por lo que no se aprecia como rematan los faldones de la cubierta en el pórtico, así como la bruma no deja ver la definición de la torre, es posible describir dos importantes elementos que componen la fachada. 


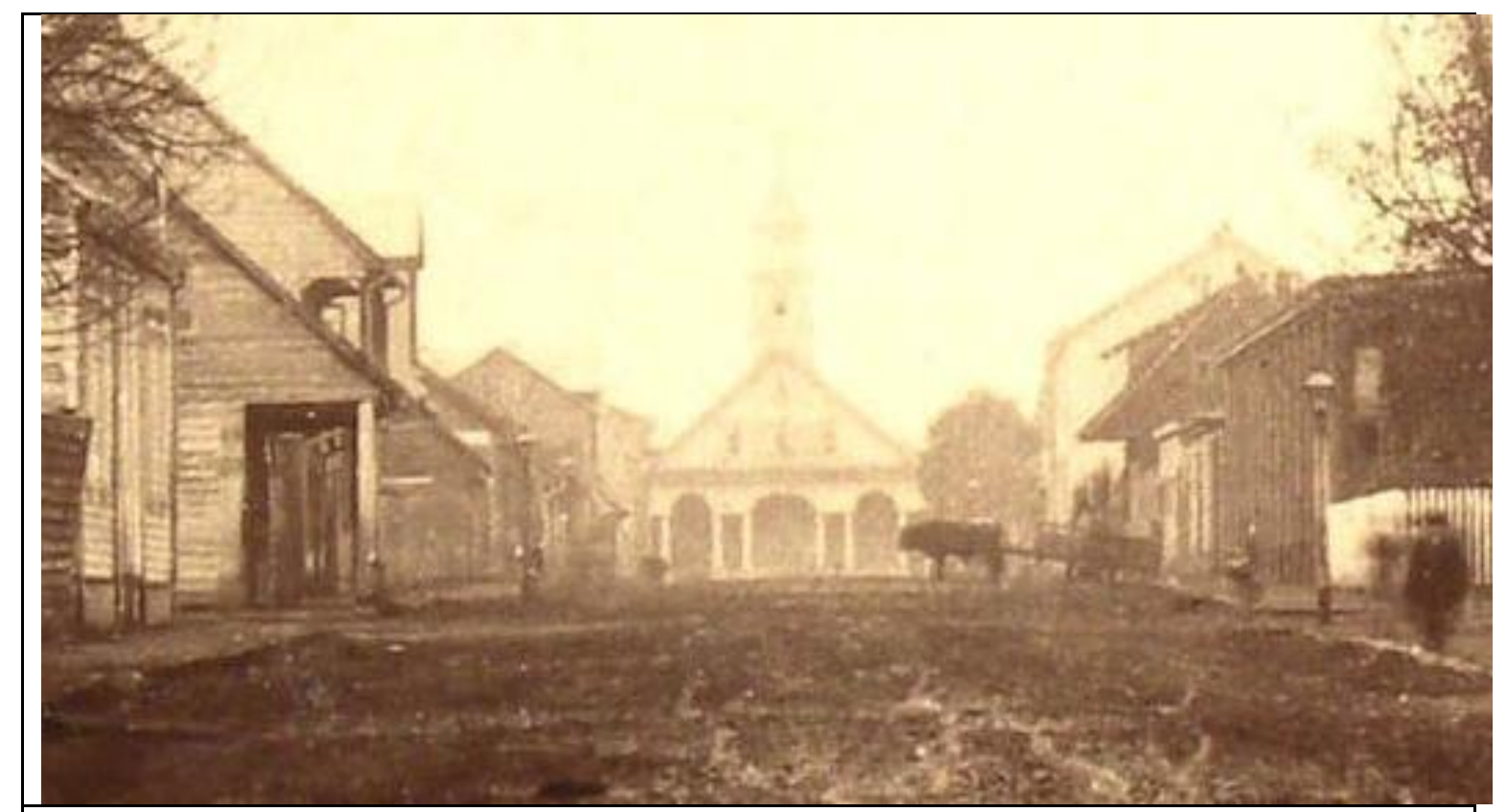

Figura $\mathrm{N}^{\circ} 16$. Segmento de la fotografía de Calle Letelier, en donde se aprecia la iglesia franciscana de Osorno construida en 1844. (Foto: Jerman Wiederhold 1893).

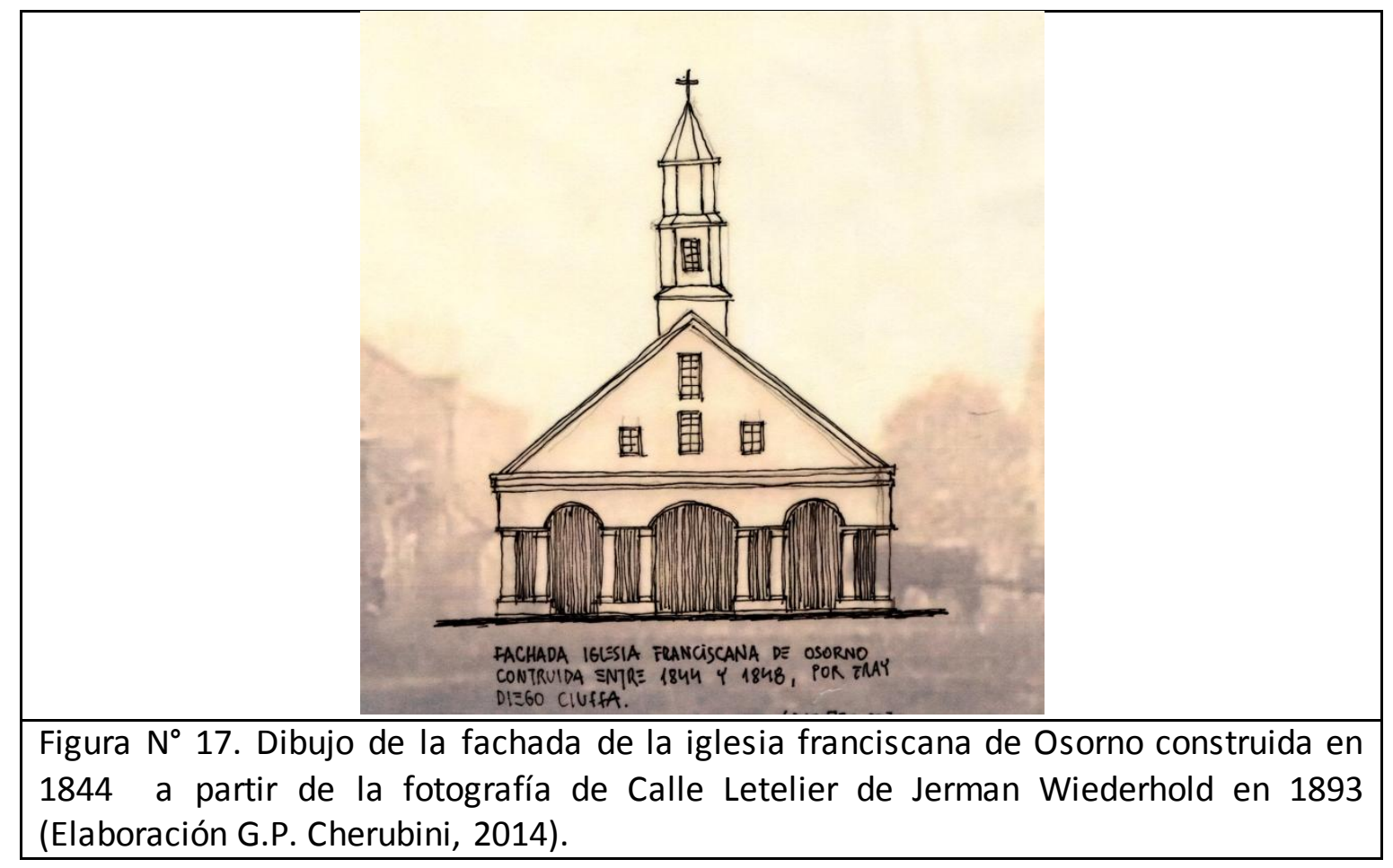

El primer elemento que destaca, es el pórtico compuesto por cuatro pares de columnas, separadas por un vano y unidas por un arquitrabe sobre el ábaco del capitel, entre los cuales se ven tres arcos, que son de medio punto, los laterales y rebajado el central. Salvo por el arco rebajado, este detalle del pórtico es semejante al que usó Andrea Palladio en el siglo XVI en la reestructuración de la Basílica de Vicenza ${ }^{110}$ para corregir las distancias desiguales entre los muros interiores, por medio

110 La Basílica Palladiana fue construida en el siglo XV como Palazzo della Ragione, es decir sede del gobierno y de los tribunales, por lo tanto ubicada en la Piazza dei Signori. Cuando una parte del 
de un elemento unitario que era el arco de medio punto flanqueado por columnas paradas, conocido como "ventana palladiana".

\begin{tabular}{|l|l|} 
Figura $\mathrm{N}^{\circ}$ 18. La ventana palladiana se \\
caracteriza por que a ambos lados del \\
arco de medio punto se colocan dos \\
vanos flanqueados por dos columnas o \\
una columna y un muro, de manera que \\
la pequeña variación entre los \\
distanciamientos de un muro no es \\
perceptible a simple vista. Este recurso \\
fue ampliamente usado por los \\
arquitectos neoclásicos. (Imagen \\
gentileza del arquitecto Gian Piero \\
Cherubini)
\end{tabular}

Sobre este pórtico una ancha cornisa lo unifica y recibe los faldones de la cubierta, conformando el tímpano que aloja cuatro ventanas, dos de ellas sobrepuestas sobre el eje de simetría de la fachada y otras dos, una a cada lado sobre el vano entre las columnas pareadas, lo que otorga un carácter marcadamente neoclásico a la fachada. A su vez, sobre el tímpano, un pequeño dado da principio a una elegante torre de dos cañas coronada con un chapitel sobre el que se ubica la cruz.

Esta breve descripción permite aseverar que esta iglesia es de importancia basilar para este estudio. Esta afirmación se fundamenta en el hecho que tanto la de Castro, construida en 1857, que fue la que irradió como modelo al resto de las localidades de Chiloé, así como esta de Osorno, fueron construidas por los frailes de la congregación franciscana, con trece años de diferencia, y en ambas construcciones le cupo una importante función a fray Diego Chuffa.

Esto permite asegurar que la iglesia de Osorno es un precedente formal de la escuela chilota de iglesias de madera, que tiene su origen en la acción evangelizadora de los frailes franciscanos italianos, que se instalaron en 1837 en Castro.

\section{EVOLUCIÓN HISTÓRICA ARQUITECTÓNICA DE LA IGLESIA DE OSORNO EN EL SIGLO XIX.}

PRIMERO. En la refundación de Osorno en 1795, se instala una primera capilla.

Esta queda terminada casi en 1800 , no hay antecedentes gráficos de ella y solo fuente escrita. "Enaltece el espíritu religioso de los nuevos pobladores el hecho de que 4 años más tarde ya existía una iglesia de 30 por 12 varas forrada de madera blanca con papel pintado en el presbiterio..., poseía una casa parroquial que al mismo tiempo servía de

edificio se vino abajo, el consejo de la ciudad resolvió solicitar la reconstrucción al arquitecto Andrea Palladio, quien añadió una nueva estructura exterior de mármol, que contenía una logia y un pórtico, con los que aprovechó de regularizar estéticamente las diferentes de distanciamiento entre los muros del edificio, siendo el primer ejemplo de la llamada ventana palladiana. 
escuela."(Pape, 2008, p. 94).

SEGUNDO. La siguiente capilla de reemplazo tiene también una breve existencia entre 1807- 1837. Este templo de acuerdo a antecedentes gráficos y escritos, estaba compuesta por un volumen principal, nave o naves, con muros de piedra de cancagua y cubierta a dos aguas de madera, con ábside adosado y dos torreones o campanarios de madera adosados a cada extremo de la fachada.

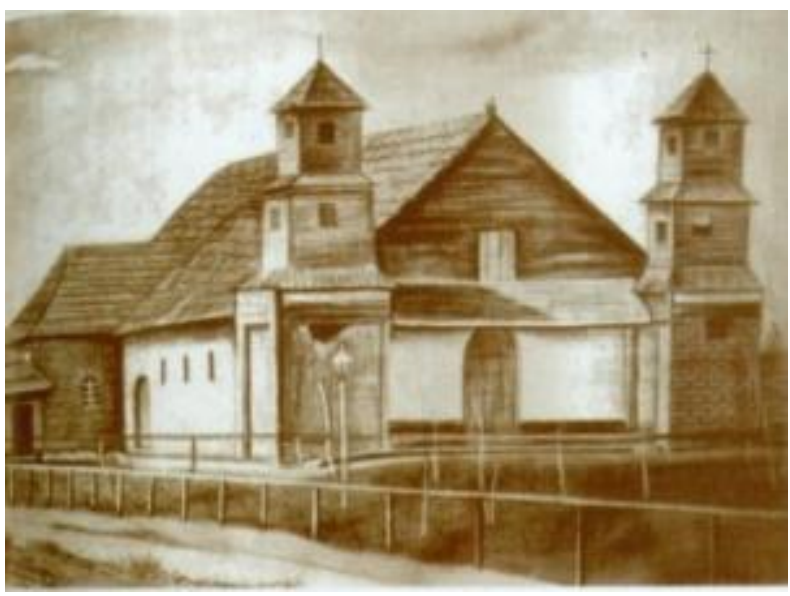

“El 7 de noviembre de 1837, un violento terremoto arruinó casi por completo la iglesia parroquial. Este templo de cancagua, inaugurado en 1807, había sucedido al primero, de madera, construido en 1797, en la actual calle Martínez de Rozas. A causa del terremoto se derrumbó una parte de las torres y el frontispicio se llevó consigo una parte del techo. Toda la iglesia quedó agrietada" (Pape, 2008, p. 95).

El terremoto de 1807 derrumbó el frontis y la iglesia se agrietó, sin embargo la dibujó Rodulfo A. Philippi en 1852, lo que significa que el frontis no era el que la iglesia tenía antes del terremoto.

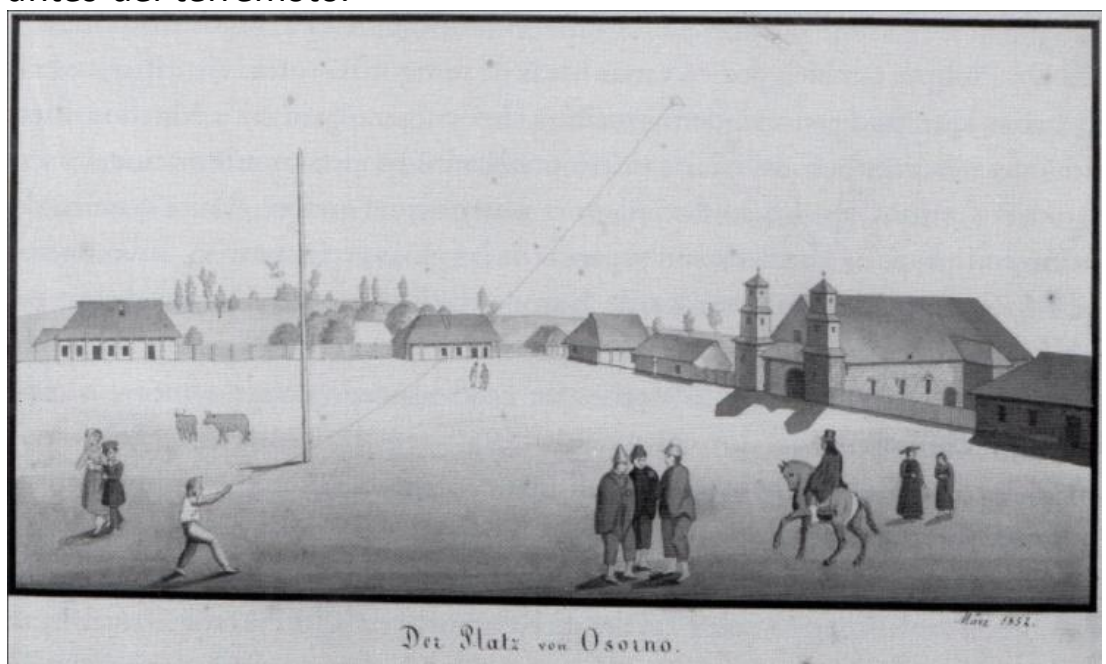

Platz von Osorno. Rodulfo A. Philippi. 1852. Se aprecia la iglesia inaugurada, según Pape, en 1807.

\section{Tercero. Posteriormente se suceden dos capillas de interés.}

Una, levantada por los misioneros franciscanos a cargo de Diego Chuffa, que inician a su llegada a Osorno en 1844, en el sitio actual que disponen en el remate oriente de calle Ramírez, antigua calle Letelier. Esta capilla se levanta con el convento como las edificaciones principales requeridas para el nuevo Colegio de Osorno, que tomó el 


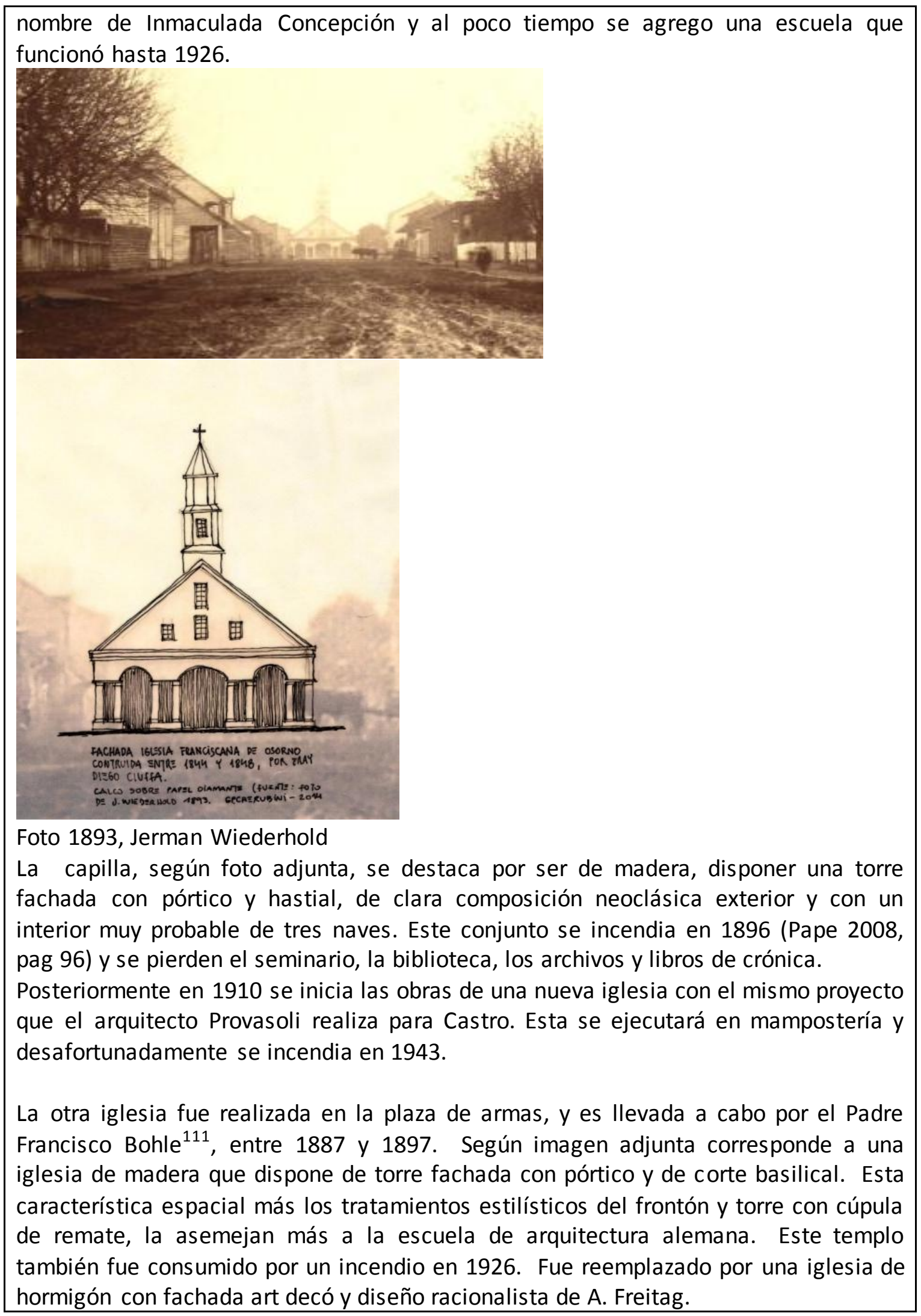

111 Este sacerdote es el mismo que realiza los planos de la capilla de Curaco de Vélez en 1901, que corresponde a la Iglesia tradicional chilota. 


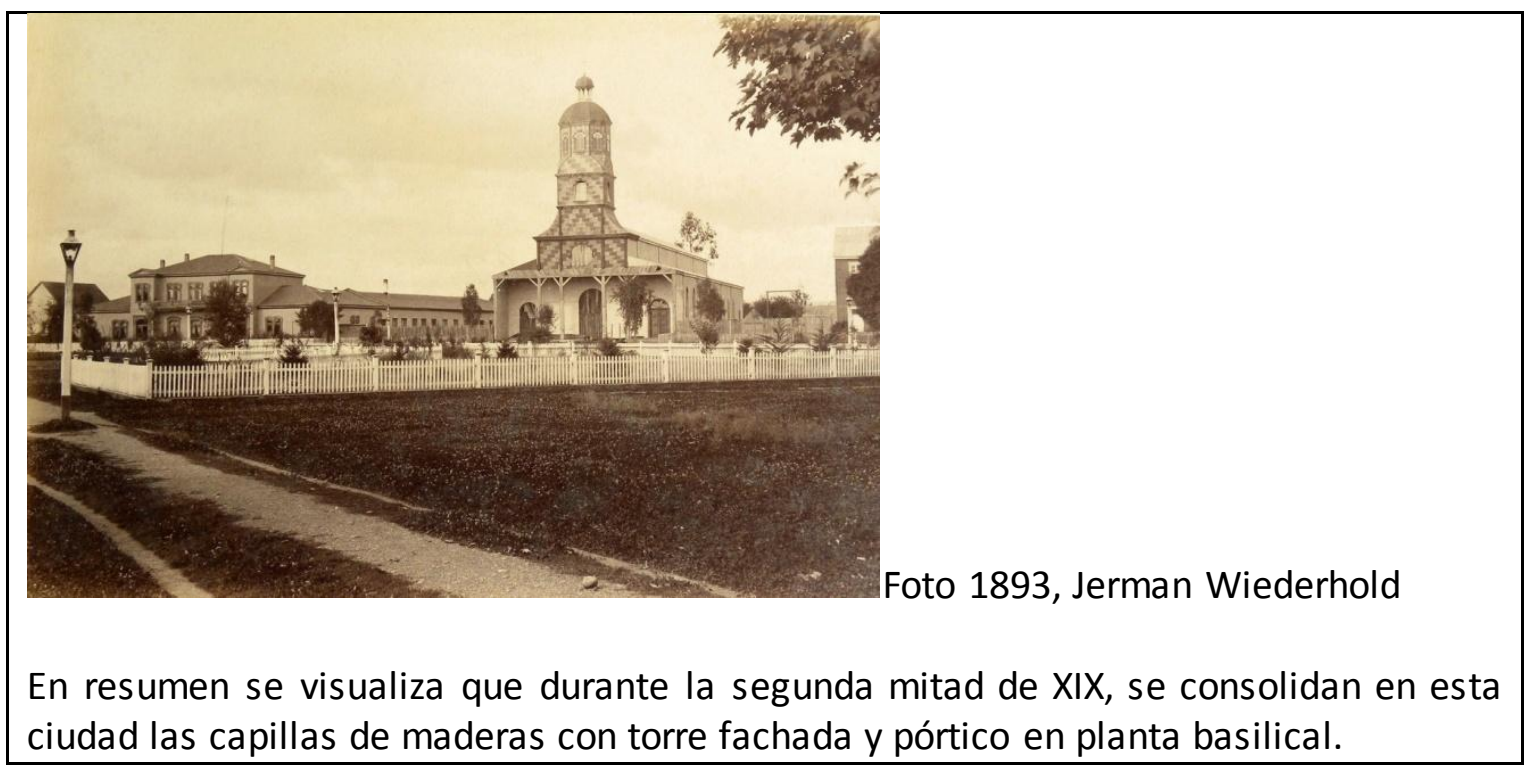

Por último y para ahondar más en los seguimientos realizados al interior de la Araucanía y de las misiones iniciadas por los franciscanos italianos desde el Colegio de Castro, se puede verificar con las realizaciones en el Departamento de La Unión, al sur de Valdivia, en que la capilla tendrá una evolución tipológica y composicional similar a Chiloé y Osorno. Es el caso de la misión de Daglipulli o Quinchilca entre otras. De acuerdo a los dibujos de Philippi y Gay (Figuras $N^{\circ} 18 \mathrm{a}$ y $18 \mathrm{~b}$ ), muy coincidentes entre ellos, la capilla de Daglipulli tiene una torre escalonada, o telescópica, adosada a la nave.

Fray diego Chuffa describe estas misiones de la manera siguiente ${ }^{112}$ :

En la vacante misión de Quinchilca se halla una casa en regular estado pero sin Iglesia, cual siendo de materiales se cayó por el temblor del 37: tiene una extensión de terreno competente como de 15 cuadras; su jurisdicción espiritual se extiende más de 10 leguas, tiene existentes como 360 indios cristianos, y colinda con los infieles de Panipulli inmediatos a Villarrica: dista de la Plaza de Valdivia 14 leguas y cerca de 8 de la misión de Arique.

En el Departamento de la Unión la suprimida misión de Dallipulli, la más extensa y adelantada de todas en la Provincia, tiene un Iglesia de madera como nueva de 50 varas de largo, levantada por el misionero, que se hallaba al cargo de ella sobre los escombros de la antigua de materiales destruida por el temblor del 37: la casa misional y habitaciones de los indios de rezo aunque viejos, son de regular servicio; mas la separación del misionero, y el poco cuidado que se tiene de estas fabricas le ocasiona y apresura su ruina. El terreno de esta misión son 40 cuadras; su jurisdicción espiritual se extiende más de 16 leguas: el número de indios por estado es del 35, hecho por el misionero Fr. José Gil ascendía a 4500; en la actualidad se calculan existentes en ella 2000 y tantos, y entre estos 30 moros ancianos; dista 18 leguas de Valdivia; legua y media de la villa de la Unión. (Menard \& Foerster, 2007, p.75- 76)

\footnotetext{
112 Estas descripciones están anotadas en las cartas de fray Chuffa, en el capítulo X, Archivo nacional, Fondo Ministerio Interior; vol. 694, 1844, junio 5.
} 
De lo anterior se desprende que estas capillas son construidas por los franciscanos italianos. La de Daglipulli se mantendrá similar, pero Quinchilca y otras de la zona serán remplazadas por igual tipología a la Iglesia de Castro u Osorno a cargo de los Capuchinos italianos a partir de 1850. En el caso de Quinchilca (figura $N^{\circ} 20$ ), iniciadas las obras por el padre Constantino de Voire, es el padre Fortunato de Drena quien la termina en 1883 y también habría participado el padre Bernabé de Lucerna. Las capillas de esta zona, como de la zona de Osorno, no estaban consideradas usualmente en la historiografía como emparentadas, pero estos sucesos y hechos demuestran que son producto de un proceso común.
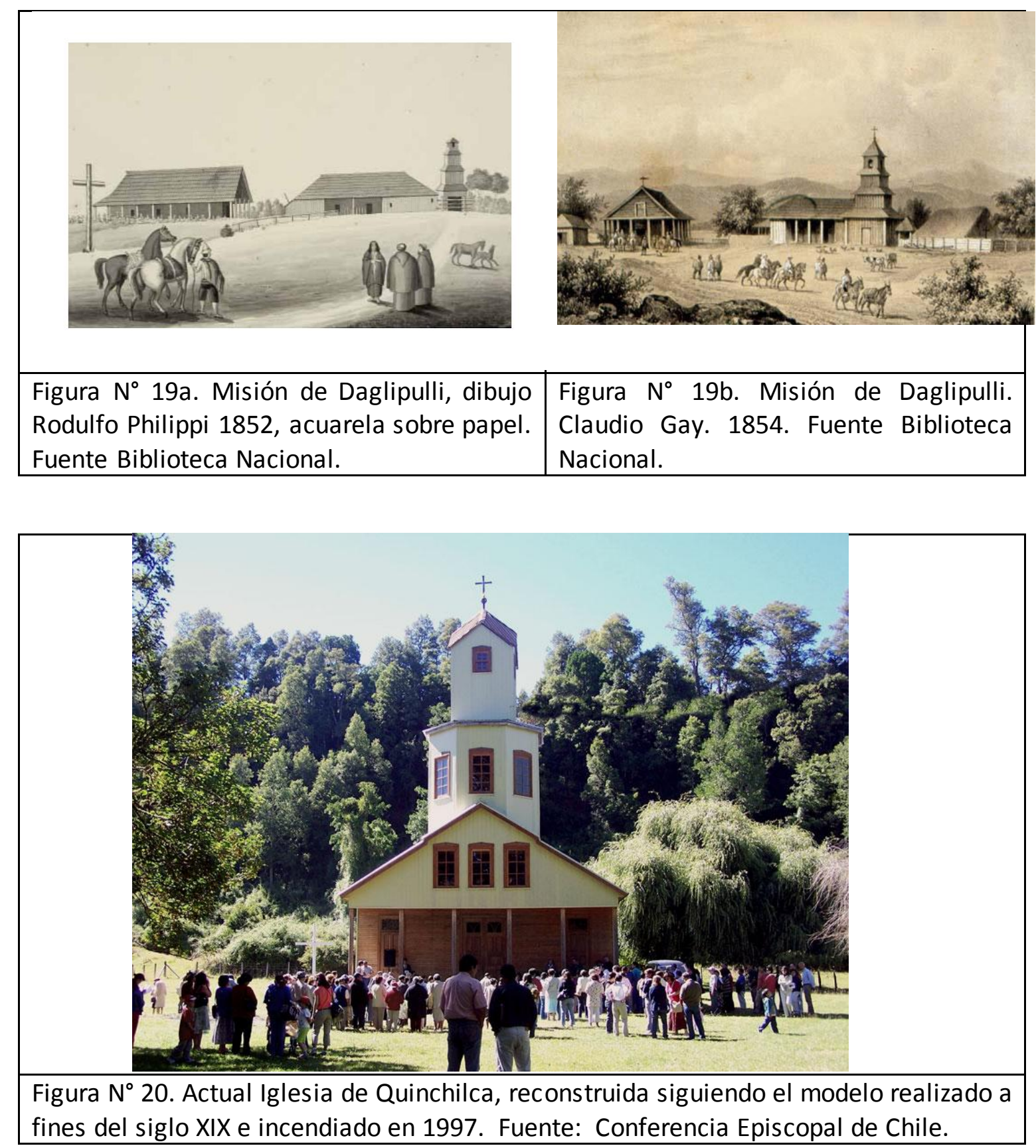


\subsection{Conclusiones de las Misiones en Osorno y Castro.}

Un aspecto evidente, es que la Iglesia de Castro fue la matriz tipológica para el archipiélago de Chiloé, la realizada en Osorno se inició en 1844 y por lo tanto es más antigua y es la matriz tipológica en la parte continental del sur de Chile, ambas dirigidas por Fray Chuffa y sus hermanos franciscanos. Estos dos templos fueron las sedes principales de las respectivas provincias de los misioneros y los centros de irradiación de una determinada manera de componer los edificios, conteniendo todas las características de la arquitectura tradicional religiosa: objetivo central de este estudio.

Una de las maneras en que se desarrolla el oficio del hacer arquitectura, es sobre la base de la reflexión crítica acerca de lo obrado, es decir sobre la autoevaluación, lo que sin duda produjo que el templo de Castro sea más depurado que el de Osorno, ya que seguramente, los frailes buscaron la oportunidad de conocer más sobre el oficio del arte de componer un edificio, sea conversando con especialistas o hurgando en sus propios recuerdos, en este caso, su lugar de origen en la península itálica. Venían claramente cargados de una tradición de casi medio milenio y una misión encomendada con la sentencia divina "Francisco, repara mi Iglesia, pues ya ves que está en ruinas".

En el caso de Castro, se demuestra que los misioneros llevaron a cabo su modelo de edificio, porque junto con tener una planimetría básica ${ }^{113}$ sabían perfectamente lo que querían, con o sin la figura de un arquitecto formal e incluso sin ser carpinteros experimentados, Fray Chuffa con el Fray Guardián pudieron trasmitir y guiar a carpinteros hacia la realización de su templo. También las descripciones de este edificio por parte de fray Manuel Cárcamo, demuestra que hay un claro dominio del lenguaje de la arquitectura neoclásica. En Castro hay una gestión organizada con tres agentes de participación, que son: El Estado quién financia, designando una comisión de fábrica para el control económico; los misioneros, quienes llevan la dirección del Proyecto y; la mano de obra conformada por carpinteros chilotes y apoyo especializado del ejército. La mayoría del resto de las capillas son realizadas con un mayor protagonismo de cada comunidad local.

Se podía conjeturar que la iglesia de Castro, construida por los franciscanos apenas llegaron a la capital insular y destruida en el incendio de marzo de 1857, tenía las características que conformarán la tipología tradicional de las capillas chilotas. Es evidente que en todo acto fundacional de magnitud que comprende de varias y nuevas edificaciones, normalmente corresponde y se instala un patrón, está ya demostrado el antecedente de la capilla de Osorno y varias otras en ambas provincias. Por otra parte las dimensiones descritas en planta para esta capilla de 1840 son prácticamente iguales a la iniciada en 1857, la primera era de 22 va ras y su largo 80 , de sur a norte y la segunda de $21.3 / 4$ varas de ancho y 84 varas de largo.

\footnotetext{
113 A modo de hipótesis, se puede especular que este proyecto realizado como encargo de los franciscanos, pudo participar el arquitecto italiano Eusebio Chelli radicado en Chile, ya que según lo expresado anteriormente fue un fiel colaborador de la orden y la iglesia de Castro de 1857, está en la corriente tipológica y estilística utilizada por él.
} 
Otra conclusión es que se anula una posible influencia de la escuela de carpinteros alemanes de Puerto Montt, en la definición del modelo de iglesia caracterizado por la torre-fachada, ya que el origen es posible situarlo entre 1837 y 1844, año en que recién se estaba gestando la llegada de los colonos alemanes a la región. 
ANEXOS

ANEXO 1. Parroquias y vice parroquias atendidas por el Colegio de Castro, 18451905.

Fuentes: Angel C. Pérez, op. cit., pág. 70. Bernardino Díaz, op. cit., págs. 24- 57

\begin{tabular}{|l|l|l|l|}
\hline Parroquias & & & \\
\hline $1850-60$ & 1870 & 1880 & $1890-1905$ \\
\hline Castro & Castro & Castro & Castro \\
\hline Chonchi & Queilén & Queilén & Queilén \\
\hline Queilén & Tenaún & Tenaún & Tenaún \\
\hline Lemuy & Ancud & Chacao & Chacao \\
\hline Tenaún & Chacao & Achao & Achao \\
\hline Ancud & Achao & Quenac & \\
\hline Chacao & Quenac & Dalcahue & \\
\hline Achao & Maullín & & \\
\hline Quenac & Dalcahue & & \\
\hline Calbuco & Osorno & & \\
\hline Maullín & & & \\
\hline Osorno & & & \\
\hline Vice parroquias & & & \\
\hline Lliuco & & & \\
\hline Chelín & & & \\
\hline
\end{tabular}




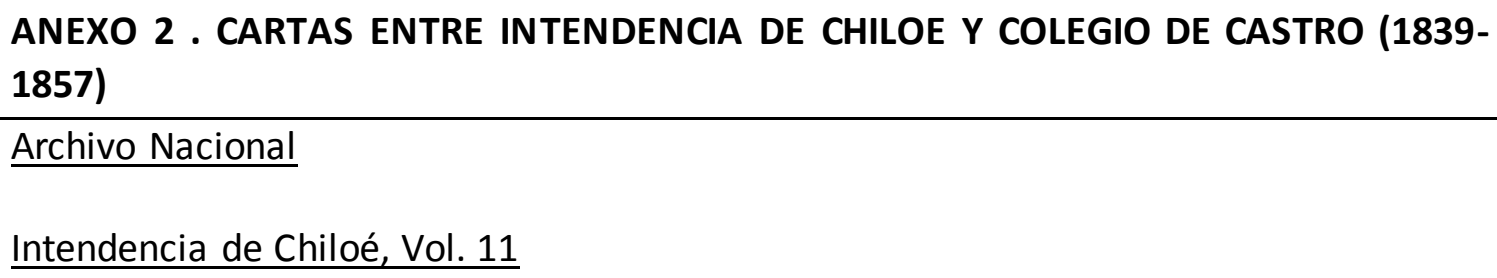

Archivo Nacional

Intendencia de Chiloé, Vol. 11

Santiago, marzo 23 de 1839

A consecuencia de una nota del Prefecto general de misioneros Fr. Manuel Unzurrunzaga, el Presidente de la República se sirvió expedir el 18 del corriente el decreto que sigue:

"Expídase orden al Intendente de Chiloé para que disponga se franquee al guardián del colegio de propaganda de Castro la madera que el mismo intendente conceptuare exactamente necesaria para la construcción de la pieza destinada para noviciado de aquel colegio, tomándose de la que perteneciese al Estado, bajo del formar cuenta y recibo; y avisando oportunamente al gobierno y a las oficinas respectivas de la madera que en virtud de esta orden se entregase, a fin de que se cargue su importancia al ramo de vacantes, de donde conforme a la ley deben hacerse los gastos de misiones. Refréndese y tómese razón."

Lo transcribo a VS. para su inteligencia y fines consiguientes.

Dios guarde a VS.

Mariano de Egaña [firma]

Al Señor Intendente de Chiloé

Santiago, Agosto 24 de 1839

En virtud de la nota de VS fecha 5 de abril último me encarga el Presidente de la República prevenir a VS que en el caso de que los padres misioneros del colegio de propaganda fide de esa provincia no hayan tenido que abandonar su convento para seguir las parroquias vacantes de Lemuy, Chonchi, Tenaún, Quenac y Carelmapo como VS expresa en su citada nota, continúen ejerciendo provisoriamente aquel ministerio hasta nueva disposición suprema.

Dios guarde a VS.

Mariano de Egaña [firma]

Al Señor Intendente de Chiloé

Santiago, noviembre 26 de 1839

A continuación de una nota dirigida a este Ministerio por el padre fr. Antonio Foraste, misionero de Colegio de propaganda de Castro, el Presidente de la República ha expedido con fecha de ayer el decreto que sigue:

"Considerando que el colegio de misioneros de propaganda de la ciudad de Castro, es un establecimiento de la más alta importancia, del cual se ha propuesto el Gobierno sacar los mayores bienes espirituales y temporales, en beneficio de la 
conversión y civilización de los indios y de su incorporación al seno de la República.

Considerando igualmente que con este objeto se ha procurado facilitar todos los medios posibles para su fundación y conservación, y que faltando ya muy poco para la conclusión de su edificio material, quedaría este parado y expuesto a perderse lo trabajado hasta aquí, si el gobierno no proporcionase los medios de concluir tan interesante obra.

Considerando que se han sentado otros arbitrios para ocurrir a los gastos de esta fábrica, sin gravamen del erario y que no han produjo efecto alguno.

Considerando, por último, que está dispuesto por la ley, que el producto de las vacantes mayores y menores de las iglesias, se aplique e invierta precisamente en primer lugar en los misioneros apostólicos destinados a la reducción y enseñanza de los indios infieles, como obra oía en grado eminente, la más acepta y recomendada por todos los derechos, y de la primera y más principal atención del gobierno, he acordado y decretado:

Los Ministros de Tesorería general entregarán al síndico del colegio de propaganda de Castro, don Joaquín Iglesias para la continuación y conclusión del edificio material de dicho colegio, la cantidad de dos mil pesos, cuya entrega la verificarán en la forma siguiente: mil pesos de pronto, quinientos en día primero de febrero de 1840 y otros quinientos el día primero de abril del mismo año; y el Intendente de Chiloé dispondrá que de las maderas que existen en aquella provincia perteneciente al Estado, se entreguen con el mismo fin y a la orden del padre Prefecto de Misioneros, fr. Manuel Unzurrunzaga, veinticinco mil tablas de alerce, siempre que el importe de cada una de ellas no exceda de un cuadrillo de real-dos mil tablones de alerce, mil cuartones de ciprés, dos mil tablones de avellano y quinientas madrinas de ciprés, siempre que el valor de cada pieza de estos cuatro últimos artículos no exceda de un real. Refréndese, tómese razón y transcríbase al Intendente de Chiloé y Prefecto del Misiones fr. Manuel Unzurrunzaga".

Lo transcribo a VS. para su inteligencia y fines consiguientes.

Dios guarde a VS.

Mariano de Egaña [firma]

Al Señor Intendente de Chiloé

\section{Intendencia de Chiloé. Vol. 61}

\section{Gobierno Departamental}

Castro, marzo 22 a las $91 / 2$ de la noche de 1857

Señor Intendente:

Con el más profundo sentimiento comunico a V.S. que a las ocho de esta noche principió a incendiarse el convento e Iglesia de regulares de esta ciudad que en hora y media ha sido concluido por las llamas todos los edificios, y una sola casa del pueblo; y si se ha salvado la iglesia parroquial y las casas del pueblo, ha sido merced de no haber habido mucho viento, y las serias y activas providencias que se han tomado.

Los padres han perdido casi completamente todos sus intereses; pues cuando se vio y tocó a fuego el cañón del noviciado entró a ama[_], los padres en esa hora 
estaban cenando.

Inmediatamente hago poner incomunicados a los religiosos que vivían por donde principió a arder el convento para seguir un sumario indagatorio.

Un anciano nombrado Santiago Vásquez ha sido quemado en el mismo lecho en que se encontraba enfermo, y algunas otras averías de poca consideración.

Lo angustioso del tiempo por una catástrofe harto lamentable, no me ser más en término.

Dios guarde a V.S.

Fruct. Sánchez [firma]

$\mathrm{N}^{\circ} 72$

Gobierno Departamental

Castro, marzo 23 de 1857.

Señor Intendente:

Adhiriéndome al parte que pasé a V.S. anoche por la desgracia ocurrida en esta ciudad debo decirle que con actividad se sigue el sumario indagatorio para ver de descubrir cómo ha sucedido el incendio.

A las ocho horas en que se vio por los vecinos el fuego ya en su mayor fuerza, los P.P se encontraban en el refectorio. El fuego principio en el noviciado en el $2^{\circ}$ piso en la parte más interior del Convento materialmente imposible de que hubiese resultado de otra manera que de un descuido o por obra de alguno de los que ocupaban esos departamentos.

Se han socorrido como la 4ta parte del equipaje de los religiosos, pero no por eso han dejado de quedar algunos hasta sin hábitos: La biblioteca pudo socorrerla el infrascrito con sólo dos hombres en medio de las devoradoras llamas, aunque no toda.

Los ornamentos, vasos sagrados, órgano, piano \& todo ha sido quemado, y aun más el dinero que el R. P. Bula acababa de recibir de la Tesorería puso entre los escombros solo se han podido encontrar cincuenta cóndores, unos intactos y otros medios y derretidos.

Así es Señor Intendente que el estrago asu[_] lamentable en sólo hora y media quedaron reducidos $\$ 10.000$ mal calculados.

Viendo que esta pobre comunidad tan numerosa no tenían adonde poderse defender de la intemperie del tiempo y dispuesto suspender las dos escuelas fiscales para darles hospitalidad en estos edificios, no dudando que esta medida merecerá la aprobación a V.S. Por conclusión debo decir a V.S que es preciso tocar todos los medios posibles que estén al alcance de las autoridades para proporcionar a estos desgraciados religiosos una casa provisional en que pueda vivir.

Dios guarde a V.S.

Fruct. Sánchez [firma]

Al Intendente de Provincia.

$N^{\circ} 94$

Gobierno Departamental

Castro, abril 9 de 1857 


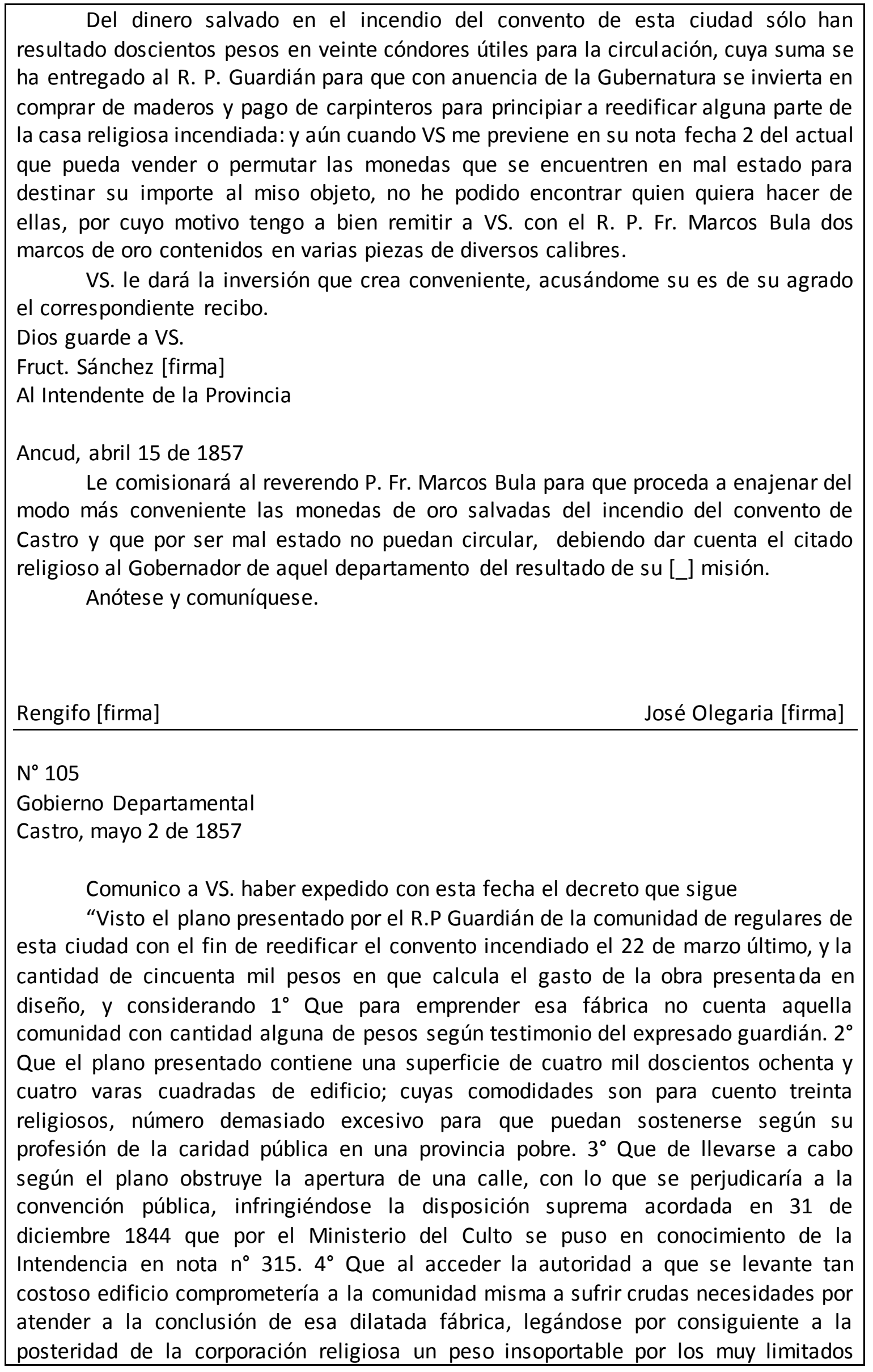


recursos con que cuenta. $5^{\circ}$ Que habiéndose hecho examinar el expresado plano por el ingeniero Dn. Daniel Shepard lo ha desaprobado en todas sus partes por razones bien calificadas.

En su virtud con la facultad que me confiere el art. 125 tit. $5^{\circ}$ de la ley del régimen interior de la República desapruébase el diseño presentado por el $\mathrm{P}$. $\mathrm{V}$. Guardián, debiéndose en consecuencia únicamente edificar un convento que contenga las comodidades necesarias para los cincuenta religiosos de que actualmente se compone aquella comunidad, quedando aprobado para el efecto el plano que por encargo de la gubernatura ha presentado el señor Shepard., con el que son conformes la materia de los religiosos. Anótese, comuníquese al R. Guardián y dese cuenta al Sr. Intendente de la Provincia.

Lo digo a VS. para su inteligencia y fines consiguientes.

Dios guarde a VS.

Fruct. Sánchez [firmas]

Al Señor Intendente de la Provincia.

\section{$\mathrm{N}^{\circ} 118$}

Gobierno Departamental

Castro, mayo 12 de 1857

Tengo a bien remitir a VS. copia del plano levantado por el ingeniero norte americano Dn.. Daniel Shepard para reedificar el Convento de los PP regulares de esta ciudad, y el presupuesto asciende a $23.000 \$$ en que dicho ingeniero calcula el costo de aquel edificio trabajado de material.

Si es que merece el expresado plano la aprobación de VS, no lo creo fuera del caso el que por un órgano se eleve a S. E al Señor Presidente de la República, pues no son des [_]cidas las grandes ventajas que encierra su edificio de esa naturaleza, y sobre todo lo mucho que ganaría la provincia con la fábrica de ladrillos que este individuo quiere introducir en la parte más atrasada del horizonte chileno.

Dios guarde a VS.

Fruct. Sánchez [firmas]

Al Señor Intendente de la Provincia

Nota: No van los presupuestos por haberse inutilizado cuando estaban al concluirse, los que se remitirán oportunamente los 23.000 \$ sobre todo por el convento.

$N^{\circ} 229$

Gobierno Departamental

Castro, octubre 28 de 1857

Remito a VS. la cuenta instruida y documentada de la inversión que se le dieren a los doscientos pesos pertenecientes al tesoro nacional que fueron salvados entre los escombros del incendio del colegio de esta ciudad, de los cuales VS. dispuso en nota fecha 25 de marzo de este año se empleasen en edificar algunas habitaciones para que puedan vivir los desgraciados religiosos.

La gubernatura no ha tenido injerencia en la distribución de la suma que antecede por haberse hecho cargo de la obra de Padre Chufas, quien ha principiado 
con ese dinero y las limosnas colectadas en esta provincia a colocar los mejores cimientos del convento que van a levantar.

Oportunamente daré cuenta a VS. de las fuerzas militares que se han empleado y se emplean en auxilio de esa obra; previniéndole desde luego que la gubernatura no se ha extendido ni se extenderá más de allá, que acceder la junto de los Batallones de este departamento que no concurrieron a la composición del camino de Caicunco en el presente año; habiéndoseles impuesto a la fuerza inasistente la muy limitada tarea de seis días de trabajo a cada hombre.

Habiendo obrado en la forma ya relacionada VS. verá que de ningún modo ha sido ni es gravoso a la tropa, pues una sola compañía única de carpinteros que hay en el departamento se ocupó en arreglar los maderos, cuyas fuerzas para la parte de la composición de camino que les está designada, será reemplazada por una partida de los que no asistieron en el presente año.

Dios guarde a VS.

Fruct. Sánchez [firma]

Al Sr. Intendente de la Provincia 
ANEXO 3. Documento contable la Iglesia de Castro de 1883. Extracto. Primera partida fabrica $p 1$.

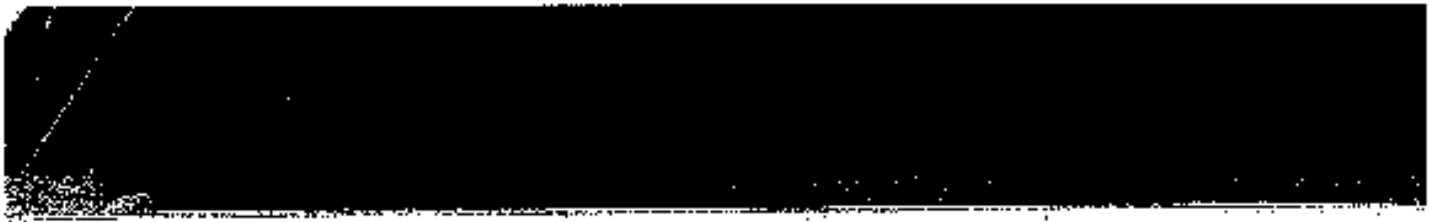

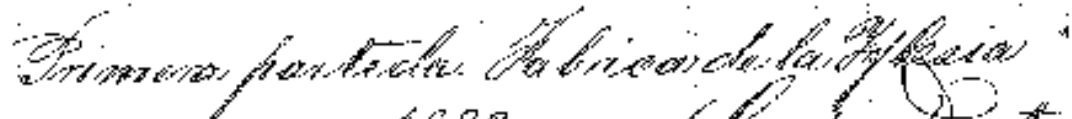

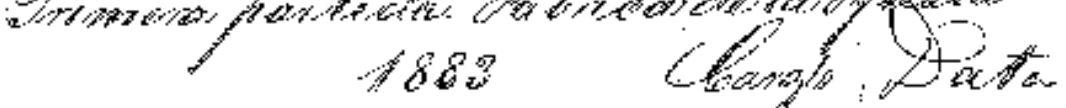

4 Fe

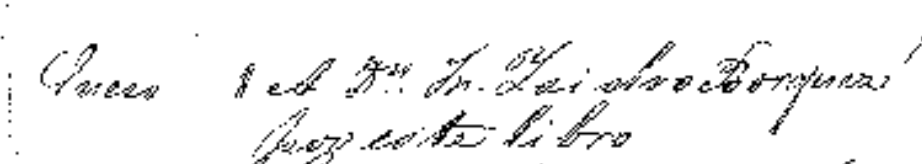

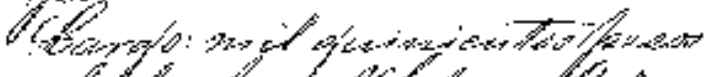

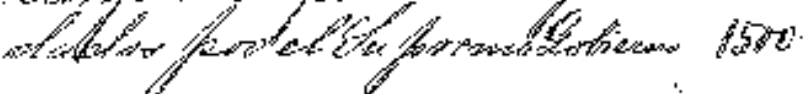

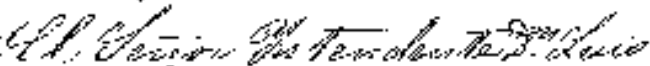

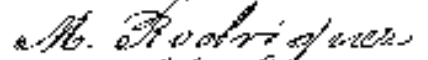
LE

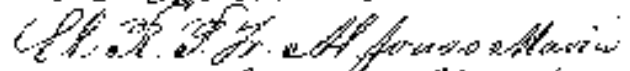

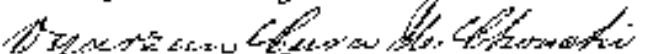

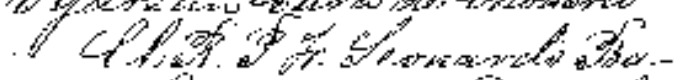
rez

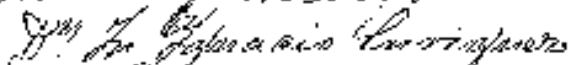
e落 \%

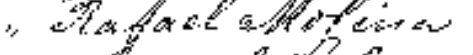

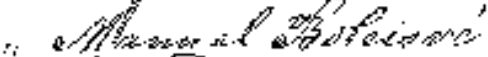

$\because$ If 1 से

"xay

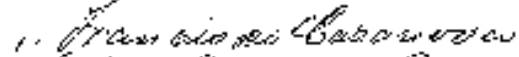
W. 400 $\$ 00$

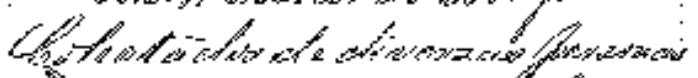

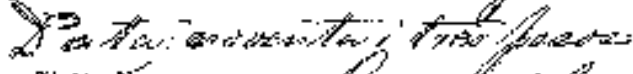

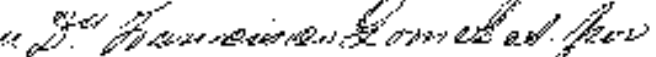

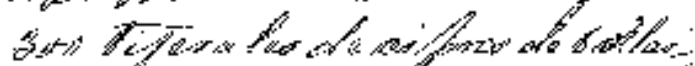
: $\quad y^{\prime}$. ATos, 


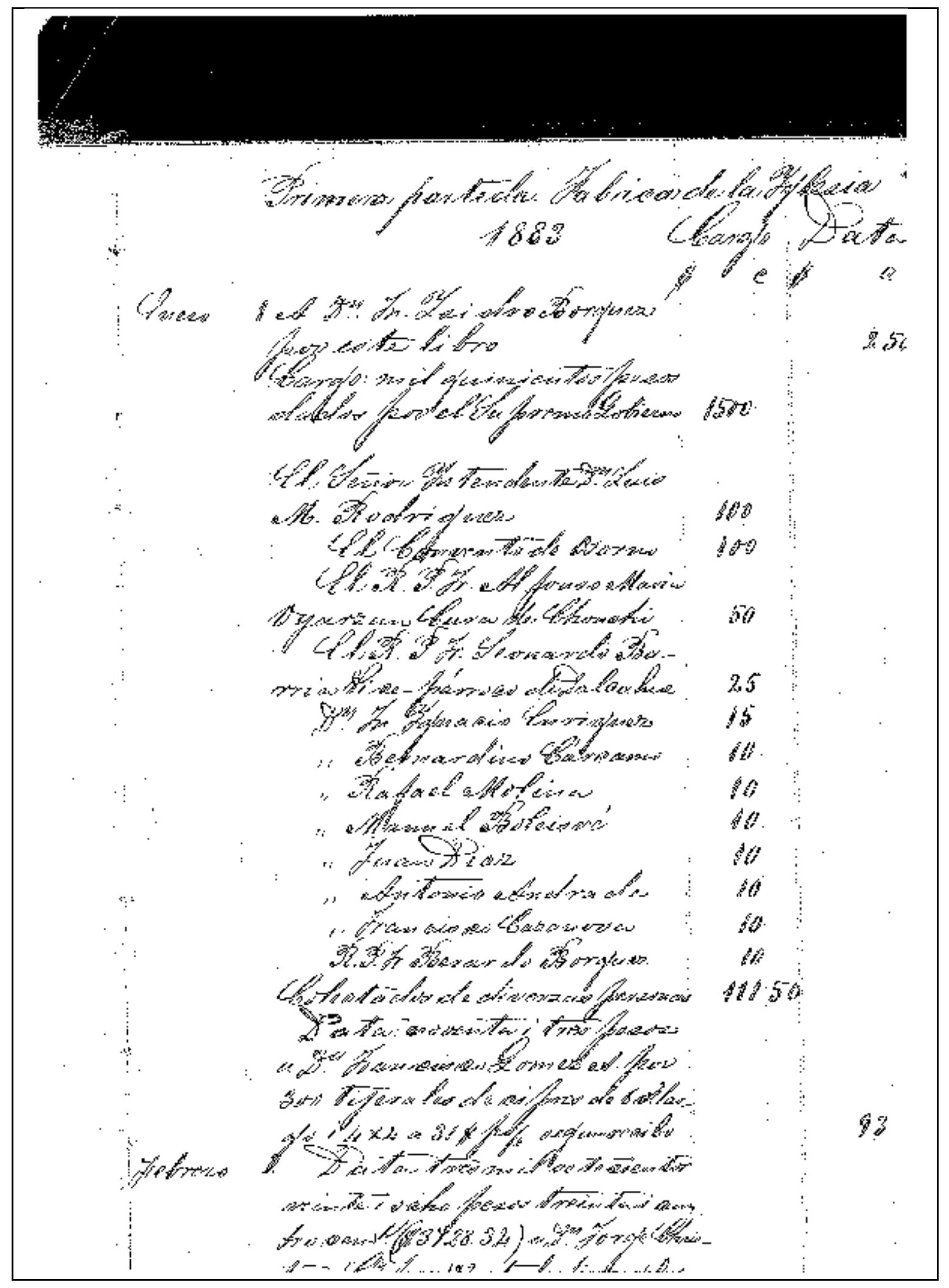

169 


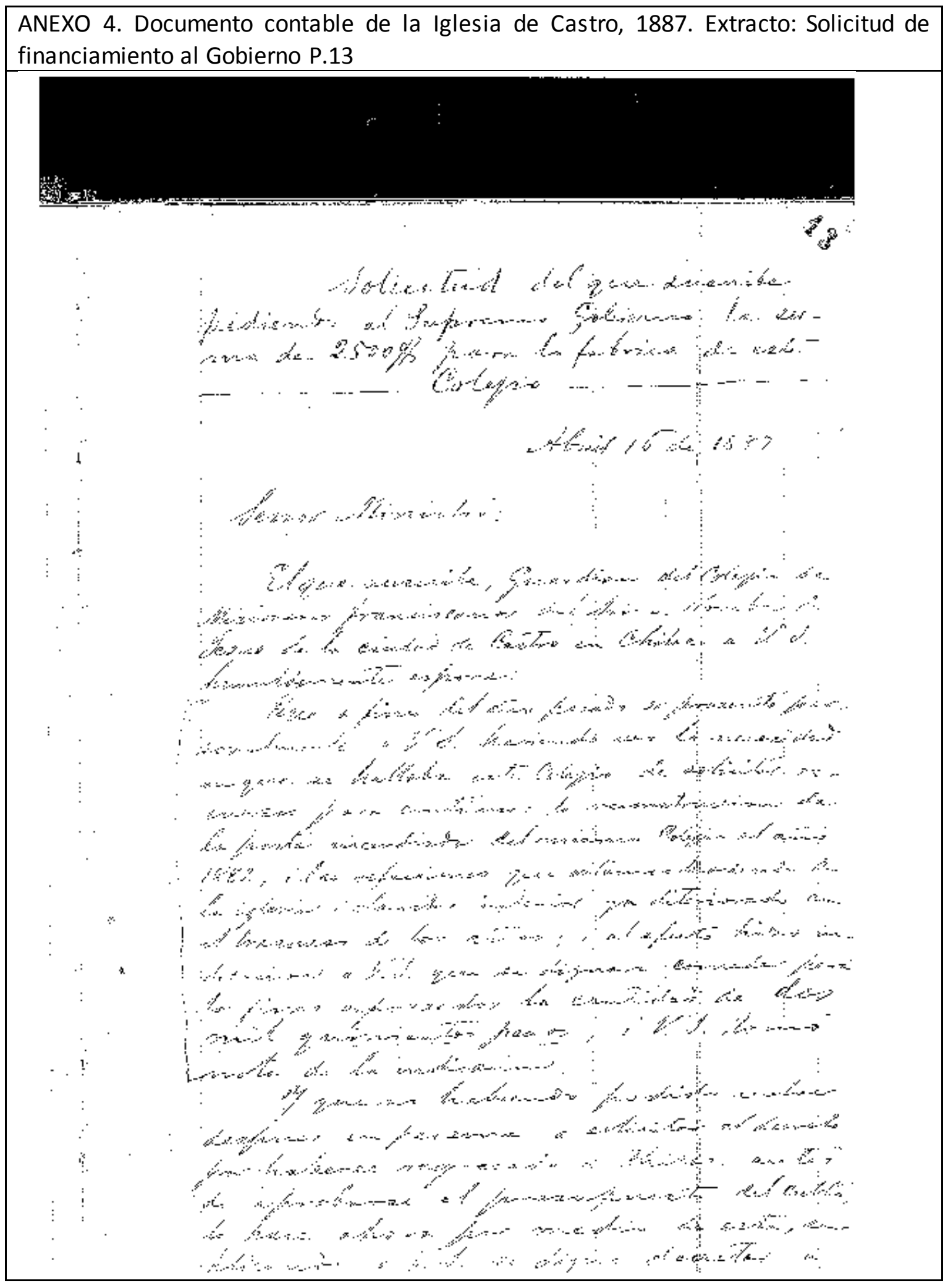




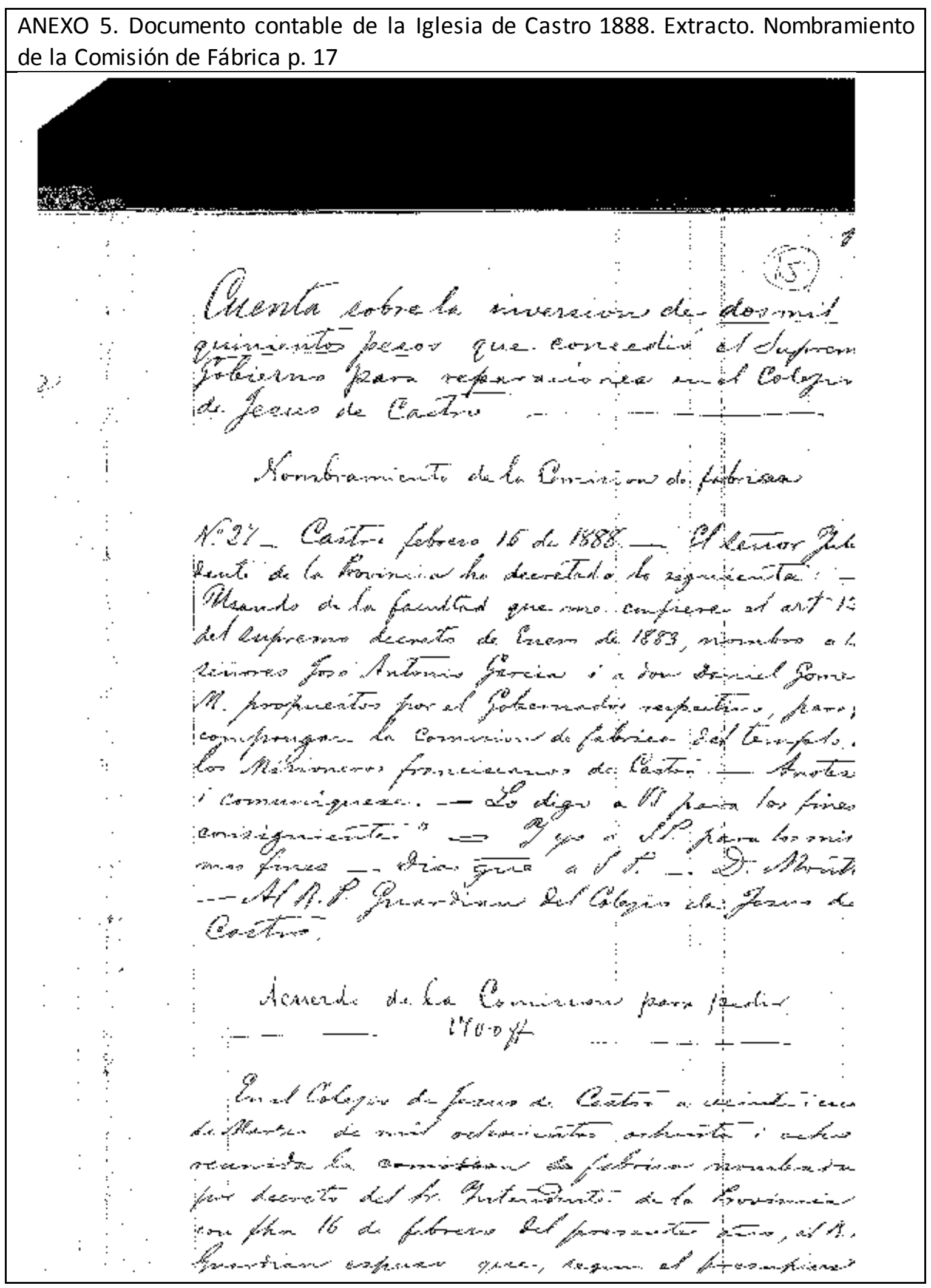




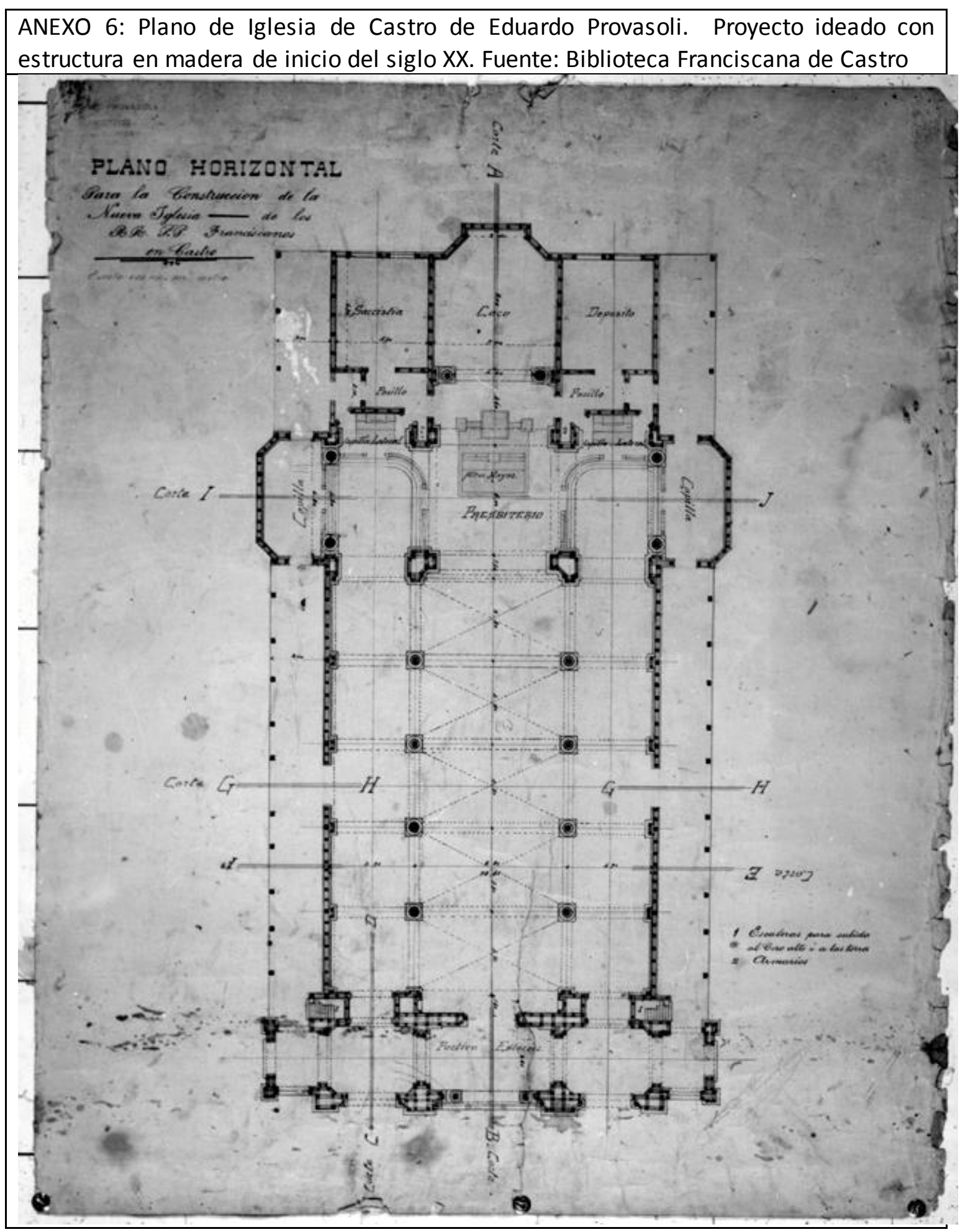




\section{CAPITULO 5. OTROS CONTACTOS DEL SIGLO XIX: La colonización alemana.}

\subsection{CONTEXTO SOCIO CULTURAL.}

En lo expuesto en capítulos anteriores, la lejanía, el aislamiento geográfico y la carencia de minerales de valor, fueron factores que determinaron el desarrollo cultural y tecnológico de Chiloé. A esto se sumó el que la población vivía dispersa en el territorio, juntándose solo para las fiestas religiosas en torno a las capillas o en las pocas ciudades, las que presentaban un aspecto desolador el resto del año. A su vez se juntaban en Chacao una vez al año para comerciar su producción de maderas, jamones o ponchos con los marinos del barco que traía el Real Situado al archipiélago desde Perú. A esto se sumó el abandono producido después de la anexión a la república el año 1826, y el empobrecimiento que esto produjo por la pérdida del comercio con Lima, sin embargo como ya se verá, pronto irá a producirse una nueva oleada desde el exterior, que impactará a la tranquila vida del archipiélago.

Como ya se ha mencionado, la independencia de las colonias españolas y su transformación en estado y nación recibe la influencia de otros países como Inglaterra, Alemania, Francia e Italia; son los nuevos referentes y aportes de población. Conjuntamente se producirá el auge comercial marítimo del Pacífico, siendo el estrecho de Magallanes el acceso y Chiloé su primera recalada. Los puertos son los grandes centros de intercambio, y la arquitectura un producto más de estos permanentes fenómenos de internacionalización. Esta vez los europeos exporta rán la Ilustración y el Neoclásico, los habitantes de la isla se encargarán de adaptarlos a su medida.

Pasaron tres siglos de un Chiloé colonial, con un grado de mestizaje y asimilación tan profundo que los chilotes no tuvieron el ímpetu independentista del resto del país, siendo indistinto para ellos pertenecer a España o a la nueva República. En definitiva Chiloé es de los últimos territorios de la colonia española en América y sólo pasa a ser parte de Chile en 1826 con el Tratado de Tantauco. Es necesario señalar, además, que el grueso del ejército realista que peleó en las campañas de la guerra de independencia de Chile era chilote.

El auge mercantil tendrá un impacto importante en los sistemas productivos. Chiloé, abastecedor a pequeña escala de productos agrícolas al continente, comenzará una explotación mayor de recursos naturales, particularmente de la madera, que incidirá en los roles y crecimiento de ciudades y en la transformación del territorio. Se produce un enriquecimiento económico de grupos sociales que sacarán provecho del proceso; como es habitual en estos fenómenos; se marcarán brechas y condiciones de vida dispares. Es época de migraciones Ilegan nuevos colonos des de Europa, comerciantes, profesionales y artesanos, los chilotes vislumbran la quimera urbana y aprovechando sus oficios se asientan en las ciudades o se van a las estancias ganaderas de la Patagonia. (Berg, Lobos \& Rojas, 2006).

Los antiguos pueblos se han activado y comienza a engranarse un desarrollo semi industrial. Ancud, puerto y capital de la provincia desde 1826, tiene cervecerías, curtiembre y almacenamientos; Castro centro de servicios y de abastecimiento, Achao 
articula las islas interiores, Dalcahue un descanso a medio camino; Chonchi centro de explotación del ciprés, Quellón Viejo posee una destilería; Quemchi, explotará madera y astilleros. La conectividad mejora con la implementación a partir de 1893, de la línea férrea de trocha angosta entre Ancud y Castro, realizada sobre el antiguo camino de Caicumeo, ruta de tierra que unía ambas ciudades (Berg, Lobos \& Rojas, 2006). Con esta acción del poder central, la utopía del desarrollo llega a Chiloé.

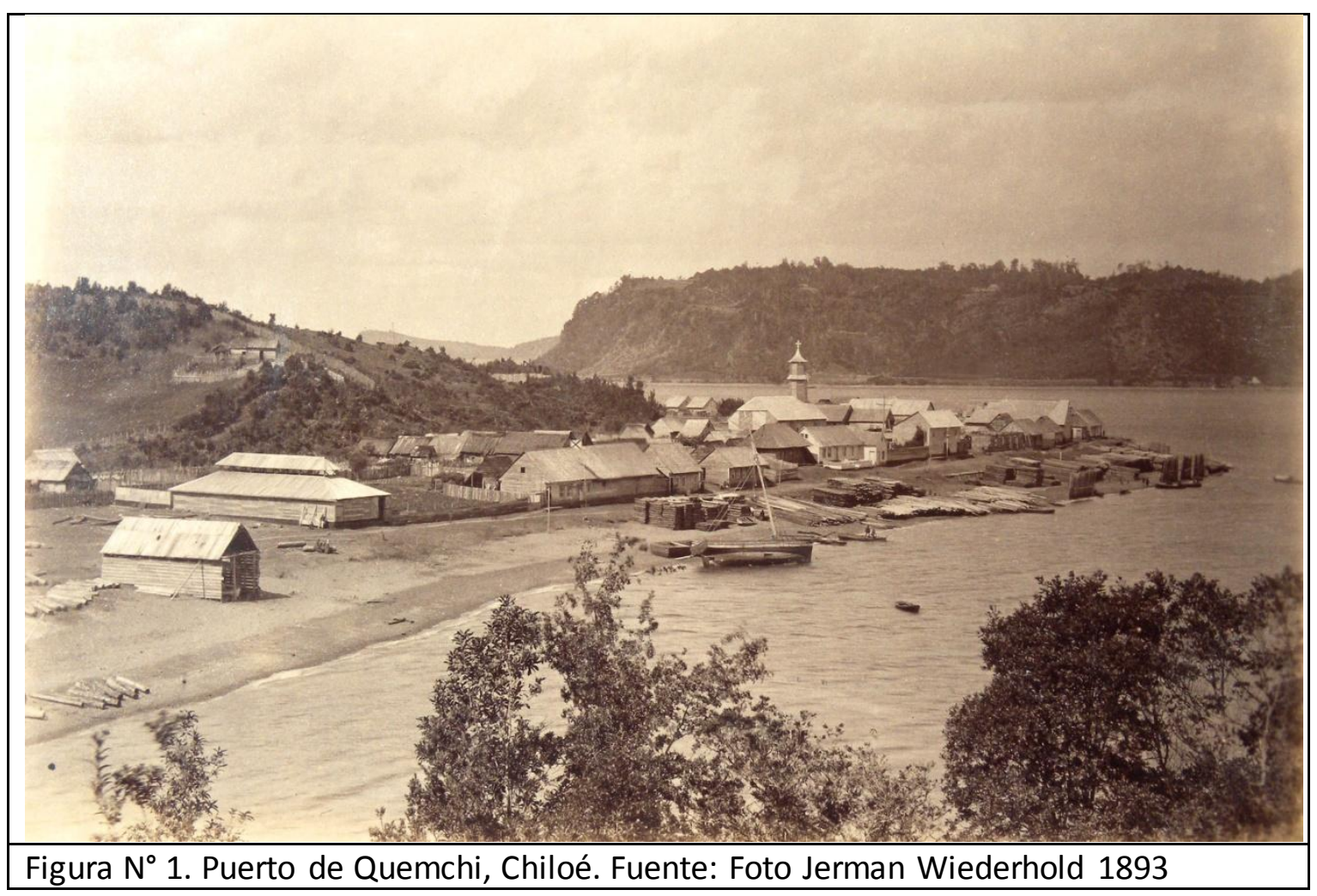

El auge mercantil impulsó la actividad edilicia en cantidad y en calidad, la arquitectura de ciudades y pueblos adquieren otra estilística. Surgen nuevas expresiones formales, técnicas y materiales, recogidos de ilustraciones de catálogos o de la memoria de los viajeros o inmigrantes europeos, muchos con oficios vinculados a la construcción. Estas nuevas formas son aprendidas o captadas por los carpinteros locales y en el quehacer conjunto de lo propio y lo externo se elabora el estilo neoclásico chilote o vernacular (Berg, Lobos \& Rojas, 2006, p. 83).

En Chiloé, la reinterpretación es un fenómeno fecundo y singular; distorsiona y, por esto, hace propio algunos preceptos formales del estilo: es nuevo y nunca ortodoxo. Las plantas no sufren variaciones de importancia, siendo el estilo fundamentalmente un asunto de fachadas. En estas, tampoco algunas constantes estilísticas de primer orden, como la simetría, son realmente respetadas. Siempre existe en el conjunto un tono general de cierta ingenuidad característica, suma de desproporciones y desobediencias a una arquitectura de origen y pretensión oficial (Fischer, 1987, p. 8)

Entre las oleadas de nuevos inmigrantes será fundamental la influencia cultural en la arquitectura y la construcción que traerá la colonización alemana, que se concentrará 
en el continente entre Valdivia por el norte y Puerto Montt por el sur, a partir de mediados del siglo XIX y que también se asentará en Ancud y localidades cercanas en el norte de la Isla grande de Chiloé.

\subsubsection{La colonización alemana (Neoclásico, mecanización y el sistema fachwerk).}

La colonización del sur tuvo como objetivo primordial la ocupación de un vasto territorio para hacer soberanía e incorporarlo a la economía de la naciente república.

Sus prolegómenos se hunden en el periodo de la conquista y la colonia. Pero fue después de la independencia cuando comenzó a configurarse como una posibilidad cierta. En 1811 José Miguel Carrera pidió a José Antonio Pinto que contratara colonos irlandeses, como le había sugerido Bernardo O`Higgins (Blancpain, 1985). Posteriormente, Mariano Egaña contrató al General español Antonio Quiroga y al inglés Richard Guerney para contratar a 500 familias inglesas que ocuparían el territorio entre los ríos Biobío e Imperial. También la Sociedad de agricultura ${ }^{114}$ propuso atraer parte de las personas que emigraban a América del Norte, a Chile. En 1842 el súbdito de la corona inglesa Andreas Dow prometió traer diez mil colonos europeos católicos para colonizar el sur del país. Sin embargo, ninguna de estas propuestas se concretó (Held. 1970).

En 1831 pasó por Valparaíso, por primera vez, Bernardo Philippi de veinte años, como grumete del vapor comercial Princessin Lousie. Volvió a pasar en 1837, esta vez como tercer piloto del mismo barco a vapor. Asociado con el dr. Carlos Segeth, médico del vapor, decidió quedarse en Valparaíso para recolectar animales y plantas para el Museo de Historia Natural de Berlín, con el cual el doctor Segeth tenía un contrato para tal efecto. La sociedad duró poco y Philippi se trasladó a Perú. Enfermo, probablemente de malaria, le recomendaron recuperarse en el sur de Chile, lo que lo Ilevó de vuelta a Valparaíso y de allí viajó a Chiloé a reponerse. En 1840 regresó a Europa para vender sus colecciones y obtuvo un contrato por dos años con el Museo de Historia Natural de Berlín, para recolectar animales y plantas. Se instaló en Valdivia e inició las exploraciones necesarias para honrar su contrato. Movido por la curiosidad por verificar las historias y leyendas que se contaban sobre los grandes lagos del interior, viajó a Ancud y de allí al astillero de Cayenel donde existía un caserío estacional que albergaba a los hacheros contratados por las casas comerciales de Calbuco para la explotación de alerce. Desde el astillero, junto con tres compañeros y tres guías locales, quienes los abandonaron temerosos de los peligros que encerraba el zona interior, llegaron al lago Llanquihue, lo bordearon hacia el poniente y cruzaron el nacimiento del río Maullín llegando presumiblemente hasta Punta Larga. La expedición salió el 27 de enero de 1842, regresando el día 6 de febrero al astillero. Impresionado por las bellezas naturales y la bastedad del espacio geográfico, Philippi empezó a idear un proyecto de colonización de la zona, pensando en la gran cantidad de europeos que emigraban a Norteamérica y Brasil, en busca de mejores condiciones de vida para sí mismos y para su familia. Después de esta primera exploración, el

\footnotetext{
114 La sociedad de agricultura es la asociación gremial más antigua de Chile. Fue fundada el 18 de mayo de 1838 con el objetivo de reunir a todos los participantes de las actividades agrícolas y agroindustriales y velar por sus intereses
} 
mismo año recorrió el camino real de Ancud a Carelmapu, Maullín y Osorno, y remontó el río Maullín hasta su nacimiento en el Lago Llanquihue. Junto con su informe de exploración, presentó un mapa donde aparece dibujado por primera vez el llago Llanquihue, y en donde trazó una ruta alternativa al Camino Real, trazado a fines del siglo XVIII, que unía Osorno con el astillero de Cayenel o Melipulli. Esta ruta partía del astillero de Melipulli, al que se accedía por barco, cruzaba la selva hasta la ribera sur del lago, de allí se navegaba el lago hasta la ribera norte y se continuaba por tierra, por lugares relativamente planos, hasta llegar a Osorno. Este plano es de gran importancia pues es el "segundo proyecto sobre el territorio de la región de los Lagos", después del ya citado plano del Camino Real (Berg y Cherubini, 2009, p. 116), y que fue la base de la ocupación del territorio interior de la región.

Bernardo Philippi promocionó su idea de colonizar la zona sur al más alto nivel gubernamental, ayudado por el intendente de Valdivia José Luis Sanfuentes, de quien se había hecho amigo, lo que trajo como consecuencia que se dictara la Ley de Colonización o ley sobre Tierras y Terrenos Baldíos, el 18 de noviembre de 1845, que autorizaba al Presidente de la República a establecer y apoyar económicamente colonias productivas en los terrenos desocupados de propiedad del estado. Esta ley complementó la del 10 de julio de 1823 que declaraba como propiedad del estado todos los terrenos desocupados y abandonados.

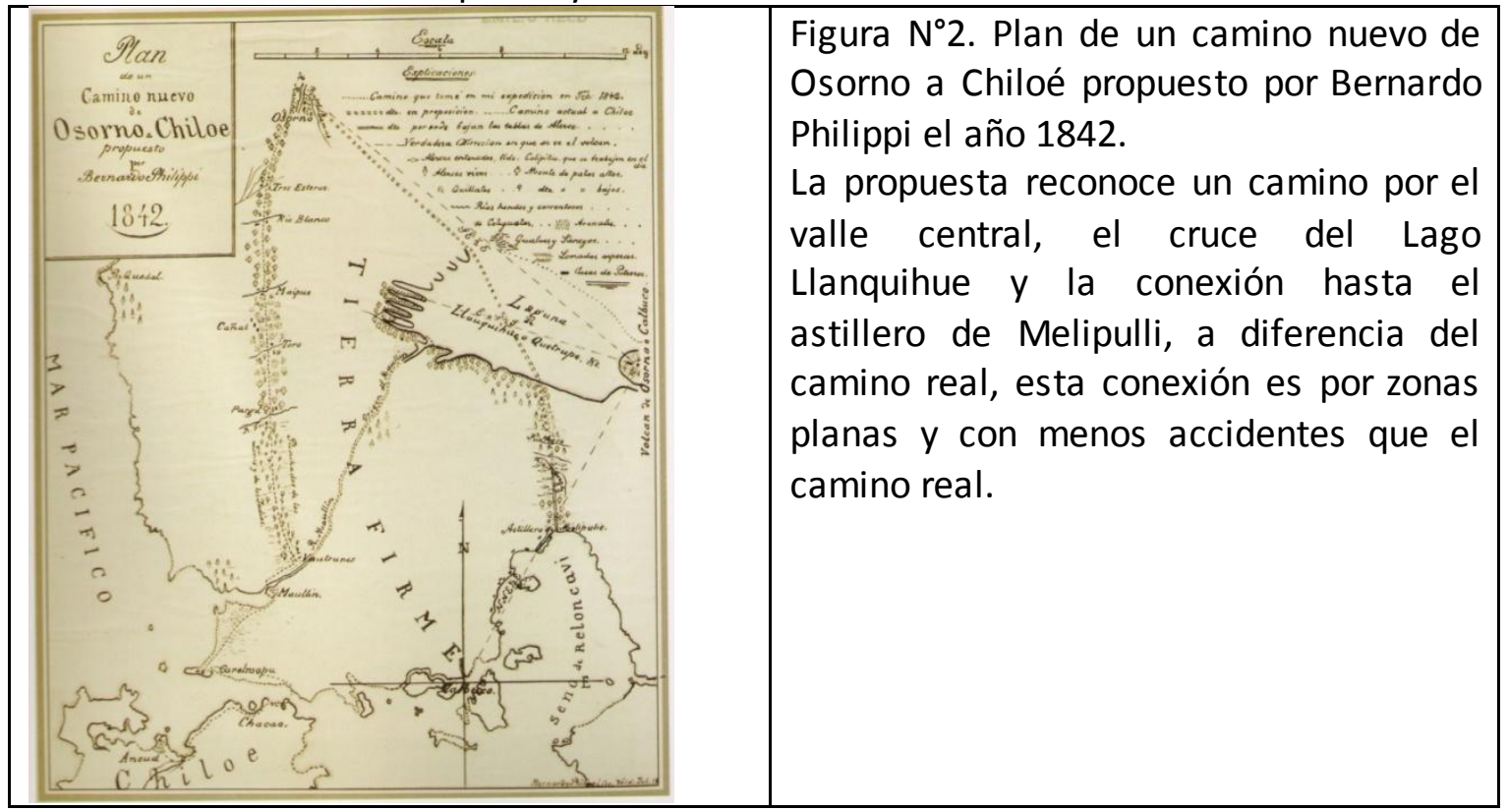

Bernardo Philippi se asoció en Valparaíso con Ferdinand Flindt, cónsul honorario de Prusia y gerente de la empresa de navegación Canciani e hijos, para lo cual compraron una propiedad al sur de Trumao y pidieron al hermano de Philippi residente en Cassel en el principado de Hesse, que contratara nueve familias de artesanos con conocimientos y experiencia en agricultura.

Cuando estos colonos llegaron a Valdivia el 25 de agosto de 1846, Flindt se había declarado en quiebra, vendiendo la hacienda de Bellavista a Franz Kindermann, por lo que Philippi fue separado del proyecto de colonización. 
Volvió entonces a promocionar su proyecto de colonización en el gobierno, siendo nombrado agente para contratar colonos en los estados de la confederación germana $^{115}$ en julio de 1848, iniciando de esta manera un proceso regular de colonización del sur de Chile, que permitió la llegada de agricultores, artesanos y profesionales, que cambiaron la imagen de la región en un lapso de treinta años, entre 1846 y 1875, año este último en que finalizó la llegada de colonos a la región (Blancpain, 1985).

Entre los colonos llegaron agricultores, artesanos y profesionales. Entre los artesanos, Held registró ciento setenta carpinteros e igual número de mueblistas (Held, 1970, p. 23), cuya acabada formación técnica y teórica permitió que tuviesen una activa e importante participación en la definición de las ciudades de la zona sur y de su arquitectura. Los artesanos trajeron una gran cantidad de herramientas para trabajar la madera, como sierras, serruchos, formones, gubias, gramiles, diversos tipos de cepillo, taladros, etc. Muchas de estas herramientas eran desconocidas en la zona.

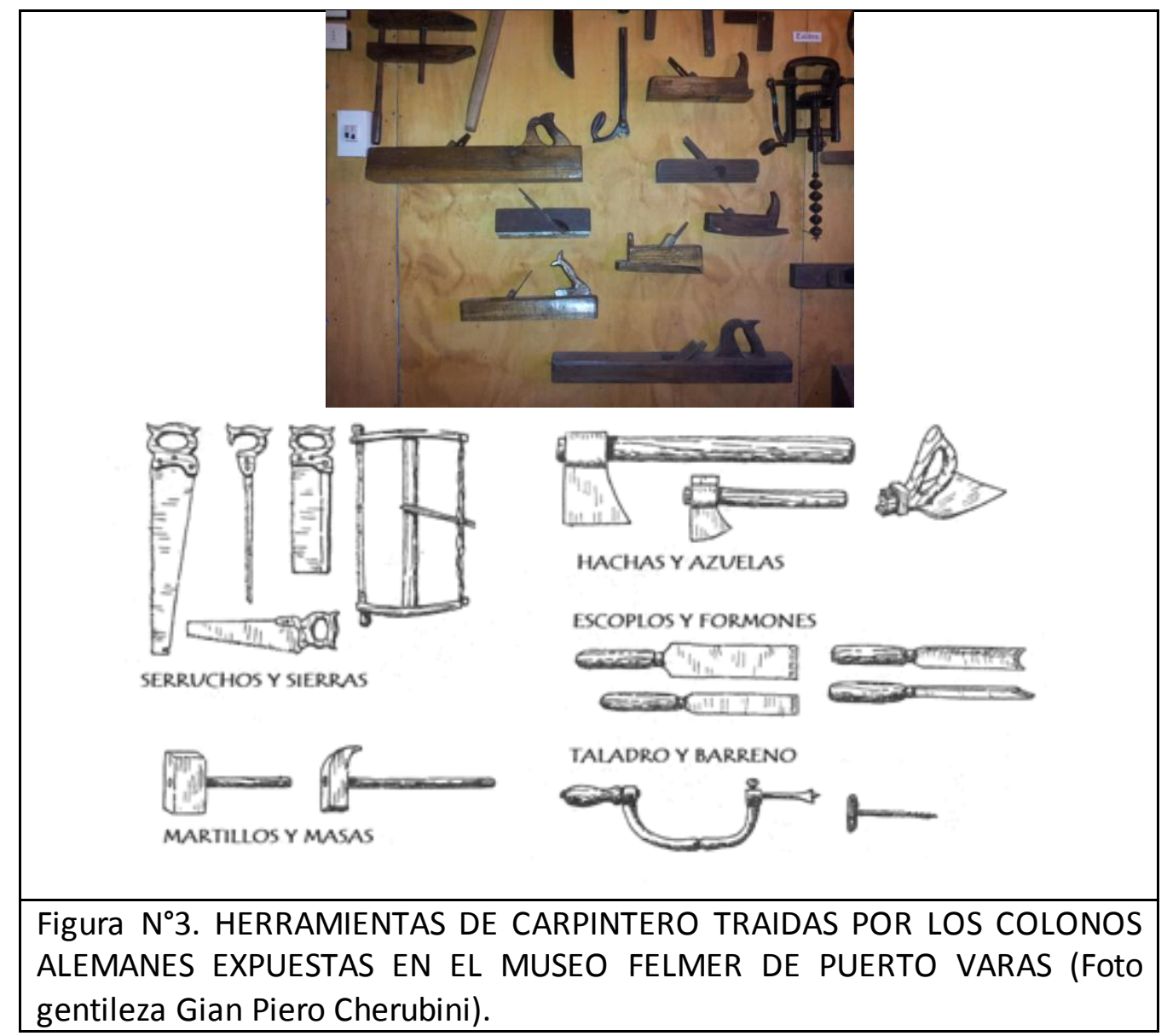

${ }^{115}$ Cuando se inició la colonización alemana, el contingente de colonos tanto los que fueron contratados como los que vinieron por decisión propia, provenía de un conjunto de 39 zonas, entre imperios, reinos, principados, granducados, ducados, y ciudades libres, asociados en la Confederación Germánica, los que conservaban su autonomía jurídica y legislativa. Esta confederación, heredera del Sacro Imperio Romano Germánico, y de la Confederación del Rhin, dependía del equilibrio entre el imperio austro húngaro y el reino de Prusia, cuya ruptura el año 1866 llevó a la formación del imperio alemán el año 1871. Estos hechos narrados sucintamente, sucedieron mientras ocurría la colonización alemana del sur de Chile. 
En 1842 llegó a Valdivia el polifacético abogado berlinés Wilhelm Frick ${ }^{116}$, quien antes de emigrar estudió ciencias naturales, física, química, inglés y castellano, además de oficios artesanales como carpintería y tornería. En Valdivia desarrolló una prolífica actividad, destacándose en el ámbito de la música, siendo considerado el músico más importante del siglo XIX del país.

Preconizó con su actitud una colonización voluntaria y desgermanizada, de una fusión sin reticencia con la población y la cultura local, lo que no consideraba como un hecho regresivo (Blancpain 1974). Como agrimensor hizo exploraciones y levantamiento de tierras para recibir a nuevos colonos, y rehízo los catastros de tierras y propietarios, perdidos después de la incorporación de Valdivia a la república de Chile en 1820 (Blancpain 1974, p. 99). Wilhelm Frick, fue un factor clave en la definición de nuevas formas constructivas y modelos arquitectónicos, no conocidos en la zona hasta ese momento.

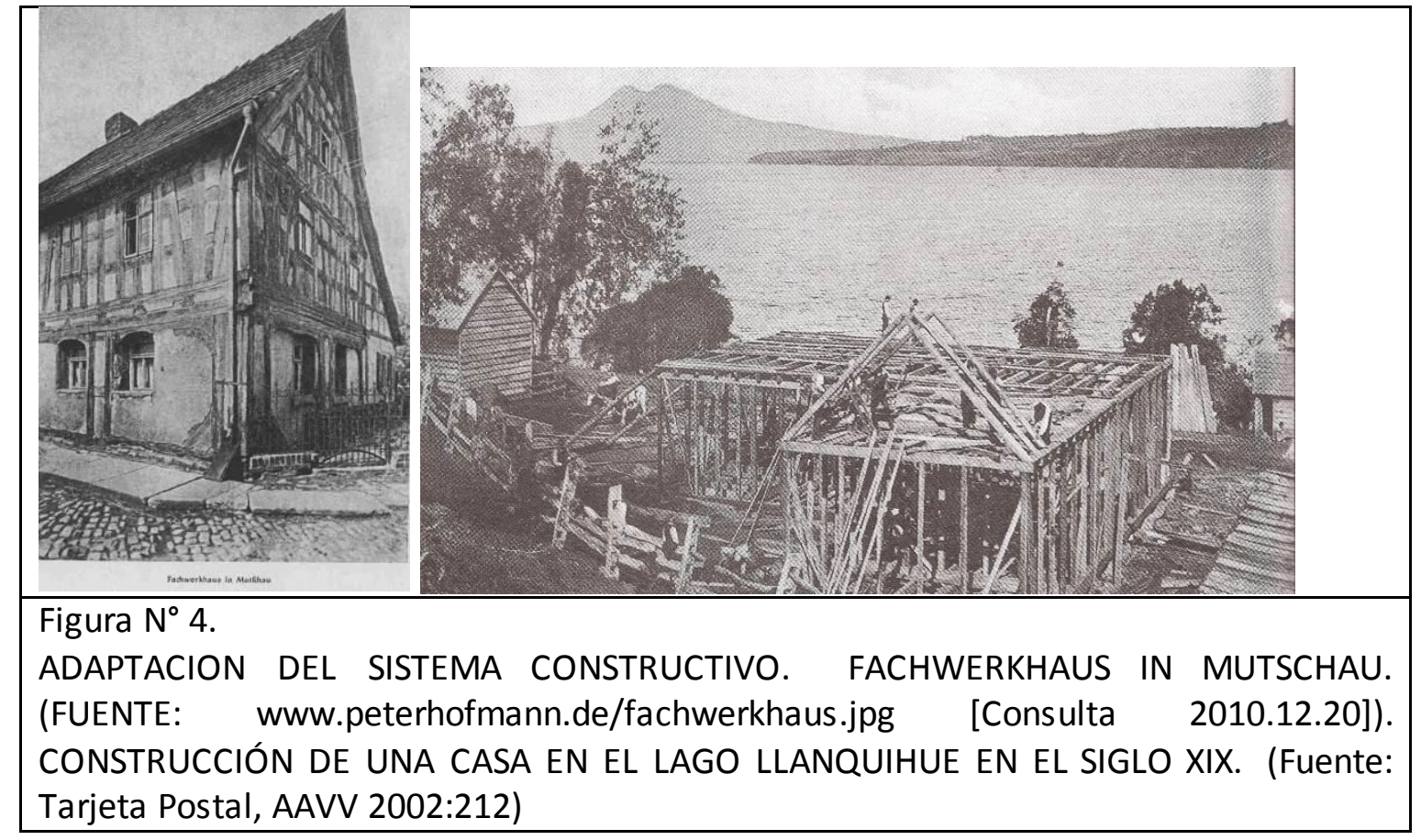

En el ámbito de la construcción adaptó el sistema de entramado nord europeo, conocido como fachwerk, a la realidad local revistiéndolo con tinglado de tablas, cubriendo las estructuras con tejuela en tres capas a la usanza europea (Cherubini, 2011).

\footnotetext{
${ }^{116}$ Wilhelm o Guillermo Frick nació en Berlín el año 1815. Estudio leyes por deseo familiar doctorándose el año 1834. Al quedar huérfano decidió emigrar a Chile. Amigo de Ia familia del naturalista Adalberto von Chamisso, quien pasó una temporada en Chile, se cree que fue quien lo influenció a emigrar a este país. Decidido a emigrar, reingresó a la universidad para estudiar química y tecnologías, recibiéndose en 1839. Llegó a Chile en 1840, recorriendo el norte del país, para finalmente fijar su residencia en la ciudad de Valdivia.
} 
Según Rasmussen el sistema constructivo de entramado había alcanzado en Europa un alto grado de estandarización que obligaba a los maestros a desarrollar importantes niveles de especialización (Rasmussen, 1957). Además el hecho que el distanciamiento entre pies derechos fuese siempre el mismo permitía la prefabricación de puertas y ventanas. Estos hechos entregaban como resultado una obra estéticamente ordenada y atractiva.

Otro aporte hecho por Frick fue la planta con corredor central que distribuye a los recintos interiores, como se presenta en el plano de una vivienda realizado por él y datado en 1850 (Guarda 1995) en donde se aprecia otra importante innovación, la del mirador como un volumen perpendicular a la fachada y centrado sobre el acceso (Guarda, 1995).

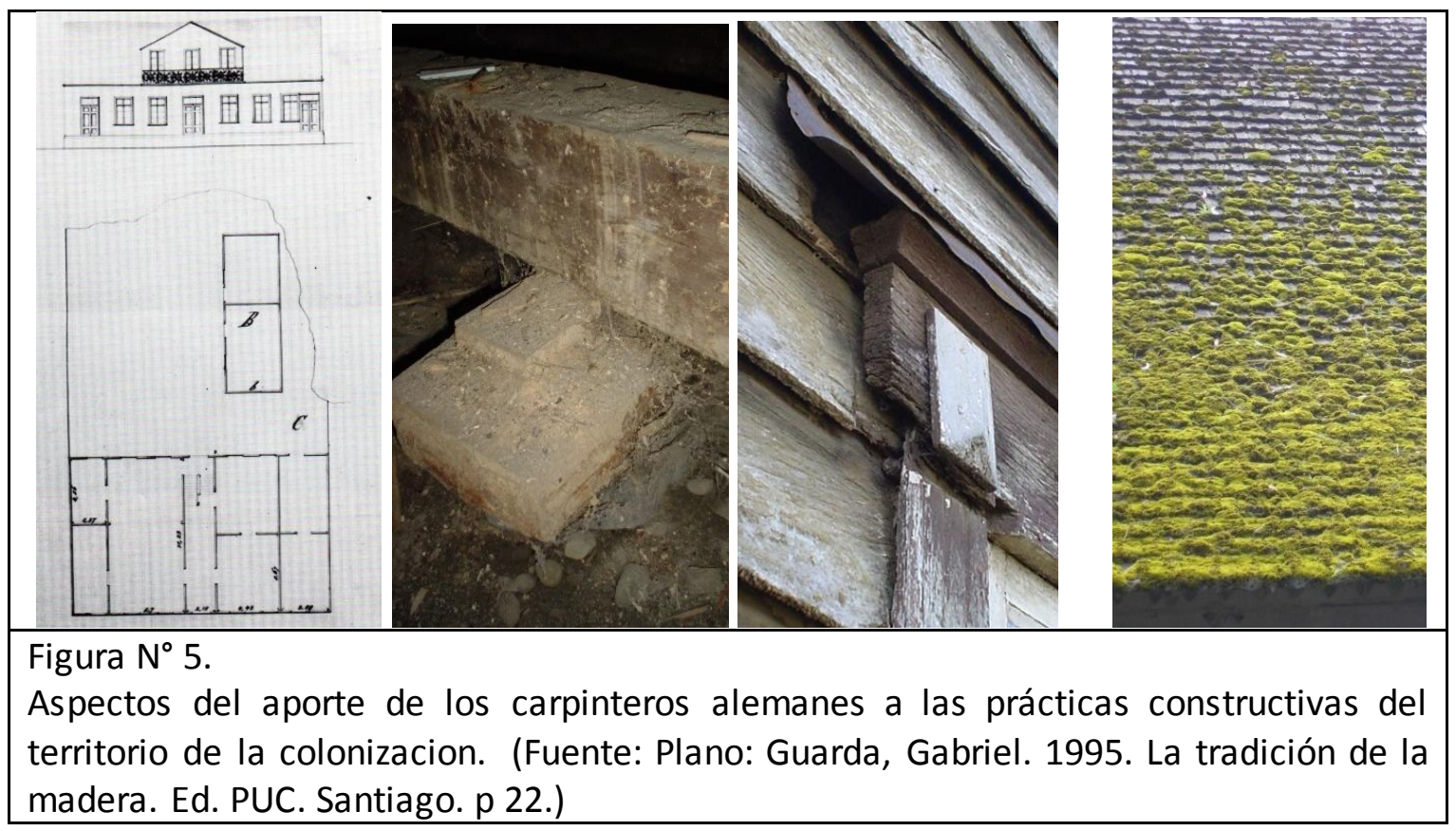

A partir de la obra desarrollada por Frick en Valdivia, el aporte de los colonos alemanes se puede concentrar en tres áreas (Cherubini, 2014). La primera son los aspectos técnicos entre los que están: el uso de fundaciones de piedra o madera para separar los edificios de la humedad del suelo y el uso de estructuras de entramados de madera con el sistema de plataforma, adaptados del fachwerk nord europeo, con revestimiento tinglado y cubiertas de tejuela.

El segundo aporte tiene que ver con los aspectos formales, entre los que destaca la planta compartimentada con recintos indiferenciados con pasillo central, la galería vidriada para trabajar los días de lluvias y la "stube", espacio calefaccionado por una cocina a leña o "estufa", una novedad en una región acostumbrada al fogón en el suelo, en el centro del rancho, lo que transformó la forma de vida en la región.

Por último están los aspectos formales y estéticos con las diferentes tipologías constructivas, la influencia del estilo neoclásico en las construcciones civiles y del neogótico en las construcciones religiosas, el uso de la simetría y el ritmo, estos 
últimos, consecuencia del sistema modular y estandarizado de la construcción con sistema de entramado de madera.

Estos aportes a la construcción de la arquitectura, son la base que dio sustento a la formación de la escuela de carpinteros de Puerto Montt, (Cherubini, 2011). Importante en la consolidación de esta escuela fue Matthias Doggenweiler, natural de Andelfingen en el reino de Wunttemberg, carpintero de profesión quién llegó a Corral en Agosto de 1852, trasladándose al astillero de Melipulli en noviembre de 1852. En su corta estadía en Valdivia, tuvo tiempo suficiente para enterarse de las formas y sistemas constructivos con los que se estaba construyendo la ciudad, de la mano de los activos maestros alemanes, con los aportes y adaptaciones hechas por Wilhelm Frick (Cherubini, 2011).

Una vez en la futura ciudad de Puerto Montt, se dedicó a ejercer su oficio, participando en la construcción de la casa del gobernador conocida como "el palacio", denominación que denota la calidad diferente en el diseño, en relación con lo que se había construido hasta ese momento en la zona. También construyó la catedral y el hotel Bellavista en Puerto Varas, todos edificios en los que se reflejaba la impronta neoclásica que imprimió a sus obras, es decir edificios donde gracias al uso de zócalos y cornisas es posible identificar los volúmenes sencillos que se apilan para dar forma a la obra. Es importante destacar que en enero de 1854 el comerciante español avecindado en Puerto Montt, José Díaz Belunzarán fue comisionado por el agente de la colonización para contratar trabajadores en el departamento de Achao para terminar los edificios fiscales (Held, 1980, p. 70), entre ellos el "palacio", en los que trabajaba el carpintero Doggenweiler. Esta relación permitió que los obreros chilotes aprendieran el oficio de la carpintería tal y como se practicaba en el norte de Europa, y les cupo la tarea de propagarlo más allá de la colonia del lago Llanquihue, ya que al no ser considerados colonos, no tenían derecho a tierras, por lo que pudieron circular libremente, llevando estos conocimientos y formas constructivas más allá de los límites del territorio de la colonización (cfr. Cherubini, 2011).

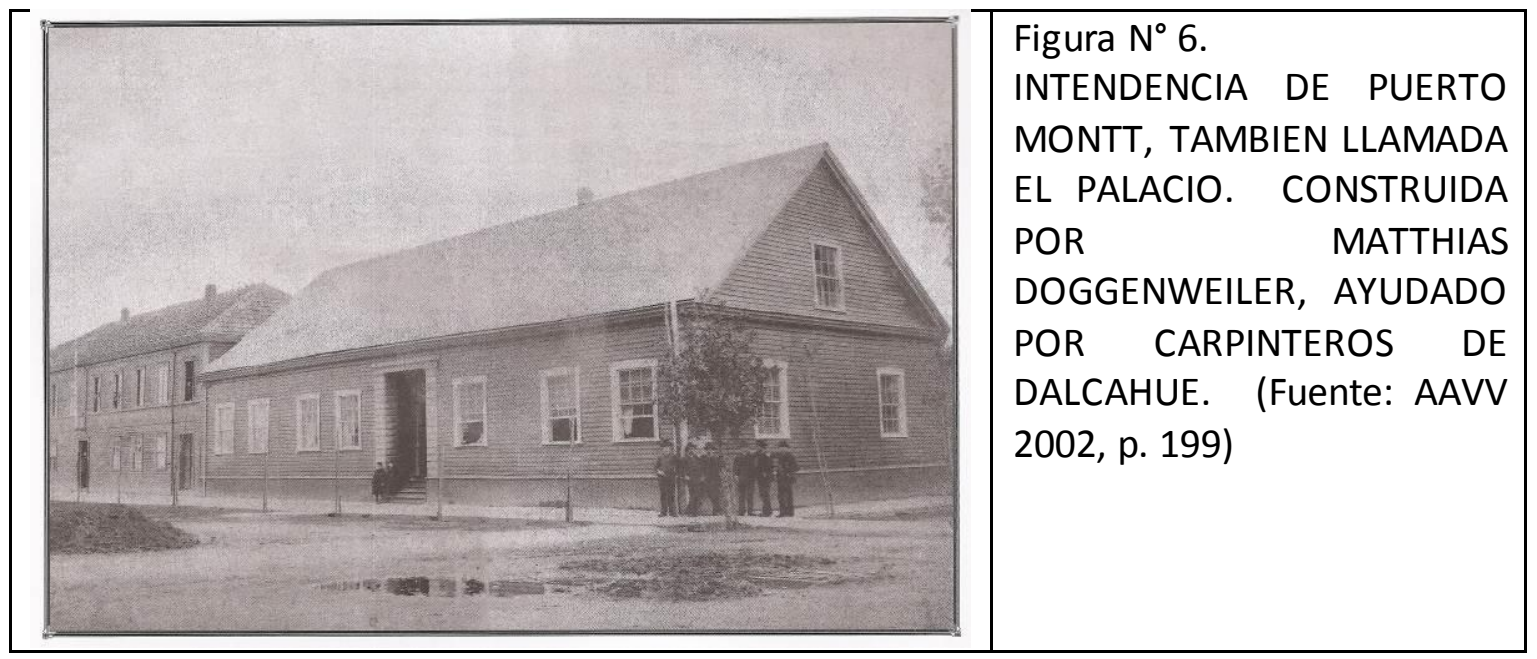

Otro aspecto novedoso que produjo la colonización alemana fue la mecanización de algunos procesos de la construcción, entre ellos el aserreo de la madera y la preparación de molduras prefabricadas. Los primeros aserraderos hidráulicos se 
construyeron en Valdivia en el siglo XVI, usados para obtener tablones y tablas (Guarda 1973). Seguramente, salvo las sierras de corte, eran construidos totalmente de madera, abasteciendo a mueblistas, constructores y carpinteros de ribera. Estos aserraderos desaparecieron después de la ruina de las siete ciudades.

La refundación de Valdivia en 1643 produjo el reflorecimiento de la industria de la madera y la reinstalación de los aserraderos hidráulicos (Berg \& Cherubini 2009). Después de la independencia, la economía de Valdivia decayó notablemente por la pérdida del comercio con el Perú. A pesar de esto, se construyeron tres aserraderos hidráulicos, uno de propiedad de un irlandés (Berg \& Cherubini 2009). Esto deja en claro que el desarrollo de la industria en general y la de la madera en particular, en Valdivia, era notoriamente diferente al de Chiloé, que mantuvo características artesanales y con bajo contenido tecnológico.

La llegada de los colonos alemanes significó un impulso para el desarrollo industrial, de tal magnitud que a fines del siglo XIX, después de creada la Sofofa, quince de las ochenta industrias que la formaban estaban en la región (Berg \& Cherubini 2009).

Después de fundada la ciudad de Puerto Montt, como enclave para colonizar las tierras en torno al lago Llanquihue, se inició la producción industrial de maderas en este sector. En 1867 ya había en la ciudad tres aserraderos hidráulicos, mientras un cuarto, ubicado en la localidad del Arrayán (actual ciudad satélite de Alerce), propiedad de Dartnell y Cia., era movido con vapor (Berg y Cherubini 2009). Este hecho facilitó la producción de madera dimensionada, la cual una vez en obra era trabajada con serrucho y azuela para darle la dimensión y terminación definitiva.

\subsubsection{Arquitectura Portuaria. ¿Sistema De Plataforma O Ballón Frame?.}

Todo lo descrito permitió el desarrollo de una arquitectura particular construida con sistema de plataforma derivado del fachwerk nord europeo ${ }^{117}$.

El sistema constructivo fachwerk consiste en envigados de madera sobre los que se apoyan los entramados o tabiques de primer piso formados por grandes piezas de sección cuadrada para los pies derechos, diagonales y cortafuegos ${ }^{118}$, los que a su vez reciben otros envigados sobre los que se arman otros tabiques que dan forma al segundo piso, y así sucesivamente hasta completar dos, tres o cuatro pisos. Finalmente, sobre el último envigado se construían uno, dos o tres tabiques, paralelos al volumen general, de diferente altura para colocar los tijerales que dan forma a la cubierta. Mientras sobre los envigados de piso se colocaban tablones, los intersticios de los entramados de muro se rellenaban con ladrillos, con adobes, tapial, o con un enrejado de ramas cubierto con una pasta formada por barro y estiércol.

De la descripción del sistema fachwerk se deduce que se trata de una variante del sistema de plataforma, cuya principal diferencia está en que en este último, el

\footnotetext{
117 La traducción de la palabra fachwerk hace referencia a los entramados de madera.

118 El cortafuegos es una pieza corta colocada en horizontal entre pies derechos y diagonales, usada entre otras cosas para que los elementos verticales no se flecten por el peso que reciben. En la Región de Los Lagos y en el sur en general, se les Ilama barrotes.
} 
revestimiento se coloca sobre el entramado de madera, de manera tal que éste queda hueco por dentro.

Para Rasmussen el sistema constructivo de entramado había alcanzado un alto grado de estandarización que obligaba a los maestros a desarrollar importantes niveles de especialización (Rassmussen 1957). Además el hecho que el distanciamiento entre pies derechos fuese siempre el mismo, permitía la prefabricación de puertas y ventanas. Estos hechos entregaban como resultado una obra estéticamente ordenada y atractiva.

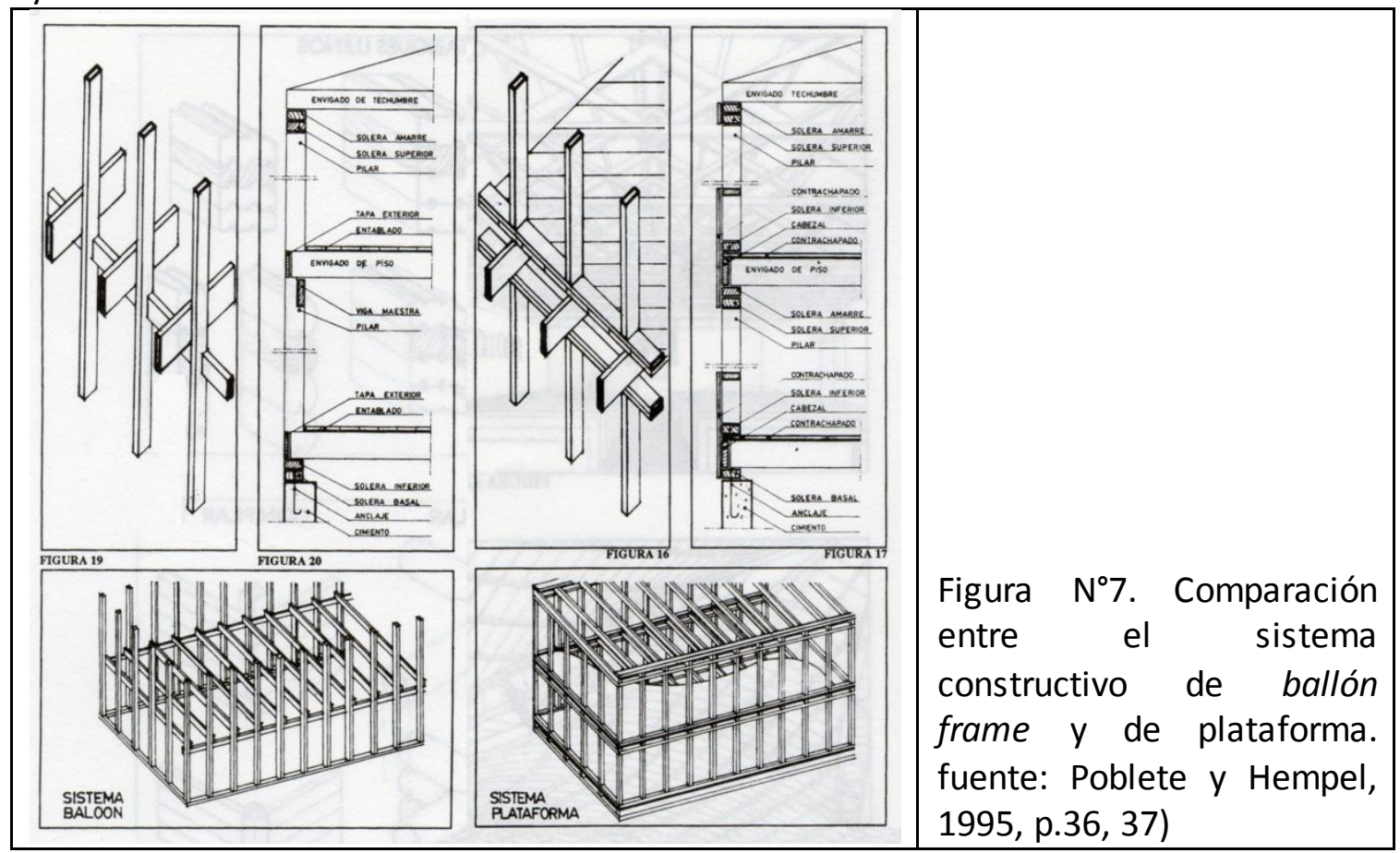

La tradición historiográfica en Chile ha propuesto que el sistema constructivo usado en la arquitectura tradicional del sur de Chile fue el Ballón frame, llegado al país con los barcos procedentes de California. Según el historiador Sigfried Giedion el sistema surgió en los Estados Unidos de Norteamérica en torno al año 1840, teniendo en la fabricación industrial de los clavos, uno de los factores que favorecieron su rápido desarrollo. El sistema de uniones clavadas hizo que la construcción fuese más rápida y eficiente (Giedion, 1941). El sistema de ballón frame consiste en que una vez construido el envigado del primer piso se levantan los tabiques exteriores, se arma la estructura de cubierta, se reviste y se techa, de manera tal que se puede trabajar en las divisiones interiores protegido de las inclemencias del tiempo. Es decir que se construye la cáscara (de allí la denominación de "Ballón"), para después rellenarla con divisiones de recintos, escaleras y envigados de entrepisos, revestimiento de interiores y terminaciones.

La lectura del libro de Giedion, así como la visión de las casas de Chiloé, en donde primero se arma la estructura resistente formada por tabiques de entramado de madera, plataformas de entrepisos y tijerales de cubierta, para después colocar la techumbre y revestir, para poder hacer las terminaciones interiores protegidos del clima, produjo esta confusión, que sin entrar en definiciones encontró aceptación en los ambientes profesionales. 


\subsubsection{Nuevos Imaginarios, Simbología Y Materiales.}

La colonización de la zona sur con contingente nord europeo proveniente de la confederación germánica primero, y del imperio alemán después, fue el hecho destinado a transformar profundamente el territorio de la actual región de Los Ríos y de Los Lagos.

La arquitectura no fue indiferente a este fenómeno. No sólo cambió la construcción con nuevos sistemas constructivos como el de plataforma, sino que nuevas tipologías formales aumentaron el imaginario de los habitantes de la región, tipologías que estaban presentes en los lugares de origen de los colonos.

Junto con sus enseres y herramientas, los colonos trajeron su forma de vida y de ocupación del espacio, a lo cual no renunciaron. Tempranamente construyeron sus viviendas desarrollando un amplio repertorio de formas arquitectónicas, cuya base fue la planta de cuatro recintos con un amplio pasillo central en donde era posible colocar una escalera sin interrumpir el paso, definiendo las topologías arquitectónicas de la primera etapa de la colonización y ocupación del territorio, que se extendió entre 1846 y 1875 (Berg \& Cherubini, 2009).

Mientras los colonos construían un sencillo edificio provisorio en sus parcelas, para cobijarse durante las faenas de despeje de terreno para iniciar las siembras, en Puerto Montt se construían casas de un piso con techo a dos aguas, cuyas vertientes eran paralelas a la calle con y sin mirador de dos pisos, con techo a cuatro aguas. En los edificios de dos pisos se construyeron también las casas de altos que tenían dos viviendas separadas en donde el pasillo del segundo piso es paralelo a la calle. Estas son las construcciones que se aprecian en las primeras imágenes conocidas de Puerto Montt.

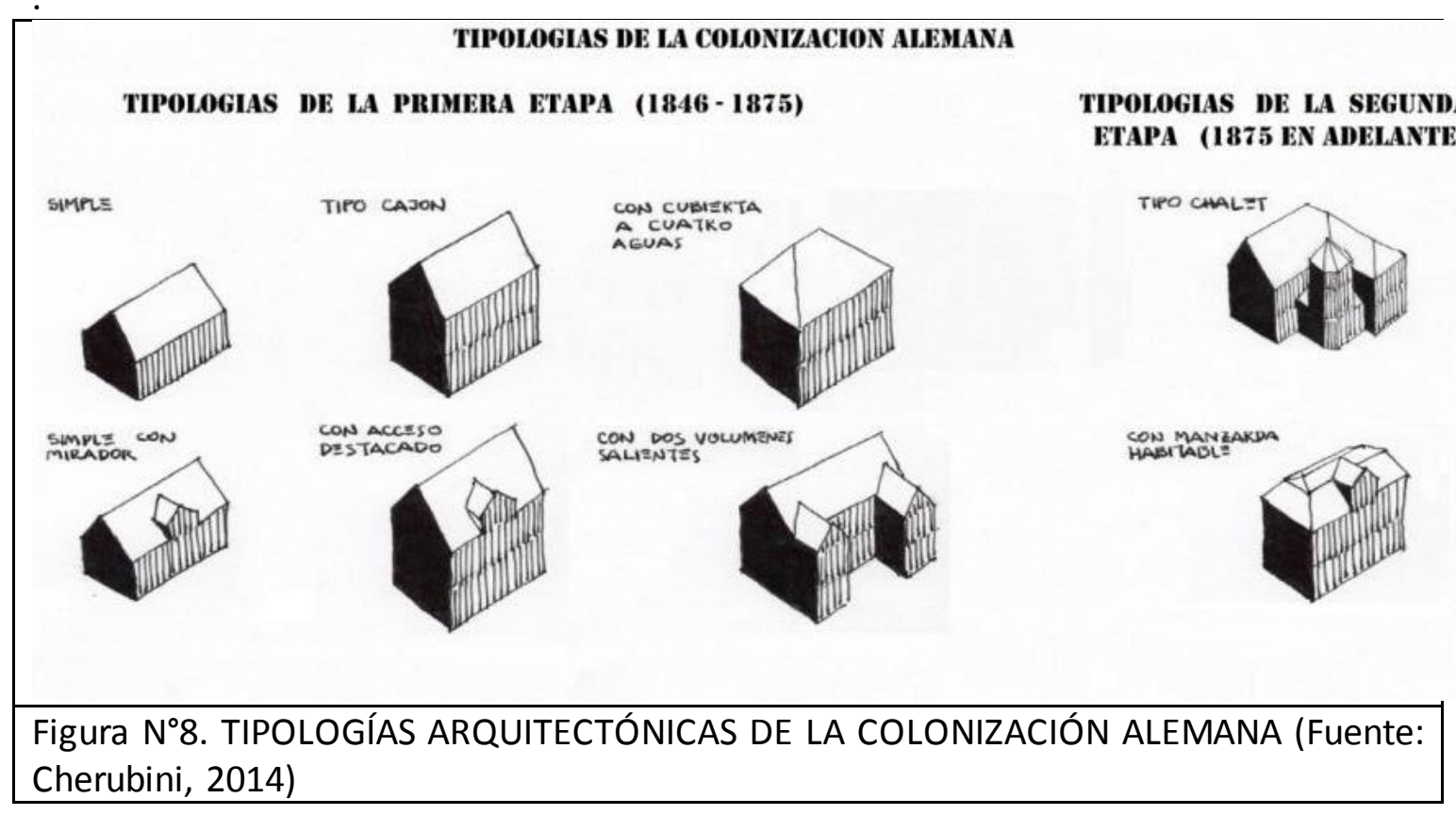


La planta de estas construcciones estaba determinada por una concepción estructural rígida, estandarizada y modular (Moraga, 2014), basada en el distanciamiento de los pies derechos, tal como lo describe Rasmussen (1957, p. 102-103), cuyos recintos no tenían una función predeterminada

Según el padre Guarda, tempranamente se construyeron edificaciones más complejas, tanto en su concepción estética como estructural. A este respecto cita la casa Werkmeister construida en Valdivia en 1864, siguiendo como modelo la casa del escritor Gotthold Ephraim Lessing ubicada en Wolfenbüttel en Baja Sajonia, la que estaba aislada de los vecinos, y tenía una planta en " $U$ " abierta hacía la calle generando un pequeño patio con un jardín de ingreso, y un juego de cubiertas amansardadas (Guarda, 1995Posterior al año 1870 la casa Stumpfoll en Osorno incorpora un torreón poligonal a un lado de la fachada (Guarda, 1995). Esto es un ejemplo de que las diversas tipologías que se desarrollaron en el periodo de la colonización eran parte del bagaje técnico y artístico que introdujeron a la región los maestros carpinteros, y son una prueba que pese a la precariedad de los inicios de la colonia, no abandonaron su forma de vida en el viejo continente .

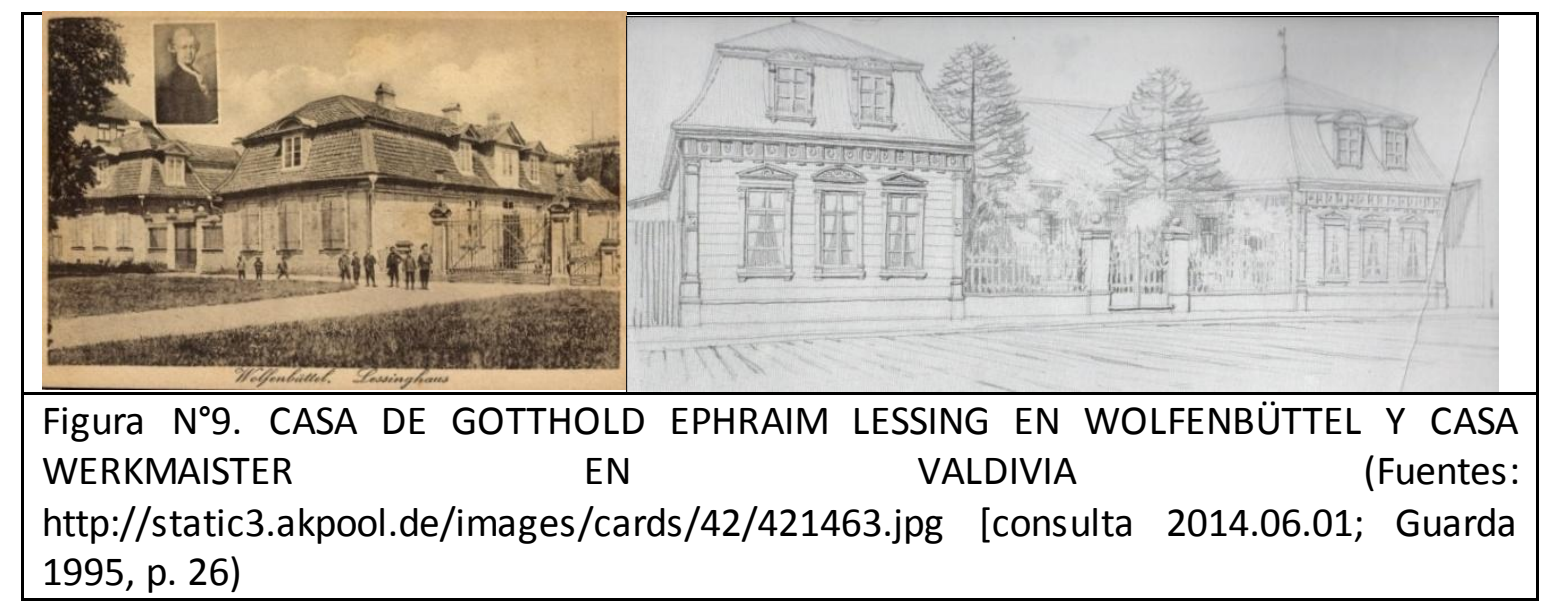

Sin embargo, estos modelos más complejos no prosperaron inmediatamente. Hubo que esperar que la confederación alemana sucumbiera a su propia conformación y diera paso al imperio alemán, hubo que esperar a que el pasado europeo de los "nuevos chilenos" se convirtiera en añoranzas romanticistas, hubo que esperar que el progreso del naciente imperio llegue a América impreso en postales, revistas, catálogos, o como narración en cartas de parientes y amigos, hubo que esperar que la "Epopeya" colonizadora pasara, y los colonos y sus descendientes volvieran a tomar el cauce de una vida normal, donde convivirían alegrías y tristezas, añoranzas y realidad.

Mientras tanto, la escuela de carpinteros alemanes de Puerto Montt, así como las variantes tipológicas que desarrollaron, maduró lo suficiente como para que los carpinteros se liberaran de la rigidez formal que imponía el sistema constructivo (Moraga, 2014). Apareció la villa aislada que propuso una nueva disposición de los recintos a partir de una sala de distribución, conocida como "hall de ingreso" que daba cuenta de la totalidad de la casa y que permitió una mayor libertad creativa (Cherubini, 2014 b), dando origen a una arquitectura de influencia romanticista, en donde las 
plantas asimétricas eran adornadas con torreones de planta circular o poligonal, con cubierta bulbosa con cúpula o con faldones rectos, con volúmenes salientes de diversa altura; los tímpanos eran decorados con elementos estructurales que recordaban las estructuras de madera que conformaban todo el edificio; los adornos de puertas y ventanas mezclaban motivos neoclásicos, neorrenacentistas, neogóticos.

Esta transformación desarrollada en el último cuarto del siglo XIX acogió el "jugenstil" como una forma más a inicios del siglo XX y a partir de 1930 en Puerto Montt de la mano del arquitecto Alberto Oettinger Stegmaier ${ }^{119}$ (Cherubini, 2014, b).

Un nuevo universo creativo se abrió al desarrollo arquitectónico de la región, construido en madera, cuyas formas y métodos constructivos permanecieron hasta pasado la mitad del siglo XX, en paralelo a nuevos modelos como los propuestos por el jugenstil o el movimiento moderno en arquitectura.

\subsection{Iglesias en el territorio de la colonización del lago Llanquihue.}

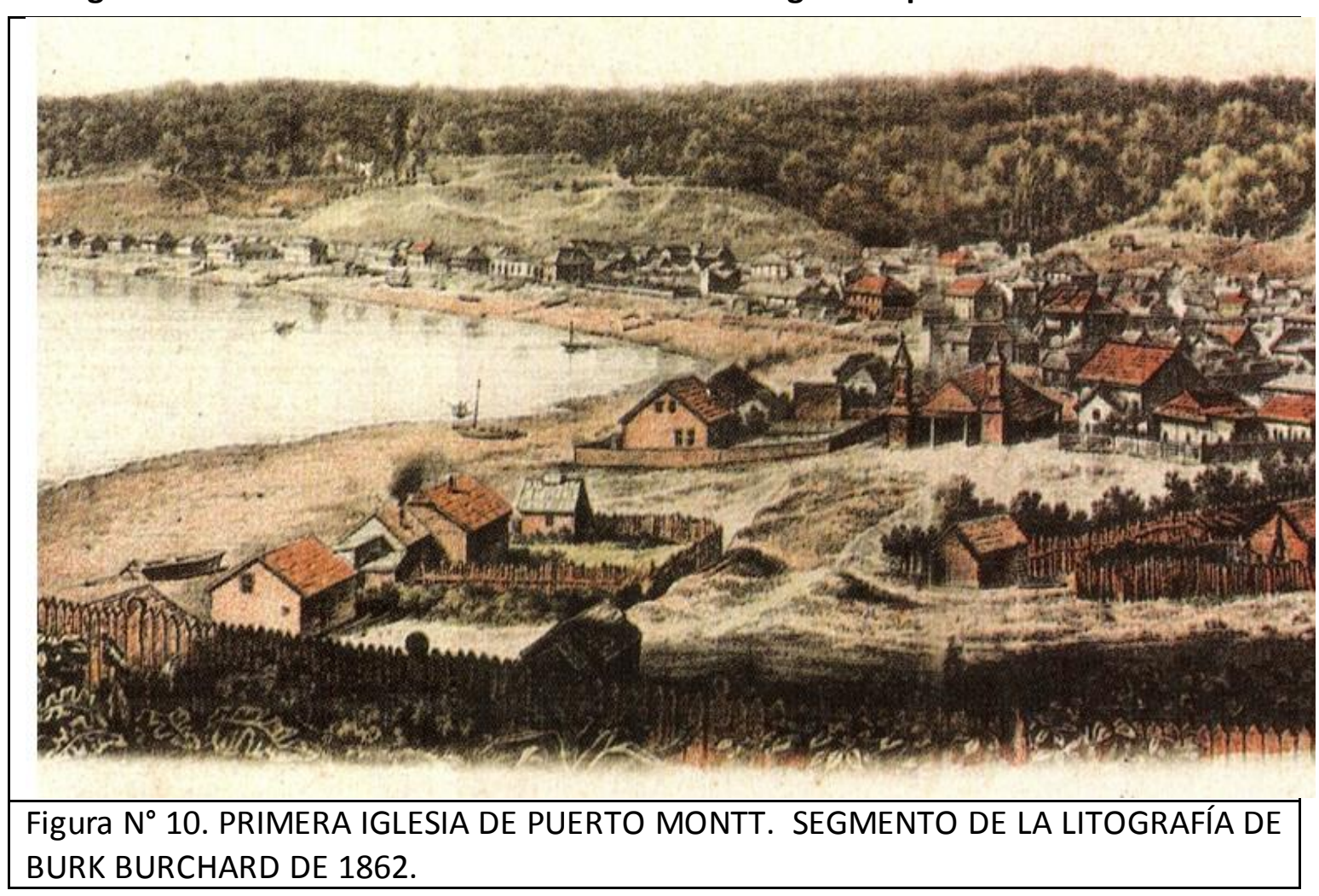

Resumiendo brevemente el desarrollo tipológico de las iglesias católicas ${ }^{120}$ de la cuenca del Lago Llanquihue, en lo que corresponde al antiguo territorio de la

${ }^{119}$ Alberto Oettinger Stegmaier nació en Valdivia en 1889. Estudió arquitectura en la Universidad de Chile. Empezó a trabajar en Valdivia. En 1930 se trasladó a Puerto Montt. Se tituló por méritos en 1936. En 1940 se trasladó a Puerto Varas en donde continuó su fructífera labor. Falleció en 1970. Fue el principal promotor del Jugenstil y del movimiento moderno, esto último influenciado por el arquitecto Elizardo Bravo Scherdel (Cherubini, 2014 ,b). 
colonización alemana es posible concluir que tuvo un carácter más experimental, lo que se expresa en la forma con que fue variando el modelo de acuerdo a los requerimientos y experiencias de los colonos.

Interesante destacar que los artífices de estos edificios fueron colonos o sus descendientes (Guarda, 1984), o como en el caso del padre Enrich, llegaron a apoyar la colonización.

La primera iglesia de Puerto Montt era un volumen simple al que se agregaron dos torres en el pórtico que flanqueaban la entrada. Esta iglesia construida en 1854 era de un modelo similar, aunque más pequeña, a la iglesia diocesana ubicada en la plaza de Osorno de la cual se trata en otro apartado. Su construcción se asocia a los inmigrantes alemanes, y entre ellos al maestro carpintero Matthias Doggenweiler, uno de los principales artífices de la escuela de carpinteros alemanes de Puerto Montt (Cherubini, 2011). En 1865 ya estaba en malas condiciones, siendo destruida por un incendio (Held, 1988).

En 1867 el profesor Miguel Majewsky ${ }^{121}$ construyó en Playa Maitén una pequeña capilla de tres naves y presbiterio entre la sacristía y la bodega, con un volumen sencillo techado a dos aguas con pórtico y torre de planta cuadrangular de una caña sobre el pórtico. Este modelo con pórtico en la fachada no prosperó, ya que tres años después, construyó otra capilla, esta vez en Puerto Fonk, con planta de tres naves con la sacristía más ancha que la bodega y coro sobre el acceso, cuya fachada ostenta una puerta y un rosetón circular sobre ésta como única decoración. La torre, también de una caña era de planta octogonal (Cfr. Guarda, 1983).

La llegada de los jesuitas a Puerto Montt trajo como consecuencia la construcción de un interesante conjunto de capillas en diversos sectores del Lago Llanquihue.

Siguiendo este modelo más sencillo el padre Francisco Enrich S.J. ${ }^{122}$ construyó una capilla en Puerto Varas dedicada al Sagrado Corazón de Jesús, el año 1872 en el sitio que ocupa actualmente la plaza de la ciudad (Horn, 1983.). Dicha iglesia sucumbió en un confuso incendio el año 1890, que algunos historiadores han asociado a disputas entre católicos y luteranos.

${ }^{120}$ En este caso en especial es necesario precisar que otra vertiente de análisis de interés en lo que se relaciona con edificios de carácter religiosos, son los templos luteranos, los que no sean tratado en mayor profundidad, para no desviar la atención del objeto principal de este estudio.

121 Michael Majewskyllegó a Corral el año 1863, contando cincuenta años de edad. Se inscribió en las listas como religioso (Held, 1970.). Trabajó como profesor en Frutillar, Playa Maitén y Puerto Varas. Las crónicas se refieren a él con el nombre de Nicolás (Held ,1986.).

122 El padre Francisco Enrich S.J. nació en la ciudad catalana de Manresa el año 1817. Ingresó a la Compañía de Jesús en 1832. En 1837 fue destinado a Argentina en donde fue ordenado sacerdote. Expulsado de ese país durante el gobierno dictatorial de José Manuel de Rosas, pasó a Chile el año 1848. Una vez en Chile, el Prepósito General de la Compañía le solicitó que escribiera la Historia de la Compañía en Chile, la que se imprimió en forma póstuma. Hizo una misión popular en Puerto Montt el año 1860, regresando el año 1869 como Superior de la residencia. En donde permaneció hasta el año 1877. Falleció en la residencia de Concepción el año 1883. 

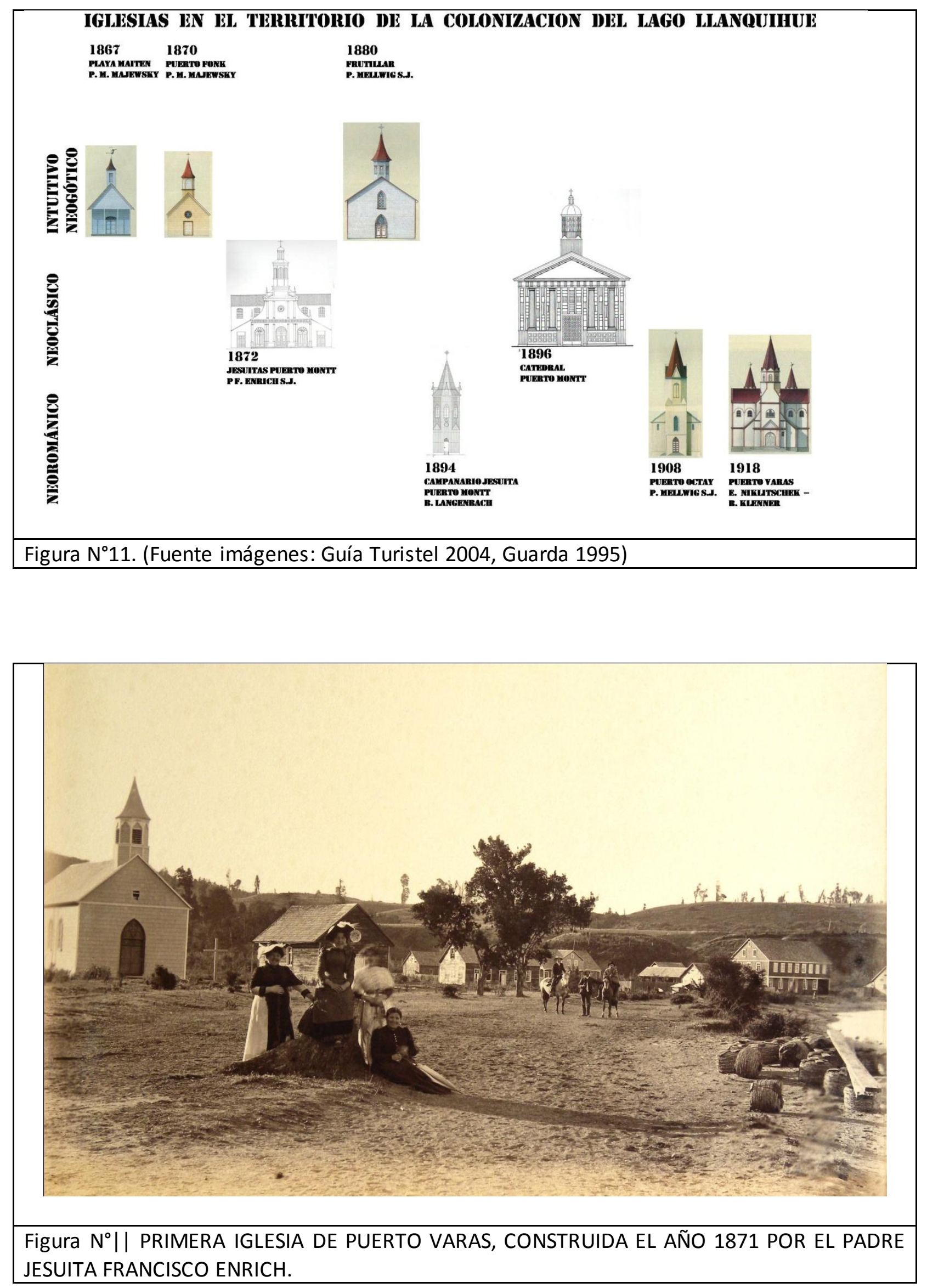
La iglesia de Frutillar sigue el mismo esquema de la de Puerto Fonk, aunque de mayor dimensión. Fue construida en 1884 (Tampe, 1983) ${ }^{123}$ por el padre Juan Mellwig S.J. ${ }^{124}$ con una marcada influencia gótica. El padre Mellwig fue un activo constructor de iglesias, para lo cual involucraba a la comunidad de cada localidad. En 1892 construyó la capilla titulada a María Auxiliadora en Nueva Braunau que se desplomó con el terremoto de 1960; la de la Asuncion de la Virgen en Quilanto en el año 1886; la de San Pedro Claver en Ensenada en 1892, la de San Juan Evangelista de Colegual y la de la Virgen del Carmen en Línea Santa María, ambas el año 1893, y la de Paraguay Chico el año 1902 (Tampe, 1983). Todas estas capillas seguían el esquema de la de Frutillar, es decir un volumen sencillo, sin pórtico y con torre octagonal.

En 1872 el padre Francisco Enrich S.J. construyó la iglesia de la Compañía en Puerto Montt con planta en cruz latina y fachada compuesta en estilo neoclásico siguiendo el modelo de fachada tradicional de otras iglesias jesuitas, a la que agregó un dado y una torre circular que imita el templo de Bramante en San Pietro in Montuorio en Roma (Cherubini 2006), un modelo único en la zona en cuanto a la precisión estilística, de la cual se hizo una reproducción popular en el sector de Quetrolauquen en la Isla Huar (Mansilla, 1991) $)^{125}$.

En 1894 lo padres de la Compañía pidieron al carpintero Teodoro Langebach la construcción de un campanario, el que tenía dos cañas, la primera de planta cuadrada y la de arriba de planta octogonal, conectadas por medio de faldones triangulares y coronado por una cubierta de gran pendiente (Cherubini, 2007, b).

En 1896 se bendijo la iglesia Catedral de Puerto Montt en cuya construcción trabajaron los principales maestros constructores de la ciudad, entre ellos Mathias Doggenweiler. Sigue al mismo esquema volumétrico simple con torre octogonal, al que se le sobrepuso en la fachada un portal dórico tetrástilo como si fuera un retablo (Cherubini, 2007, a).

En 1908 el padre Juan Mellwig S.J. párroco de Puerto Octay reconstruyó la iglesia incendiada el año anterior (Tampe, 1992), con un edificio que ostenta una torre centrada en el acceso, y que avanza sobre el volumen principal resaltando de esta manera el acceso, reforzando el carácter vertical del templo. La torre de dos cañas repite la forma general del campanario de los jesuitas en Puerto Montt, diferenciándose de esta en los tímpanos que coronan las cuatros caras de la caña superior.

123 Otros autores entregan como fecha el año 1880 , la cual es poco probable, ya que el padre Mellwig llegó a Puerto Montt el 19 de octubre de 1881.

${ }^{124}$ El padre Juan Mell wig nació en Scherdefe en Westfalia el año 1845. Ingresó a la compañía el año 1868. Participó como enfermero en la guerra franco-prusiana, después de la cual fue desterrado a Inglaterra en donde concluyó sus estudios ordenándose sacerdote el año 1880. Al año siguiente emigró a Chile, embarcándose en Liverpool. En este país se dedicó principalmente a las misiones en la Colonia del Lago Llanquihue. El año 1893 fue párroco de Puerto Varas. El año 1904 fue destinado a Puerto Octay en donde construyó la iglesia y la reconstruyó el año 1908 después del incendio. Murió en este poblado el año 1928 (Tampe 1983 b: 38-34).

${ }^{125} \mathrm{El}$ historiador José D. Mansilla Almonacid presenta una imagen de la iglesia Tres Torres de Quetrolauquén, en la contratapa de su libro La Misión Jesuita de los indios Chonos en San Felipe de Huar (Edicion Particular del autor de 1991), la cual es un facsímil de un sello postal, basada en una fotografía tomada por Isidro Vásquez de Acuña. 


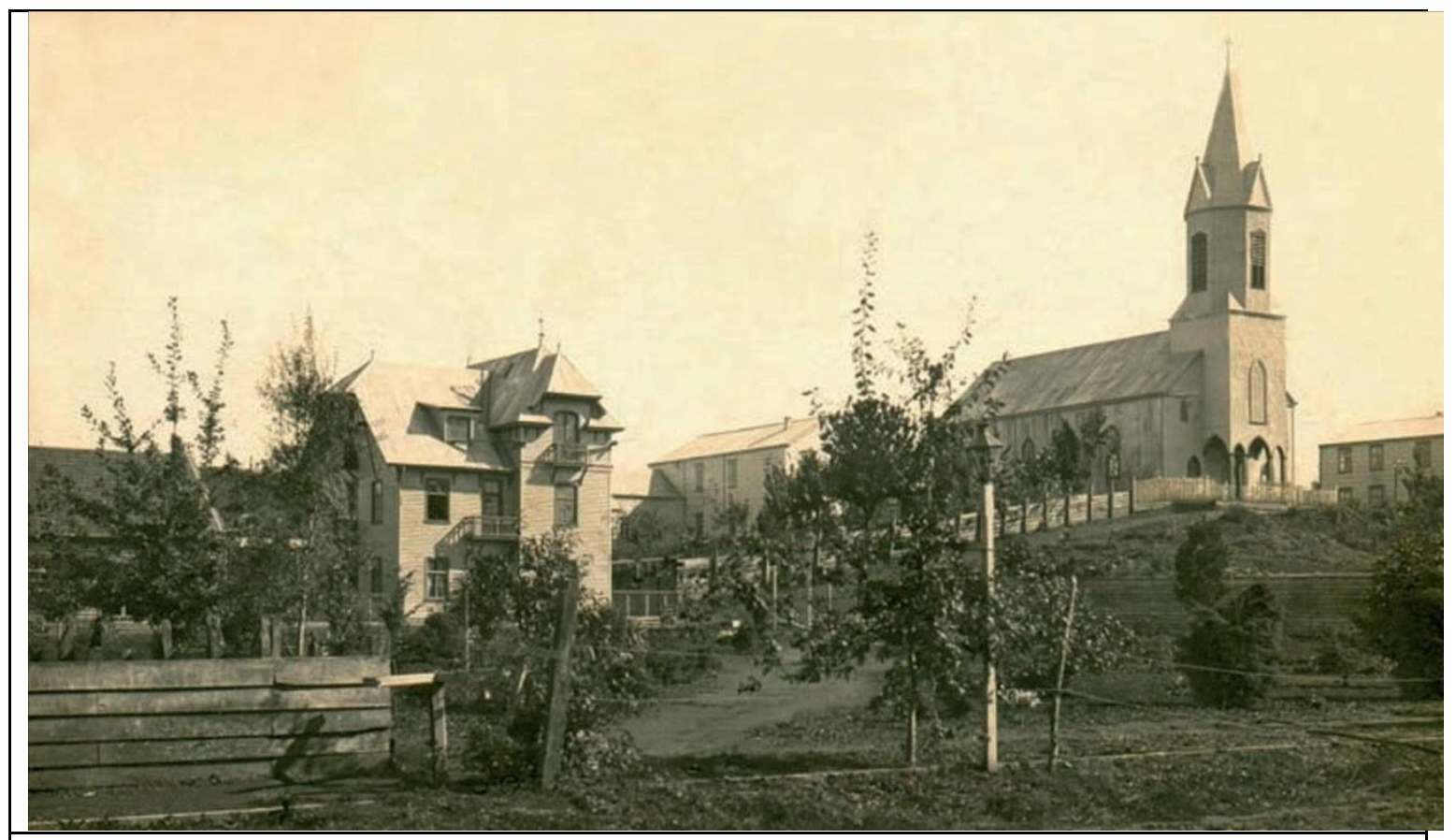

Figura $\mathrm{N}^{\circ}$ 12. IGLESIA DE PUERTO OCTAY. EL INGRESO BAJO LA TORRE APARECE DESCUBIERTO, COMO FUE ORIGINALMENTE.

Entre 1914 y 1918 se construyó la iglesia del Sagrado Corazón de Puerto Varas, siguiendo el proyecto de la Marienkirche en la Selva Negra en Alemania (Horn, 1983, p. 24-27), con planta en cruz latina con deambulatorio cerrado para colocar la sacristía. La interesante volumetría está dominada por la torre del acceso que avanza sobre el plano de la fachada similar al citado modelo del campanario de los jesuitas, y que determina la influencia neorománica en estas iglesias, tanto del campanario jesuita como de la iglesia de Puerto Octay que las acerca a una idea romanticista de la historia.

Este resumen deja entrever como la evolución tipológica de las iglesias en la colonia del Lago Llanquihue se desarrollaron en base a un modelo intuitivo de una torre y sin pórtico en la fachada. La forma sencilla de estas primeras iglesias es un manifiesto a la necesidad de albergar a la comunidad en un clima hostil. Sin embargo los ejemplos culminantes de estas iglesias, como son el templo de la Compañía de Puerto Montt, así como la iglesia del Sagrado Corazón de Puerto Varas, tienen planta en cruz latina, con cúpula sobre el crucero y claristorio sobre la nave central, las que responden a complejos cánones estilísticos del neoclásico y del neorrománico. Otro hecho interesante de rescatar es el aumento de complejidad con el paso del tiempo, en los estilos arquitectónicos y en los detalles constructivos.

De lo anterior podemos establecer que se trató de un desarrollo independiente en sus aspectos estilísticos, y que con el tiempo trató de vincularse con la arquitectura neorománica y neogótica, que se identificaba mejor con los países del norte de Europa, un aspecto que delata el romanticismo que imperó en la arquitectura de la época. 


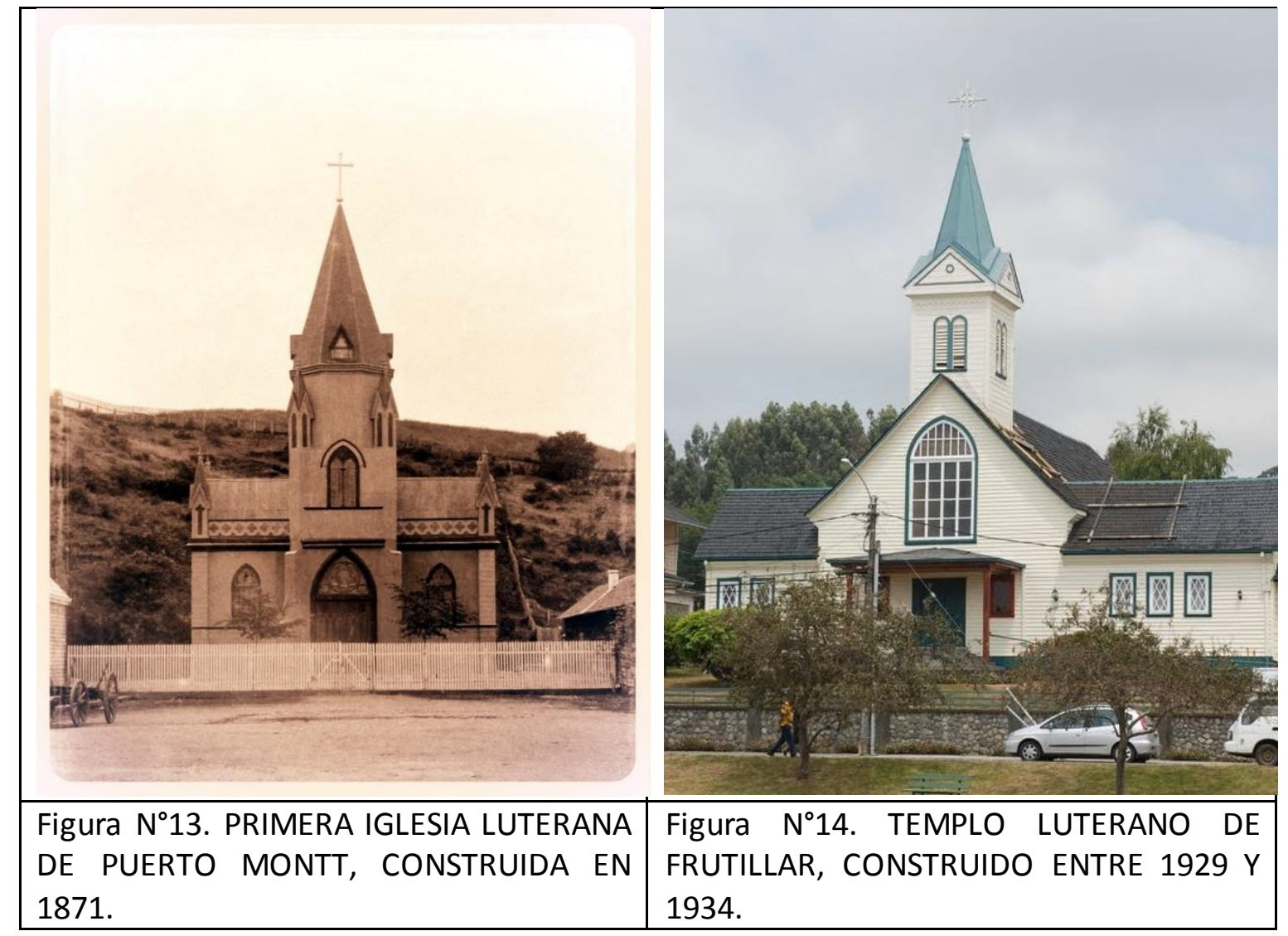

Esta búsqueda de una identidad nacional, que se dio en la arquitectura religiosa católica, estuvo ausente en el caso de los luteranos, quienes tempranamente construyeron un templo de influencia neogótica en Puerto Montt, mientras que el de Frutillar, construido entre 1929 y 1934, a pesar de la influencia neogótica, sus líneas más contemporáneas reflejan el espíritu menos conservador y más progresista de la comunidad. 


\section{CAPITULO 6. LA REALIZACION DE LAS CAPILLAS TRADICIONALES DEL SIGLO XIX.}

\subsection{La configuración tipológica de las capillas tradicionales de Chiloé.}

Los modelos de los franciscanos en la Iglesia de Osorno y Castro, sucesores de los jesuitas, son el resultado de una serie de variables que van de alguna manera conduciendo a los diversos ejecutores isleños (arquitectos, constructores y carpinteros) hacia una solución arquitectónica tremendamente eficiente en el medio en que se insertaba y como respuesta local a su tiempo.

La estética epocal. Cada momento histórico se ha expresado con determinados gustos estéticos que los representan mejor. En este caso de las capillas chilotas fue la influencia del Neoclásico, traída por los misioneros franciscanos italianos. Esta corriente estilística usa ciertas maneras de componer los edificios públicos y religiosos, entre los cuales muchos se caracterizaron por disponer de una torre en el eje de acceso de la fachada principal. Esta composición fue muy utilizada en Chile a partir de la instalación de la República, a diferencia del período Colonial donde la torre o campanario normalmente iba a un costado o se usaban dos, flanqueando la fachada de los templos. La tipología de torre única y centrada en el acceso, se da en muchos templos religiosos señeros en Chile, solo por citar algunos están: la Iglesia de la Recoleta franciscana, el Buen Pastor en Santiago, la de Cerro Barón en el modelo de Provasoli en Valparaíso y concretamente todas las chilotas.

Esta disposición contiene desde el punto de vista formal un gran simbolismo y pregnancia para un edifico religioso, al acusar jerárquicamente el punto de entrada al edificio y de encuentro entre un eje vertical (celestial) con el eje de la nave (terrenal), de tal modo señala la relación exacta entre Dios y el hombre. Por lo demás la torre se sitúa en el eje exacto de la simetría especular, controlando todo el orden y la regularidad del trazado en forma perfecta, siendo un principio básico de las nociones de belleza y orden en que se inspira la arquitectura clásica, según los cánones de diseño antropomórficos ${ }^{126}$ (Norberg-Schulz, 1983).

La expresión neoclásica en las capillas chilotas se presenta no solo en la configuración arquitectónica de la torre fachada, sino que también en el tratamiento de detalles que se manifiestan en ella como en el interior, referido a los decorados y ornamentos que se utilizan. Esta viene a ser una de las particularidades de tales edificios, que por el exterior manifiestan en la torre fachada una carpintería siguiendo, algunas veces más $u$ otras veces menos, una connotación neoclásica. Sin embargo el volumen horizontal de la nave mantendrá una expresión exterior absolutamente austera que expone la

\footnotetext{
${ }^{126}$ Actualmente numerosos estudios científicos han demostrado que nuestra mente, a este tipo de organización de simetría especular las valida como las más hermosas, basado en que es la principal condición estética para que nos atraigan más o menos los miembros de nuestra especie.
} 
más verdadera presencia de una fábrica de madera, de muros solo revestidos en tabla o tejuela y ventanas de formato vertical, todos estos sin ningún decorado.

Presencia en el paisaje, la irrupción de un elemento vertical como una torre en entornos geográficos ya sea en núcleos urbanos o rurales son indudablemente hitos de referencia que sitúan un lugar específico. En el caso de Chiloé adquirirán mayor valor dado que el sistema de comunicación era por mar haciendo que las torres definitivamente se constituyan en faros de navegación, lo que aún sigue vigente. Una mayor altura de estos elementos también contribuye al tañir de las campanas y su efecto en la vecindad, junto con señalar jerárquicamente el lugar de la capilla y de Dios.

Racionalidad y Economía formal. Esta arquitectura decantó en una forma perfectamente acondicionada a los requerimientos simbólicos, funcionales y climáticos. Junto con sintetizar a través de dos cuerpos simples, el volumen horizontal, la nave para los hombres, y el volumen vertical, la torre hacia Dios, alcanzando una composición muy simple, coherente con una lógica estructural y constructiva absolutamente integrada como sistema. Se puede describir que llega en este proceso a un punto de máxima decantación y síntesis tipológica.

Por un lado, la política de ensayo y error habitual en el desarrollo de la arquitectura tradicional (la cual se "decanta» por sí misma cuando encuentra el punto correcto de equilibrio) supone un componente experimental y una adecuación a las condiciones físicas que la arquitectura "histórica», que opera sobre seguro, no podía realmente aspirar a alcanzar de hecho... (Maldonado \& Rivera, 2005, p 690).

Es un hecho que la idea de máxima decantación se cifra en una fábrica que combina una potente imagen de edificio religioso interior y exterior modelado en madera para emplazarse en un territorio lluvioso y frío. De tal modo que la modelación, en este contexto, más eficiente es aquella que permite levantar signos claros con formas precisas que permitan resolver un espacio sagrado protegido con el único recurso material existente y el saber local heredado: la carpintería.

Bajo estas condiciones la fábrica de madera debe ser modelada volumétricamente, por la naturaleza del material y el ambiente en que se emplaza, a partir de planos exteriores inclinados y verticales con el único propósito de hacer bajar el agua de Iluvias al terreno. No existe ningún plano horizontal que permita que se aloje el agua, produciendo la pudrición de las maderas, sino que son una secuencia de planos verticales e inclinados tanto la torre como la nave. De hecho se ha eliminado prácticamente todo elemento o volumen que incorporen limahoyas y así impedir ingresos de aguas, solo existe en el encuentro de la nave y torre, único punto débil en la hermeticidad de la envolvente. Incluso las ventanas con celosías para ventilar, son sin vidrios, y con tablillas en diagonal. Estos principios permiten, mediante una buena mantención periódica, lograr larga data a estos edificios, superando centurias de viento y lluvia, como ya lo han demostrado. 


\subsection{La multiplicación del tipo en modelos por el archipiélago, la racionalidad constructiva.}

\subsubsection{Sistema estructural y constructivo o implicancias composicionales del sistema constructivo.}

Primero se tratará la racionalidad del sistema de medidas y sus efectos en la lectura de las proporciones.

El profesor danés Kaare Klint, "descubrió que es imposible encontrar un sistema coherente en las proporciones de los edificios cuando estos se medían en metros y centímetros, pero cuando se medían en pies y pulgadas todo se volvía claro y sencillo" (Rasmussen, 1957, p. 104). Esta aseveración tiene sentido, ya que los edificios antiguos fueron ejecutados con un sistema de medidas diferentes al sistema métrico decimal creado en 1791 y aceptado oficialmente en Chile el año 1908, cuando se firmó la convención del metro. Además muchas de estas construcciones fueron realizadas siguiendo cánones estéticos precis os que se ajustan a otros sistemas de medidas.

En Chiloé, la implantación del sistema métrico decimal tomó tiempo, superponiéndose con el sistema de varas y pies castellanos. En los registros de las iglesias anotados en el libro Las Iglesias Misionales de Chiloé (Montecinos et al 1995) aparece citado por primera vez el metro como patrón de medida en 1888, cuando se indican las dimensiones de la iglesia de Santa María de Achao. Sin embargo, en los mismos registros, pero esta vez en 1903 se vuelve a citar la vara como patrón para indicar las medidas de los terrenos de propiedad de la iglesia (Montecinos et al 1995)

Cuando el padre Bohle trazó el plano de la iglesia de San Judas Tadeo de Curaco de Vélez, el año 1901, anotó que esta medirá cuarenta y cuatro varas de largo y dieciocho de ancho, mientras que para la altura señala veintisiete varas (Montecinos et al 1995, p. 69-70). Lo mismo sucedió con las dimensiones anotadas por Agustín Guaiquín en al plano para la torre de Tenaún, y la escala gráfica del proyecto para la iglesia de Quinchao sin embargo para esta se indicaba en 1883 que medía 59,77 metros de largo y 23,41 metros de ancho.

Los edificios durante el periodo colonial y republicano hasta finales del siglos XIX se construían utilizando sistemas de medidas basadas en la del cuerpo humano como la pulgada, el palmo (9 pulgadas), el pie (12 pulgadas), el codo (18 pulgadas) o la vara (3 pies o 36 pulgadas), lo que implicaba que los sistemas de proporciones, cuya finalidad era la de controlar el resultado estético del edificio, se basaban en la forma de medirlos, que en si mismo representa una aproximación, ya que en obra se usaba una barreta o regla de manera previamente dimensionada como patrón de medida. Es usual, aun hoy en día, que en las zonas rurales de Chiloé, las varas de leña se calculan utilizando el astil del hacha, la misma herramienta usada para trozarla, el que mide aproximadamente 85 centímetros.

Para dimensionar una obra, se usaba una pieza de madera del largo adecuado al que se le hacían marcar, usando un serrucho o un cuchillo, para indicar las subunidades 
como la media vara (o codo), el pie o tercio de vara (doce pulgadas), el medio pie (seis pulgadas, sexma o sexto de vara) el palmo (medio codo, un cuarto de vara o nueve pulgadas). Todas estas medidas eran usadas para dimensionar las piezas de madera y los edificios. Una forma simple de graduar la regla es usando un elemento flexible, como un trozo de lana o una cinta de cuero que se doble en dos o en tres partes según sea el caso. Esta pieza tenía que corresponder con el patrón metálico depositado en la ciudad de Burgos de acuerdo a lo señalado en la Pragmática Real del 24 de junio de 1568, dictada en San Lorenzo del Escorial por el Rey Felipe II. La que fue incorporada a las Leyes de Indias para poblaciones, con el fin de evitar arbitrariedades.

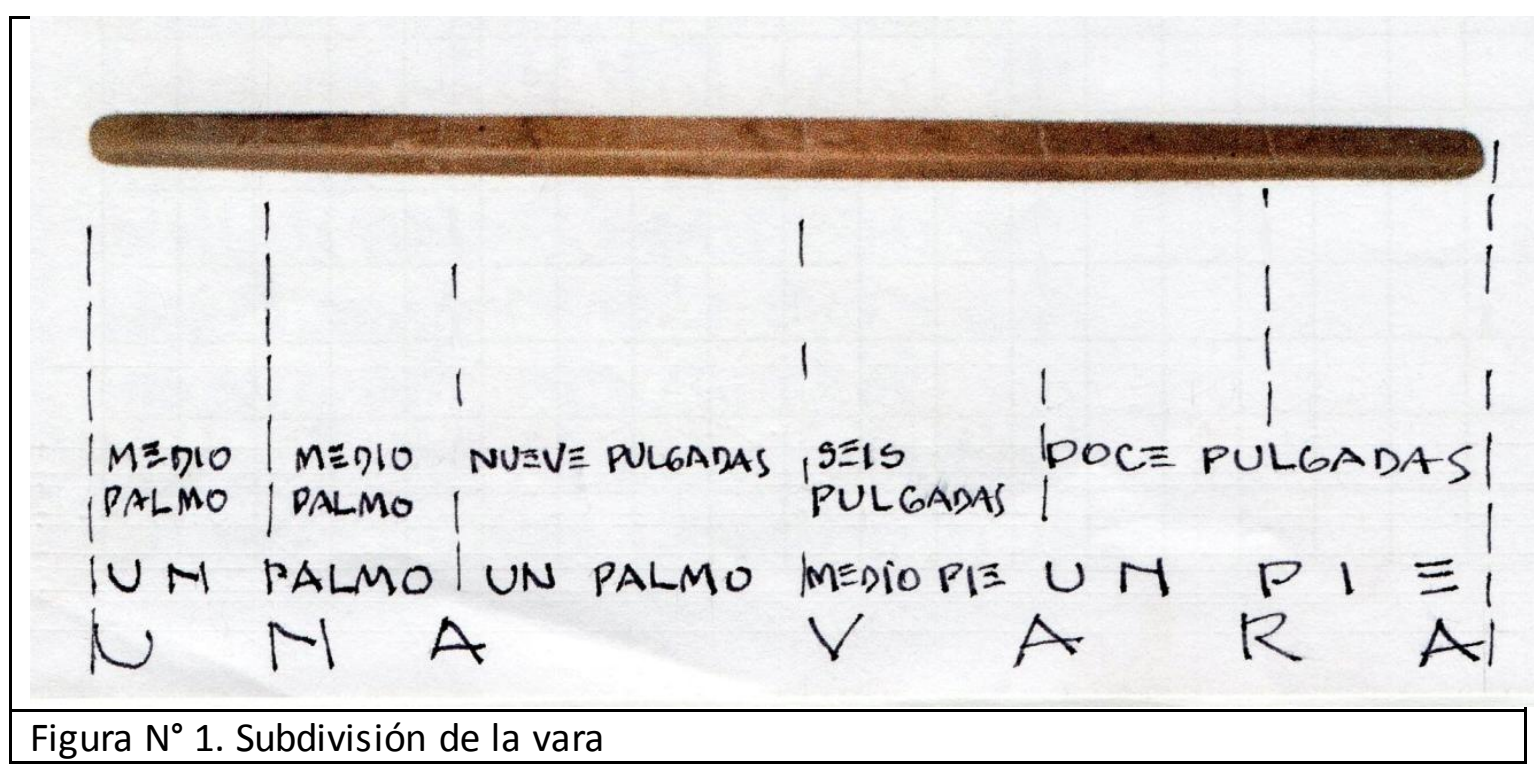

En la capitanía General del Reino de Chile, se creó tempranamente el cargo de "Fiel Ejecutor" en 1569, el que, entre otras cosas, debía controlar los artefactos para pesar y medir de acuerdo a un "fiel de las medidas que la ciudad tuviere", es decir de acuerdo a un patrón que debía conservarse en las bodegas del cabildo. El fiel ejecutor debía además entregar un segundo patrón de medidas, en este caso la Vara con todas sus correspondientes líneas, a un carpintero elegido entre los "buenos oficiales y de buena vida y forma". A pesar de las dificultades que se tuvieron para ordenar el sistema, especialmente el de pesos, y para hacer cumplir las normas, existía en el país una normativa conocida por los habitantes, así como por los artífices, y una constante preocupación de las autoridades al respecto. (De Ramón \& Larraín, 1979). En Chile esta norma rigió (por lo menos en los aspectos legales), hasta el 29 de enero de 1848, cuando se dictó la "Nueva Ley de Pisos y Medidas", que adoptaba el sistema métrico decimal como únicas unidades para usar en el país (De Ramón \& Larraín, 1979, p. 713).

No se han encontrado indicios de instrumentos de medidas de su uso en Chiloé, tal vez porque la herramienta al ser de madera y carecer de sofisticación no era tomada en cuenta por los legos. Por ejemplo al revisar las listas de los bienes que dejaron los jesuitas en 1767 aparecen serruchos de una y dos manos, cepillos, formones y gubias, limas, martillos, gramiles, guillames, escoplos, acanaladores, hachas, azuelas, barrenos, fierros de tornear, junteras (seguramente prensas), etc. (Vásquez de Acuña, 1956), pero ningún instrumento de medidas, solamente cuatro compases en el colegio de 
Castro, uno de ellos en el cuarto del padre misionero Joseph García, y uno en la misión de Achao. Aparecen citados algunos fierros y fierritos de carpintería, pero sin mayores definiciones, no es posible suponer que se trataba de patrones o instrumentos de medida. A pesar de lo anterior, las crónicas de la época al referirse a las dimensiones de los edificios anotan varas y sus submúltiplos.

Hay otros conceptos que se refieren al arte de construir y que se sabe fueron usados en Chiloé por los resultados, es decir, por los edificios construidos, entre ellos las iglesias pero sobre los cuales no se ha podido encontrar trazas documentales, ya que en general se describen hechos y edificios, pero no se describen los procedimientos.

El primero es el trazado del ángulo recto para lograr una planta rectangular o cuadrada, es decir un paralelogramo. Para esto existen dos métodos de extremada sencillez, que aún hoy en día conocen y son utilizados por los maestros carpinteros.

Uno de ellos es el uso del "tres, cuatro, cinco", como se conoce en la jerga de los carpinteros al triángulo pitagórico, también conocido como triángulo sagrado egipcio, porque fue usado para construir las pirámides. Se trata de un triángulo escaleno cuyos lados miden respectivamente, tres, cuatro y cinco unidades de medida, y que se ajusta al teorema de Pitágoras que dice que "en todo ángulo rectángulo la suma del cuadrado de los catetos es igual al cuadrado de la hipotenusa".

Este triángulo tiene varias propiedades. Antes que nada tiene un ángulo recto, que es lo que permite cuadrar una construcción. Además está formado por números sencillos, de fácil memorización y uso. Su forma práctica más sencilla es la de utilizar una cuerda con nudos equidistantes. Estéticamente corresponde a una razón sesquitercia (3/4), que es una de las proporciones presentes en los tratados del Renacimiento.

También es un numero "mágico" ya que la suma de sus lados es doce $(3+4+5=12)$, que es igual al producto de los catetos $(3 \times 4=12)$. El número tres representa a la divinidad y el cuatro representa a los elementos que forman el mundo según los antiguos griegos. Se podría seguir estableciendo relaciones numéricas para el triangulo pitagórico, que si bien es cierto pueden ser de interés, exceden el ámbito de este estudio.

Otra forma de "cuadrar" una construcción rectangular o cuadrada es midiendo los diagonales, los que deben tener la misma dimensión, para que se verifique que sus cuatro ángulos son rectos. También se basa en una propiedad geométrica del rectángulo. Este método tiene la propiedad de ser independiente de las dimensiones de los lados. En la construcción se puede realizar con una cuerda tensada, un alambre o una vara suficientemente larga.

Otro concepto útil en construcción es que el que busca responder la duda acerca de cómo nivelar una construcción, es decir que el pavimento (o piso) sea un plano horizontal, así como el nivel superior de las soleras de los tabiques. 


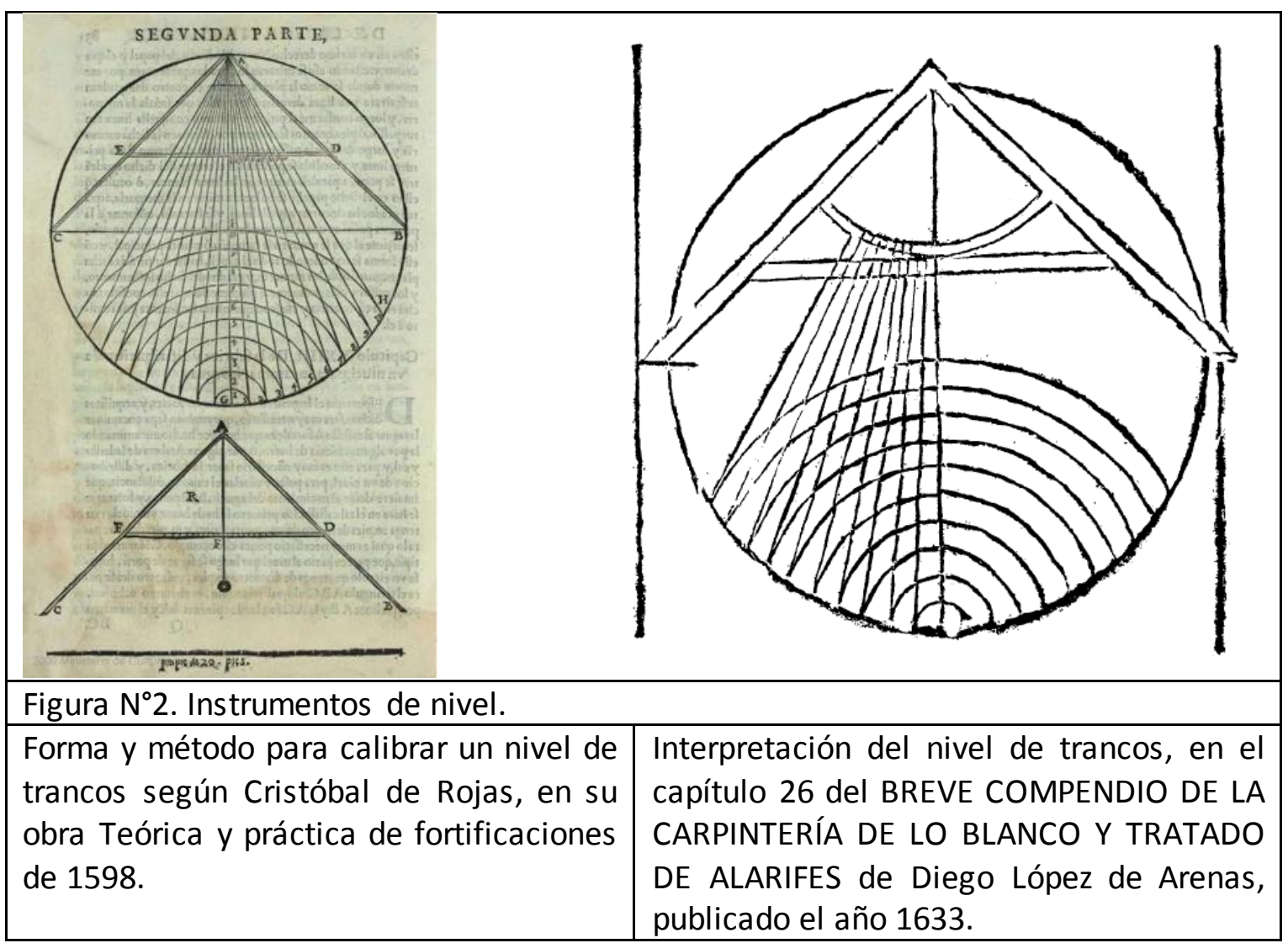

El más simple de estos instrumentos es la escuadra para nivelar, llamada nivel tipo " $\mathrm{A}$ ", o nivel de trancos, adjudicado al arquitecto español Juan de Herrera (Piñeiro \& Vicente, 1991), pero cuyo uso es aun más antiguo. Este consiste en el de una escuadra con un travesaño en la mitad de los lados formando una letra A mayúscula, en cuyo vértice cuelga una plomada. Este instrumento se basa en el principio geométrico que establece que la mediana de un triangulo isósceles desde la base al ángulo opuesto es perpendicular a la dicha base. Luego como la plomada es atraída hacía el centro de la tierra, entonces la base es horizontal. Su fabricación requiere precisión y meticulosidad, sin embargo se hace con pocos o sencillos elementos. Usado desde la antigüedad para nivelar acueductos, fue descrito ya en el renacimiento. Su uso en construcción es muy simple ya que una vez dispuestas las vigas sobre las piedras de fundación, se ubicaba el instrumento sobre esta y por medio de cuñas puestas entre las piedras y la parte inferior de la viga estas se nivelaba. El procedimiento se seguía en todos los elementos estructurales que se querían nivelar.

Otro instrumento para nivelar fue la libra acuaria, que pareciera ser consistía en dos tubos de vidrio conectados y firmemente atados en los extremos de los intestinos de un animal, el que funcionaba por el principio de los vasos comunicantes (Moreno, 2004). 
No se han encontrado en los documentos revisados referencias a algún sistema para nivelar construcciones, pero la sencillez de los descritos permite hipotizar su uso por los maestros que construyeron las iglesias de Chiloé, debido a que tanto el piso como el cielo de estas construcciones es horizontal.

En lo que respecta a los sistemas de proporciones, Andrea Palladio recomendaba solo 7 razones para dimensionar la planta de los salones. Estas eran el cuadrado (1/1), la circunferencia, los rectángulos cuyos lados están en proporción de $1 / 2 ; 3 / 4 ; 2 / 3 ; 3 / 5$ ), y el rectángulo que se forma con la diagonal del cuadrado como segundo lado. Las seis primeras se forman con proporciones en base a números naturales $(1,2,3,4$ y 5$)$, es decir que se basan en razones medibles. Mientras la última se forma con un numero irracional, con infinidad de decimales, como es la raíz cuadrada de dos. La última fue la única proporción que no fue usada por Palladio en sus obras, así como por la mayoría de los arquitectos del renacimiento (Wittkover 1962), debido a la inconmensurabilidad.

Cabe señalar que para la cultura renacentista y por lo tanto para la neoclásica, para que algo fuera bello tenía que estar relacionado con la armonía del universo, cuya estructura según Pitágoras, estaba organizaba en base a los números uno, dos, tres, cuatro, ocho, nueve y veintisiete y correspondía con la armonía musical, de la cual derivan algunos términos usados en las proporciones, como el diapasón (proporción de 1/2), el diapente (proporción de 2/3), o el diatesaron (proporción de 3/4). En la figura conocida como epogdoon que representa la proporción del largo de las cuatros cuerdas de una lira, se grafican de manera clara y sencilla estas proporciones, conocidas por los arquitectos y artistas del renacimiento, toda vez que es parte del fresco que Rafaello Sanzio pintó en la "Stanza della segnatura", en el Vaticano entre 1510 y 1512.

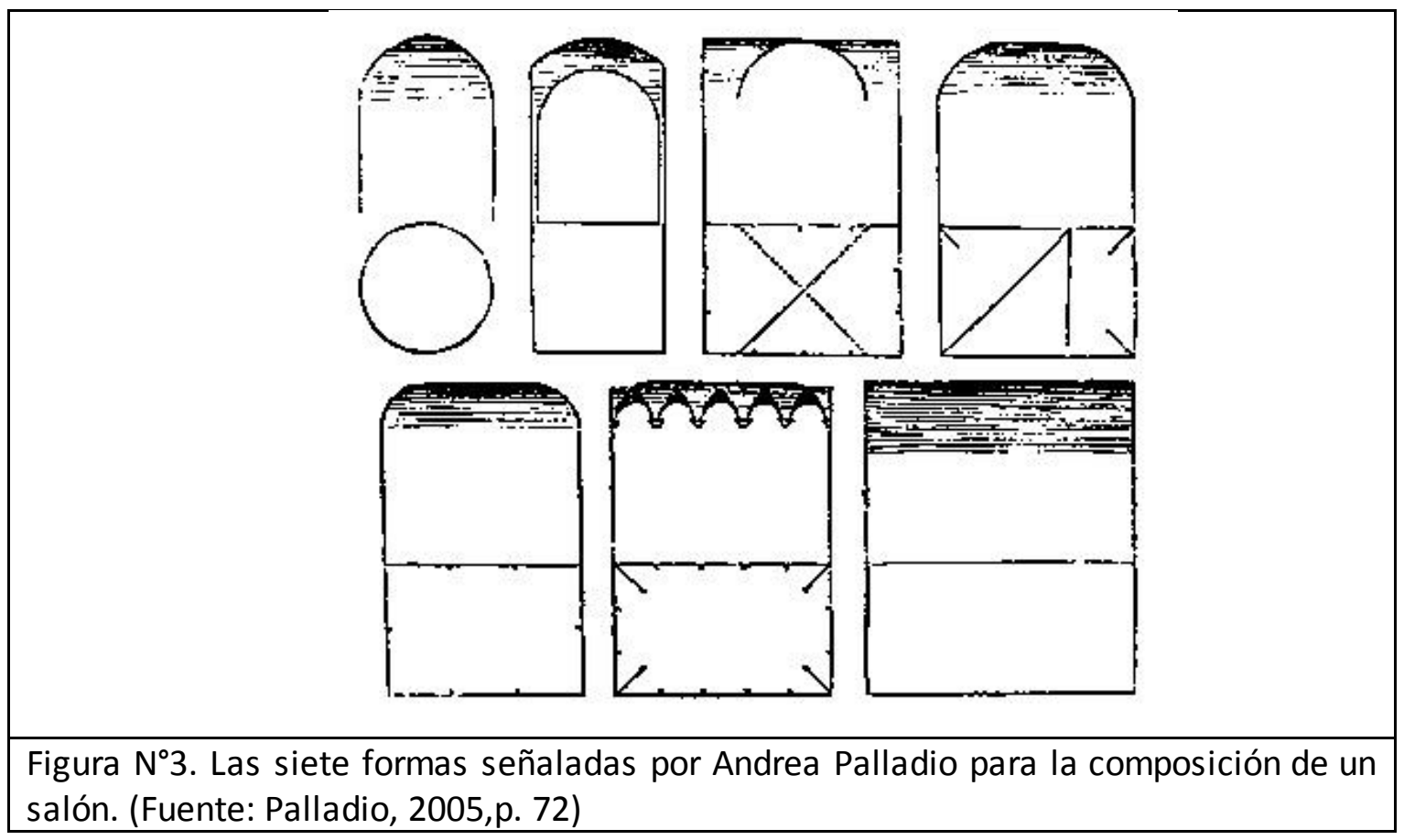



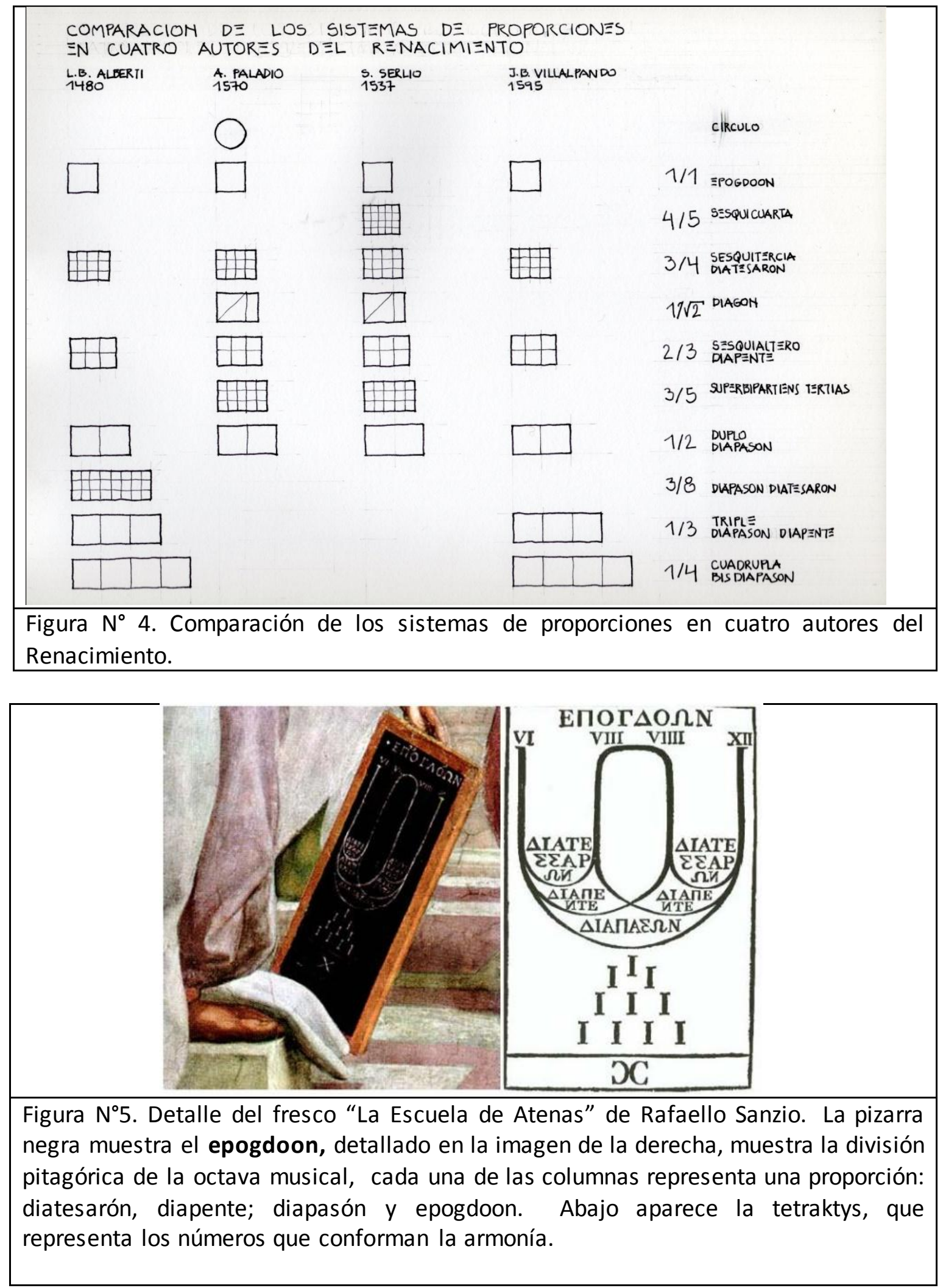
Las proporciones señaladas no solo son de fácil construcción, sino que su sencillez facilita la "lectura" y por lo tanto la percepción de edificio, no por la exactitud de las medidas, sino que por la idea que subyace en ellas (Rasmussen, 1957).

A fines del siglo XVI el sacerdote jesuita Juan Bautista Villalpando S. J., quién además era un acucioso geómetra y arquitecto, discípulo de Juan de Herrera, desarrolló la idea de un sexto orden en la arquitectura, un orden armónico, que se creía inspirado por Dios cuando ordenó al Rey Salomón construir el templo. La reconstrucción de este templo fue el objeto de un erudito libro Ilamado In Ezechielem Explanationes, que publicó junto al padre Jerónimo Prado S. J., que en tres tomos lograron reconstruir el citado templo de Salomón.

Según Villalpando Dios reveló a Salomón la armonía musical como base de la belleza. Para el jesuita solo era posible alcanzarla, con los tres acordes simples y los dos acordes compuestos establecidos por la escuela pitagórica, es decir diapasón (1/2), diapente (2/3) diatessaron (3/4), diapasón diapente (1/3 ó 3/6/9) y bis diapasón (1/4) (Wittkower, 1962), todas proporciones simples que se obtienen con los cuatro números que forman la tetraktys pitagórica, es decir el 1,2,3 y 4 cuya suma es 10 .

A este respecto conviene citar al padre Christiano Rieger S.J. de quién ya se ha hablado. Para el sacerdote la belleza de la arquitectura no se encuentra en la decoración ni la elegancia, sino que está en "la exacta proporción... aunque en lo demás aparezca una obra simple y tosca" ya que en la "proporción se encuentra el alma de la perfección" (Rieger, 1763, p. 28-29).

Además señala, que las proporciones se deben hacer con números pequeños "porque juzgándose solamente bueno lo que se percibe por los sentidos no podrán estimarse las razones arquitectónicas, que no se pueden conocer, sino con mucha dificultad, y tales serían las que contasen de muchos números o de fracciones enredosas" (Rieger, 1763, p. 30-31).

Rieger separa las proporciones en tres tipos. Las primeras son las que se relacionan con el número uno, es decir el cuadrado (1:1) y los rectángulos duplo (1:2), tercio (1:3), etc. La segunda clase son los de números pequeños seguidos como dos es a tres $(2: \cdot 3)$, tres es a cuatro (3:4). Etc. La última es entre números pequeños cuya diferencia también es pequeña como tres es a cinco (3:5), tres es a siete (3:7), etc. Rieger, formado en el espíritu de los tratadistas del renacimiento, relaciona estas razones matemáticas con la consonancia musical, por lo que deben preferirse a otras proporciones más complejas de ejecutar en obra. 


\subsubsection{Racionalidad constructiva, prefabricación y efecto estético.}

Una particularidad de desarrollo tecnológico de la construcción en madera, es el aumento progresivo de la racionalidad de los procesos, sea en la ejecución como en la obtención de materiales. En la medida que se produzca un real avance en estos aspectos, aumentará la calidad constructiva de la obra, lo que tendrá un efecto en el aspecto, es decir en el resultado estético.

Rasmussen (1957, p. 102-103) describe que la construcción en madera en el norte de Europa se había desarrollado a tal grado durante el siglo XIX, que alcanzó importantes niveles de estandarización en los distanciamientos de pies derechos y envigados, en función de elementos prefabricados como puertas, ventanas y largo de las maderas, lo que se "expresaba en números simples en pies y pulgadas" usadas en las construcciones. En estos casos la crujía de los recintos era de dos, tres o cinco varas, dependiendo de la función que cumplía y de su importancia.

Lo anterior también se puede inferir en la arquitectura de Chiloé y tiene implicancia en las proporciones de la planta de los edificios como resultado del uso de números enteros, lo que se manifestará, en las elevaciones al usar piezas de madera de medidas estandarizadas, permitiendo construir fachadas armónicas de manera intuitiva o usando conceptos de composición sencillos como la simetría, sin que medien para ello complejos sistemas geométricos o de trazados reguladores.

La dimensión de la madera era importante, no solo para su uso como parte de la estructura, sino que además para definir "la proporción del volumen" (Montecinos et al 1995, p. 32), ya que el largo de las piezas se transforma en una limitante para la construcción, especialmente si se desconocen la formas constructivas complejas como las vigas de celosía o enrejadas, o las cerchas, las que presentan dificultades complejas de resolver, especialmente en la ejecución de las uniones.

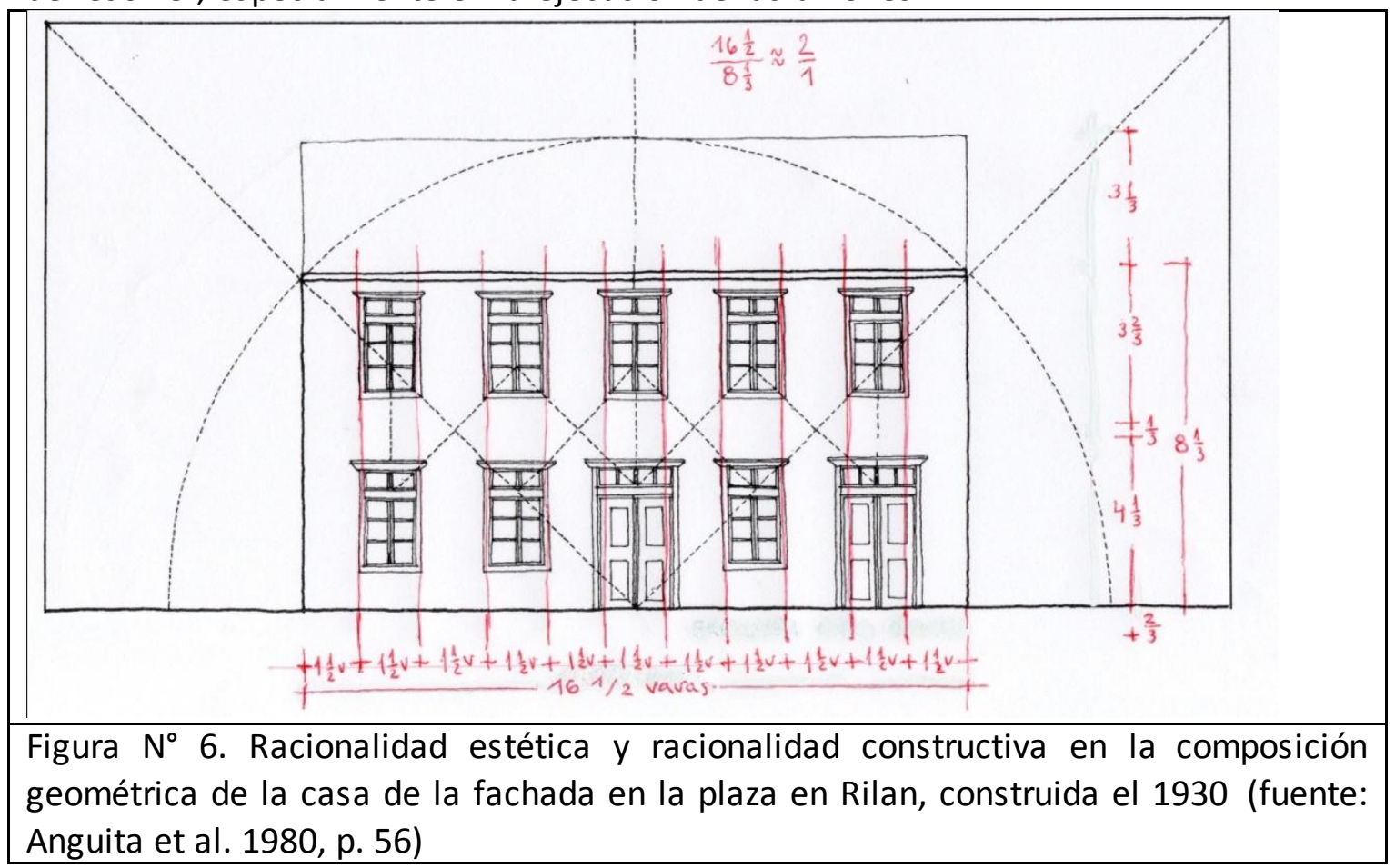


Un caso que ejemplifica lo anterior es la Casa de la Fachada en la Plaza de Rilán, construida en 1930 (Anguita et al.1980, p. 56-57), cuyo ritmo de llenos y vacíos en la fachada es el resultado del distanciamiento de los elementos estructurales, cuyos pies derechos se encuentran cada una y media varas, así como las alturas exteriores dependen del largo estandarizado de las piezas de madera y de la costumbre de construir el segundo piso de una altura inferior a la del primero. Todo esto permitió "construir" un sistema geométrico subyacente a la forma visible que estructura la fachada principal de la casa, la que es posible reducir a un sistema de trazados reguladores, que se ajusta a la proporción dupla, o al rectángulo en el cual la razón de la base con la altura es de uno es a dos.

\subsubsection{1 Épocas y dimensiones del madereo del alerce.}

En el análisis de los sistemas constructivos es importante considerar la dimensión de los materiales usados, ya que han permitido estandarizar las construcciones, así mismo que revelan el sistema de medidas usadas en las obras.

En un interesante estudio, la historiadora Ximena Urbina entrega valiosa información relacionada con la producción de la madera de alerce a fines del periodo colonial e inicios del periodo republicano en Chiloé (Urbina, 2011). En este trabajo anota dimensiones para las tablas de alerce que incluyen dos y media, tres y cuatro varas de largo. A su vez Rondizzoni (1854) agrega largos de 8 varas. Para el ancho Urbina señala doce, nueve y seis pulgadas, mientras los espesores eran de una a una y media pulgadas. En estas medidas consignadas por Urbina y Rondizzoni sólo se indican números enteros y medias unidades, lo que señala una base de un sistema dimensional usado durante la colonia y aplicado a las construcciones de madera de Chiloé, en base al largo de las piezas de madera dimensionadas en varas y en pulgadas castellanas. Esta es una consideración importante para cualquier análisis dimensional de las edificaciones coloniales en la isla de Chiloé y aún en el territorio de la colonización del lago Llanquihue, ya que representa una restricción técnica a las infinitas posibilidades de la arquitectura.

Sin duda que el sistema dimensional era el español de Castilla, que consideraba varas de 835,9 milímetros, pies de 278,6 milímetros y pulgadas de 23,2 milímetros, usado por mandato del Rey de España para ser usado en todos los lugares del reino.

\begin{tabular}{|l|l|l|l|}
\hline & LARGO & ANCHO & ESPESOR \\
\hline Mediados ss XVIII & $2.1 / 2$ varas & 12 pulgadas & \\
\hline $\begin{array}{l}1790 \text { ca (Fray Francisco } \\
\text { Menéndez) }\end{array}$ & 3 varas & 9 pulgadas $\left.*^{*}\right)$ & 1 pulgada \\
\hline $\begin{array}{l}1791 \text { (Fray González de } \\
\text { Agüeros) }\end{array}$ & 4 varas & $6-7$ pulgadas & $1.1 / 2$ pulgadas \\
\hline 1842 (Philippi) & 9 pies (3 varas) & 9 pulgadas & $\begin{array}{l}1 / 2- \\
\text { pulgadas }\end{array}$ \\
\hline 1903 (Weber) & $2.1 / 2$ varas & 6 pulgadas & $1 / 2$ pulgada \\
\hline $\begin{array}{l}\text { DIMENSIONES DE LAS TABLAS DE ALERCE UTILIZADAS DURANTE LA COLONIA } \\
\text { (URBINA, 2011) } \\
\left({ }^{*}\right) \text { Un palmo equivale a un cuarto de pie. }\end{array}$ \\
\hline
\end{tabular}


Urbina (2011, p. 64) también señala los nombres de las piezas producidas, sin especificar dimensiones. Estas son tablas (piezas de 1.1/2 pulgada de espesor y sobre 4 pulgadas de ancho) ${ }^{127}$, tablones (piezas desde 1.1/2 pulgada de espesor y sobre 6 pulgadas de ancho), cuartones (piezas cuyo espesor y ancho fluctúa entre 2 y 6 pulgadas, usados generalmente como pies derechos), viguetas (de sección rectangular y cortas) y vigas (piezas de 6 a 10 pulgadas de ancho y de 6 a 10 pulgadas de espesor). A estas piezas Rondizzoni (1854), agrega las madrinas (vigas maestras en contacto con la humedad).

\subsubsection{Cuatro proyectos originales para la construccion de iglesias y una interpretación geométrica.}

Los habitantes de los poblados, en tiempos de la construcción de iglesias eran precarios y carentes de recursos, por lo que para la construcción de sus templos requerían aportes, sea del obispado, como de gobierno, al que recurrían con frecuencia. Una vez obtenidos los fondos y la autorización del obispo, la construcción era una faena colectiva en la que participaba toda la comunidad, cada uno aportando de acuerdo a sus propias capacidades y recursos, algunos con mano de obra, ayudando a los maestros constructores que generalmente venían de otras partes, otros con materiales $u$ otras especies como alimentos para los operarios (Guarda, 1995), en esta última tarea se afanaban las mujeres del poblado (Oyarzún, 2006).

Para la solicitud de recursos, en general acompañaban listas de materiales, presupuestos de mano de obra y en algunos casos, algunos planos que ejemplificaban la obra que se quería realizar. Este fue el caso para la construcción de la iglesia de nuestra señora de Quinchao en 1863, del proyecto de la torre de la iglesia de Tenaún con plano realizado por el maestro constructor Agustín Guaiquío en 1875, y de la iglesia de Tenaún con planos elaborados por el padre Francisco Bohle.

Estos planos son de gran valor para entender el nivel de comprensión del proceso constructivo, así como las implicancias en la forma y estructura estética de las iglesias, ya que son la expresión de una intensión previa a la construcción. En ellos se refleja el pensamiento, la cultura y los conocimientos técnicos de los artífices. Quien dibuja el plano de un edificio, en este caso de una iglesia, de alguna manera expresa en él sus creencias mundanas y religiosas.

De acuerdo al levantamiento de información realizada por Montecinos et Al (1995), los planos se hacían para cumplir dos objetivos, que no siempre iban aparejados. Estos eran el de informar a la autoridad episcopal sobre la necesidad de construir un templo, como en el caso de Chonchi, en que en 1863 se enviaron los planos para informar que se construiría el templo, o para informar y solicitar fondos, como sucedió el año 1894, cuando se enviaron los planos y el presupuesto para construir la torre de la iglesia de Tenaún, así como en 1901, cuando el padre Bohle envió los planos y el presupuesto para construir la iglesia de Curaco de Vélez. Esto produjo como efecto que lo que se había proyectado y lo que se construía no coincidía, salvo en las dimensiones

${ }^{127}$ Entre paréntesis se ha anotado la definición, adaptada de Corma (1955, p.18) 
generales. Es decir que el resultado formal de las iglesias no se puede atribuir a una idea preconcebida, sino que hay que buscar la respuesta en otro ámbito como, por ejemplo, es el de la naturaleza del proceso constructivo y la de los materiales.

\section{a) PLANO DE NUESTRA SEÑORA DE GRACIA DE QUINCHAO.}

Para solicitar autorización para renovar el templo, el 22 de junio de 1863 se envió al obispo de Ancud, el padre mercedario Fray Francisco de Paula Solar Mery "el diseño de la iglesia de Quinchao y el de las capillas colaterales" (Montecinos et al 1995, p. 125).

El citado diseño consta de dos dibujos, aparentemente dibujados con lápiz grafito. Se especifica en ellos que "el plano que representa a la vista es como una cruz; sus definiciones son escritas sacado para la escala de varas que lleva al pie" (Montecinos et al 1995, p.125). Efectivamente el plano tiene una escala gráfica en varas, que permite medirlo con un compás o una regla, obteniendo las dimensiones del proyecto.

El primero de estos planos corresponde a una elevación juntos el imafronte o fachada principal y la fachada lateral. En el imafronte, que es simétrico, se reconoce el pórtico con una puerta central y dos ventanas a cada lado. La pendiente del techo se alarga hacia los costados en sendos corredores porticados. La fachada está coronada con una torre de dos tambores bajos de planta cuadrada, el de arriba de base más pequeña que el de abajo, coronado por un chapitel rematado con una cruz. En el tímpano trunco aparece una ventana que ilumina el coro sobre el pórtico.

Esta forma de componer la torre representa una etapa intermedia entre la de la iglesia de Castro dibujada entre 1829 y 1835 por Philip Parker King y la torre clásica con un dado y tres tambores que caracteriza a las iglesias de Chiloé. También establece tempranamente una forma de construirlos, ya que la estructura del más pequeño se inserta dentro del más grande, formando una estructura llamada telescópica, lo que permite darle estabilidad a la torre. Además posibilita el uso de maderas de dimensiones más pequeñas y por lo tanto más livianas para levantarlas.

Los corredores que servían para proteger las fundaciones de la lluvia y la humedad, a la vez que acogían a los peregrinos, establecen una relación, por lo menos teórica, con las iglesias de las misiones de Paraguay.

El segundo dibujo es la planta del edificio presentado al obispo de Ancud (Figura №7). Se trata de un esquema en cruz latina, con tres brazos iguales de doce varas de arista y otro mayor de veintiséis varas de largo, lo que entrega un largo total de cincuenta varas y un ancho total de treinta y seis varas para el transepto. Los cuerpos interiores se dividen en tres naves: las laterales de dos varas de profundidad y la nave mayor 0 central de cuatro varas de ancho, en una razón de 1:4:1. A su vez la nave mayor, en los brazos cortos se encuentran en proporción sesquiáltera, es decir de dos es a tres (2:3), lo que en términos de composición clásica corresponde al diapente. 


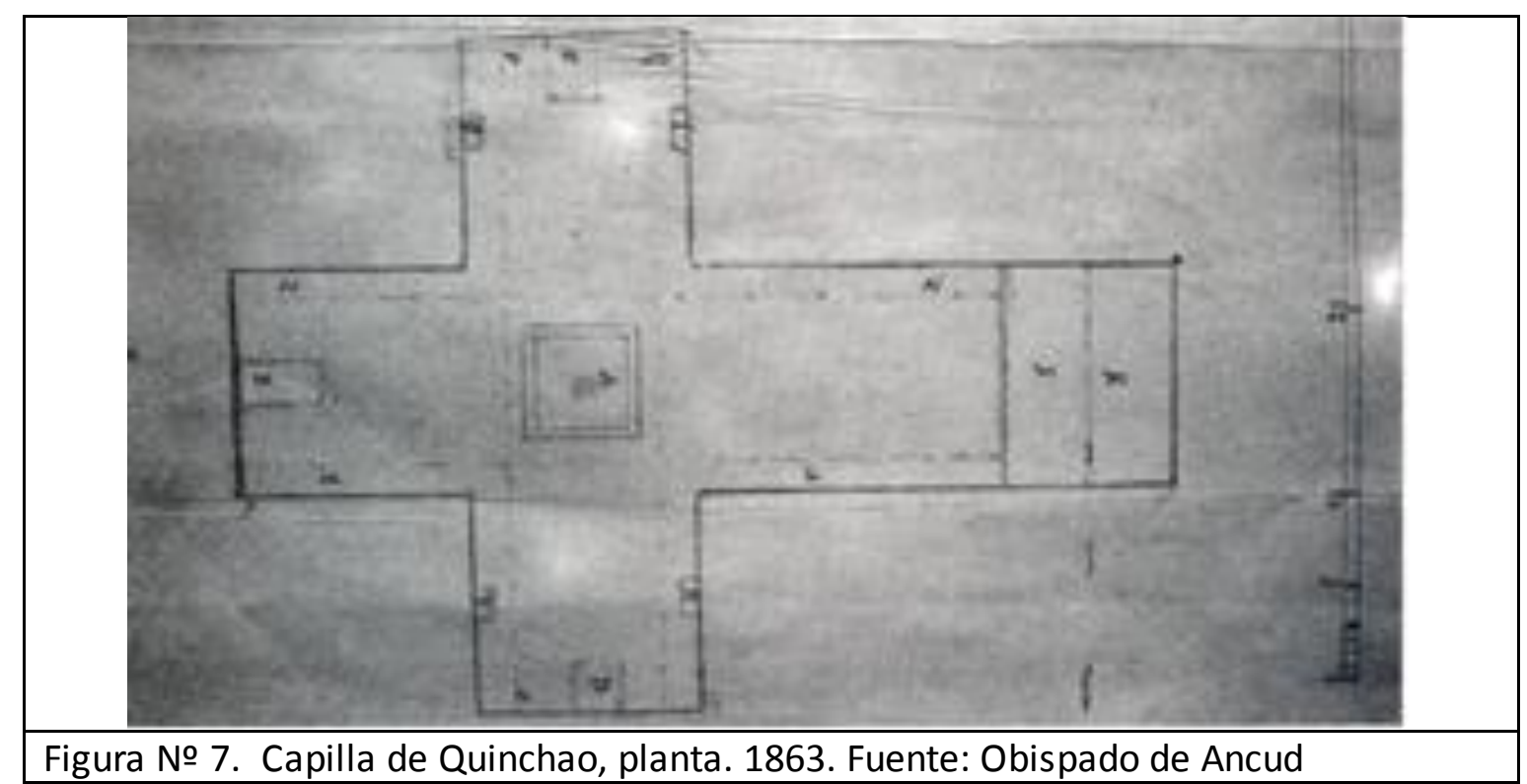

La distribución de la planta no deja de ser curiosa. Primero por alejarse del modelo tradicional de planta basilical. También porque la testera del brazo mayor está ocupada por la sacristía y el presbiterio, al contrario de lo que sucede en una iglesia de planta en cruz latina en donde estos recintos están en el brazo menor de la nave mayor. Esta planta tiene tres puertas principales: una en cada frente del transepto y del brazo corto de la nave mayor. Junto con lo anterior, y alejándose de la planta tradicional de las iglesias chilotas, tanto la sacristía como el presbiterio ocupan ambos todo el ancho de la iglesia, con una profundidad de cuatro y media varas. A esto se suma el espacio para la asamblea, frente al presbiterio, que ocupa un total de diecisiete varas. Como hecho curioso, la razón de los lados de la asamblea corresponde a la raíz de dos, es decir a la diagonal del cuadrado, mientras que la suma de las dimensiones del presbiterio y de la sacristía están en proporción sesquitercia, es decir de tres es a cuatro (3:4), lo que en términos de composición clásica corresponde al diatesarón.

Finalmente, la iglesia que se construyó es diferente a la que se proyectó, cuyos planos fueron enviados al obispado de Ancud el 22 de junio de 1862. De hecho, entre 1866 y 1870 se construyó una nueva iglesia de doce y media varas de ancho y treinta y siete varas de largo, medidas que se aproximan a las indicadas en los planos, pero sin incluir el transepto. En 1880 está en tan mal estado que se decide construir otro templo. Sin embargo también difiere del proyecto de 1862. De hecho la fachada tiene cinco arcadas en vez de las tres indicadas en el proyecto; a su vez la torre construida tiene dos tambores de planta octogonal en vez de los de planta cuadrada del proyecto. En las dimensiones las diferencias son grandes. Mientras el proyecto consideraba doce varas de frente y cincuenta de largo, en 1883 se indicaba que la construcción medía 59,77 metros de largo, (aproximadamente 70 varas) y 23,41 metros de ancho (aproximadamente 28 varas de ancho), medida que incluía los corredores laterales (mediaguas) de tres varas de ancho que tenía originalmente, como se informa en la nota inventario de 1889 del archivo diocesano (Montecinos et al. 1995, p. 125-129). 


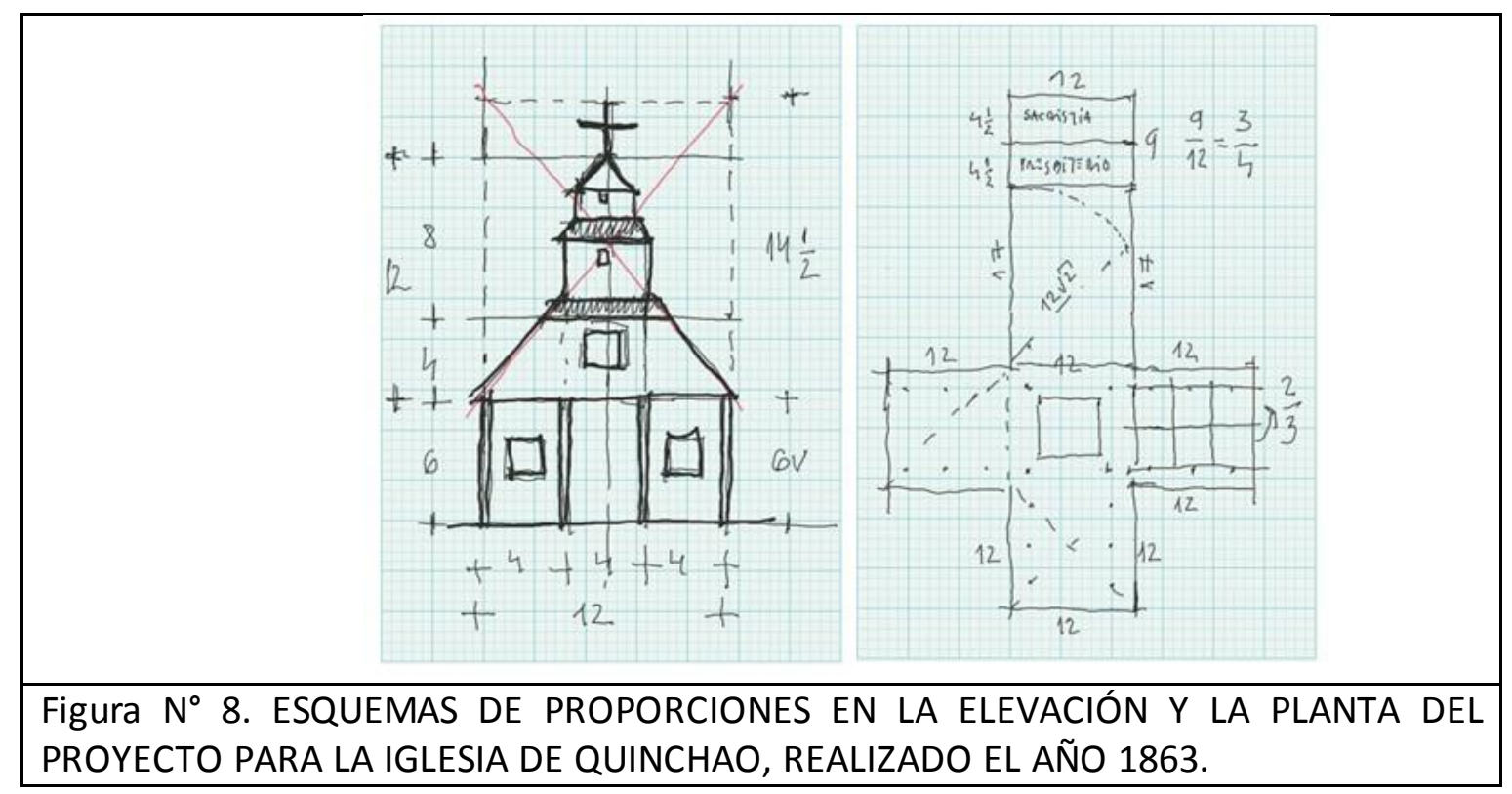

Otra curiosidad es que el altar se ubica bajo el crucero, convirtiendo la planta en una especie de panóptico, que controla todos los lugares del templo y que complejiza enormemente la celebración de la eucaristía, ya que la asamblea rodea el altar.

Interesante destacar que la medida que prevalece en la planta es el doce, como los doce apóstoles, pilares de la iglesia católica. Esta cifra era común en las pequeñas iglesias de tablazón y techo de paja de Chiloé, que persistían del tiempo de las misiones jesuíticas, ya que en 1865, al describir las nueve iglesias que correspondían a la parroquia de Tenaún se indica que estas "son de 24 por 12 varas" (Montecinos et al 1995, p. 158).

Estas medidas son fáciles de obtener con las piezas de las dimensiones habituales de las maderas producidas por los hacheros y tableros de Chiloé, lo que facilitaba la construcción de las iglesias. Por ejemplo, para la construcción del envigado de la plataforma del piso, el cual se apoyaría en piedras dispuestas en el suelo, se podría usar una pieza de nueve varas y una de cuatro varas convenientemente traslapadas, lo que permitiría realizar la unión entre piezas sin mayor dificultad, así como darle mayor firmeza y solidez. Así mismo la altura deducida de los planos indica seis varas para los muros laterales, que corresponde a una pieza de manera posible de obtener, sin necesidad de solicitarla de antemano.

Cabe destacar que tanto la planta como la elevación del proyecto para la iglesia de Quinchao no corresponden entre ellas, lo que deja entrever el poco conocimiento técnico que tenía el artífice en materias de representación de la arquitectura, lo que sin duda alguna tiene una explicación, pero permite concluir que las proporciones encontradas en la planta son, más el resultado de una concepción estructural del edificio, que un motivo preestablecido utilizado para el diseño de la iglesia. 


\section{b) LA TORRE DE GUAIQUIO PARA LA IGLESIA DE TENAÚN.}

Se trata de una lámina que tiene un dibujo que se muestra incompleto. La forma de mostrar el proyecto, conocido como representación global ${ }^{128}$, muestra el corte y su estructura, sobrepuesta a la planta.

Fue datado 1875 (Montecinos et al 1995), sin embargo en las notas recolectadas en el mismo libro figura la siguiente nota:

1894 ... se digne, si lo tiene a bien, de recabar del Supremo Gobierno unos mil quinientos pesos $(\$ 1.500)$ que se necesitarían para dicha obra y otros trabajos de la misma iglesia según el plano y apuntes que ha hecho el carpintero constructor Dn. Agustín Guaiquio,.. (Montecinos et al 1995, p. 162).

Es decir que sería esta la fecha de la lámina de la torre y no correspondería a 1875.

Sobre un lado de la planta se lee "largo del cuerpo de la iglesia= 42 varas". Falta la parte inferior del plano, donde seguramente estaba indicado el ancho de la iglesia. Si el plano está a escala, esta dimensión sería aproximadamente 20 varas.

En el plano se indica la altura del piso hasta el nivel superior del dado de la torre, coincidente con la cumbrera de la iglesia, que es de 15 varas, sobre esta se señala la altura del primer tambor que es de siete y media varas, sobre este está la del segundo tambor que es de seis y media varas, y finalmente la del chapitel que es de tres varas y media, lo que da una altura total de la torre, sin la cruz, de treinta y dos varas y media. Interesante resaltar que la razón entre el alto y el ancho (sin la cruz) es aproximadamente la razón áurea, mientras que la pendiente de la techumbre está en proporción de dos es a tres.

El dibujo de la estructura resume una tradición de construcción de torres que se ha perpetuado en el tiempo. Esta estructura se inicia con los pilares centrales del pórtico, los que se prolongan hasta el dado, el que sobresale sobre el tímpano. La prolongación de los pilares sobre las aguas de la cubierta produce un efecto estético que relaciona visualmente los elementos que componen la fachada: en el sentido horizontal generan el pórtico, mientras en el sentido vertical permiten armar la torre, relación que se enfatiza con los faldones de la cubierta. Bajo la viga superior del dado se construye una plataforma sobre la que se apoya el primer tambor, el que puede ser de base cuadrada u octagonal, que al ser más pequeño queda encajado y fijado a las paredes del dado que lo contiene, como si fuera un telescopio. Lo mismo sucede con el segundo tambor, encajado en la estructura del primero. A su vez el chapitel se arma sobre una plataforma que corona el último tambor.

${ }^{128}$ Esta forma de representación, dibujada en proyección ortogonal, incluye partes en planta y otras en elevación, de manera de dar una idea de la forma y distribución espacial. Se conservan excelentes ejemplos de esta forma de representación de villas suburbanas y jardines del antiguo Egipto. 


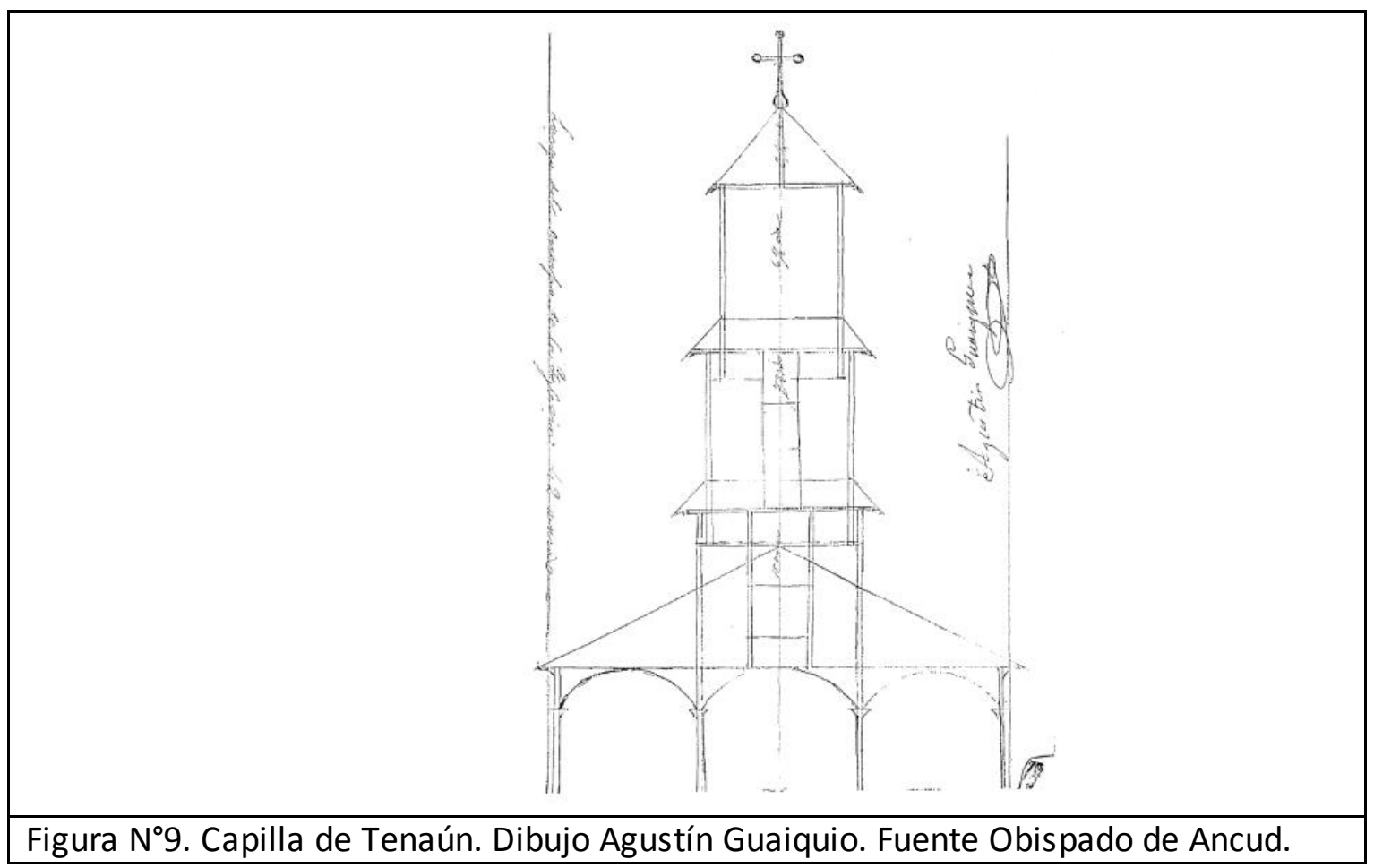

Esta forma de construir permite unir estructuralmente las partes superiores de la torre, trabándolas unas con otras, además que consiente el uso de maderas de dimensiones más cortas que el alto total de la torre. En este caso piezas de no más de ocho varas de largo. Además, el volumen se desmaterializa, perdiendo peso, ya que los volúmenes más pequeños son más livianos, acentuando la sensación de verticalidad y elevación.

El plano del maestro constructor Agustín Guaiquio es el resultado de una experiencia práctica anterior, que corresponde con la iglesia de Quinchao de 1863 y con los levantamientos realizados por profesores y alumnos del Departamento de Historia y Teoría de la Arquitectura de la Universidad de Chile.

Esta forma de construir torres revela un problema de posible filtración de agua lluvia a través de los intersticios producidos por la superposición de tambores y al ejecutar los faldones de las cubiertas. La solución, producida con el sistema de prueba y error, requirió de tiempo y solo fue posible con la masificación del uso del fierro galvanizado a inicios del siglo XX.

Lo anterior se verifica al leer los Expedientes Histórico-Arquitectónicos contenidos en el libro Las Iglesias Misionales de Chiloé (Montecinos et al 1995, p. 49 en adelante). En esta recopilación son recurrentes las notas referidas a la construcción de torres en las iglesias, las que aproximadamente después de veinte años estaban en mal estado, por lo cual se solicitaba dinero para su reparación. 


\section{c) LA IGLESIA DE CURACO DE VÉLEZ: EL PROYECTO DEL PADRE FRANZ BOHLE.}

El año 1900 monseñor Ramón Ángel Jara obispo de Ancud creó la parroquia de Curaco de Vélez, enviando como párroco al padre Francisco Bohle, quien en aquel entonces contaba con cuarenta años. Dotado de una personalidad enérgica, cambió la imagen del caserío trazando las calles, construyendo la casa parroquial, la iglesia y la casa de socorro.

Para el padre Bohle esta fue la tercera iglesia en la que estuvo involucrado. Si bien es cierto que de la primera solo fue testigo, es innegable que dejó una imagen indeleble en la mente del futuro sacerdote, ya que la iglesia que construyó en Osorno presenta reminiscencias de la iglesia Jesuita de Puerto Montt, principalmente en los modillones invertidos que relacionaron el ancho de la nave principal con el de la torre, así como la coronación en forma de templete sobre la cúpula octogonal de la torre.

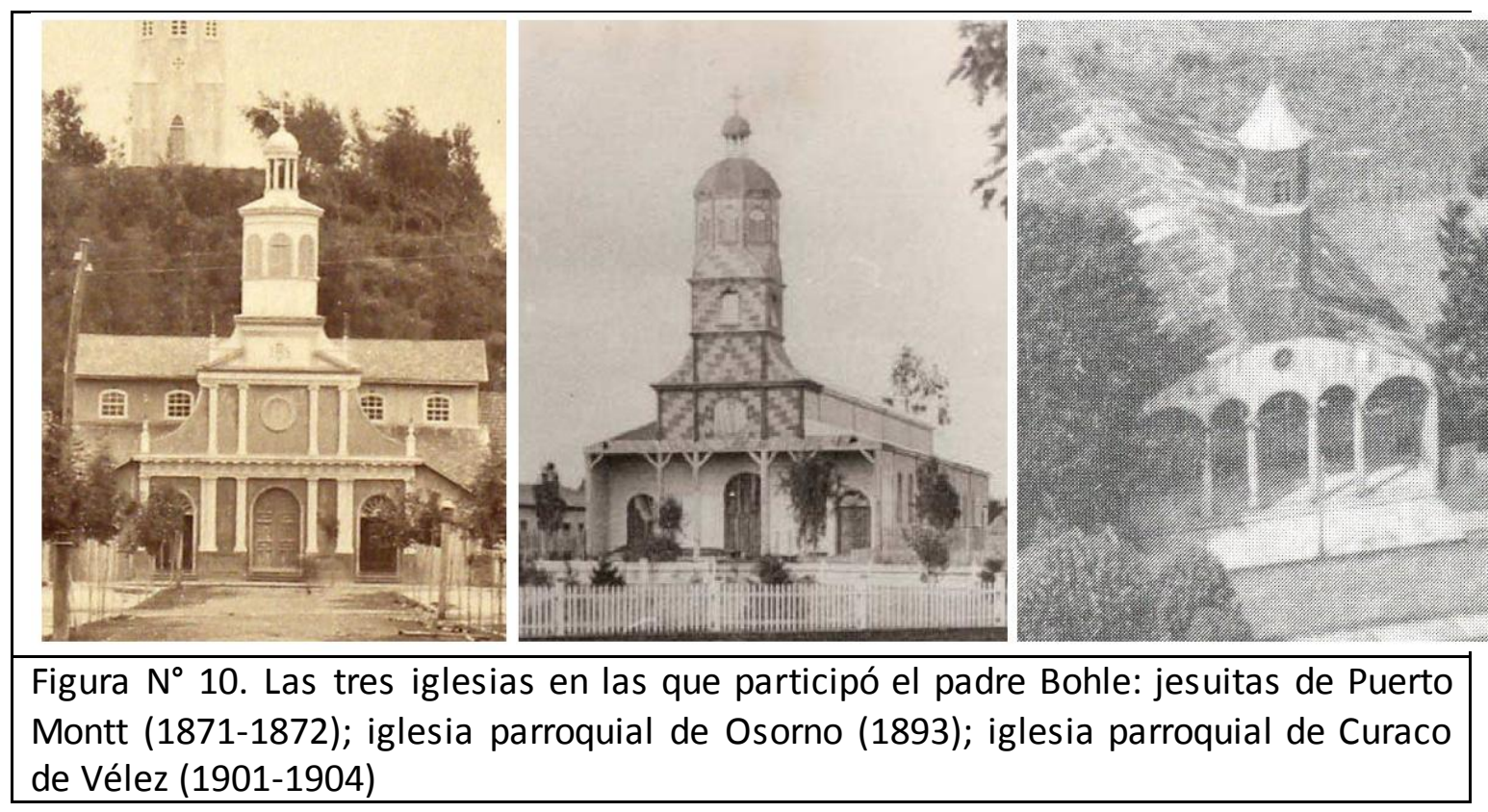

Un año después de asumir como párroco en Curaco de Vélez, el sacerdote enfrentó la construcción de la iglesia parroquial, para lo cual aprovechó los conocimientos de dibujo lineal aprendidos en el convictorio San José, el trabajo de la madera aprendido de su tío carpintero Gaspar Bohle, la gestión de la obra realizada en Osorno y sus dotes de liderazgo para motivar a sus parroquianos, de quienes sabía que tenían pocos recursos materiales pero una profunda fe.

Para la construcción el padre Bohle comprometió a todos los habitantes del lugar. La madera fue traída en balsas por José Bustamante, y en lancha para ser aserrada en Curaco de Vélez. Lindor Vidal, fiel colaborador del padre Bohle y vecino de Curaco de Vélez, también aportó con maderas. La obra fue dirigida por el carpintero mayor Evangelista Oyarzún de Huyar Bajo, y los maestros Lorenzo Andrade, Daniel Vásquez, Belisario Hernández, Antonio Mansilla, Bautista Oyarzún y José del Carmen Muñoz. A su vez la comunidad aportó con trabajo personal y con alimento para los constructores (Oyarzún 2005, p. 109-110). 
Para poder construir, el padre Bohle solicitó el permiso al obispo de Ancud Ramón Ángel Jara, en un momento en que se finalizaba la catedral de Ancud. Junto con la solicitud presentó un conjunto de planos en los que se representa el detalle de la estructura del templo, mostrando la planta, los cortes de los ejes de la "culata" (testera), de la "barandilla" (muros de la sacristía), de la portada y coro alto, el pórtico y la torre. En estos planos se refleja la clara impronta chilota que le quería dar a la iglesia.

Al revisar la planta es posible darse cuenta que hay dos módulos. El primero es de cuatro varas y se despliega en el sentido del largo, que es de 44 varas, dividido en once espacios y doce ejes. Este último número corresponde al de los apóstoles, primeros seguidores de Jesús. Estos espacios son de dos tipos: con tres pies intermedios derechos distanciados una vara, y con dos pies derechos intermedios distanciados una vara y un tercio, que incluye una ventana.

El segundo módulo es de cuatro y media varas y corresponde al ancho de la fachada, considerando un módulo para las naves laterales y dos para la nave central.

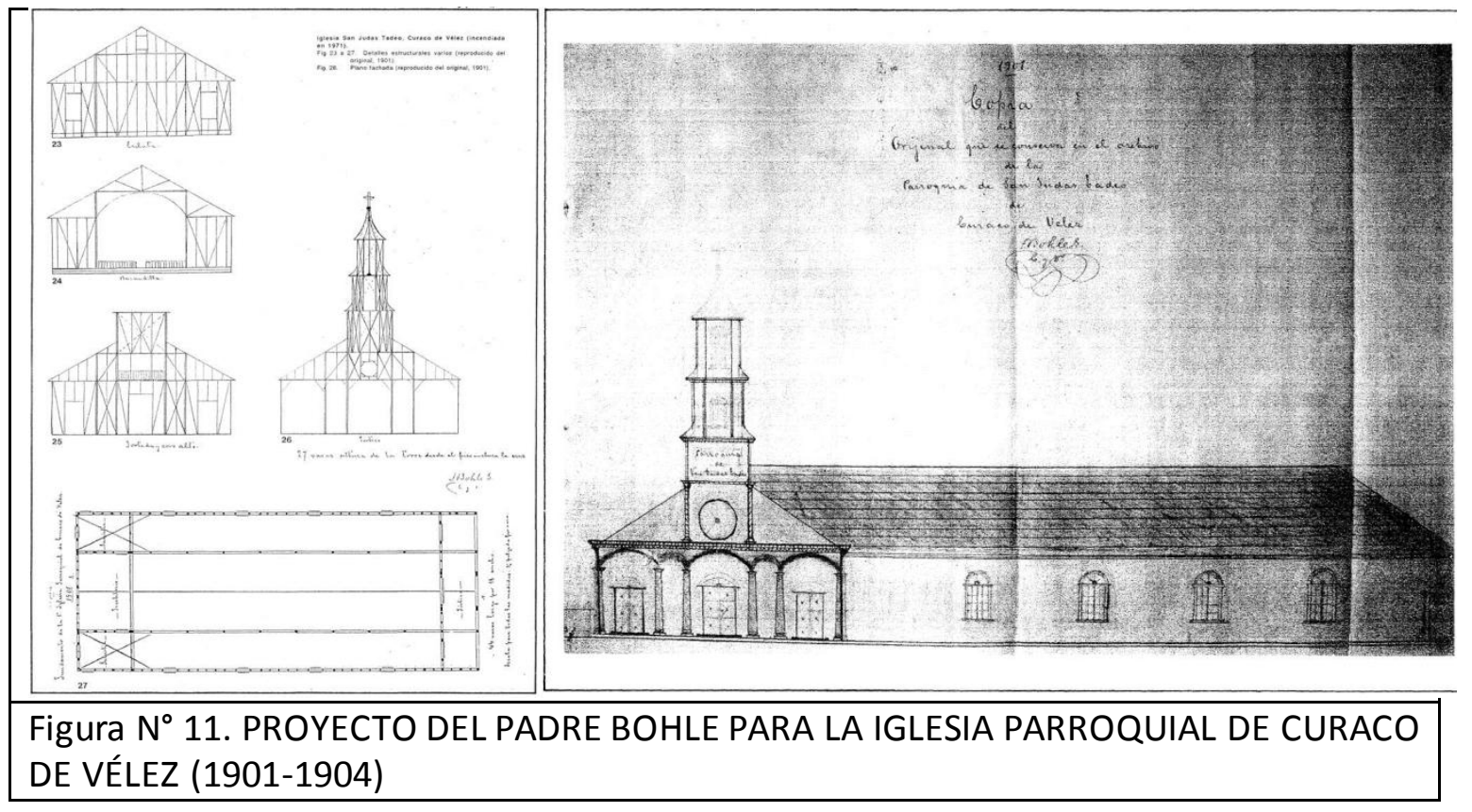

En términos de armonía se establece una relación entre los dos módulos de un tono (8/9) que corresponde a la mínima diferencia audible entre dos notas y a la mínima diferencia perceptible que permite diferenciar un cuadrado de un rectángulo.

Para la fachada, el padre Bohle definió un ancho de dieciocho varas, que equivale a cuatro veces el citado módulo de cuatro varas y media para el ancho. Así mismo estableció la altura de la torre "desde el piso inclusa la cruz" en veintisiete varas. En consecuencia con lo ya referido, el veintisiete no resulta un número casual ya que es la tercera potencia de tres $(3 \times 3 \times 3=27)$, número que representa la Santísima Trinidad, Dios uno y trino. También es el primer número real ya que contiene principio, medio y 
fin (Wittkover, 1962), además de ser el último de los siete números que conforman el universo según Platón, por lo tanto importante para la armonía de la arquitectura.

El dibujo del pórtico reproduce en su forma y proporciones, el del templo que el padre Bohle construyó en Osorno.

La razón de las dimensiones de la fachada, es decir el ancho de dieciocho metros y la altura de veintisiete metros, está en proporción sesquiáltera o diapente (2/3), al igual que la pendiente del techo dibujada por el padre Bohle.

A su vez la altura se divide en tramos de nueve varas. El inferior incluye el pórtico de seis varas y el coro de tres varas. Arriba de este, el dado y el primer tambor, ambos de cuatro y media varas, finalmente el segundo tambor y la cruz.

Se podría seguir buscando relaciones geométricas y con toda certeza encontraríamos algunas posibles de asociar a números irracionales. Como por ejemplo la que se obtiene al considerar la distancia desde el eje más alejado de la torre y la altura del primer tramo hasta el coro, razón que se asemeja a la raíz cuadrada del número de oro.

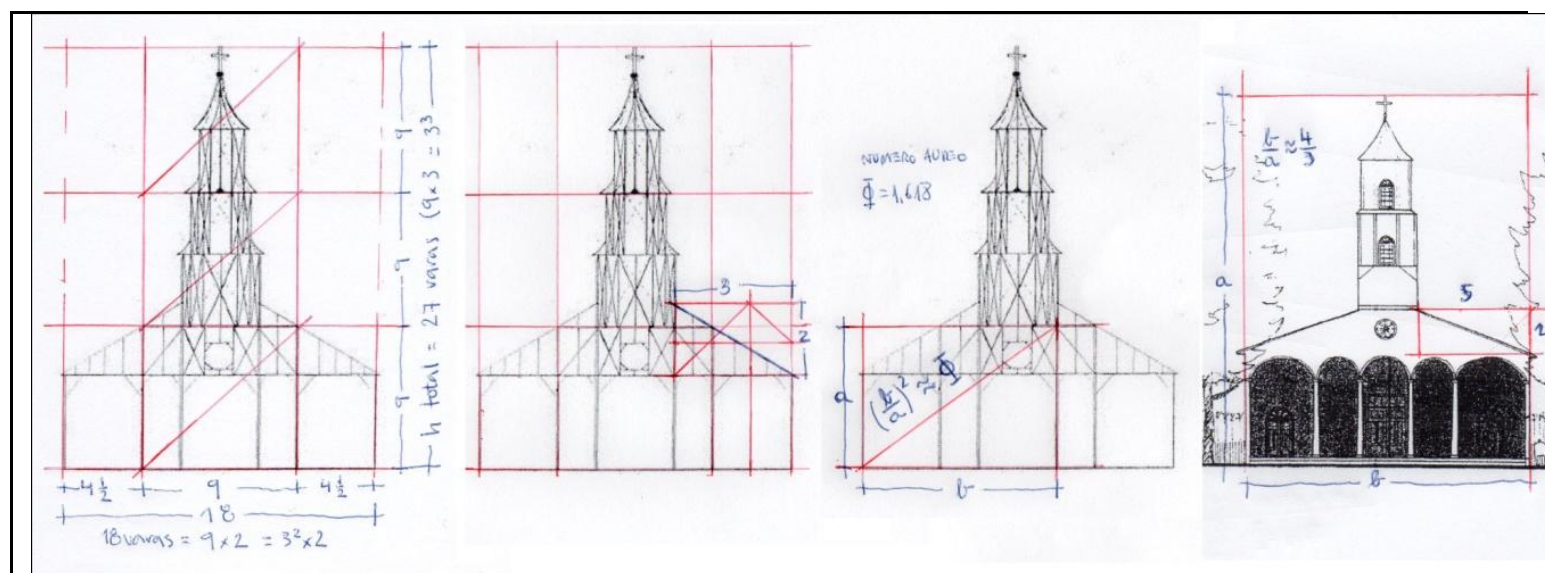

Figura $\mathrm{N}^{\circ} 12$. Esquemas geométricos en la iglesia de Curaco de Vélez. El tercero indica una hipótesis de trazado regulador sobre la base de un rectángulo dinámico relacionado con el numero áureo. La cuarta imagen indica las relaciones geométricas en la iglesia construida realmente.

Sin embargo cuando el padre Bohle anota el ancho y la altura, lo que hace es hacer una declaración del principio rector del edificio que es la razón sesquiáltera (2/3), fácil de relacionar con las tres personas de la santísima trinidad, presente en la proporción general, en la pendiente de la cubierta, en la de la altura de la nave lateral, en el tramo central del pórtico, por citar algunas. Es decir usa proporciones en base a números sencillos y fáciles de construir usando como patrón de medida una vara de largo. A esto se suma el hecho de que las medidas anotadas y sus submúltiplos son fáciles de obtener usando piezas de madera de dimensiones típicas entre las producidas por los leñadores chilotes es decir tres, cuatro y ocho varas.

El templo del padre Bohle fue enteramente consumido por un incendio el año 1971 cuando se preparaba el expediente para su declaratoria como Monumento Nacional. De las fotografías que le sobrevivieron, así como de los levantamientos, es posible ver que lo construido no corresponde a cabalidad con el plano presentado al obispado, el 
cuál con toda seguridad no regresó a Curaco, y como no se hizo una copia de él, la construcción se realizó sin usarlos como referencia.

Entre estas diferencias destacan tres en la fachada. La primera es que el distanciamiento de los pilares centrales no diferencia el intercolumnio central. Sigue el hecho de que la pendiente de la cubierta se redujo a un tercio, lo que jerarquizó el pórtico por sobre el resto de los componentes del imafronte. Por último la primera caña se hizo como continuación del dado, ochavándose las esquinas tal como hizo entre la primera y segunda caña, en el proyecto de la iglesia parroquial de Osorno, lo que acerca esta torre a la tradición constructiva de la colonia del lago Llanquihue, sin renunciar a su raigambre chilota.

\section{d) LA IGLESIA DE SAN JUAN: SOFISTICADO EJERCICIO GEOMÉTRICO.}

Un interesante y sofisticado estudio dimensional y de proporciones fue realizado el año 1981 por los, en aquel entonces, estudiantes Oxiel Schneider Z. y Elvio Valassina en el marco de los seminarios de investigación de la Escuela de Arquitectura de la Universidad de Chile, dirigido por el profesor Hernán Montecinos Barrientos. En este trabajo se hipotiza que la iglesia fue trazada siguiendo un complejo sistema de proporciones relacionado con una sofisticada manera de calcular las proporciones usando el numero áureo, un numero con infinitos decimales cuya determinación implica elaboradas operaciones geométricas.

Se desconocen mayores antecedentes sobre la construcción de la iglesia, salvo lo indicado por Schneider y Valassina, es decir que fue construida usando la vara como patrón de medida y que sufrió algunas modificaciones en el tiempo, especialmente en la fachada. Se hace la salvedad que a raíz de lo que se indica en el presente trabajo, se estima que se usó la vara castellana de 836 milímetros de largo, en vez de la vara tradicional de 866 milímetros de largo, como lo señalan los citados autores.

Inspirados en los rectángulos dinámicos, es decir aquellos en donde la proporción de los lados es un número irracional, llevaron el estudio de las proporciones al límite de lo imaginable, llegando incluso a forzar las situaciones y dejando algunos vacíos difíciles de explicar.

Analizando las dimensiones anotadas en los planos dibujados por los estudiantes y los cálculos de las proporciones surge la pregunta: ¿Hasta qué submúltiplo de una unidad de medida es posible diferenciar en el momento de construir?.

Lo más probable es que en el caso de las iglesias de Chiloé el maestro constructor hubiese usado una vara graduada, lo que representa una limitación para la construcción de proporciones irracionales e inconmensurables, así como la subdivisión del módulo de una vara en una cifra menor, ya que en la regla se marcaban sólo algunos submúltiplos de la unidad de medida considerada. 
Lo anterior significa que las distancias en obra se medían en cierta cantidad de varas y una fracción de ella, de acuerdo a las dimensiones de las piezas que se usarían considerando los ajustes necesarios producto de las uniones.

Otro hecho que es necesario destacar, es que el proceso del proyecto, en el caso en que se hubieran elaborado los planos de la iglesia, quedaba trunco por la dificultad de contar con una copia de los mismos en la obra, por lo tanto la fidelidad entre proyecto y obra quedaba supeditada a la memoria del maestro mayor y principalmente a su experiencia en la construcción de otras iglesias, facilitando la modificación y la adaptación de la obra a medida que se avanzaba. Esto explicaría en parte la similitud formal entre algunas iglesias como la de Quicaví, San Juan y Colo, construidas respectivamente en 1885, 1887 y 1890.

Sobre los trazados reguladores, los mismos autores advierten que los rectángulos dinámicos pueden descomponerse en una infinidad de figuras afines a la razón original, por lo cual el análisis geométrico resulta ser un ejercicio tautológico.

Llama la atención que en la definición de los trazados curvos, la parte trasera de la bodega y de la sacristía no se haya ajustado al trazado, sino que se haya hecho de 2 y media varas de profundidad, una dimensión habitual de los largos de las maderas.

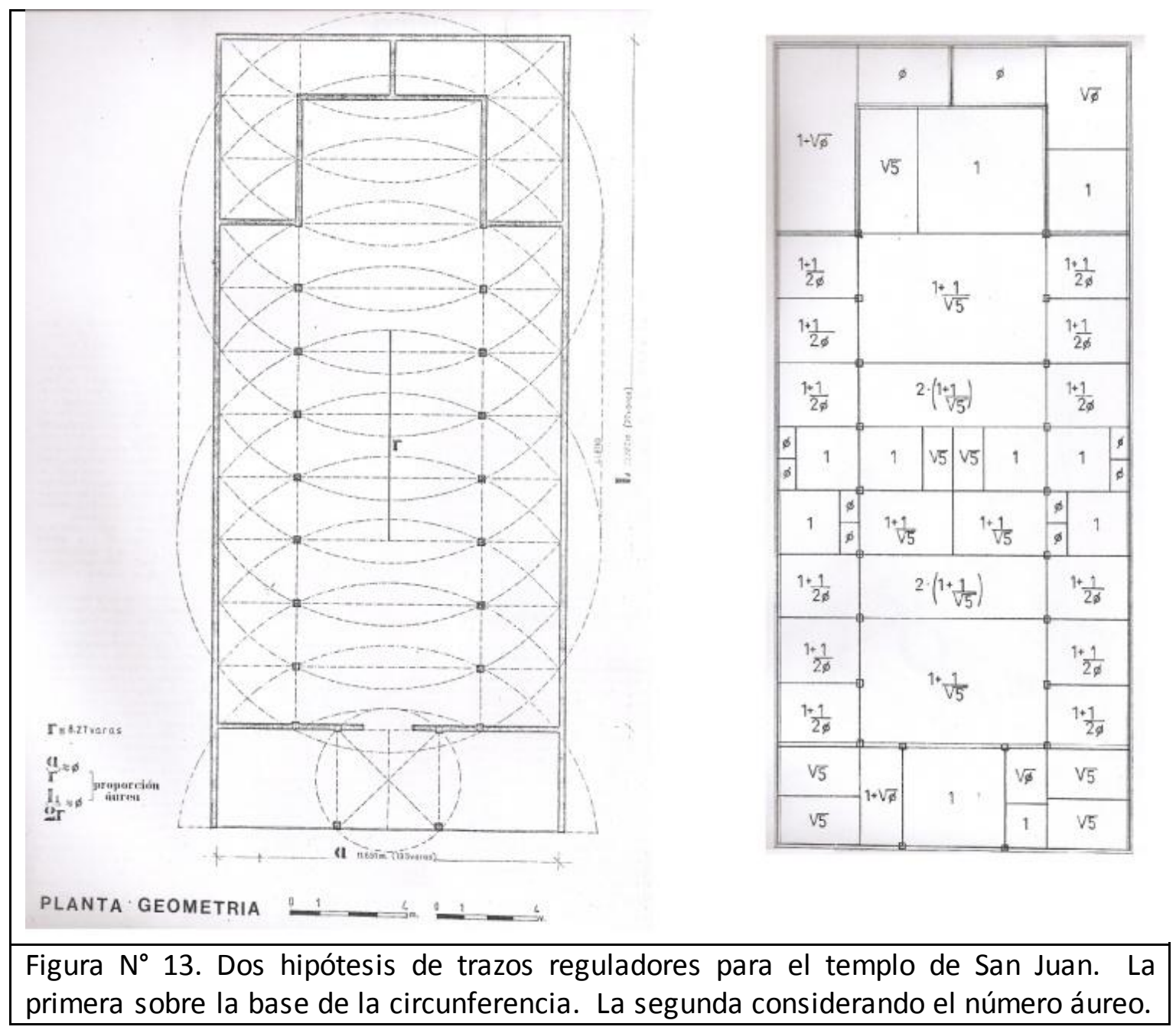


En cuanto a la relación dimensional, las medidas consideradas en la construcción están todas comprendidas en los largos típicos de las maderas producidas por los hacheros de Chiloé. En el sentido transversal, el ancho de la nave lateral y de la nave central corresponde con las piezas de cuatro y ocho varas respectivamente, así mismo la distancia entre columnas está comprendida en el largo de las piezas de dos y media varas. Al ser las dimensiones consideradas más cortas que el largo de las maderas, se podían descabezar y cuadrar los extremos eliminando las irregularidades producto del corte hecho con hacha al trozar los árboles, se podían ejecutar las uniones entre ellas (como por ejemplo el rayo de Júpiter, o media madera o el traslapo de piezas), sin requerir elementos adicionales de refuerzo. Una rápida revisión del libro Restauración Iglesias de Chiloé (Berg, 2005), permite avalar esta idea ya que es posible constatar cómo las uniones traslapadas, sea en envigados de piso como en los pares de las estructuras de cubierta, era una solución recurrente en estas construcciones.

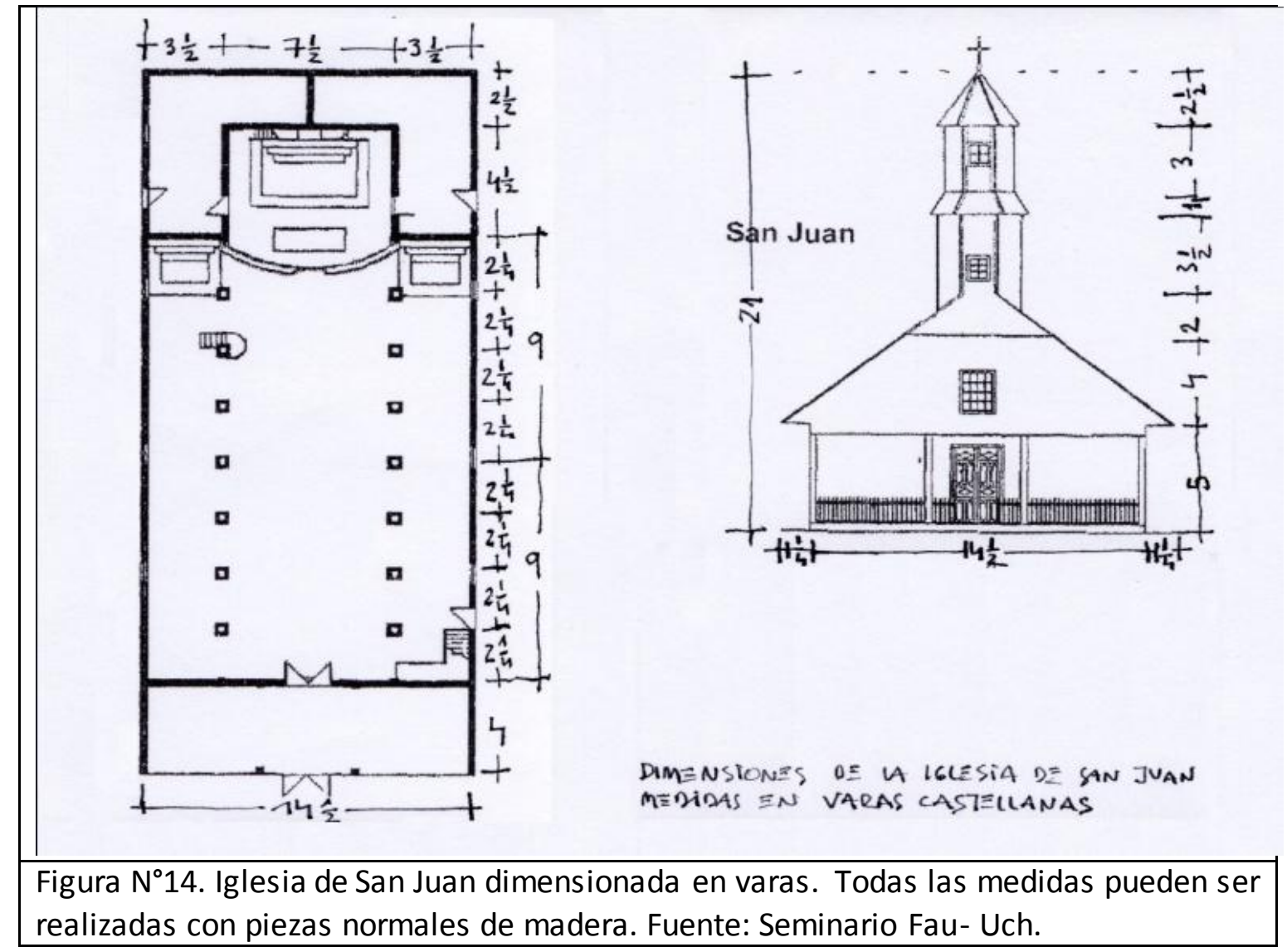

Así mismo, el pórtico con una profundidad de cuatro varas, actúa como una unidad separada, entendida su construcción como inmediatamente después o traslapada en el tiempo, respecto al cuerpo principal de la iglesia.

Lo indicado dificulta la realización de la construcción, sobre la base de un complejo sistema de trazados reguladores. Todo esto lleva a pensar que los trazados reguladores son el resultado de la sencillez de la distribución interior, de la regularidad del sistema constructivo en base a tabiquerías y a las dimensiones tipificadas de las maderas de construcción. 


\section{e) LA IGLESIA NUEVA DE CHONCHI. INTUICIÓN CONSTRUCTIVA.}

El año 1890 el obispo de Ancud, Monseñor fray Agustín Lucero Lazcano autorizó demoler la antigua iglesia de Chonchi y reutilizar las maderas en la construcción de una nueva. Tres años después se inició la construcción, para lo cual se utilizó madera de ciprés. Los días de lluvia los maestros trabajaban labrando las maderas y preparando los ensambles al interior de la iglesia, ya en mal estado (Montecinos et al 1995). Este hecho revela una práctica en la construcción poco conocida, como lo es la de prefabricar las piezas con sus empalmes (media madera, cola de Milán, cajas y espigas, etc.) para que una vez que estas estaban listas, iniciar el montaje de la obra gruesa. Esto significa que había una concepción del edificio como la de un sistema posible de ejecutar por etapas, considerando la recepción y preparación del material, es decir dejar las piezas listas para el montaje, como la primera de estas etapas. A esta que seguía el montaje propiamente tal o armado de la estructura, para seguir con la colocación del revestimiento exterior y el piso, y finalmente colocar las terminaciones interiores.

El templo mide diecisiete varas de ancho y cuarenta y ocho varas de largo incluido el pórtico. La medida del ancho no es casual, como se explica más adelante. La altura interior es de seis varas, alcanzando nueve varas en la bóveda. La pendiente del techo es semejante a tres cuartos, es decir que está en proporción sesquitercia.

Siguiendo el esquema propuesto de la existencia de una racionalidad derivada del proceso constructivo y las dimensiones de los materiales usados, se señala que al interior de la iglesia el intercolumnio es de tres varas y media, lo que se cubre con "madrinas" o vigas maestras de cuatro varas de largo. En el sentido transversal, la nave lateral mide cuatro varas y la central siete, lo que permi tió usar piezas de cuatro y ocho varas de largo, apoyadas en el tabique de tres varas de alto ubicado sobre el eje de las columnas. Sobre esta viga se cuelga la bóveda rebajada o de carpanel.

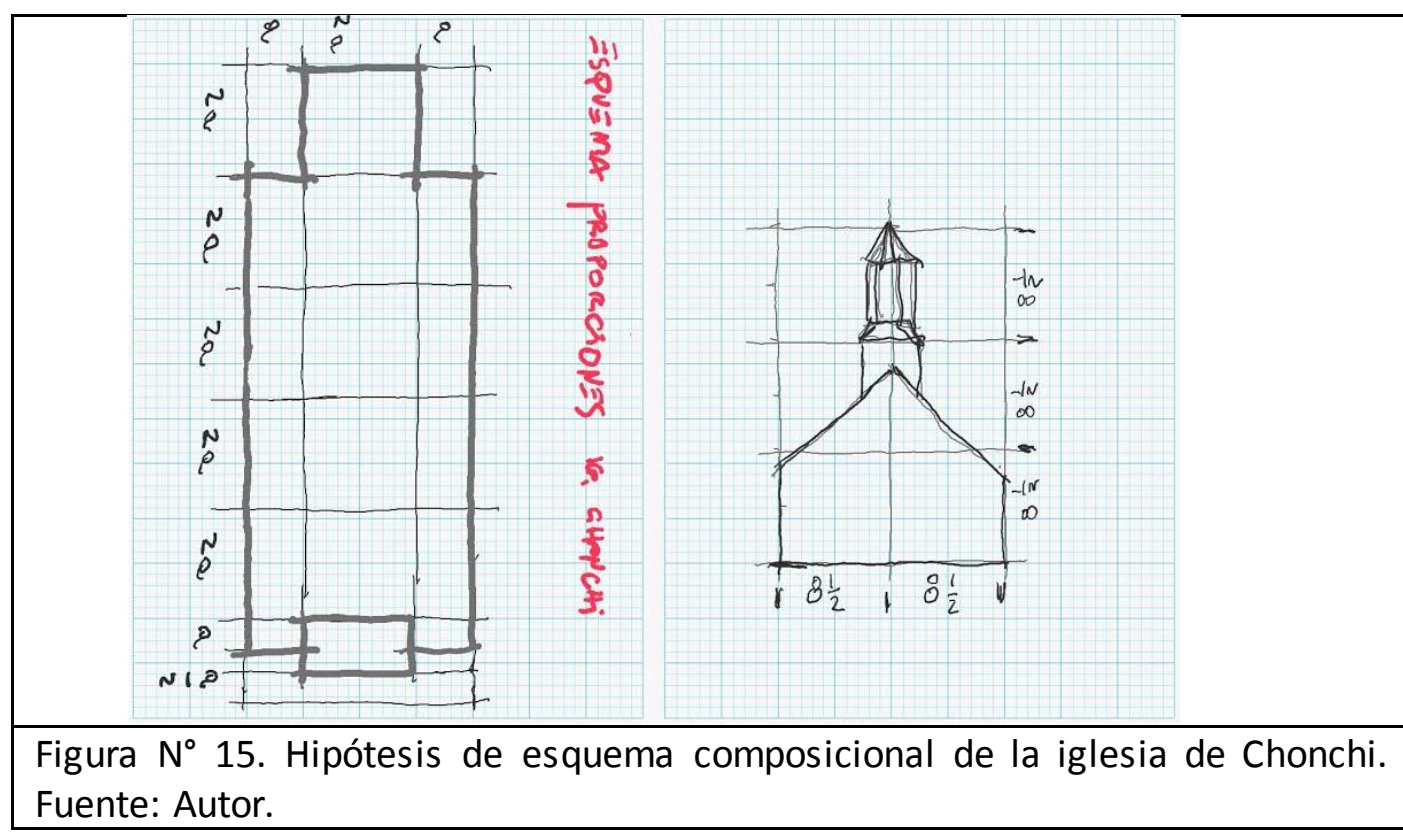


En el imafronte la altura desde el nivel del piso del coro hasta la solera superior del lado es de siete varas y un cuarto, el primer tambor mide cinco varas y el segundo cuatro varas y un cuarto, lo que permite construir la torre con piezas de ocho y seis varas de largo, trabando el segundo tambor con el primero y este con el dado, dándole firmeza a la construcción de la torre.

En cuanto a la fachada, considerando hasta la altura del capitel, esta se inscribe en un rectángulo cuyos lados están en proporción sesquiáltera, es decir de dos a tres (2/3).

\subsection{La fabrica de madera: sistema estructural y proceso constructivo.}

Las capillas tradicionales introducidas a partir de mediados del siglo XIX, reemplazan el sistema de postería labrada realizado por los jesuitas en el periodo colonial que se vio en Achao y que también adoptaron los franciscanos de Ocopa en sus nuevas capillas en Ancud. El sistema que comienza a utilizarse en las estructuras de tabiques y que lo diferencia del periodo anterior, son del tipo de entramado en base a pilares, normalmente en secciones de $5 \times 5$ " distanciados en forma regular, con el uso de diagonales, eventualmente, solo para las esquinas y por lo tanto las estructuras están arriostradas exclusivamente por los revestimientos de tablas por el lado interior, mientras que por el exterior llevará tejuela corta, larga o tabla (Figura $n^{\circ} 15$ ). Este sistema constructivo que se usaba en Europa ${ }^{129}$ y traspasado a las costas del Pacífico, es introducido en Chiloé inicialmente por misioneros llegados al archipiélago y las sucesivas oleadas de inmigrantes a la zona, , sin embargo su utilización masiva fue producto de la colonización alemana en la zona del Llanquihue y Valdivia, según lo descrito en el capítulo 5, que transmitió las técnicas a los carpinteros locales implementando una construcción más eficiente y rápida, una suerte de prefabricación de los edificios, que implicaba una solución avanzada no solo a la arquitectura civil y de viviendas, sino que a la arquitectura religiosa, ya que facilitará la multiplicación de los modelos y a soluciones cada vez mas estandarizadas.

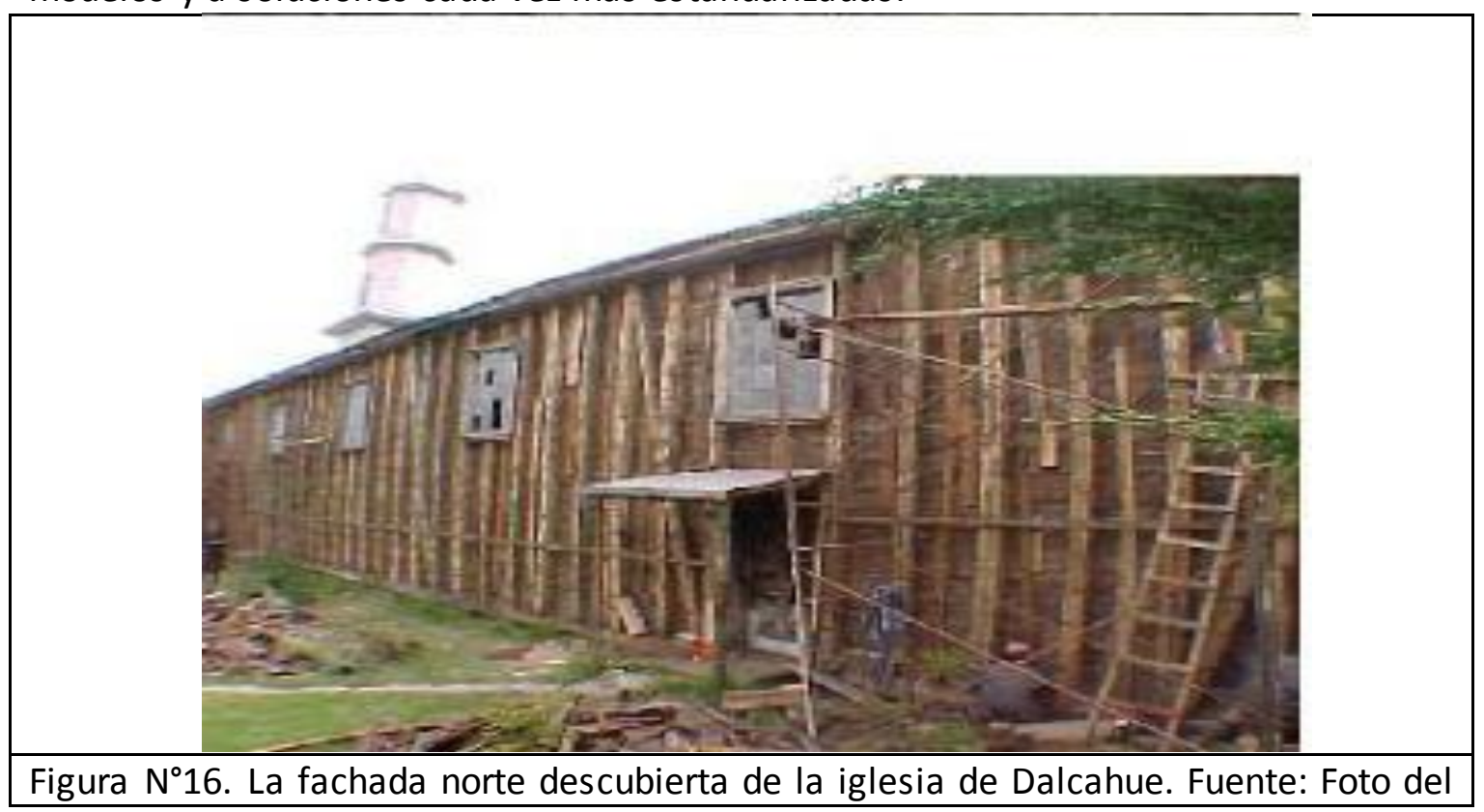

\footnotetext{
${ }^{129}$ Denominado Fachwerk en Alemania; En Francia era conocido como "pan de bois court (entramados de madera cortos) o colombages (colombarios)" (Tampone, 1990, p. 132).
} 
autor, 1998.

En tal sentido lo interesante aquí es la adopción de un sistema de producción y proceso técnico de construcción que se va ajustando a las condiciones y necesidades locales para ser más efectivo, en términos de realizar una obra de magnitud y complejidad tal, que pueda desde su idealización o proyectación, materializarse en sus diferentes fases que van desde el trazado, hasta los detalles de terminación.

Para efectos de esta tesis, enfocada a la concepción tipológica de las capillas, se centra en el nivel de la ejecución de la carpintería mayor, más que en la de detalles decorativos u ornamentales. Entendida esta como carpintería de armar y cuyo objetivo es lograr que los elementos estructurales y de cerramientos puedan ser ajustados en obra a través de un sistema lógico, con el uso de ensambles entre los maderos. Es este lapso histórico y en las propiedades de esta carpintería de armar donde se comprende que "el entramado es el sistema que representa el auténtico armazón constructivo (cuyas derivaciones conceptuales como sabemos, llegan hasta la arquitectura moderna) y se halla amplísimamente difundido en el conjunto de la arquitectura popular..."(Maldonado \& Rivera, 2005, p. 689)

Se distinguen dos escalas de procesos o secuencias, una que tiene que ver con la realización de la carpintería de armar (escala menor de los elementos constructivos) y otra con la edificación de las diversas partes de fábrica (escala mayor de los componentes arquitectónicos). Ambos dependen del proyecto, ya sea la existencia de una planimetría acabada o un esquema general, según se ha visto en los casos de las capillas estudiadas previamente.

Para la escala menor, la secuencia de trabajos en la carpintería de armar, se identifican las siguientes fases generales: selección de las maderas, preparación de los elementos madereros, instalación o fijación de estos y acabados.

Para la escala mayor, relativa a la secuencia de las faenas de edificación de las capillas y que interesa profundizar más en detalle, destaca una característica fundamental, las torres son realizadas en forma estructuralmente independiente de las naves (Berg, 2005) e incluso podían estar desfasados totalmente en el tiempo, según lo que se confirma al revisar los documentos del obispado (Montecinos, 1995). En el caso de Nercón, la torre se ejecuta 15 años después de la nave, no obstante se ve como una composición unitaria. Este procedimiento tendría su lógica, pues lo primero es construir la nave para la asamblea y el altar, dando así cabida a las funciones religiosas que son la liturgia y los sacramentos. En cambio, la torre fachada tiene un fin simbólico y por lo tanto es "secundaria" en el proceso constructivo. 


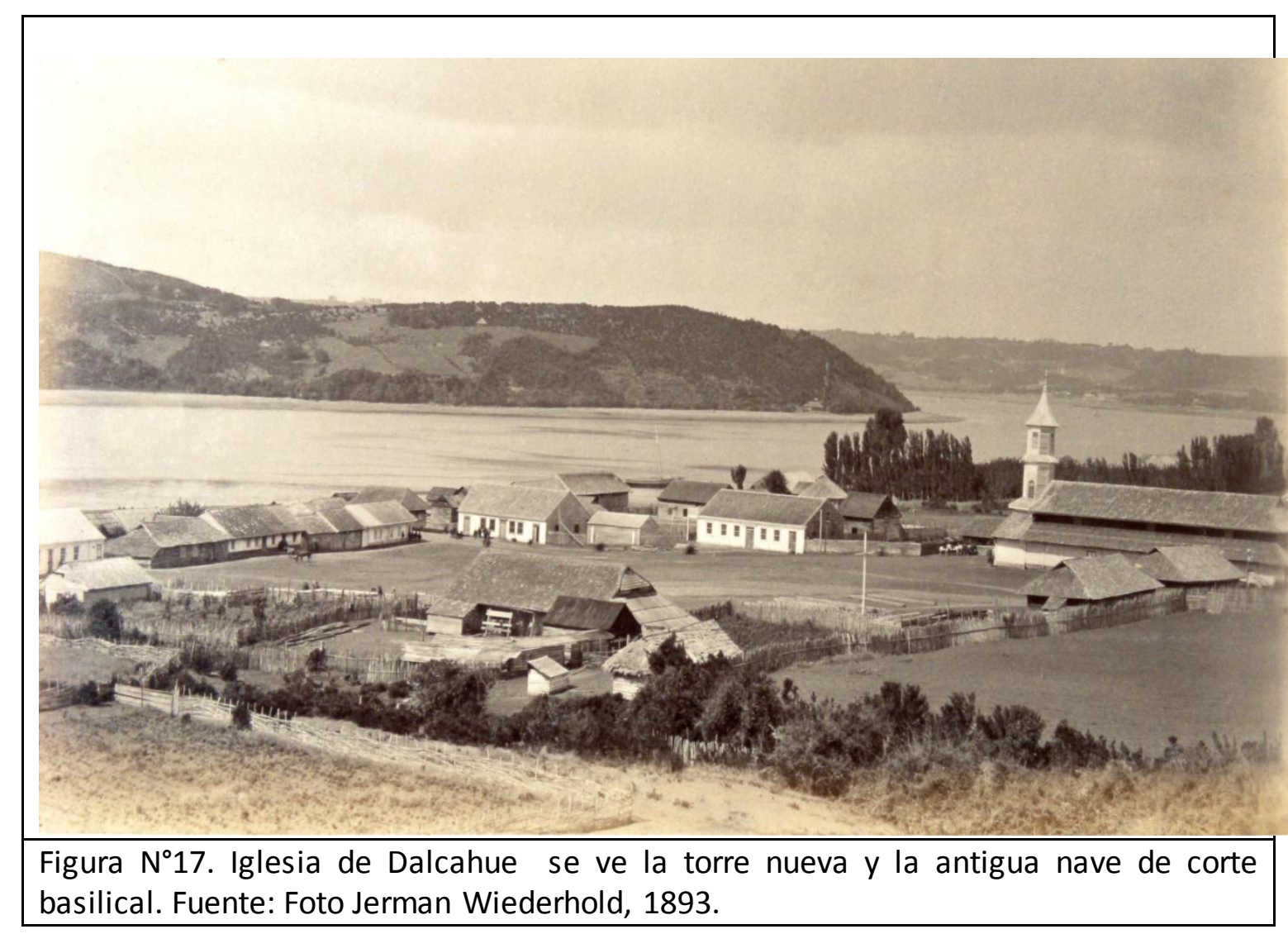

En el caso de Dalcahue y según la foto de Wiederhold, se aprecia la torre nueva en la tipología tradiconal, mientras la nave es una fabrica más antigua, que posteriormente se hace completamente nueva. Esto corrobora la tesis de la independencia de ambos elementos (Figura № 17).

En una fábrica entera de madera sería más lógico considerar un sistema perfectamente unitario y continuo, sin embargo la autonomía entre torre y nave representa incógnitas. Pudiendo estar entre las respuestas la funcionalidad de usos prioritarios entre nave y torre; un mejor aprovechamiento de los recursos físicos disponibles en razón a los ingresos económicos para el avance financiero de la obra; realizadas por cuadrillas o equipos de maestros diferentes especialidades, al menos en las capillas mayores.

Sin embargo, pareciera ser que la razón fundamental de la parcialización de la obra o fábrica en nave y torre tiene que ver con el contexto geográfico, en un clima lluvioso y de viento, el armar cuerpos o volúmenes separados de manera más acelerada es el principal objetivo del proceso constructivo. Es lo que en Chiloé se llama cerrar o techar la construcción, como forma de lograr una rápida protección y refugio para la propia fábrica. Esta práctica que se mantiene en la actualidad en el archipiélago seguramente es una tradición antiquísima desde las primeras rucas indígenas.

Según lo anterior, la secuencia constructiva básica en las capillas es la siguiente, una primera fase que requiere ejecutarse en forma continua y un plazo de tiempo determinado, idealmente algunos meses, para dejar "cerrada" la nave y protegido los 
elementos constructivos de las inclemencias del clima, que son fundaciones, estructura y revestimientos exteriores (muros y cubierta). Posteriormente viene una segunda fase de terminaciones interiores que no requieren ejecutarse en forma continua ni en un plazo de tiempo determinado y que podía durar años. En esta segunda fase era importante, al menos, tratar de concluir o "de vestir" la nave por el interior para dejar el espacio religioso y no dejar desnudas las estructuras y dar una mala impresión ${ }^{130}$. Por lo tanto la colocación de los revestimientos interiores de pisos, muros, columnas y cielos era prioritario, Posteriormente se realizaban el alhajamiento de altares, pulpitos, retablos y otros mobiliarios adosados o no al edificio. Se dejaba para el final la sacristía, contrasacristía, bodegas o casemita ${ }^{131}$, ya que no era considerado como un espacio religioso propiamente tal, lo que incluso podía darse que nunca se terminaban por el interior, es el caso de Chonchi, un gran templo y con un buen nivel de decorados internos, pero cuya sacristía ha permanecido con la estructura al desnudo hasta el día de hoy.

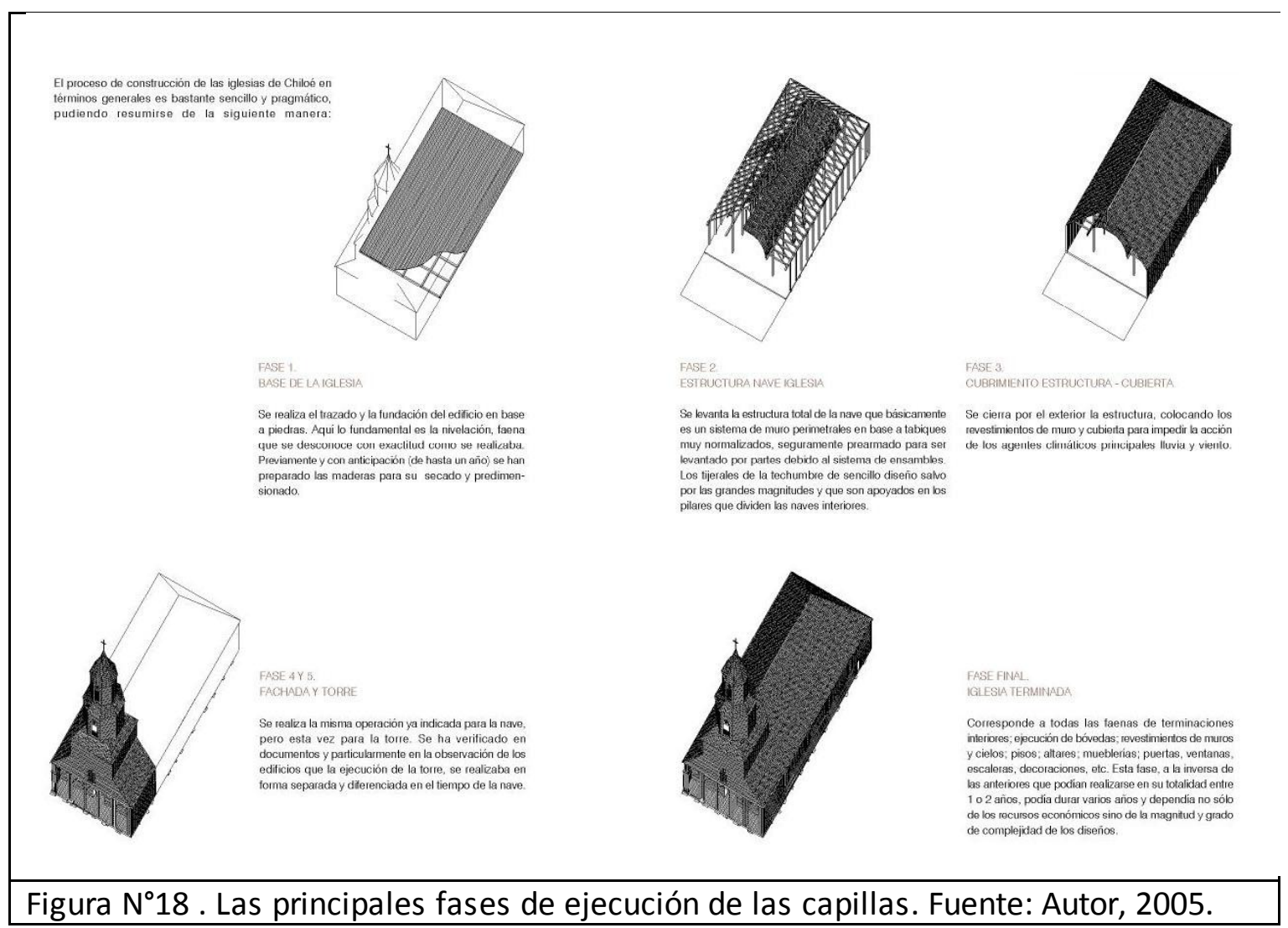

\footnotetext{
${ }^{130}$ Con las Ilamadas imágenes religiosas de vestir era similar, ya que son piezas que tienen talladas solo cabezas, manos y pies y ellas están unidas por una pequeña estructura de madera que nunca era expuesta así en la iglesia, se considera un sacrilegio, no obstante se haga en los museos, siempre eran cubiertas por hermosos ropajes. Cabe destacar que las imágenes son cuidadas por sus patrones, vecinos de la comunidad, y algunas de estas pueden ser más antiguas que la Iglesia y son traspas adas de la antigua a la nueva capilla.

${ }^{131}$ Es una pequeña construcción adosada o no a la capilla para fines de servicios o almacenaje de apoyo a la capilla.
} 
En la torre fachada la secuencia de faenas es similar, son fundaciones, estructura y revestimientos exteriores (Tabiques y cubierta) con la diferencia que en la fase de terminaciones están solo acotadas al pórtico y la instalación de las campanas

En forma detallada, el proceso constructivo de la nave se considera como sigue: Fundaciones con basas de piedras; Envigado de piso; Tabiques externos, internos y columnas; Envigados de las naves laterales; envigados nave central; Cumbrera apoyada en el envigado de la nave central; Envigado de techumbre sobre la nave central; Envigados sobre naves laterales; Cubierta; Revestimientos exteriores; Revestimientos interiores y; alhajamientos, decorados y mueblería.

\subsubsection{Fundaciones y envigados de piso.}

Estas se realizaran con basas de piedra asentadas sobre un terreno liso, siguiendo el esquema Jesuita, normalmente son bloques irregulares de entre $60 \mathrm{a} 80 \mathrm{~cm}$ de ancho y unos $40 \mathrm{~cm}$ de alto, pero con la condición que una cara debía ser relativamente plana para asentar la estructura de piso. Así como las basas de piedra no están enterradas, las vigas del entrepiso tampoco se afianzan a las piedras, sino que van simplemente apoyadas y en algunos casos con pequeñas cuñas de madera para dar una nivelación correcta e impedir el deslizamiento de las vigas maestras.

La práctica y uso de piedras, a pesar de su condición rústica, demostró que daba una gran resistencia y estabilidad como material de contacto con el terreno, generalizándose ampliamente su uso en el archipiélago llegando hasta las viviendas. Implicó un avance técnico importante al permitir un piso de madera ventilado y aislado del terreno húmedo. Entrado el siglo XX, se abandonará totalmente la utilización de las basas de piedra por fundaciones aisladas de concreto o en las construcciones más sencillas se seguirán utilizando los pilotes de madera de luma (Luma apiculata) o Ciprés de las Guaitecas (Pilgerodendron uviferum). En la actualidad se ha llegado a tal impericia y falta de valoración de fundaciones de piedra preexistentes, que en la Iglesia de Rilán fueron retirados en los trabajos de reconstrucción del nuevo edificio.

Los envigados de piso corresponden normalmente a un entramado en un solo plano de piezas de 5 x5 "ensambladas con cola de milano".

\subsubsection{De las estructuras de la nave.}

Esta faena es fundamental en el proceso, para generar una geometría y envolvente de la nave en forma segura, correcta y sobretodo muy cohesionada o solidaria, en tal sentido los entramados verticales o tabiques, los entramados horizontales o pisos y los envigados conforman un todo absolutamente conectado. Es lo que denomino un gran mecano de madera (Berg, 2005). Lo interesante aquí es poder deducir el montaje, si bien no se han encontrado testimonios escritos o gráficos del procedimientos de ejecución, se puede inducir a partir de la misma fábrica y del sistema constructivo. De alguna manera sigue el esquema de plataforma, ya que sobre la plataforma del entramado de piso se levantarán tabiques y pilares de la nave central ${ }^{132}$, posteriormente el entramado de vigas dispuestas en el nivel del plano superior de los

\footnotetext{
${ }^{132}$ A diferencia del periodo colonial, que el uso de plataforma y de pisos era escasos y las estructuras murarias iban directamente hincadas en el terreno.
} 
tabiques servirán de base para poder situarse los carpinteros y apoyar el levantamiento de los tijerales o más bien envigados. Lo que demostraría un nivel de desarrollo técnico importante, sumado al ingenio para suplir la falta de implementos o equipos mayores, sino que solo con el uso de la fuerza humana o animal y elementos auxiliares simples como andamios, cuerdas y seguramente roldanas.

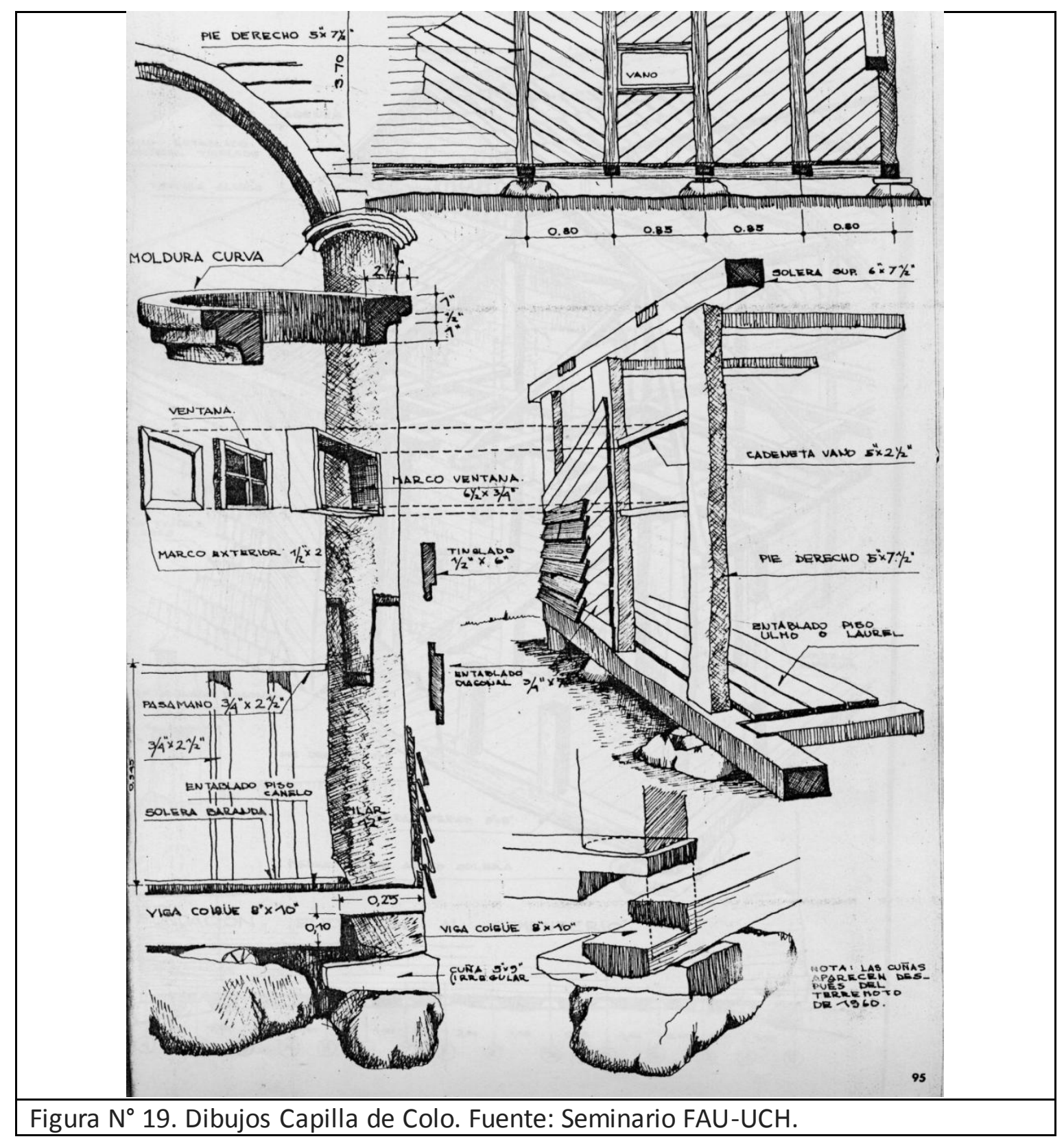

Las opciones para levantar estas tabiquerías son básicamente dos:

a. Se armaba cada tabique directamente. Este trabajo se puede catalogar como el más artesanal en el sentido de que cada pieza se va midiendo, cortando y fijando en el lugar que le corresponde en el edificio. Esta operación constructiva es probable que se haya realizado en algunas capillas menores y donde no existía una mano de obra muy especializada en la carpintería de 
armar. Es lento y puede inducir a ciertos errores si no considera un buen sistema o guía con niveles y aplomes.

b. Se prearmaba cada tabique en el piso y se levantaba entero o de manera parcial posteriormente. El levantado o alzado de tabiques enteros es dudoso que se haya logrado realizar en las capillas chilotas, dado las grandes dimensiones y peso que tienen estas y los escasos equipos que se contaban para tal efecto. Por lo tanto lo más probable es que el alzado de los tabiques se haya hecho en forma parcial, hay piezas de maderas en algunas estructuras que dan cuenta de ser dispositivos para amarrar y levantar los elementos.

Siendo el prearmado en el piso el más probable sistema utilizado para las capillas chilotas, siguiendo la lógica de la carpintería de armar, por lo tanto durante la etapa de preparación de los maderos previo a su fijación en obra el objetivo es la normalización de los elementos, con la particularidad de tratar de ocupar las piezas estructurales principales en la longitudes que venían del aserradero.

De esta manera inicialmente se preparaban las piezas de madera según su función en la armadura, ya sea vigas, soleras, pies derechos, diagonales u otros, definiendo la longitud, escuadría y ensamble o uniones para cada uno de ellos, de acuerdo al plano o esquema previo de la obra.

Los dimensionamientos, rebajes y especies requeridas de las maderas fue el resultado de convenciones que la tradición carpintera trajo de Europa y la práctica local fue adquiriendo ${ }^{133}$. Si los jesuitas previamente habían logrado introducir una carpintería de armar en entramados de maderas de grandes dimensiones, con uniones de encaje entre los elementos constructivos, este panorama para el siglo XIX logra un máximo repertorio en el uso de ensambles como son la de caja y espiga, media madera, cola de milano, empalme de quijera, o rayos de Júpiter ${ }^{134}$. Cada uno de ellos responderá a una situación particular, la cola de milano se hallará siempre entre el encuentro de las vigas de piso y las vigas maestras o la caja y espiga entre pilares y soleras (Cherubini, 2014). También la típica unión a media madera para dar continuidad a las soleras, son las soluciones denominadas empalmes, que dentro de los sistemas de ensambles carpinteros tienen la función de permitir conexiones para dar mayor longitud a un elemento constructivo. Por otra parte aparecen las escuadras, como elementos de rigidización o apoyo, normalmente usado entre pilares y vigas, que en Chiloé adquieren en algunos casos la peculiaridad de ser piezas casi al natural sin labrado y/o cepillado mayor.

\footnotetext{
133 Respecto a los dimensionamientos, estos eran producto de la experiencia carpintera, el prestigioso tratadista francés Jonsse indica una definición orientativa de las escuadrías de los maderos, indic ando para algunas de las construcciones de su tratado las dimensiones que utiliza, manifestando en numerosas ocasiones su incapacidad para dar una regla universal a este respecto, utilizando frases como "Y le darás dos, tres o más pulgadas según la grandeza del edificio". (Candelas, 1998)

134 Estas técnicas son reproducidas en toda la región tanto en la arquitectura residencial, civil y religiosa. La diferencia en esta última es un mayor dimensionamiento.
} 


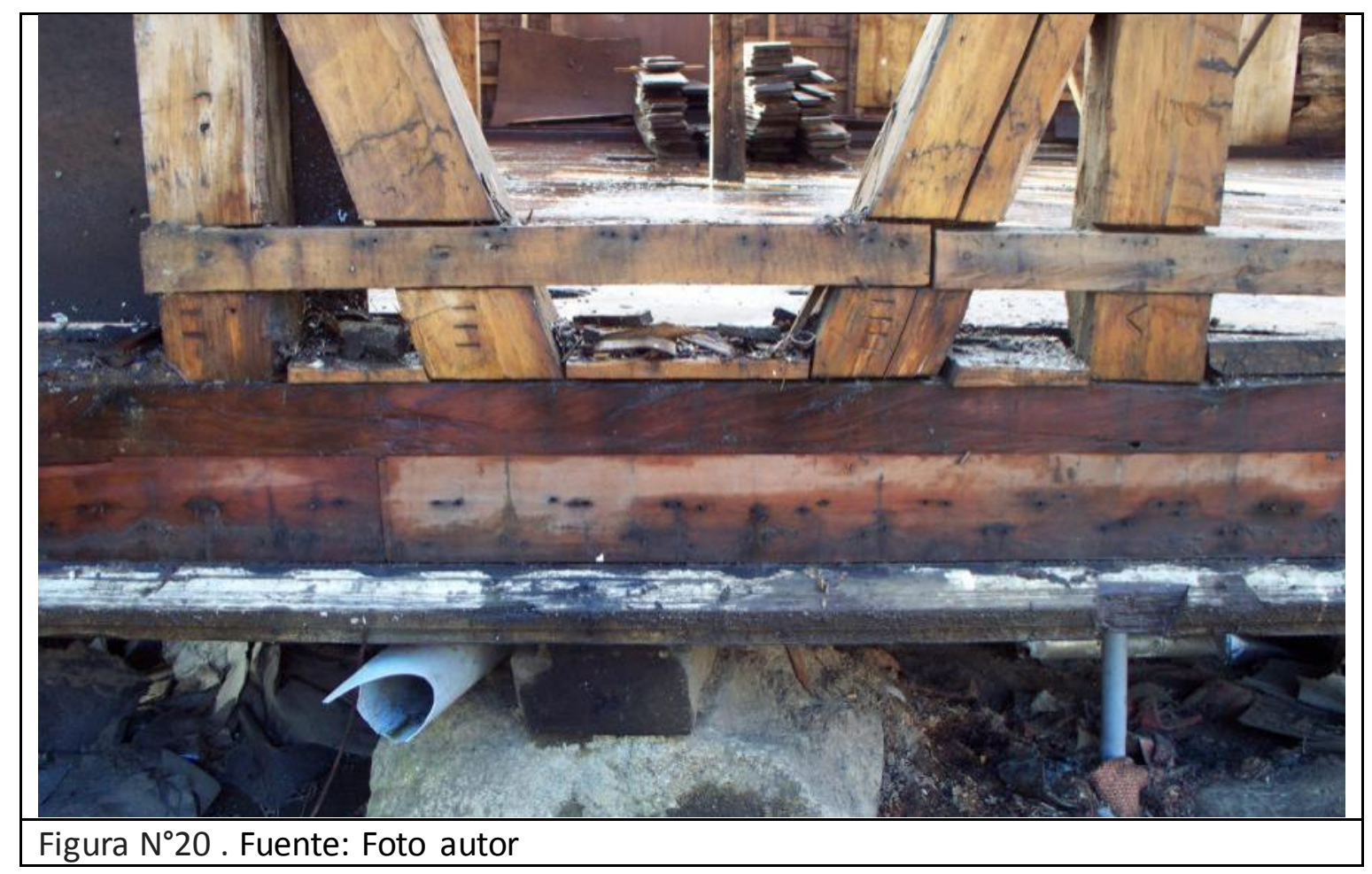

La tendencia a la prefabricación y la hipótesis del mecano queda demostrada con hallazgos últimos en capillas chilotas tradicionales (Rilán y Carelmapu) y otras edificaciones de la colonización alemana. En estas obras que son de fines del siglo XIX e inicios del XX, se han encontrado marcas con números en la base de pie derechos y soleras, que demuestran fueron realizados previamente durante la preparación de los elementos para fijar su ubicación exacta posterior en las fase de instalación o fijación final en la fábrica. En tal sentido a cada pie derecho con su espiga estaba señalado con su correspondiente caja a ensamblar en la solera (Figura $\mathrm{N}^{\circ} 20$ ).

Las secciones madereras serán siempre sobredimensionadas y pareciera que la historia de temblores y temporales australes que derrumbaban o debilitaban las estructuras en su proceso de construcción, fueron dando las medidas más requeridas. Es sintomático que las secciones en los pie derechos en grandes y pequeñas capillas son prácticamente los mismos, igual sucede con los envigados y que normalmente son de secciones cuadradas, que demuestra un innecesario sobredimensionamiento. Sin embargo estas características han multiplicado la resistencia y estabilidad de estos edificios, que los han hecho perdurar en el tiempo. 


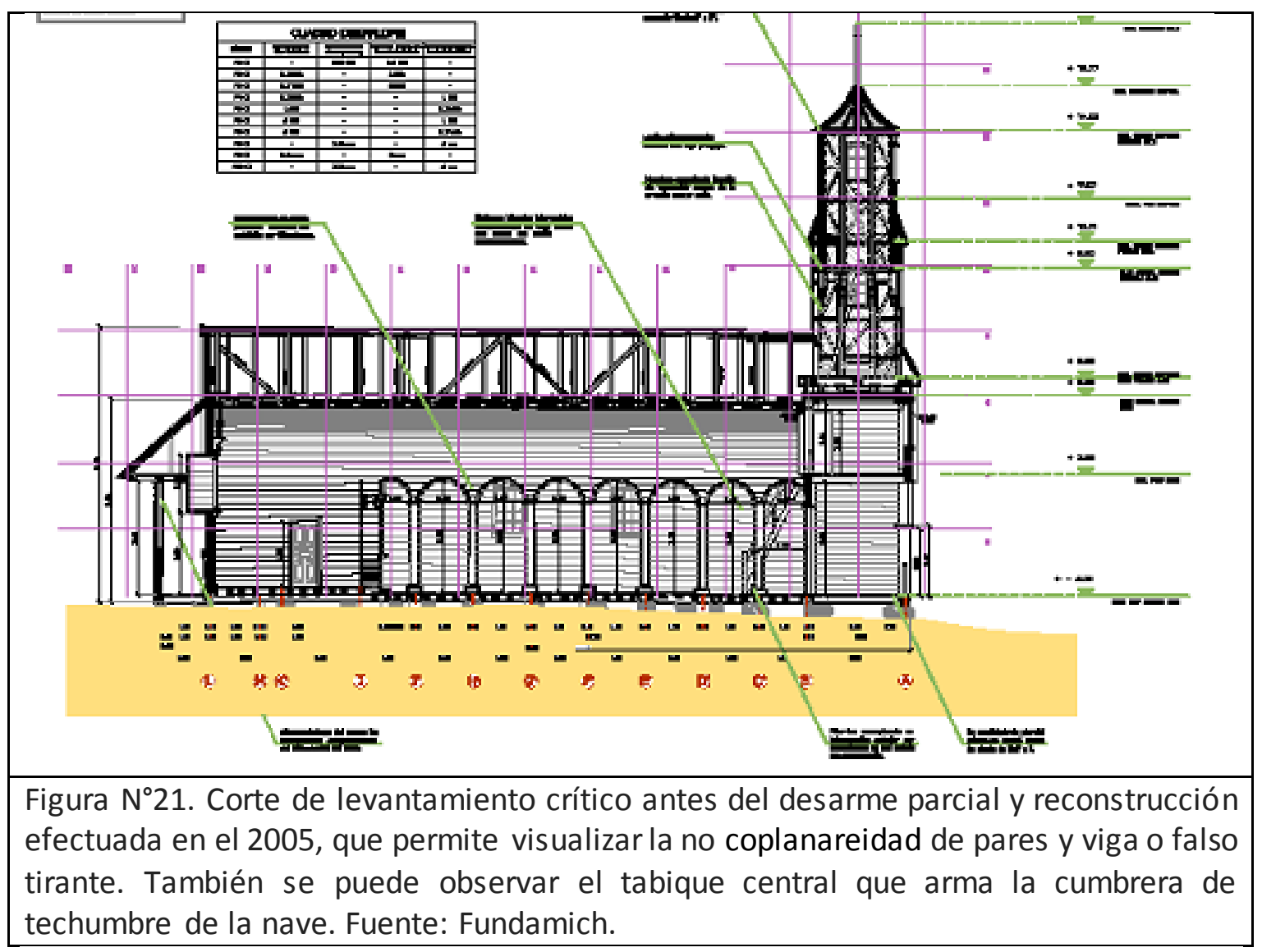

Respecto a la estructura de techumbre, se modificará en el siglo XIX, aunque prácticamente todos los escritos existentes describen que se mantiene el sistema introducido por los jesuitas en base a tijerales de par y nudillo y que se puede visualizar en la capilla de Achao. Dicho tipo de tijeral, dispone del nudillo como barra horizontal entre los pares y aproximadamente a dos tercios de altura, otorgando mejor rigidez y estabilidad a la estructura. Siendo este tipo de armadura una de las más simples para cubiertas, es muy eficiente y dio permanentes buenos resultados en los siglos previos.

Las capillas tradicionales chilotas del XIX e inicios del XX aparentan esta solución, pero un análisis más preciso evidencia que la armadura de techumbre no se resuelve mediante par y nudillo, ni tijerales, ni cerchas. Todos esos sistemas requieren coplanariedad, vale decir que pares y tirantes comparten un mismo plano. El sistema de estructura de techumbres que se popularizó en Chiloé, es similar al usado en galpones y viviendas, que es a base de envigados simples. En el caso de las capillas se disponen de grandes vigas transversales, que van entre las columnas sobre la nave central, a modo de pórtico. Estas vigas transversales normalmente no están en la modulación o en el plano de las vigas de cubierta y al centro de su luz llevan pie derechos o montantes con una solera superior, una suerte de tabique longitudinal, que hace de cumbrera y sobre la cual descansan las vigas de cubierta (Figura $\mathrm{N}^{\circ}$ ). El hecho que no coincidan las modulaciones de vigas y pares se resuelve colocando un estribo sobre las puntas de las vigas con una unión rebajada (junta y rebajo) para que no deslice por los esfuerzos laterales de los tijerales. Sobre este estribo se apoyan los pares, por lo que pueden disponerse a una distancia diferente al de las vigas. 


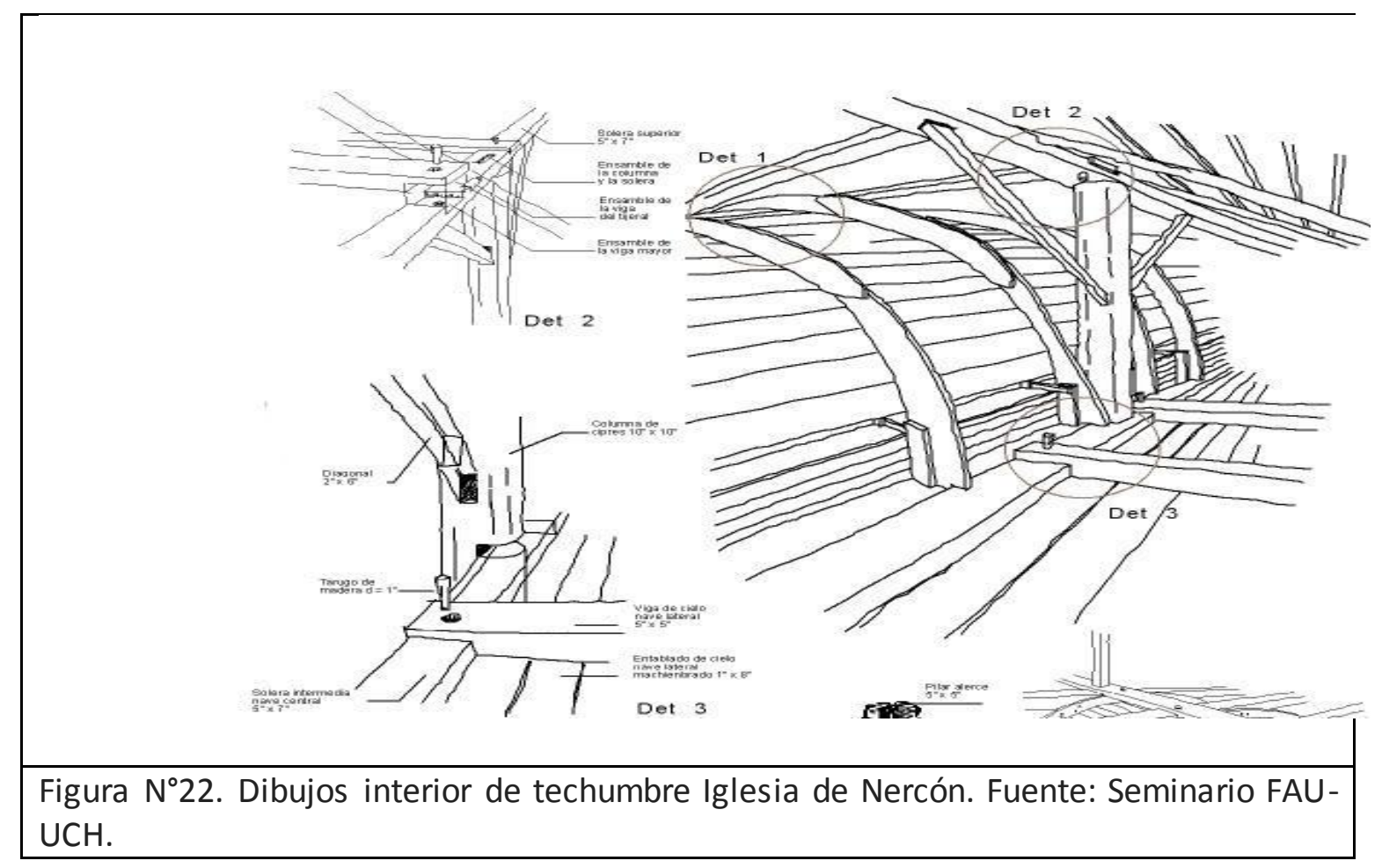

Este sistema tiene su lógica al permitir una plataforma sobre la cual pueden circular y trabajar los carpinteros, haciendo las veces de andamio de obra, a la vez de facilitar la instalación del sistema de envigados, que dada su altura y dimensiones de maderos es más fácil que el montaje de tijerales.

Similar situación sucede en las naves laterales, que se cubre con envigados ya sea de una luz desde la cumbrera o un madero entre eje de columna y tabique longitudinal.

Esta operación y sistema constructivo de armado de la techumbre se asocia a una técnica más artesanal y de tradición popular que está en una fase de preestandarización, no obstante está en la lógica de la racionalidad y economía formal de la arquitectura chilota para los medios que disponía en la época.

Un problema habitual de este tipo de envigados de techumbre es el empuje que ocasionan hacia los muros laterales con el tiempo, situación que se resuelve incorporando un elemento adicional que son los puntales y se pueden encontrar en capillas como Nercón o Caguach. Una forma de solución de este problema y evitar los puntales es colocar crucetas en el plano de cielo de la nave lateral como la existente en la capilla de Achao.

\subsubsection{Las columnas.}

Estos elementos organizan espacialmente la nave central y están siempre realizados en escuadrías cuadradas, normalmente de $8 \times 8$, , de una sola pieza de madera para producir continuidad estructural y disminuir posibilidad de deformaciones, en el caso que se introdujeran ensambles. Usualmente realizadas en Ciprés de las Guaitecas (Pilgerodendron uviferum) y Coigue o Coihue (Nothofagus dombeyi) pueden alcanzar alturas extremas de 9, 20 mts en Rilán o las más corrientes de 6, 70 mts en Aldachildo o Ichuac, ambas en la isla de Lemuy. Van alojadas a la viga maestra de piso mediante 
caja y espiga ${ }^{135}$, de esta manera emergen de la plataforma de piso y por lógica fueron levantadas de a una, con cuerdas y apoyos de puntales.

Sobre la estructura de columnas, esta afianzado el sistema de envigados transversales que permiten tanto el amarre entre ellas, los tabiques perimetrales y la instalación de la cubierta. En tal sentido cumplen una función central de conexión. Uno de los problemas principales de la arquitectura de las naves, es lograr espacios amplios, los que están sujetos a la longitud de las vigas de madera que son de una sola pieza, cuestión que se resuelve "acortando la luz" desde las columnas, de manera tal que se introducen diagonales de apoyo y que además rigidizan la estructura. Estos "artificios" están contenidos en las zonas de entretechos de las naves, que siendo muy simple, quedan absolutamente ocultos desde la vista del espacio religioso interior.

Este sistema de pórtico, igualmente permite introducir y alojar una constante morfológica de estas capillas, como son las bóvedas de maderas. Normalmente se han relacionado como una solución de la carpintería de ribera insular, pero la solución constructiva es más simple y básica que la realizada en las embarcaciones que funciona unitariamente ensamblada. La bóveda chilota en la práctica, esta armada por cuadernas que son una serie de elementos rectos clavados entre sí, que forman un poligonal, colgadas de la techumbre, por cuya cara inferior se han cortado con el trazado de la geometría de la curva del cielo en las cuales se fijan con clavos las tablas de cielo, de este modo el famoso bote invertido es un bote falso que muestra el ingenio insular ${ }^{136}$. Entonces, similar al sistema de armado de la techumbre, la bóveda chilota es una solución de carácter más popular, en ambas está la lógica de un cierto nivel de prefabricación que permite una fábrica más regular y rápida de ejecutar.

\subsubsection{Las cubiertas.}

Llevarán tejuelas de madera fijadas directamente sobre costaneras de aprox. $2 \times 2$ " y estas sobre envigados. Las tejuelas en alerce (Fitzroya cupressoide) o Ciprés de las Guaitecas (Pilgerodendron uviferum), traslapadas de modo tal que siempre haya un espesor equivalente a tres tejuelas para dar mayor hermeticidad, a diferencia de muros o tabiques exteriores que se usará normalmente el equivalente a dos tejuelas. Este espesor permite que las tejuelas trabajen casi como un diafragma que permite rigidizar el plano del faldón.

Las pendientes utilizadas para las cubiertas son similares entre capillas, la cual corresponden una convención constructiva de un porcentaje o gradiente bastante estricto, ya que normalmente tienen $77,7 \%$ o $35^{\circ}$ para dar un buen escurrimiento de las aguas lluvia sobre las tejuelas. Ha sido difícil rastrear la razón de esta convención para las cubiertas de tejuela, aunque es un guarismo muy cercano a $2 / 3$, una relación

\footnotetext{
135 Solo en la capilla de Achao, están las columnas directamente alojadas a las basas de piedra

${ }^{136}$ Ese tipo de bóveda que no tiene un compromiso estructural y se vincula a similares castellanas, a diferencia de las bóvedas encamonadas del virreinato del Perú o vinculadas al tratadista francés De L’Horme. ( Hurtado, 2011)
} 
geométrica arquitectónica y constructiva lógica, pero en definitiva queda por ahora en una interrogante la elección de esta gradiente.

Es interesante ver que dicha pendiente se cambia de material de cubierta y que demuestra la racionalidad de los procesos constructivos en las capillas, esto queda claramente demostrado entre el proyecto de Bohle en Curaco de Vélez pensado en tejuela y el construido en plancha metálica (figura № 12).

Es sabido que el ancho de las naves está determinado por el tipo de armadura de cubierta, y en este caso es la viga maestra transversal intercolumnios la que fija el ancho de la nave central y su capacidad de soportar la techumbre. Lo normal serán anchos de 6 a $7 \mathrm{mts}$ y en el caso de las capillas principales o parroquias (Dalcahue, Rilan, Chonchi), como las dedicadas a las grandes fiestas religiosas (Caguach y Quinchao) estarán entre 8 y $9 \mathrm{mts}$ de ancho. Pero como se ha explicado, estas luces se acortan mediante la introducción de diagonales desde las columnas.

\subsubsection{Las torres.}

Las torres son de gran envergadura, realizadas en forma telescópica para cumplir requisitos estéticos de la época, en la búsqueda de lograr las mayores alturas posibles. El cambio de torres paralelepípedas a telescópicas, permitió darles mayor rigidez a las estructuras por el traslapo entre tambores, ya explicado, y a la vez ofrecer menor resistencia al viento, el cual es una amenaza mayor que los sismos, ya que ante estos, las estructuras de maderas por su comportamiento flexible responden mejor. De hecho muchas veces los tambores no son de planta cuadrada sino que son octogonales, seguramente para disminuir la resistencia al viento.

La estructura telescópica de las torres corresponde también a una racionalidad constructiva (tal como ocurre en las naves) en que cada tambor constituye el andamiaje para la construcción del siguiente. Tal racionalidad de hacer de la estructura andamiaje y traslapo entre tambores, es la que permite alcanzar con seguridad constructiva para la fabrica y operarios, elevadas alturas con las torres y con excelentes resultados en cuanto a estabilidad y resistencia ${ }^{137}$.

\footnotetext{
137 Frecuentemente se ha considerado que estas técnicas de estructuras en madera son de conocimiento e influencia de los pueblos germánicos, pero como lo han apreciado algunos autores, la cultura constructiva de españoles e italianos para levantar sus espigadas torres de piedra requerían de andamiajes y cimbras de maderas previas, de gran calidad y con la geometría estructural de la arquitectura de los edificos. Estos edificios chilotes no hacen más que visibilizar una forma estructural ausente.
} 


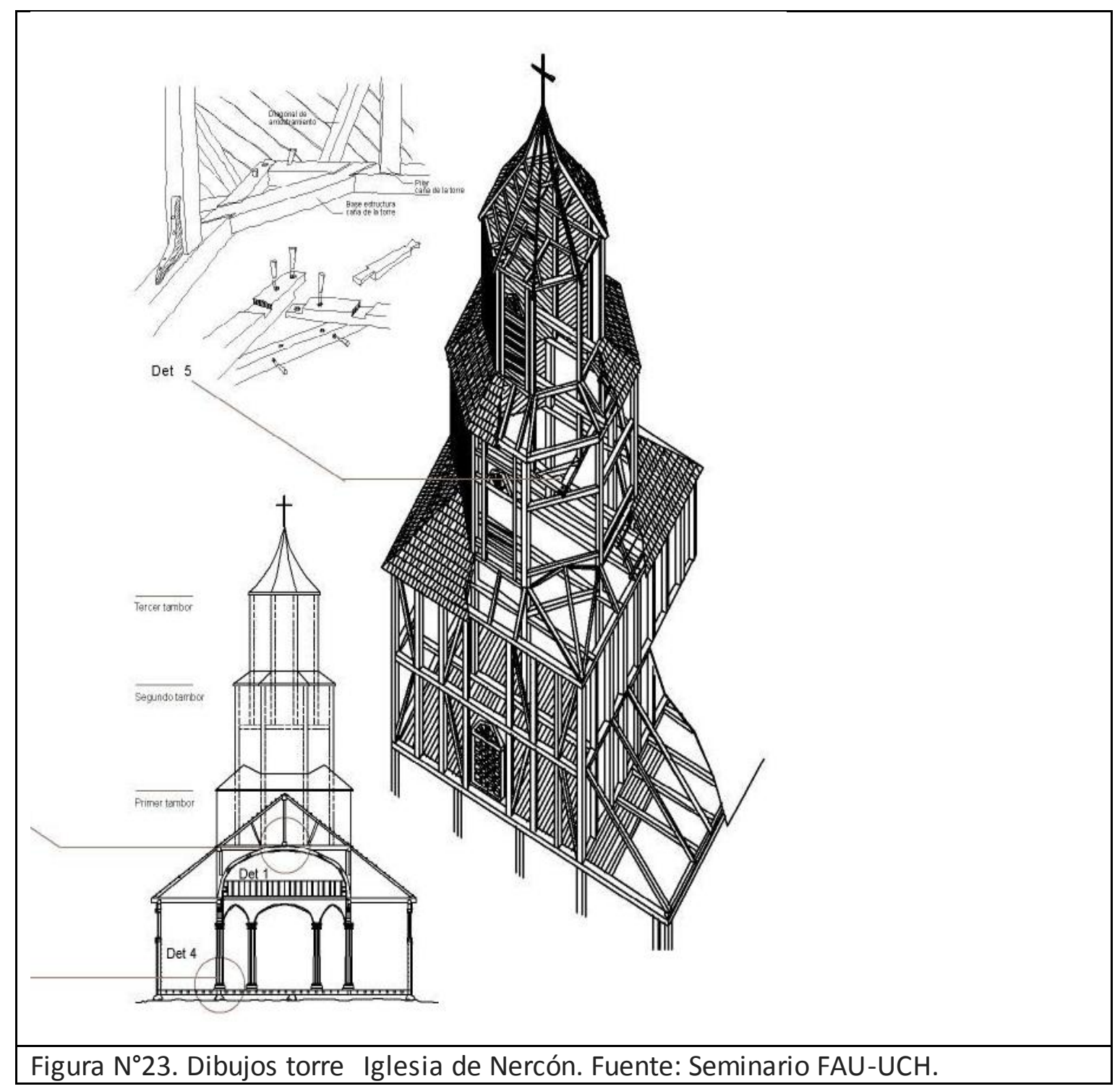

La particularidad, entonces, del traslapo entre tambores permite disponer de dos plataformas, la inferior o de transferencia y la superior o de fijación, esta restringe el giro de las columnas centrales del cuerpo superior, otorgando continuidad estructural firme a las solicitaciones horizontales (González, 2005). De esta manera se mantiene la lógica de crear entramados horizontales para estructurar, dar una plataforma de trabajo a los carpinteros y permitir lugares de apoyo para sujetar y levantar los maderos. Esto va complementado con la escotilla o vacío central que se deja en cada plataforma para permitir la subida y bajada de materiales durante la ejecución de la torre, así como permitir la subida de la campana al final del proceso. Las campanas son importadas y fabricadas en fierro y junto con dar los avisos de misas u otros actos religiosos, servían para dar estabilidad y disminuir las oscilaciones por acción del viento o sismo debido a su gran peso. Seguramente fueron levantadas con sistemas de roldana y tiradura de bueyes desde la explanada.

Por otra parte, ante las oscilaciones de los vientos y sismos, las torres, a pesar de su autonomía constructiva, están estructuralmente apoyadas en las naves, ya que los faldones de techumbre en general rodean la estructura de la torre (González, 2005, p. 
98). Esto se maximiza al disponer las naves en orientación norte, lo que aminora el efecto predominante del viento de los temporales que soplan en dicha dirección, lo que al dejar el pórtico en orientación sur permite un acceso a la capilla mas cobijado. La torre siempre estará con su geometría enmarcada a partir del pórtico. Es decir los pilares esquineros del primer dado, corresponden a elementos que descargan puntualmente en ejes de columnas de la nave, a través de nuevamente una plataforma, esta vez a nivel de la base del hastial. A diferencia de las estructuras de la nave en el caso de la torre, los maderos diagonales estarán siempre presentes en las caras de los tambores para arriostrar los planos verticales. En muchos casos en su ausencia se complementan con la colocación de entablado, a modo de placa, colocadas en diagonal.

\subsection{Los carpinteros chilotes.}

La labor desarrollada por los carpinteros locales ha sido difícil escudriñar a falta de documentación escrita y documentación histórica que aun los mantiene bastante en el anonimato. A la fecha solo hay detalle de los planos de Guaiqueo, anteriormente estudiados; los planos de Quinchao son anónimos y además de esto, las referencias de nombres de maestros que trabajaron y estuvieron a cargo de algunas capillas, a partir de los documentos del Obispado son escasos.

\begin{tabular}{|c|c|c|c|c|c|c|}
\hline & $\begin{array}{l}\text { AÑO } \\
\text { CONSTRU } \\
\text { C. }\end{array}$ & $\begin{array}{l}\text { PLANO } \\
\text { BASE }\end{array}$ & $\begin{array}{l}\text { PROYECTIS } \\
\text { TA }\end{array}$ & $\begin{array}{l}\text { Dirección } \\
\text { de obra }\end{array}$ & $\begin{array}{l}\text { Carpintero } \\
\text { Mayor }\end{array}$ & $\begin{array}{l}\text { Carpinte } \\
\text { ro } \\
\text { segundo }\end{array}$ \\
\hline $\begin{array}{l}\text { CASTRO } \\
\text { ANTERIOR }\end{array}$ & $\begin{array}{l}1859- \\
1866\end{array}$ & $\begin{array}{l}\text { SI, } \\
\text { desconoci } \\
\text { do }\end{array}$ & & $\begin{array}{l}\text { Fray } \\
\text { Diego } \\
\text { Ciuffa }\end{array}$ & & \\
\hline $\begin{array}{l}\text { Reconst. } \\
\text { parcial }\end{array}$ & $\begin{array}{l}1883- \\
1890 \\
\end{array}$ & $\begin{array}{l}\text { No hay } \\
\text { mencion }\end{array}$ & & $\begin{array}{l}\text { Fray } \\
\text { Jesús M. } \\
\text { Barría } \\
\end{array}$ & & \\
\hline $\begin{array}{l}\text { CASTRO } \\
\text { ACTUAL }\end{array}$ & $\begin{array}{l}1910- \\
1912 \\
\end{array}$ & $\begin{array}{l}\text { SI } \\
\text { conocido }\end{array}$ & $\begin{array}{l}\text { Eduardo } \\
\text { Provasoli }\end{array}$ & $\begin{array}{l}\text { Fray } \\
\text { Angel } \\
\text { Subiabre } \\
\end{array}$ & $\begin{array}{l}\text { Salvador } \\
\text { Sierpe }\end{array}$ & $\begin{array}{l}\text { Santiago } \\
\text { Subiabre }\end{array}$ \\
\hline QUINCHAO & $\begin{array}{l}1863- \\
1888\end{array}$ & $\begin{array}{l}\text { SI } \\
\text { conocido } \\
\text { (modificad } \\
\text { o) }\end{array}$ & & $\begin{array}{l}\text { Fray } \\
\text { Bernardin } \\
0 \\
\text { Carcamo? }\end{array}$ & \begin{tabular}{|l} 
Pedro \\
Barria (en \\
1875) \\
Felipe \\
Navarro \\
(en 1878) \\
\end{tabular} & \\
\hline DALCAHUE & $\begin{array}{l}1892- \\
1903\end{array}$ & $\begin{array}{l}\mathrm{SI}, \\
\text { desconoci } \\
\text { do }\end{array}$ & & & $\begin{array}{l}\text { Agustín } \\
\text { Guaiquin }\end{array}$ & $\begin{array}{l}\text { Vital } \\
\text { Cárcamo }\end{array}$ \\
\hline NERCÓN & $\begin{array}{ll}1879- & \\
1897 \\
1898\end{array}$ & $\begin{array}{l}\text { No hay } \\
\text { mención }\end{array}$ & & $\begin{array}{l}\text { Francisco } \\
\text { Bórquez }\end{array}$ & $\begin{array}{l}\text { Francisco } \\
\text { Bórquez }\end{array}$ & \\
\hline $\begin{array}{l}\text { RILÁN } \\
\text { RILÁN } \\
\text { ANTERIOR }\end{array}$ & $\begin{array}{l}\text { 1908- } \\
1920 \\
\text { dura } \\
\text { entre }\end{array}$ & $\begin{array}{l}\text { No hay } \\
\text { mención } \\
\text { No hay } \\
\text { mención }\end{array}$ & & & José Oyarzo & \\
\hline
\end{tabular}




\begin{tabular}{|c|c|c|c|c|c|c|}
\hline & $\begin{array}{l}1868- \\
1907 \\
\end{array}$ & & & & & \\
\hline CHONCHI & $\begin{array}{l}1893- \\
1900\end{array}$ & $\begin{array}{l}\text { No hay } \\
\text { mención }\end{array}$ & & & \begin{tabular}{|l|} 
Salvador \\
Calisto \\
repara en \\
1907 \\
después de \\
incendio \\
\end{tabular} & \\
\hline \multicolumn{7}{|l|}{ ACHAO } \\
\hline TENAÚN & $\begin{array}{l}1893- \\
1902\end{array}$ & $\begin{array}{l}\text { SI } \\
\text { conocido } \\
\text { (modificad } \\
\text { o) } \\
\end{array}$ & $\begin{array}{l}\text { Agustin } \\
\text { Guaiquin }\end{array}$ & $\begin{array}{l}\text { Agustin } \\
\text { Guaiquin }\end{array}$ & $\begin{array}{l}\text { Agustin } \\
\text { Guaiquin }\end{array}$ & \\
\hline $\begin{array}{l}\text { Curaco de } \\
\text { Vélez }\end{array}$ & $\begin{array}{l}1901- \\
1904\end{array}$ & $\begin{array}{l}\text { SI } \\
\text { conocido }\end{array}$ & $\begin{array}{l}\text { Rev. } \\
\text { Francisco } \\
\text { Bohle }\end{array}$ & \begin{tabular}{|l} 
Rev. \\
Francisco \\
Bohle
\end{tabular} & \begin{tabular}{|l|} 
\\
\\
Evangelista \\
Oyarzún de \\
Huyar Bajo
\end{tabular} & \begin{tabular}{|l} 
Lorenzo \\
Andrade, \\
Daniel \\
Vásquez, \\
Belisario \\
Hernánd, \\
Antonio \\
Mansilla, \\
Bautista \\
Oyarzún, \\
José del \\
Carmen \\
Muñoz
\end{tabular} \\
\hline CAGUACH & $\begin{array}{l}\text { ¿Aprox } \\
\text { 1900? }\end{array}$ & & & & & \\
\hline CHELÍN & $\begin{array}{l}1888- \\
1890\end{array}$ & $\begin{array}{l}\text { No hay } \\
\text { mención }\end{array}$ & & $\begin{array}{l}\text { Fray } \\
\text { Pedro } \\
\text { Bórquez }\end{array}$ & $\begin{array}{l}\text { maestro de } \\
\text { Curahue }\end{array}$ & \\
\hline VILUPULLI & $\begin{array}{l}\text { ¿Aprox } \\
\text { 1900? }\end{array}$ & $\begin{array}{l}\text { No hay } \\
\text { mención }\end{array}$ & & & & \\
\hline SAN JUAN & $\begin{array}{l}\text { ¿Aprox } \\
\text { 1900? }\end{array}$ & $\begin{array}{l}\text { No hay } \\
\text { mención }\end{array}$ & $\begin{array}{l}\text { ¿Agustín } \\
\text { Guaiquin? }\end{array}$ & $\begin{array}{l}\text { ¿Agustín } \\
\text { Guaiquin } \\
\text { ? } \\
\end{array}$ & $\begin{array}{l}\text { ¿Agustín } \\
\text { Guaiquin? }\end{array}$ & \\
\hline $\begin{array}{l}\text { ALDACHIL } \\
\text { DO }\end{array}$ & $\begin{array}{l}\text { ¿Aprox } \\
1900 ?\end{array}$ & $\begin{array}{l}\text { No hay } \\
\text { mención }\end{array}$ & & & & \\
\hline COLO & $\begin{array}{l}\text { ¿Aprox } \\
1900 ?\end{array}$ & $\begin{array}{l}\text { No hay } \\
\text { mención }\end{array}$ & $\begin{array}{l}\text { ¿Agustín } \\
\text { Guaiquin? }\end{array}$ & $\begin{array}{l}\text { ¿Agustín } \\
\text { Guaiquin } \\
?\end{array}$ & $\begin{array}{l}\text { ¿Agustín } \\
\text { Guaiquin? }\end{array}$ & \\
\hline DETIF & $\begin{array}{l}\text { ¿Aprox } \\
\text { 1900? }\end{array}$ & $\begin{array}{l}\text { No hay } \\
\text { mención }\end{array}$ & & & & \\
\hline
\end{tabular}


Con estos escasos antecedentes, es difícil verificar exactamente cuáles fueron su roles dentro del proceso de diseño o ideación hasta las etapas de terminación de las capillas, puede ser una deuda pendiente, no solo de esta tesis sino también de la cultura constructiva chilota, es probable que el único camino posible sea de tratar de levantar testimonios a partir de la historia oral insular, o que definitivamente no haya forma de rastrearla y que solo se mantenga un nombre de un carpintero asociado a alguna(s) capilla (s).

De todos modos de lo estudiado se pueden aventurar ciertas consideraciones. Es posible reconocer que gran parte del legado arquitectónico y de las técnicas constructivas en Chiloé fueron introducidas por los contactos culturales externos (españoles, jesuitas, franciscanos y colonización alemana), no obstante la mayoría de las capillas tradicionales fueron ejecutadas por carpinteros chilotes.

Es indiscutible la habilidad natural de los isleños con la madera y su gran capacidad para convertirse con relativa facilidad en carpinteros, pero en el nivel que amerita este tipo de edificios al parecer fueron siempre pocos los isleños más preparados. La alta carpintería requiere tiempo, dedicación, práctica y lo más importante cierto nivel de conocimientos de geometría, estructuras y construcción. Preparar y dimensionar un madero para hacer ensambles, definir su tipo y posición, así como instalarlo en faena requiere de alto aprendizaje. No basta con cortar y clavar, que es lo que hace el carpintero común, se requiere trazar, dibujar, hacer plantillas, una serie de prácticas que exige técnicas y oficios que van aparejados de niveles de abstracción mental que demanda la carpintería de $\operatorname{armar}^{138}$.

Una primera generación de chilotes aprendió del arte de la carpintería de su convivencia y trabajo guiado por jesuitas como Muller y Vogel. Una segunda generación con los franciscanos de Ocopa como Reyna y Fernández. Una tercera generación con los franciscanos italianos (Ciuffa, Scatulini o Gavilucci) y la colonización alemana. Serían los principales contactos culturales que van dando los sustratos carpinteros a la denominada formación de la escuela chilota.

\subsubsection{La experiencia con los carpinteros actuales chilotes}

Esta tesis se puede asimilar a lo sucedido a través de la Escuela de Carpinteros iniciada por la Fundación Cultural Amigos de las Iglesias de Chiloé, Fundación Andes y Unión Europea (Berg \& Boldrini, 1995) y que fue necesaria para restaurar las iglesias antes de su declaratoria como Patrimonio de la Humanidad por la Unesco. Esta escuela reciente fue fundamental implementar porque en el archipiélago habiendo centenares de carpinteros, no habían más de cinco capacitados y con el oficio suficiente para de trabajar en este tipo de edificios. Como tampoco existían los arquitectos, escasos, que pudieran dirigir este tipo de obras y me atrevo a decir ninguno capaz de hacer de carpintero. Sin embargo tales arquitectos eran capaces de guiar en un trabajo colaborativo con los carpinteros de mayor oficio, la realización de operaciones constructivas de un nivel de complejidad que exigen estas fabricas.

${ }^{138}$ En Francia o Alemania un carpintero se forma en 6 a 7 años. 
El mejor ejemplo pueden ser dos carpinteros quienes participaron en el primer curso, Torres y Chicuy, al inicio del curso se les pidió que hicieran una sencilla labor en la torre de Aldachido ${ }^{139}$ al poco andar del trabajo, se les tuvo que pedir suspendieran las faenas por la mala calidad de su realización. Al año después del desarrollo del curso, volvieron, ya estaban preparados para hacerlo bien y cumplieron. Lo más notable que estos mismos carpinteros fueron los principales artífices del aplome de las torres de la Iglesia de Castro, dos años después, en lo que probablemente ha sido una las obras de carpintería más complejas realizadas en Chiloé en los últimas décadas ${ }^{140}$.

Con el anterior ejemplo se puede argüir y demostrar tanto la complementación técnica entre el trabajo del arquitecto (teórico) y el carpintero (práctico). La denominada escuela chilota de arquitectura religiosa, ha sido a la luz de los antecedentes, compuesta por un reducido o puñado de notables maestros carpinteros capaces de interpretar y posteriormente reproducir modelos en determinados periodos históricos, a partir de procesos de enseñanza/aprendizaje a niveles teóricos/prácticos de la carpintería en conjunto con los arquitectos formales o no.

De esta premisa, el modo realizador de la llamada Escuela chilota es seguramente la que operó durante el período de los franciscanos italianos, quienes como directores de obra (arquitectos no formales), influyeron y determinaron con las capillas matrices de la tipología, Castro y Osorno, a los carpinteros locales de una técnica compositiva y constructora de capillas que se consolida con la influencia ejercida por otros "arquitectos": los colonos alemanes.

Tal nivel de aprendizaje capitalizado por carpinteros chilotes tiene una vertiente influenciada por los contactos externos, pero también hay de propia formación que se va acumulando en la práctica permanente del oficio y en la heredada. En este sentido no es menor la existencia de familias carpinteras chilotas y que se van traspasando el oficio de generación en generación, como el caso de Guaiquin que aprendió de su padre y éste de Fray Fernández ${ }^{141}$.

El rápido aprendizaje y dominio de una tipología arquitectónica y constructiva tan racional, por parte de un avezado grupo de carpinteros chilotes es lo que les permitió dotarlos de una alta autonomía en el oficio y de generar múltiples modelos siguiendo una matriz composicional. Esta capacidad en el oficio de los carpinteros locales, la permanencia de la fe y la relativa abundancia de la madera difundió por primera vez en su historia: Capillas de envergadura arquitectónica y constructiva por todos los poblados del archipiélago. Hasta mediados del siglo XIX solo reservadas para las

\footnotetext{
${ }^{139}$ Me confieso que yo ni el resto de arquitectos o constructores de esa época lo hubiésemos hecho mejor.

${ }^{140}$ Aplome que se realizó sin desarmar la torre sino que por un proceso de cirugía puntual retirando y cambiando solo piezas dañadas.

${ }^{141}$ También el caso contemporáneo de José Calisto, santero chilote único, hijo de carpintero y que trabajó como dibujante con el reconocido arquitecto Edward Rojas. En Chiloé a José Calisto se le llama el Arquitecto.
} 
ciudades principales, se llega así al punto culmine y de mayor desarrollo de la arquitectura religiosa.

Este proceso de autonomía constructiva por parte de los carpinteros isleños y de pertenencia a una filiación arquitectónica, produce una rica variedad de eje mplos que chilotizan las capillas según su propio imaginario. Algunas muy cercanas a la matriz tipológica y composicional como la de Chelín, otras más estilizadas como Vilupulli y otras más rusticas como Colo. También sucede con ciertas licencias constructivas como puede ser el sistema de envigados de techumbre, adaptado desde tradiciones vinculadas a la arquitectura de viviendas o galpones, en vez de realizar sistemas de tijerales de par y nudillo.

\subsection{Agustín Guaiquio, gran maestro carpintero de capillas.}

A partir de los escasos antecedentes escritos y orales de carpinteros, Guaiquin es la única figura que se repite como carpintero de capillas quien se encuentra registrado en documento del Obispado en tres oportunidades para la realización de Iglesia de Tenaún y que siendo citas cortas se descubre el protagonismo que tuvo este carpintero en la capillas chilotas:

Estando toda la madera necesaria lista para comenzar el trabajo que hay que hacer en la iglesia parroquial esto es vestir las columnas con sus respectivos arcos y cornisa, es necesario que vuestra Señoría me faculte para invertir los fondos necesario en dicho trabajo, y para contratar con el carpintero mejor que hay en esta parroquia que es Don Agustín Guaiquio quien me dice que entregará el trabajo concluido por la cantidad de ciento veinte y cinco pesos....Abril $1^{\circ}$ de 1884 .

... se digne, si lo tiene a bien, de recabar del Supremo Gobierno unos mil quinientos pesos $(\$ 1.500)$ que se necesitarían para dicha obra y otros trabajos de la misma iglesia según el plano y apuntes que ha hecho el carpintero constructor Dn. Agustín Guaiquio, que ha levantado todas las iglesias existentes en esta parroquia y en varias otras. 1894

Agustín Guaiquio, feligrés de la Parroquia de Tenaún, con el mayor respeto a S.S.I. expongo: que más de cuarenta años a esta fecha, he estado prestando los servicios de mi profesión de carpintero en todos los trabajos que se han presentado en esta Parroquia, así también en la parroquia de Lemuy, Chelín, Lliuco y en más de diez siete iglesias de esta Parroquia y de las de Quenac y Lliuco y en las que he sido director y carpintero por la mitad de mis honorarios. Además, cuando se reedificó la iglesia parroquial de Tenaún trabajé como carpintero y director cuarenta y dos días gratuitamente, en la casa parroquial veinticinco días y últimamente en alargar la Iglesia Parroquial y levantar tres torres, también cobré sólo la mitad de mi honorario como carpintero mayor.1899. (Documentos Obispado de Ancud en Montecinos, 1995, p. 160162) 
De la primera cita se desprende que Guaiquio es reconocido como el mejor carpintero en la jurisdicción de la parroquia, que comprende varias localidades ${ }^{142}$.

De la segunda cita se desprende que Guaiquio no solo hace el plano ya comentado sino que se le identifica como carpintero de varias capillas de la jurisdicción de la parroquia $y$ en varias otras.

De la tercera cita, una carta del propio Guaqueo, quién identifica unas 17 capillas de la parroquia de Tenaún que habría edificado. Esto demostraría tanto la alta producción de capillas de este carpintero y en la jurisdicción. Además ha trabajado en otras Parroquias como Lemuy, Chelín, Lliuco. En el caso de Lemuy podría ser la capilla de Puqueldón, cabecera principal de la isla, fotografiada por Wiederhold que ya no existe y es una excelente modelo de capilla chilota epocal (Figura $N^{\circ} 25$ ) y al igual que la capilla de Chelín, atribuida a un maestro de Curahue sin nombre, pero perfectamente podría corresponder a Guaiqueo. De Lliuco no hay más antecedentes, ni escritos, ni gráficos de la capilla de la época.

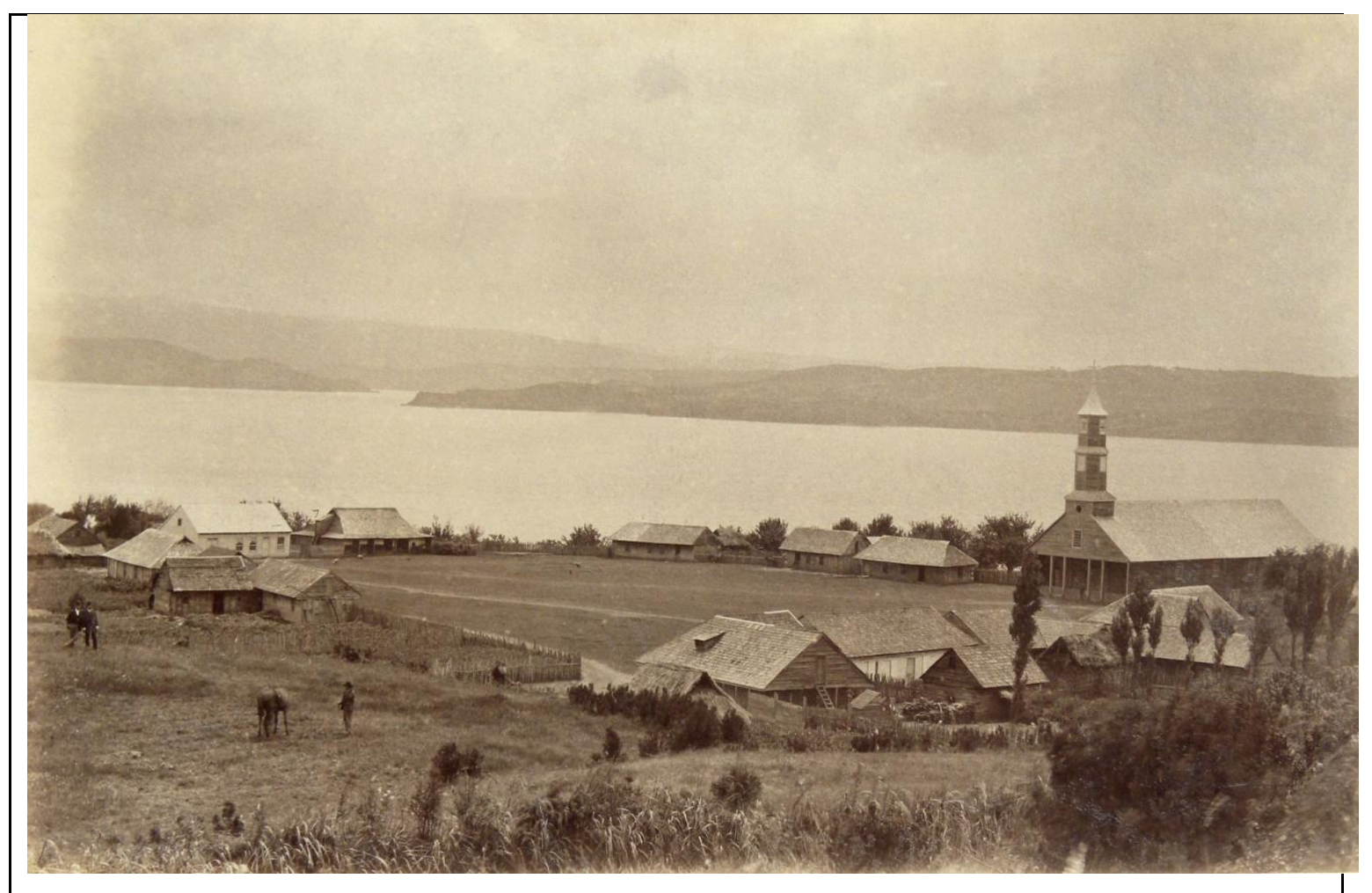

Figura $\mathrm{N}^{\circ} 25$. Capilla de Puqueldón, Isla de Lemuy, ya no existe. Fuente: Jerman Wiederhold 1893

Por lo visto Guaiqueo fue un gran director, constructor y carpintero de capillas y probablemente el más prolífico del archipiélago. Según historia oral de su terruño, Calen y San Juan, habría trabajado en unas 40 capillas ${ }^{143}$. Estas seguramente las trabajaba en paralelo según los ingresos disponibles para cada una y los distintos

142 Las capillas que pertenecen a la Parroquia son San Juan, Calen (reedificándose), Cocaví (Quicaví), San Antonio de Coló, Chaurague, Añihue, Chiñian , Chauques grandes. Entre Enero 1863 Noviembre 1890.

${ }^{143}$ Hace dos años a un descendiente de Agustin Guaiqueo se le entregó un reconocimiento póstumo por la obra notable realizada por este carpintero. 
encargos. Guaiqueo con su dibujo de Tenaún demuestra la capacidad de abstracción mental que disponía al dibujar perfectamente fachada, torre y nave en un solo plano haciendo todas la relaciones métricas y constructivas en forma simultánea. Con extrema claridad ilustra el traslapo de tambores, que en el caso de Bohle teniendo varias vistas y dibujos muy precisos no muestra este detalle fundamental.

Se puede sostener que Guaiqueo, tenía en su mente con claridad extrema el esquema básico constructivo de la capilla, al igual que los carpinteros de ribera chilotes que no realizan planos de sus lanchones, sino que como sostienen la mayoría de ellos tienen el dibujo en su cabeza (Montiel, 2005).

Guaiqueo demostraría la tesis de la "relativa facilidad" para armar capillas para un experimentado carpintero como él, aprendió la fórmula para replicarla, convirtiéndose probablemente en el mayor protagonista y difusor de la Escuela chilota de la arquitectura tradicional de Chiloé. 


\section{Conclusiones.}

\subsection{Los contactos culturales}

De los primeros dos capítulos se puede sostener que hay evidencias que la tipología de la capilla tradicional chilota ya está constituida a fines del siglo XIX y esta se encuentra en su fase de propagación por el archipiélago, por lo tanto se puede afirmar que es el tiempo previo a este donde hay que investigar profundamente, a partir de los contactos culturales que impactan en Chiloé y que van modelando la arquitectura religiosa insular.

Del periodo jesuita en Chiloé (capitulo 3), a inicios del siglo XVII hasta su expulsión en 1767 , se instituye la misión circular y el establecimiento de las capillas como elemento fundacional del urbanismo insular. A la expulsión de estos misioneros se registran 84 capillas y solo aquellas existentes en Castro, Achao y Chonchi se reconocen como edificios mayores y formales que expresan su carácter de espacio religioso cristiano, el resto son construcciones muy rusticas donde solo la cruz las hace reconocibles como capillas. Los templos mayores acusan características comunes, destacando estar construidas completamente en maderas nativas con el uso de ensambles simples para las estructuras de postería labrada que van asentadas en fundaciones de piedra; plantas de 3 naves con cielos abovedados o de cañón; grandes cubiertas con tijeral de par y nudillo; uso de corredores en Castro y Achao.

De estas capillas mayores solo Castro evidencia según documentos escritos y gráficos de la época la existencia de torre y centrada en la fachada, no obstante hay registros de usos de torres en algunos modelos previos.

Del periodo franciscano en Chiloé (capitulo 4), se reconoce tres sub-periodos dependiendo del origen de su administración, estos son el Colegio San Idelfonso de Chillán (1767-1771), Monasterio peruano de Santa Rosa de Ocopa (1771-1820 aprox.) y los franciscanos capuchinos italianos (1837-1905). El primer periodo de protagonistas es brevísimo y no logran adaptarse al medio; el segundo periodo de religiosos mantiene el sistema de la misión circular, construye nuevas capillas con distintos composiciones arquitectónicas, permanece el sistema constructivo instaurado por jesuitas y se realizan interiores de gran calidad como la capilla de Achao. Es en el tercer periodo, a la luz de todos los antecedentes disponibles que se puede afirmar que las capillas tradicionales de Chiloé son ideadas, materializadas y difundidas como tipología arquitectónica, con la llegada de los misioneros italianos en el contexto de la pacificación del sur de Chile.

Con la colonización alemana (capitulo 5), a partir de la segunda mitad del siglo XIX en la zona, se aportó el repertorio de conocimientos y técnicas de la carpintería de armar, tanto con la sustitución de sistema de postería labrada por la introducción de un perfeccionamiento de la tabiquería tipo fachwerk a un sistema de plataforma y uso del despliegue del sistema de uniones los elementos de madera en las estructuras. Estos colonos serían influyentes en la formación de carpinteros chilotes que contrataron para sus obras, los cuales llevarían de vuelta mayores habilidades y recursos técnicos para construir en el archipiélago edificios más grandes y altos, como lo exigía la fe. 


\subsection{La introducción tipológica}

Es la figura de su Viceprefecto de misiones fray Diego Chuffa quien dirigió y partici pó en la construcción de tres iglesias franciscanas. De la primera, construida en Castro en 1839 han quedado solo las dimensiones de la planta. De la segunda, construida en Osorno en 1844 ha permanecido una fotografía. De la tercera, construida en Castro hay una descripción de la arquitectura y dos fotografías. Esto es un hecho de importancia basilar para comprender la evolución de la composición de la torrefachada.

Un aspecto evidente es que la iglesia de Osorno es un precedente formal de la de Castro. Además, por la semejanza entre estas dos iglesias se podía conjeturar que la de Castro, construida por los franciscanos apenas llegaron en 1837 y destruida en el incendio de marzo de 1857, tenía estas mismas características, es decir pórtico, tímpano y torre en un arreglo de influencia neoclásica.

De esta manera, mientras la Iglesia de Castro fue la matriz tipológica para el archipiélago de Chiloé, la realizada en Osorno lo es de algunas de las construidas en la parte continental del sur de Chile (Figura 1).

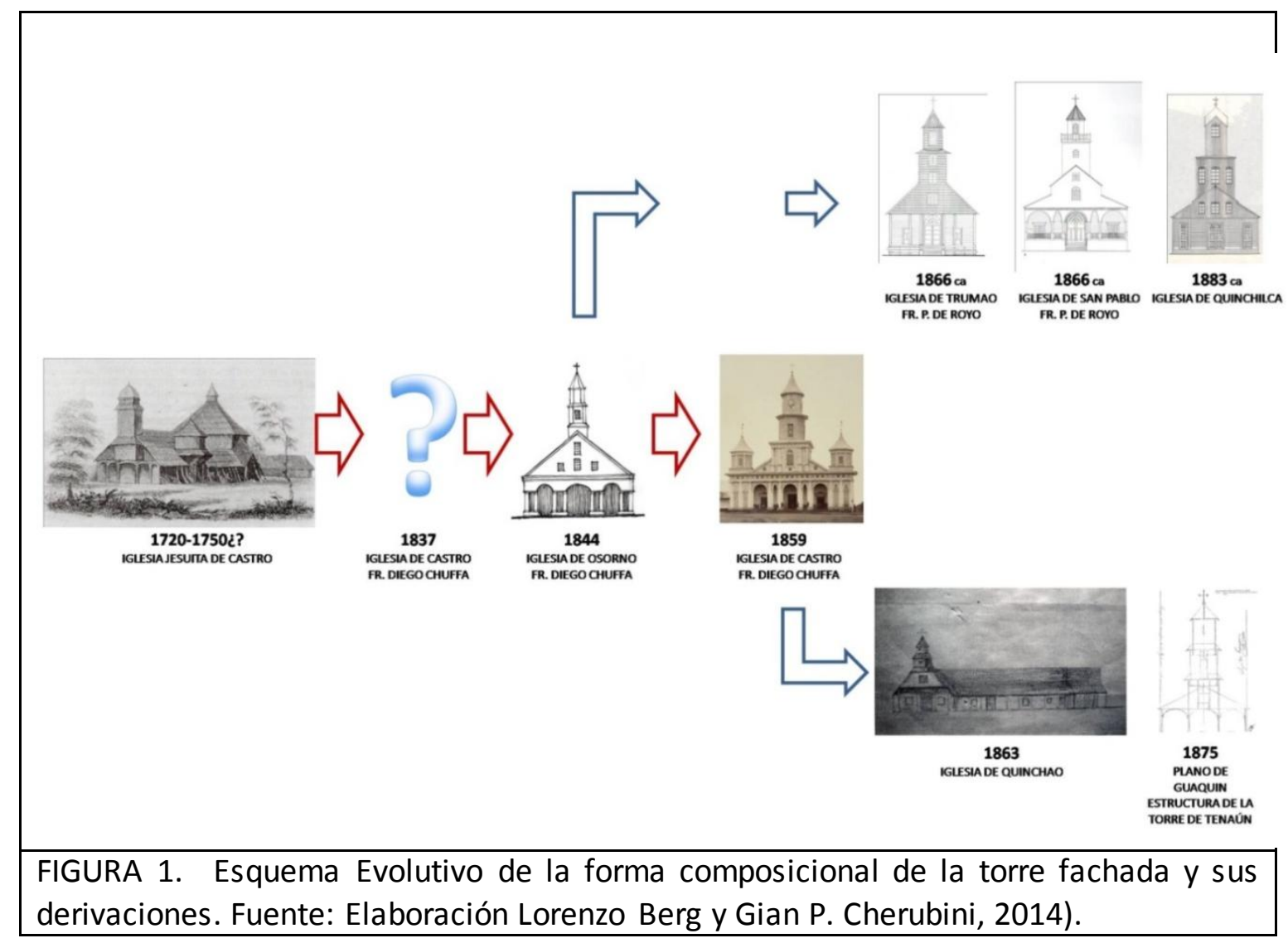

Tanto Castro como Osorno fueron las sedes principales de las respectivas provincias de los misioneros, estas ciudades fueron los centros de irradiación en la región de una 
determinada manera de componer los edificios conteniendo y conformando todas las características de la arquitectura tradicional religiosa chilota ${ }^{144}$.

También en esta línea de composición arquitectónica de los edificios religiosos, planta basilical y la torre en la fachada sobre un pórtico o un nártex, pero ejecutados con materiales diversos está el aporte de los frailes italianos tanto en la zona de la Araucanía al norte de Chiloé y en la zona central del país (Zona de San Felipe y Valparaíso), influencia tipológica- estilística que llegó a casi todo el territorio chileno. En este sentido el Colegio de Castro y Osorno fueron puntos de irradiación y transmisión de una cultura arquitectónica a nivel nacional.

La escasez de documentos tanto escritos como icónicos de la época, dificultan el poder asociar las iglesias construidas por los franciscanos en Castro y en Osorno, con la que construyeron los jesuitas en Castro, y que figura en los inventarios hechos con motivo de la expulsión de estos del archipiélago, dibujada por Philip Parker King en 1829 y por la expedición de Charles Darwin en 1834, la que con toda certeza aún estaba en pie cuando llegaron los franciscanos italianos a Castro, tres años después.

El hecho que en Italia, y en general en la cuenca del mediterráneo, las iglesias fuesen con campanario exento, dificulta la comprensión acerca de la aparición de estas iglesias de mano de los misioneros franciscanos italianos, pero se ha demostrado que la imagen y los cánones compositivos de la arquitectura neoclásica con el uso de la simetría y torre fachada en edificios religiosos era una marca de la época, los cuales se introdujeron al país y fueron difundidos por arquitectos y constructores durante el siglo XIX.

Por otra parte el uso de la torre fue fundamental como símbolo de presencia y orientación en el paisaje que en el caso de Chiloé será fundamental, representando el hito religioso en los poblados y ciudades junto con ser faro de navegación en donde la manera habitual de comunicarse en una geografía de islas y canales era vía marítima.

\subsection{La materialización y multiplicación de las capillas}

La arquitectura de las iglesias chilotas, junto a su poderosa imagen simbólica y religiosa, está asociada a criterios racionales de composición y construcción. De tal modo se pueden destacar tres aspectos esenciales para estos edificios en madera.

- Uno, la dupla básica de solo un par de volúmenes horizontal (nave) y vertical (torre) resuelven con gran calidad la espacialidad interior, pero sobre todo ha sido resuelto eficientemente para el clima de viento y lluvia del sur. Utilizando en las envolventes exteriores solo planos verticales y diagonales, con tablas o tejuelas traslapadas, de manera de llevar lo más rápido y directo posible las aguas desde el edificio al terreno. La torre de madera con estructura telescópica se comporta bien ante los sismos y los

\footnotetext{
${ }^{144}$ Cabe destacar que de estas iglesias construidas por los misioneros franciscanos italianos en la zona de Osorno ya no quedaría al guna, pero si las hay en Chiloé como son varias delas analizadas en esta tesis.
} 
tambores en disminución de sección hacia lo alto, ofrecen menor resistencia al viento, que es una acción dinámica permanente en el archipiélago.

- Dos, la racionalidad del sistema de medidas y sus efectos en la lectura de las proporciones. Es un hecho que estos edificios fueron trazados usando las medidas en que venían las piezas de madera de la época, varas y múltiplos de estas, de manera que gran parte de las relaciones de medidas son resultado de los elementos constructivos.

- Tres, vinculado a lo anterior y quizás lo más importante, es que el sistema utilizado busca y logra estandarizar medidas de elementos constructivos que vienen de aserraderos y por ende la fábrica de madera se puede normalizar y construir en forma regular. Esta técnica favoreció la prefabricación de piezas y del edificio en base a la carpintería de armar y por lo tanto disponer de una matriz tipológica arquitectónica que era posible reproducir en múltiples modelos diversos. Este sistema también favoreció un armado relativamente económico, rápido y seguro del edificio, donde la propia estructura en base a plataformas permitió hacer de andamiaje de sí misma.

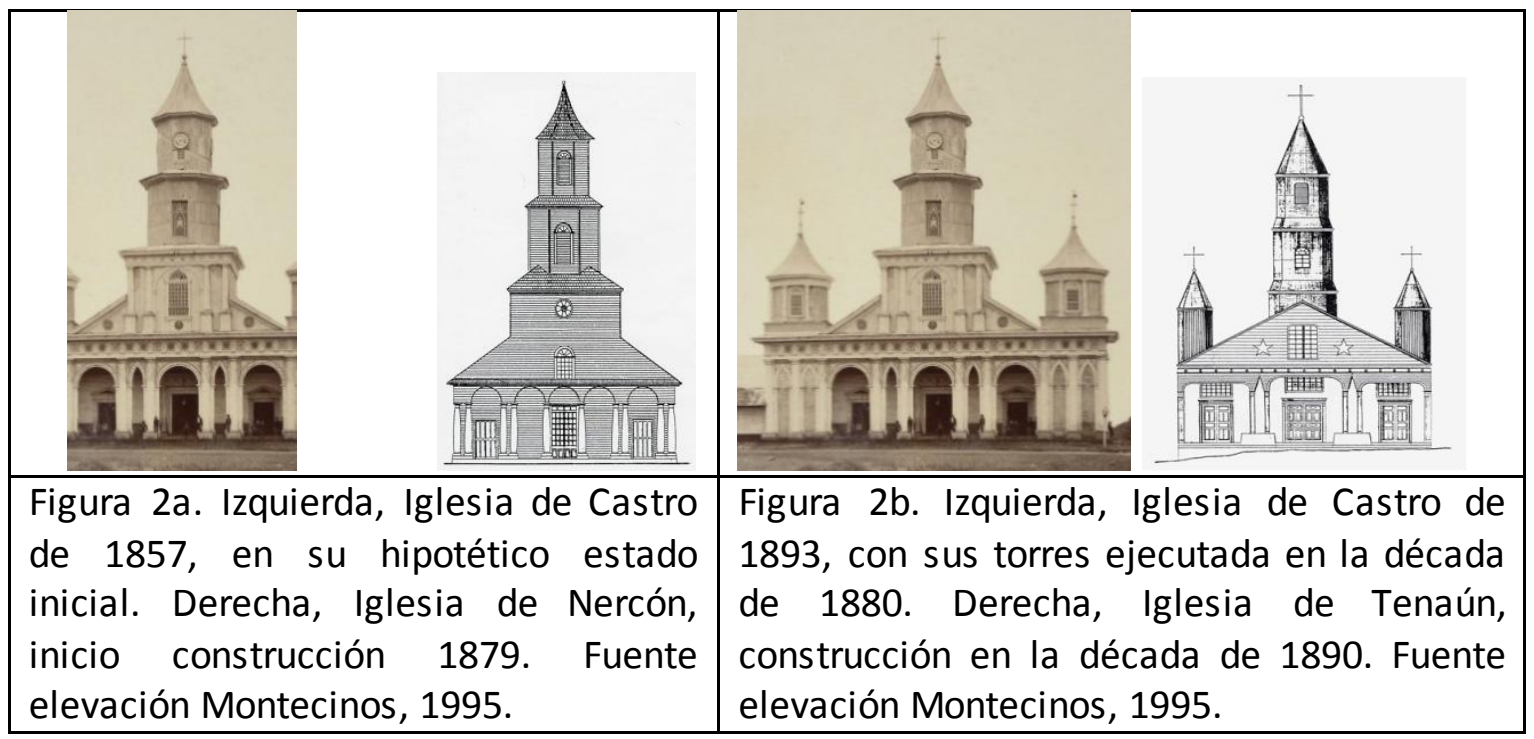

Así la Iglesia de Castro de 1857 en su primera versión es la que copian o más bien "reproducen a la chilota" los carpinteros locales para su capilla de Nercón (Figura 2a). Como es muy probable que la Iglesia de Castro con su añadido de dos torres laterales haya sido la imagen para la de Tenaún, que también dispone de elementos verticales en los extremos (Figura 2b). Con lo cual se podría ir deduciendo la "genealogía formal" de capillas.

Consta que en la Iglesia de Castro del año 1857, matriz de las capillas chilotas, participaron carpinteros especializados del ejército, así como carpinteros chilotes. Los antecedentes demuestran que estos últimos llevaron a cabo las numerosas capillas, donde sobresale la figura de Agustín Guaiqueo, quien era hijo a su vez de un carpintero local instruido por Fray Norberto Fernández de origen andaluz. 
Se puede sostener, que la denominada escuela chilota tiene cuatro vertientes de formación y que se dieron como transmisión del oficio de la carpintería en forma tradicional. Dos vertientes debidas fundamentalmente a los contactos culturales con los misioneros jesuitas, durante la colonia, y franciscanos, en la formación de la Republica. Otra vertiente dada por el contacto de los colonos alemanes en la zona. Pero la vertiente aún más desconocida es la interna o de la carpintería local, que si bien no funcionó como Escuela formal ni gremios o asociaciones instituidos. Fue conducida y trasmitida por algunos artífices chilotes, como el caso de Guaiqueo, capaces no solo de levantar fábricas de madera sino de crear nuevos modelos con el ingenio que les permitía la técnica y conocimientos adquiridos a su alcance.

De acuerdo a lo avanzado en la tesis se puede sostener que los carpinteros chilotes fueron fieles a la carpintería de armar inculcada desde afuera, principalmente en el uso de una geometría volumétrica estricta y de una estructura en base a elementos de madera bien dimensionados y unidos, con las técnicas centroeuropeas de ensambles. De esta manera lograron dar mejor resistencia y estabilidad a edificios, cuyo objetivo era que duraran en el tiempo; los únicos inmuebles en Chiloé pensados así, en el sentido más profundo de una cristiandad deseosa de signos de perpetuidad y divinidad.

Las variantes locales están dadas principalmente en la simplificación formal, que se explicaría por razones técnicas a nivel teórico y práctico en el arte de la arquitectura y la construcción. Se pueden observar fundamentalmente en la simplificación de la expresión de fachadas y naves interiores. En Nercón se evita todo el detalle de un entablamento decorado sobre el pórtico o en Tenaún de colocar unas estrellas con pequeñas tablillas en el hastial, soluciones que un constructor ilustrado o académico no se permitiría, pero si la sabiduría popular. Lo interesante de estas simplificaciones y muchas otras, es que no disminuyen la calidad del edificio y mucho menos su simbología cristiana, sino que por el contrario, se convierten en la aparición de una mayor racionalidad al casi dejar el edificio con sus elementos o componentes justos para cumplir con sus fines fundamentales. La vieja triada, firmitas, venustas y utilitas de Vitruvio que para el caso de los procesos de decantación de la arquitectura tradicional y popular en madera pareciera lograr este nivel de lógica y racionalidad (Maldonado y Rivera, 2005, p. 689). Las capillas chilotas son un ejemplo de esta decantación, logran ser tan bien depuradas que aunque habiendo una gran diversidad de modelos, cada una es el tipo en su forma más prístina, recurriendo a la teoría de Rossi (1966) se puede decir que estas iglesias son la arquitectura de las ciudades y pueblos del archipiélago.

También hay otras simplificaciones importantes que se constatan en todos los modelos, como son las bóvedas en las naves centrales, que no corresponden a la técnica constructiva de botes chilotes, como normalmente se ha señalado. Solo hay una aparente relación formal, ya que ni siquiera se usa cuadernas, elementos estructurales de una pieza como en la carpintería de ribera. Sino que una suma de elementos cortados y clavados para armar la poligonal. Para un cielo en un interior de capilla y que solo debe autosoportarse, es una solución más lógica y simple, ingeniosa para cuando hay pocos recursos físicos y económicos disponibles. Algo similar sucede 
con las estructuras de techumbre, normalmente señaladas de par y nudillo, solución muy europea. Pero la realidad es otra, se derivó en simples vigas apoyadas a una solera superior, similares a las que se realizan para las techumbres tradicionales de las viviendas del sur. ¿Otra apropiación?

Si de alguna manera numerosos cronistas denotaron la simplicidad y rusticidad de la carpintería chilota en pleno siglo XIX, seguramente esta condición técnica y cultural tradujo des de lo complejo, el tipo edilicio a copiar, en algo más sencillo resaltando una imagen más nítida y pura, pero tan concreta como la original. Es posible sugerir que aquí radica en gran parte el saber hacer y la apropiación que consigue la buena carpintería chilota. Usar el ingenio técnico para hacerlo más fácil, con los escasos recursos disponibles, sin perder la coherencia compositiva, estructural y constructiva, tanto para idear como materializar una nueva capilla a imagen y semejanza del tipo.

\subsection{Palabras finales}

Retomando la teoría de control cultural de Bonfil, planteada en el capítulo 2. Pareciera indiscutible que la primera oleada hispánica y jesuítica trajo a la población nativa, que disponía de decisiones autónomas, una serie de elementos ajenos produciendo una aculturación o cultura impuesta. Esta fue decantando en decisiones más propias, tanto por el aislamiento como por el mestizaje social al interior del archipiélago, lo que permitió alcanzar una forma cultural apropiada. Es decir que los recursos o elementos culturales externos/importados se puedan transformar desde decisiones internas. El solo ejemplo expuesto de la Iglesia de Castro, construida casi como un modelo foráneo es tomado por los carpinteros chilotes y reinterpretado en otras variaciones más sencillas y curiosamente, más puras, en diversas localidades insulares.

Esta tesis no puede responder a cabalidad todas las preguntas iniciales, ni tampoco las nuevas, que surgen explícita o implícitamente de la investigación sobre la arquitectura de las iglesias, sin embargo se ha rastreado y analizado intensamente para fijar ciertas respuestas/resultados. Avanzando algunos pasos más para ampliar y profundizar en un capítulo relevante y aún abierto a la cultura de la madera y religiosa de Chiloé que dio una forma única de arquitectura. Siglos de diversos contactos, desde la plena imposición a una forma de apropiación, sencilla y lógica, que cristalizó en la denominación de las iglesias de Chiloé en Patrimonio de la Humanidad. 


\section{BIBLIOGRAFÍA GENERAL Y ESPECÍFICA}

\section{A.- ARQUITECTURA Y URBANISMO}

- Anguita, P. López, R. Modiano, I. \& Zechetto, R. (1980). Casas de Chiloé. Santiago: Universidad de Chile.

- Benavides, J. Pizzi, M. \& Valenzuela, M. (1994). Ciudades y arquitectura portuaria: Los puertos mayores del litoral chileno. Santiago: Editorial Universitaria.

- Berg, L. (2005). Restauración Iglesias de Chiloé, conservando lo Infinito: Proyectos y obras 1988-2002, Santiago, Universidad de Chile, Universidad de Los Lagos: Editorial Universitaria.

- Berg, L. \& Cherubini, G. P. (2009). Ocupación, Arquitectura y Paisaje: Región de los Lagos. Santiago de Chile: Editorial Universitaria.

- Berg, L. Lobos, J. \& Rojas, E. (2006). Guía de Arquitectura de Chiloé. Sevilla: Ediciones Junta de Andalucía.

- Berg, L. \& Boldrini, G. (1995). Memoria del Curso de carpinteros itinerantes de Chiloé. Santiago: Ed. Fundamich.

- Cáceres, O. (2007). La arquitectura del Chile Independiente. Concepción: Universidad del Bío-Bío.

- Calatrava, J. \& Sambricio, C. (2008). Christian Rieger y la teoria de la arquitectura en España a mediados del siglo XVII. Sevilla: Junta de Andalucía.

- Cárdenas, R. (1997) El libro de los lugares de Chiloé. Santiago Chile: Orígenes.

- Cerda, G. Fox, H. Urbina, M. \& Urbina, R. (1988). Castro 1930-1960: Revista Arquitecturas del Sur, (12). Concepción.

- Concha, L. Errázuriz, P. \& Gaissinsky, E. (1979). Sistemas constructivos de la arquitectura tradicional de Chiloé. Seminario de Historia de la Arquitectura de la Facultad de Historia de la Arquitectura de la Universidad de Chile.

- Cherubini, G.P. (2006). La Iglesia de los Jesuitas en Puerto Montt: Muestra de fé que se mantiene en pie. Revista Vivir el Sur, Separata del Diario El Llanquihue, Puerto Montt, (Diciembre).

- Cherubini, G. P. (2007a). La Catedral: Testigo Histórico de Puerto Montt . Revista Vivir el Sur, Separata del Diario El Llanquihue, Puerto Montt, (Enero).

- Cherubini, G. P. (2007). El campanario de los Jesuitas: Monumento junto al cerro. Revista Vivir el Sur, Separata del Diario El Llanquihue, (Febrero).

- Cherubini, G. P. (2011). Influencia alemana en la tradición de construcción en madera en la región de los Lagos. Bariloche: Miradas transcordilleranas. Selección de trabajos del IX Congreso Argentino Chileno de Estudios Históricos e integración cultural. Paula Núñez, Compiladora. IID PyCa-UNRN-conicet. (Pp. 56-70).

- Cherubini, G. P. (2015). La escuela de carpinteros alemanes de Puerto Montt: su formación e influencia más allá de las fronteras. En prensa. Editorial Universitaria.

- Cherubini, G. P. (2014b). Notas para una historia de la arquitectura en Puerto Montt: el dilema entre el ser y el querer ser en la arquitectura local y el 


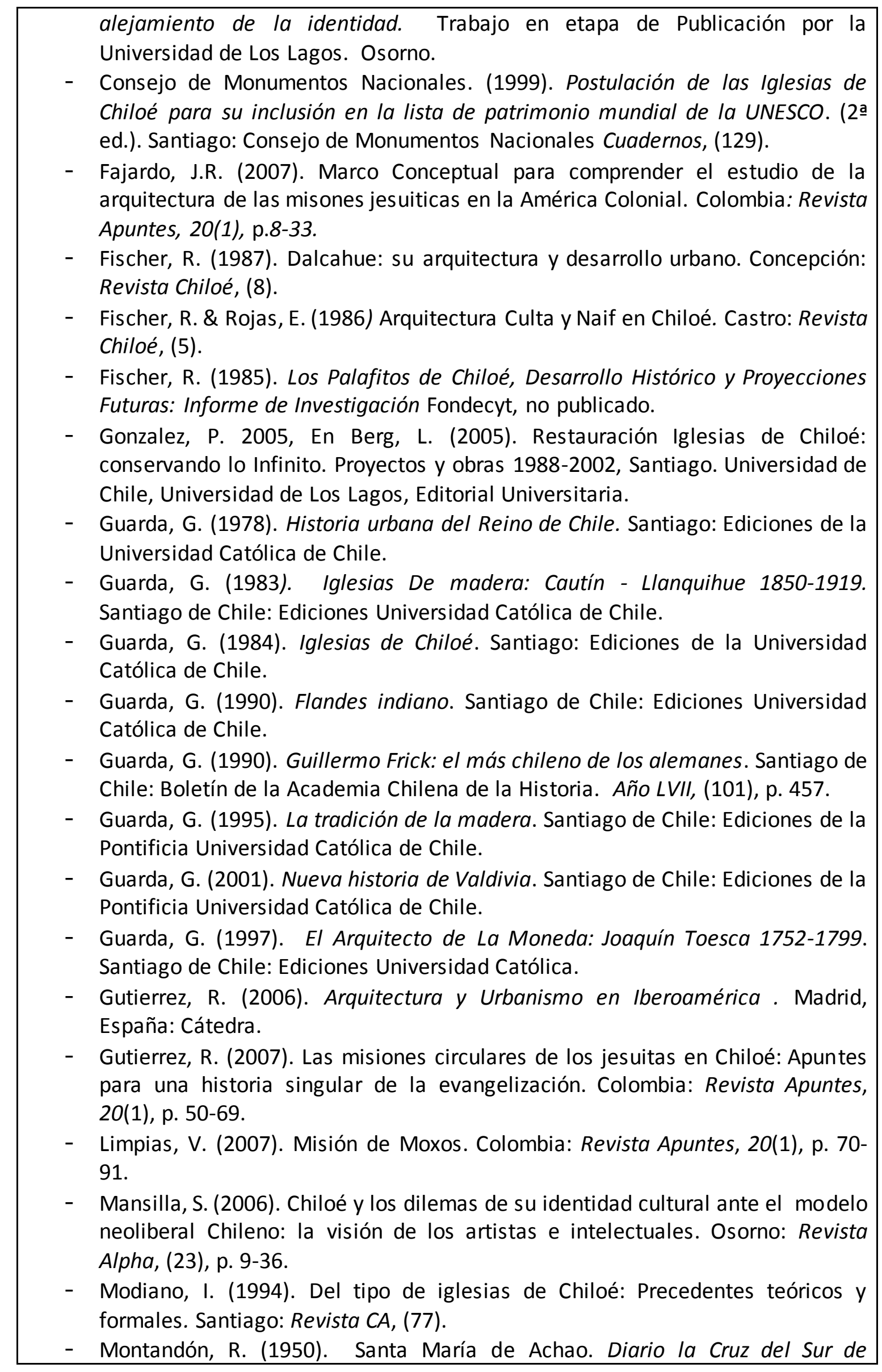


Ancud,(25 de abril).

- Montecinos, H. (1976). Arquitectura de Chiloé. Santiago: Universidad de Chile.

- Montecinos, H. Salinas, I. \& Basáez, P. (1995). Las Iglesias Misionales de Chile. Santiago: Departamento de Historia y Teoría de la Arquitectura, Universidad de Chile.

- Moraga, P. (2014). Estructura, Forma, Planta: Alcances del legado de la arquitectura de la colonización. Inédito. Puerto Varas.

- Rodríguez, H. (2012). Guía Patrimonial de Calera de Tango. Santiago de Chile: Universidad de los Andes, Municipalidad de Calera de Tango.

- Rodriguez de Ceballos, A. (2002). La arquitectura de los jesuitas. Madrid: Edilupa.

- Rojas, E. \& Irigoyen, A. (1996). El Reciclaje Insular. Bogotá: ESCALA.

- Rojas, E. \& Jiménez, P. (2005). Castro, 1936-1976: La modernidad vernacular de Chiloé. en Gutiérrez Viñuales, Rodrigo (coord...), Arte Latinoamericano del siglo $X X$. Otras historias de la Historia, Zaragoza: Prensa Universitarias.

- Sahady, A. Bravo, J. \& Quilodrán, C. (2009) La cocina chilota: el genuino lugar de encuentro de una comunidad borde marina. Santiago: Revista INVI, 24(67).

- Sahady, A. Gallardo, F. \& Bravo, M. (2010). El espacio religioso en tiempos de fiesta. Santiago: Naval Ltda.

- Schneider, O. Valassina, E. (1981). San Juan, Caserío de los dos entornos. Seminario de Historia de la Arquitectura de la Facultad de Historia de la Arquitectura de la Universidad de Chile. Inédito.

- Trebbi, R. (1987). Consideraciones en torno a la arquitectura tradicional en Chiloé. Concepción: Revista Chiloé, (8).

- Urbina, R. (1987). Los pueblos de Chiloé. Concepción: Revista Chiloé, (8).

- Urbina, X. (2011) Análisis histórico-cultural del alerce en la Patagonia Septentrional occidental: Chiloé, siglos XVI al XIX. Chile: Revista MAGALLANIA, 39(2), p. 57-73.

- Vivaldi, R \& Rojas, E. (1978). Chiloé: cultura y bordemar. Castro: Puertazul.

- Vivaldi, R (1994). Arquitectura actual en Chiloé: ni tanto ni tan poco sino... todo lo contrario. Santiago: Revista $C A,(78)$.

\section{- HISTORIA DE CHILOÉ Y CHILE}

- A.A.V.V. (2002). Pioneros del Llanquihue: 150 años de la emigración alemana al Lago Llanquihue, 1852-2002. Santiago de Chile: Edición Liga Chileno Alemana.

- ANCh, Ministerio del Interior. Vol. 169 A MPF 1837-1850. Informe de la Prefectura General de Misiones al Ministerio de Justicia, Culto e Instrucción Pública, 20 de marzo de 1840. P. 59- 60.

- Aránguiz, H. (1967) Notas para el estudio de la hacienda de la calera de tango: 1685 -1783. Revista Historia. Instituto de Historia de la Pontificia Universidad Católica de Chile. (6), p. 221-262.

- Astaburuaga, F. (1867). Diccionario Geográfico de la República de Chile. Nueva York: D. Appleton y Compañía. 
- Benavides, A. (1988). La arquitectura en el Virreinato del Perú y en la Capitanía General del Reino de Chile. (3a ed.). Santiago de Chile: Editorial Andrés Bello.

- Beranguer, C. (1873). Relación jeográfica de la provincia de Chiloé. Santiago de Chile: Imprenta Cervantes.

- Blancpain, J. P. (1985). Los alemanes en Chile (1816-1945). Santiago de Chile. Dolmen Ediciones.

- Cárcamo, P. (1993). El Colegio de Castro, (1873). Santiago de Chile: Reedición PAF (26), $178 \mathrm{p}$.

- Cárdenas, M. (1990). El Colegio de Misiones de Castro, (1897). Santiago de Chile: Reedición PAF (5), 76 p.

- Cavada, F. (1940). Historia de la Diócesis de Ancud, Ancud: Imprenta San Francisco.

- Darwin, C. (2005). Darwin en Chile (1832-1835): Viaje de un naturalista alrededor del mundo. Santiago de Chile: Universitaria.

- De Ramón, A \& Larraín, J.M. (1979). Una metrología Colonial para Santiago de Chile: de la medida castellana métrico decimal. Revista Historia. Instituto de Historia de la Pontificia Universidad Católica de Chile, (14), p. 5-69.

- De Ovalle, A. (2003) (1646). Histórica Relación del Reino de Chile. Santiago de Chile: Pehuén Editores.

- De Rosales, D. (1969) (1877). Historia General del Reino de Chile: Flandes Indiano. Santiago: Editorial Universitaria,

- Díaz, B. (1990). Franciscanos de Chiloé. Santiago de Chile: Reedición PAF (6), 70 p.

- Díaz, M.S. (2011) Conjunto de Altares-retablos de la iglesia San Francisco: y de cómo hacer tangible lo intangible. Tesis de Postítulo, Universidad de Chile.

- Enrich, F. (1891) Historia de la Compañía de Jesús en Chile. Chile: Imprenta de Francisco Rosal.

- González Venegas, S. (2004). Historia de la iglesia y convento de La Recoleta Franciscana. Tesis de Licenciatura. Universidad de Chile.

- González de Agüeros, P. (1791). Descripción Historial de la Provincia de Chiloé. Madrid: Imprenta de Don Benito Cano.

- Hanisch, W. (1982). La isla de Chiloé: capitana de rutas australes. Santiago: Academia Superior de Ciencias Pedagógicas de Santiago.

- Held, E. (1970). Documentos sobre la colonización del sur de Chile. Santiago de Chile: Talleres Gráficos Claus von Plate.

- Held, E. (1986). Crónica de las primeras escuelas fundadas por los colonos alemanes en la colonia de Llanquihue. Santiago de Chile: Instituto Geográfico Militar.

- Held, E. (1996). Colonización Alemana del Sur de Chile: documentación de su origen. Valparaíso: Editado por IGES, Ingeniería de Gestión Ltda.

- Horn, B. \& Kinzel, K. (1983). Puerto Varas: 130 Años de Historia, 1852-1983. Puerto Varas: Imprenta y Librería Horn.

- Horn, B. (1983). Parroquia del Sagrado Corazón de Jesús de Puerto Varas: 90 años de historia, 1893 - 1983. Puerto Varas: Talleres Horn y Cia. Ltda.

- Iturriaga, R. (1987). Los Franciscanos de Chiloé: Misioneros de la Araucanía. Edición Franciscana. 
- León, M. A. (2005). Franciscanos, Misioneros y Chilotes: El Colegio del Santísimo Nombre de Jesús de Castro (1837-1905). Santiago: PAF (86),140 p.

- Mansilla, J. (1997). La Misión Jesuita de los indios Chonos en San Felipe de Huar. Calbuco: edición de autor.

- Menard, A. \& Foerster, R. (2007). Cartas y memorias del vice prefecto de misiones Fr. Diego Chuffa (1842-1854). Publicaciones del Archivo Franciscano Santiago de Chile (98)

- Montiel, F. (2006). Los últimos constructores de artilugios de madera en Chiloé. Editorial Austral.

- Moraleda I Montero, J.M. (1888). Exploraciones jeográficas e hidrográficas. Santiago de Chile: Imprenta Nacional.

- Moreno Gallo, I. (2004). Topografía romana. Actas del II Congreso de las Obras Publicas Romanas. Disponible en: www.traianvs.net.

- Moreno Jeria, R. (2007). Misiones en Chile Austral: Los jesuitas en Chiloé. 1608-1768. Sevilla: Imprenta Grafites.

- Muñoz Sougarret, J. (2010). Contaminación de creencias. Trabajadores en tránsito y el mercado laboral urbano de Osorno, Chile (1880-1891). Osorno: Colección Monográficos - Editorial Universidad de Los Lagos.

- Olguin, C. (1971). Instituciones políticas y administrativas de Chiloé en el siglo XVIII. Santiago de Chile: Editorial jurídica de Chile.

- Oyarzún, C. (2006). Apuntes históricos de Curaco de Vélez, un pueblo de Chiloé. Puerto Montt: Impresos Printus.

- Pape, C. (2008). La iglesia en Osorno: pasado y presente. Osorno: Diócesis de Osorno.

- Pereira, E. (1965). Historia del arte en el reino de Chile. Santiago de Chile: Ediciones de la Universidad de Chile.

- Peralta, G. (1995). Biografía histórica de Osorno. Río Negro: Editorial Imprenta Liceo José Toribio Medina..

- Peralta, G. \& Hipp, R. (2004). Historia de Osorno desde los inicios del poblamiento hasta la transformación urbana del siglo XX. Osorno: Impresos Gráficos.

- Pérez Rosales, V. (1971) (1882). Recuerdos del Pasado. 1814-1860. Santiago de Chile: Ed. Francisco de Aguirre.

- Philippi, R. (1901). Valdivia en 1852. Santiago de Chile: Revista de Chile, (73), p. 297-300.

-Pinto, J. (1993). Jesuitas, Franciscanos y Capuchinos italianos en la Aaraucanía. Madrid: Revista Complutense de Historia de América, (19) p. 109-147.

-Pinto, J. (1993). Misioneros italianos en la Araucanía, 1600-1900 Evangelización e Interculturalidad. En (ed. Baldomero Estrada), Presencia italiana en Chile, Serie Monografías Históricas, Instituto de Historia, Universidad Católica de Valparaíso.

- Rondizzoni, J. (1854). Memoria que el intendente de Chiloé presenta al señor ministro de estado en el departamento del interior dando cuenta de todos los ramos de la administración. Ancud: (S.n)

- Rosales, P. \& Diego, S. J. (1877) Las casas de los chonos. Historia General del Reyno. Valparaíso: Imprenta de El Mercurio, Tomo I, p. 151. 
- Rovegno, J. (2001). Misiones entre los Araucanos (Memoria de los Prefectos), s. $X I X$. Santiago: PAF (70), $104 \mathrm{p}$.

- SINE NOMINE. (1996). El Llanquihue y sus 111 años de historia. Puerto Montt: Diario el Llanquihue, (12 de febrero).

- Tampe, E. (1983a). Desde Melipulli hasta Puerto Montt: trayectoria de ciento treinta años. Santiago de Chile: Tomo II. Ed. E. Tampe.

- Tampe, E. (1992). Desde Melipulli hasta Puerto Montt. Santiago de Chile: Ed. Publigráfica.

- Tampe, E. \& Schmidt, C. (2011). Colegio San Francisco Javier de Puerto Montt. Un siglo y medio de tradición ignaciana. Santiago de Chile: World Color Impresiones.

- Urbina, R. (1983). La periferia meridional indiana: Chiloé en el siglo XVIII. Valparaíso: Ediciones Universitarias de Valparaíso.

- Urbina, R. (1986). El papel de los misioneros en la formación de los pueblos chilotes de los siglos XVIIy XVII. Concepción: Surco.

- Urbina, R. (1990). El modo de comerciar de los chilotes a fines del siglo XVIII, en: Economía y comercio en América Hispana. Santiago: Serie Nuevo Mundo, Cinco Siglos, (5).

- Urbina, R. (1990). Las Misiones Franciscanas de Chiloé a fines del siglo XVIII: 1771-1800. Valparaíso: Monografías Históricas, Instituto de Historia, Universidad Católica de Valparaíso.

- Urbina, R. (2002). La vida en Chiloé en los tiempos del fogón. Valparaíso: Editorial Puntángeles, Universidad de Playa Ancha.

- Urbina, X. (2009). La frontera de arriba en Chile Colonial. Interacción hispanoindígena en el territorio entre Valdivia y Chiloé e imaginario de sus bordes geográficos, 1600-1800. Valparaíso: Centro de Estudios Diego Barros Arana, Dirección de Bibliotecas, Archivos y Museos, y Ediciones Universitarias de Valparaíso, Pontificia Universidad Católica de Valparaíso.

- Urbina, X. (2011). Análisis histórico-cultural del alerce en la Patagonia septentrional occidental, Chiloé, siglos XVI al XIX. Punta Arenas: Revista Magallania, 39(2), 57-73.

- Vázques De Acuña, I. (1956). Costumbres religiosas de Chiloé y su raigambre hispana. Santiago de Chile: Centro de estudios antropológicos Universidad de Chile.

- Weber, A. (1903). Chiloé, su estado actual, su colonización, su porvenir. Santiago de Chile: Imprenta Mejia.

\section{TEORÍA:}

- Bonfil, G. (1987). Los Pueblos Indios, sus Culturas y las Políticas Culturales. En (Néstor García ed.), Políticas Culturales en América Latina. México: Ed. Grijalbo S.A.

- Bonfil, G. (1988). Teoría del Control Cultural en el Estudio de los Procesos Étnicos. En Anuario Antropológico/86. Brasilia: Ed. Universidad de Brasilia, Tempo Brasileiro.

- Bonfil, G. (1992). La Teoría del Control Cultural. En: Pensar nuestra cultura. 
México: Alianza Editorial.

- Candelas, A. (1998). La carpintería de armar en los tratados europeos de los siglos XVI y XVII. En Actas del Segundo Congreso Nacional de Historia de la Construcción. Madrid: Instituto Juan de Herrera, Imprenta Efca.

- Chuecagoitía, F. (1981). Invariantes castizos de la arquitectura española. España: Ed. Dossat.

- Feilden, B. \& Jokilehto, J. (1993). Management Guidelines for World Cultural Heritage Sites. Ed. ICCROM.

- Fernández, C. (1990). Arquitectura y Modernidad Apropiada. Santiago: Taller América.

- Uribe, F. (2011). Tareas de la teología franciscana en el futuro. El Agora.USB Medellín-Colombia: 1(11), p. 1- 231.

- Gutiérrez, R. (1992) Arquitectura y Urbanismo en Iberoamérica. Madrid: Editorial Cátedra.

- Hernández, J.A. (2005) El salomonismo de Villalpando y el proceso de concepción aúreo del espacio denominado Capilla de Loreto en Sn Luis de Potosí. Recuperado de http://www.iifl.unam.mx/pnovohispano/.

- Heidegger, M. (1951). Construir, Habitar, Pensar, Vortäge und Aufsätze, G. Neske, Pfullingen, Darmstadt.

- Hurtado, P. (2011). Bóvedas encamonadas: origen, evolución, geometría y construcción entre los siglos XVII y XVIII en el Virreinato de Perú. Tesis Doctoral Universidad Politecnica de Madrid.

- lammarrone, G. (1978). Possibilità, senso e compiti di una 'Teologia francescana' in sé e per il momento attuale, en Miscellanea Francescana, 78, 344-345.

- Larsen, K \& Marstein, N. (1994). 8th International Symposium, 1902 En Icomos International Wood Committee (IIWC). Ed. Tapir.

- López de Arena, D. (1633). Breve compendio de la carpintería de lo blanco y tratado de alarifes. Sevilla: Luis Estupiñan Impresor.

- López de Arena, D. 1912- (1633). Carpintería de lo Blanco. Madrid: Imprenta de los hijos de Il. Álvarez .

- Lobos, J. (2007). Arquitectura cultural. Tesis de Maestría en Teoría y práctica del proyecto arquitectónico, Universidad Politécnica de Cataluña.

- Maldonado, L. \& Rivera, D. (2005), El entramado de madera como arquetipo constructivo: De la arquitectura tradicional a los sistemas modernos. Actas del Cuarto Congreso Nacional de Historia de la Construcción, ed. S. Huerta, Madrid: p 690.

- Martín, Á. (1999). Teoría de la cultura. Madrid: Editorial Síntesis.

- Martí, C. (1993). Las variaciones de la identidad. Ensayo sobre el Tipo en Arquitectura. Barcelona: Reedicion Demarcación de Barcelona del Colegio de Arquitectos de Cataluña.

- Norberg-Schulz, C. (1983). Arquitectura occidental. Barcelona: Ed. Gustavo Gili.

- Nuere, E. (2010). Dibujo, geometría, y carpinteros en la arquitectura. España: Real academia de Bellas Artes de San Fernando.

- Palladio, A. (2005). Los cuatro libros de la arquitectura. Traducción al español por Arq. Carlos Pérez Infante de la versión en inglés de Isaac Ware (1738). 


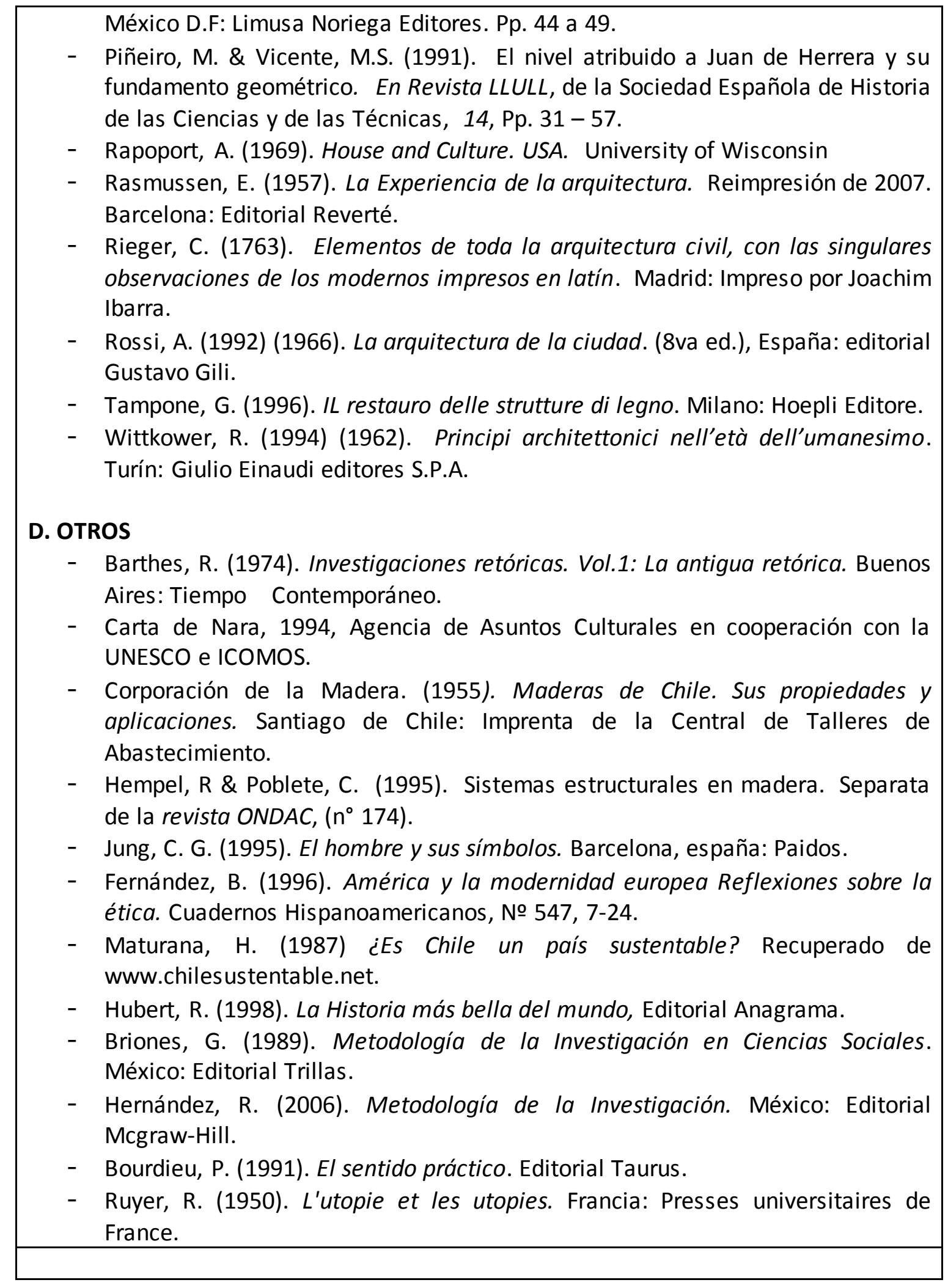

